\title{
DOMÍNIOS TECTÔNICOS DO SUDESTE DO PARANÁ E NORDESTE DE SANTA CATARINA: GEOCRONOLOGIA E EVOLUÇĀO CRUSTAL
}

Oswaldo Siga Júnior

Orientador: Prof. Dr. Miguel Angelo Stipp Basei

TESE DE DOUTORAMENTO

COMISSÃO JULGADORA

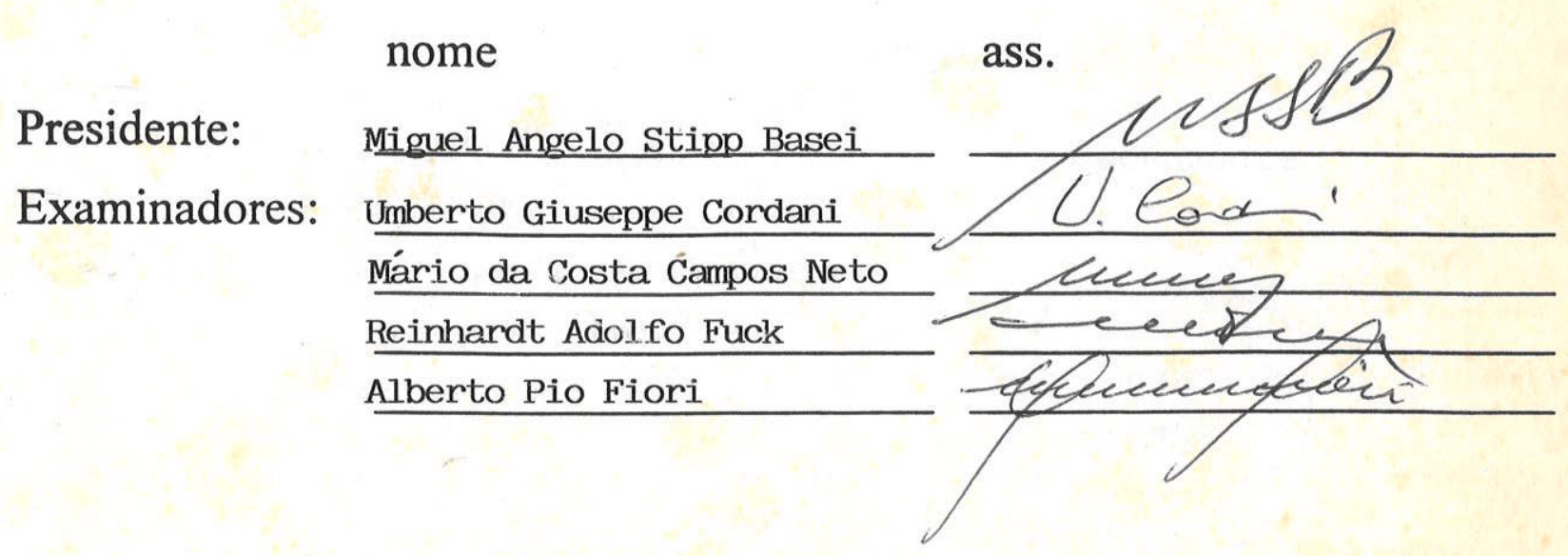




\title{
UNIVERSIDADE DE SÃO PAULO INSTITUTO DE GEOCIÊNCIAS
}

\section{DOMÍNIOS TECTÔNICOS DO SUDESTE DO PARANÁ E NORDESTE DE SANTA CATARINA: GEOCRONOLOGIA E EVOLUÇÃO CRUSTAL}

\author{
Oswaldo Siga Júnior
}

Orientador: Prof. Dr. Miguel Angelo Stipp Basei

TESE DE DOUTORAMENTO

Programa de Pós-Graduação em Geoquímica e Geotectônica 1995

DEDALUS - Acervo - IGC

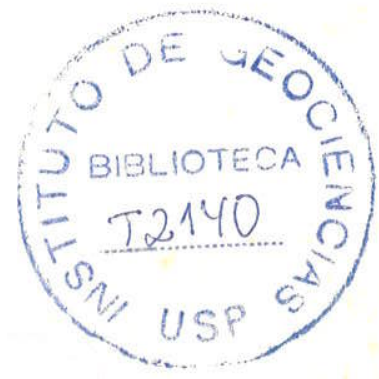


DOMINIOS TECTONNICOS DO SUDESTE DO PARANÁ E NORDESTE DE SANTA CATARINA: GEOCRONOLOGIA E EVOLUCÃO CRUSTAL

Resumo 1

Abstract 3

Agradecimentos 5

\section{Capítulo 1}

INTRODUÇÃO 7

1.1 - Definição de Propósitos e Área Investigada .......................................... 7

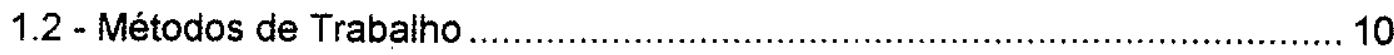

1.2 .1 - Estudos Geológicos Convencionais......................................... 10

1.2 .2 - Estudos Geocronológicos ............................................... 11

- Potássio-Argônio (K-Ar) .................................................. 11

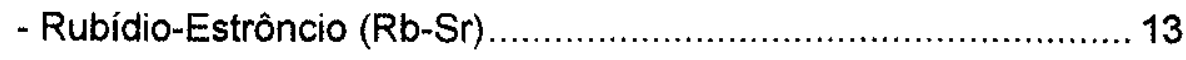

- Urânio-Chumbo (U-Pb) ....................................................... 14

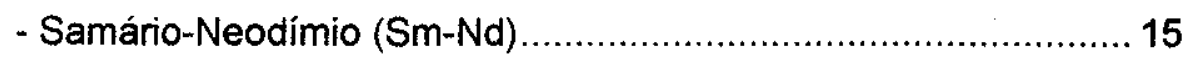

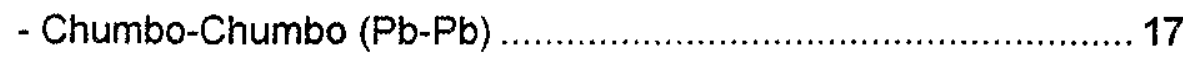

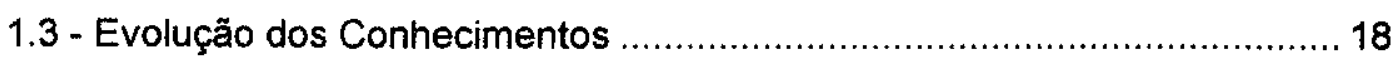

\section{Capitulo 2}

COMPARTIMENTAÇÃO TECTÓNICA

\section{Capítulo 3}

DOMINIO LUÍS ALVES 36

3.1 - Rochas Gnáissico-Granulíticas Regionais ........................................ 36

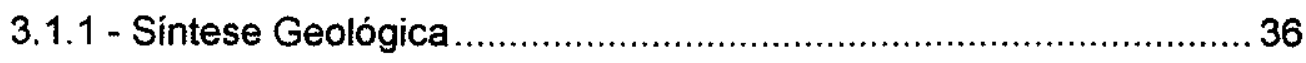

3.1 .2 - Geocronologia ............................................................. 43 
3.2 - Rochas Metabásicas e Metaultrabásicas das Regiões de Piên-Tijucas do Sul 61

3.2.1 - Síntese Geológica .........................................................61 61

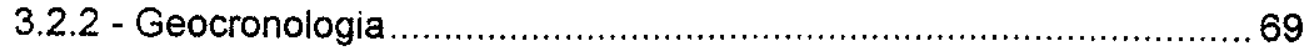

\section{Capítulo 4}

DOMINIO CURITIBA. 75

4.1 - Rochas Gnáissico-Migmatíticas Regionais ...................................... 73

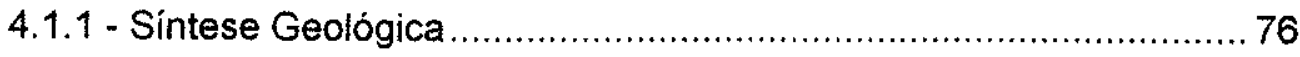

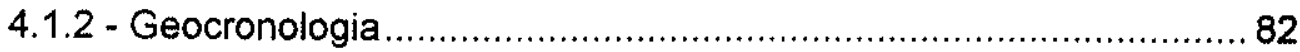

Capítulo 5

DOMÍNIO PARANAGUÁ 101

5.1 - Rochas Graníticas Regionais ....................................... 102

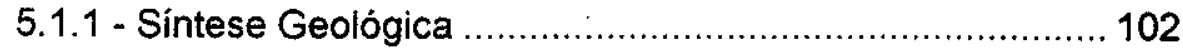

5.1 .2 - Geocronologia ................................................ 108

Capítulo 6

MAGMATISMO E SEDIMENTAÇÃO DE REGIMES EXTENSIONAIS PÓS-

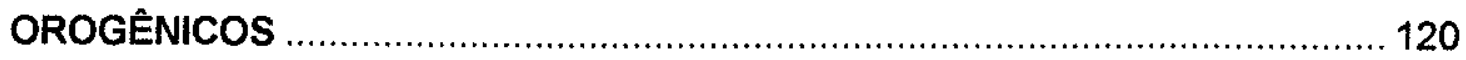

6.1 - Granitóides Alcalinos-peralcalinos ............................................ 120

6.1.1 - Aspectos Geológicos.................................................. 121

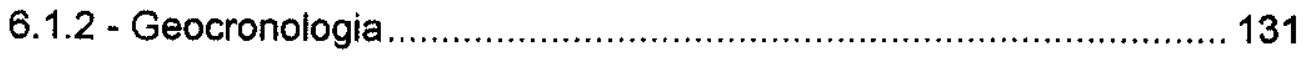

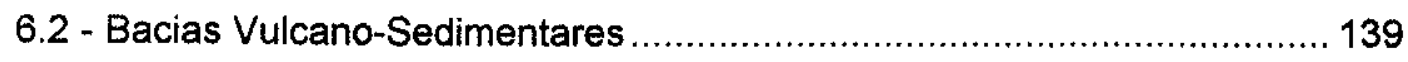

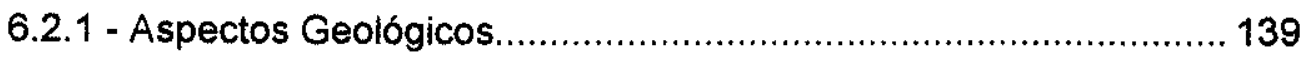

6.2 .2 - Geocronologia............................................................. 143

\section{Capitulo 7}

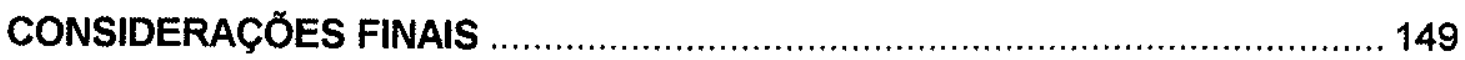

7.1 - Síntese das Informações Geocronológicas..................................... 149

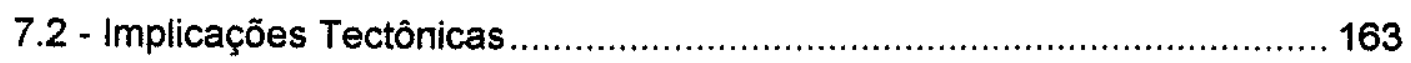




\section{Capítulo 8}

REFERÊNCIAS BIBLIOGRÁFICAS.

\section{Apêndices:}

1 - Dados geocronológicos 188

2 - Dados Geoquímicos 208

\section{Pranchas Fotográficas:}

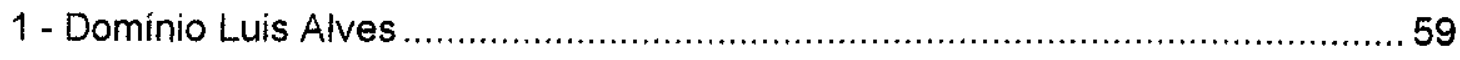

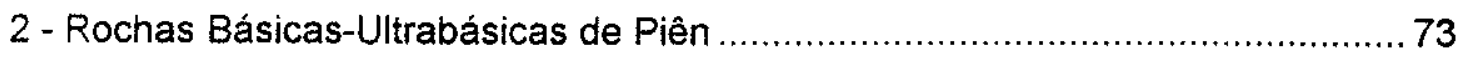

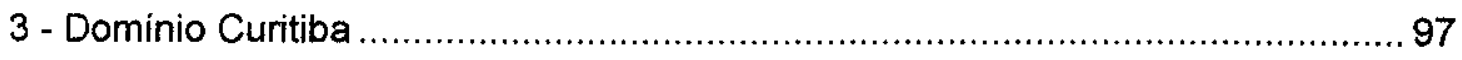

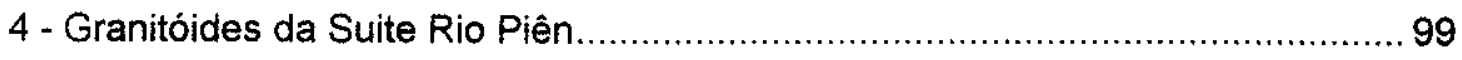

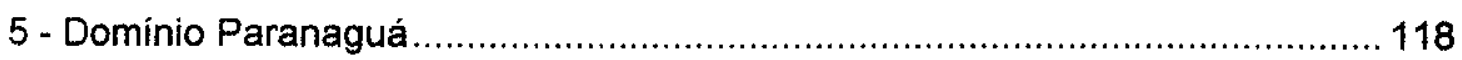

6 - Granitóides Alcalinos-Peralcalinos................................................... 147

\section{Anexos:}

1 - Esboço Geotectônico do Pré-Cambriano de parte dos Estados do Paraná e Santa Catarina.

2 - Mapa de Localização das Amostras Datadas.

3 - Dados Estruturais - Terrenos localizados entre os Cinturões Ribeira (norte) e Dom Feliciano (sul). 


\section{Índice das Figuras:}

- Fig. 1.1 Localização e vias de acesso da área de estudos.

- Fig. 2.1 Compartimentação Tectônica da porção sudeste do Paraná e nordeste de Santa Catarina

- Fig. 2.2 Perfil Curitiba-Areia Branca-Agudos do Sul-Piên-São Bento do Sul .... 34

- Fig. 2.3 Perfil Curitiba-Paranaguá (BR-277). 35

- Fig. 3.1 Diagrama triangular QAP (Streckeisen, 1976) - Gnaisses granulíticos do Dominio Luís Alves (inclui dados de Silva e Dias, 1981; Moreira e Marimon, 1980 e Machiavelli, 1991). 40

- Fig. 3.2 Diagrama $R_{1}-R_{2}$ (De La Roche et al. 1980) - Domínio Luís Alves. ... 42

- Fig. 3.3 Padrão de Terras Raras - Rochas Gnáissico-Granuliticas do Domínio Luís Alves.

- Fig. 3.4 Diagrama Isocrônico Rb-Sr - Rochas granulíticas dos arredores de Luís Alves (Hartmann et al. 1979 - modificado).

- Fig. 3.5 Diagrama Isocrônico Rb-Sr - Rochas gnáissico-granulíticas dos arredores de Pomerode.

- Fig. 3.6 Diagrama Isocrônico Rb-Sr - Migmatitos dos arredores de Luís Alves (Basei, 1985 - modificado)

- Fig. 3.7 Diagrama Isocrônico Rb-Sr - Rochas Gnáissico-Granulíticas da Região de Dona Francisca.

- Fig. 3.8 Diagrama Isocrônico Rb-Sr - Rochas Gnáissico-Granuliticas dos arredores de Blumenau (Basei, 1985)

- Fig. 3.9 Diagrama Isocrônico Rb-Sr - Rochas Gnáissico-Granulíticas dos arredores de Luis Alves.

- Fig. 3.10 Diagrama Isocrônico Rb-Sr - Rochas Gnáissico-Granulíticas dos arredores de Jaraguá do Sul. 49

- Fig. 3.11 Diagrama Isocrônico Rb-Sr em rocha total - Rochas Gnáissico-Granulíticas das proximidades de Piên (Girardi et al. 1974). 49

- Fig. 3.12 Diagrama Isocrônico $\mathrm{Rb}-\mathrm{Sr}$ para os Gnaisses Granuliticos das proximidades de São Bento do Sul (Machiavelli 1991). 50

- Fig. 3.13 Diagrama Isocrônico Rb-Sr em rocha total - Rochas Gnáissico-Granulíticas dos arredores de Serra Negra (Basei 1979). 50 
- Fig. 3.14 Diagrama Isocrônico utilizando a média das relaçöes $\mathrm{Sr}^{37} / \mathrm{Sr}^{86}$ e $\mathrm{Rb}^{87} / \mathrm{Sr}^{86}$ de isócronas Transamazônicas.

- Fig. 3.15 Diagrama Isocrônico Pb-Pb - Rochas dos arredores de Luís Alves (Basei 1985).

- Fig. 3.16 Diagrama U-Pb - Rochas Gnáissico-Granuliticas de Luis Alves (Basei 1985). 53

- Fig. 3.17 Diagrama U-Pb - Migmatitos da Região de Luís Alves (Basei 1985) ...53

- Fig. 3.18 Diagrama U-Pb em zircões - Gnaisses Granulíticos - Dona Francisca. 54

- Fig. 3.19 Diagrama U.Pb em zircões - Gnaisses Granulíticos - Dona Francisca. 55

- Fig. 3.20 Diagrama Isocrônico Sm-Nd em minerais. Rochas Granulíticas dos arredores de Barra Velha (Hartmann et al. 1994) 55

- Fig. 3.21 Histograma K-Ar - Domínio Luis Alves. 57

- Fig. 3.22 Rochas Básicas e Ultrabásicas de Campina dos Maias e Trigolândia (Streckeisen 1976). 62

- Fig. 3.23 Peridotitos, Piroxenitos e Gabronoritos de Piên - Elementos Maiores e Traços $\times$ MgO. 66

- Fig. 3.24 Padrão de distribuição de ETR - Metaperidotitos de Piên (normal. Evensen et al. 1978)

- Fig. 3.25 Padrão de distribuição de ETR - Metapiroxenitos de Piên (normal. Evensen et al. 1978) .67

- Fig. 3.26 Padrão de distribuição de ETR - Metagabronoritos de Piên (normal. Evensen et al. 1978) 68

- Fig. 3.27 Diagrama Isocrônico Sm-Nd - Rochas Ultrabásicas de Campina dos Crispins. .70

- Fig. 3.28 Diagrama Isocrônico caracterizando a dispersão dos pontos analíticos em relação a reta construída de $2.000 \mathrm{Ma}$ - Rochas Básicas e Ultrabásicas de Campina dos Crispins. 71

- Fig. 4.1 Diagrama QAP mostrando a classificação dos Granitóides Deformados segundo a proposição de Streckeisen (1976) e petrogenética segundo Lameyre e Bowden (1982). 79

- Fig. 4.2 Diagrama $R_{1} \times R_{2}$ (De La Roche et al. 1980) - Domínio Curitiba.......... 80

- Fig. 4.3 Padrão de Terras Raras - Domínio Curitiba. 80 
- Fig. 4.4 Diagrama Isocrônico Rb-Sr em rocha total para os Gnaisses Granulíticos localizados a norte de Curitiba.

- Fig. 4.5 Diagrama U-Pb em zircões - Gnaisses Granulíticos da Pedreira CESB Norte Curitiba.

- Fig. 4.6 Diagrama Isocrônico Rb-Sr - Gnaisses Granulíticos da Região da Graciosa.

86

- Fig. 4.7 Diagrama Isocrônico Rb-Sr em rocha total. Biotita Anfibólio Gnaisses bandados localizados a NE de Curitiba (BR-116). 86

- Fig. 4.8 Diagrama Isocrônico Rb-Sr em rocha total - Migmatitos da Pedreira Atuba Curitiba.

- Fig. 4.9 Diagrama Isocrônico $\mathrm{Rb}-\mathrm{Sr}$ em rocha total e minerais - Migmatitos da Pedreira Atuba - Curitiba 88

- Fig. 4.10 Diagrama U-Pb em zircões - Anfibólio Gnaisses dos arredores de Mandirituba 89

-Fig. 4.11 Diagrama Isocrônico Rb-Sr em rocha total - Anfibólio Gnaisses dos arredores de Mandirituba. 89

- Fig. 4.12 Diagrama Isocrônico Sm-Nd em minerais e rocha total. Anfibólio Gnaisses dos arredores de Mandirituba. 90

- Fig. 4.13 Diagrama Isocrônico Rb-Sr em rocha total - Gnaisses Migmatíticos dos arredores de Quitandinha. (A) - Leucossomas, (B) - Mesossomas. 91

- Fig. 4.14 Diagrama Isocrônico Rb-Sr em minerais de mobilizados de rochas Graníticos de rochas Gnáissico Migmatiticas dos arredores de Quitandinha. 92

- Fig. 4.15 Diagrama U-Pb em zircões - Granitóides localizados a norte de Piên (Machiavelli et al. 1993) 93

- Fig. 4.16 Diagrama U-Pb em zircões - Granitóides localizados a norte de Piên. 94

- Fig. 4.17 Diagrama isocrônico Rb-Sr em rocha total - Granitóides da Região de Piên. (A) - Detalhe alinhamento inferior. 95

- Fig. 4.18 Histograma K-Ar - Rochas do Domínio Curitiba. 96

- Fig. 5.1A Diagrama $R_{1} \times R_{2}$ (De La Roche et al. 1980, Batchelor \& Bowden 1985) Granitóides tipo Morro Inglês (1 à 4) e Rio do Poço (5) 106

- Fig. 5.1B Diagrama Rb $\times$ Y +Nb (Pearce et al. 1984) - Granitóides tipo Morro Inglês (1 a 4) e Rio de Poço (5). 107 
- Fig. 5.2 Diagrama de Multielementos - Granitóides tipo Morro Inglês e Rio do Poço (norm - Pearce et al. 1984) 108

- Fig. 5.3 Diagrama Isocrônico Rb-Sr para os Granitóides Porfiriticos dos arredores de Paranaguá - Tipo Morro Inglês. 109

- Fig. 5.4 Diagrama Isocrônico Rb-Sr para os Granitóides Porfiriticos das proximidades de Matinhos - Tipo Morro Inglês.

- Fig. 5.5 Diagrama Isocrônico Rb-Sr para os Granitóides Porfiríticos próximos a Guaratuba - Tipo Morro inglês 110

- Fig. 5.6 Diagrama Isocrônico Rb-Sr para os Granitóides Porfiríticos Tipo Morro Inglês. 111

- Fig. 5.7 Diagrama U-Pb em zircões - Granitóides Porfiriticos tipo Morro Inglês Dominio Paranaguá. 112

- Fig. 5.8A e B Modelo da Plumbotectônica de Zartman e Doe (1981) para os Granitóides Tipo Morro Inglês. 113

- Fig. 5.9 Diagrama U-Pb em zircões - Granitóide Rio do Poço. 115

- Fig. 5.10 Diagrama Isocrônico Rb-Sr - Granito Estrela. 115

- Fig. 5.11 Diagrama U-Pb em zircöes - Granito Estrela. 116

- Fig. 5.12 Histograma K-Ar - Granitóides do Domínio Paranaguá. 117

- Fig. 6.1 Diagrama QAP (Streckeisen 1976) - Maciços Graníticos da Porção SE do Paraná e NE de Santa Catarina. 128

- Fig. 6.2 Diagrama $R_{1} \times R_{2}$ para granitos da porção $S E$ do Paraná e NE de Santa Catarina. 129

- Fig. 6.3 Diagrama de Multielementos para os Maciços Graníticos da Porção SE do Paraná e NE de Santa Catarina (Pearce et al. 1984). 130

- Fig. 6.4 Diagrama de Multielementos Rochas Graníticas do Maciço Agudos do Sul (Pearce et al. 1984) 130

- Fig. 6.5 Diagrama U-Pb em zircões - Granito Agudos do Sul. 132

- Fig. 6.6 Diagrama Isocrônico Rb-Sr em rocha total - Granito Agudos do Sul. 132

- Fig. 6.7 Diagrama Isocrônico Rb-Sr em rocha total - Granito Agudos do Sul. (Girardi et al. 1974). 133

- Fig. 6.8 Diagrama U-Pb em zircões - Granito Corupá. .................................. 134

- Fig. 6.9 Diagrama Isocrônico Rb-Sr em rocha total - Granito Corupá. ............ 134

- Fig. 6.10 Diagrama Isocrônico Rb-Sr - Granito Graciosa. 135 
- Fig. 6.11 Diagrama U-Pb em zircões - Granito Graciosa.

- Fig. 6.12 Diagrama Isocrônico Rb-Sr em rocha total - Granito Anhangava....... 136

- Fig. 6.13 Diagrama U-Pb em zircões - Granito Morro Redondo. ...................... 137

- Fig. 6.14 Diagrama Isocrônico Rb-Sr em rocha total - Granito Morro Redondo...... 138

- Fig. 6.15 Histograma K-Ar - Maciços Graníticos da Porção NE de Santa Catarina e SE do Paraná.

- Fig. 6.16 Diagrama Isocrônico Rb-Sr - Riolitos da Bacia de Guaratubinha. ...... 144

- Fig. 6.17A Diagrama Isocrônico Rb-Sr - Riolitos da Bacia de Campo Alegre. ......... 144

- Fig. 6.17B Diagrama isocrônico Rb-Sr - Riolitos da Bacia de Campo Alegre. ......... 145

- Fig. 6.18 Diagrama U-Pb em zircões - Riolitos das Bacias de Campo Alegre e Guaratubinha.

- Fig. 7.1 - Padrão de Distribuição de idades Rb-Sr, U-Pb e K-Ar - Porção Sudeste do Paraná e Nordeste de Santa Catarina. 152

- Fig. 7.2 Histograma de ldades $\mathrm{Rb}-\mathrm{Sr}, \mathrm{U}-\mathrm{Pb}$ e $\mathrm{Sm}-\mathrm{Nd}$ para os terrenos localizados no setor SE do Paraná e NE de Santa Catarina. 153

- Fig. 7.3 Histograma K-Ar para as rochas da porção NE de Santa Catarina e SE do Paraná. 154

- Fig. 7.4 Diagrama de Evolução das Relações $\mathrm{Sr}^{87} / \mathrm{Sr}^{86}$ - Rochas do Porção NE de Santa Catarina e SE do Paraná. 155

- Fig. 7.5 Diagrama de Evolução do $\varepsilon_{\mathrm{Nd}}$ 156

- Fig. 7.6 Perfil K-Ar - Trecho Curitiba-Paranaguá........................................ 161

- Fig. 7.7 Perfil K-Ar - Trecho Curitiba-São Bento do Sul. ............................. 162

- Fig. 7.8 Correlação Geológica-Brasil x África............................................ 165

- Fig. $7.9 \varepsilon_{\text {Nd }} \times$ tempo - Dados do Setor SE do Paraná e NE de Santa Catarina 168 


\section{RESUMO}

O objetivo deste trabalho é discutir a evolução geotectônica de terrenos PréCambrianos localizados na porção sudeste do Paraná e nordeste de Santa Catarina.

As diferenças litológicas, petrográficas, estruturais, acopladas principalmente aos estudos geocronológicos, permitiram reconhecer neste setor a existência de três grandes domínios geotectônicos com evoluções próprias e distintas.

O primeiro domínio (Luis Alves), tem grande expressão na porção meridional estudada, afilando-se rumo nordeste, sentido Serra Negra, estendendo-se provavelmente até o Maciço de Itatins, já no estado de São Paulo. É balizado na porção noroeste pelos terrenos pertencentes ao Domínio Curitiba e no setor oriental pelo Domínio Paranaguá, contatos estes definidos por importantes zonas de cisalhamento. A sul, mostra-se recoberto pelos sedimentos do Grupo Itajaí, relacionados a evolução do Cinturão Dom Feliciano. O Domínio Luís Alves é representado, em grande parte, por rochas de alto grau metamórfico, tendo como litotipo principal gnaisses granulíticos formados no Arqueano (2.800-2.600Ma), e no Paleoproterozóico (2.200-1.900Ma). Grande parte desses terrenos encontrava-se relativamente frio no Neoproterozóico, temperaturas inferiores a $300^{\circ}-250^{\circ} \mathrm{C}$, representando possivelmente nessa época um segmento continental, posicionado entre os Crátons do Congo (África) e do Paraná (Brasil).

O segundo dominio (Curitiba) ocupa a porção setentrional estudada, sendo limitado no setor noroeste, através de zonas de cisalhamento, pelas seqüências metassedimentares dos Grupos Açungui e Setuva. Predominam neste domínio rochas gnáissico-migmatiticas do fácies anfibolito, ocorrendo em sua borda meridional granitóides cálcio-alcalinos (Suite Rio Piên). Caracteriza-se por mesossomas formados no Paleoproterozóico (2.200-1.800Ma), com leucossomas e porções graníticas do Neoproterozóico (640-560Ma), periodo esse em que as isotermas atingiram temperaturas superiores a $500^{\circ} \mathrm{C}$. Esses terrenos (Dominio Curitiba) podem representar a borda do Domínio Luís Alves, intensamente deformada, migmatizada e granitizada no Neoproterozóico. Essa tectônica seria decorrência da movimentação relativa, que teria colocado os terrenos Luís Alves por debaixo do Cinturão Ribeira. $O$ transporte relativo, envolvendo tanto as seqüências metassedimentares como a margem continental retrabalhada do microcontinente colidente teria sido de NW para 
SE. Tal processo ter-se-ia iniciado ao redor de $700 \pm 50 \mathrm{Ma}$, periodo este em que o arco magmático Três Córregos seria gerado, na borda do Cráton do Paraná. O fechamento completo do oceano existente entre o Domínio Luís Alves e o Cráton do Paraná, e consequente colisão, teria ocorrido em épocas anteriores a 620-600Ma, periodo este associado ao resfriamento (idades K-Ar) do Domínio Curitiba. Os granitóides deformados (Suite Rio Piên) que balizam o contato entre os Dominio Curitiba e Luís Alves, poderiam ter sua colocação relacionada a zonas transcorrentes, que limitam essas rochas magmáticas.

O terceiro domínio (Paranaguá), ocupa grande parte do setor oriental estudado, sendo representado por uma variedade de granitóides heterogeneamente deformados (Morro Inglês, Canavieiras) e isótropos (Rio do Poço, Estrela), ocorrendo ainda como encaixantes, gnaisses, xistos, quartzitos e anfibolitos. A justaposição do Domínio Paranaguá deu-se tardiamente a colagem dos terrenos Luís Alves e Paraná. Os dados geocronológicos sugerem a formação desses granitóides principalmente no intervalo 620-570Ma. O padrão K-Ar (560-480Ma) indica ainda que o resfriamento deste segmento ou de parte dele, atingiu o Cambro-Ordoviciano evidenciando provaveimente processos relacionados à aglutinação dos Crátons Congo-Kalahari e os Crátons São Francisco-Paraná e, consequente, formação do Gondwana Ocidental.

Durante a justaposição do Domínio Paranaguá, registra-se no âmbito dos terrenos adjacentes, já relativamente estabilizados, expressivo magmatismo de natureza alcalina-peraicalina (600-570Ma), representado pelos maciços graníticos da Graciosa, Anhangava, Marumbi, Serra da Igreja, Agudos do Sul, Morro Redondo, Dona Francisca, Pirai, Corupá e Serra Alta. Neste mesmo período, ocorre intenso vulcanismo ácido-intermediário, relacionado a evolução das Bacias de Campo Alegre, Guaratubinha e Corupá. Tais manifestações sugerem uma associação com regimes tectônicos distensivos produzidos pelos ajustes crustais decorrentes de uma procura de condiçōes de maior estabilidade, após o espessamento provocado pelo tectonismo precedente.

Finalmente, expressivo vulcânismo básico, de idade Juro-Cretácea, distribui-se no âmbito desses terrenos, relacionado a processos tectônicos que culminaram com a formação do Atlântico Sul. 


\section{ABSTRACT}

The aim of this study is a discussion of the geotectonical evolution of Precambrian terrains in the southeast of the Parana and northeast of Santa Catarina. Three large domains with individual and distinct evolutionary histories are recognised by lithological, petrographic and structural differences, reinforced by geochronological data.

The Luiz Alves domain occurs mainly in the southern part of the study area, but narrows northwestwards in the direction of Serra Negra and probably continues up to Itatins massif in São Paulo State. Its contacts with the Curitiba Domain in the northwest and with the Costeiro Domain in the east are formed by expressive shear zones. In the south, the Luiz Alves Domain is covered by sediments of the Itajai Group formed during development of the Domínio Feliciano Belt. The Luiz Alves Domain is mainly composid of high grade rocks, tipically granulite gneisses formed during the Archaean $(2,800$ $2,600 \mathrm{Ma})$ and Paleoproterozoic $(2,200-1,900 \mathrm{Ma})$. A large part of this domain was relatively cool during the Neoproterozoic, with inferred temperatures lower than 250 $300^{\circ} \mathrm{C}$. At this time, the domain was a continental segment - the Luiz Alves microplate between the Congo (Africa) and Paraná (Brazil) Craton.

The Curitiba domain occurs in the northern part of the study area. It is separated from the metasedimentary sequences of the Açungui and Setuva Groups, to the northwest, by shear zones. Amphibolite facies gneiss-migmatites predominate in this domain. Deformed calc-alkaline granitoids occur along its southern border. The mesosomes were formed in the Paleoproterozoic $(2,200-1,800 \mathrm{Ma})$, while leucosimes and granitic segregations were formed in the Neoproterozoic (640 - 560Ma). During this period, the isotherms reached temperatures higher than $500^{\circ} \mathrm{C}$. These terraines are believed to have formed the border of the Luiz Alves microplate, which was strongly deformed and suffered migmatization and granite intrusion during the Neoproterozoic.

This tectonic situation resulted from the movement which thrust the Luís Alves terranes under the Ribeira belt. The transport, which envolved both metasedimentary sequences and the continental margins of the colliding microcontinent, was from northwest to southwest. The process started at $700 \pm 50 \mathrm{Ma}$ at a time when the Três Corregos magmatic arc was formed at the margin of the Paraná craton. The total closure of the ocean which existed between the Luís Alves and Paraná terranes and 
the subsequent continental collision occurred before $620-600 \mathrm{Ma}$ when late tectonic processes (uplifth/cooling) were affecting the Curitiba domain. The deformed granitoids of the Rio Piên suite, which outline the contact between the Curitiba and Luis alves Domains, may have been intruded into the transcurrent zones which define their contacts.

The Costeiro Domain occupies a large part of the eastern part of the study area. It is formed by various heterogeneously deformed (Morro Inglês), Canavieiras) to isotropic (Rio Poço/Estrela) plutons, together with gneisses, schists, quartzites and amphibolites which form the host rocks. The Costeiro Domain arrive at its present position late during the college of the Luiz Alves and Paraná Domains. The geochronological data shows that the granitoids were formed during the interval 620 $570 \mathrm{Ma}$.

The K-Ar age pattern shows that this sector remained hot, with isotherms above $250-300^{\circ} \mathrm{C}$, during a long time interval from the Cambrian to the Ordovician, and may provide evidence of uplift and agglutination of the Congo and Kalahari cratons to the São Francisco, Paraná and Amazonian cratons which resulted in the formation of West Gondwana.

During the arrival of the Costeiro Domain. The adjacent terrains were relatively stable. Abundant alkaline-peralkaline granite intrusion, represented by the Graciosa, Anhangava, Maruni, Serra da Igreja, Morro Redondo, Dona Francisca, Piraí and Corupá massifs, occurred within these terrains at 600 - 570Ma.

During this same period, acid-intermediate volcanism occurred during the evolution of the Campo Alegre, Guaratubinha nad Corupá basins. This manifestations are a consequence of crustal rearrangement eithin relatively stable segments under distensive regimes.

Finally, Jurassic-Cretaceous mafic volcanism occurred eithin these Domains, related to the tectonic processes which the opening of the Atlantic. 


\section{AGRADECIMENTOS}

A realização deste trabalho tornou-se possivel graças a colaboração de diversos colegas, aos quais o autor quer manifestar os mais sinceros agradecimentos.

Inicialmente, o autor deseja consignar ao seu orientador e amigo Prof. Dr. Miguel Angelo Stipp Basei sua profunda gratidão pela incansável participação em todas as etapas deste trabalho, pelas inúmeras sugestões e grande estímulo recebido. Os agradecimentos são igualmente extensivos aos amigos do CPGeo-USP, Prof. Dr. Koji Kawashita, Prof. Dr. Umberto G. Cordani, Prof. Dr. Wilson Teixeira, Prof. Dr. Colombo C. G. Tassinari, Kei Sato, Helen M. Sonoki, Ivone K. Sonoki, José Elmano Gouveia de Almeida, Liliane Aparecida Petronilho, Artur Takashi Onoe, Décio Duarte Rosas, Margarida Martins, Walter M. Sproesser, João A. Monteiro Neto, Cláudio dos Santos, Cláudio Comerlatti, Jorge Gouveia de Almeida, Paulo A. dos Santos Filho e Valéria Cristina S. R. Santos, pela imensa colaboração e apoio recebido nas diferentes fases desta pesquisa.

Durante os trabalhos de campo contamos, em algumas oportunidades, com a participação dos geólogos José Manoel Reis Neto, Osama Mohamed Harara, Benjamim B. Brito Neves, Neivaldo A. Castro, Adilson Machiavelli, Paulo Santarém, Eleonora M. G. Vasconcellos, Elizete D. Salvador, Cláudia R. Passarelli, Jefferson de L. Picanço, Sérgio B. Citroni, João Paulo B. C. De Vasconcellos e Pedro F. T. Kaul. A todos esses colegas nossos agradecimentos pelo grande auxillio recebido.

Nas descrições petrográficas o autor recebeu inestimável ajuda dos colegas da Universidade Federal do Paraná, José Manoel Reis Neto, Neivaldo A. Castro, Raquel Mari Buba e Eleonora M. G. Vasconcellos. Pelos mesmos motivos, somos imensamente gratos aos colegas lan McReath, Gergely A. J. Szabó, Valdecir A. Janasi, Maria Angela F. Candia, Silvio R. F. Vlach, José M. De Azevedo e Francisco Rubens Alves. Nossa gratidão é extensiva aos Profs. Elimar Trein, Alberto Pio Fiori, Paulo César Soares e Omar Ferreira Lopes pela forma gentil e amigável que nos receberam sempre que passávamos na Universidade Federal do Paraná.

Durante o desenvolvimento deste trabalho, discussões e sugestões de alguns colegas, foram de fundamental importância. Entre esses colegas, aos quais expressamos nossos sinceros agradecimentos, destacamos os Professores Doutores Mário da Costa C. Neto, Wilson Teixeira, Ian McReath, Benjamim B. de Brito Neves e 
Vitor A. Ramos. Do mesmo modo, o autor deseja agradecer ao incentivo, apoio e motivação recebida dos colegas Mário C. H. Figueiredo, Rômulo Machado, Ivo Karmann, Magda Bergmann, Coriolano M. Dias Neto, Antônio Romalino S. Fragoso César, Armando M. Coimbra, Cláudio Riccomini, George R. Sadowski, Marly Babinski, Adilson Carvalho, Roland R. Trompette, Marcos Egydio da Silva, José P. P. Pinese, Luis Rogério e Lucy G. Sant'Anna.

Somos gratos aos Professores Dr. W. R. Van Schmus (Universidade de Kansas) e Dr. Nuno Machado (Universidade de Quebec) que muito nos auxiliaram no desenvolvimento da metodologia U-Pb no CPGeo-USP.

No transcorrer desta tese contamos com grande ajuda dos geólogos Luis Emílio Trevizoli Jr. e Maria Manuela Galvão Monteiro, na execução de análises geocronológicas e Fernando Mancini no tratamento de dados estruturais, aos quais somos muito gratos.

O autor deseja expressar sinceros agradecimentos a Helen M. Sonoki e Ivone K. Sonoki pela incansável e prestimosa colaboração recebida nos trabalhos de digitação e elaboração dos diagramas isocrônicos. Do mesmo modo, somos imensamente gratos a Reynaldo Peña Castellon, Elizete D. Salvador, Cláudia R. Passarelli, pela colaboração recebida na confecção de inúmeras figuras, mapas e revisão bibliográfica.

As láminas petrográficas foram confeccionadas pelo colega Cláudio Hopp e sua equipe técnica, a quem agradecemos.

Ao setor gráfico somos gratos ao Sr. Dalton Machado da Silva e sua equipe e no setor fotográfico ao $\mathrm{Sr}$ Jaime de Souza Marcos que muito nos auxiliaram na reprodução, encadernação e ilustração deste trabalho.

A FAPESP que, durante o transcorrer dos estudos, concedeu-nos recursos financeiros para o desenvolvimento das pesquisas de campo e análise químicas.

O autor agradece aos amigos José Carlos, Marcelo, Edgar, Jair e Adilson pelas visitas forçadas à inúmeros afloramentos durante as pescarias em Icapara, Iguape, Ariri e Superagui.

Por fim, o agradecimento profundo à minha esposa Lena e aos meus filhos Guilherme, Andréa de Cássia e Carolina e a minha mãe Nair, cujo carinho e compreensão constante possibilitou o desenvolvimento deste trabalho. 


\section{CAPÍTULO 1}

\section{INTRODUÇÃO}

\section{1 - DEFINIÇÃO DE PROPÓSITOS E ÁREA INVESTIGADA}

Este trabalho, iniciou-se em 1988, tendo como principal objetivo o estudo geocronológico do então denominado Maciço de Joinville (Hasui et al. 1975), reconhecido como uma entidade antiga (Arqueana e Paleoproterozóica), instalada entre os Cinturões Ribeira (à norte) e Dom Feliciano (ao sul).

Com o desenvolvimento da pesquisa, e o reconhecimento de diferentes segmentos tectônicos neste setor, a proposta inicial foi sendo modificada, gerando a necessidade de maior controle estrutural, geoquímico e petrográfico, além de análises geocronológicas envolvendo medotologias com diferentes valores interpretativos, numa tentativa de reconstituir os principais traços evolutivos desta região.

A região de interesse limita-se a norte com as seqüências metavulcanossedimentares dos Grupos Açungui e Setuva (Cinturão Ribeira), a sul com as rochas sedimentares do Grupo Itajai (Cinturäo Dom Feliciano), a oeste com as rochas sedimentares da Bacia do Paraná, atingindo a costa na porção oriental. Envolve predominantemente rochas gnáissico-granulíticas (Domínio Luís Alves), rochas gnáissico-migmatíticas (Domínio Curitiba) e rochas granito-gnáissicas (Domínio Paranaguá). Adicionalmente, ocorre no âmbito desses domínios importante magmatismo representado por inúmeros batólitos e "stocks" graníticos de natureza alcalina-peralcalina, bem como pelas seqüências vulcânicas ácidas a intermediárias associadas as bacias de Campo Alegre, Guaratubinha e Corupá.

É preocupação maior desse trabalho caracterizar geocronológicamente os diferentes dominios tectônicos em termos de idade e de evolução crustal e promover a integração dos resultados radiométricos com os dados de campo, numa escala de reconhecimento, tendo em vista que a região estudada ocupa uma área superior a $16.000 \mathrm{~km}^{2}$.

O esboço geotectônico apresentado (anexo-1) retrata principalmente os trabalhos realizados pela Comissão da Carta Geológica do Paraná nas escalas 1:50.000 e 1:70.000 (1965-1970), os Projetos Leste do Paraná com seis folhas 
1:100.000 e três folhas 1:50.000 (DNPM-CPRM 1977), o Mapa Geológico do Estado de Santa Catarina 1:500.000 (DNPM 1986), o Mapa Geológico do Estado do Paraná 1:650.000 (DNPM-MINEROPAR 1989), e o Mapa Geológico da Serra da Prata 1:250.000 (Lopes 1987a e b).

Destacam-se no setor estudado (Fig. 1.1) as cidades de Curitiba, São José dos Pinhais, Paranaguá, Guaratuba, Antonina, Piraquara e Morretes (no Paraná) e Blumenau, Joinville, São Bento do Sul e Jaguará do Sul (em Santa Catarina).

Os acessos mais importantes são as rodovias BR-116, BR-101 e BR-376. Adicionalmente, há importantes estradas de ligação, tais como a da Graciosa (410), Curitiba-Paranaguá (277), Paranaguá-Garuva (412), São Bento do Sul-Joinville (280), São Bento do Sul-São Francisco do Sul (301) e Guaramirim-Blumenau (474).

$A$ rede de drenagem da região tem nos rios Itajai-Açu, Capivari, Itapocu, Negro, Iguaçu, Cubatão, Palmital, São João, Sai-Guaçú, Cachoeira e Cedros os seus mais expressivos representantes (Fig. 1.1).

A Serra do Mar é o divisor de águas das bacias hidrográficas dos rios que fluem para o litoral e aqueles que, apesar de possuirem suas origens nas proximidades do litoral, fluem para o interior como tributários dos rios Paraná e Uruguai.

Podem ser caracterizadas quatro unidades geomorfológicas principais, representadas pelas Serranias Costeiras, Planícies Costeiras, Planalto Cristalino Atlântico e Planalto Sedimentar (Almeida 1952, Maack 1961).

A Serrania Costeira está relacionada principalmente a Serra do Mar, alcançando altitudes superiores a 1.000 metros, atingindo 1.524 metros no pico Marumbi, os vales possuem perfis em $\mathrm{V}$, com grande abertura e vertentes côncavas, tendendo ao entalhamento.

Nas Planícies Costeiras, o relevo é parcialmente ondulado e as altitudes alcançam poucos metros acima do nivel do mar. Os vales apresentam formas de $V$, bem abertos, com vertentes suaves a levemente inclinadas.

O Planaito Cristalino Atlåntico, também conhecido no Paraná como Primeiro Planalto ou Planalto de Curitiba, é formado pelo reverso da Serra do Mar e suas escarpas. A norte-nordeste tem continuidade com o Planalto Cristalino Atlântico de São Paulo. 


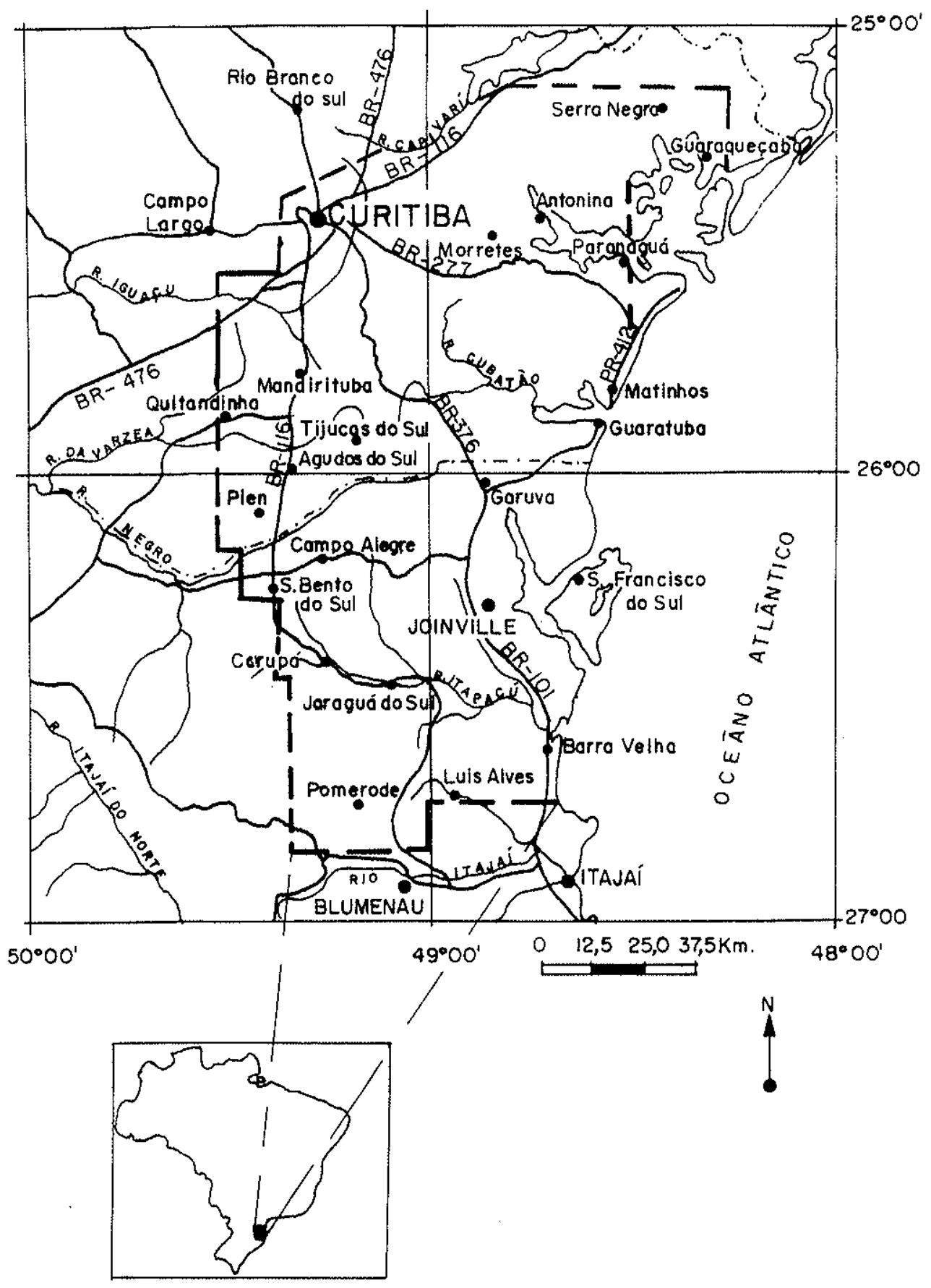

Fig. 1.1 - Localização e principais Vias de Acesso da Área de Estudo. 
Em Santa Catarina, o Planalto Cristalino restringe-se a uma pequena área localizada no extremo nordeste do estado, desaparecendo sob as rochas do Planalto Sedimentar. Trata-se de uma superfície relativamente plana, localizada entre as altitudes de 800 a 900 metros, com desniveis variáveis entre 40 e 60 metros.

O Planalto Sedimentar é representado pelas rochas sedimenatres da Bacia do Paraná, onde predomina uma forma de relevo com feições tabulares. Estão elevados sobre o embasamento cristalino em paredões esculpidos, com desniveis que atingem 200 metros.

\section{2 - MÉTODOS DE TRABALHO}

Serão discutidas aqui as metodologias utilizadas pelo autor para a confecção deste trabalho. Tal discussão será desenvolvida em duas partes, abrangendo inicialmente os estudos geológicos convencionais $e$, a seguir, os métodos geocronológicos, que constituíram a base do presente trabaiho.

\subsection{1 - Estudos Geológicos Convencionais}

As sucessivas etapas pelas quais passou esta pesquisa podem ser assim resumidas:

- Análise bibliográfica, com a finalidade de selecionar publicaçöes de interesse a região estudada.

- Viagem de campo, visando o reconhecimento das principais unidades geológicas pré-cambrianas do Paraná e Santa Catarina. Foram utilizados nesta etapa os mapas geológicos disponíveis e, como base topográfica as folhas plani-altimétricas do IBGE, COMEC e Min. do Exército nas escalas 1:50.000, 1:100.000 e 1:250.000.

- Análise de imagens de radar, na escala 1:250.000.

- Trabalhos de campo e confecção de perfís geológicos tendo por objetivos a caracterização das diferentes unidades e efetuar coleta de amostras para análises petrográficas, geoquímicas e principalmente geocronológicas. Os trabalhos de campo envolveram o estudo de cerca de 1.000 afloramentos. 
- Trabalhos laboratoriais, em que foram realizadas a observação de lâminas delgadas ao microscópio, com a finalidade de promover a seleção e a preparação de amostras principalmente para as determinações radiométricas.

- Confecção de um esboço geológico-geotectônico do setor nordeste de Santa Catarina e sudeste do Paraná, na escala 1:500.000.

\subsection{2 - Estudos Geocronológicos}

Atualmente, a região estudada conta com cerca de 650 determinações geocronológicas, envolvendo os métodos $\mathrm{K}-\mathrm{Ar}, \mathrm{Rb}-\mathrm{Sr}, \mathrm{U}-\mathrm{Pb}, \mathrm{Sm}-\mathrm{Nd}$ e $\mathrm{Pb}-\mathrm{Pb}$. A maioria dessas análises foi realizada nos laboratórios do Centro de Pesquisas Geocronológicas do Instituto de Geociências da Universidade de São Paulo - CPGeoUSP. Dispõe-se também, de análises realizadas através de cooperação científica com laboratórios de Kansas (EUA), Milton Keynes (UK), Clermont Ferrant (FR) e Montpellier (FR), especificadas no Apêndice-1.

As interpretações geocronológicas obedeceram às particularidades específicas inerentes a cada metodologia, conforme comentário a seguir.

\section{Potássio-Argónio (K-Ar)}

O setor sudeste do Paraná e Nordeste de Santa Catarina conta atualmente com cerca de 200 determinações radiométricas através do método K-Ar, realizadas principalmente em anfibólios e biotitas. Tais minerais mostram-se favoráveis as datações K-Ar por apresentarem temperaturas criticas de difusão/retenção de gás argônio relativamente precisas, permitindo delimitar com nitidez diferentes provincias geocronológicas.

$O$ argônio, na qualidade de gás nobre, encontra-se preso mecanicamente ao retículo cristalino dos minerais, tornando-se susceptivel a migrações por simpies excitação térmica. A temperatura critica para a retenção de argônio parece representar, na verdade, um intervalo muito restrito (de alguns poucos graus) em que se passa de uma situação de perda completa (acima da temperatura critica), para uma situação de retenção completa (abaixo da temperatura crítica). Os limites críticos 
variam, de mineral para mineral, sendo por exemplo da ordem de $450^{\circ}-500^{\circ} \mathrm{C}$ para os anfibólios e da ordem de $250^{\circ}-300^{\circ} \mathrm{C}$ para as micas (Faure 1986, Haner 1991).

O padrão de idades aparentes K-Ar indica tão somente épocas relacionadas ao resfriamento regional, idades consideradas minimas, e que podem ser muito mais jovens que os episódios reais de cristalização magmática ou recristalização metamórfica que deram origem às paragêneses minerais observadas.

Em áreas policíclicas, por outro lado, pode ocorrer uma degaseificação incompleta de argônio, sendo os resultados obtidos nestes casos superiores aos de resfriamento regional e, sem significado geológico.

A aplicação do método K-Ar em rochas Pré-Cambrianas do sudeste Paranaense e nordeste Catarinense permitiu não sỏ a caracterização do padrão de resfriamento dos domínios estudados, como também traçar inferências sobre a tectônica que atuou na justaposição desses terrenos. A confeç̧ão de perfís térmicos permitiu uma análise detalhada dos processos termais que atuaram nos limites tectônicos envolvendo os diferentes terrenos.

Para obtenção dos resultados K-Ar foram observados basicamente os procedimentos técnicos discutidos por Amaral et al. (1966) com inúmeras modificações introduzidas, desde então, pelo corpo técnico do CPGeo.

As análises de $\mathrm{K}$, em duplicata, foram realizadas por ataque químico convencional e sua quantificação foi obtida por fotometria de chama em aparelho Micronal, modelo B-262. O argônio foi extraido em unidades de ultra alto vácuo, sob pressões inferiores a $10^{-7} \mathrm{mmHg}$ e purificado em fornos de cobre e titânio.

A reprodutibilidade analítica do método é da ordem de 2 a $3 \%$, com base na utilização de padrões laboratoriais variados. Para o cálculo das idades, realizado em microcomputador, utilizou-se as constantes recomendadas por Steiger \& Jäeger (1978), listadas a seguir:

$$
\begin{aligned}
& \lambda_{\beta}=4,962 \times 10^{-10} \text { anos }^{-1} \\
& \lambda_{k}=0,581 \times 10^{-10} \text { anos }^{-1} \\
& \left(\operatorname{Ar}^{40} / \mathrm{Ar}^{36}\right)_{\text {atm }}=295,5 \\
& \mathrm{~K}^{40}=0,01167 \% \mathrm{~K}_{\text {total }}
\end{aligned}
$$




\section{Rubídio-Estrôncio (Rb-Sr)}

A grande maioria das análises aqui apresentadas e discutidas referem-se ao método $\mathrm{Rb}-\mathrm{Sr}$, interpretadas através de diagramas isocrônicos, envolvendo sistemas minerais e rocha total. No caso dos minerais é fundamental que eles tenham sido gerados no mesmo processo petrogenético, sendo a interpretação da idade isocrônica obtida similar a observada através do método K-Ar (Faure 1986).

As idades isocrônicas em rocha total, relativas a conjuntos cogenéticos indicam, por outro lado, episódios formadores de rochas, em sentido extenso, por meio de quaisquer processos petrogenéticos que conduzam ao aparecimento de associações minerais bem definidas, provenientes de cristalização magmática ou de recristalização metamórfica. Na grande maioria dos casos são datáveis pelo método $\mathrm{Rb}-\mathrm{Sr}$ processos petrogenéticos diversificados que levam a formação de rochas do tipo granítica ou assemelhada, processos estes referidos como granitização, anatexia, palingênese, metassomatismo, migmatização e metamorfismo de fácies anfibolito (Faure 1986, Cordani 1980).

A relação inicial $\left(\mathrm{Sr}^{87} / \mathrm{Sr}^{86}\right)_{i}$ isocrônica pode ser utilizada como traçador petrogenético, em que, de modo grosseiro, as rochas com r.i. $>0,705$ indicam fontes crustais e aquelas com r.i. $<0,705$ sugerem origem do manto superior ou crosta inferior. Os parâmetros citados necessitam de suportes adicionais, obtidos através de outras metodologias ( $\mathrm{Pb}, \mathrm{Nd})$, uma vez que devem ser levados em conta a possibilidade de heterogeneidade do manto, bem como de mistura de materiais oriundos de diferentes fontes.

Nos modelos de cáiculo de idades isocrônicas $\mathrm{Rb}-\mathrm{Sr}$, cabe mencionar que os métodos de regressão incluem fatores de peso alicerçados em desvios e erros analíticos em relação à reta, com base num nível de confiança estabelecido (e.g. Williamson 1968, Brooks et al. 1972). Adicionalmente, uma análise comparativa dos principais modelos de cálculo aplicados a exemplos brasileiros foi apresentada por Kawashita et al. (1990), com comentários a respeito de seleção de amostras e aspectos geológicos, que influenciam no sistema $\mathrm{Rb}-\mathrm{Sr}$.

O espectrômetro de massa utilizado foi o VG-354 termoiônico com 5 coletores (taças de Faraday) e com um detector Daly. Neste equipamento podem ser colocadas 
até 16 amostras que são analisadas de forma automática ou semi-automática. 0 detector Daly tem uma sensibilidade 100 vezes maior que a taça de Faraday.

Os valores $\mathrm{Sr}^{87} / \mathrm{Sr}^{86}$ foram normalizados em função da relação $\mathrm{Sr}^{86} / \mathrm{Sr}^{88}=$ 0,1194 , sendo as constantes utilizadas aquelas recomendadas por Steiger \& Jäeger (1978):

$$
\begin{aligned}
& \lambda_{R b}=1,42 \times 10^{-11} \text { anos }^{-1} \\
& \left(\mathrm{Rb}^{85} / \mathrm{Rb}^{87}\right)_{\mathrm{N}}=2,59265
\end{aligned}
$$

\section{Urânio-Chumbo (U-Pb)}

Trata-se de uma ferramenta que tem permitido a resolução de problemas geológicos complexos devido, principalmente, a excepcional resistência do retículo cristalino dos zircões com relação a modificações posteriores à sua formação. A "memória" dos zircões, retendo idades de eventos iniciais, mesmo que apenas em seu núcleo, favorece sua aplicação ao estudo da evolução de terrenos policíclicos. Além disso, a resistência aos processos intempéricos permite a análise de zircões oriundos de rochas sedimentares. É também um método muito utilizado na datação de deformações polifásicas onde, associados aos dobramentos tem-se mobilizados neossomáticos com zircões, esfenos ou monazitas neoformados.

A metodologia utilizada observou os procedimentos técnicos descritos em Krogh $(1973,1982 a$ e b) e Corfu \& Stott (1986). Estas técnicas implicam num cuidadoso procedimento experimental, de modo a concentrar frações de zircões com diferentes susceptibilidades magnéticas, para posterior seleção em lupa. Os zircões analisados neste trabalho foram, após seleção, submetidos a um processo de abrasão mecânica (5-6hs) através de um sistema que envolve ar comprimido e pirita, visando a eliminação de suas porções mais externas. Estas, normalmente, sofrem perdas significativas de chumbo, que são responsáveis pela discordância entre as idades $\mathrm{U}^{238}$, $\mathrm{U}^{235}$ e $\mathrm{Pb}^{207} / \mathrm{Pb}^{206}$. Quando os cristais de zircão apresentam núcleo e sobrecrescimento, o procedimento de abrasão pode ser controlado opticamente, de modo a serem analisados somente suas porções mais internas, que permitem muitas vezes, a caracterização de terrenos metamórficos complexamente deformados $e$ de história policíclica. 
Aos trabalhos de Ahrens (1955) e posteriormente de Wetherill (1956) deve-se o conceito de curva Concórdia, que representa o lugar geométrico dos pontos com idades concordantes, obtidas pelos dois cronômetros $\mathrm{U}^{238} / \mathrm{Pb}^{208}$ e $\mathrm{U}^{235} / \mathrm{Pb}^{207}$ e, por conseguinte, também do par $\mathrm{Pb}^{207} / \mathrm{Pb}^{206}$.

Desde que um ponto analítico não esteja situado sobre a curva Concórdia as três idades deixam de ser iguais. Os resultados fornecidos pelos cronômetros, separadamente, são diferentes, tendo-se então uma discordância. A reta que contém os diferentes pontos discordantes recebe o nome de Discórdia.

A intersecção superior da reta Discórdia com a curva Concórdia caracteriza a época de cristalização dos zircões. Para a intersecção inferior existem interpretações que a relacionam com uma perda episódica ou então, a uma perda contínua. Por outro lado, a idade definida pela intersecção superior será mais confiável quanto mais concordantes foram os pontos analíticos.

A instalação da metodologia $U-\mathrm{Pb}$ na Universidade de São Paulo se concretizou durante o desenvolvimento deste trabalho, sendo os dados aqui obtidos pioneiros no CPGeo-USP. As caracteristicas e rotina analítica do laboratório U-Pb, encontram-se sintetizadas em Basei et al. (1994).

O espectrômetro de massa utilizado foi o VG-354, sendo os resultados obtidos, calculados utilizando-se o "software" ISOPLOT (Ludwig 1990), disponivel em micros compativeis PC.

As constantes utilizadas nos cálculos das idades foram as seguintes (Steiger \& Jäeger 1978):

$$
\begin{aligned}
& \lambda_{U 238}=1,55125 \times 10^{-10} \text { anos }^{-10} \\
& \lambda_{U 235}=9,8485 \times 10^{-10} \text { anos }^{-1} \\
& U^{238} U^{235}=137,88
\end{aligned}
$$

\section{Samário-Neodímio (Sm-Nd)}

O desenvolvimento do método $\mathrm{Sm}-\mathrm{Nd}$ em materiais terrestres iniciou-se na década de 1970, a partir de estudos de meteoritos e rochas lunares (Lugmair et al. 1975; Nakamura et al. 1976). Com a melhor compreensão do comportamento dos isótopos de $\mathrm{Sm}$ e $\mathrm{Nd}$ nos processos geológicos e de suas características geoquímicas 
no manto superior e na crosta continental, a sistemática Sm-Nd tem se mostrado uma importante ferramenta para os estudos de evolução crustal.

O Sm e o Nd säo dois elementos do grupo dos Terras Raras (ETR) ou

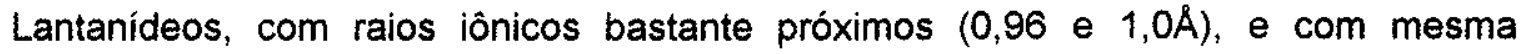
valência, o que os tornam praticamente elementos isoquímicos, ao contrário do sistema $\mathrm{Rb}-\mathrm{Sr}$, onde os elementos possuem ciclos geoquímicos opostos. Este fato resulta em razōes $\mathrm{Sm}-\mathrm{Nd}$ pouco diferenciadas, variando de 0,1 a 0,37 entre os diversos minerais e rochas. Como os ETR têm uma forte densidade de carga $(3+)$ e um número atômico elevado (57 a 71), não se difundem facilmente no estado sólido, resultando em pouca mobilidade desses elementos, em escala de rocha total. Por outro lado, a nivel mineral, ocorre uma redistribuição do $\mathrm{Sm}$ e $\mathrm{Nd}$ entre as fases minerais neo-formadas, durante os processos de recristalização metamórfica (Faure 1986, De Paolo 1988).

O Sm e o Nd são encontrados em quase todas as rochas, em geral substituindo os elementos de íons grandes.Ocorrem principalmente nos clinopiroxênios, anfibólios, granadas, micas e feldspatos, que constituem os principais minerais a serem analisados por este método. Em alguns minerais acessórios de rochas graniticas, como por exemplo, as allanitas, monazitas, xenotimio, columbita-tantalita, fluorita, schelita, ocorre enriquecimento dos ETR. Quando o sistema rocha total é enriquecido nesses minerais acessórios pode ocorrer o fracionamento de $\mathrm{Sm}$ e de $\mathrm{Nd}$, modificando substancialmente a razäo original Sm-Nd (Pimentel \& Charnley 1991).

O significado geológico das idades isocrônicas $\mathrm{Sm}-\mathrm{Nd}$ em rocha total é similar ao observado através de isócronas $\mathrm{Rb}-\mathrm{Sr}$ em rocha total e U-Pb em zircões. $\mathrm{A}$ vantagem na aplicação do método $\mathrm{Sm}-\mathrm{Nd}$ se deve a pouca mobilidade desses elementos em escala de rocha total. O sistema Sm-Nd dificilmente é perturbado por eventos geológicos superpostos (De Paolo 1988). Acrescente-se que as razões Sm-Nd são normalmente mais elevadas em rochas ultramáficas, permitindo a aplicação do método isocrônico, que dificilmente seria conseguido por outra metodologia mais tradicional. Entretanto para tais rochas, as concentrações de $\mathrm{Sm}$ e de $\mathrm{Nd}$ são muito baixas, na maioria dos casos, inferiores a 4 ppm.

O fato da razão $\mathrm{Sm}$-Nd modificar-se significativamente sómente durante a diferenciação manto-crosta permite, calcular idades denominadas modelo, interpretadas como da época em que os precursores crustais (protolitos) se 
diferenciaram do manto superior. Os modelos de evolução isotópica de $\mathrm{Nd}$ para o manto superior, envolvem principalmente a evolução dos condritos (CHUR Reservatório Condrítico) e manto empobrecido (DM - Depleted Mantle). Este último modelo admite processos envolvendo fracionamento, resuitando em manto residual, enriquecido na relação $\mathrm{Sm}-\mathrm{Nd}$ e empobrecido em elementos litófilos de ions grandes. A existência de mistura de magmas na formação de rochas podem levar a obtenção de idades Sm-Nd hibridas e sem significado geológico (Arndt \& Goldstein 1987)

A comparação da razão $\mathrm{Nd}^{143} / \mathrm{Nd}^{144}$ da amostra, e do reservatório condrítico (CHUR), para a época de formação da rocha ou mesmo para o período atual, possibilita a utilização dos isótopos de $\mathrm{Nd}$ como indicadores petrogenéticos. Tal

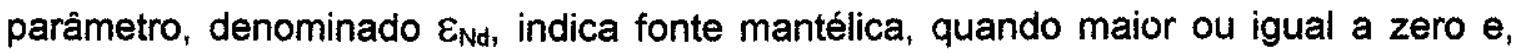
contribuição crustal, quando negativo.

Informaçōes relacionadas a implantação dessa metodologia no CPGeo-USP, envolvendo a utilização dos isótopos de $\mathrm{Nd}$, bem como procedimentos químicos e espectrométricos (VG-354) encontram-se publicadas em Sato et al. (1994).

As constantes utilizadas no cálculo das idades foram as seguintes (Michard et al. 1985):

$$
\begin{aligned}
& \lambda_{147}=6,54 \times 10^{-12} \text { anos }^{-1} \\
& \left(\mathrm{Nd}^{143} / \mathrm{Nd}^{144}\right)_{0} \mathrm{CHUR}=0,512638-\mathrm{DM}=0,513114 \\
& \left(\mathrm{Sm}^{147} / \mathrm{Nd}^{144}\right)_{0} \mathrm{CHUR}=0,1967-\mathrm{DM}=0,222
\end{aligned}
$$

\section{Chumbo-Chumbo (Pb-Pb)}

$\mathrm{O}$ emprego do método $\mathrm{Pb}-\mathrm{Pb}$, isocrônico (em rocha total) e em feldspatos é ainda pouco representativo na região estudada. As poucas dataçōes existentes foram obtidas através de cooperações científicas com laboratórios do exterior (Montpellier, Oxford, Kansas).

De modo geral, o padrão Pb207/Pb206 isocrônico, em rocha total, obtido em conjuntos cogenéticos mostra valor interpretativo semelhante ao método $\mathrm{Rb}-\mathrm{Sr}$ (Rosholt et al 1973, Moorbath \& Taylor 1981, Moorbath et al 1981. A relação (U238/Pb204), denominada de $\mu 1$, constitui um importante parâmetro petrogenético, indicando fontes mantélicas (entre 7,5 e 8,1$)$, de crosta inferior $(<7,5)$ e superior $(>8,1)$. 
Estudos relatados em rochas carbonáticas (Moorbath et al 1987, Jahn 1990, Reis Neto 1994), e em BIFs (Barton 1983) têm ampliado significativamente o potencial interpretativo deste método em termos de definição de idades de sedimentação.

Esta metodologia pode ainda ser aplicada a feldspatos de granitóides, possibilitando através de modelos da Plumbotectônica (Zartman e Doe 1981) traçar inferências sobre a origem dos materiais (manto, crosta superior, crosta inferior e orogênico). Neste último caso, o modelo considera orogênese como uma transferência de material, envolvendo os três grandes reservatórios, durante a qual $\mathrm{Pb}, U \in T$ Th são extraídos de cada reservatório, ingressando no sistema orogênico, resultando em mistura química e isotópica.

Em termos de estudos isotópicos de $\mathrm{Pb}$ aplicados às mineralizações merece ressaltar as pesquisas realizadas em galenas do Vale do Ribeira (idades modelo), que indicaram origens distintas para os depósitos Perau e Panelas (Tassinari et al. 1990).

As constantes utilizadas nos cálculos das idades foram as seguintes (Steiger \& Jäeger 1978):

$$
\begin{aligned}
& \lambda_{U 238}=1,55125 \times 10^{-10} \text { anos }^{-1} \\
& \lambda_{U}^{235}=9,8485 \times 10^{-10} \text { anos }^{-1} \\
& \lambda_{U}{ }^{232}=4,9475 \times 10^{-11} \text { anos }^{-1} \\
& a_{0}=\left(\mathrm{Pb}^{206} / \mathrm{Pb}^{204}\right)_{T}=9,307 \\
& b_{0}=\left(\mathrm{Pb}^{207} / \mathrm{Pb}^{204}\right)_{T}=10,294
\end{aligned}
$$

\section{3 - EVOLUÇÃO DOS CONHECIMENTOS}

Os trabalhos pioneiros relativos ao setor nordeste catarinense $e$ sudeste paranaense enfocam, de modo geral, um domínio gnáissico de alto grau metamórfico, de idade arqueana, considerado mais antigo que o domínio dos epimetamorfitos do Grupo Açungui, tidos como do Algonquiano. Dentre essas contribuiçōes destacam-se as de Branner (1919), Erichsen (1925), Oliveira (1925, 1927), Carvalho (1936), Carvalho \& Pinto (1938), Barbosa (1940), Oliveira \& Leonardos (1943), Fraya (1944), Lanari (1944). Noe \& Wahle (1945), Abreu (1945), Maack (1947, 1953, 1961).

Em termos cartográficos salienta-se o trabalho de Maack (1953) que reune as informações geológicas, até então disponiveis, no mapa do Estado do Paraná 
(1:750.000). Posteriormente Takeda (1958) apresenta o esboço geológico de Santa Catarina na escala 1:2.000.000.

Informações mais detalhadas foram obtidas, na década de 60 , através do programa de levantamento geológico efetuado pela Comissão da Carta Geológica do Paraná, responsável pelo acervo cartográfico de grande parte do estado, nas escalas, 1:50.000. 1:70.000 e 1:75.000. Dentre os trabalhos publicados, frutos desse mapeamento, destacam-se para a área estudada os de Bigarella (1965), Muratori (1966), Lopes (1966), Fuck (1966), Fuck et al. (1967a, b e c), Cordani \& Girardi (1967), Marini (1967) e Trein (1967).

$\mathrm{Na}$ uniformização adotada para a legenda dos mapas produzidos pela Comissão da Carta, foi adotada a denominação de migmatitos proposta por Jung \& Roques (1952), que implicou no agrupamentos das rochas metamórficas regionais em dois conjuntos principais: migmatitos heterogêneos e migmatitos homogêneos. A primeira denominação caracterizou as rochas bandadas, que alternavam faixas de anfibolitos, biotita-xistos e quartzitos com bandas de composição granítica (destacamse nas cartas os epibolitos), e a segunda foi aplicada principalmente a gnaisses grosseiros de aspecto granitóide (destacando-se nos mapas os embrechitos).

Os estudos geocronológicos concentram-se nesta época, nos ultramafitos da região de ltajubá (SC), onde foram obtidas as primeiras idades arqueanas K-Ar do sulsudeste brasileiro (Bartorelli et al. 1968).

Nos arredores de Piên, são reconhecidas seqüências de serpentinitos, peridotitos, talco-xistos e noritos, que recebem então, a designação de Complexo Básico-Ultrabásico de Piên (Trein et al. 1969a).

$\mathrm{Na}$ década de 70 merece destaque o programa de mapeamento e integração geológica realizado pela CPRM, envolvendo os projetos Leste de Santa Catarina (1:250.000) e Leste do Paraná (1:50.000 e 1:100.000). Em Santa Catarina, Schulz Jr.et al.(1969) cartografaram na escala 1:250.000 a quadrícula Rio do Sul, designando - embasamento desta região de Grupo Taboleiro, correlacionado pouco depois por Albuquerque et al. (1971) à rochas do fácies granulito que ocorrem a norte do Grupo Itajaí nas quadrículas Blumenau e Joinville.

No Paraná, foram cartografadas na escala $1: 50.000$ as folhas Barra do Rio Pitangui, Ponta Grossa e Palmeira e, na escala 1:100.000, as folhas Pirai do Sul, Campo Largo, Cêrro Azul, Curitiba, Apiai e Guaraqueçaba, sendo utilizada para as 
rochas granito-gnássicas regionais, similarmente à Carta Geológica, a nomenclatura de migmatitos. O estudo da região leste Paranaense prossegue com Girardi (1971) que caracteriza origem ortometamórfica para os anfibolitos da região de MorretesAntonina, baseado em dados mineralógicos, petrográficos e químicos.

Minioli (1972) descreve a geologia da faixa litorânea Piçarras-Barra Velha (SC), datando pelo método K-Ar, principalmente, rochas uitramáficas dessa região. Foram então identificadas idades aparentes de 3,$4 ; 2,8 ; 2,0$ e 0,65 $\mathrm{Ba}$. Os resultados geocronológicos foram comentados por Cordani (1974), que propõe a existência de uma área cratônica na região de Barra Velha.

Os estudos geológicos da região de Piên têm continuidade com os trabalhos de Girardi (1974, 1976); Girardi et al. (1974) e Girardi \& Ulbrich (1978) que abordam aspectos petrográficos, químicos e geocronológicos das seqüências máficasultramáficas dessa área. Tais rochas foram interpretadas como comagmáticas, submetidas a metamorfismo de fácies granulito no Evento Transamazônico e de fácies anfibolito e xisto verde no Ciclo Brasiliano.

A identificação de idades transamazônicas em Piên e Morretes e as numerosas exposições do embasamento rumo nordeste levaram Cordani (1974) a concluir que a região cujo eixo estaria disposto segundo Piên, Morretes, Serra Negra, Jacupiranga, estendendo-se para Norte, provavelmente até o Maciço de Itatins, já em São Paulo, ter-se-ia portado como um alto tectônico durante o final do pré-cambriano.

Em termos geotectônicos, Hasui et al. (1975) propõem uma compartimentação para o domínio Costeiro brasileiro, enquadrando os terrenos, ora em estudo no Maciço Mediano de Joinville, que Carneiro (1974) denominara de Maciço Barra VelhaMorretes.

Estudos relativos as rochas granuliticas que ocorrem nos arredores de Luís Alves foram realizados por Hartmann (1976), Hartmann et al. (1979a), envolvendo aspectos petrográficos, geoquímicos e geocronológicos. Os dados obtidos pelos autores citados indicaram para a formação dessas rochas granulíticas idade de 2.700Ma. Propõem a designação de Complexo Granulítico de Santa Catarina ao conjunto de rochas metamórficas dos fácies granulito e anfibolito que ocorrem no segmento setentrional do Escudo Catarinense. Admitem ainda, correlação de tal complexo com o Cinturão Granulítico Atlântico. As rochas cataclásticas da região de 
Luis Alves, foram por Hartmann et al. (1979b) caracterizadas como parcialmente afetadas pelo ciclo Brasiliano, em condições do fácies xisto-verde.

Hartmann \& Nardi (1980) mencionam a existència, na região de Luís Alves, de ultramafitos que se apresentam como enclaves com formas e tamanhos variados nas seqüências gnáissico-granulíticas, recomendando para tais rochas a designação de brechas uitramafito-granulito.

As rochas ultramáficas que ocorrem na região de Barra Velha (SC) foram abordadas por Soares et al. (1978) principalmente sob o aspecto petroquímico, indicando uma natureza ortometamórfica em condições do fácies granulito.

Uma origem ortometamórfica foi também sugerida para as rochas gnáissicogranulíticas de Santa Catarina através de estudos petrográficos e petroquímicos realizados por Moreira \& Marimon (1980).

Uma visão geral dos maciços graníticos do sul do Brasil, com ênfase à aspectos petrográficos foi apresentada por Wernick \& Penalva (1978), granitóides esses que foram incluídos por Kaul (1985) na suite Serra do Mar. O caráter polidiapírico do Granito Agudos do Sul, na região homônima foi proposta por Fiori (1978), que evidencia a presença de cinco fácies distintas para esse maciço.

Teixeira (1979 e 1982) apresenta, com base em novos dados radiométricos, uma compartimentação geocronológica no âmbito das Folhas ao Milionésimo Assunción, Curitiba e Iguape. Reconhece uma província antiga, pré-brasiliana, representada pelos gnaisses granuliticos do setor NE de Santa Catarina, bem como porções gnáissicas afetadas pela orogênese brasiliana.

O desenvolvimento do Projeto Geoquímica na área de Guaratubinha - Piên, executado pela CPRM (Daitx \& Carvalho 1980), foi de grande importância para o conhecimento geológico da região estudada, em especial das bacias vulcanossedimentares. de Campo Alegre, Guaratubinha e Corupá. Neste projeto, foram cartografadas, na escala $1: 100.000$ as folhas Jaraguá do Sul, São José dos Pinhais e Paranaguá, as duas últimas de modo parcial.

A porção compreendida entre os Lineamentos de Blumenau e Corupá foi denominada por Kaul (1979) de "Área Cratônica ou Cráton Luis Alves", correlacionável ao Cráton do Congo. Caracteriza entre o Lineamento Corupá e a Faixa de Dobramentos Apiaí, um "embasamento retrabalhado e rejuvenescido" que correlaciona ao substrato da Bacia Cuanza (oeste de Angola). 
O limite NE do Cráton de Luís Alves foi estendido por Kaul (1980) até a falha de Itariri, já no sul de São Paulo, englobando toda porção costeira, que admite como de consolidação pré-brasiliana. Os terrenos localizados a norte do lineamento de Corupá, proiongado paralelamente a costa até a falha de Itariii, foram interpretados como relacionados ao embasamento retrabalhado e rejuvenescido.

A denominação Cráton Rio de La Plata, proposta por Almeida et al. (1973) para terrenos antigos expostos na Argentina e no Uruguai, foi estendida ao Escudo Sul Riograndense e ao setor nordeste de Santa Catarina por Fragoso César (1980), Fragoso César \& Soliani Jr. (1984) e Soliani Jr. et al. (1984).

Kaul \& Teixeira (1982) apresentam uma síntese dos conhecimentos geológicogeocronológicos do setor nordeste de Santa Catarina e sudeste do Paraná, limitando o Cráton Luís Alves pelos lineamentos de Corupá e de Guaruva. Os terrenos localizados a sul de Curitiba e na porção costeira são referidos como pertencentes ao embasamento retrabalhado e rejuvenescido, incluidos por Kaul et al. (1984) no Complexo Paraiba do Sul.

Silva \& Dias (1981a) cartografaram em escala 1:50.000 quatro folhas da porção centro-norte de Santa Catarina (Barra Velha, Itajai, Gaspar e Blumenau). Nesse trabalho que contêm estudos detalhados de petrografia e petrogênese, o Complexo Granulítico de Santa Catarina foi admitido como pertencente a uma área cratônica arqueana, sendo composto por 10 unidades litoestratigráficas (gnaisses-granulíticos leucocráticos, milonitos granulíticos, blastomilonitos de derivação granulítica, ultramafitos, gnaisses calcossilicáticos, gnaisses kinzigíticos, anortositos, quartzitos, formaçōes ferríferas e gnaisses cataclásticos). Caracterizaram adicionalmente uma importante zona de cisalhamento (Lineamento Garuva), separando os terrenos migmatíticos (a norte) do Cinturão Granulítico (a sul).

Em Santa Catarina, Silva (1984a) propõe denominar de "Cinturão Móvel de Joinville" toda extensão dos terrenos de alto grau metamórfico, isolando porções que denominou de Protocrátons de São Francisco e de Piên (setor setentrional). Posteriormente no texto explicativo relativo ao mapa geológico de Santa Catarina, na escala 1:500.000, Silva (1987) caracteriza o Cráton de Garuva-São Francisco do Sul e - Cinturão Móvel Granulítico, de provável idade Transamazônica. Nesta publicação, Basei \& Teixeira (1987) realizam uma integração e reavaliação dos dados geocronológicos de Santa Catarina, destacando a norte, os terrenos Transamazônicos 
e pré-Transamazônicos do Complexo Granulítico, e a sul o Cinturão Dom Feliciano, desenvolvido no Proterozóico Superior.

Basei (1985) sugere uma compartimentação interna dos terrenos localizados no setor nordeste de Santa Catarina e sudeste do Paraná, em duas unidade maiores, denominadas Maciço Marginal de Curitiba e Cráton Rio de La Plata. Apresenta, adicionalmente, para a porção cratônica novos dados isotópicos, utilizando-se dos métodos $\mathrm{U}-\mathrm{Pb}$ (zircões), $\mathrm{Pb}-\mathrm{Pb}, \mathrm{Rb}-\mathrm{Sr}$ e $\mathrm{K}-\mathrm{Ar}$, sugerindo um magmatismo precursor anterior a $2.600 \mathrm{Ma}$, um metamorfismo regional de fácies granulito a $2.400 \pm 200 \mathrm{Ma}$, com soerguimento e consequente resfriamento a $1.800 \mathrm{Ma}$. Admite reativaçōes localizadas durante o Ciclo Brasiliano (800-600Ma).

Os principais lineamentos e compartimentos tectônicos do Pré-Cambriano paranaense envolvendo as seqüencias metavulcanossedimentares dos Grupos Açungui e Setuva foram enfocados por Góis et al.(1985); Fassbinder et al. (1985), e Fiori (1985).

Em termos geotectônicos, Kaul (1985) sugere um esquema evolutivo da crosta continental, no sul-sudeste do Brasil, durante o Proterozóico Superior-Eopaleozóico, através do desenvolvimento de um fundo oceânico (Sistema Dobrado Apiaí) com subducção do tipo B, seguida de colisão continental.

Soares (1987 e 1988) apresenta um quadro evolutivo, de parte das bacias Setuva e Açungui, envolvendo colisão arco-rontinente, no Proterozóico Médio e continente-arco-continente, no Proterozóico Superior, sugerindo transporte tectônico respectivamente para sudeste e suidoeste.

No âmbito da faixa de dobramentos Apiai, Campanha et al. (1987) e posteriormente Campanha (1992) sugerem um modelo evolutivo énvolvendo subducção de placa oceânica de SE para NW e posterior colisão continental. Neste esquema, o Maciço Catas Altas representaria parte do arco magmático.

Ramos (1988) apresenta um quadro evolutivo para o Proterozóico e Paleozóico Superior da América do Sul, sugerindo subducção e colisão continental entre o Cráton Rio de La Plata e os terrenos Pelotas.

Issler \& Freire (1985) mostram as diversidades graníticas brasilianas da região sul-brasileira, associando as atividades ígneas orogênicas aos regimes de tectônica de placas e anorogênicas a processos de rifteamento. 
Merecem destaque os trabalhos de mapeamento geológico executados pelo Departamento de Geologia da Universidade Federal do Paraná (Curso de Graduação: 1987-1988) nos arredores de Piên. Os mapas obtidos, na escala 1:25.000, identificaram os granitóides deformados que ocorrem nesse setor, permitindo uma separação faciológica dos mesmos.

Utilizando-se de isótopos de $\mathrm{Nd}$ e $\mathrm{Pb}$, Mantovani et al. (1987), identificam para os terrenos granulíticos de Santa Catarina e do Rio Grande do Sul idades entre 3,3 e $2,6 \mathrm{Ba}$. Tal intervalo de idade foi interpretado como relativo ao período principal de acresção de material diferenciado do manto à crosta.

Para a Serra da Prata, localizada na porção oriental do Paraná, a SW de Paranaguá, Lopes (1987a, b, c) realiza estudos petrogenéticos, apresentando um mapa geológico na escala 1:250.000 onde identifica os granitóides porfiróides Morro Inglês, os leuco-granitos Rio do Poço e Rio Canavieiras, os granitos cataclásticos porfiróides Cubatãozinho, os granitos porfiróides melanocráticos Estrela e os metassedimentos Rio das Cobras. Sugere uma evolução arqueana para a região.

Hartmann (1988) caracteriza através de cálculos geobarométricos nos granada piroxênio-plagioclásio-quartzo-granulitos de Santa Maria Chico (RGS), pressões da ordem de $9 \mathrm{~Kb}$ e temperaturas próximas de $800^{\circ} \mathrm{C}$ para a formação dessas rochas. Temperaturas similares obteve para os granulitos de Santa Catarina, admitindo pressöes de $7 \mathrm{~Kb}$.

Com base em dados gravimétricos, Mantovani et al. (1989) apresentam um modelamento abrangendo o Cinturão Dom Feliciano, o Cráton Luís Alves, em Santa Catarina, e o Maciço de Curitiba, no Paraná. O padrão obtido permitiu a delimitação de três unidades crustais distintas, indicando forte anomalia positiva entre as regiões de Agudos do Sul e Jaraguá do Sul, atribuida ao soerguimento de segmentos de crosta inferior durante os processos de justaposição dessas unidades.

Biondi et al. (1989) publicam o Mapa Geológico do Estado do Paraná $(1: 650.000)$ reunindo e reinterpretando as informaçōes até então disponíveis. Neste mapa, a região em estudo é, sob o ponto de vista geotectônico, enquadrada no Bloco Costeiro.

Chiodi Filho et al. (1989) sugerem através de estudos de elementos Terras Raras, que os maciços graníticos Morro Redondo, Serra da Igreja, Anhangava, Marumbi, Graciosa, Mandira e Guaraú, tiveram suas origens ligadas a fusão de crosta 
continental, caracterizando esses corpos como de natureza pós-colisionais. $O$ granito tipo Três Córregos foi interpretado como pré-colisional e de derivação mantélica.

Com base em dados geológico-estruturais e geocronológicos Siga Jr et al. (1990a) identificam no setor NE de Santa Catarina e SE de Paraná, três domínios geotectônicos distintos: Meridional (representado principalmente por ortogranulitos quartzo-feidspáticos); Setentrional (representado por rochas granito-gnáissicas e migmatíticas) e Costeiro (representado, principalmente, por granitóides porfiríticos).

Siga Jr. et al. (1990b) caracterizam através de um perfil térmico K-Ar, envolvendo os domínios Setentrional e Meridional do Maciço de Joinville e o Cinturão Dom Feliciano, diferenças marcantes entre os limites desses compartimentos geotectônicos. Sugerem um contato frontal a frio para o limite sul e uma justaposição com contato quente para o limite norte.

Para os granitóides porfiríticos que ocorrem no setor oriental paranaense e nordeste catarinense, denominados de Batolito Paranaguá, foram obtidas idades Rb$\mathrm{Sr}$ e U-Pb do intervalo 614-540Ma, Basei et al. (1990a). Esse magmatismo foi interpretado como gerado em regime tectônico compressivo, decorrente de processos colisionais do final do Proterozóico Superior, que atuaram em toda a borda sul e nordeste do Maciço de Joinville. Sugerem a correlação desse dominio com parte dos terrenos pertencentes aos Cinturöes Ribeira e Dom Feliciano.

Basei et al. (1990b e c), denominam os terrenos granito-gnáissicos e migmatíticos, da porção setentrional do Maciço de Joinville de Nappe Rio Iguaçu. Interpretam esses terrenos como representantes da infra-estrutura do Cinturão Ribeira (Setuva e Açungui) que teriam sido lançados sobre os terrenos mais antigos, granulíticos, pertencentes ao Cráton Luís Alves. Caracterizam para esses terrenos vergência para sul e sugerem a possibilidade dos corpos básico-ultrabásicos que ocorrem nos arredores de Piên representarem restos de material oceânico obductado. O limite sul do Maciço de Joinville com o Cinturão Dom Feliciano é representado nesse trabalho pelas Nappes Brusque e Florianópolis com vergèncias para NW.

Através de dados geológico-estruturais, geoquímicos e geocronológicos, Machiavelli et al. (1991) propōem que os granitóides deformados que ocorrem nos arredores de Piên, representem um arco vulcânico maturo, formado no Proterozóico Superior. Machiavelli (1991) apresenta um mapa geológico, na escala 1:100.000, bem como novos dados geoquímicos, geocronológicos e estruturais, envolvendo os 
granitóides deformados, as rochas básicas e ultrabásicas, os gnaisses granulíticos e parte do corpo granitico de Agudos do Sul.

Figueiredo et al. (1991) propõem através de dados geoquímicos dos granulitos localizados nos arredores de Barra Velha uma evolução cogenética para os termos básicos e ácido-intermediários. Sugerem ambiente de arco insular para a formação desses terrenos.

Sob o ponto de vista geotectônico, Fragoso César (1991) correlaciona o domínio gnáissico-migmatítico localizado a norte de Piên com parte dos Blocos São Gabriel e Taquarembó no Rio Grande do Sul, incluindo esses terrenos no Cinturão Ribeira. Admite evolução similar entre os Cinturões Dom Feliciano em Santa Catarina e no Rio Grande do Sul.

Basei et al. (1992) sugerem, para o setor NE de Santa Catarina e SE do Paraná, o abandono do termo Maciço de Joinville, propondo a existência de três compartimentos geotectônicos distintos, representados pelas microplacas Curitiba e Luís Alves e pelo Cinturão Granitóide Costeiro. Neste trabalho os terrenos granulíticos representantes da Microplaca Luís Alves estendem-se para nordeste, envolvendo o Maciço Serra Negra. Admitem uma evolução para essas três unidades geotectônicas envolvendo processos de subducção seguidos de colisão, durante o Proterozóico Superior, com sentido predominantemente de acresção de $E$ para $W$.

Na região de Tijucas do Sul-Vossoroca (NE de Piên), Ribas (1993) identifica corpos de metaperidotitos, metapiroxênitos, serpentinitos e talco-xistos, similares aos que ocorrem nos arredores de Piên, apresentando um mapa geológico deste setor, na escala 1:50.000. Os estudos petrográficos sugerem para essas rochas um generalizado retrometamorfismo do fácies anfibolito, e os dados geoquímicos indicam dois "trends" distintos para as seqüências básicas e ultrabásicas.

Campos Neto e Figueiredo (1994) caracterizam dois ciclos orogênicos para o sudeste brasileiro, a Orogênese "Brasiliana I", cuja evolução ocorreu durante o Neoproterozóico atingindo há cerca de 600Ma o estágio pós-orogênico, e a Orogênese Rio Doce, desenvolvida entre 590-480Ma.

Siga Jr. et al. (1994a) apresentam uma compartimentação geotectônica do setor NE de Santa Catarina e SE do Paraná com base, principalmente, em novos dados geocronológicos. Neste trabalho, o Domínio Meridional representa um segmento continental antigo, preservado da tectônica Neoproterozóica, que afeta o Domínio 
Setentrional, interpretado como relacionado a borda do Cráton de Luís Alves, intensamente migmatizada nesse periodo. A justaposição do Domínio Paranaguá terse-ia dado tardiamente à evolução dos demais setores.

Dados estruturais relativos as rochas básicas e ultrabásicas dos arredores de Piên bem como dos gnaisses granulíticos próximos a zona de cisalhamento foram apresentados por Harara et al. (1994). Neste trabalho os autores mostram que a foliação principal relacionada a essas rochas são paralelas com as estruturas dos granitóides deformados, sugerindo o envolvimento tectônico da margem noroeste da "Microplaca Luís Alves" durante o Neoproterozóico.

Aspectos petrográficos, geoquímicos e geocronológicos relacionados aos maciços graníticos da Serra do Mar, no leste do Paraná, foram apresentados por Kaul \& Cordani (1994). Relacionam a maior parte desses maciços a manifestações plutônicas de caráter pós orogênico, onde os magmas envolvidos teriam se consolidados em condições predominantemente subsolvus.

O intervalo de idades 595-550Ma é caracterizado através do estudo radiométrico $\mathrm{Rb}-\mathrm{Sr}$ e U-Pb para a colocação dos maciços graníticos de natureza alcalina-peralcalina da porção nordeste de Santa Catarina e sudeste do Paraná por Siga Jr. et al. (1994b).

Machiavelli et al. (1994), com base em características estruturais, geoquímicas e geocronológicas sugerem para a formação dos granitóides deformados de Piên (Suite Granítica Rio Piên) ambiente de arco vulcânico maturo, segundo definição de Brown (1982).

Estudos envolvendo as rochas vulcânicas e vulcanoclásticas pertencentes a Formação Guaratubinha foram apresentados por Castro et al. (1994). Mostram através de evidências texturais e estruturais que a regiäo sofreu um intenso vulcanismo aéreo e possivelmente subaquoso. Sugerem cogeneticidade entre os termos riolíticos e andesíticos.

A abordagem realizada revela a existência de inúmeras propostas de modelamento geológico, envolvendo parcial ou totalmente a região estudada, exemplificadas pelas diversas denominaçöes de cunho geotectônico (Maciço Barra Velha-Morretes, Alto Tectônico Piên-Morretes, Maciço Mediano de Joinville, Complexo Granulítico de Santa Catarina, Cráton Rio de La Plata, Cráton Luís Alves, Cinturão Móvel de Joinville, Maciço Marginal de Curitiba, Cráton Garuva-São Francisco do Sul e 
Cinturão Móvel Granulítico, Microplacas Curitiba, Luis Alves e Cinturão Granitóide Costeiro).

Neste trabalho, a evolução desses terrenos, localizados entre os Cinturões Ribeira (norte) e Dom Feliciano (sul) é enfocada através da interação de entidades tectônicas distintas, envolvendo subducções seguidas de colisões continentais, com sentido predominante de acresção de leste para oeste. Tais compartimentos tectônicos encontram-se representados pelos Domínios Luís Alves, Curitiba e Paranaguá. 


\section{CAPITULO 2}

\section{COMPARTIMENTAÇÃO TECTÔNICA}

No anexo-1 é apresentado um esboço geotectônico da porção nordeste de Santa Catarina e sudeste do Paraná, localizada entre os Cinturões Ribeira (N)e Dom Feliciano (S), onde destacam-se três unidades tectônicas maiores: Domínio Luís Alves, Domínio Curitiba e Domínio Paranaguá. Ocorrem ainda, no âmbito desses domínios, expressiva granitogênese de natureza alcalina-peralcalina, bem como importante vuicanismo ácido a intermediário relacionado às bacias distensionais pós-orogênicas. O esboço geotectônico (Fig. 2.1) apresenta uma visão geral destes terrenos, que ocupam uma área superior a $16.000 \mathrm{~km}^{2}$.

O Domínio Luís Alves limita-se na porção setentrional com os gnaisses migmatíticos do Domínio Curitiba, na porção oriental em parte atinge a costa brasileira e em parte é balizado pelo Domínio Paranaguá e, na porção meridional, faz contato com o Cinturão Dom Feliciano. Os estudos realizados permitiram caracterizar a continuidade deste segmento para nordeste, rumo a Serra Negra, onde ocorre como uma estreita faixa, entre os Domínios Curitiba e Paranaguá.

Litologicamente, o Domínio Luís Alves é representado por ortognaisses granulíticos, bandados a maciços, de composição tonalito-granodiorítica, com frequentes variações a granulitos básicos. Ocorrem adicionalmente, ultramafitos, quartzitos, gnaisses kinzigíticos, formações ferríferas e migmatitos. $O$ padrão geocronológico indica a presença de terrenos formados no Arqueano e no Paleoproterozóico (ciclo Transamazônico).

Nos Domínios Curitiba e Paranaguá observam-se indicadores cinemáticos, sugestivos de um transporte de baixo ângulo em direção ao Domínio Luís Alves. Zonas de cisaihamento, com importante componente lateral ocorrem, nòtadamente próximo aos limites setentrional e oriental do Domínio Luís Alves. No setor meridional os metassedimentos anquimetamórficos do Grupo Itajaí se distribuem em parte sobre os gnaisses granulíticos do Domínio Luís Alves.

- Domínio Curitiba limita-se no setor noroeste com as seqüências metassedimentares e metavulcanossedimentares dos Grupos Açungui e Setuva, que apresentam indicações de transporte de NW para SE (Fiori 1992), sugerindo a 
colocação dos terrenos pertencentes ao Cinturão Ribeira sobre as rochas gnáissicomigmatíticas. Importantes zonas de cisalhamento com caráter transcorrente ocorrem próximo ao limite desses terrenos. Predominam neste domínio gnaisses bandados e migmatitos (mesossoma de biotita anfibólio gnaisses e leucossoma de composição tonalito-granodiorítica), gnaisses graníticos bandados, além de leucogranitos, anfibolitos e xistos magnesianos. $\mathrm{Na}$ borda meridional deste domínio ocorrem granitóides deformados cálcio-alcalinos potássicos, de composição predominantemente monzogranitica (Suite Rio Piên).

Geocronologicamente, este domínio caracteriza-se por paleossomas formados no Paleoproterozóico e neossomas e porções graníticas no Neoproterozóico.

Num perfil, de norte para sul (Curitiba - Piên - Fig. 2.2) observa-se grosseiramente a presença de dois pacotes de gnaisses bandados (gnaisses migmatiticos e gnaisses graníticos), que passam na borda meridional, através de zonas de cisalhamento, aos granitóides cálcio-alcalinos potássicos (Lineamento Mandirituba - Piraquara) e destes às rochas básicas e ultrabásicas de Piên e aos gnaisses granuliticos, já no Domínio Luís Alves (Lineamento Piên - Tijucas do Sul). Do ponto de vista estrutural, verifica-se um comportamento coerente para os terrenos Curitiba (Fig. 2.2), com uma orientação predominantemente nordeste para a foliação $S_{n}$ (principal) dos gnaisses bandados, dos granitóides deformados e que incluem, nos terrenos Luís Alves, os ultramafitos de Campina dos Crispins (Piên). Observa-se um padrão de dobras cilíndricas da foliação $S_{n}$, admitindo uma direção axial NE-SW. Nos gnaisses bandados é um dobramento $D_{3}$ enquanto nos granitóides é uma fase $D_{2}$. Os esteogramas da figura 2.2. indicam para os eixos construídos e lineaçōes de estiramento orientações de $\mathrm{N} 30^{\circ}$ a $60^{\circ} \mathrm{E}$, com caimentos fracos a médios $\left(05^{\circ}\right.$ à $\left.40^{\circ}\right)$.

A orientação do bandamento no domínio dos gnaisses granulíticos é francamente noroeste, diferente do padrão nordeste dos demais conjuntos. Esse bandamento, uma superfície $\$ 2$ gerada em condições de alto grau, apresenta-se dobrado com atitude do plano axial, predominantemente NW-SE e eixos com orientação $530^{\circ}-50^{\circ} \mathrm{E} / 40^{\circ}$ a $60^{\circ}$ e $\mathrm{N} 20^{\circ}-60^{\circ} \mathrm{W} / 40^{\circ}$ a $80^{\circ}$.

O Domínio Paranaguá ocupa grande parte da porção oriental estudada, sendo representado por granitóides heterogeneamente deformados bem como por granitóides isótropos, gerados no Neoproterozóico (Morro Inglês, Canavieiras, Rio do Poço e Estrela). Como restos de rochas encaixantes ocorrem xistos aluminosos, como 
os descritos na Serra do Prata por Lima \& Lopes (1985), biotita gnaisses, mica xistos, quartzitos e anfibolitos. Faixas miloniticas espessas são frequentes em meio aos granitóides Morro Inglês e Canavieiras. Os limites destes terrenos com o Domínio Luís Alves são representados por expressivas zonas de cisalhamento (Lineamento do Rio Palmital, Alexandra e Serra Negra).

As descrições efetuadas ao longo do perfil Curitiba - Piên são igualmente válidas para a metade oeste da secção Curitiba - Paranaguá (Fig. 2.3), onde são observadas na mesma seqüência as unidades de gnaisses bandados migmatíticos, de granitóides deformados e de gnaisses granulíticos, descritos anteriormente.

A porção leste desse segundo perfil é caracterizada pelas diferentes gerações de granitóides do Domínio Paranaguá. A principal foliação observada nesses granitóides é uma superfície $S_{1}$, heterogênea, ocorrendo porções que se mostram praticamente isótropas, porções bastante deformadas, e áreas onde é difícil a distinção entre feições associadas a fluxo magmático e superfícies geradas tectônicamente. A orientação principal neste domínio é nordeste e corresponde no âmbito dos gnaisses e xistos a uma segunda fase de deformação. Verifica-se na majoria das unidades, o dobramento cilíndrico da foliação $S_{n}$, admitindo uma direção axial predominantemente NE-SW (Fig. 2.3).

As diferenças, litológicas, estruturais e, principalmente geocronológicas, permitiram caracterizar evoluções próprias e distintas para cada um dos domínios ora discutidos. Tratam-se de segmentos que apresentam individualmente uma coerencia quanto ao padrão metamórfico, estrutural e geocronológico, representando portanto, distintos dominios tectônicos.

Os dados gravimétricos disponiveis indicam para o Domínio Luís Alves, compreendendo seu prolongamento rumo ao Maciço Serra Negra, anomalias mais positivas que as observadas para os terrenos adjacentes. Os limites NW e SE, respectivamente com os terrenos Curitiba e Paranaguá são marcados por importantes anomalias negativas, sugerindo a existência de três unidades crustais distintas (Mantovani et al. 1989, Hallinan et al. 1993)

Finalmente, importante atividade magmática Neoproterozóica, com características pós orogênicas, é representada na área por inúmeros "stocks" e batólitos graniticos, notadamente de natureza alcalina a peralcalina (Suite Serra do Mar, Kaul 1984) e por seqüências vulcânicas predominantemente ácidas a 
intermediárias, associadas a evolução de expressivas bacias vuicano-sedimentares. Nesse contexto, destacam-se os maciços graniticos da Serra da Graciosa, Anhangava, Marumbi, Serra da Igreja, Agudos do Sul, Dona Francisca, Pirai do Sul, Corupá e Morro Redondo e as bacias vulcano-sedimentares de Campo Alegre, Guaratubinha e Corupá (Fig. 2.1). 


\section{LEGENDA}

$\because \because$ DEPÓSITOS CENOZÓICOS E COBERTURA PALEOZOICA DA BACIA DO PARANA

UNIDADES LITOLOGICAS ATRIBUIDAS AOS GRUPOS AÇUNGUI E SETUVA (CINTURÃO RIBEIRA - A NORTE) E AOS GRUPOS ITAJAI E BRUSQUE (CINTURÃO DOM FELICIANO - À SUL)

\section{MAGMATISMO E SEDIMENTAÇÃO DE REGIMES EXTENSIONAIS PÓS-OROGÊNICOS}

००. BACIAS VULCANO - SEDIMENTARES: CA - CAMPO ALEGRE, G - GUARATUBINHA, C - CORUPÁ

1 GRANITOIDES ALCALINOS - PERALCALINOS: 1 - GRACIOSA, 2 - ANHANGAVA, 3-MARUMBI, 4 - SERRA DA IGREJA, 5 - AGUDOS DO SUL, 6 - MORRO REDONDO, 7 - DONA FRANCISCA, 8 - PIRAI, 9 - CORUPÁ

\section{DOMINIO TECTONNICO PARANAGUÁ}

‡ GRANITÓIDES (MORRO INGLÊS, RIO DO POÇO, CANAVIEIRAS, ESTRELA), GNAISSES, MIGMATITOS EXISTOS

\section{DOMINIO TECTÔNICO CURITIBA}

$\not \not$ SUITE RIO PIEN: GRANITÓIDES CÁLCIO - ALCALINOS POTÁSSICOS DEFORMADOS

$\ulcorner$ GNAISSES BANDADOS, MIGMATITOS E ANFIBOLITOS

\section{DOMINIO TECTÔNICO LUIS ALVES}

ORTOGNAISSES GRANULITICOS COM INTERCALAÇÖES DE CORPOS MÁFICOSULTRAMÁFICOS, QUARTZITOS, FORMAÇŐES FERRIFERAS, PARAGNAISSES 


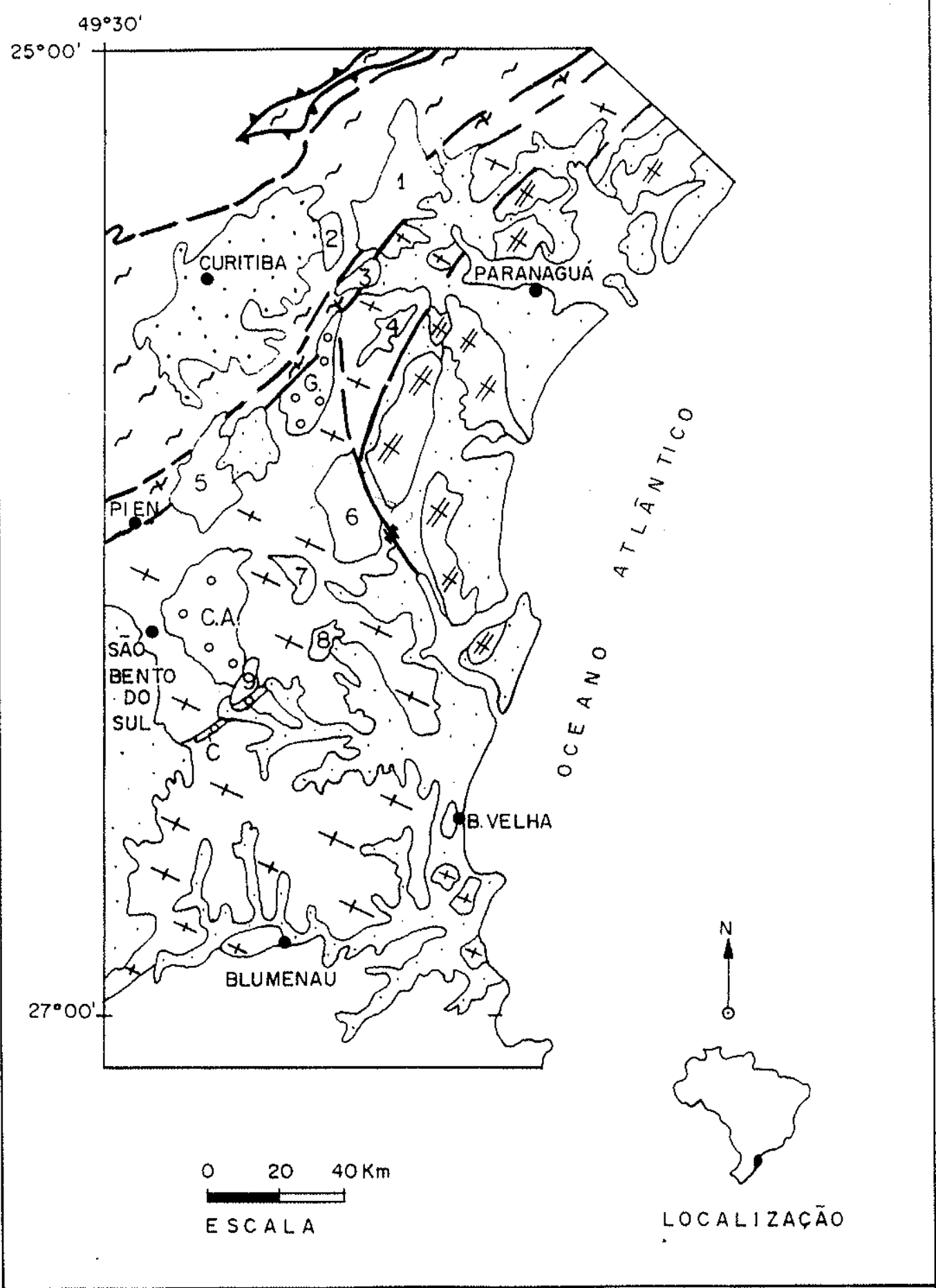

FIG:2.1 - COMPARTIMENTACÃ̃O TECTŌNICA DA PORCĀ̃O SUDESTE DO PARANÁ E NORDESTE DE SANTA CATARINA. 


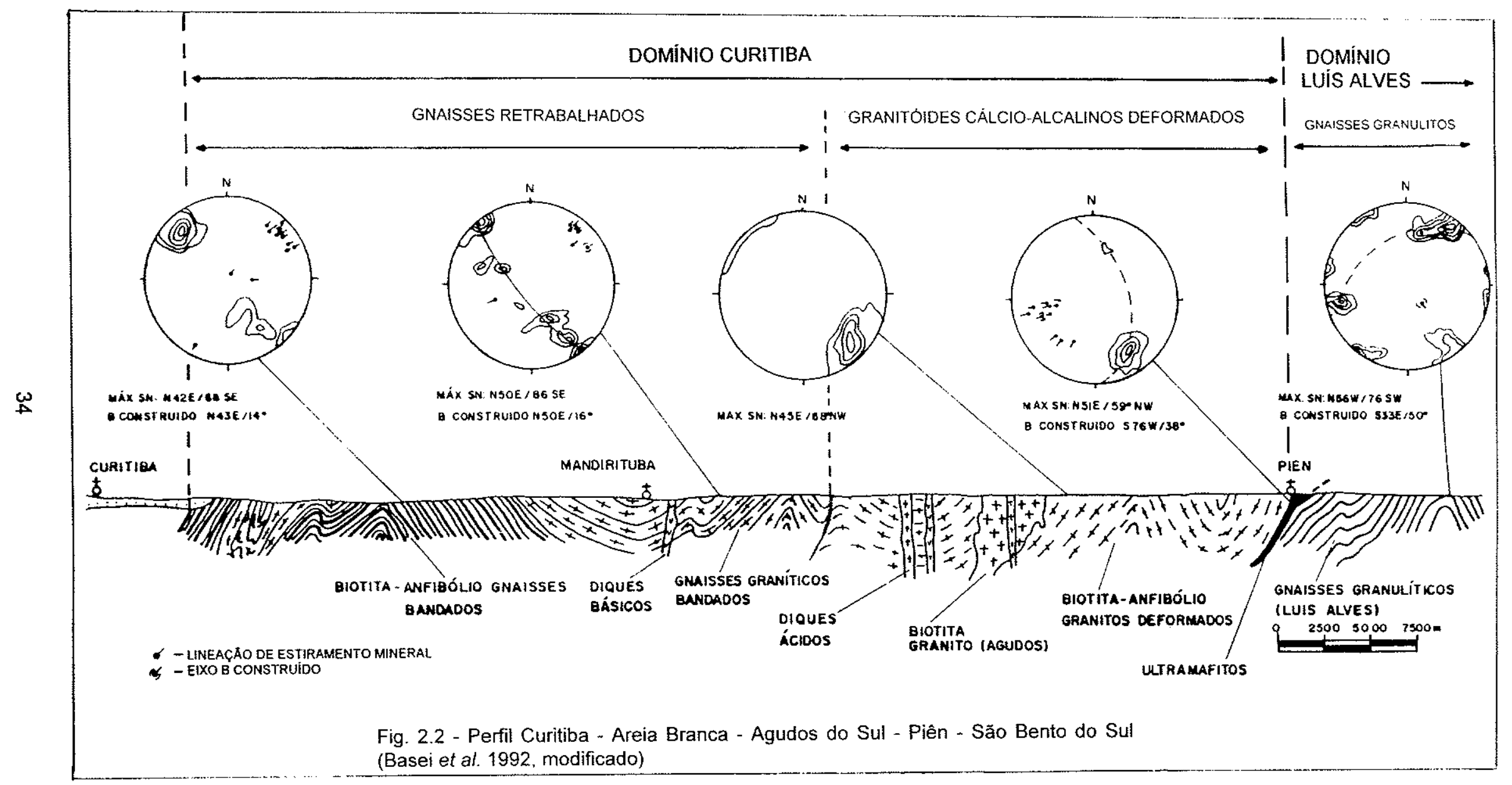




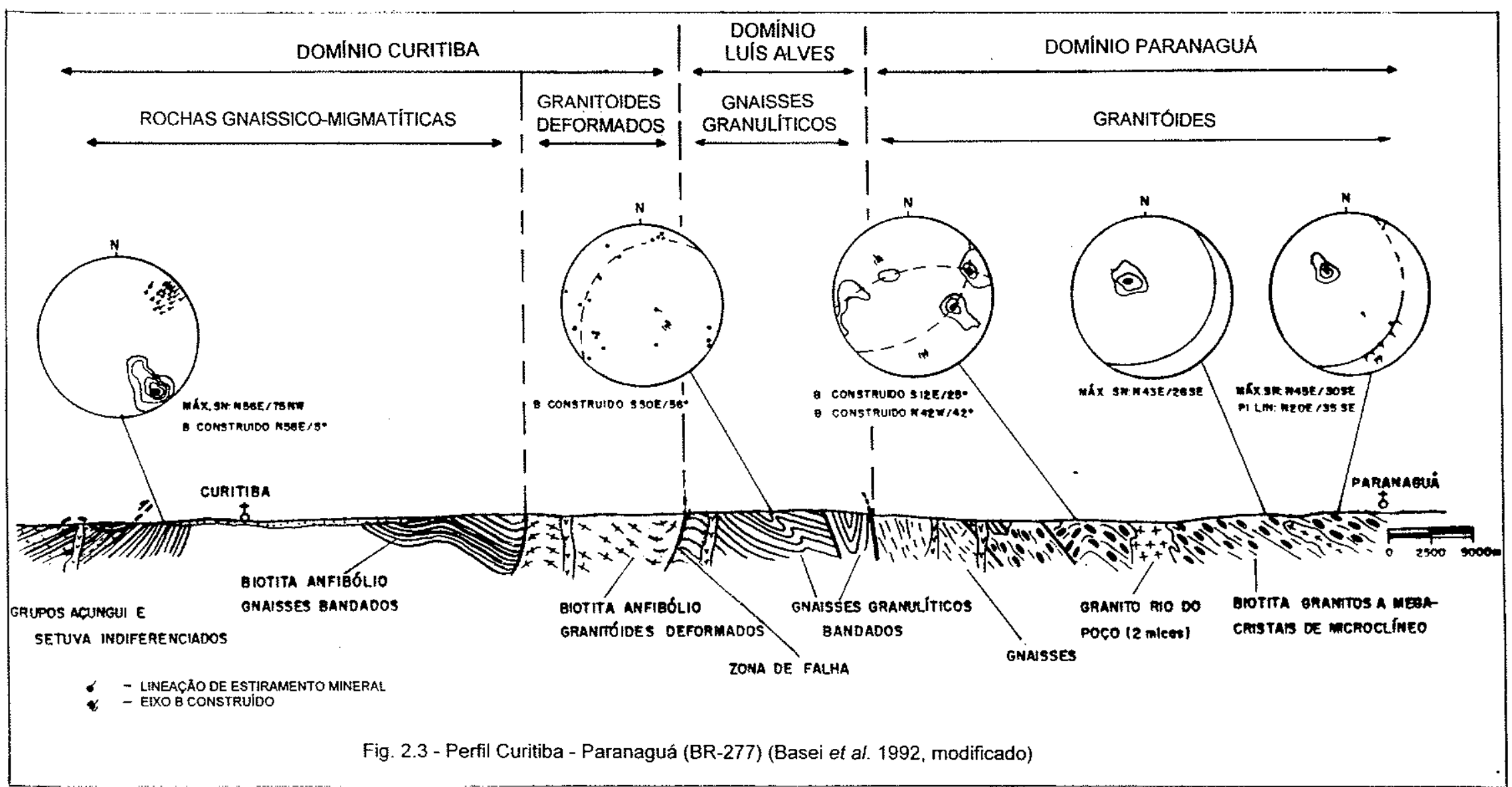




\section{CAPITULO 3}

\section{DOMÍNIO LUIS ALVES}

O Domínio Luís Alves é representado, em grande parte, por rochas de alto grau metamórfico, tendo como litotipo principal gnaisses granulíticos, bandados a maciços de composição tonalito granodioritica, com frequentes variações a granulitos básicos. Inclui seqüências de natureza básica e ultrabásica, que em alguns locais, a exemplo de Barra Velha, Piên e Tijucas do Sul constituem-se na litologia predominante.

A maior expressão, em área, desse domínio, ocorre na porção meridional (regiões de Luís Alves, Blumenau, Barra Velha, Joinville, Jaraguá do Sul e São Bento do Sul), onde também se concentram a grande maioria dos trabaihos publicados. Os estudos realizados em campo, bem como os dados petrográficos e geocronológicos permitiram caracterizar a continuidade desses terrenos gnáissico-granulíticos para nordeste, rumo a Morretes e Serra Negra onde ocorrem como uma estreita faixa, afilada, entre o Domínio Curitiba e o Domínio Paranaguá (anexo 1).

As rochas metabásicas e metaultrabásicas dos arredores de Piên e Tijucas do Sul, serão discutidas neste capítulo, à parte dos demais litotipos. Isto se deve ao posicionamento geotectônico de alguns desses corpos, constituindo um verdadeiro balizamento entre os Domínios Curitiba e Luís Alves, sendo referidos na literatura, ora como associados à evolução de um desses compartimentos, ora de outro.

\section{1 - ROCHAS GNÁISSICO-GRANULITICAS REGIONAIS}

\subsubsection{Síntese Geológica}

Os terrenos pertencentes ao Domínio Luís Alves são constituídos, predominantemente, por rochas gnáissicas, foliadas a bandadas, caracterizadas pela alternância milimétrica a centimétrica de niveis quartzo-feldspáticos e de minerais máficos (anfibólios, piroxênios, biotitas). Apresentam tonalidades cinza-esverdeada, normalmente leuco a mesocráticas e granulação variando de fina a média. 
A presença de hiperstênio em muitas dessas rochas caracteriza o grau alto de metamorfismo (zona regional do hiperstênio - Winkler 1978). Em alguns litotipos gnáissicos, no entanto, normalmente quartzo-feldspáticos, contendo em maior ou menor proporção biotita e/ou hornblenda, o hiperstênio está ausente. Embora essas rochas não possuam mineralogia característica do grau alto, apresentam-se em campo intimamente associadas aos litotipos à hiperstênio. É comum também a presença de granulitos básicos, principalmente como bandas milimétricas a centimétricas, boudinadas, ou ainda com formas angulosas ou manchas difusas em meio aos tipos ácido-intermediários.

Associam-se ainda porções de aspecto igneo e composições enderbíticas a charnoenderbíticas, que constituem em alguns locais, a exempio de Dona Francisca, Cacatú e Serra Negra os litotipos predominantes.

As rochas granuliticas ácidas, intermediárias ou básicas, podem constituir, a litologia principal de um determinado setor, embora normalmente, muitas dessas variedades sejam observadas ao longo de um único afloramento.

Gnaisses cataclásticos ou miloníticos, normalmente com tonalidade cinzaesverdeada e granulação fina, foram observados ao longo de inúmeras zonas de cisalhamento que rasgam esse domínio, apresentando padröes com direções WNWESE e NE-SW.

Ocorrem ainda neste domínio rochas migmatíticas, normalmente caracterizadas pela alternância de bandas félsicas (quartzo-feldspáticas) e máficas (biotita, anfibólio, e, mais raramente, piroxênios e granadas), intercalando bandas, centimétricas a métricas de gnaisses granulíticos.

Essas feições, relacionadas a cataclase e a migmatização, são marcantes, notadamente nas proximidades das zonas de contato com os domínios adjacentes (Domínio Curitiba, Domínio Paranaguá e Cinturão Dom Feliciano).

Subordinadamente, observam-se rochas quartziticas, as vezes portadoras de magnetita, formações ferríferas, gnaisses calciossilicáticos e gnaisses kinzigíticos, normalmente sob a forma de pequenas lentes, intercaladas nos litotipos granulíticos.

Uma característica marcante em todo Domínio Luís Alves é a presença de rochas de natureza básica e ultrabásica, que ocorrem associadas aos gnaisses, sob a forma de enclaves de dimensões e formas variadas. Tratam-se principalmente de piroxênitos, metagabro noritos, anfibolitos e xistos magnesianos. Suas dimensões 
variam de poucos decimetros a dezenas de metros de largura, atingindo algumas centenas de metros de comprimento. Seus limites são concordantes com as direções estruturais dos gnaisses granuliticos, com os quais mostram muitas vezes passagem gradacional. Silva \& Dias (1981b e c) reconheceram na extremidade leste da Folha de Barra Velha oito corpos maiores, que formam um rosário com cerca de $21 \mathrm{~km}$ de extensão.

Merecem destaque, devido sua maior expressão, os corpos localizados na porção SE da área, arredores de Barra Velha, uma vez que aqueles situados nas proximidades de Piên e Tijucas do Sul serão, devido ao seu posicionamento geotectônico, discutidos à parte. As rochas básicas e ultrabásicas dos arredores de Barra Velha, mostram-se normalmente isótropas a levemente foliadas, com granulaçäo que varia de milimétrica a centimétrica (cristais, notadamente de hornblenda, atingem 5 a $10 \mathrm{~cm}$ de comprimento), e tonalidades cinza esverdeada a francamente esverdeada.

O reconhecimento, em campo, de rochas gnáissico-granulíticas, relativamente contínuas rumo a Morretes e Serra Negra, foi dificultado, em muitos setores, devido a diferenças significativas que apresentam tanto no aspecto composicional como textural, quando comparadas as rochas da porção sul do Domínio Luís Alves. Tais rochas mostram tonalidade cinza-esverdeada, granulação fina a média, estrutura normalmente cataclástica a milonítica, contendo muitas vezes, bandas de natureza básica e ultrabásica, Petrograficamente, alguns desses gnaisses cinza-esverdeados, preservam ainda texturas poligonizadas, contendo restos de hiperstênio em meio a cristais de hornblenda, biotita, tremolita/actinolita e clorita. Sob o ponto de vista estrutural, recupera-se uma superficie NW-SE, anterior a foliação NE-SW. Essas feições foram observadas em afloramentos localizados a leste de Tijucas do Sul, ao longo da BR-376 (Campo Alto-Vossoroca), BR-277 (oeste da Serra da Igreja), a oeste de Morretes, nos arredores de Cacatú, Serra Negra e próximo a divisa São PauloParaná (BR-116).

Na regiäo de Morretes-Antonina, os trabalhos de Cordani \& Girardi (1967), Girardi (1969 e 1971), Ruberti (1977) e Ruberti \& Gomes (1977) caracterizam a presença de quartzitos, magnetita-quartzitos, xistos magnesianos, gonditos e anfibolitos, normalmente como lentes, de espessura variável (centimétrica a decimétrica), intercaladas concordantemente com os gnaisses regionais. Esses 
autores distinguem, com base na composição de plagioclásios e características geoquímicas, três grupos distintos de anfibolitos (andesina-labradorita, oligoclásioandesina e albita-anfibolitos), para os quais sugerem origem ortometamórfica e retrometamorfismo do fácies anfibolito e xisto-verde.

Do ponto de vista petrográfico, foram analisadas cerca de 40 lâminas, envolvendo principalmente rochas gnáissico-granulíticas de composição quartzofeldspáticas. Tal estudo, realizado de modo superficial, em amostras coletadas para fins geocronológicos, visou a melhor compreensão dos dados radiométricos obtidos.

De modo genérico, nessas rochas gnáissicas predominam texturas granoblásticas, normalmente poligonizadas, ocorrendo ainda texturas nematoblásticas e cataclásticas. O quartzo é intersticial e xenomórfico, o plagioclásio é subidiomórfico, podendo os cristais apresentar-se límpidos ou levemente sericitizados, com composições variáveis entre oligoclásio $e$ andesina, intercrescimentos antipertíticos são comuns e, ocasionalmente, as lamelas das maclas mostram-se encurvadas. 0 feldspato potássico normalmente apresenta geminação gradeada e difusa. A hornblenda é idiomórfica a subidiomórfica, ocorrendo como cristais bem desenvolvidos, com pleocroismo em diversos tons de verde, podendo ser límpida ou conter restos de piroxênio em seu interior, ou mesmo apresentar inclusões poiquiloblásticas. O hiperstênio mostra-se normalmente subidiomórfico a xenomórfico, com pleocroismo variando de verde claro a rosado, com frequentes inclusöes de minerais opacos, por vezes parcial ou totalmente substituidos por agregados fibrosos (talco, clorita, serpentina). O diopsídio mostra-se subidiomórfico, com pleocroismo variando de incolor a verde claro. A biotita apresenta-se subidiomórfica a xenomórfica com pleocroismo de marrom avermelhado a amarelo pálido, ocorrendo isoladamente $e$ nas bordas de anfibólios e piroxênios. De modo subordinado ocorrem minerais opacos, apatita, zircão, epídoto, esfeno e granada. Carbonato e talco podem ser encontrados como produtos de alteração. Girardi (1974) menciona a presença de safirina em gnaisses granuliticos dos arredores de Piên.

As porcentagens modais dos minerais, foram obtidas por estimativas visuais, não tendo sido efetuada contagem dos mesmos em nenhuma das amostras. Acrescente-se que alguns desses minerais ocupam lugar de destaque em determinadas amostras, estando totalmente ausentes em outras. Esses gnaisses, quando analisados em diagrama QAP (Streckeisen, 1976, Fig. 3.1) distribuem-se nos 
campos das rochas enderbíticas, charnockíticas, charnoenderbiticas, noriticas, quartzo-jotuníticas, jotuníticas a quartzo-mangeriticas. Observa-se duas tendências calcio-alcalinas: uma tonalítica (norito-enderbítica) e outra norito-jotunito-opdalitocharnockítica.

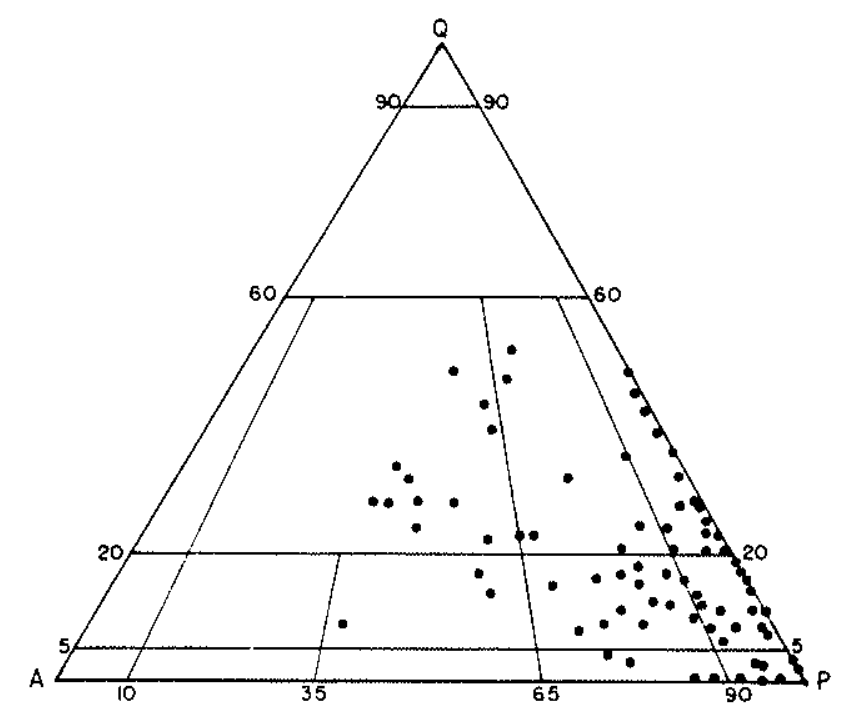

Fig. 3.1 - Diagrama Triangular QAP (Streckeisen 1976) - Gnaisses Granulíticos do Domínio Luís Alves (inclui dados de Silva \& Dias 1981b,c, Moreira \& Marimon 1980 e Machiavelli 1991)

Em termos metamórficos, um evento de recristalização no fácies granulito é sugerido, mesmo quando o hiperstênio está ausente, fato verificado em campo através da intima associação entre os litotipos mencionados, e petrograficamente devido as texturas granoblásticas poligonizadas, presença de plagioclásios antipertíticos e biotita titanifera. Hartmann (1988) utilizando-se de piroxênios de amostras dos arredores de Luis Alves, obteve para o metamorfismo dessas rochas, valores de temperatura da ordem de $800^{\circ} \mathrm{C}$, similar as observadas por Girardi e Ulbrich (1980) em granulitos das proximidades de Piên, onde as pressões estimadas encontram-se entre 5 e $7 \mathrm{~Kb}$.

Evidências petrográficas indicando que após sofrerem metamorfismo no fácies granulito, essas rochas teriam sido afetadas por evento retrometamórfico do fácies anfibolito, é sugerida, na região de Piên, por Girardi (1974) e Girardi \& Ulbrich (1980), 
nos arredores de Luis Alves por Moreira \& Marimon (1980) e Hartmann (1988) e nas proximidades de Tijucas do Sul por Ribas (1993). Esses autores mencionam a presença de duas gerações de anfibólios, um perfeitamente em equilíbrio com a paragênese de alto grau e outro, produto da transformação retrometamórfica de antigos piroxênios.

Silva \& Dias (1981b e c) estudando os granulitos da região de Luís Alves sugerem que feições de desequilibrio como anfibólios, por vezes com relictos de piroxênios em seu interior, com bordas reabsorvidas, auréolas de reação, e mesmo a presença de biotitas nas bordas de hornblendas, devam ainda representar condições $\mathrm{P}$ e $\mathrm{T}$ do fácies granulito, com acesso restrito de água.

Os estudos petrográficos realizados por Minioli (1972), Moreira \& Morimon (1980) e Silva \& Dias (1981b e c) em seqüências máficas e ultramáficas, notadamente nos arredores de Barra Velha evidenciam a predominância de diopsidio e hiperstênio em proporções variadas, além de homblenda (verde oliva) normalmente com textura poiquiloblástica e mais raramente, plagioclásio e biotita. Os principais minerais de transformação incluem clorita, serpentina, carbonatos e talco. Mencionam texturas reliquiares indicativas de origem ígnea (ofitica, intercúmulus, plagioclásio zonado), e texturas granoblásticas poligonizadas, sugestivas de recristalização metamórfica no fácies granulito. A presença de hornblenda é discutida pelos autores, podendo tratarse de um único processo metamórfico do fácies granulito ou mesmo de um retrometamorfismo no fácies anfibolito.

Em termos geoquímicos, foram analisados elementos maiores, traços e terras raras (GEOLAB-GEOSOL) de apenas cinco amostras de gnaisses granuliticos da porção centro-sul do Domínio Luís Alves. Devido ao número pouco representativo de amostras analisadas, esses dados foram lançados em diagrama $R_{1} \times R_{2}$ conjuntamente com os obtidos por Figueiredo et al. (1991), que integram os dados de Moreira \& Marimon (1980) e Hartmann (1988). Observa-se para essas rochas uma afinidade cálcio-alcalina, com termos variando de máficos a félsicos (Fig. 3.2). Figueiredo et al. (1991) sugerem que os termos básicos e ácido-intermediários representem uma seqüência cálcio-alcalina cogenética, onde os primeiros representariam toleitos de alto alumínio e os demais tonalitos de alto alumínio e granodioritos (Fig. 3.2). Segundo esses autores, os piroxênitos de Barra Velha têm padrōes compatíveis com cumulatus de piroxênio. Sugerem uma gênese envolvendo 


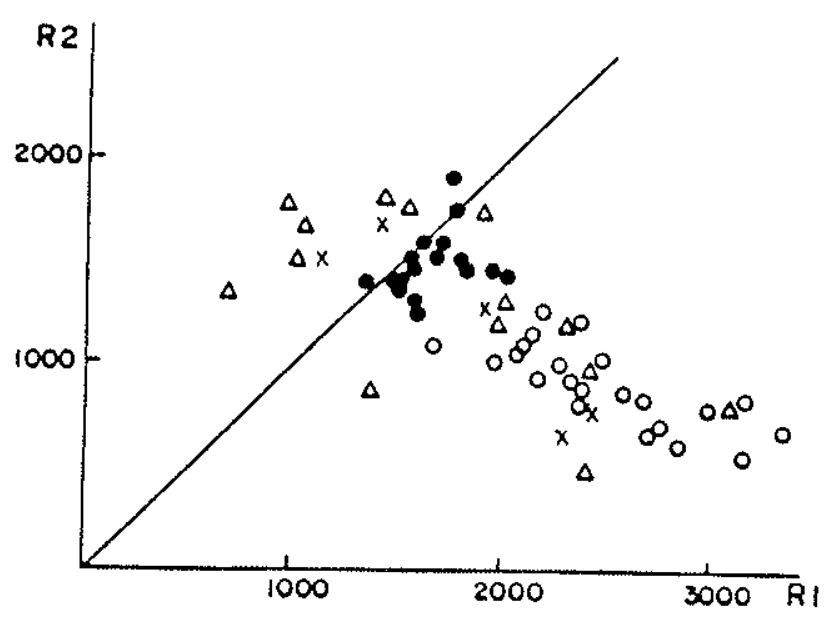

- - granulitos básicos

(Figueiredo et al. 1991)

o - granulitos ácidos interme-

diários (Figueiredo et al. 1991)

$\Delta$ - rochas não cogenéticas

(Figueiredo et al. 1991)

$x$ - granulitos

indiferenciados (neste trabalho)

Fig. 3.2 - Diagrama $R_{1}-R_{2}$ (De La Roche et al. 1980) - Domínio Luís Alves

fusão parcial de manto e posterior diferenciação desse magma por cristalização fracionada.

O padrão de terras raras denota expressivo fracionamento em quatro das amostras analisadas, com relação La/Yb variando de 12 a 28 (Fig. 3.3). Distingue-se desse padrão a rocha gnáissico-granulítica localizada nos arredores de Piên (MJ-92), com razão $L a / Y b$ pouco superior a 6 . Observa-se, adicionalmente, em três dessas rochas ( $\mathrm{MJ}-10, \mathrm{MJ}-41.3$ e $\mathrm{MJ}-15 \mathrm{a}$ ), anomalias positivas de Eu, sugestivas de acumulação de feldspatos durante o processo de cristalização fracionada ou no resíduo refratário de fusão parcial. Padrão similar foi obtido por Hartmann (1988) em rochas granulíticas do Complexo Santa Maria Chico (RGS) onde, parte das amostras analisadas apresentaram fortes anomalias positivas de Eu.

Os perfis regionais realizados na porção sul deste domínio, bem como em alguns setores de seu prolongamento nordeste, caracterizam para o bandamento gnáissico uma orientação francamente noroeste. É marcada pela orientação de feldspatos, piroxênios, anfibólios e biotitas e pelo forte estiramento do quartzo. Essa superfície, transpõe claramente uma anterior, fato verificado em alguns dos afloramentos estudados, bem como em lâminas delgadas, através da presença de dobras intrafoliais e charneiras perdidas. Trata-se, portanto, de (pelo menos) uma superficie $S_{2}$ gerada em condições de alto grau. 


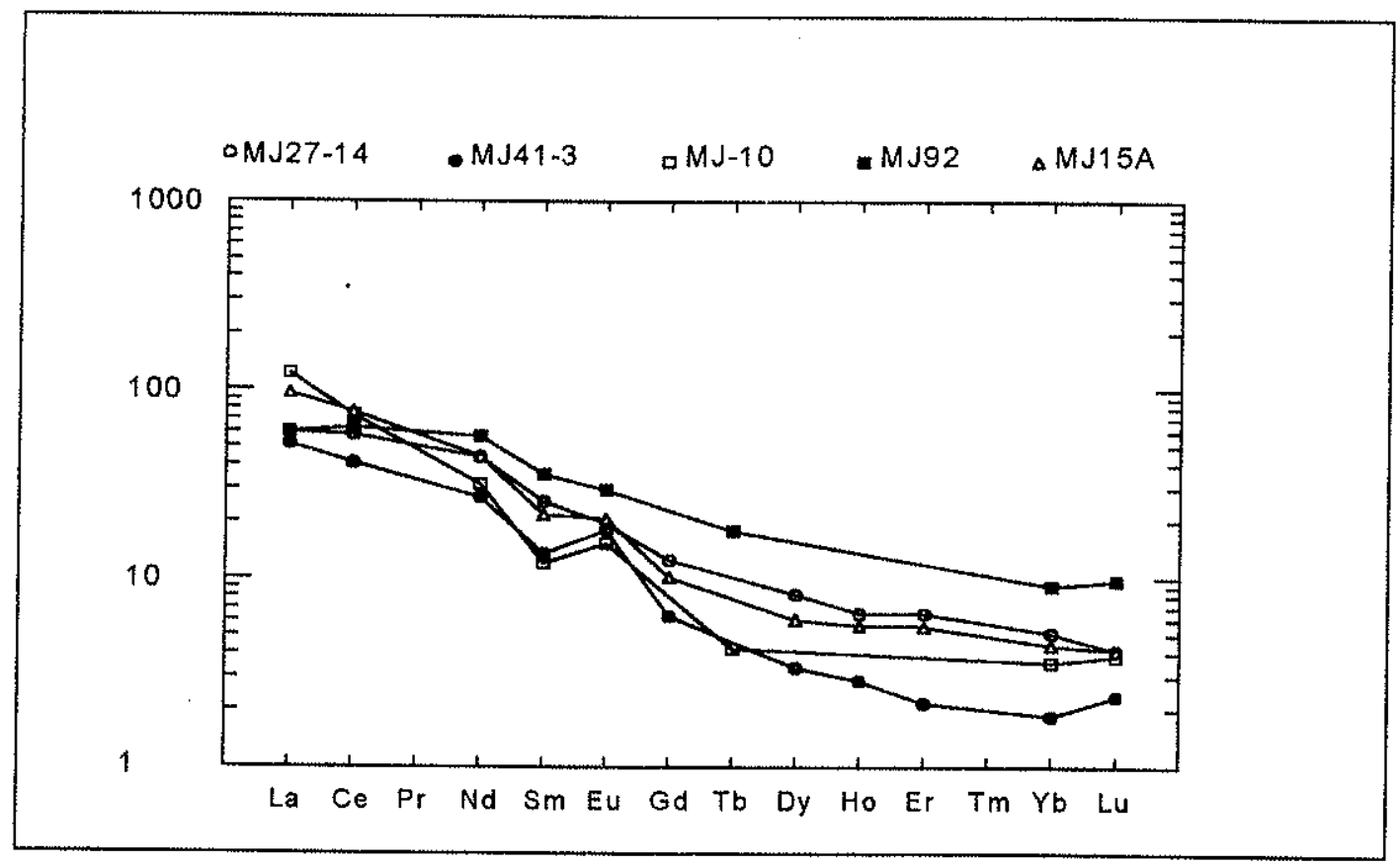

Fig. 3.3 - Padrão de Terras Raras - Rochas Gnáissico-Granuiíticas do Domínio Luís Alves (Normalizado segundo Evensen et al. 1978).

Em bons afloramentos e regionalmente através do tratamento de dados em, estereogramas, caracteriza-se o dobramento dessa superfície $S_{2}$, gerando dobras abertas com orientação NW-SE (Anexo 3, diagramas: 9, 10, 12, 15, etc.).

\subsubsection{Geocronologia}

Os dados geocronológicos atualmente disponíveis para as rochas gnáissicas do Domínio Luís Alves, totalizam cerca de 250 análises através dos métodos K-Ar (minerais e rocha total); $\mathrm{Rb}-\mathrm{Sr}$ (rocha total); $\mathrm{U}-\mathrm{Pb}$ (zircões, monazitas e esfenos); $\mathrm{Pb}$ $\mathrm{Pb}$ (rocha total) e $\mathrm{Sm}-\mathrm{Nd}$ (minerais e rocha total), conforme Apêndice 1.

Neste trabalho foram efetuadas mais de 100 determinações radiométricas, que juntamente com as análises pré-existentes permitiram um melhor conhecimento da evolução geocronológica desses terrenos.

Os trabalhos de cunho geocronológico existentes (Girardi et al. 1974, Hartmann et al. 1979a, Kaul \& Teixeira 1982, Basei 1985, Basei \& Teixeira 1987, Siga Jr. et al. $1994 a$ e b) sugerem a presença de núcleos gnáissico-granuliticos antigos, com idades 
do intervalo $2.800-2.400 \mathrm{Ma}$, bem como de rochas formadas no Paleoproterozóico, ciclo Transamazônico (2.200-2.000Ma).

As rochas gnáissico-granulíticas deste domínio apresentam de modo geral, baixos teores em $\mathrm{Rb}$ e, relativamente elevados em $\mathrm{Sr}$, fornecendo razões $\mathrm{Rb}^{87} / \mathrm{Sr}^{86}$ baixas e normaimente com valores bastante próximos (entre 0 e 1,0 - raramente atingindo valores superiores a 1,0). Tal fato, prejudica a distribuição dos pontos analíticos em diagrama isocrônico, causando imprecisão nas idades obtidas.

A existência de núcleos antigos (Arqueanos) na porção sul deste domínio é sugerida através de alinhamentos isocrônicos $\mathrm{Rb}$-Sr precários (errócronas) envolvendo afloramentos de rochas gnáissico-granulíticas dos arredores de Luís Alves, Pomerode e de região localizada a leste de Campo Alegre (estrada Dona Francisca).

O diagrama isocrônico (Fig. 3.4) contêm seis pontos analíticos relativos a rochas gnáissico-granulíticas localizadas nas imediações de Luís Alves. A idade obtida, de 2.663 $\pm 72 \mathrm{Ma}$ para uma relação inicial $\left(\mathrm{Sr}^{87} / \mathrm{Sr}^{86}\right)_{i}$ de $0,70397 \pm 0,00046$ é definida principalmente pela amostra de número de campo PLA-16B, cuja razão $\mathrm{Rb}^{87} / \mathrm{Sr}^{86}$ (próxima de 2,0 ), é significantemente superior às demais (inferiores a 0,4 ).

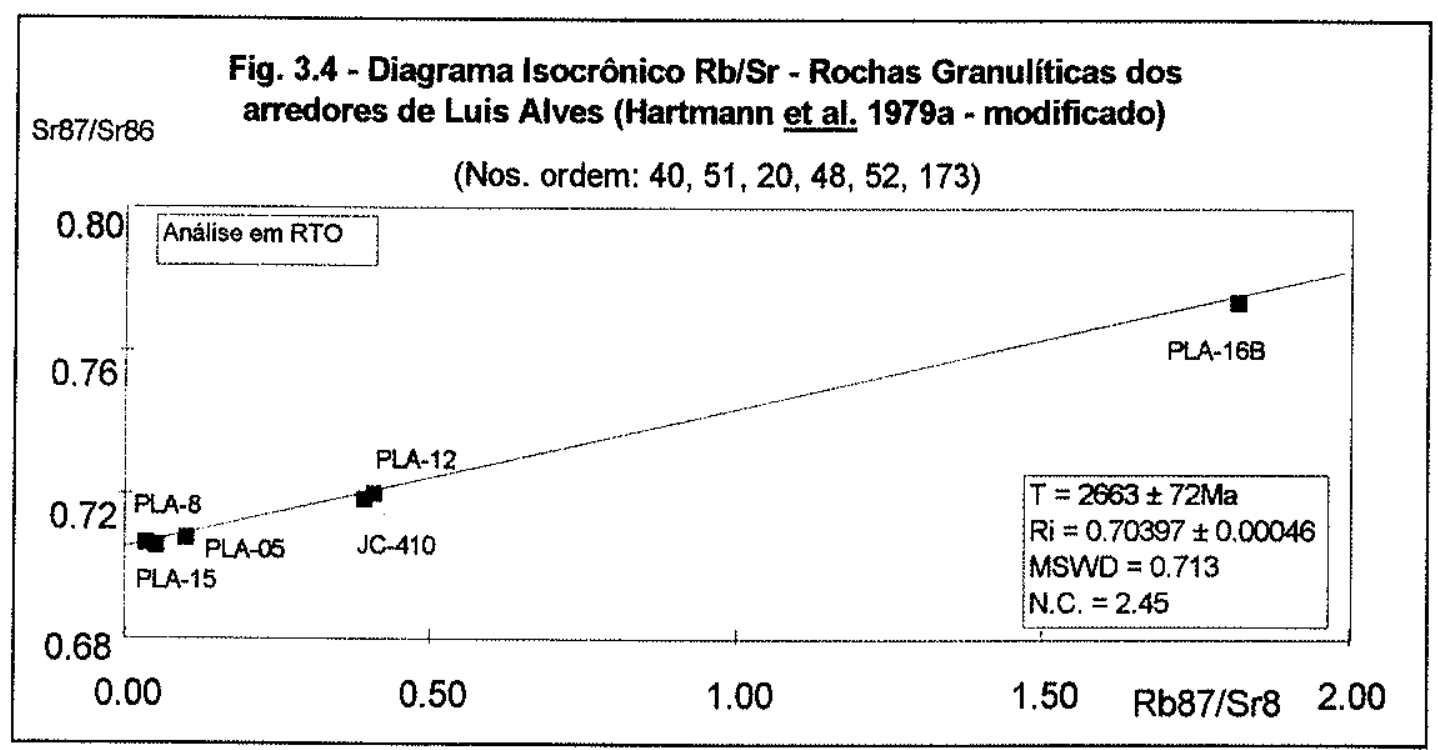

Para os gnaisses granuliticos localizados nas proximidades de Pomerode (afloramentos $\mathrm{MJ}-29,30,31$ e 34), os dados analiticos $\mathrm{Rb}-\mathrm{Sr}$, distribuiram-se no eixo das abcissas do diagrama isocrônico entre 0,12 e 0,44 (Fig. 3.5). Dois alinhamentos 
foram traçados, um de maior inclinação (não computando a amostra de número de campo MJ-34), com idade de $2.666 \pm 173 \mathrm{Ma}$ e outro de menor inclinação (computando-se todas as amostras), com idade de $2.478 \pm 37 \mathrm{Ma}$, e razão inicial de $0,70129 \pm 0,00010$. Tal dispersão reflete um desequilíbrio isotópico do sistema $\mathrm{Rb}-\mathrm{Sr}$ responsável pela imprecisão na idade de formação dessas rochas gnáissicogranulíticas.

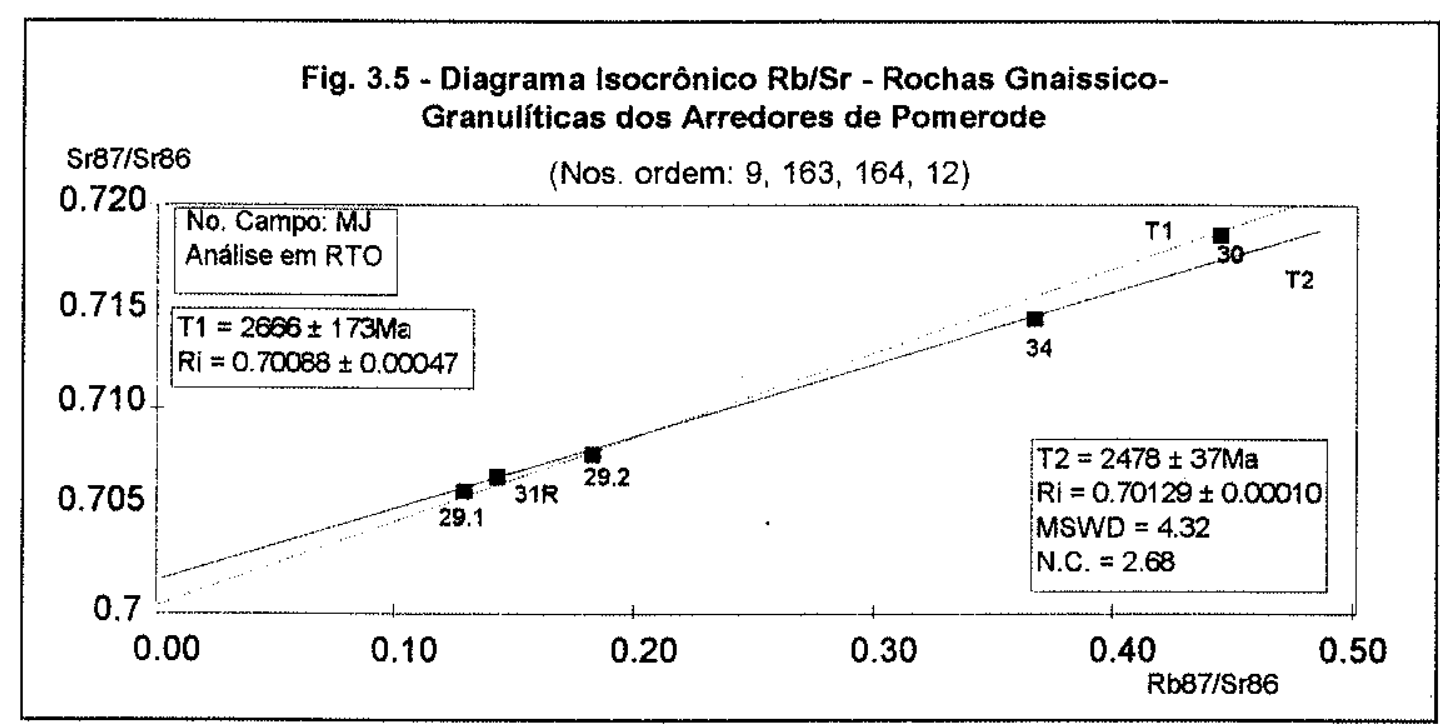

Padrão isocrônico $\mathrm{Rb}-\mathrm{Sr}$ interessante foi observado para as rochas migmatíticas do afloramento de número de campo SCMB-172, localizado a SE de Luís Alves. Neste diagrama, os pontos analíticos relativos aos mesossomas posicionaramse relativamente aos demais, de natureza leucossomática, mais próximos a origem (Fig. 3.6, Basei 1985, modificado). Embora esses dados se mostrem bastante dispersos no diagrama, ocasionando elevados erros nas idades obtidas, um "trend" mais antigo, possivelmente Arqueano $(2.800-2.600 \mathrm{Ma})$ é sugerido para as porções mesossomáticas e um mais jovem, Paleoproterozóico para as porções leucossomáticas $(\sim 1.900 \mathrm{Ma})$.

A norte de Schröeder (ao longo do Rio do Júlio), bem como na estrada Dona Francisca (Campo Alegre-Pirabeiraba), várias amostras de gnaisses-granulíticos foram coletadas e analisadas através do método $\mathrm{Rb}$-Sr. Esses dados, apresentaram relações $\mathrm{Rb}^{87} / \mathrm{Sr}^{86}$ relativamente baixas (inferiores a 0,5 ), denotando em diagrama isocrônico uma dispersão generalizada dos pontos analíticos (Fig. 3.7). Em que pese o patente 
distúrbio isotópico dessas amostras, um alinhamento grosseiro pode ser sugerido, envolvendo os afloramentos de números de campo MJ-191, 195, 259 e 194A, todos localizados ao longo da estrada Dona Francisca e portadores de hiperstênio.
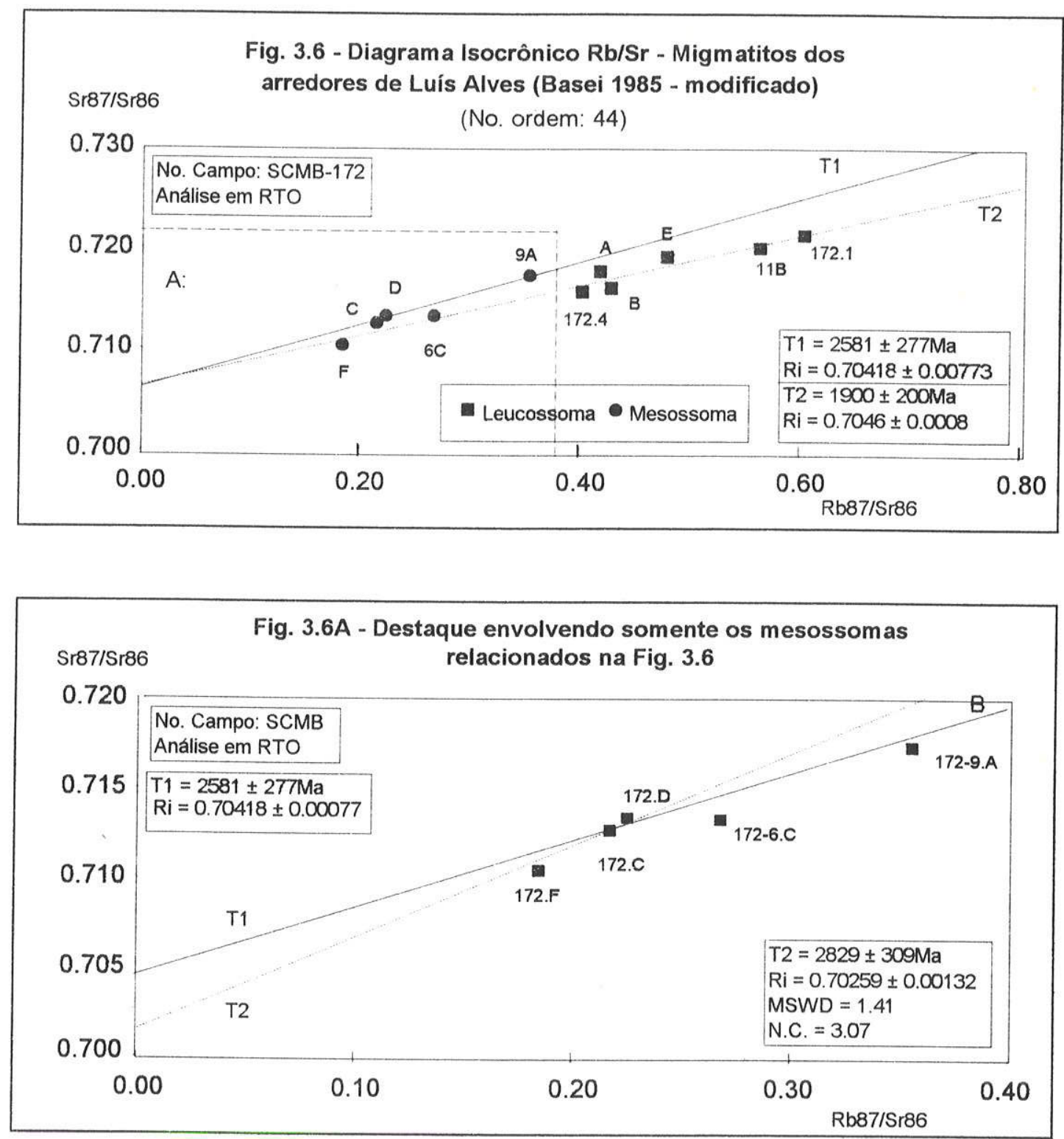

Esse alinhamento fornece uma idade próxima de $2.700 \pm 90 \mathrm{Ma}$, para uma relação inicial $\left(\mathrm{Sr}^{87} / \mathrm{Sr}^{86}\right)_{i}$ ao redor de 0,704 (Fig. 3.7.A). As amostras pertencentes ao afloramento de número de campo MJ-192, embora da mesma região, não contêm hiperstênio, predominando entre os minerais máficos a hornblenda (verde e poiquilítica) e alguma biotita. As duas análise $\mathrm{Rb}-\mathrm{Sr}$ efetuadas em rochas desse afloramento (MJ-192 a e b), bem como nas demais, localizadas ao longo do Rio do 
Júlio, apresentaram distribuiçōes distintas no diagrama isocrônico, denotando forte desequilibrio isotópico, reflexo possivelmente de episódios tectônicos relacionados ao Paleoproterozóico (Fig. 3.7B).
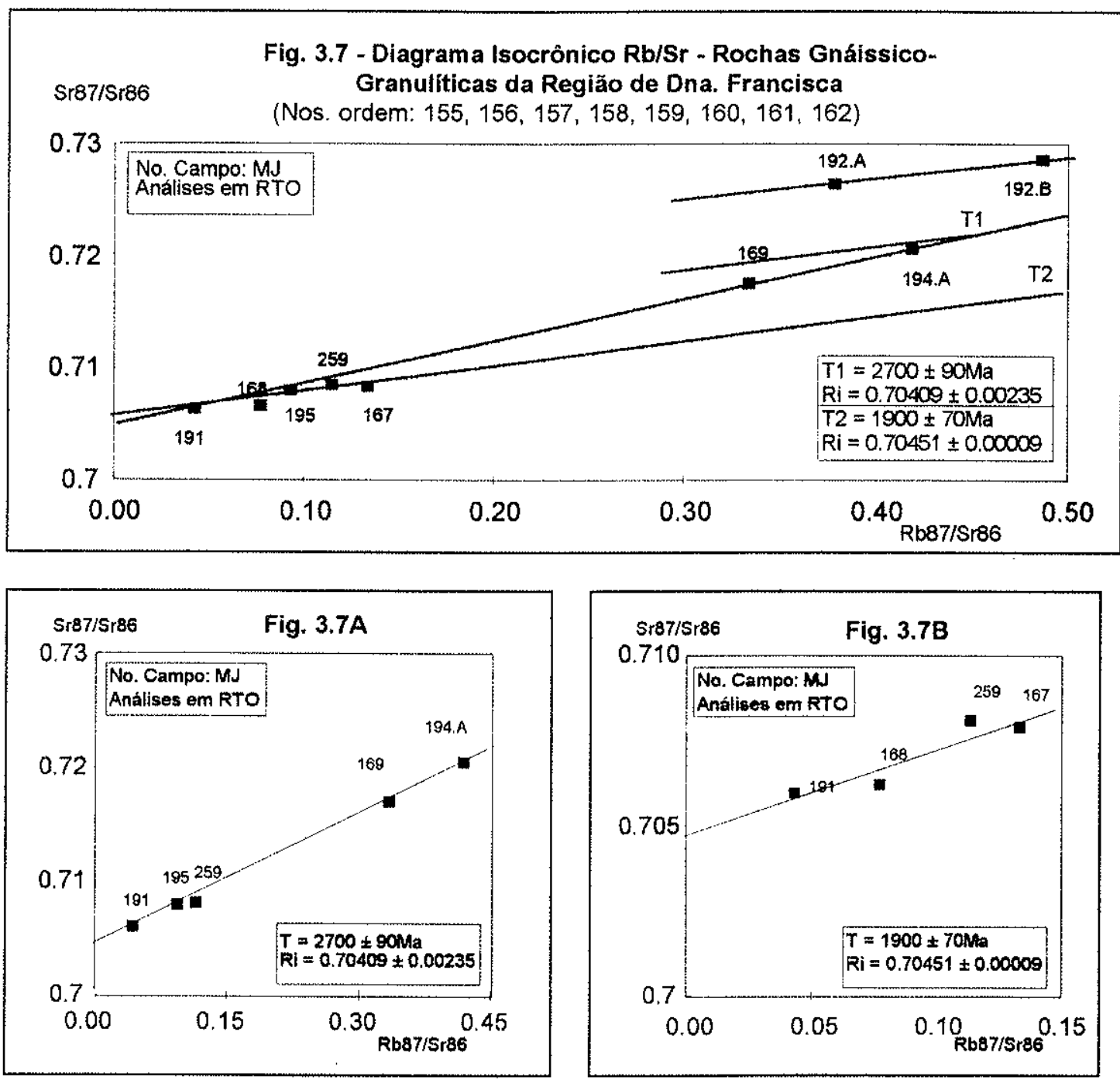

Valores isocrónicos $\mathrm{Rb}-\mathrm{Sr}$ relativos ao Paleoproterozóico (ciclo Transamazônico) foram caracterizados em rochas gnáissico-granulíticas, distribuidas por todo Domínio Luis Alves, notadamente onde a ocorrência de hiperstênio é restrita, predominando como mineral máfico, a hornblenda.

Valor isocrônico de $2.169 \pm 177 \mathrm{Ma}$, com uma relação inicial $\left(\mathrm{Sr}^{87} / \mathrm{Sr}^{86}\right)$, próxima de 0,70150 foi obtido para rochas gnáissico-granuliticas pertencentes a dois afloramentos (MJ-41 e 38), localizados a norte de Blumenau (Fig. 3.8). 


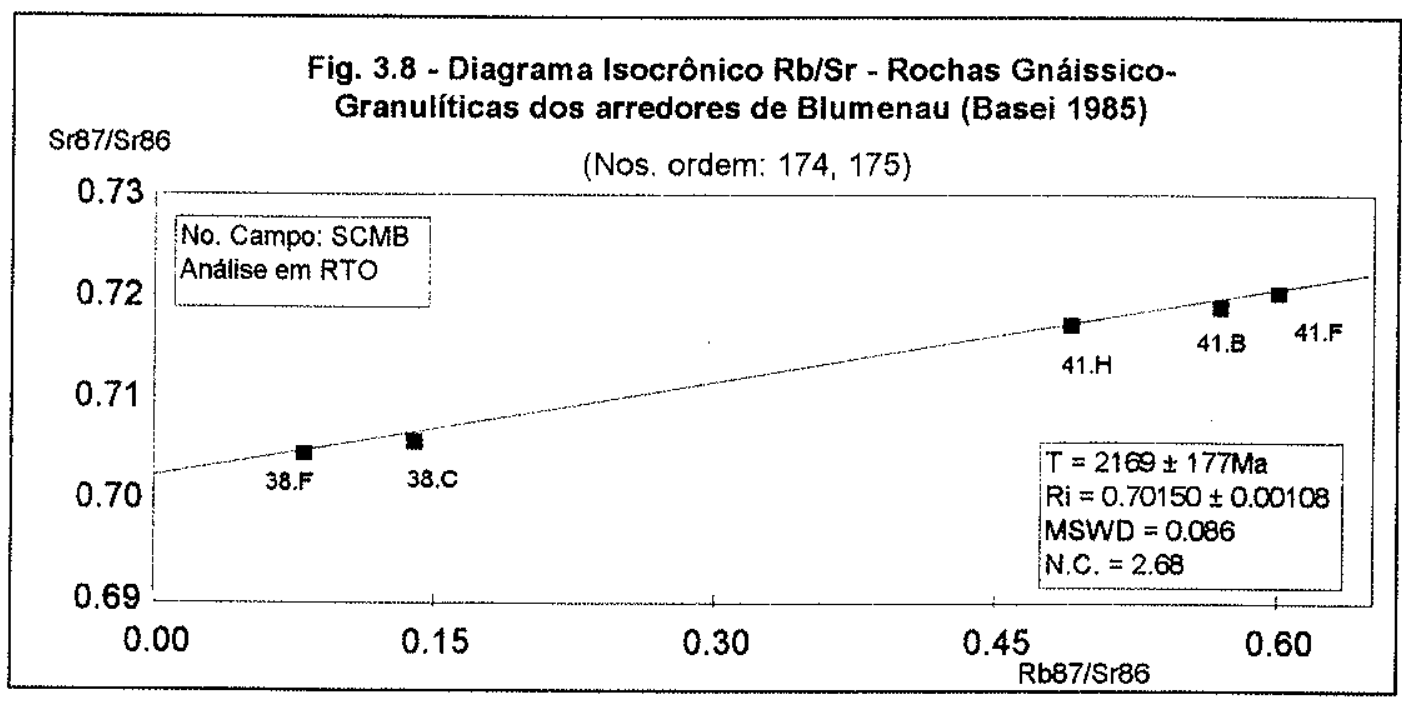

Nas proximidades de Pomerode ocorrem rochas gnáissico-granuliticas cujas relações $\mathrm{Rb}^{87} / \mathrm{Sr}^{86}$ apresentaram-se inferiores a 0,20 . Foram realizadas nove análises $\mathrm{Rb}-\mathrm{Sr}$ em amostras pertencentes a dois afloramentos (MJ-27 e 29). Esses dados apresentaram-se bem alinhados em diagrama isocrônico, indicando uma idade de $1.970 \pm 36 \mathrm{Ma}$, para uma relação inicial $\left(\mathrm{Sr}^{87} / \mathrm{Sr}^{86}\right)_{i}$ de $0,70245 \pm 0,00006$ (Fig. 3.9).

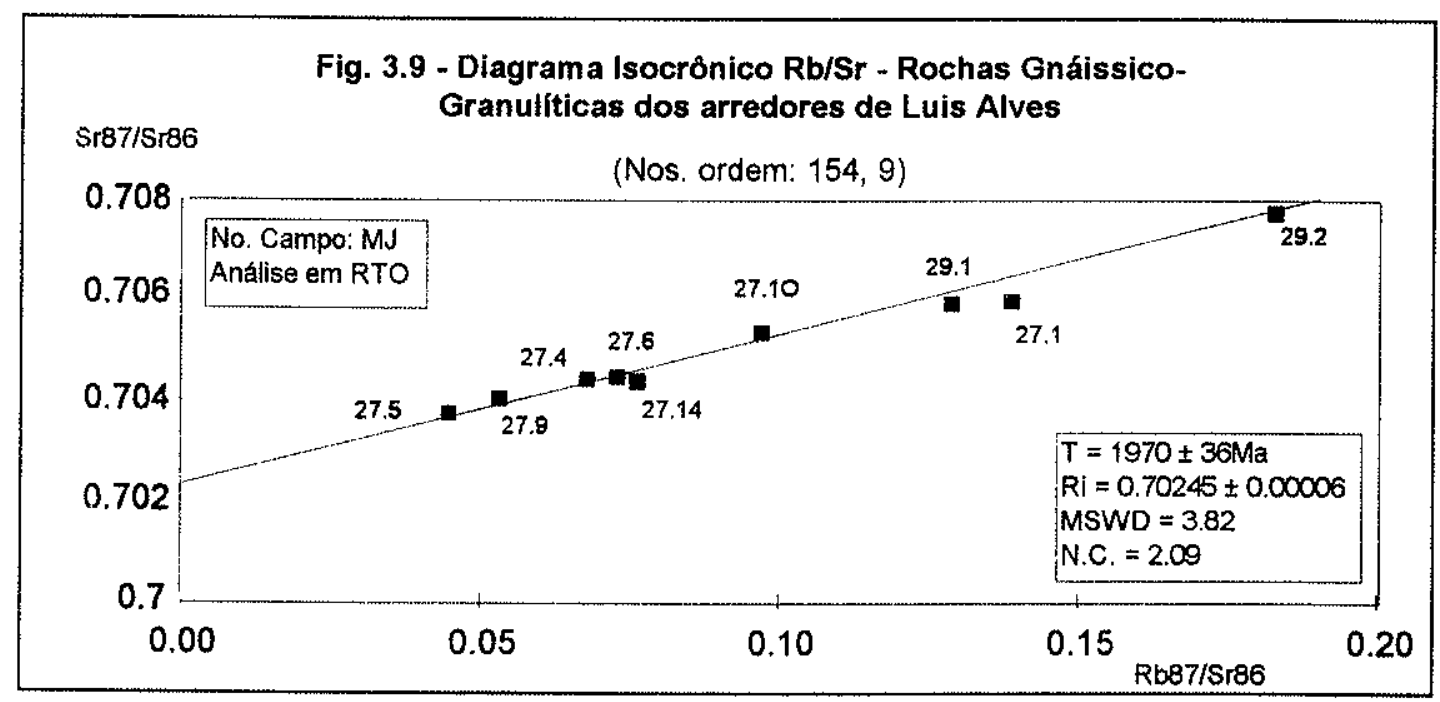

Idades isocrônicas $\mathrm{Rb}-\mathrm{Sr}$ relativas ao Paleoproterozóico (ciclo Transamazônico) foram também obtidas no setor centro ocidental do Domínio Luis Alves, em rochas gnáissico-granulíticas de afloramentos localizados a nordeste de Jaguará do Sul 
(2.184 $\pm 48 \mathrm{Ma}$, para uma relação inicial de $0,70257 \pm 0,00010$, Fig. 3.10), nas proximidades de Piên $(2.067 \pm 199 \mathrm{Ma}$, para uma relação inicial de 0,70244 $\pm 0,00047$, Girardi et al. 1974, Fig. 3.11) e de São Bento do Sul (2.107 $\pm 69 \mathrm{Ma}$, para uma relação inicial de 0,70284 $\pm 0,00024$, Machiavelli 1991, Fig. 3.12).

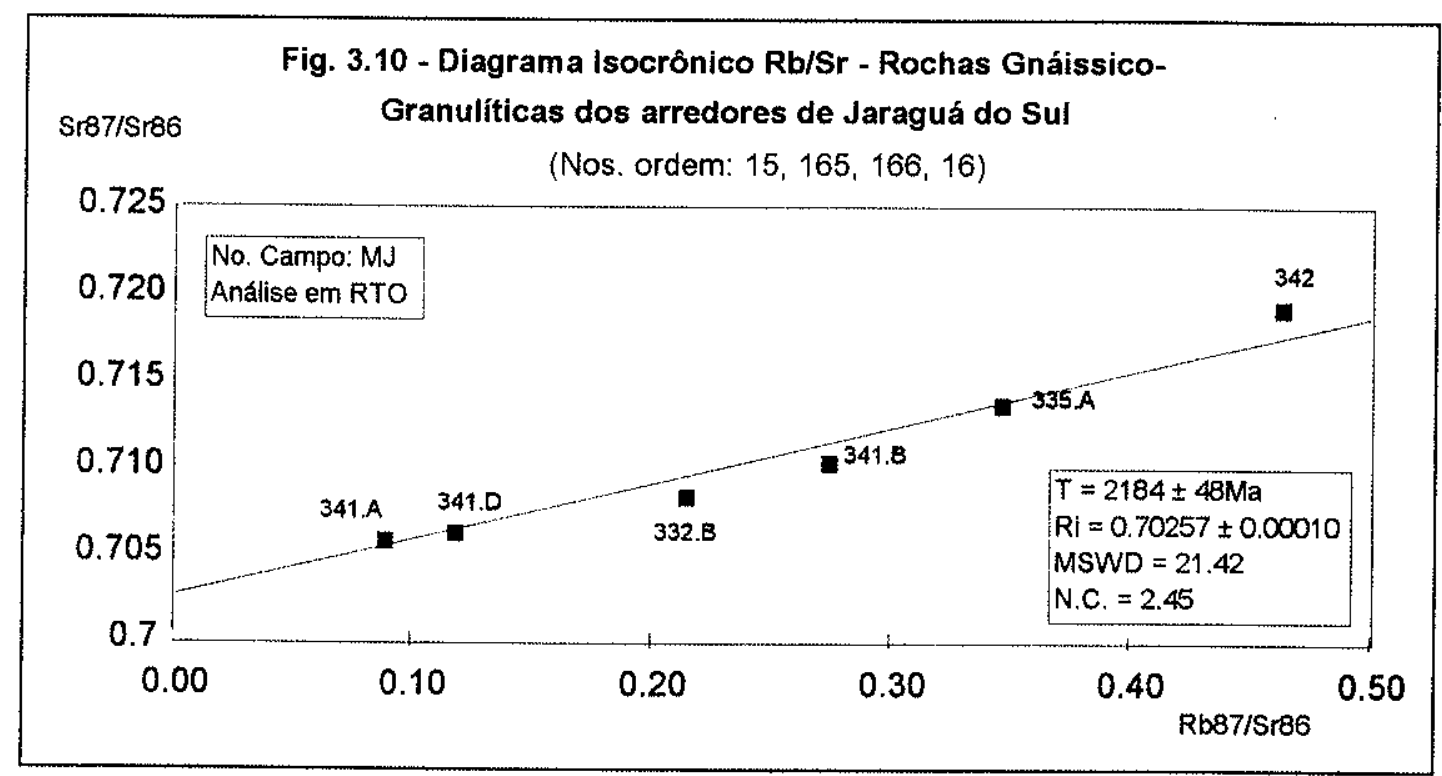

Fig. 3.11 - Diagrama Isocrônico $\mathrm{Rb} / \mathrm{Sr}$ em rocha total - Rochas

Gnáissico-Granuliticas das proximidades de Piên (Girardi et al. 1974)

Sr87/Sr86

(Nos. ordem: $56,176,177,57$ )

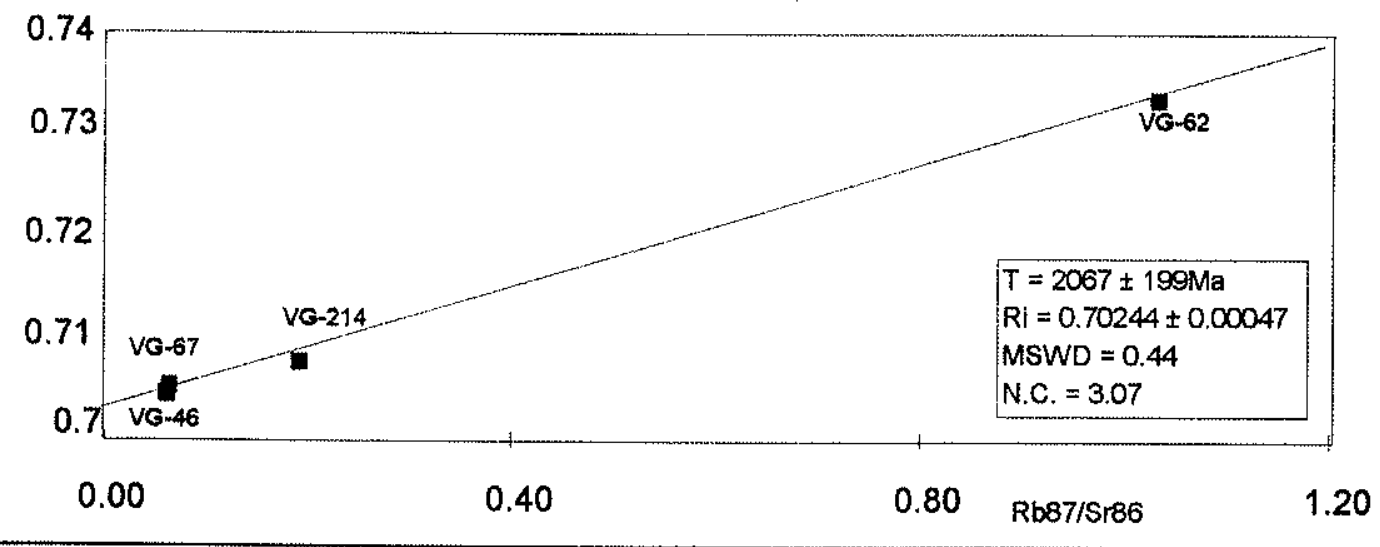




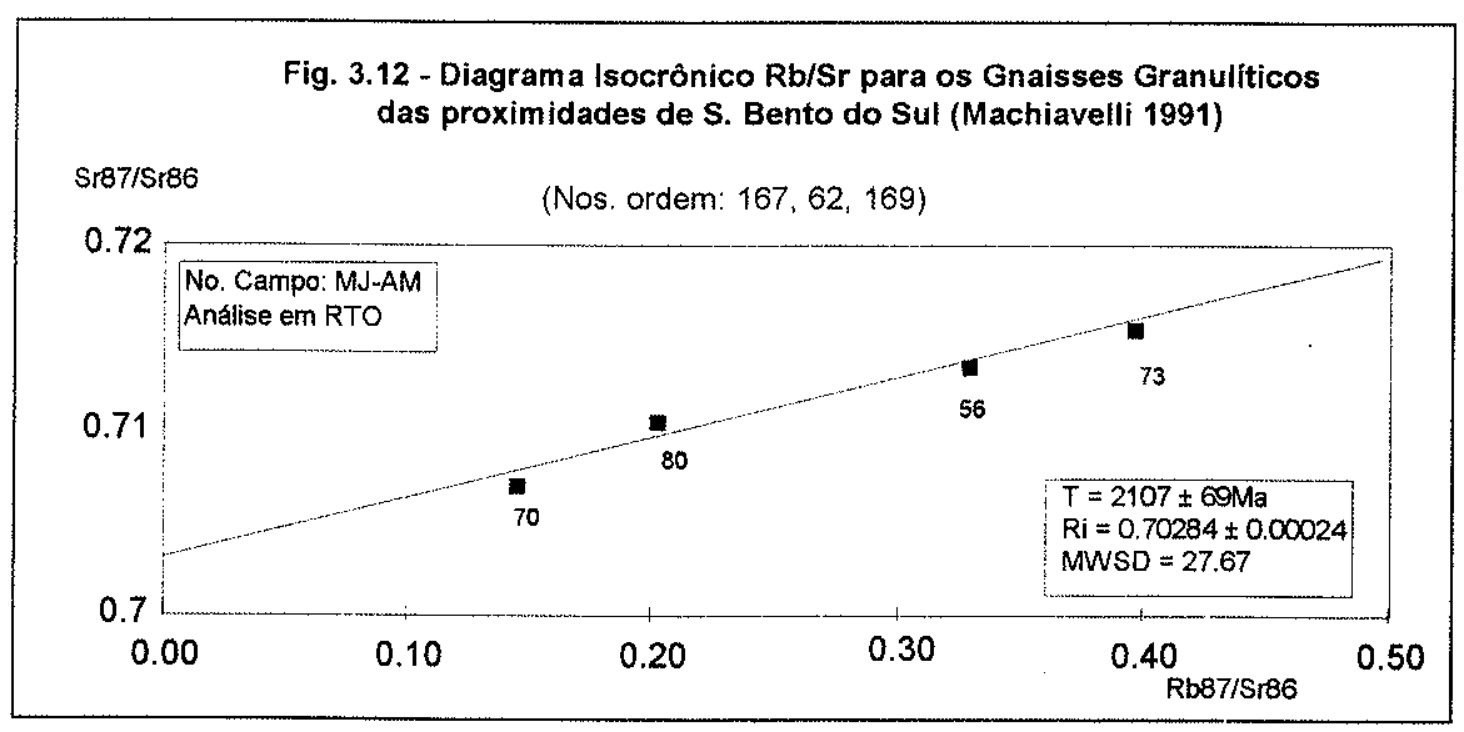

$\mathrm{Na}$ porção nordeste desse domínio, arredores de Serra Negra, os dados analíticos $\mathrm{Rb}$ - $\mathrm{Sr}$, relativos à rochas gnáissico-granulíticas, concentraram-se bastante próximos à origem do diagrama isocrônico, a exceção da amostra de número de campo $\mathrm{SN}-3$, que apresentou relação $\mathrm{Rb}^{87} / \mathrm{Sr}^{86}$ mais elevada $(0,92)$, definindo a idade de $2.200 \pm 100 \mathrm{Ma}$ (Fig. 3.13).

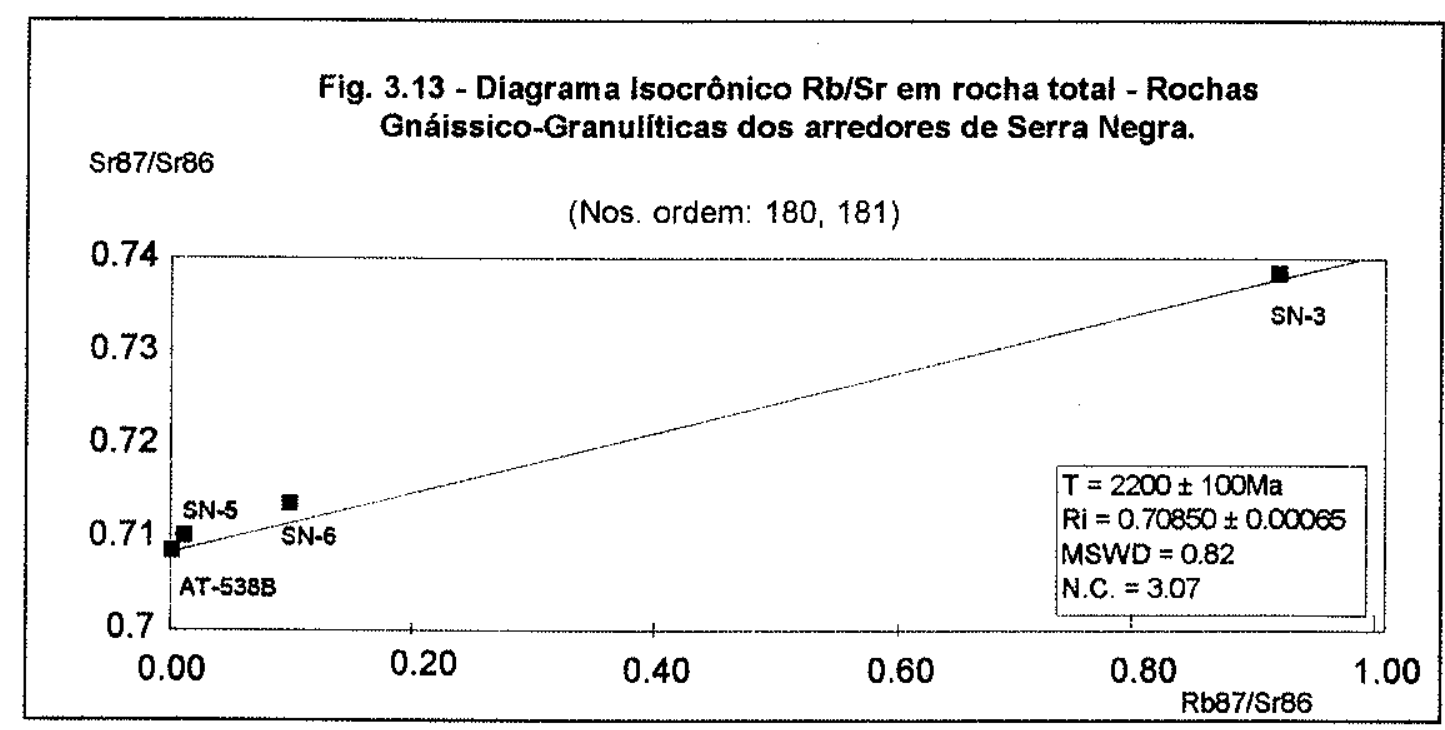

O padrão $\mathrm{Rb}-\mathrm{Sr}$ observado para o Domínio Luís Alves, embora apresente sistematicamente pontos analíticos mal distribuídos e dispersos nos diagramas isocrônicos, sugere a presença de rochas antigas, formadas no Arqueano (2.800- 
2.600Ma), parcial ou totalmente rehomogeneizadas no Paleoproterozóico (ciclo Transamazônico: 2.200-1.900Ma).

Fato interessante é observado quando lançamos em diagrama as médias das relações $\mathrm{Sr}^{87} / \mathrm{Sr}^{86}$ e $\mathrm{Rb}^{87} / \mathrm{Sr}^{86}$ de isócronas representativas de rochas formadas no Paleoproterozóico (ciclo Transamazônico). Observa-se uma tendência desses pontos médios alinharem-se próximos a reta de $2.700 \mathrm{Ma}$, indicando uma homogeneização isotópica no Paleoproterozóico (ciclo Transamazônico) a nivel de afloramento, mas nem sempre entre afloramentos distintos (Fig. 3.14).

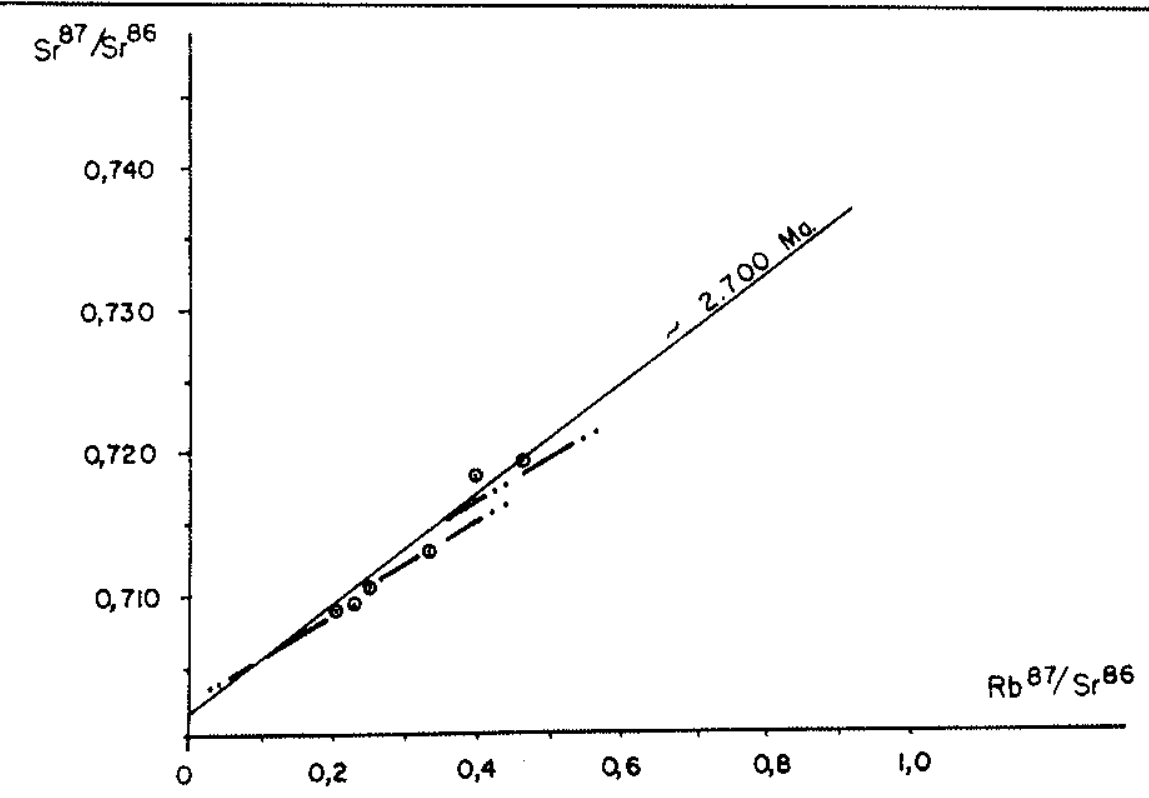

Fig. 3.14 - Diagrama Isocrônico utilizando a média das relações $\mathrm{Sr}^{87} / \mathrm{Sr}^{86} \mathrm{e}$ $\mathrm{Rb}^{87} / \mathrm{Sr}^{86}$ de isócronas Transamazônicas.

Análises $\mathrm{Pb}-\mathrm{Pb}$ (Apêndice-1) realizadas em gnaisses quartzo feldspáticos, gnaisses máficos, anfibolitos e veios pegmatíticos do afloramento SCMB-1103, localizado nos arredores de Luís Alves, apresentaram-se relativamente concentradas em diagrama isocrônico, indicando idade de formação de $2.100 \pm 500 \mathrm{Ma}$, para um coeficiente $\mu_{1}$ de 8.9 , característico de rochas oriundas de reservatórios crustais (Basei 1985, Fig. 3.15). 


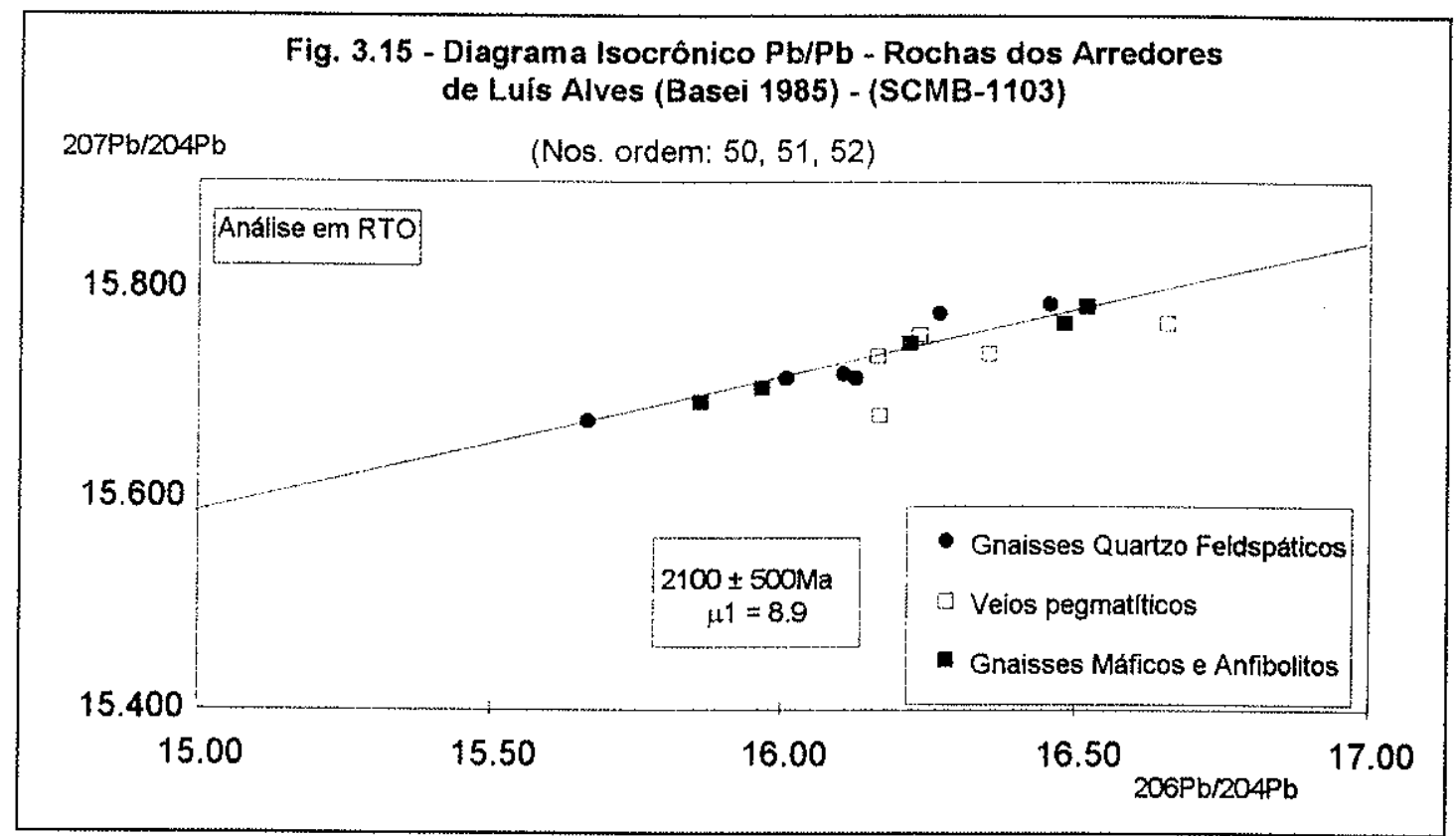

Os dados U.Pb (Apêndice-1), obtidos em zircões, envolvendo adicionalmente esfeno e monazita, concentrados de rochas gnáissicas quartzo-feldspáticas (afloramento SCMB-174) e migmatiticas (afloramento SCMB-172) do trecho entre Luis Alves e Itajai indicam, em diagramas Concórdia, idades arqueanas e paleoproterozóicas (Basei 1985; Fig. 3.16 e 3.17). Os interceptos superiores apontam para valores, respectivamente de 2.400 e $2.890 \mathrm{Ma}$, não retratando com clareza acerca da atuação do ciclo Transamazônico, evidenciado nessas rochas através dos métodos Rb-Sr e K-Ar. É possível que o evento Transamazônico, apesar de gerar migmatitos, não tenha sido suficientemente intenso para rejuvenescer completamente os zircões, provocando o desequilíbrio isotópico observado. Neste caso, a posição atual dos zircões pode refletir a combinação de suscessivas modificações introduzidas pelos episódios que atuaram na área, devendo ser interpretada segundo um polígono de crises com vértices possíveis a 2.200; 2.700 e maior que $3.000 \mathrm{Ma}$. Uma indicação da atuação do evento Transamazônico é sugerida por um esfeno, da amostra SCMB172, que apesar da imprecisão, pois o ponto posiciona-se acima da Curva Concórdia, fornece uma idade convencional da ordem de 2.100Ma. Uma monazita analisada apresentou idade de $570 \mathrm{Ma}$, indicando provavelmente um evento retrometamórfico local, que afetou parcialmente essas rochas durante o Neoproterozóico. Tal valor deve 
refletir processos hidrotermais localizados, do fácies xisto verde, que teriam gerado além da monazita, muito epidoto.
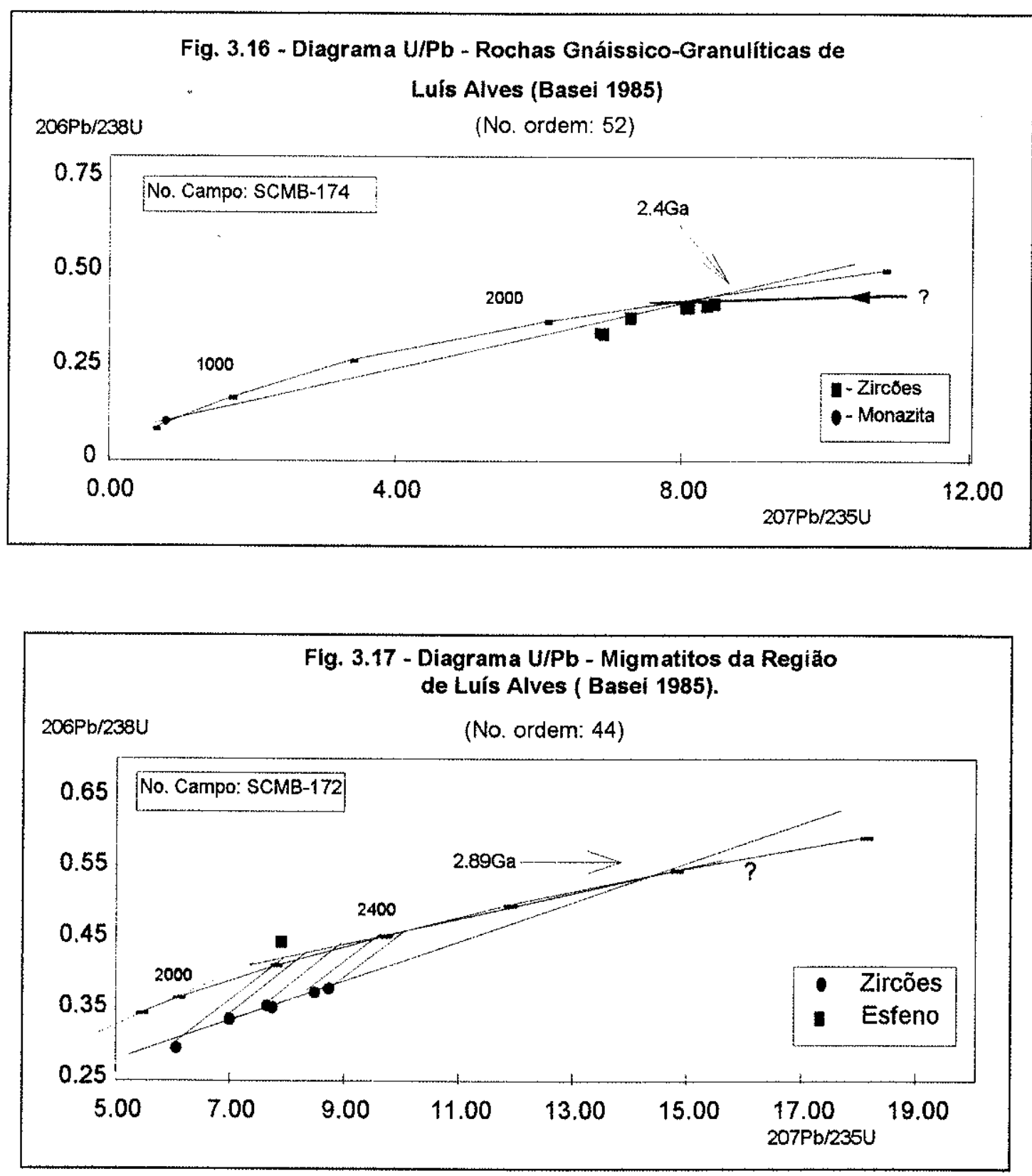

Determinações radiométricas $\mathrm{U}-\mathrm{Pb}$, foram adicionaimente realizadas em concentrados de zircões de rochas gnáissico-granulíticas pertencentes a dois afloramentos localizados a NW de Joinville (estrada Dona Francisca). Os dados analíticos referentes à três frações da amostra de número de campo $\mathrm{MJ}-192 \mathrm{C}$, 
posicionaram-se sobre a da curva Concórdia, indicando a idade de $2.200 \pm 2 \mathrm{Ma}$ como relativa a época de cristalização dos zircões (Fig. 3.18).

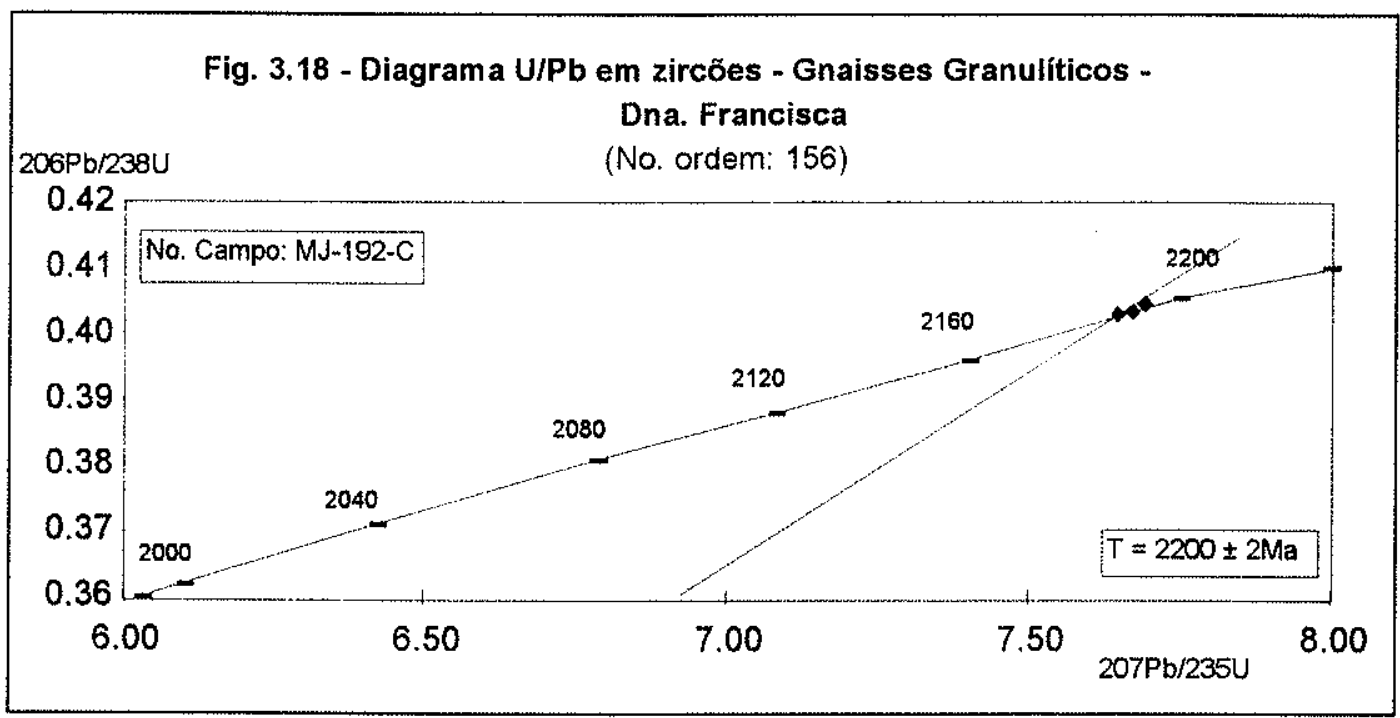

A amostra de número de campo MJ-258, coletada em afloramento localizado a a leste do anterior, apresentou populações de zircões rosados e população de zircōes marrons, analisadas separadamente. Três fraçōes relativas aos zircōes rosados indicaram em diagrama Concórdia idade de cristalização de $2.247 \pm 18 \mathrm{Ma}$ (Fig. 3.19). Para a população de zircões marrons foram realizadas datações de cinco frações, que apresentaram forte dispersão dos pontos analiticos, com idade calculada de $2.360 \pm$ 100Ma (Fig. 3.19). O comportamento complexo observado, deve refletir modificações importantes introduzidas durante o Paleoproterozóico (cicio Transamazônico) afetando zircões oriundos de rochas mais antigas, causando o desequilibrio isotópico do sistema U-Pb.

Dados Sm-Nd (Apêndice-1) em minerais (clinopiroxênios, anfibólios, esfenos, microclínio e allanita) concentrados de rocha gnáissica localizada nas proximidades de Barra Velha, indicaram para a formação dessa paragênese idade de $2.258 \pm 67 \mathrm{Ma}$, sugerindo novamente a atuação do ciclo Transamazônico nesse setor (Hartmann et al. 1994; Fig. 3.20).

As idades modelo $\mathrm{Sm}$-Nd ( $\mathrm{T}_{\mathrm{DM}}$ ) apontam períodos de acresção/diferenciação de material do manto por volta de $3.100 \mathrm{Ma}$, bem como entre $2.800-2.700 \mathrm{Ma}$ e 2.350 - 

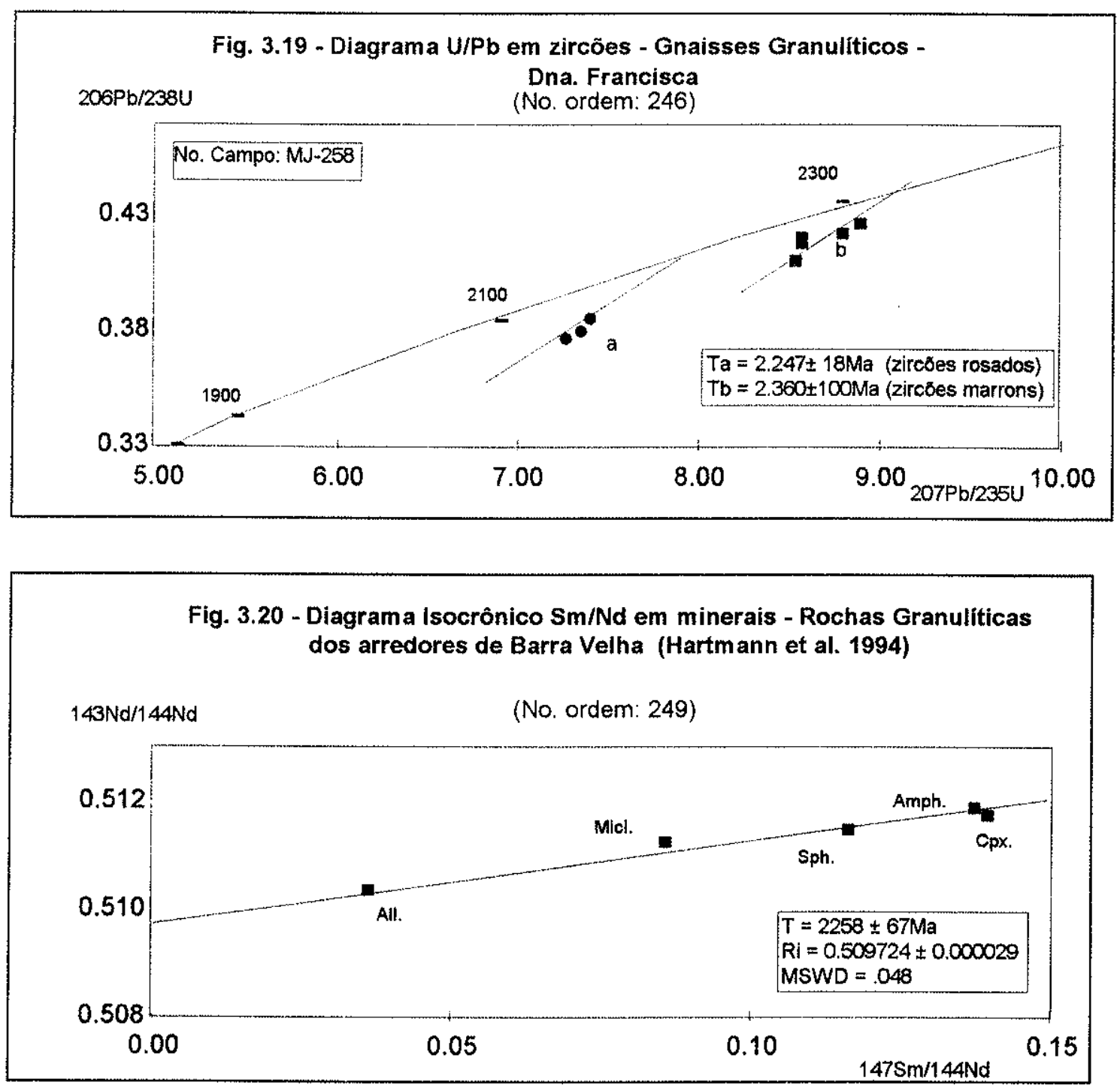

2.200Ma, reforçando interpretações efetuadas através de outras metodologias radiométricas (Apêndice 1).

As análises $\mathrm{K}-\mathrm{Ar}$ realizadas em rocha total e minerais (anfibólio, biotita, plagioclásio, piroxênio e K-feldspato) envolveram rochas gnáissico-granulíticas, gnáissicas quartzo-feldspáticas, migmatíticas, anfibolíticas além de básicas e ultrabásicas (Apêndice 1). Esses dados quando tratados em histograma (Fig. 3.21), indicam uma grande concentração de idades no intervalo 2.000-1.700Ma, abrangendo principalmente anfibólios e biotitas de rochas pertencentes, tanto à porção meridional como à seu prolongamento em direção a Morretes-Antonina-Serra Negra. Neste setor, nordeste do Domínio Luís Alves, os dados K-Ar assumem fundamental importancia, 
por caracterizar a existência de uma faixa afilada que permaneceu relativamente fria, frente a tectônica Neoproterozóica (ciclo Brasiliano) impressa nos domínios adjacentes. Idades do intervalo 2.000-1.700Ma foram obtidas neste setor, principaimente em anfibólios de rochas gnáissicas e anfibolíticas distribuidas nos arredores de Tijucas do Sul, ao longo da BR-376 (a NE de Tijucas do Sul), proximidades de Morretes e a oeste da Serra da Igreja (BR-277).

Idades $\mathrm{K}-\mathrm{Ar}$ mais antigas (Arqueanas/Paleoproterozóicas) foram obtidas principalmente em anfibólios, plagioclásios, piroxênios e rocha total de rochas de natureza básica e ultrabásica dos arredores de Barra Velha, cujos teores em potássio, mostram-se extremamente baixos, dificeis de precisar analiticamente, devendo, portanto, serem encaradas com cuidado. Se considerarmos os teores de potássio superiores a $0,3 \%$ (mais confiáveis) verificamos a existência de dois intervalos principais de idade para essas rochas, o mais antigo entre $2.800-2.600 \mathrm{Ma}$, e o mais jovem entre 2.200-2.000Ma.

Os valores K-Ar do Paleoproterozóico, observados ao longo de todo o Domínio Luís Alves, indicam que esses terrenos encontravam-se abaixo da isoterma de $500^{\circ} \mathrm{C}$ nessa época (dados em anfibólios). Adicionalmente, o arrefecimento da temperatura para valores inferiores a $300^{\circ} \mathrm{C}$ é sugerido em grande parte desse domínio, no mesmo período (idades $\mathrm{K}-\mathrm{Ar}$ em biotitas), caracterizando o soerguimento regional desses terrenos durante o Paleoproterozóico.

Acrescente-se ainda que as idades distribuidas no histograma K-Ar entre 1.700 a $600 \mathrm{Ma}$ foram observadas principalmente em rochas gnáissicas e anfibolíticas posicionadas próximas as zonas de borda desse domínio, sugerindo seu envolvimento parcial ou total na tectônica Neoproterozóica, registrada nos terrenos adjacentes. 


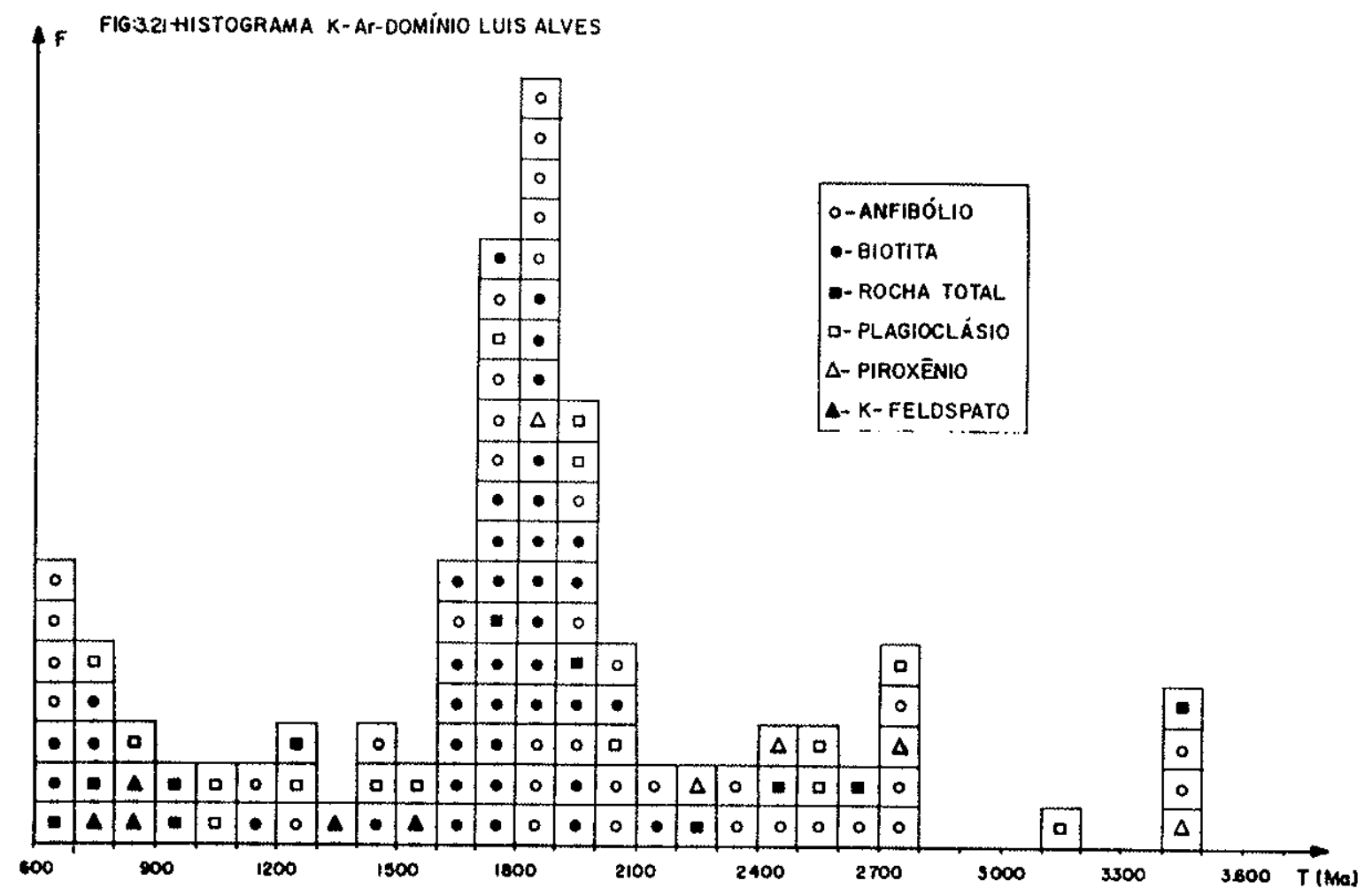

Fig. 3.21 - Histograma K-Ar - Domínio Luís Alves. 
O quadro abaixo representa uma síntese da evolução geotectônica do Domínio Luís Alves, com base na interpretação dos dados geológicos e geocronológicos apresentados.

\begin{tabular}{|c|c|c|}
\hline Fenômeno & Características & Idade (ba) \\
\hline $\begin{array}{l}\text { Diferenciação } \\
\text { Manto/crosta }\end{array}$ & $\begin{array}{l}\text { Épocas de acresção de material do manto. (ldades } \\
\left.\text { Sm/Nd }-T_{D m}\right)\end{array}$ & $>2,6$ \\
\hline $\begin{array}{l}\text { Metamorfismo } \\
\text { regional do fácies } \\
\text { granulito }\end{array}$ & $\begin{array}{l}\text { Desenvolvimento das paragêneses a ortopi- } \\
\text { roxênio (?) - valores imprecisos: Rb-Sr e U-Pb }\end{array}$ & $2,6 \pm 0,2$ \\
\hline $\begin{array}{l}\text { Metamorfismo } \\
\text { regional do fácies } \\
\text { anfibolito }\end{array}$ & $\begin{array}{l}\text { Metamorfismo do fácies anfibolito com migma- } \\
\text { tização e desenvolvimento do bandamento } \\
\text { gnáissico }\left(\mathrm{S}_{\mathrm{N}}\right) \text {. Valores isocrônicos } \mathrm{Pb}-\mathrm{Pb}, \mathrm{Rb}-\mathrm{Sr} \text { e } \\
\text { U-Pb. Possível adição de material juvenil à crosta } \\
\left.\text { (valores } \mathrm{Sm}-\mathrm{Nd}-\mathrm{T}_{\mathrm{DM}}\right)\end{array}$ & $2,0 \pm 0,2$ \\
\hline $\begin{array}{l}\text { Estabilização } \\
\text { Tectônica }\end{array}$ & $\begin{array}{l}\text { Alçamento e resfriamento regional (valores } \mathrm{K}-\mathrm{Ar} \\
\text { em minerais). }\end{array}$ & $1,9 \pm 0,2$ \\
\hline Reativações & $\begin{array}{l}\text { Próximo as zonas de contato com os Domínios } \\
\text { Curitiba, Paranaguá e Cinturäo Dom Feliciano e em } \\
\text { zonas de falhas. }\end{array}$ & $0,6 \pm 0,1$ \\
\hline
\end{tabular}


DOMíNIO Luís ALVES

PRANCHA FOTOGRÁFICA 1 
- Foto 1a - Aspecto geral dos metapiroxenitos de Barra Velha. Rocha intensamente fraturada, levemente foliada, de granulação fina e cor cinza escura. Apresenta textura granoblástica poligonizada, predominando diopsídio e hiperstênio em proporções variadas, além de hornblenda e, mais raramente, plagioclásio.

- Foto 1b - Gnaisses ganulíticos leucocráticos, cinza-esverdeados, granulação fina a média, mostrando alternância milimétrica de níveis claros (plagioclásio e quartzo) e escuros (hornblenda, diopsídio, hiperstênio e biotita). Normalmente com texturas granoblásticas poligonizadas. Detalhe da foliação $\mathrm{Sn}$ transpondo uma superfície anterior (MJ-27 - sul de Pomerode).

- Foto 1c - Gnaisses granulíticos finamente foliados, denotando forte estiramento mineral. Cor cinza a cinza esverdeada. Predominam orto e clinopiroxênios, hornblenda poiquilítica, plagioclásio e quartzo azulado. Textura nematoblástica (MJ-41 - arredores de Massaranduba).

- Foto 1d - Gnaisses granulíticos bandados, leucocráticos, cinza a cinza esverdeados, de granulação média, mostrando alternância de níveis claros (plagioclásio e quartzo) e níveis escuros (clinopiroxênio e hornblenda). Textura granoblástica poligonizada (MJ-385 - BR-277 Curitiba - Paranaguá).

- Foto $1 e$ - Fotomicrografia de gnaisse granulítico da porção setentrional do Domínio Luís Alves (MJ-386 - BR-277 - Curitiba - Paranaguá). Detalhe mostrando ortopiroxênio com estreita borda de transformação para hornblenda (pol. descruzados - 100X).

- Foto 1f - Fotomicrografia de gnaisse granulítico dos arredores de Massaranduba (MJ-05). Detalhe mostrando ortopiroxênio (massa na parte superior a NE) em meio a hornblenda (pol. descruzados 100X). 

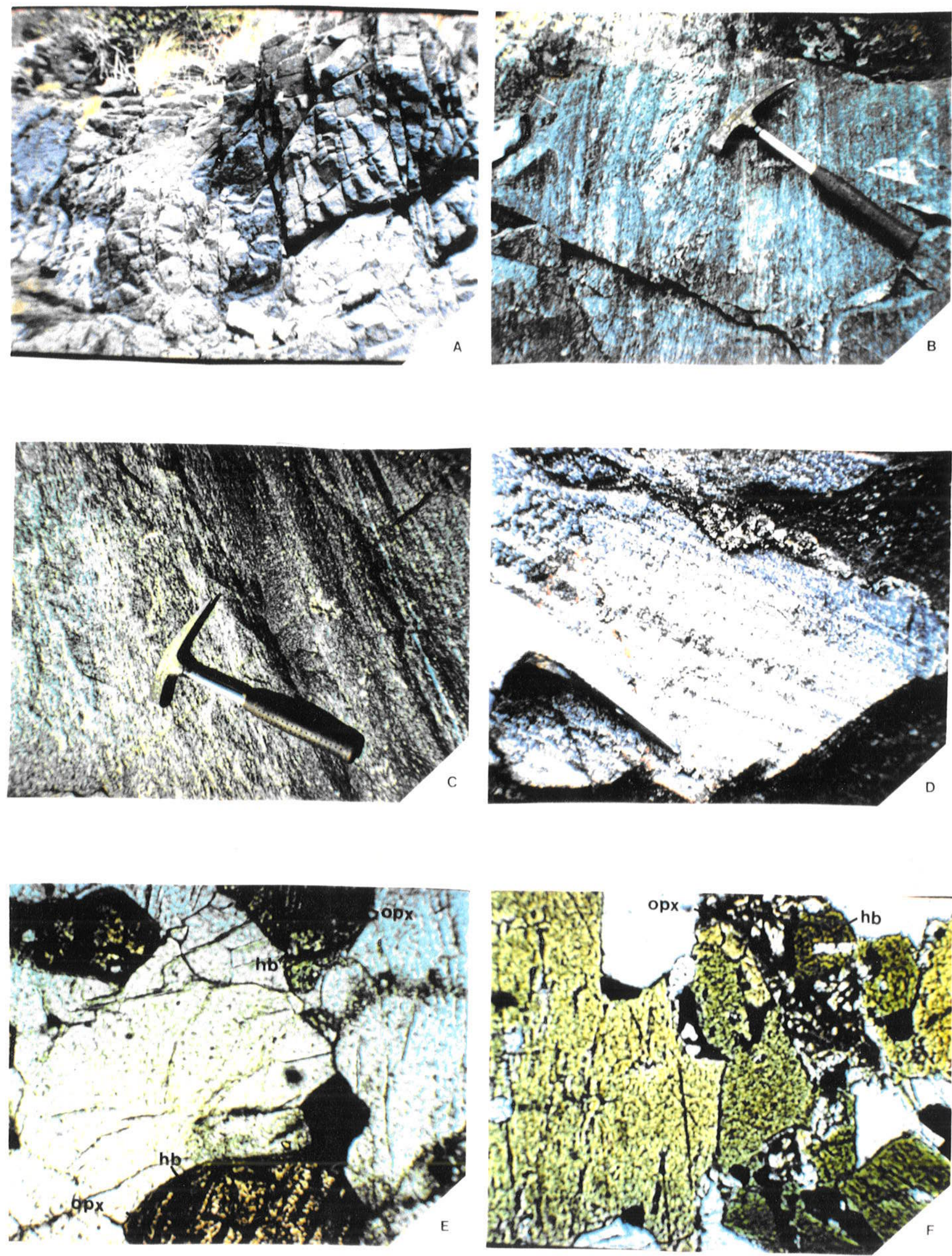


\section{2 - ROCHAS METABÁSICAS E METAULTRABÁSICAS DAS REGIÕES DE PIÊN-TIJUCAS DO SUL}

\subsection{1 - Síntese Geológica}

Nos arredores de Piên-Tijucas do Sul ocorrem rochas de natureza metabásica metaultrabásica, distribuídas próximo ao contato dos gnaisses granulíticos pertencentes ao Domínio Luís Alves e os litotipos gnáissico-migmatiticos do Domínio Curitiba. Alguns desses corpos, a exemplo dos que ocorrem em Campina dos Crispins (proximidades de Piên) e Ribeirão do Meio-Vossoroca (arredores de Tijucas do Sul), parecem balizar o limite noroeste dos gnaisses granulíticos, enquanto outros, à exemplo de Campina dos Maias, Trigolândia, distribuem-se mais a sul, internos ao Dominio Luís Alves (Anexo -1).

Acrescente-se ainda a ocorrência de inúmeras lentes de xistos magnesianos notadamente, nos arredores de Cacatú, já no prolongamento NE do domínio gnáissicogranulítico, próximas ao contato com litotipos gnáissico-migmatíticos do Domínio Curitiba (Anexo -1).

De modo genérico, as rochas metabásicas e metaultrabásicas ocorrem sob a forma de pequenas lentes, centimétricas a decamétricas, ou constituindo corpos que atingem, no máximo, $10 \mathrm{~km}$ de extensão por $2 \mathrm{~km}$ de largura. Tratam-se de rochas normalmente de coloração cinza escura, granulação fina a média, apresentando, quando alteradas, tonalidades cinza-esverdeadas. A variação composicional pode ser observada em alguns dos afloramentos estudados, onde niveis centimétricos ricos em piroxênios (olivina websteritos) alternam-se com niveis a piroxênio e olivinas (Iherzolitos ou harzburgitos), e niveis essencialmente olivínicos (dunitos). Tanto nos arredores de Piên, como nos arredores de Tijucas do Sul são comuns exposições de serpentinitos, sugerindo porções mais ricas em olivinas (dunitos, harzburgitos, Iherzolitos). Nestas rochas foram observadas estruturas nodulares centimétricas de composição piroxenítica, caracterizadas por aglomerados de piroxênios em meio aos serpentinitos.

Os serpentinitos ocorrem adicionalmente, como enclaves de dimensões centimétricas a métricas no Maciço Granítico Agudos do Sul, notadamente a NW de Tijucas do Sul (sentido Palermo). 
O estudo petrográfico realizado, envolvendo a observação de cerca de 30 lâminas deigadas, teve por objetivo principal selecionar amostras favoráveis aos estudos geocronológicos. Abrangeu as seqüências metabásicas e metaultrabásicas de Campina dos Crispins, Campina dos Maias e Trigolândia, com maior ênfase ao primeiro corpo. A mineralogia presente permitiu distinguir, grosseiramente, três grupos principais de rochas (Fig. 3.22). Dois deles, referem-se à seqüências metaultrabásicas de composições peridotíticas (dunitos, harzburgitos, Iherzolitos) e piroxeniticas (olivina ortopiroxênito, olivina websteritos e piroxênitos). O terceiro grupo engloba rochas portadoras de plagioclásio, caracterizando a presença de litotipos metabásicos, de composição gabronorítica (clinopiroxênio noritos).

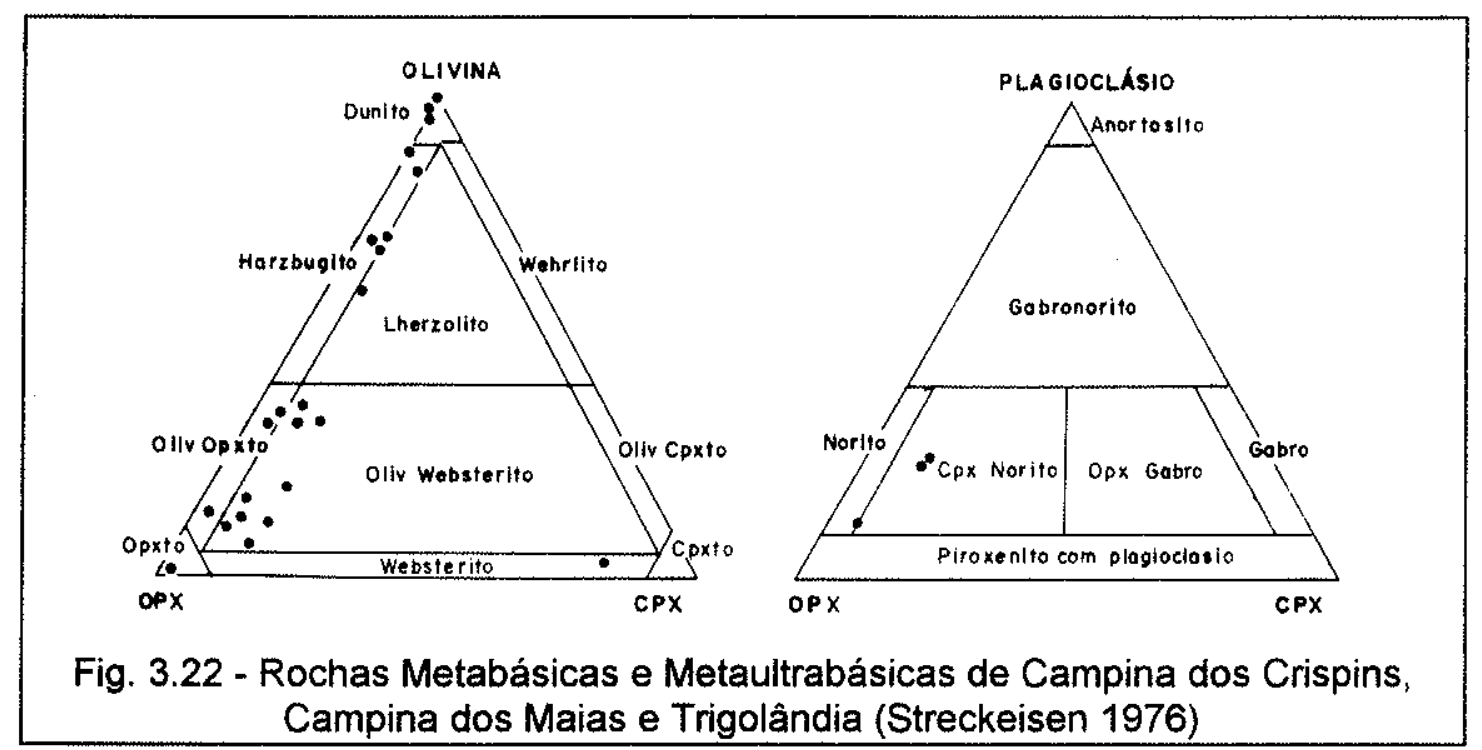

Nos metaperidotitos predominam ortopiroxênios, olivinas, além de serpentinas e, de modo subordinado, clinopiroxênio, espinélio, opacos e, raramente, anfibólio. Nos metapiroxênitos, normalmente, o ortopiroxênio é mais abundante que o clinopiroxênio, ocorrendo adicionalmente olivina, espinélio, anfibólios (pargasita e tremolita-actinolita), além de serpentina, talco, clorita, flogopita, carbonato e opacos.

$O$ aumento da quantidade de plagioclásio em rochas constiutídas predominantemente por ortopiroxênios, define composições gabronoriticas. Nestas rochas ocorrem, subordinadamente, clinopiroxênio, espinélio, anfibólio e opacos.

Os serpentinitos parecem ter-se originado de rochas mais ricas em olivinas, de composição peridotítica. Nestas rochas, a serpentina constitui mais de $80 \%$ dos 
minerais observados, podendo ainda serem identificados restos de olivina e piroxênio, além de clorita e opacos.

Os metaperidotitos, metapiroxênitos e metagabronoritos apresentam, de modo geral, texturas granulares, denotando muitas vezes ângulos de $120^{\circ}$ entre os minerais. Existe grande dificuldade em se esclarecer se a paragênese observada é de origem magmática ou de recristalização metamórfica. Feições retrometamórficas em condições de baixo grau (fácies xisto-verde) foram evidenciadas através da presença de anfibólios e piroxênios, parcialmente transformados em anfibólios fibrosos (tremolita-actinolita), além da presença de talco, serpentina, flogopita e clorita.

Reis Neto et al.(1993) advoga, principalmente, através de texturas tipo adcumulada, onde cristais de ortopiroxênios, clinopiroxênios e olivinas crescem até praticamente se tocarem, apresentando os contornos marcados por minerais opacos, uma origem magmática para esses corpos básicos e ultrabásicos.

Girardi $(1974 ; 1976)$ e Girardi \& Ulbrich (1980) realizaram estudos petrográficos e geoquímicos detalhados nas rochas metabásicas e metaultrabásicas de Piên, envolvendo principalmente os corpos de Campina dos Crispins e de Campina dos Maias. Sugerem através de relações de campo, variação contínua nos parâmetros geoquímicos, composição de olivinas, espinélios e piroxênios, bem como de características petrográficas, uma íritima associação entre esses corpos e rochas de natureza básica que ocorrem nas proximidades (hornblenda-metagabros, anfibolitos e gnaisses anfibolíticos). Englobam esses litotipos no Complexo Básico-Ultrabásico de Piên, sugerindo origem magmática, recristalização em condições do fácies anfibolito alto à granulito e posterior retrometamorfismo no fácies xisto-verde. Sob o ponto de vista petrográfico, além das texturas poligonais, evidenciam nos metaperidotitos a presença de olivinas envolvendo ortopiroxênios, presença em metapiroxênitos de anfibólios (pargasitas a hornblenda tschermakíticas) em desequilíbrio, provenientes da transformação de piroxênios. Sugerem a existência de duas gerações de anfibólios castanhos. Através da análise de piroxênios (de rochas metapiroxeníticas) indicam pressões de cristalização entre 5 e $7 \mathrm{~Kb}$ e temperaturas da ordem de $880^{\circ}-750^{\circ} \mathrm{C}$.

Siga Jr. et al. (1990a, 1993); Machiavelli (1991); Basei et al. (1992) mencionam a possibilidade das rochas metabásicas e metaultrabásicas de Piên representarem restos de um fundo oceânico obductado no Neoproterozóico, definindo assim, uma possivel sutura entre os Domínios Luís Alves e Curitiba. 
Machiavelli (1991) adicionalmente, contesta a cosanguinidade proposta por Girardi $(1974,1976)$ e Girardi \& Ulbrich (1980) entre as rochas metabásicas e metaultrabásicas de Piên e seqüências, predominantemente metabásicas, adjacentes (homblenda metagabros, anfibolitos e gnaisses anfiboliticos), sugerindo uma associação mais intima destes últimos litotipos com os gnaisses granulíticos.

$\mathrm{Na}$ região de Tijucas do Sul-Vossoroca, ocorrem rochas metabásicas e metaultrabásicas, estudadas por Ribas (1993), que menciona a possibilidade de tratarem-se de seqüências correlacionadas às de Piên. Caracteriza a presença de metaperidotitos comumente serpentinizados, metapiroxênitos, talco-xistos, além de rochas de natureza metabásica, representadas por hornblenda metagabros, anfibolitos e hornblenditos, as quais associa geoquimicamente com os gnaisses granulíticos do Domínio Luís Alves. Petrograficamente, Ribas (1993) menciona para as rochas metaultrabásicas, texturas ígneas preservadas ("cumulus" de piroxênio), bem como feições relacionados à recristalização em condições metamórficas de alto grau (poligonização, olivinas envolvendo ortopiroxênios, presença de duas gerações de anfibólios castanhos, "kink bands" em piroxênios e espinélios verdes). O retrometamorfismo do fácies xisto-verde é indicado pela transformação de anfibólios e piroxênios em anfibólios fibrosos (tremolita-actinolitas), presença de clorita, além de talco e serpentina.

Ribas (1993) caracteriza ainda a ocorrência nessa região de testemunhos de seqüências sedimentares, sob a forma de lentes, representadas por magnetitaquartzitos, de caráter itabirítico, granada-quartzitos e granada sillimanita quartzitos, com presença de cristais de clinopiroxênios e ortopiroxênios de origem metamórfica em formação ferrífera.

Em termos geoquímicos, foram analisadas quatorze amostras, envolvendo rochas de composição piroxeníticas, peridotíticas e gabronoríticas, pertencentes aos corpos de Campina dos Crispins, Campina dos Maias e Trigolândia (Apêndice 2). A utilização de diagramas discriminantes de ambientes tectônicos foi prejudicada, devido a imprecisão obtida nos teores de grande parte dos elementos traços, função de concentrações bastante baixas, muitas inclusive inferiores aos limites de detecção.

Os elementos maiores e traços quando tratados em função de MgO mostram, apesar da dispersão dos pontos, a existência de um "trend" entre as rochas de composição peridotítica e piroxenítica e, uma significante inflexão deste alinhamento, 
quando consideradas as rochas de composição gabronorítica (Fig. 3.23). A distribuição desses pontos no eixo das abcissas dos diagramas reflete concentrações de MgO entre $39-37 \%$ (peridotitos), $36-30 \%$ (piroxenitos) e $21-17 \%$ (gabronoritos). Padrão similar fora observado por Girardi (1974) nesta mesma região e por Ribas (1993) em seqüências básicas e ultrabásicas de Tijucas do Sul-Vossoroca.

Quanto ao padrão de distribuição dos ETR, observa-se que as rochas metaperidotíticas apresentam um leve fracionamento em terras raras leves (ETRL), entre sete e tres vezes o valor do condrito. Os valores em terras raras pesadas (ETRP) mostram-se inferiores aos do condrito (Fig. 3.24).

As rochas metapiroxeniticas apresentam comportamento similar quanto aos ETRL, distinguindo-se devido aos teores mais elevados em ETRP, atingindo quatro vezes o valor do condrito. Tal padrão deve refletir a maior afinidade dos ortopiroxênio e clinopiroxênios pelo ETRP, comparativamente as olivinas (Fig. 3.25).

As rochas de composição gabronorítica denotam enriquecimento em ETRL, atingindo cinquenta vezes o valor do condrito (Fig. 3.26), e padrão de ETRP similar ao observado para os metapiroxênitos. $O$ enriquecimento em ETRL deve refletir a maior afinidade dos plagioclásios e anfibólios por esses elementos, comparativamente aos piroxênios e olivinas.

As rochas de composição peridotítica e piroxenítica apresentam anomalias negativas de Eu, denotando a menor afinidade das olivinas e dos piroxênios por esse elemento.

As rochas básicas e ultrabásicas analisadas indicam um enriquecimento em ETR que as distingue do padrão observado para as rochas toleiticas de fundo oceânico, formadas a partir de um manto do tipo N-MORB. Tais características sugerem proveniência de um manto enriquecido em ETR, do tipo E-MORB (Wilson 1989). Adicionalmente, não devem ser descartadas as possibilidades de modificações geoquímicas significativas terem sido introduzidas por processos metamórficos, de serpentinização, talcificação, saussuritização e mesmo de contaminação crustal. 

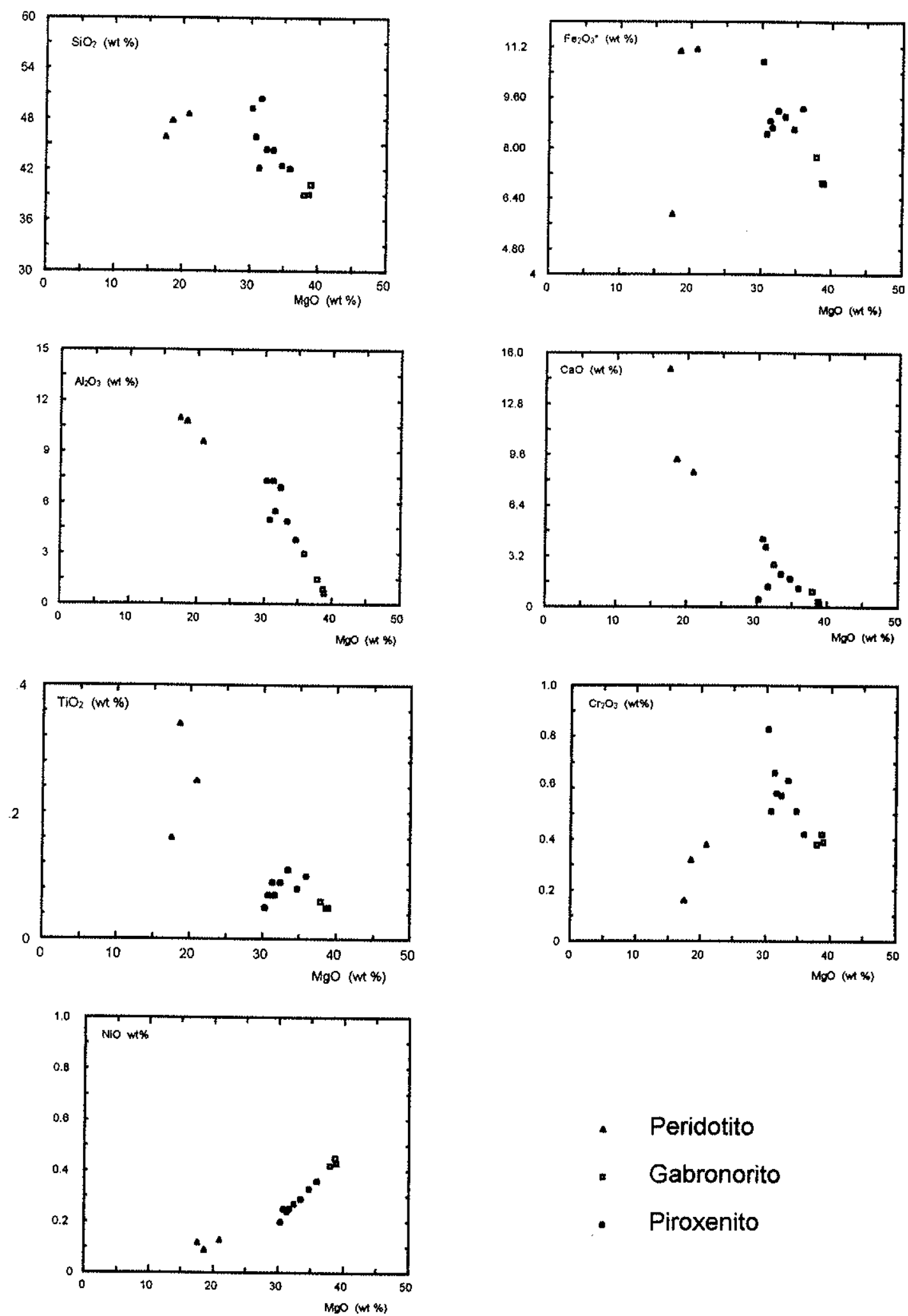

- Peridotito

- Gabronorito

- Piroxenito

Fig. 3.23 - Peridotitos, Piroxenitos e Gabronoritos de Piên - Elementos Maiores e Traços $\times$ MgO. 


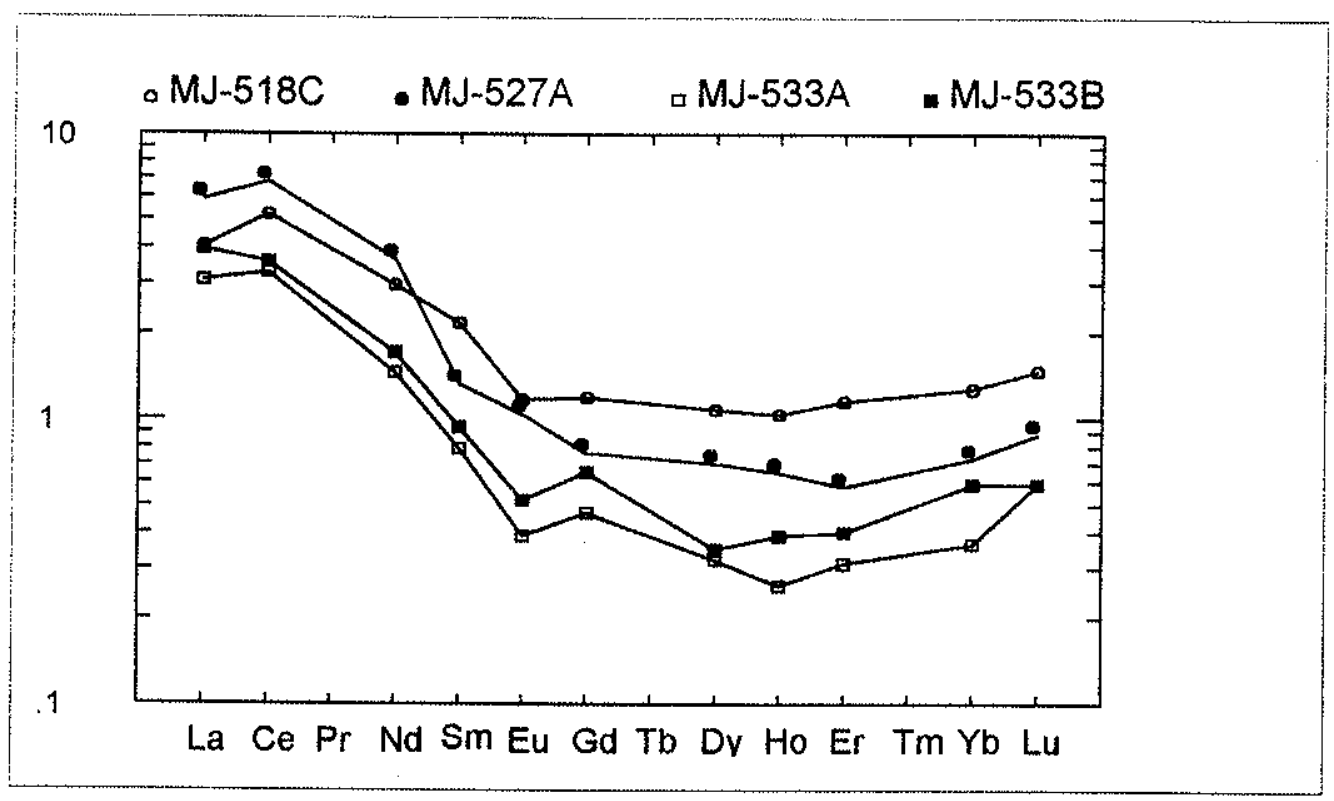

Fig. 3.24 - Padrão de distribuição de ETR - Metaperidotitos de Piên (normal. Evensen et al. 1978)

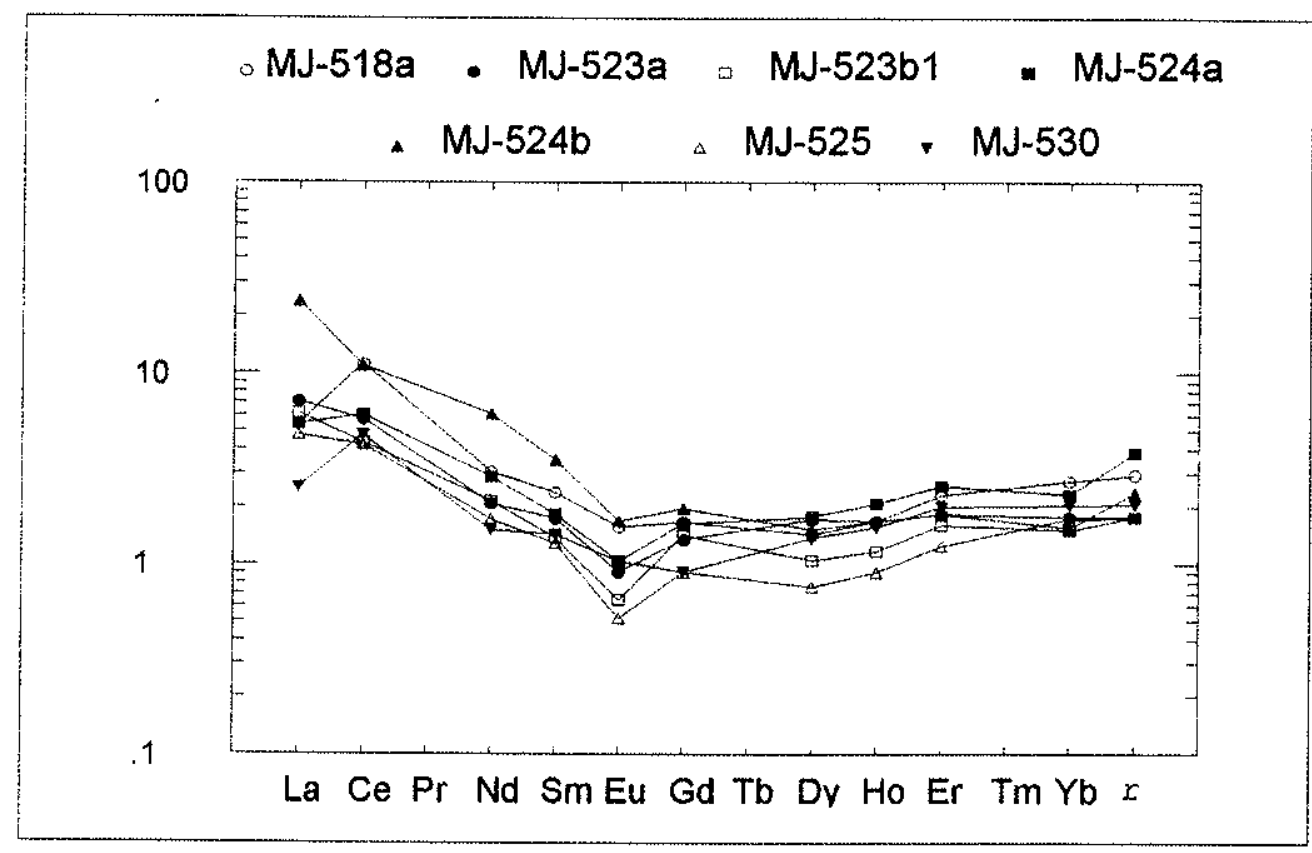

Fig. 3.25 - Padrão de distribuição de ETR - Metepiroxenitos de Piên (normal. Evensen et al. 1978) 


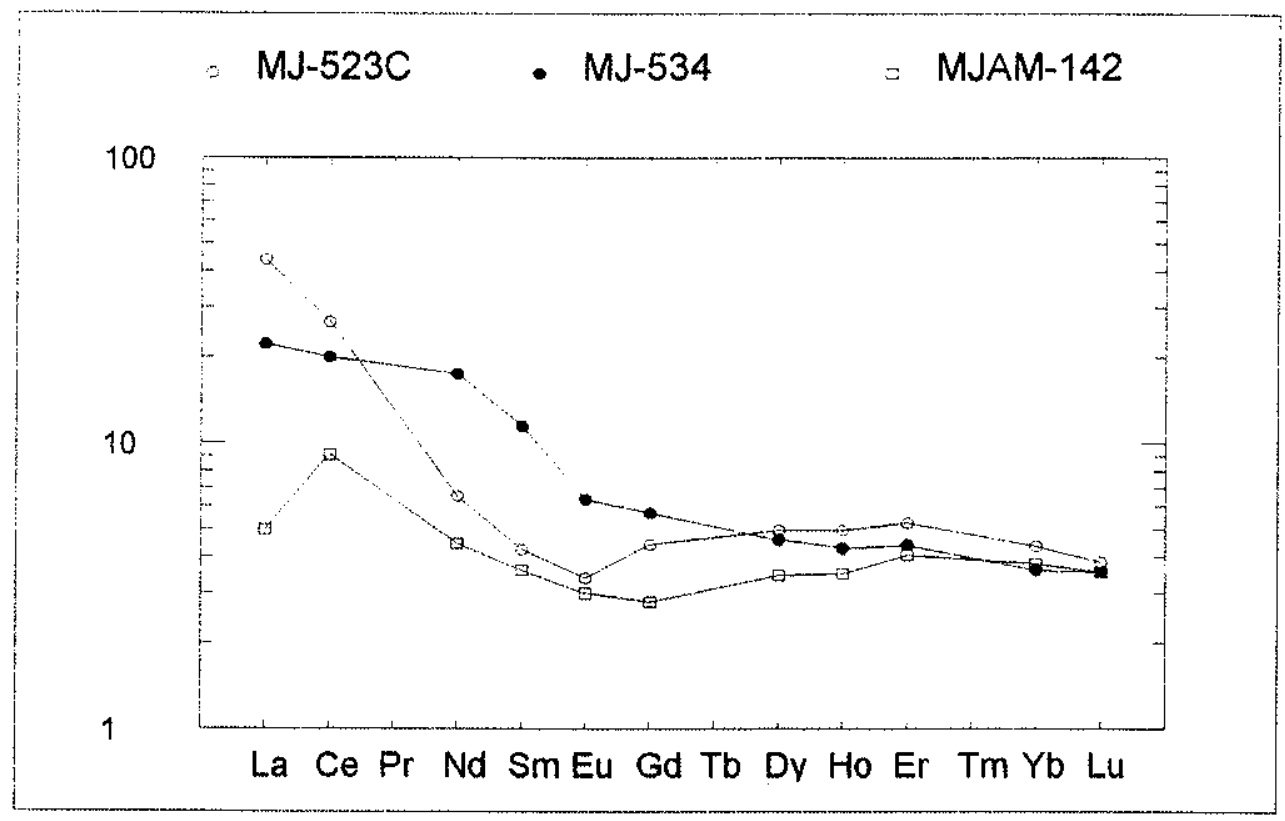

Fig. 3.26 - Padrão de distribuição de ETR - Metagabronoritos de Piên (normal. Evensen et al. 1978)

Do ponto de vista estrutural, essas rochas metabásicas e metaultrabásicas caracterizam-se por apresentarem uma foliação subparalela ao bandamento composicional, que se mostra em alguns afloramentos, plano axial de dobras normalmente centimétricas, isoclinais.) Uma clivagem oblíqua, com desenvolvimento de serpentinas, talco, cloritas, tremolita-actinolitas pode ser regionaimente reconhecida. Essa clivagem mostra-se plano axial de dobras métricas, abertas, bem visivel na pedreira de serpentinitos localizada nas proximidades de Piên.

Para a seqüência metabásica-metaultrabásica de Campina dos Crispins observa-se uma orientação predominantemente nordeste para a foliação $S_{n}$, com características de cisalhamento dúctil. O comportamento espacial dessas superfícies pode ser observado no estereograma $\left(N^{\circ} 8\right.$, Anexo 3) que apresenta máximo à $\mathrm{N} 51^{\circ} \mathrm{E} / 59^{\circ} \mathrm{NW}$. Tal diagrama sugere adicionalmente, o dobramento cilíndrico dessa foliação, observado a nivel de afloramento, com atitude para o eixo construido de $\$ 76^{\circ} \mathrm{W} / 38^{\circ}$, similar ao padrão observado para as rochas granito gnáissicas do Domínio Curitiba.

As estruturas lineares geradas nesse processo de deformação (Fig. 8, Anexo-3) incluem lineações do tipo b (eixos de dobras e lineaçöes de intersecção), bem como 
lineações do tipo a, relacionadas ao eixo $x$ do elipsóide, presentes na foliação $\mathrm{S} n$. As lineações minerais ou do tipo a, acopladas a indicadores cinemáticos são extremamente importantes, uma vez que podem fornecer informações acerca do transporte tectônico. Embora, tais rochas não tenham se mostrado favoráveis ao desenvolvimento dessas estruturas, foi possivel em alguns afloramentos observar nos planos da foliação Sn uma lineação, representada principalmente pelo estiramento de agregados minerais, muitas vezes fibrosos. Estas lineações sugerem uma tectônica de cisaihamento cuja movimentação envolve uma componente lateral bastante expressiva. A escassez de indicadores cinemáticos, por outro lado, não permitiu caracterizar o sentido de movimento.

Os corpos localizados mais a sul, na localidade de Campina dos Maias, demostram um comportamento estrutural um pouco distinto, com dobras intrafoliais e foliação apresentando baixos mergulhos $\left(S_{n}\right.$ máximo de N68E/19NW). Acrescente-se que a foliação $S_{n}$ dos gnaisses granulíticos, localizados nas proximidades, apresenta concentração máxima em N62E $75 \mathrm{NW}$, com lineações minerais concentradas em $\mathrm{S} 70^{\circ} \mathrm{W} / 45^{\circ}$, sugerindo o envolvimento da margem noroeste do Domínio Luís Alves nessa tectônica controlada por cisalhamentos (Harara et al. 1994).

\subsubsection{Geocronologia}

Análises isotópicas de rochas de natureza básica e principalmente ultrabásica, necessitam de acompanhamento petrográfico cuidadoso, uma vez que é comum a presença de minerais parcial ou totalmente talcificados, serpentinizados e saussuritizados.

Determinações radiométricas através do método $\mathrm{K}-\mathrm{Ar}$ em minerais, tornam-se possiveis somente em plagioclásios, quando este ainda preserva suas caracteristicas primárias. A separação de anfibólios, quando presentes, é impraticável, pois piroxênios, olivinas e espinélios normalmente estão associados. Junte-se a isto os teores extremamente baixos em potássio que compõem a mineralogia presente.

Os teores de $\mathrm{Rb}$ e $\mathrm{Sr}$ também bastante baixos impedem suas quantificaçöes precisas, mesmo utilizando-se de metodologias refinadas com emprego de spikes (diluição isotópica). Além disso, a mobilidade desses elementos pode ser facilitada através de processos secundários, principalmente de serpentinização e talcificação. 
Uma das poucas metodologias radiométricas aplicada com sucesso em seqüências ultramáficas, refere-se ao método isocrônico $\mathrm{Sm}-\mathrm{Nd}$, em rocha total. Isso se deve as relações $\mathrm{Sm} / \mathrm{Nd}$ mostrarem-se mais elevadas nessas rochas permitindo uma significativa dispersão dos pontos analíticos em diagrama.

Análises $\mathrm{Sm}-\mathrm{Nd}$, em rocha total, foram realizadas, pioneiramente no CPGeo, envolvendo quatro amostras da seqüência metaultrabásica de Campina dos Crispins, selecionadas em função de pré-dosagens efetuadas nos laboratórios da Geosol (Apêndice 1). Para garantir uma completa dissolução e homogeneização dessas rochas, o ataque químico foi efetuado em bombas de teflon colocadas em estufas à $200^{\circ} \mathrm{C}$, por vários dias.

Os dados obtidos apresentaram-se relativamente bem distribuídos e alinhados em diagrama isocrônico $\mathrm{Sm}-\mathrm{Nd}$, fornecendo idade de $2.248 \pm 46 \mathrm{Ma}$, para uma relação inicial $\mathrm{Nd}^{143} / \mathrm{Nd}^{144}$ de $0,50961 \pm 0,00005$ (Fig. 3.27). Tal valor é aqui interpretado como relativo a época de formação dessas rochas.

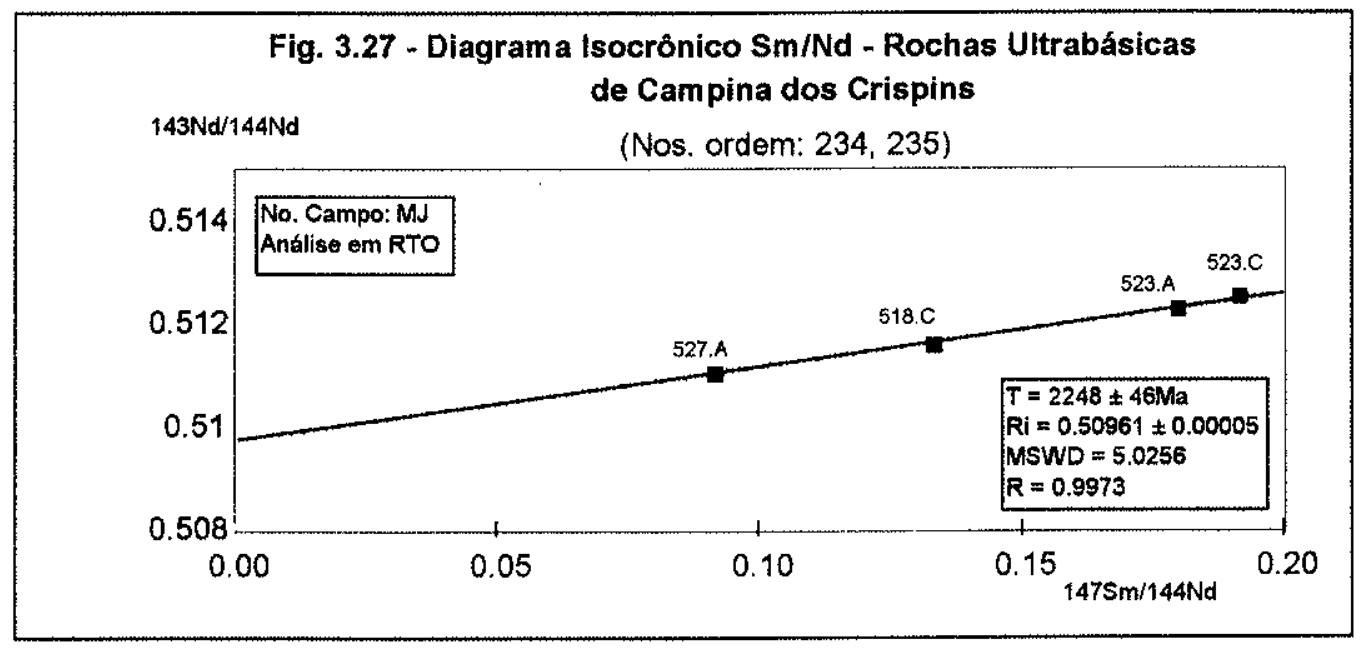

As idades modelo $\mathrm{Sm}-\mathrm{Nd}\left(\mathrm{TD}_{\mathrm{M}}\right)$, por outro lado, que permitem inferir acerca da época de diferenciação desse material do manto distribuem-se entre 2500-3650Ma (Apêndice 1). Tal intervalo de valores indica diferenças significativas nas relações Sm$\mathrm{Nd}$ por ocasião do fechamento do sistema ( $\pm 2250 \mathrm{Ma}$ ), propiciando evoluções distintas nas razōes $\mathrm{Nd}^{143} / \mathrm{Nd}^{144}$. A idade modelo $\left(\mathrm{T}_{D M}\right)$ de $2.750 \mathrm{Ma}$ representa o valor médio, possivelmente mais próximo a realidade quanto a época de derivação desse material do manto. 
O parâmetro $\varepsilon_{\mathrm{Nd}}$ de $-2,5$, calculado para a idade de $2.250 \mathrm{Ma}$, sugere um período de residência crustal desse material, indicando épocas anteriores para sua diferenciação do manto. Os dados obtidos sugerem, preliminarmente, que a diferenciação desse material do manto teria ocorrido no Arqueano (épocas próximas de $2.750 \mathrm{Ma}$ ). Processos de recristalização metamórfica em alto grau com consequente fechamento isotópico do sistema (colocação a niveis crustais superiores) teria ocorrido durante o Paleoproterozóico, ciclo Transamazônico (2.250Ma). Padrão similar foi observado para as rochas gnáissico-granuliticas adjacentes, indicando que tais épocas devam corresponder a marcos geotectônicos importantes na evolução deste setor.

O Apêndice 1 mostra uma tentativa de datações $\mathrm{Rb}-\mathrm{Sr}$ em rochas ultramáficas de Campina dos Crispins, selecionadas em função das baixas porcentagens em minerais secundários. As análises foram realizadas em duas etapas, envolvendo quantidades relativamente elevadas de amostra $(0,1$ a $0,3 \mathrm{~g})$. A primeira, efetuada com intuito de pré-quantificar os teores de $\mathrm{Rb}$ e $\mathrm{Sr}$ presentes, permitindo assim, uma precisão na dosagem dos "spikes" utilizados na segunda determinação. Os dados relativos ao corpo de Campina dos Crispins mostraram-se bastante dispersos em diagrama isocrônico, onde foi construída uma reta média de $2.000 \mathrm{Ma}$ com uma relação inicial $\left(\mathrm{Sr}^{87} / \mathrm{Sr}^{86}\right)_{i}$ de 0,703 , de pouco ou nenhum significado geológico (Fig. 3.28).

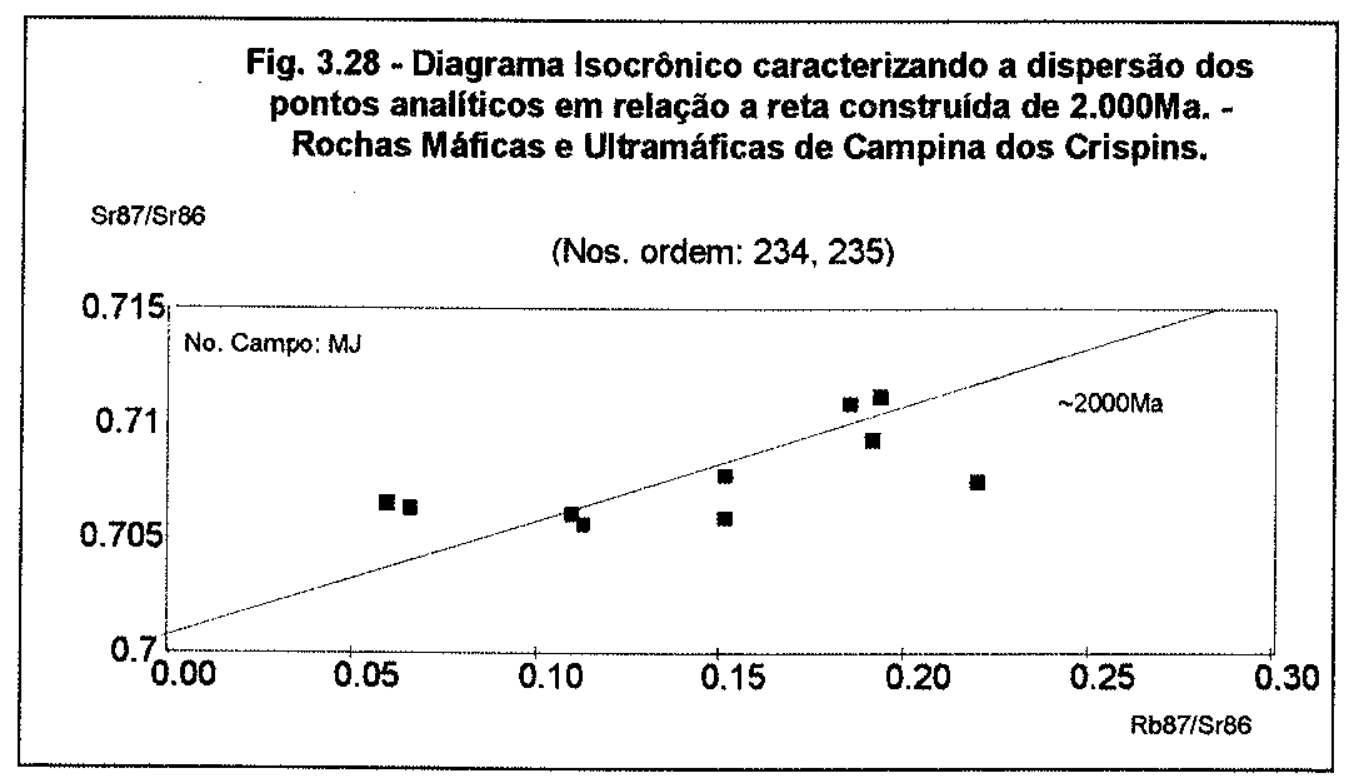


Algumas dessas análises foram realizadas em duplicata, indicando uma excelente reprodutibilidade dos dados, sugerindo que a dispersão observada em diagrama isocrônico represente um intenso desequilíbrio isotópico do sistema $\mathrm{Rb}-\mathrm{Sr}$.

Os dados K-Ar disponiveis referem-se a análises obtidas por Girardi et al. (1974) em corpos de rochas metabásicas intercalados nos gnaisses granulíticos do Domínio Luis Alves (Apêndice 1). Valores de 1.866 \56Ma (anfibólio) e $1.018 \pm 23 \mathrm{Ma}$ (plagioclásio) foram obtidos para o corpo de hornblenda matagabro dos arredores de Campina dos Maias, e do intervalo 583-456Ma (biotitas e plagioclásios) para os corpos localizados a nordeste de Piên (número de campo: VG-194) e a sul de Campina dos Maias (número de campo: VG-79). Os valores relativos ao Meso e Neoproterozóico (análises em biotitas e plagioclásios) sugerem perdas parciais $(1.018 \mathrm{Ma})$ e totais $(586$ 456Ma) de argônio, frente ao metamorfismo do fácies xisto-verde impresso nessas rochas. O anfibólio, por outro lado, acusa idade do Paleoproterozóico (ciclo Transamazônico), sugerindo que as isotermas não atingiram temperaturas superiores a $500^{\circ} \mathrm{C}$, nessa porção, durante o Neoproterozóico. 
ROCHAS BÁsICAS - ULTRABÁSICAS dE PIÊN

PRANCHA FOTOGRÁFICA 2 
- Foto 2a - Aspecto bandado realçado na superfície de alteração, mostrando a alternância de níveis piroxeníticos (maciços) e serpentiníticos (finamente foliados). Rocha de cor cinza escura a cinza esverdeada, de granulação fina, denotando em lâmina delgada textura granoblástica poligonizada (MJ-523 - borda sul do corpo de Campina dos Crispins).

- Foto $2 \mathrm{~b}$ - Aspecto geral dos serpentinitos de Campina dos Crispins. Rocha de granulação fina, cinza esverdeada, composta predominantemente por serpentinas e, subordinadamente, por hiperstênio, diopsídio, olivina, espinélio e opacos. Detalhe da foliação oblíqua ao bandamento ígneo/metamórfico regional (MJ-527 - Pedreira Campina dos Crispins).

- Foto $2 c$ - Nível de composição piroxenítica em meio a serpentinitos. Rocha de granulação fina, cinza escura a cinza esverdeada. Detalhe mostrando bandamento dobrado, com foliação plano-axial (MJ-533 Campina dos Maias).

- Foto $2 d$ - Dobras métricas em serpentinitos de Campina dos Crispins. Rocha de granulação fina, cinza esverdeada, composta predominantemente por serpentinas (MJ-521). A fase de dobramento é associada à observada na foto $2 \mathrm{c}$.

- Foto 2e - Fotomicrografia de piroxenito de Campina dos Crispins (MJ-525), mostrando textura granoblástica poligonizada entre ortopiroxênios. Presença de espinélios intersticiais (Pol. cruzados - 100X)

- Foto $2 f$ - Fotomicrografia de serpentinitos de Campina dos Maias (MJ-533) mostrando textura granoblástica poligonizada. Restos de olivinas preservadas (núcleo) em meio a porções serpentinizadas. Os opacos (magnetitas) ocorrem em fraturas e contorno dos grãos (Pol. descruzados - 100X). 

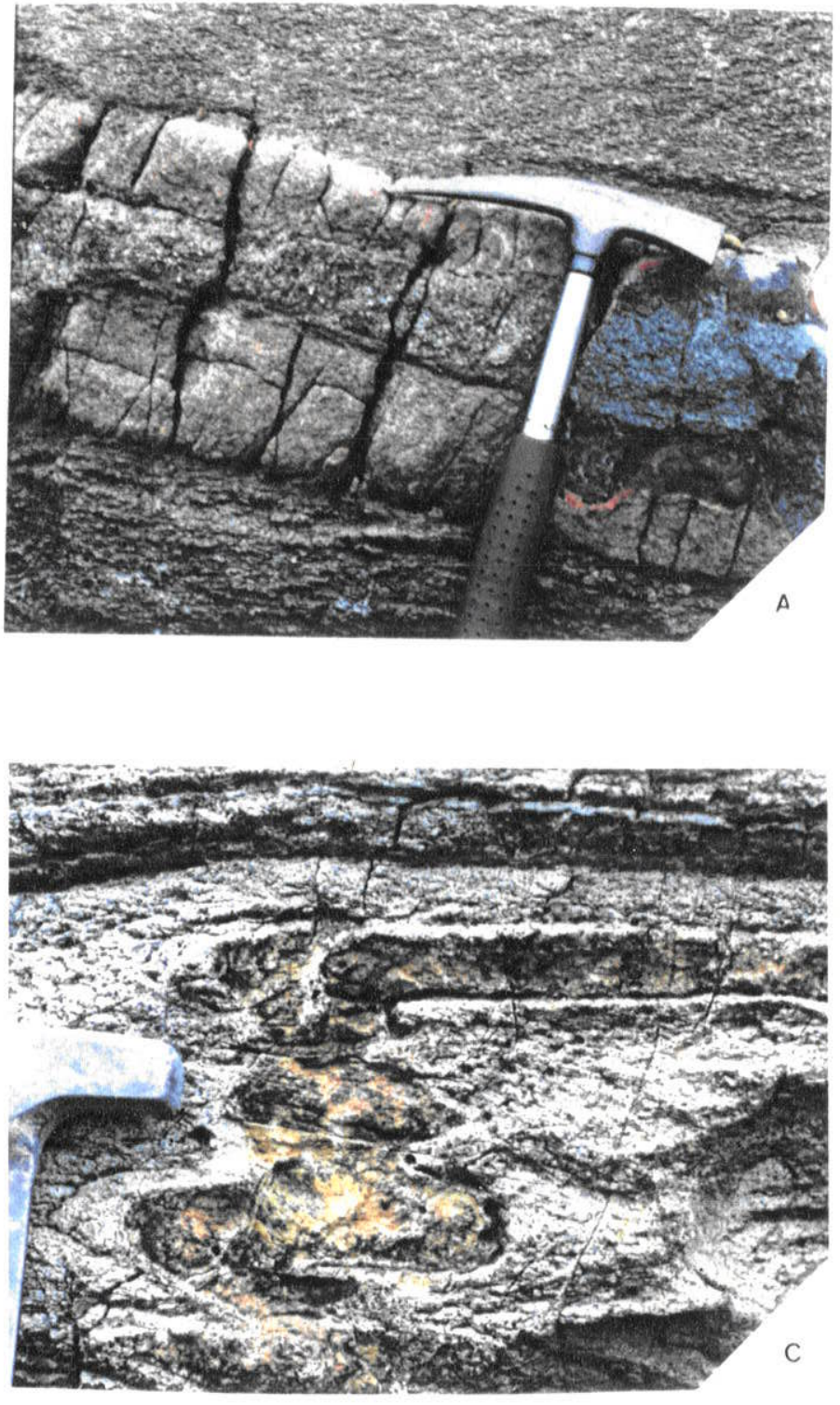
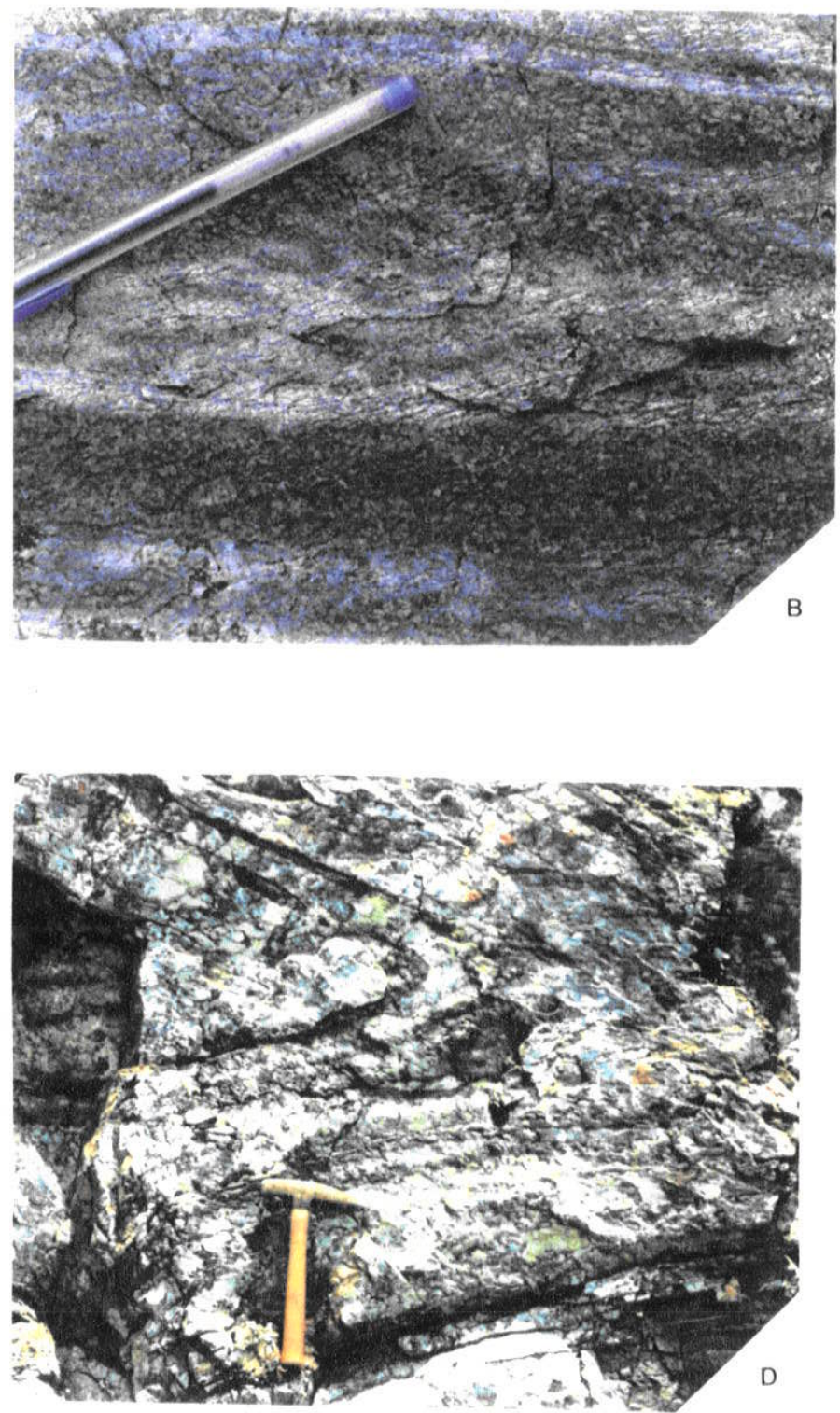

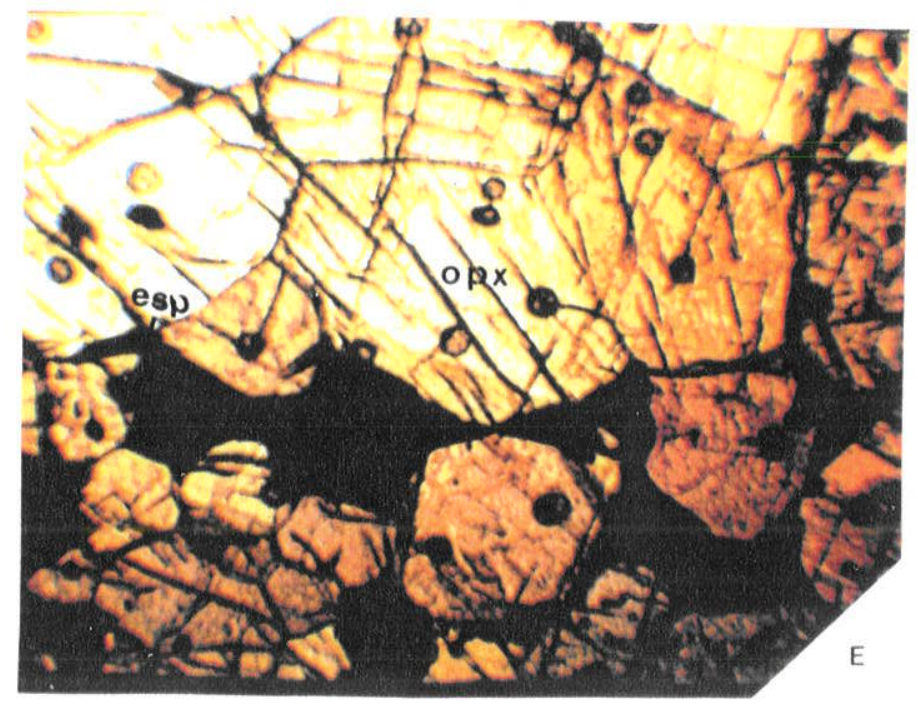




\section{CAPÍTULO 4}

\section{DOMÍNIO CURITIBA}

O Domínio Curitiba ocupa a porção setentrional estudada, constituindo uma faixa relativamente estreita (extensões médias da ordem de 50 a $60 \mathrm{Km}$ ) e alongada segundo a direção NE-SW. Limita-se no setor noroeste com as seqüências metassedimentares dos Grupos Açungui e Setuva e, a sudeste com os gnaisses granuliticos do Domínio Luís Alves, contatos esses que se fazem por importantes zonas de cisalhamento (anexo 1).

A grande dificuldade no posicionamento desses terrenos, no quadro evolutivo da região, advém de diversos fatores tais como: complexidade litológica (uma vez que inclui rochas gnáissico-migmatíticas, gnáissico-granulíticas, granito-gnáissicas, granitóides deformados, anfibolitos e xistos magnesianos), constraste metamórfico e distinto padrão estrutural e geocronológico, quando comparados aos domínios adjacentes.

Em termos cartográficos, os mapas geológicos executados, na década de 60 , pela Comissão da Carta Geológica do Paraná (1:50.000, 1:70.000, 1:75.000) e, posteriormente, na década de 70 , pela CPRM, através do Projeto Leste do Paraná (1:100.000), integrados no Mapa Geológico do Estado do Paraná, escala 1:650.000 (Biondi et al. 1989), em muito contribuiram para o estudo deste segmento.

Sob o ponto de vista geocronológico,os dados disponíveis para esse domínio eram escassos, totalizando sete análises $\mathrm{K}$-Ar em minerais e oito análises $\mathrm{Rb}-\mathrm{Sr}$ em rocha total, concentradas na porção E-NE de Curitiba. Os valores obtidos (Batolla Jr. et al. 1977; Cordani \& Abrão, inédito; Kaul et al. 1984) distribuem-se principalmente entre 600 e $500 \mathrm{Ma}$.

Quatro das análises isotópicas $\mathrm{Rb}-\mathrm{Sr}$ foram realizadas por ocasião da execução do Projeto Leste do Paraná, CPRM (Batolla Jr. et al. 1977), e indicaram em diagrama isocrônico idade de aproximadamente $1400 \mathrm{Ma}$ para uma relação inicial $\left(\mathrm{Sr}^{87} / \mathrm{Sr}^{86}\right)_{i}$ de 0.715 . Tratam-se de rochas gnáissico-migmatíticas, localizadas a norte de Curitiba, coletadas em diferentes afloramentos, cujos pontos analíticos mostram-se mal distribuidos e relativamente dispersos no diagrama, devendo portanto o valor obtido ser encarado com ressalvas. 


\subsection{ROCHAS GNÁISSICO-MIGMATÍTICAS REGIONAIS}

\subsection{1 - Sintese Geológica}

Os metassedimentos pertencentes ao Grupo Açunguí, que se distribuem na porção noroeste, fora dos limites da região estudada, mostram-se afetados por importantes zonas de cavalgamento, orientadas segundo direções NE-SW e com transporte de NW para SE (Fiori 1992). Esta tectônica coloca as rochas do Grupo Açungui por sobre as seqüências essencialmente ortognáissicas do Domínio Curitiba, onde se encontra impressa uma forte foliação milonítica orientada segundo NE-SW.

Esse contato é balizado nas proximidades de Curitiba (W-NW), por um corpo ígneo, representado por rochas graníticas hololeucocráticas, que se extende por mais de $20 \mathrm{Km}$ de comprimento, tendo de 5 a $10 \mathrm{Km}$ de largura. Tratam-se de rochas que afloram quase sempre alteradas, de granulação média a grossa, tonalidades brancorosadas, a quartzo e fesdspato, e que se apresentam fortemente foliadas.

Nesta porção setentrional, arredores de Campo Largo, estendendo-se rumo a Colombo, ocorrem corpos de dimensões desconhecidas, representados por rochas gnáissico-granuliticas, de granulação média, com tonalidades cinza-esverdeadas e composições variando de mangeríticas a noriticas (Perrota \& Morais 1992). Apresentam texturas granoblásticas, por vezes protomiloníticas, contendo em maior ou menor proporção plagioclásio (andesina-labradorita), K-feldspato (microclínio), quartzo, hornblenda (verde-oliva), piroxênios (diopsídio e hiperstênio) e granada. A foliação é definida por forte estiramento e achatamento mineral.

De Curitiba para sudeste, distinguem-se grosseiramente, dois pacotes de gnaisses bandados, migmatíticos, sendo um deles a mesossoma de biotita anfibólio gnaisses e leucossoma de composição tonalito-granodioritica. Essas rochas predominam na porção centro-norte do Domínio Curitiba, distribuindo-se à sudeste de Bocaiúva do Sul e estendendo-se como uma faixa relativamente contínua para sudoeste, arredores de Araucária. $\mathrm{Na}$ porção meridional predominam gnaisses bandados, migmatíticos, de composição granítica-granodiorítica.

Os gnaisses bandados são normalmente leucocráticos, com termos mesocráticos, de granulação média e texturas granonematoblásticas, granolepidoblásticas e por vezes, granoblásticas. Săo frequentes intercalações de corpos 
anfibolíticos, por vezes granatíferos, bem como de xistos magnesianos, cujas dimensões e formas mostram-se variadas, ocorrendo desde lentes centimétricas intercaladas nos gnaisses à corpos métricos, podendo se constituir na litologia predominante.

São comuns, feições relacionadas a uma segunda fase de migmatização, cujos mobilizados róseos, de granulação fina a média, até muito grossa, concordantes ou não com o bandamento gnáissico, são os indicadores mais evidentes.

Os gnaisses bandados limitam-se na porção meridional deste dominio, através de zona de cisalhamento (Lineamento Mandirituba-Piraquara), com granitóides heterogeneamente deformados (Anexo-1). Representa um conjunto de rochas, denominadas por Machiavelli et al. (1993) de Suite Granítica Rio Piên. Apresentam granulação média a grossa, em geral cor cinza-rosada, leucocrática, apresentando de maneira esparsa megacristais de feldspatos brancos e/ou rosados. Esses granitóides balizam o limite sul-sudeste do Domínio Curitiba e foram interpretados como pertencentes a raizes de um provável arco magmático do Proterozóico Superior (Machiavelli et al. 1991 e 1993; Machiavelli 1991).

Petrograficamente, foram observadas cerca de trinta lâminas delgadas, abrangendo, principalmente, os mesossomas dos gnaisses bandados e, em menor proporção, os granitóides da Suite Rio Piên, com objetivo de fundamentar os estudos geocronológicos realizados.

De maneira bastante sucinta, destaca-se no âmbito dos gnaisses bandados a presença de plagioclásio (albita-oligoclásio, por vezes zonado e com lamelas encurvadas), quartzo (grãos irregulares com extinção ondulante), hornblenda (pleocroismo de verde claro a verde escuro, normalmente poiquilitica), biotita (por vezes ausente, pleocroismo de marrom claro a pardo), k-feldspato (presença rara, apresentando geminação em grade, fortemente saussuritizado) e clorita (normalmente associada a biotita). Nos termos mais mesocráticos podem ocorrer, adicionalmente, hiperstênio e/ou diopsidio (relictos internos aos anfibólios) e granada. Os minerais acessórios comuns são allanita, titanita, zircão, apatita e opacos e, como produtos de alteração, epidoto e carbonato.

Observa-se a presença de arcos poligonais em hornblendas, que por vezes mostram alguns de seus cristais discordantes do bandamento dado pelos demais minerais. Tal fato, acoplado a presença de relictos de hiperstênio, internos aos 
anfibólios, é sugestivo de que o metamorfismo de grau médio impresso nessas rochas, tenha se desenvolvido sobre seqüências de mais alto grau metamórfico e, ao menos localmente, de fácies granulito. Um retrometamorfismo em grau baixo é sugerido pela presença de clorita, zoizita e epídoto.

Para os granitóides da Suite Rio Piên destaca-se a presença de plagioclásio (cristais inequigranulares, com bordas irregulares, em geral, zonados), quartzo (cristais anédricos com evidências de recuperação e recristalização), K-feldspato (ortoclásio e microclínio, por vezes, pertítico), hornblenda (pleocroismo de verde claro a escuro, associada a biotitas), e biotita (principaimente como produto da transformação de hornblendas, ocorrendo ainda como inclusão em outros cristais de biotita). Os minerais acessórios comuns são titanita, zircão, apatita, allanita e opacos, ocorrendo carbonato, epídoto e clorita como minerais secundários. Em termos de metamorfismo, as evidências de recristalização de quartzo e biotita $e$, eventualmente de microclínio e plagiociásio, sugerem para a gnaissificação regime predominantemente dúctil. Esta neoformação de minerais indica uma reestabilização sob condições de grau fraco, zona da biotita.

Quando analisados em diagrama QAP (Streckeisen 1976), conjuntamente com os dados obtidos por Machiavelli (1991), esses granitóides mostram composições quartzo-monzodioríticas, quartzo-monzoníticas, granodioriticas e monzograníticas (Fig. 4.1, estimativas visuais).

Utilizando-se a classificação petrogenética de Lameyre \& Bowden (1982), observa-se que estes granitóides posicionam-se num campo intermediário, entre as séries cálcio-alcalina granodiorítica, de médio $\mathrm{K}$ e cálcio-alcalina monzonitica de alto $\mathrm{K}$.

Geoquimicamente, foram realizadas análises, em quatro amostras deste domínio: nas rochas gnáissico-granuliticas que ocorrem a norte de Curitiba (MJ-25.3), em porções anfibolíticas contendo granada (MJ-137) e em bandas mesocráticas pertencentes aos gnaisses bandados (MJ-138 e MJ-96.3). Os dados obtidos. relativos a elementos maiores, traços e terras raras, encontram-se no Apêndice 2. 


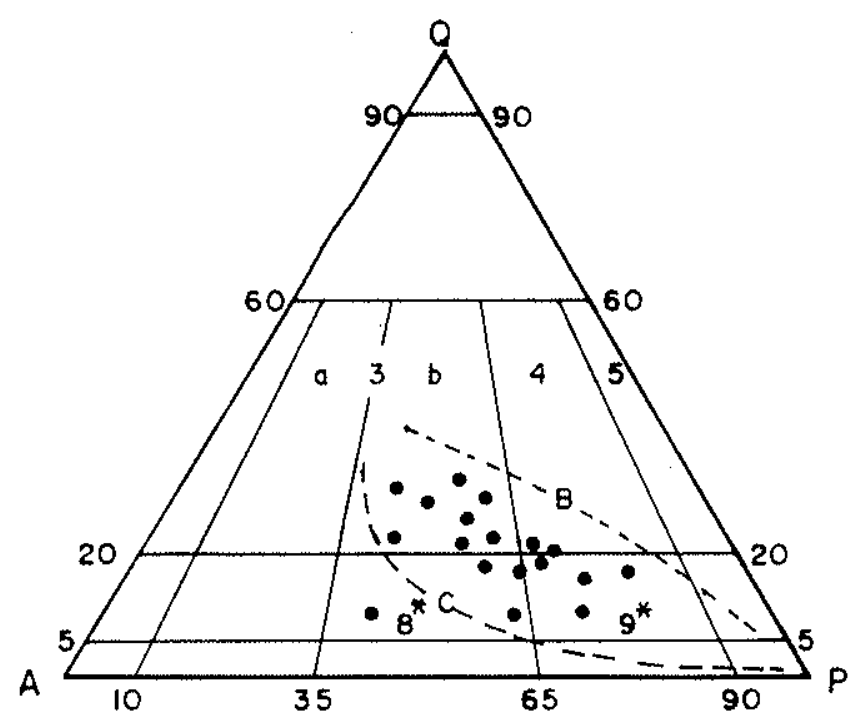

FIG.4.1-DIAGRAMA QAP MOSTRANDO A CLASSIFICAÇĀO PETROGRAFICA DOS GRANITÓIDES DE PIẼN SEGUNDO A PROPOSICAĀO DE STRECKEISEN (1.976) 3b) = MONZOGRANITO; 4) = GRANODIORITO; $8^{*}$ ) =QUARTZO MONZONITO E $\left.9^{*}\right)$ = QUARTZO MONZODIORITO, E PETROGENÉTICA SEGUNDO LAMEYRE 8 BOWDEN (1982), COM OS "TRENDS" DAS SERIES CÁLCIO-ALCALINA GRANODIORÍTICA, DE MÉDIO K (B) E CALCIO-ALCALINA MONZONÍTICA, DE ALTO $K(C)$

Embora pouco representativos deste domínio, uma vez que somente quatro amostras foram analisadas, uma afinidade cáicio-alcalina pode ser grosseiramente observada em diagrama $R_{1} \times R_{2}$, similarmente ao padrão obtido para os gnaisse granuliticos do Domínio Luís Alves (Fig. 4.2). Os padrões de terras raras são fortemente fracionados e indicam na rocha gnáissico-granulitica (amostra de número de campo: MJ-25.3) anomalia positiva de európio (Fig. 4.3). 


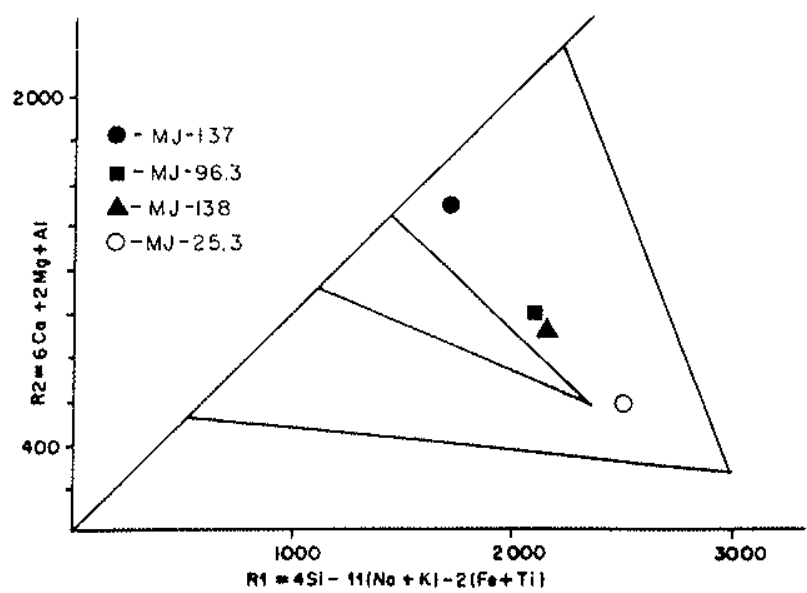

Fig. 4.2 - Diagrama $R_{1}-R_{2}$ (De La Roche et al. 1980) Domínio Curitiba

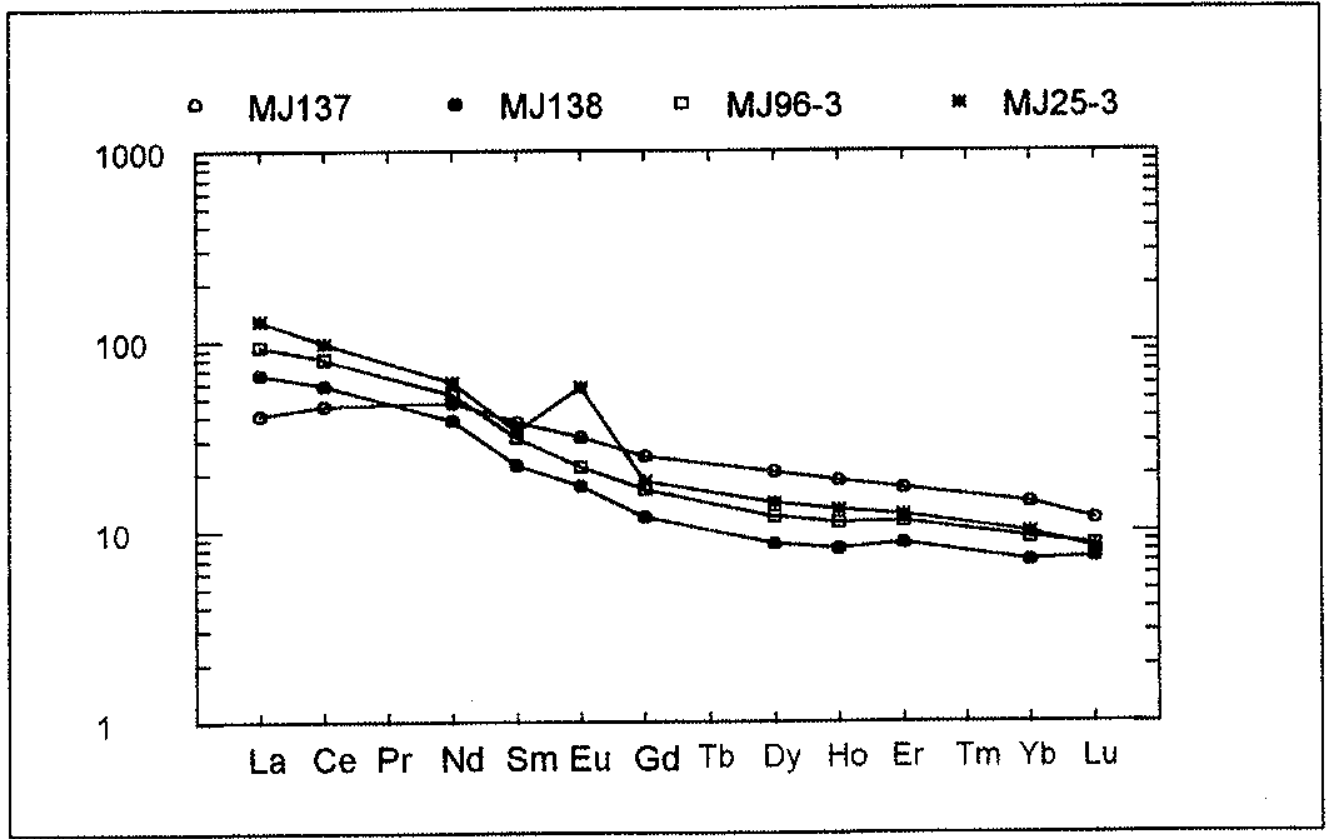

Fig. 4.3 - Padrão de Terras Raras - Domínio Curitiba (normalizado segundo Evensen et al. 1978) 
Para os granitóides da Suite Rio Piên, Machiavelli (1991) realizou análises geoquímicas em onze amostras, envolvendo elementos maiores, alguns traços e terras raras. O tratamento desses dados indicou a existência de dois conjuntos, geoquimicamente distintos, denominados de Granito Sudeste e Granito Noroeste. Tal diferenciação foi sugerida principalmente em diagramas $\mathrm{SiO}_{2} \times$ óxidos, $\mathrm{SiO}_{2} \times$ traços, bem como em diagramas discriminantes (Brown 1982, Pearce et al. 1984) que indicaram, adicionalmente, a formação desses granitóides em ambientes de arco vulcânico. Em termos de ETR, o próprio autor chama atenção ao padrão similar apresentado por esses granitóides quando comparados aos sin-colisionais (segundo Pearce et al. 1984). Entretanto, feições mineralógicas e geoquímicas, tais como o de enriquecimento em $\mathrm{Ba}$ quando comparado ao $\mathrm{Rb}$, levaram Machiavelli (1991) a admitir a formação desses granitóides em ambiente de arco vulcânico maturo.

Algumas feições, no entanto, como os elevados teores em $\mathrm{Rb}$ e baixos em $\mathrm{Ce}$ e Nb, determinam um padrão fortemente fracionado desses granitóides. As razões $\mathrm{Rb} / \mathrm{Yb}$ são da ordem de 250 , muito superiores à dos granitóides relacionados a subducção em arcos vulcânicos, a exemplo do Chile, onde tal relação é da ordem de 62. Tais valores são comparáveis a média dos granitos colisionais $(300)$ ou mesmo pós-colisionais (200), segundo Pearce et al. (1984). O enriquecimento em LILE e empobrecimento nos elementos menos incompativeis, chegando a valores de $\mathrm{Y}$ e $\mathrm{Yb}$ inferiores a 0,1 não são associados a granitóides relacionados a subducção.

Do ponto de vista estrutural, verifica-se para todo domínio norte uma orientação predominantemente nordeste, que inclui a superfície $S_{n}$ (principal) dos leucogranitos, gnaisses granulíticos, gnaisses bandados e granitóides da Suite Rio Piên. Essas superfícies correspondem a uma foliação $S_{2}$, paralela ao bandamento nos gnaisses, e uma foliação $S_{1}$, nos granitóides da Suite Rio Piên. Apresenta características que sugerem uma deformação controlada principalmente por cisalhamento dúctil, com feldspatos rotacionados, forte estiramento dos anfibólios e do quartzo, paralelo ao sentido de transporte.

Verifica-se na maioria das unidades deste domínio (estereogramas de 1 a 8 Anexo-3) dobras, provavelmente cilindricas da foliação $S_{n}$, orientadas na direção NESW. Essas dobras, observadas a nível de afloramento, admitem uma clivagem plano axial e correspondem a principal fase de dobramento regional a afetar a foliação $S_{n}$. 
Nos gnaisses bandados é um dobramento $D_{3}$, enquanto nos granitóides da Suite Rio Piên é uma fase $D_{2}$. Os estereogramas (anexo-3) indicam para os eixos construídos valores $\mathrm{N} 30-50^{\circ} \mathrm{E} / 5-30^{\circ}$ e $550-70^{\circ} \mathrm{W} / 20-40^{\circ}$.

As estruturas lineares incluem lineações $b$, representadas pelos eixos das dobras tardias e intersecções de superfícies $S_{2} / S_{3}$ (gnaisses bandados) e $S_{1} / S_{2}$ (granitóides da Suite Rio Piên), bem como lineações minerais do tipo a, relacionadas ao eixo $x$ do elipsóide de deformação. As lineações minerais referem-se principalmente a cristais de quartzo, feidspato, anfibólio, ou mesmo de agregados minerais, que se apresentam estirados nos planos da foliação $S_{n}$. Estas, distribuem-se preferencialmente no quadrante NE e mais raramente, SW e NW, apresentando mergulhos relativamente baixos (Anexo-3), sugerindo uma tectônica de cisalhamento com importante componente lateral. Os indicadores cinemáticos (relações $S_{\varepsilon} / S_{c} e$ feldspatos rotacionados) sugerem um transporte predominantemente de NE para SW.

As zonas de contato entre os granitóides da Suite Rio Piên e as rochas adjacentes (gnaisses graníticos do setor setentrional e gnaisses granulíticos do Domínio Luís Alves) são marcadas por faixas de protomilonitos a milonitos (Lineamentos: Mandirituba-Piraquara, a norte e Piên-Tijucas do Sul e Morretes-Cacatú, a sul). As rochas que ocorrem neste setor apresentam granulação fina, sendo a foliação milonítica marcada pela disposição paralela dos filossilicatos e o forte estiramento dos cristais de quartzo e feldspato, que se apresentam, na maioria das vezes, como porfiroclastos. As lineações minerais destas faixas miloníticas acopladas aos indicadores cinemáticos indicam um transporte de NE para SW, com importante vetor resultante dominantemente lateral, com sentido de movimento sinistral.

Acrescente-se que padrão estrutural bastante similar foi descrito por Fiori (1990) nos mestassedimentos do Grupo Açungui, na região de Rio Branco do Sul (norte de Curitiba).

\subsection{2 - Geocronologia}

O estudo geocronológico de rochas pertencente ao Domínio Curitiba mostrouse bastante complexo, uma vez que esses terrenos são constituídos por uma grande variedade de migmatitos. Os mesossomas incluem anfibólio gnaisses, biotita gnaisses, anfibólio biotita gnaisses, gnaisses-granulíticos, granito gnaisses, granitóides alcali- 
cálcicos, anfibolitos e xistos magnesianos. Os leucossomas presentes, em maior ou menor proporção, apresentam-se homogenea a heterogeneamente distribuídos $e$ denotam muitas vezes, ao longo de um mesmo afloramento, composições distintas (graníticas, granodioríticas, tonalíticas, incluindo mobilizados róseos, onde predomina o K-feldspato).

As variáveis envolvidas no estudo geocronológico desses terrenos incluem aspectos relacionados a representatividade do sistema rocha total das amostras coletadas, o grau de homogeneização isotópica entre os constituintes, bem como a gênese complexa dos mesmos. Tais fatos fizeram com que fossem realizados, sempre que possivel, estudos radiométricos envolvendo além do sistema rocha total, as diferentes fases minerais presentes.

São disponiveis para o Domínio Curitiba cerca de 160 determinações geocronológicas, através dos métodos $\mathrm{K}-\mathrm{Ar}$, $\mathrm{Rb}-\mathrm{Sr}$ e $\mathrm{Sm}-\mathrm{Nd}$, em minerais e rocha total, além de U.Pb em zircões.

A aplicação da metodologia $\mathrm{Rb}-\mathrm{Sr}$ (rocha total), em gnaisses granulíticos localizados a norte de Curitiba envolveu dezenas de amostras, coletadas em diferentes afloramentos, uma vez que as razōes $\mathrm{Rb} / \mathrm{Sr}$ mostravam-se constantemente baixas e relativamente próximas. Foram selecionadas para datação amostras de três corpos, que apresentaram distribuição das relaçōes $\mathrm{Rb}^{87} / \mathrm{Sr}^{86}$ entre 0,3 e 1,4. Os dados analíticos referentes as amostras do afloramento de número de campo MJ-25 mostraram certa dispersão em diagrama isocrônico, indicando idade de $1.826 \pm 96 \mathrm{Ma}$, para uma relação inicial $\left(\mathrm{Sr}^{87} / \mathrm{Sr}^{86}\right)_{i}$ de $0,71051 \pm 0,00383$ (Fig. 4.4). Os dados relativos aos corpos localizados a oeste, afloramentos de número de campo MM-87 e MM-89, apresentaram-se dispersos no diagrama isocrônico, denotando forte desequilíbrio isotópico do sistema $\mathrm{Rb}-\mathrm{Sr}$ (Fig. 4.4). Um alinhamento paralelo foi tentativamente traçado, envolvendo três das amostras datadas, indicando mesma idade ( $\sim 1830 \mathrm{Ma})$ e relação inicial inferior $(\sim 0,707)$, de pouco ou nenhum significado geológico. 
Fig. 4.4 - Diagrama Isocrônico Rb-Sr em rocha total para os Gnaisses Granuliticos localizados a Norte de Curitiba.

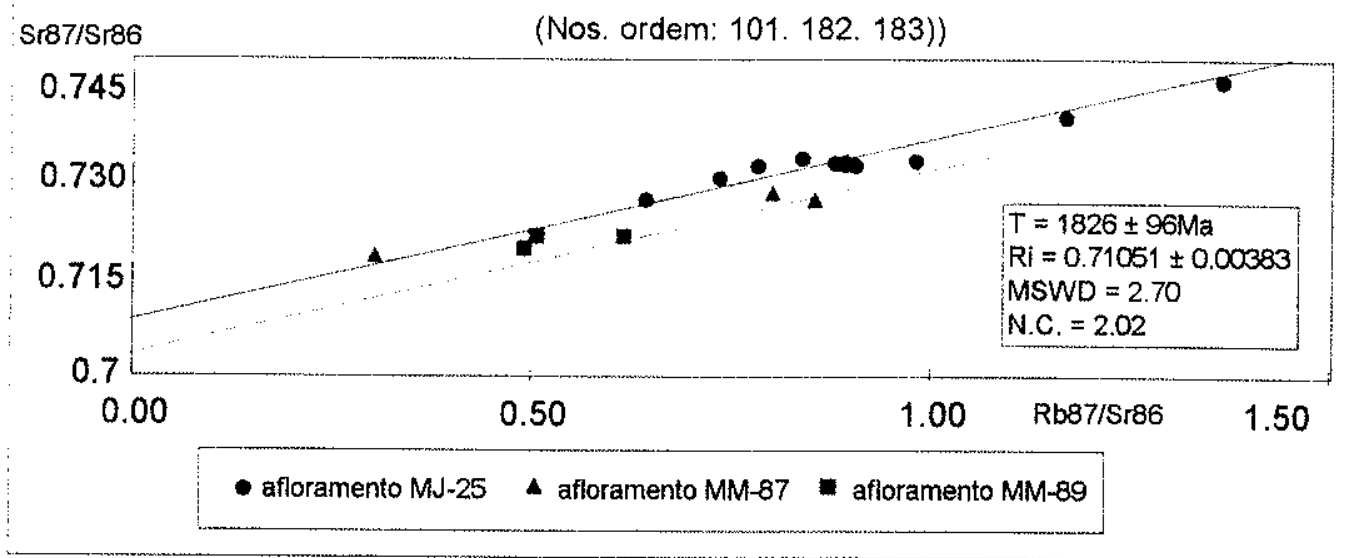

Numa tentativa de melhor definir a idade obtida, foram realizadas datações $U$ $\mathrm{Pb}$, em três frações de zircão, da amostra de número de campo $\mathrm{MJ}-25.11$, relativa aos gnaisses granulíticos acima analisados. Os pontos analiticos distribuiram-se próximos a curva concórdia, indicando idade de $2.095 \pm 5 \mathrm{Ma}$. interpretada como relacionada à época de cristalização dos zircões (Fig. 4.5).

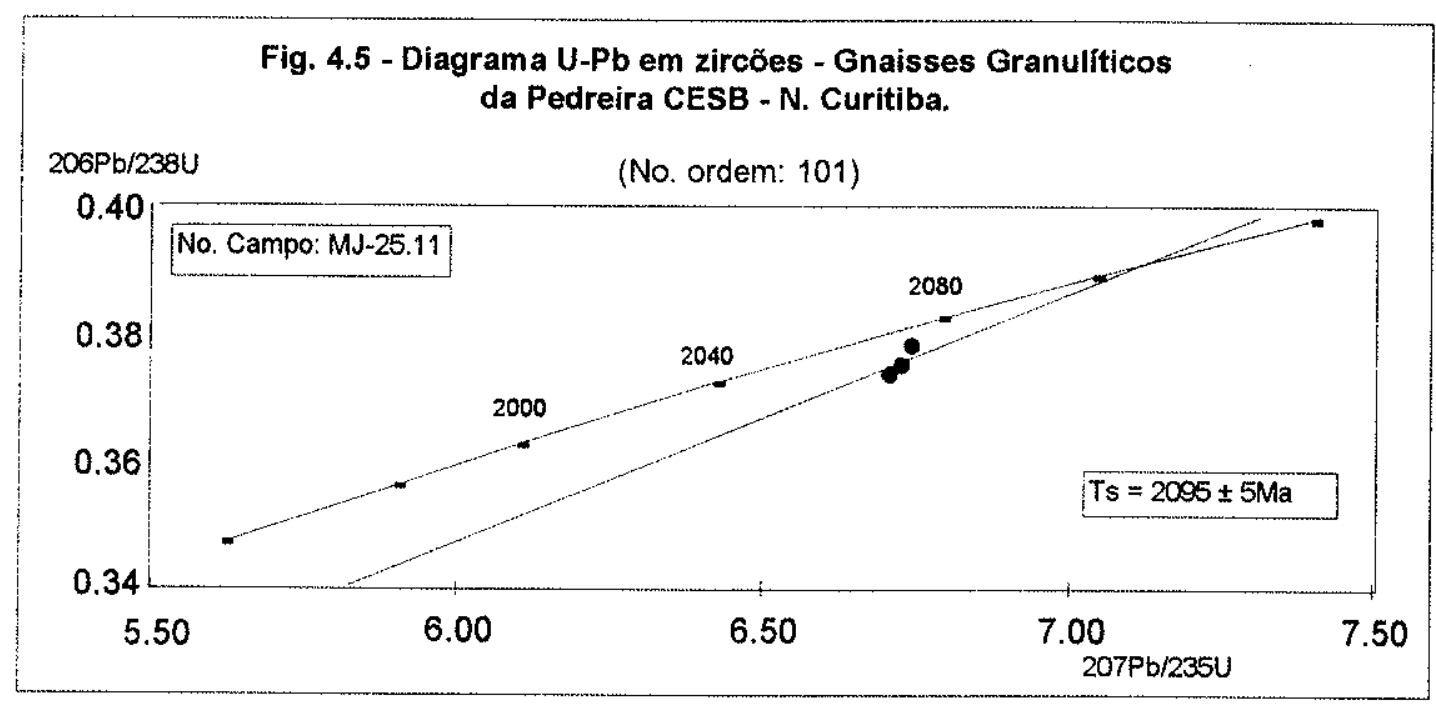

A ausência de biotita, aliada a presença de piroxênios e anfibólios, cuja separação é impraticável, restringiu a aplicação da metodologia K-Ar nesses gnaisses granulíticos. Uma única amostra (MM-89D), contendo quantidades significativas de 
anfibólios e baixa porcentagem em piroxênio, permitiu a obtenção de um concentrado com cerca de $85 \%$ de hornblenda, que indicou idade de $1.755 \pm 70 \mathrm{Ma}$ (Apêndice-1). 0 elevado erro obtido para a idade deve refletir a presença de impurezas no material analisado.

Adicionalmente, realizou-se uma análise $S m-N d\left(T_{D M}\right)$, da amostra de número de campo MJ-25.3, que acusou idade modelo de 2.822Ma, interpretada como relativa a época em que os precursores crustais dessas rochas derivaram-se do manto (Apêndice-1).

Pelo exposto, os dados obtidos caracterizam a formação dessas rochas no Paleoproterozóico (Cicio Transamazônico), indicando adicionalmente que as mesmas, encontravam-se relativamente frias (isotermas inferiores à $500^{\circ} \mathrm{C}$ ) no Neoproterozóico (Ciclo Brasiliano). Este padrão geocronológico é bastante similar ao observado para os gnaisses-granulíticos do Domínio Luís Alves, discutido em capítulo anterior.

Ainda nesta porção norte do Domínio Curitiba, ocorrem rochas gnáissicas de composições enderbíticas a charnoenderbíticas, distribuidas em três pequenos afloramentos, localizados a oeste do Maciço Granitico da Graciosa (MJ-292C), bem como no interior do mesmo (MJ-294.1 e 296). As inúmeras análises semi-quantitativas de $\mathrm{Rb}$ e $\mathrm{Sr}$ realizadas em amostras pertencentes a esses afloramentos restringiram a utilização da sistemática isocrônica, uma vez que as relações $\mathrm{Rb} / \mathrm{Sr}$ bastante similares, não permitiram a distribuição adequada dos pontos analíticos em diagrama. Mesmo assim, com 0 intuito de se verificar a possibilidade dessas rochas representarem porções antigas, pré-brasilianas, foram realizadas três análises, representativas dos afloramentos mencionados. A idade obtida, de $2.116 \pm 95 \mathrm{Ma}$, para uma relação inicial $\left(\mathrm{Sr}^{87} / \mathrm{Sr}^{86}\right)_{\text {i }}$ próxima de 0,702 (Fig. 4.6), sugere, de modo precário, tratar-se de rochas formadas no Paleoproterozóico (ciclo Transamazônico), embora sejam necessárias análises adicionais, visto que tal alinhamento, envolvendo praticamente dois pontos, pode ser fortuito e sem significado geológico.

No âmbito dos gnaisses bandados, envolvidos em maior ou menor grau pela migmatização, foram selecionados para estudos geocronológicos, afloramentos localizados nas proximidades de Curitiba, Mandirituba e Quitandinha.

Ao longo da BR-116, a NE de Curitiba, foram analisadas através do método $\mathrm{Rb}-\mathrm{Sr}$ em rocha total, cinco amostras, pertencentes a três afloramentos (MJ-550, 633.A 


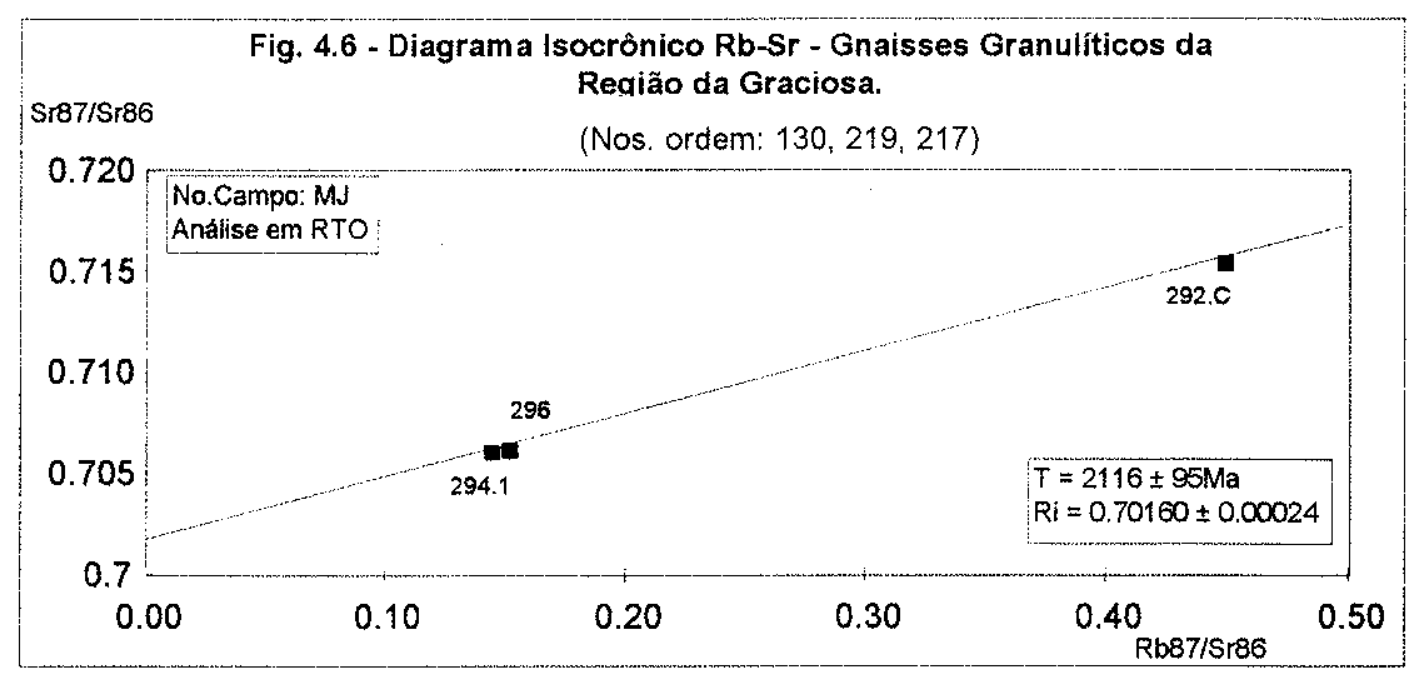

e 638.A, B, C) de biotita anfibólio gnaisses bandados de composição tonalítica. Tais amostras, apresentaram relações $\mathrm{Rb}^{87} / \mathrm{Sr}^{86}$ relativamente baixas e próximas entre si, denotando em diagrama isocrônico uma forte dispersão dos pontos analíticos, refletido no elevado valor do MSWD. A idade obtida, de $2.220 \pm 26$ Ma para uma relação inicial $\left(\mathrm{Sr}^{87} / \mathrm{Sr}^{86}\right)_{\mathrm{i}}$ de $0,70660 \pm 0,00009$, sugere, como no caso anterior, a formação dessas rochas no Paleoproterozóico (ciclo Transamazônico, Fig. 4.7).

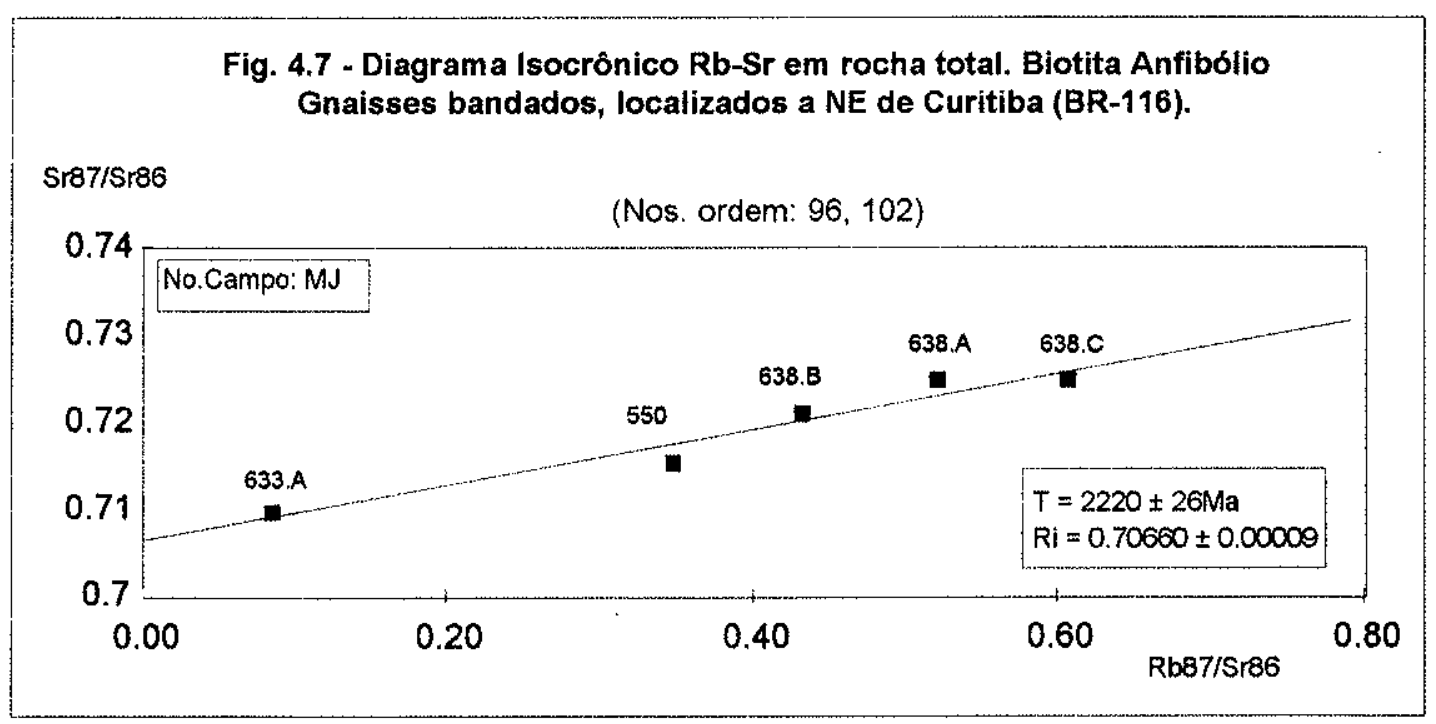

Análises $\mathrm{K}$-Ar realizadas em biotitas e anfibólios de alguns desses afloramentos (MJ-550, 638.A, 636.A e 639.1) distribuiram-se no intervalo 650-600Ma, indicando que 
Análises $\mathrm{K}$-Ar realizadas em biotitas e anfibólios de alguns desses afloramentos (MJ-550, 638.A, 636.A e 639.1) distribuiram-se no intervalo 650-600Ma, indicando que essas rochas atingiram isotermas superiores a $450-500^{\circ} \mathrm{C}$ durante o Neoproterozóico (Apêndice-1).

Ainda nas proximidades de Curitiba (Pedreira Atuba), ocorrem rochas gnáissico-migmatíticas, cujos mesossomas são predominantemente biotita anfibólio gnaisses, e os leucossomas apresentam composições tonalito-granodioriticas. Uma segunda fase de migmatização inclui bandas róseas, ricas em K-feldspato. $O$ estudo geocronológico realizado através do método $\mathrm{Rb}-\mathrm{Sr}$ envolveu principalmente as porções mesossomáticas, sendo efetuado tanto a nível de rocha total como de minerais. Os dados analíticos relativos ao sistema rocha total, mostraram-se bastante dispersos em diagrama isocrônico $\mathrm{Rb}-\mathrm{Sr}$, denotando forte desequilíbrio isotópico desses elementos. A reta que melhor se ajusta a esses pontos (inclui somente cinco amostras: MJ-96.1, 96.3, 96.4, 96.6 e 96.8), apresentou idade de $598 \pm 48 \mathrm{Ma}$, para uma relação inicial $\left(\mathrm{Sr}^{87} / \mathrm{Sr}^{86}\right)_{i}$ de $0,71650 \pm 0,00220$ (Fig. 4.8). Duas análises realizadas em bandas leucossomáticas, róseas, não se encontram representadas nesse diagrama por apresentarem relações $\mathrm{Rb}^{87} / \mathrm{Sr}^{86}$ mais elevadas, posicionando-se acima da reta mencionada.

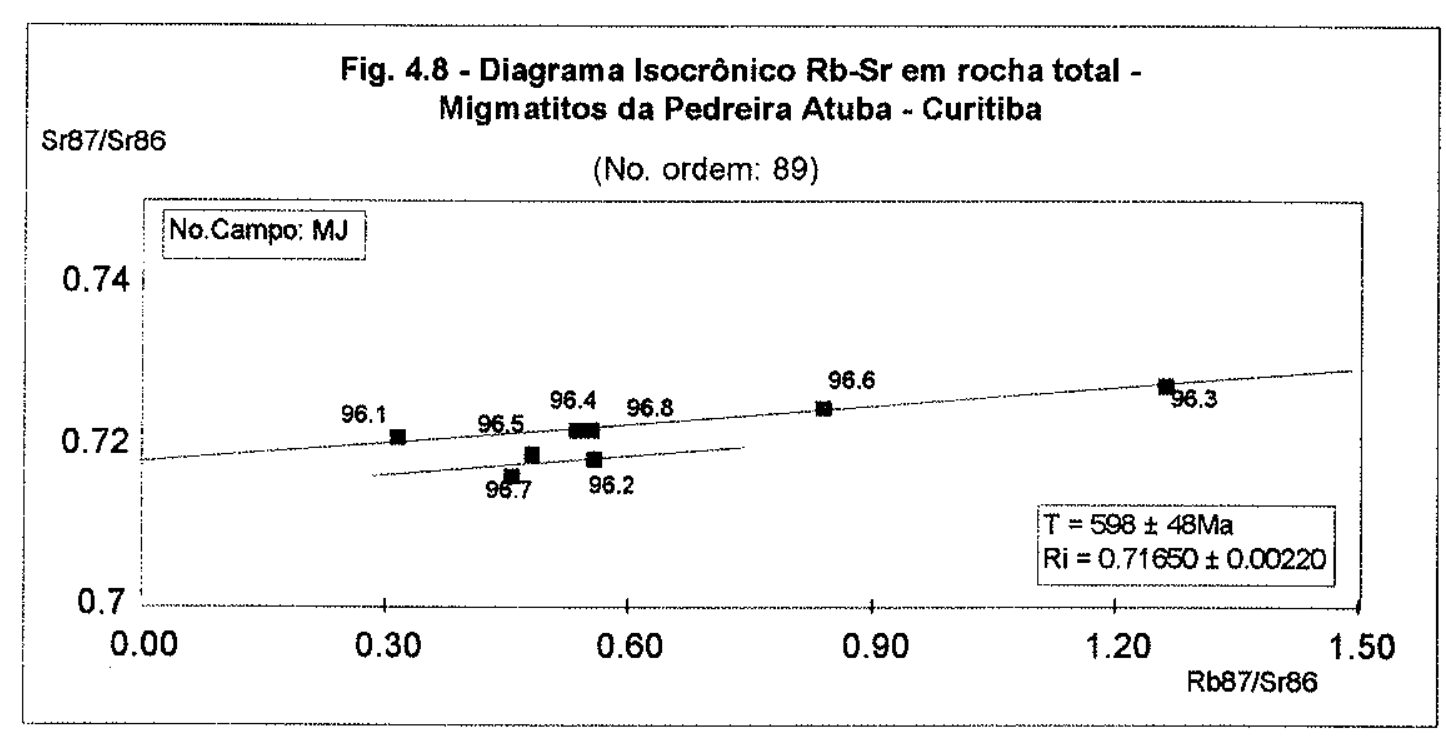

As análises $\mathrm{Rb}-\mathrm{Sr}$ em minerais (biotita e anfibólio) relativas a amostra de número de campo MJ-96.3, alinharam-se em diagrama isocrônico indicando idade de 
$617 \pm 14 \mathrm{Ma}$ para uma relação inicial $\mathrm{Sr}^{87} / \mathrm{Sr}^{86}$ próxima de 0,716 (Fig. 4.9). Valor relativamente próximo ( $588 \pm 27 \mathrm{Ma}$ ), foi obtido em biotita, concentrada da amostra de número de campo MJ-96.9, utilizando-se do método K-Ar (Apêndice-1).

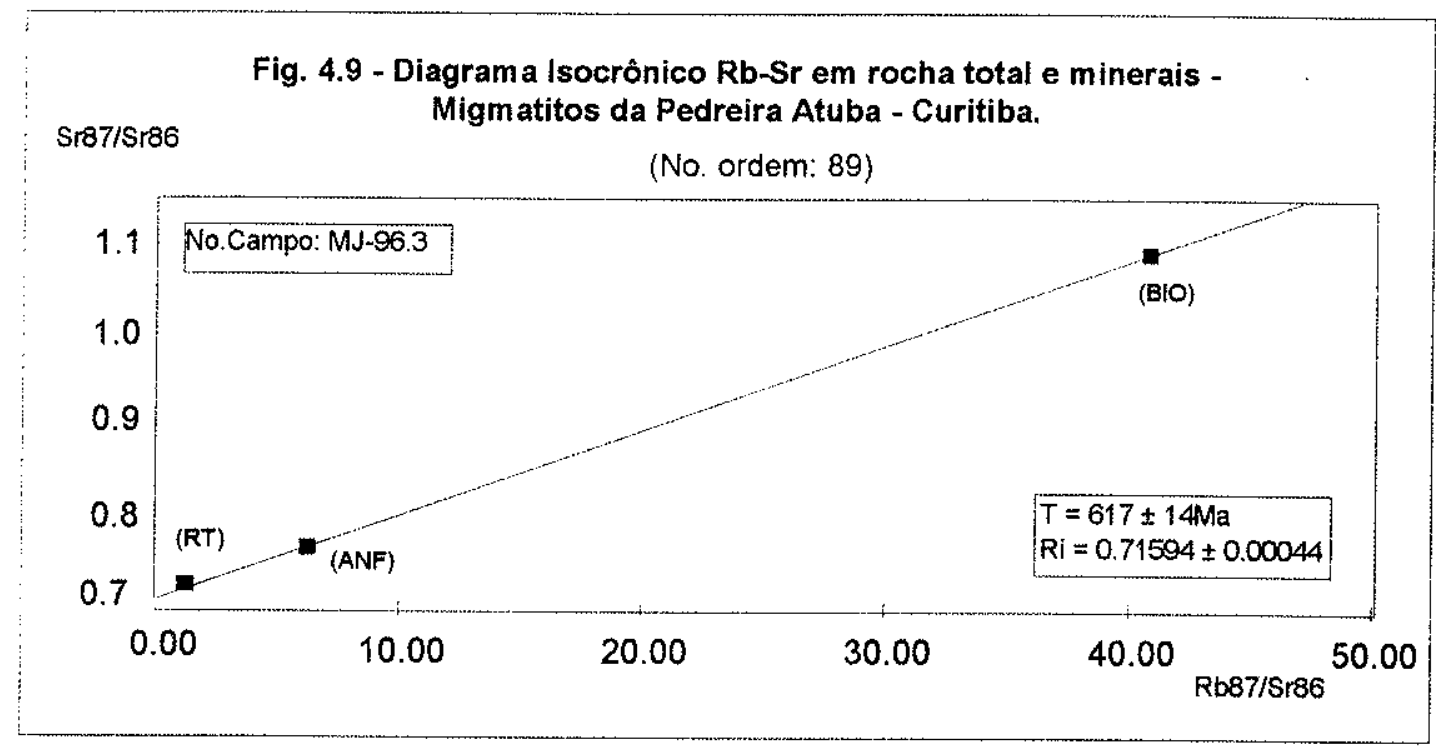

Tais dados caracterizam a grande expressão da tectônica Neoproterozóica neste domínio, responsável pela migmatização e consequente abertura dos sistema rocha total e mineral.

A sul de Curitiba, arredores de Mandirituba, foram realizados estudos geocronológicos envolvendo os métodos U-Pb, $\mathrm{Rb}-\mathrm{Sr}, \mathrm{K}-\mathrm{Ar}$ e $\mathrm{Sm}-\mathrm{Nd}$ em minerais e rocha total, em dois afloramentos (MJ-137 e 138) de anfibólio-gnaisses, relativamente preservados da migmatização, sendo o primeiro deles granatifero. As análises U-Pb referem-se a quatro frações de zircões, concentradas da amostra de número de campo MJ-138 que, em diagrama apresentaram -se alinhadas e posicionadas próximo a curva concórdia, indicando idade de $2.138 \pm 6 \mathrm{Ma}$ (Fig. 4.10). Tal valor, relativo ao Paleoproterozóico (ciclo Transamazônico) é aqui interpretado como relacionado a época de cristalização dos zircões.

Em função da similaridade observada nas relações $\mathrm{Rb}-\mathrm{Sr}$ desses gnaisses, apenas três determinações foram realizadas por esse método em rocha total, duas das quais relativas ao afloramento de número de campo $\mathrm{MJ}-137$, cujos pontos analíticos se mostraram bastante próximos, constituindo praticamente um único ponto no diagrama 
isocrônico. A idade obtida de $2.010 \pm 60 \mathrm{Ma}$, para uma relação inicial $\left(\mathrm{Sr}^{87} / \mathrm{Sr}^{86}\right)_{i}$ de $0,70327 \pm 0,00004$, apesar de relativamente concordante com o valor dos zircões (Fig. 4.11), deve ser encarada com ressalvas, necessitando de análises adicionais para que tenha significado geológico.
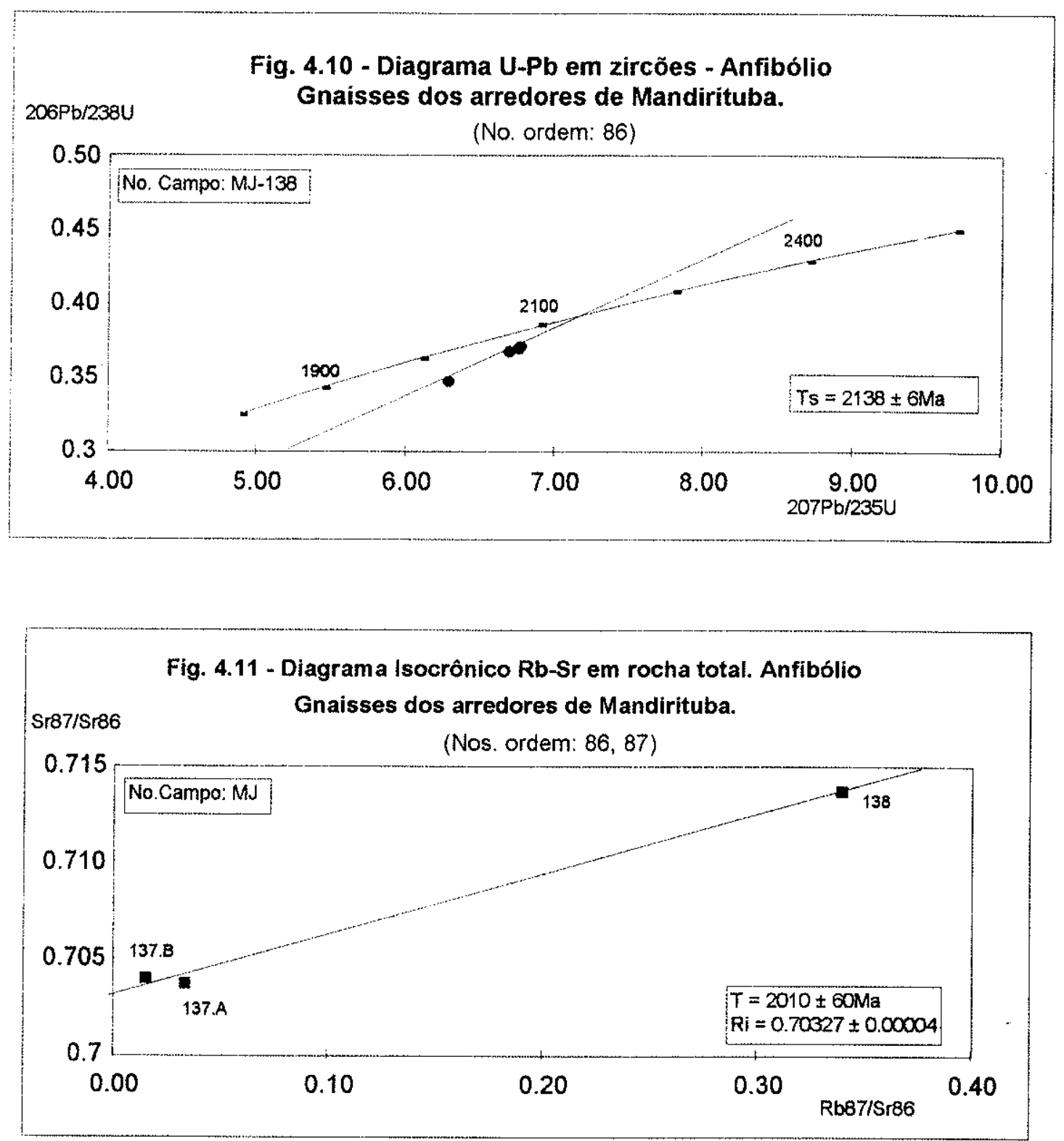

Tentativamente, com o intuito de se determinar a época de formação da paragênese mineral desses gnaisses, foram concentrados minerais (plagioclásio, anfibólio e granada) da amostra de número de campo MJ-137 que, juntamente com o sistema rocha total foram analisados através do método Sm-Nd. É importante salientar 
que o estudo petrográfico acusou a presença de restos de piroxênio (diopsídio e hiperstênio) parcial ou totalmente envolvidos por cristais de hornblenda, bem como de plagioclásios parcialmente recristalizados. Portanto, os pontos analíticos relativos ao anfibólio e ao plagioclásio podem, em realidade, conter heranças isotópicas pretéritas. No cálculo da idade foi atribuido peso menor a esses minerais, resultando na idade de $585 \pm 30 \mathrm{Ma}$ (Fig. 4.12), indicativa de uma rehomogeneização isotópica a nivel mineral, durante o ciclo brasiliano (Neoproterozóico).

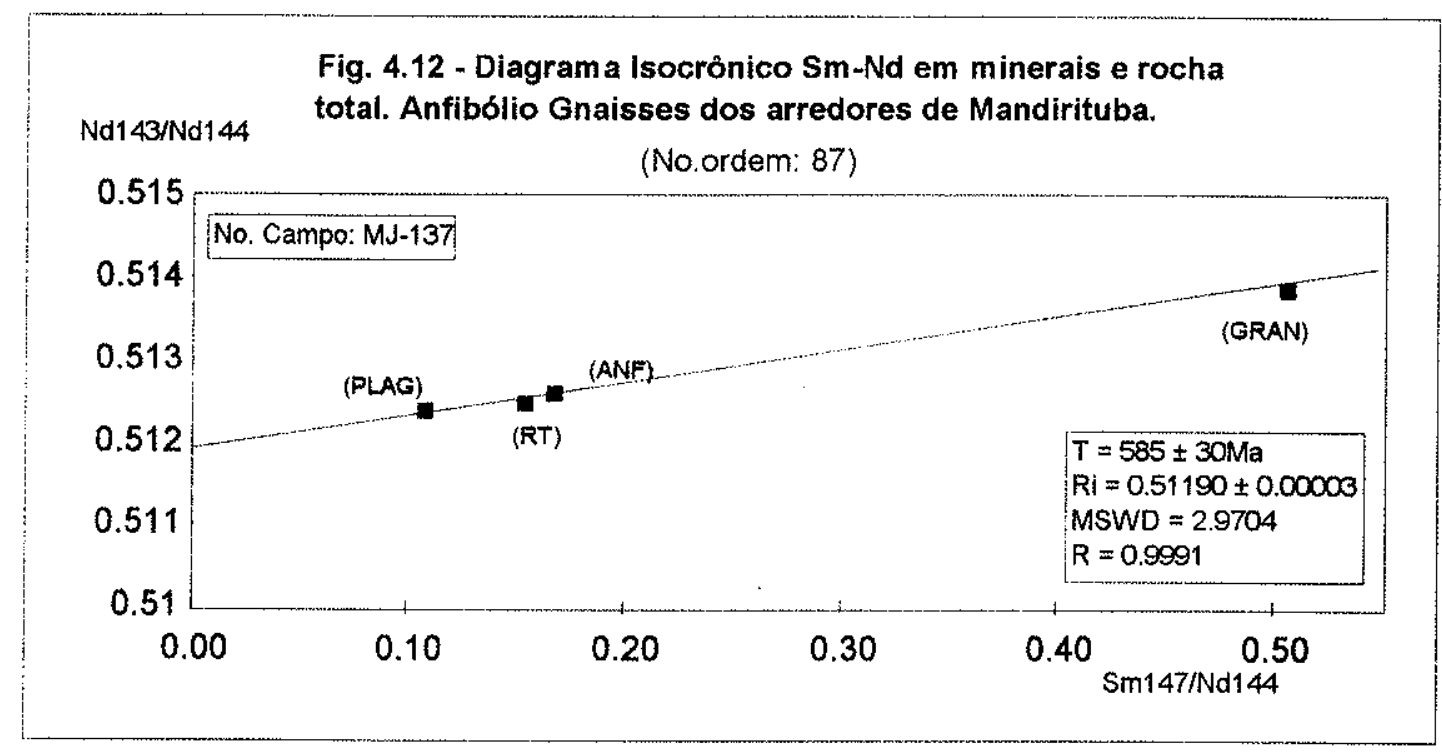

Os dados K-Ar, em biotitas, acusaram idade de $602 \pm 76 \mathrm{Ma}$ e $611 \pm 19 \mathrm{Ma}$, respectivamente para as amostras de número de campo MJ-137 e 138. O valor obtido para o anfibólio da amostra MJ-138 de $751 \pm 24$ deve ser encarado com ressalvas, devido a presença de piroxênios no sistema (Apêndice-1).

A idade Sm-Nd ( $\left.T_{D M}\right)$, indicou para a amostra de número de campo MJ-138, valor de $2.426 \mathrm{Ma}$, preliminarmente interpretada como relativa a época de diferenciação do manto dos precursores crustais dessas rochas (Apêndice-1). Valores dessa ordem não foram encontrados para os demais litotipos desse domínio. Dados Sm-Nd modelo adicionais são necessários para especular a presença de misturas ou mesmo contaminação durante ou posterior a geração desses materiais.

Ainda, no contexto das rochas gnáissico-migmatíticas, dois afloramentos (MJ315 e 316), localizados nos arredores de Quitandinha foram estudados geocronologicamente através dos métodos $\mathrm{Rb}-\mathrm{Sr}$ (rocha total e mineral) e $\mathrm{K}-\mathrm{Ar}$ 
afloramentos, porçōes mais representativas dos mesossomas, de composição tonalítico-granodiorítica e dos leucossomas, de composição granítica. Os pontos analíticos apresentaram forte dispersão em diagrama isocrônico, indicando para grande parte das amostras representativas dos leucossomas, idade de $595 \pm 41 \mathrm{Ma}$ e relação inicial $\left(\mathrm{Sr}^{87} / \mathrm{Sr}^{86}\right)$ i relativamente elevada, da ordem de 0,713 (Fig. 4.13A). Parte das amostras representativas dos mesossomas sugere, ainda que precariamente, idade mais antiga, próxima de $1.870 \mathrm{Ma}$, para uma relação inicial $\left(\mathrm{Sr}^{87} / \mathrm{Sr}^{86}\right)_{i}$ da ordem de 0,706 (Fig. 4.13B). Tal padrão, indica um forte desequilíbrio isotópico, possivelmente reflexo da tectogênese Neoproterozóica, responsável pela migmatização de rochas formadas em épocas anteriores, relacionadas ao Paleoproterozóico.
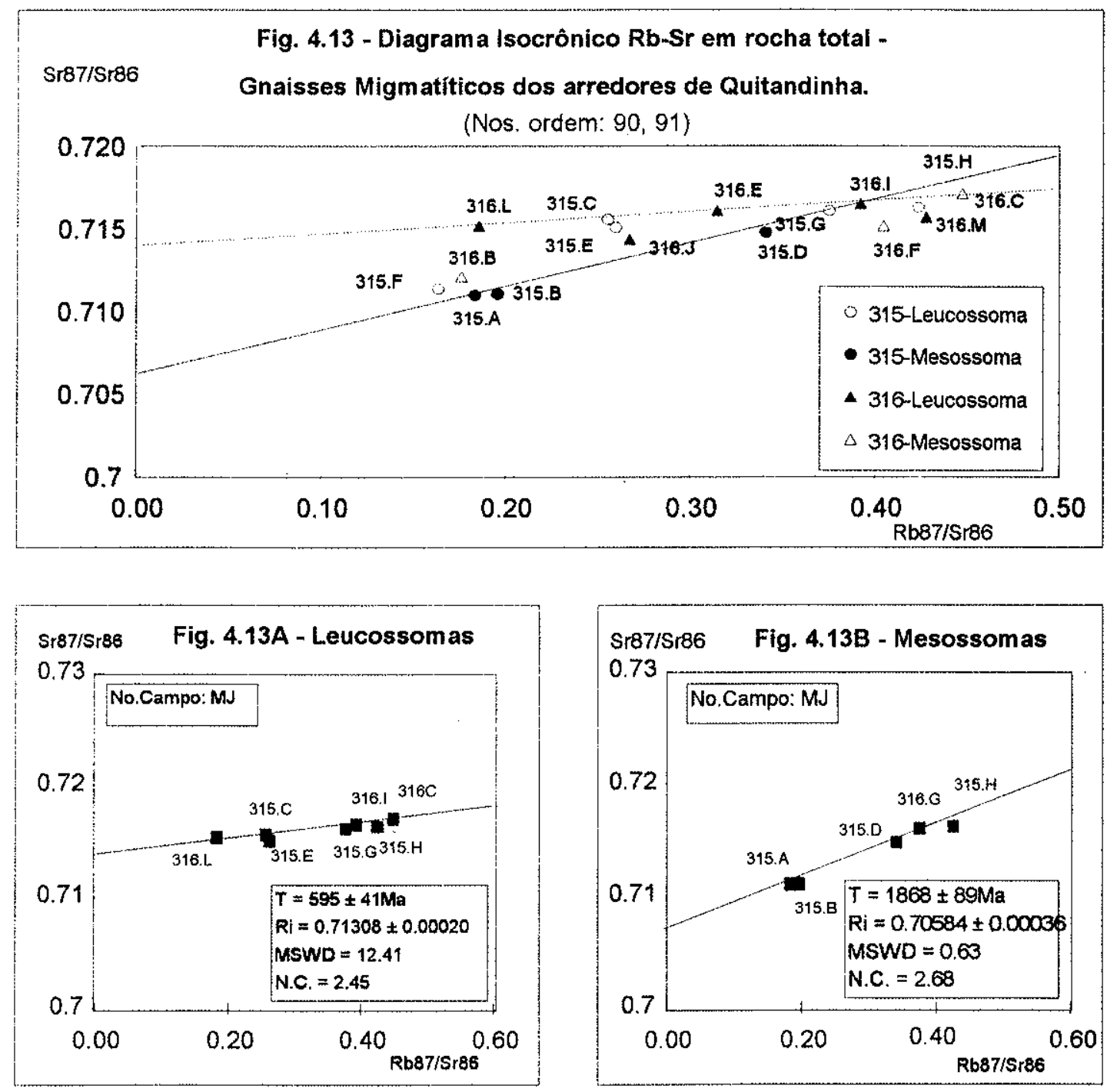
Análises $\mathrm{Rb}$-Sr realizada em minerais (feldspato, biotita e anfibólios) da porção leucossomática, indicou em diagrama isocrônico idade de $577 \pm 17 \mathrm{Ma}$ (Fig. 4.14). Valores similares, de $566 \pm 15 \mathrm{Ma}, 568 \pm 33 \mathrm{Ma}$ e $593 \pm 16 \mathrm{Ma}$, foram obtidos através do método $\mathrm{K}-\mathrm{Ar}$ em anfibólios desses afloramentos e de outro relativamente próximo (MJ310).

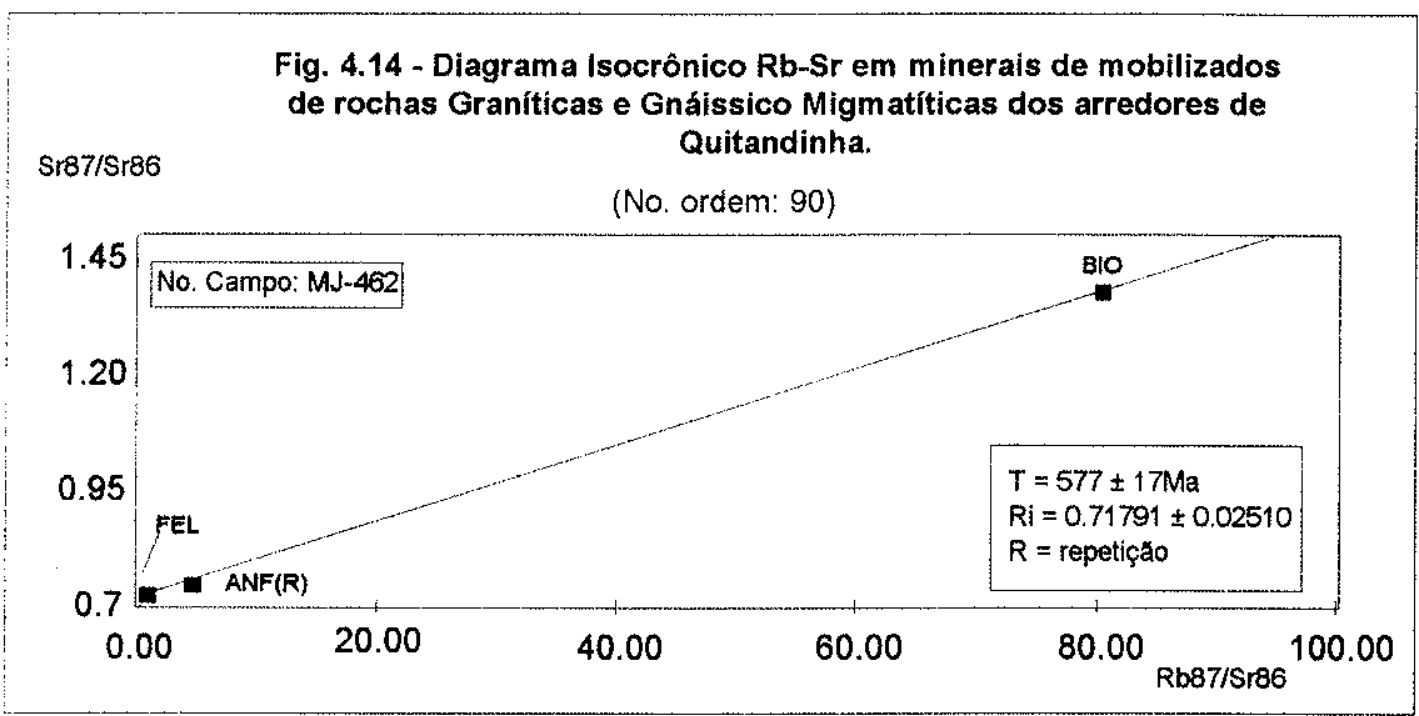

O padrão geocronológico observado para as rochas gnáissico-migmatíticas do Domínio Curitiba, permite reconhecer porções formados no Paleoproterozóico (ciclo Transamazônico), com idades $\mathrm{Rb}-\mathrm{Sr}$ distribuídas no intervalo 2200-1800Ma, e U-Pb (zircões) próximas de 2.100Ma. No Neoproterozóico (ciclo brasiliano) essas seqüencias foram intensamente migmatizadas, causando a abertura dos sistemas minerais, mas preservando, em mesossomas, heranças isotópicas, notadamente em zircões.

Considerando-se o forte desequilíbrio isotópico do sistema $\mathrm{Rb}-\mathrm{Sr}$ em rocha total, os valores obtidos (ao redor de 600Ma) tornam-se bastante imprecisos, dificultando a caracterização de idades relativas a formação dessas rochas em condições metamórficas do fácies anfibolito. Acrescente-se, que as idades isocrônicas de minerais, distribuiram-se entre aproximadamente 620 e $580 \mathrm{Ma}$, e os dados $\mathrm{K}-\mathrm{Ar}$ (anfibólio, biotita, plagioclásio e rocha total) entre 640 e $560 \mathrm{Ma}$ (com maior 
concentração entre 620 e 600Ma - Apêndice-1), caracterizando épocas relacionadas ao resfriamento desses terrenos.

Os dados Sm-Nd indicam, a exceção do mobilizado granítico coletado no afloramento de número de campo MJ-123 (que apresentou idade modelo de $2.275 \mathrm{Ma}$ ) e do anfibólio gnaisse de número de campo MJ-138 $(2.426 \mathrm{Ma})$ valores do intervalo 2.800-2.700Ma, relacionados a diferenciação do manto dos precursores crustais dessas rochas.

Finalmente, foram analisados, sob o ponto de vista geocronológico, os granitóides deformados de composição predominantemente monzogranítica a quartzo monzodiorítica, que balizam toda porção sul do Domínio Curitiba. Essas rochas foram diferenciadas por Machiavelli (1991) e Machiavelli et al. (1993), em granitos noroeste e granitos sudeste, com base principalmente em dados geoquímicos. Esses autores, obtiveram para os granitos sudeste, idade U-Pb de $715 \pm 30 \mathrm{Ma}$, admitindo tratar-se de dados preliminares, uma vez que as duas frações de zircões datadas, praticamente se sobrepunham no diagrama, constituindo um só ponto, que forçado para o zero intercepta a curva concórdia na época assinalada (amostra PP-10 $=$ MJ.321 - Fig. 4.15). Os demais dados (amostra de número de campo AM-93) mostraram-se dispersos no diagrama $\mathrm{U}-\mathrm{Pb}$, denotando forte desequilíbrio isotópico desse sistema.

Fig. 4.15 - Diagrama U-Pb em zircões - Granitóides Deformados localizados a norte de Piên. (Machiavelli et al. 1993)

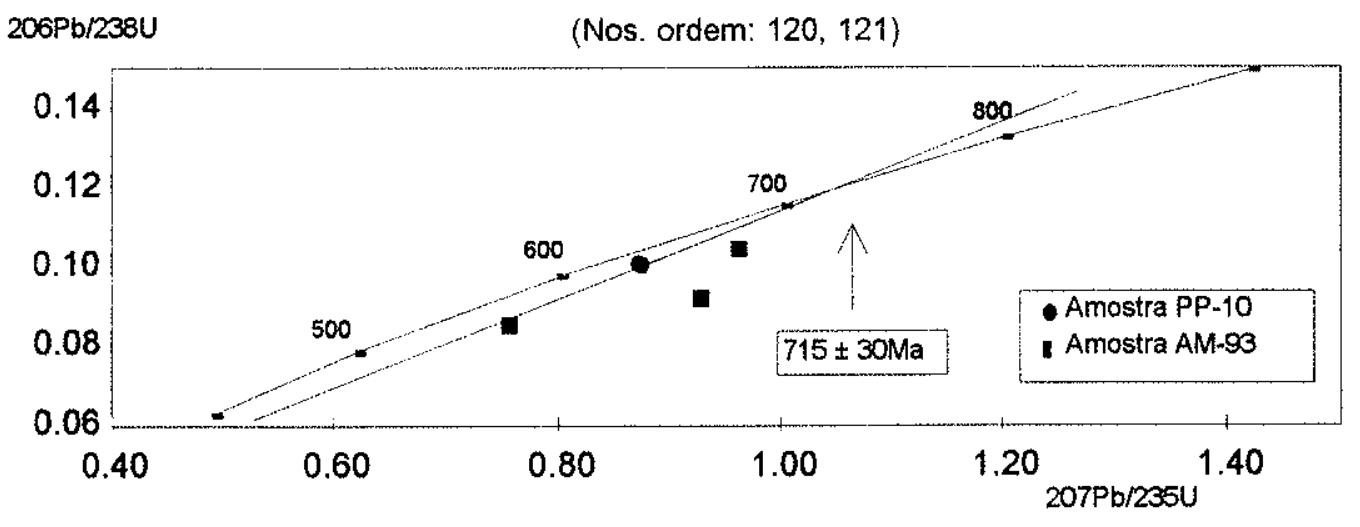


Os novos dados U-Pb obtidos (amostra de número de campo MJ-649) se referem a quatro frações de zircões, que posicionaram-se (após processo de abrasão) próximas a curva Concórdia, indicando idade de $615 \pm 29 \mathrm{Ma}$ (Fig. 4.16).

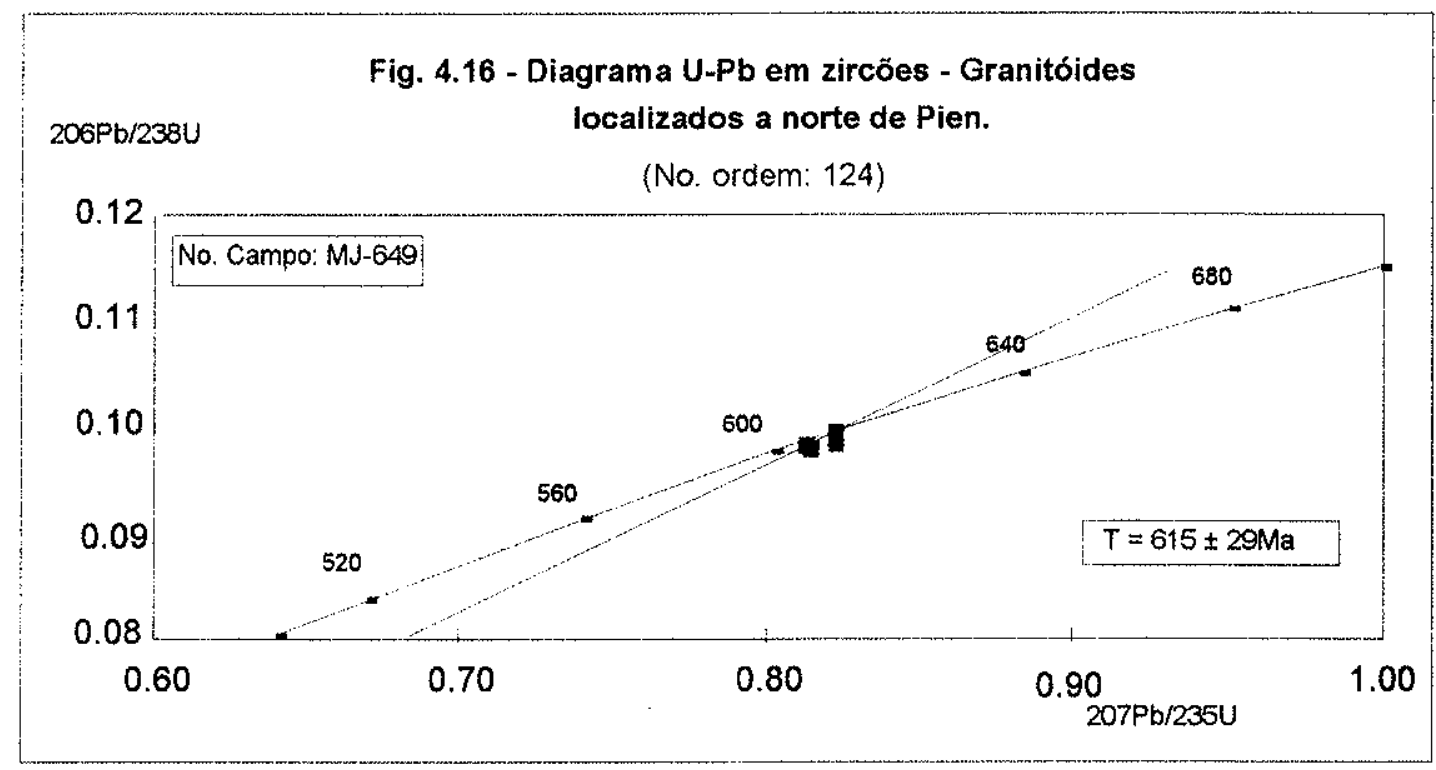

Ernbora tal valor seja analiticamente mais preciso que o obtido por Machiavelli (1991), não podemos descartar a possibilidade de tratarem-se de granitóides distintos, gerados em diferentes épocas. Os dados analíticos $\mathrm{Rb}-\mathrm{Sr}$, em rocha total, denotam padrão interessante em diagrama isocrônico, quando considerados conjuntamente os granitos noroeste e sudeste. Embora ocorra grande dispersão dos pontos analíticos, indicativo de desequilíbrio isotópico do sistema $\mathrm{Rb}-\mathrm{Sr}$, dois "trends" paralelos podem ser traçados, agrupando conjuntos pertencentes aos granitos noroeste (alinhamento superior) e granitos sudeste (alinhamento inferior). Constituem retas com idades de aproximadamente $600 \pm 30 \mathrm{Ma}$ e relaçōes iniciais $\left(\mathrm{Sr}^{87} / \mathrm{Sr}^{86}\right)_{\text {i }}$ diferentes, em torno de 0,706 e 0,704 (Fig. 4.17). Origem a partir de fontes distintas, ou mesmo processos de contaminação podem ser responsáveis pelo padrão isotópico Rb-Sr observado.

O método Sm-Nd (TOM) foi aplicado em três amostras de diferentes afloramentos desses granitóides, abrangendo tanto os denominados de noroeste como de sudeste. As idades modelo obtidas, de 1.992Ma, 2.057Ma e 2.104Ma, diferem das observadas para os gnaisses granulíticos e gnaisses bandados que mostraram-se mais antigas, aproximando-se do valor observado para os mobilizados graníticos do 
afloramento de número de campo MJ-123.A (2.275Ma). Tais valores indicam o Paleoproterozóico (ciclo Transamazônico) como o principal período de diferenciação do manto dos precursores crustais dessas rochas graníticas.
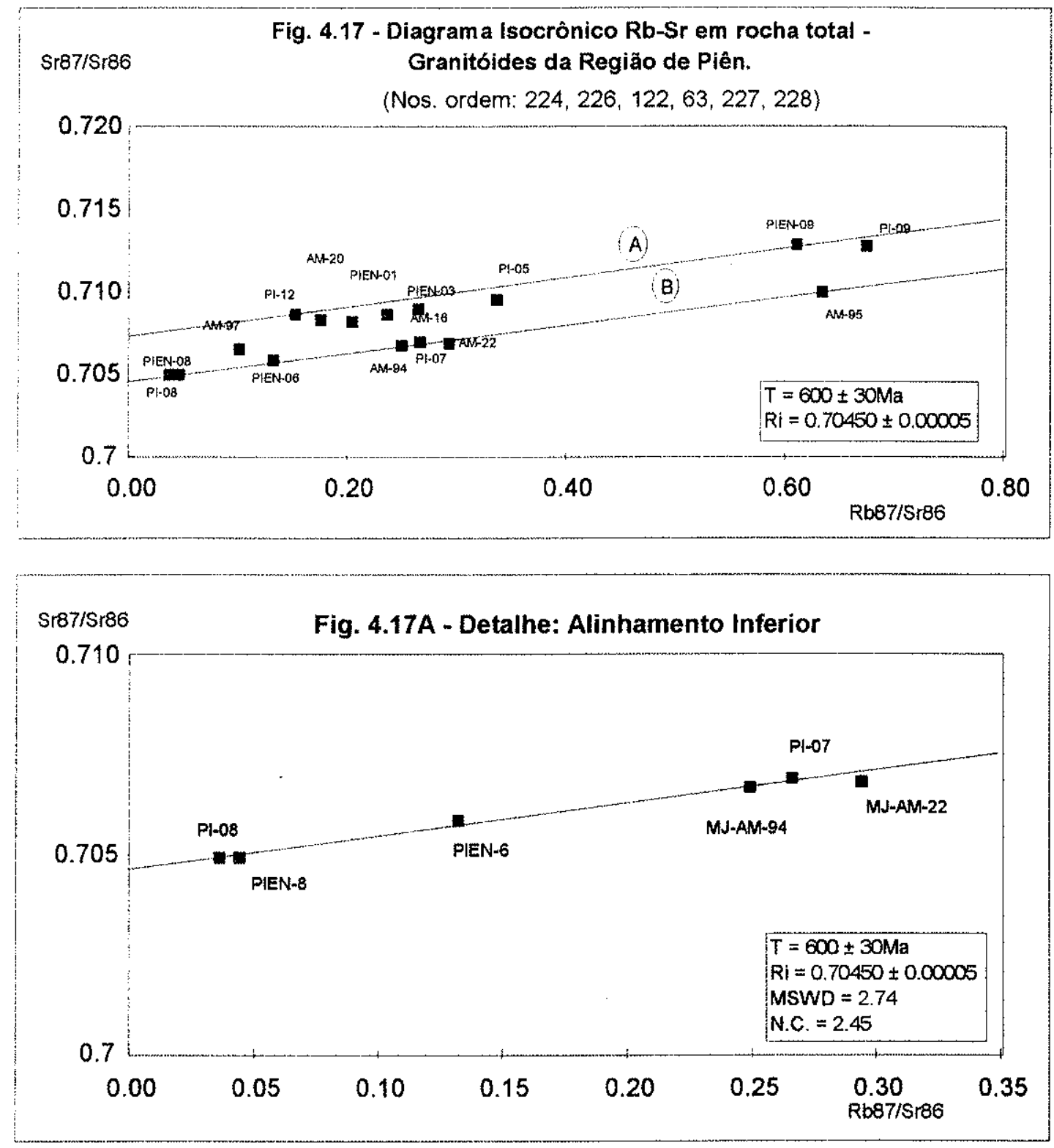

As análises K-Ar, realizadas em biotitas e anfibólios distribuiram-se predominantemente no intervalo $620-560 \mathrm{Ma}$, representando o principal periodo de resfriamento dessas rochas graniticas. Valores superiores, de $644 \pm 20$ e $679 \pm 13$, 
referem-se a análises de anfibólio e biotita impuras, devendo ser encaradas com ressaivas.

Os dados $\mathrm{K}-\mathrm{Ar}$ desses granitóides mostram-se bastante similares aos observados para as demais litologias pertencentes ao Domínio Curitiba, conforme ilustrado no histograma (Fig. 4.18), caracterizando como principal periodo de resfriamento 0 intervalo $640-560 \mathrm{Ma}$. Tal padrão, indica que esses terrenos encontravam-se a isotermas superiores a $450-500^{\circ} \mathrm{C}$ no Neoproterozóico (temperatura abaixo da qual os anfibólios retem o argônio), e que neste mesmo período atingiram temperaturas inferiores a $300^{\circ}-250^{\circ} \mathrm{C}$ (retenção de argônio pelas biotitas).

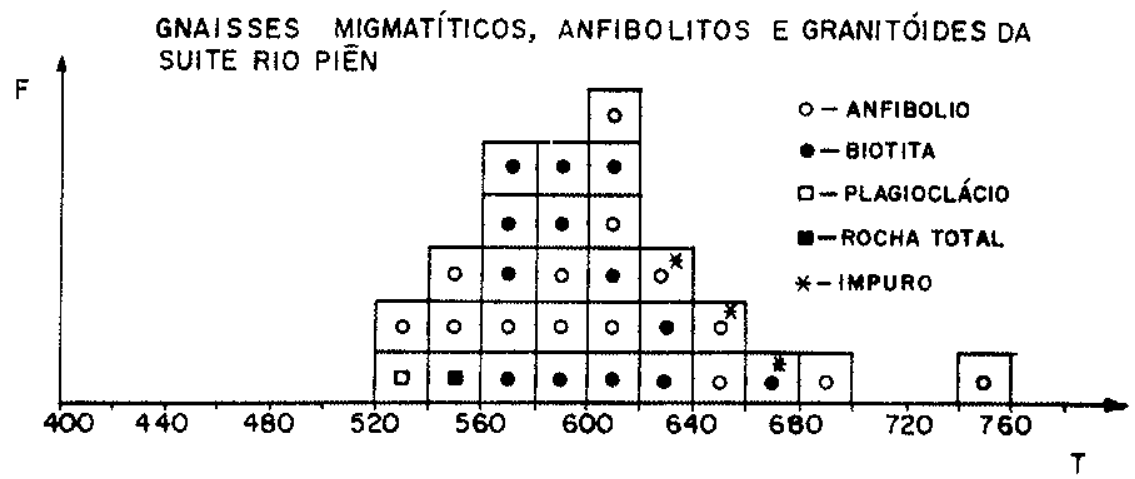

Fig. 4.18 - Histograma K-Ar - Rochas do Domínio Curitiba 
DOMíNIO CURITIBA

PRANCHA FOTOGRÁFICA 3 
- Foto $3 a$ - Aspecto geral, caracterizando injeções de granitóides leucocráticos em migmatitos da porção setentrional do Domínio Curitiba. Nestes predominam quartzo, plagioclásio, K-feldspato, biotita e hornblenda (MJ-96 - Pedreira Atuba).

- Foto $3 b$ - Detalhe do afloramento anterior, mostrando migmatitos a mesossoma de biotita anfibólio gnaisses e leucossoma predominantemente trondjemítico, intensamente transpostos (MJ96).

- Foto $3 c$ - Mesmo afloramento visto na foto $3 a$, onde se observa porções preservadas de transposição denotando grande complexidade de dobramentos, envolvendo material de alta plasticidade (MJ-96).

- Foto 3d - Detalhe de migmatitos da Pedreira Rio Vermelho. Rochas com bandas milimétricas a centimétricas, compostas por quartzo, plagioclásio, k-feldspato, biotita e anfibólio, mostrando intensa transposição.

- Foto $3 e$ - Fotomicrografia de gnaisses granulíticos do afloramento MJ-25, localizado a norte de Curitiba. Textura granoblástica a granonematoblástica envolvendo granada e ortopiroxênio, tendo hornblenda como provável produto de transformação (Pol. descruzados - 100X).

- Foto $3 \mathrm{f}$ - Fotomicrografia de gnaisses do afloramento MJ-137, localizado a sul de Curitiba (BR-116). Textura granoblástica a granonematoblástica envolvendo granada, clinopiroxênio, hornblenda e plagioclásio (Pol. descruzados - 100X) 

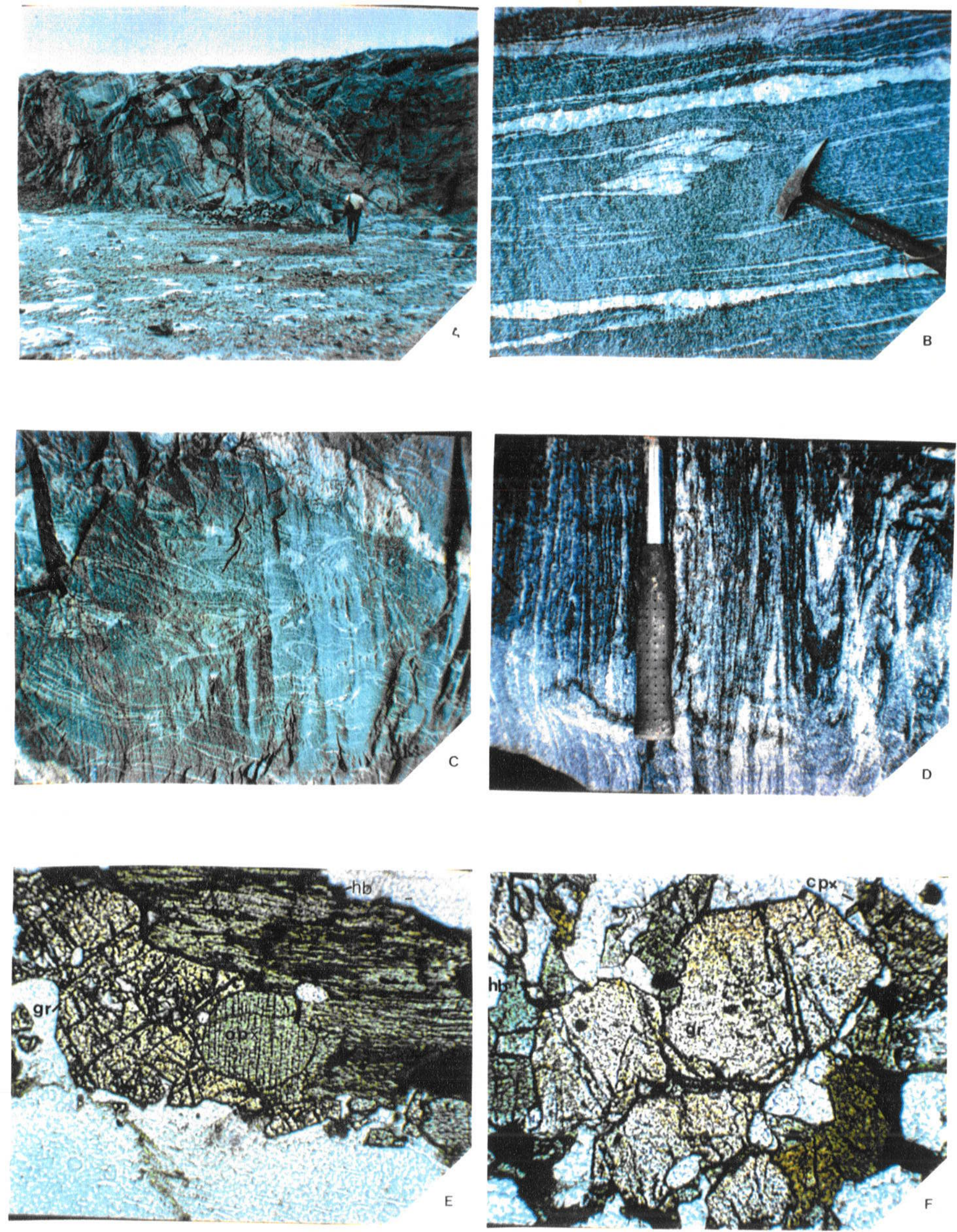
GRANITÓIDES dA SUÍte RIO PIÊN

PRANCHA FOTOGRÁFICA 4 
- Foto 4a - Granitóide leucocrático, rosado, de granulação média, equi a inequigranular, foliado, de composição monzogranítica. Ao microscópio predominam plagioclásio, k-feldspato (intensamente: saussuritizados e sericitizados), quartzo (com extinção ondulante), biotita, além de clorita e epídoto.

- Foto 4b - Granitóide leucocrático de composição quartzo-monzonítica, cinza rosado, de granulação média, inequigranular, foliado, composto por plagioclásio, k-feldspato, quartzo, biotita e clorita.

- Foto 4c - Granitóide leucocrático de composição monzogranítica, cinza, de granulação média, porfirítico, foliado, com quartzo, plagioclásio, $k$ feldspato, biotita e anfibólio.

- Foto $4 d$ - Fotomicrografia - Detalhe mostrando a forte extinção ondulante e "moagem de borda" em grãos de quartzo (Pol. cruzados - 25X).

- Foto $4 e$ - Fotomicrografia - Detalhe caracterizando a "moagem de borda" em grãos de quartzo e feldspato (Pol. cruzados - 25X). 

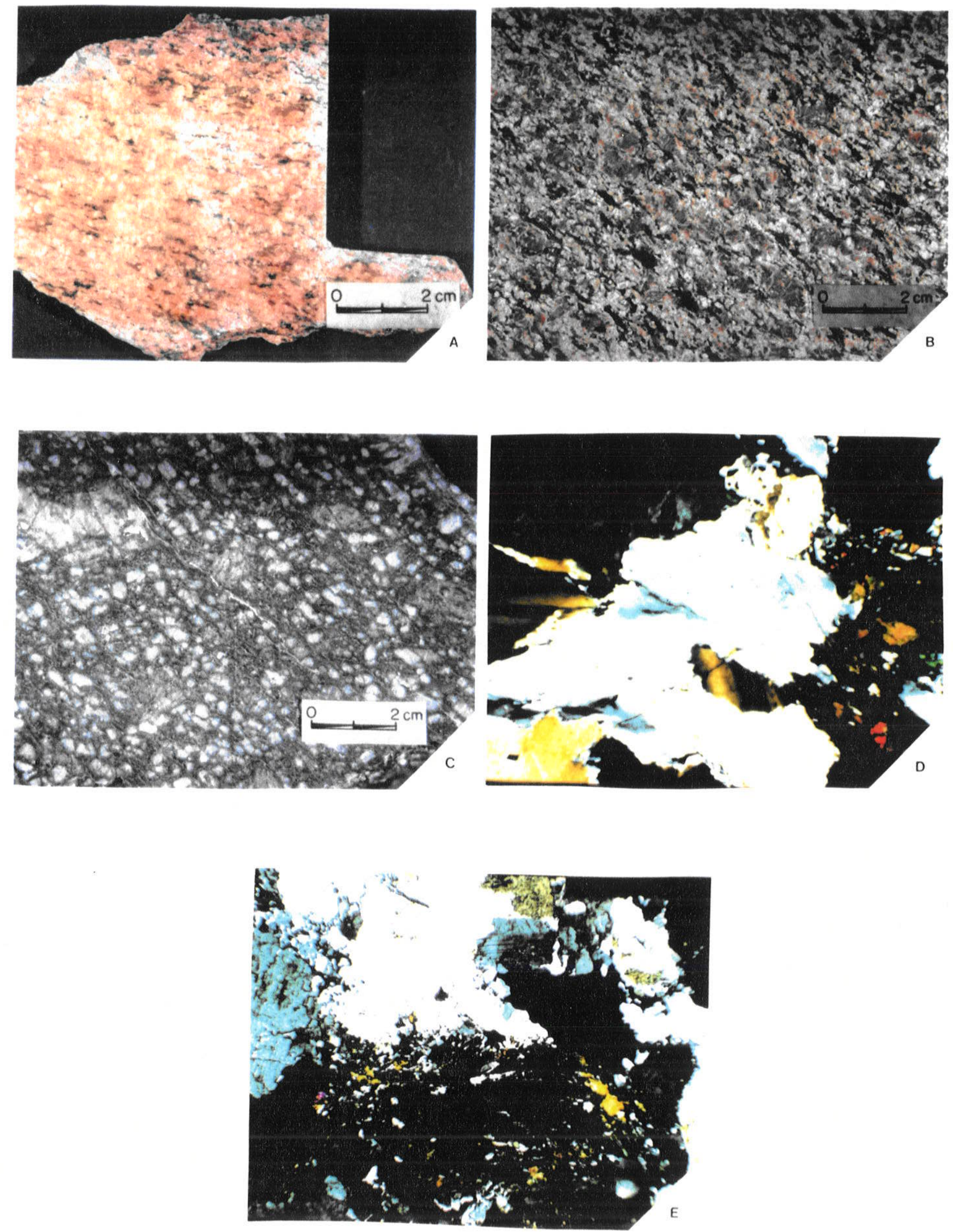

100 


\section{CAPITULO 5}

\section{DOMÍNIO PARANAGUÁ}

O Domínio Paranaguá ocupa a porção oriental estudada, sendo limitado a leste pela linha de costa e a oeste pelas rochas gnáissico-granulíticas do Domínio Luís Alves. O contato ocidental é tectônico, representado em sua porção sul-sudoeste pelo Lineamento do Rio Palmital, e no setor oeste-noroeste pelos Lineamentos Alexandra e Serra Negra (anexo-1).

Sob o ponto de vista geotectônico, esses terrenos foram, em trabalhos anteriores, incluídos (parcial ou totalmente) em diversos compartimentos, tais como: Cráton de Luís Alves (Kaul 1979, 1980 e 1985), Complexo Paraíba do Sul (Kaul et al. 1984), Protocráton de São Francisco do Sul (Silva 1987), Bloco Costeiro (Biondi et al. 1989), Batolito Paranaguá (Basei et al. 1990a) e Cinturão Granitóide Costeiro (Basei et al. 1992).

Os mapas decorrentes do programa de levantamento geológico efetuado pela Comissão da Carta Geológica do Paraná, na década de 60, que abrangem o Domínio Paranaguá, referem-se às folhas Antonina, Guaraqueçaba, Barra do Ararapira, Serra da Igreja, Paranaguá, Itha do Mel, Pedra Branca de Araraquara e Guaratuba, todas produzidas na escala 1:70.000. Na uniformização adotada para a legenda desses mapas foi utilizada a denominação de migmatitos proposta por Jung \& Roques (1952), destacando-se neste domínio a presença dos tipos embrechito e epibolito.

No Projeto Leste do Paraná, executado pela CPRM, a folha de Guaraqueçaba, na escala 1:100.000 (Paiva et al. 1977) engloba parte da região estudada, sendo adotada nas descrições das unidades geológicas, similarmente aos trabalhos da Comissão da Carta, a nomenclatura dos migmatitos.

O Domínio Paranaguá é representado em sua quase totalidade, por um complexo igneo, que inclui uma grande variedade de rochas graniticas, distribuidas ao longo de uma faixa oriental, com mais de $100 \mathrm{~km}$ de extensão (da liha de São Francisco, SC, ao sul de Itatins, SP), tendo em média cerca de $30 \mathrm{~km}$ de largura. Como encaixantes desses granitóides ocorrem gnaisses, por vezes granatiferos, mica-xistos, quartzitos e anfibolitos, que podem se apresentar migmatizados em diferentes graus. 
Os granitóides pertencentes ao Domínio Paranaguá, que ocorrem a sudoeste da cidade homônima, na Serra da Prata, foram diferenciados por Lopes (1987a). Este autor, identificou, nessa regiäo, cinco variedades graníticas denominadas de Morro Ingiês, Rio Canavieiras, Cubatãozinho, Rio do Poço e Estrela. Os metassedimentos que ocorrem na Serra da Prata, foram por Lopes (1987a) incluídos na Formação Rio das Cobras, a qual atribuiu, juntamente com os granitóides, idade arqueana.

Neste trabalho, foram mantidas as denominações propostas por Lopes (1987a), com modificações, sendo a área de ocorrência dessas rochas estendida para os setores a norte e a sul da Serra da Prata.

\section{1 - ROCHAS GRANITICAS REGIONAIS}

\subsection{1 - Síntese Geológica}

Os trabalhos de campo realizados nesses terrenos, envolveram principalmente perfís geológicos contínuos, que abrangeram a porção sul do Dominio Paranaguá, em Santa Catarina (Guaramirim-Araquari-São Francisco do Sul, Garuva-Itapoá), o setor norte, no Paraná (Antonina-Cacatú-Cachoeira de Cima, Serra Negra-Guaraqueçaba) e a parte central, ainda no Paraná (Paranaguá-Morretes, Paranaguá-MatinhosGuaratuba e ao longo dos Rios Sambaqui, Cubatãozinho e São João).

A característica litológica marcante desse dominio é a presença, ao longo de toda sua porção centro-oriental, de rochas graniticas, incipiente a intensamente foliadas, contendo megacristais de feldspato potássico brancos, com formas tabulares e, mais raramente ocelares. Esses granitóides, denominados de Morro Inglês, na região da Serra da Prata, por Lopes (1987a) se estendem desde a liha de São Francisco do Sul, em Santa Catarina, até a borda meridional do Maciço de Itatins, em São Paulo. Predominam granitóides leucocráticos, cinza claros, foliados, de granulação média a grossa, a megacristais de feldspato potássico, (2 a $5 \mathrm{~cm}$ ), que se apresentam normalmente zonados. Muitas vezes ocorrem enclaves de composição diorítica a quartzo-dioritica, de granulação fina, com formas angulares a esféricas e tamanhos que geralmente não excedem $50 \mathrm{~cm}$.

Feições migmatíticas são comuns, principalmente na porção sul deste domínio, llha de São Francisco, ocorrendo ainda variedades de granulação grossa, a muito 
grossa, onde os megacristais atingem dimensões da ordem de $10 \mathrm{~cm}$, observadas no setor norte, arredores de Guaraqueçaba.

Petrograficamente, esses granitóides são compostos por feldspato potássico, que ocorre principalmente sob a forma de megacristais, exibindo geminação em grade (microclínio) ou não, quando então mostram-se turvos, superficialmente alterados para minerais de argila. O plagioclásio (oligoclásio-andesina) ocorre tanto na matriz, como envolvido pelos megacristais de feldspato potássico. Os cristais de quartzo são normalmente anédricos, fraturados e com forte extinção ondulante. A biotita apresentase orientada, com pleocroismo de castanho a verde claro, mostrando-se as vezes cloritizada e a hornblenda, quando presente, denota pleocroismo de verde escuro a verde claro. Os principais minerais acessórios são apatita, zircão, opacos e titanita, este último presente na maioria das vezes em quantidades significativas.

Em alguns afloramentos, principalmente quando a matriz apresenta granulação grossa, esses granitóides mostram-se praticamente isótropos, com orientação somente a nivel de biotita e tendência de alinhamento dos eixos maiores dos megacristais, feições estas que podem estar associadas a processos decorrentes de fluxo magmático. Outras vezes, notadamente na porção ocidental, esses granitóides apresentam-se bastante deformados, adquirindo aspecto bandado ou mesmo migmatítico. Essa foliação, uma superfície $S_{1}$, apresenta orientação principal nordeste, com mergulhos voltados para E-SENW-NW.

Nas proximidades de Matinhos (afloramento de número de campo: MJ-301), o tratamento dos dados estruturais caracterizou para essa superficie $S_{1}$, uma orientação preferencial $\mathrm{N} 45^{\circ} \mathrm{E} / 30^{\circ} \mathrm{SE}$ e para as lineações de estiramento mineral, mergulhos de $5^{\circ}$ a $30^{\circ}$ para SE (Anexo 3 - No 29). Adicionalmente, os megacristais de feldspato potássico apresentam-se rotacionados e recristalizados adquirindo formas sigmoidais, indicando processos de cisalhamento, com importante componente de transporte para NW.

Na porção ocidental do Domínio Paranaguá, predominam rochas graníticas distintas dos litotipos porfiríticos, tipo Morro Inglês ora descritos. Tratam-se de granitóides leucrocráticos, de cor cinza claro a cinza rosado, equi a inequigranulares, de granulação fina a média e que exibem normalmente uma marcante foliação cataclástica. 
Variações composicionais são frequentes, destacando-se como tipo mais comum granitóides a quartzo (intersticial, apresentando-se em pequenos grãos de contornos irregulares e difusos, com forte extinção ondulante), feldspato potássico (exibindo geminação em grade ou não, quando mostra-se saussuritizado, sericitizado, por vezes exibindo textura granofírica) e plagioclásio (lamelas curvas, quebradas). Anfibólios e/ou biotitas apresentam-se intersticiais, transformados parcial ou totalmente em tremolita-actinolita, clorita e epídoto. Entre os minerais acessórios destacam-se apatita, titanita, zircão e opacos.

Esses granitóides distribuem-se na porção ocidental da Serra da Prata, onde foram denominadas de Rio Canavieiras (Lopes 1987a), sendo neste trabalho, reconhecidos ao longo de grande parte do segmento setentrional. Constituem corpos alongados que balizam o contato oeste do Dominio Paranaguá com os gnaisses granulíticos do Domínio Luis Alves. Esse contato é marcado por importantes zonas de cisalhamento, onde esses granitóides apresentam-se intensamente cataclasados e milonitizados. A foliação milonítica apresenta orientação N-NW, com mergulhos para E-NEN-SW, nas proximidades do Lineamento Palmital, infletindo para N-NE, com mergulhos para E-SEN-NW ao longo do Lineamento Alexandra. O padrão N-NE predomina na porção setentrional desse domínio, próximo ao Lineamento Serra Negra, com mergulhos voltados para W-NW/E-SE (Anexo 3, estereogramas: 27 a 32).

Não foram observadas relações de contato entre esses granitóides (tipo Rio Canavieiras) e os porfiriticos (tipo Morro Inglês), sendo caracterizado entre os mesmos, notadamente na Serra da Prata e a W-NW de Guaraqueçaba, uma faixa cataclástica com aproximadamente $2 \mathrm{Km}$ de largura, orientada segundo direções N10E a N30E, com mergulhos variáveis de $40^{\circ}$ a $60^{\circ}$ para SE. Lopes (1987b) define no interior dessa faixa, na Serra da Prata, o granito cataclástico porfiróide Cubatãozinho, limitando-o a leste pela Zona Cataclástica do Ribeirão Chato e a oeste pela Zona Cataclástica de Morro Alto. Adicionalmente, ocorrem no interior desta faixa, gnaisses, xistos, quartzitos, anfibolitos, além de veios pegmatóides, afetados em maior ou menor intensidade pela tectônica de cisalhamento.

As exposições, pouco expressivas, normalmente métricas a decamétricas de rochas gnáissicas (biotita-gnaisses, gnaisses granatíferos, anfibólio-gnaisses), bem como de xistos (biotita-xistos, muscovita-xistos, xistos granatiferos), quartzitos e anfibolitos, migmatizados em diferentes graus, foram reconhecidas ao longo de todo 
Domínio Paranaguá. Representam, muito provavelmente, restos de encaixantes preservadas em meio a este imenso complexo ígneo, estando em grande parte cartografadas nas folhas da Comissão da Carta Geológica do Paraná.

No Dominio Paranaguá ocorre, adicionalmente, importante atividade plutônica de características tardi a pós tectônica, representada por maciços graníticos, isótropos, de dimensões e composições variadas, em grande parte ainda não cartografados. Tratam-se de corpos graníticos de pequena expressão, intrusivos nos granitóides foliados regionais (Morro Inglês e Canavieiras). Foram reconhecidos, principalmente, nos arredores e a sul de Garuva (SC) e a nordeste de Guaraqueçaba. São normalmente leucocráticos, de cor cinza-ciaro, equi a inequigranulares, isótropos, alguns deles a duas micas.

Dentre esses corpos destaca-se o que ocorre a leste do rio Cubatãozinho (SW de Paranaguá), denominado Rio do Poço, Lopes (1987a). Neste, predominam rochas leucocráticas, de cor cinza claro, de granulação média, equigranulares, foliadas somente próximo as bordas. São constituídas por feldspato potássico (normalmente, microclínio pertítico), plagioclásio (albita-oligociásio), quartzo e biotita. Corpos graníticos similares foram identificados nos arredores e a nordeste de Antonina.

$\mathrm{Na}$ confluência dos rios Canavieiras e Cubatãozinho, Lopes (1987a) delimita outro pequeno corpo granítico isótropo, denominado Estrela. A nosso ver, entretanto, tal corpo tem grande expressão na porção centro-oriental do Dominio Paranaguá, constituindo um maciço granítico de dimensões batolíticas, que se estende por cerca de $30 \mathrm{~km}$, desde as proximidades de Garuva (a sul) até o rio Canavieiras (a norte). Em perfil realizado ao longo dos rios São João, Cubatão e Canavieiras, observam-se frequentes variações texturais e composicionais, sendo mais expressivos os litotipos leucocráticos, de cor cinza-claro a cinza-rosado, granulação média, equi a inequigranulares, raramente porfiríticos. Petrograficamente predominam nessas rochas - feldspato potássico (geminação em grade ou não), plagioclásio (oligoclásioandesina, por vezes pertíticos), quartzo, biotita (pleocroismo de verde a castanho) e hornblenda (verde). Os minerais acessórios comuns são zircão, titanita, apatita, fluorita e opacos.

Sob o ponto de vista geoquímico, cinco amostras foram analisadas nos Laboratórios da Geosol para elementos maiores, traços e terras raras (apêndice-2), quatro delas representativas dos granitóides tipo Morro Inglês (MJ-206.2, 208.A, 287 e 
301.E) e apenas uma do granitóide tipo Rio do Poço (MJ-209). Em diagrama R1 x R2 (De La Roche et al 1980) os dados analíticos relativos aos granitóides tipo Morro Inglês apresentaram afinidades com as séries cálcio-alcalina, com maior tendência a cálcioalcalina de alto $\mathrm{K}$ (Fig.5.1A). Distribuem-se grosseiramente, neste diagrama, no campo dos granitóides sin-colisionais (Batchelor \& Bowden, 1985). O único ponto relativo ao granitóide tipo Rio do Poço mostra, neste diagrama, maior tendência alcalina, posicionando-se no campo dos granitóides tardi a pós-orogênicos. Utilizando-se do diagrama $\mathrm{Rb} \times \mathrm{Y}+\mathrm{Nb}$ (Pearce et al. 1984, Fig.5.1B), observa-se uma distribuição dos dados tanto no campo dos granitóides de arco-vulcânico (VAG), como no campo dos granitóides intraplaca (WPG). Os índices de Shand (1951) denotam características metaluminosas a peraluminosas para os granitóides tipo Morro Inglês e peraluminosa para a única amostra analisada do granitóide tipo Rio do Poço (MJ-209).

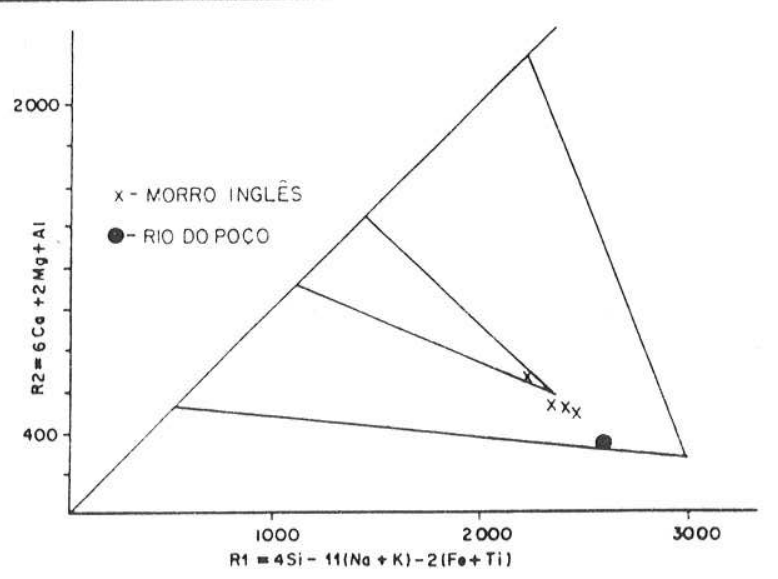

Fig. 5.1A - Diagrama R1 x R2 (De La Roche et al. 1980; Batchelor \& Bowden 1985) - Granitóides tipo Morro Inglês (1 a 4) e Rio do Poço (5). 


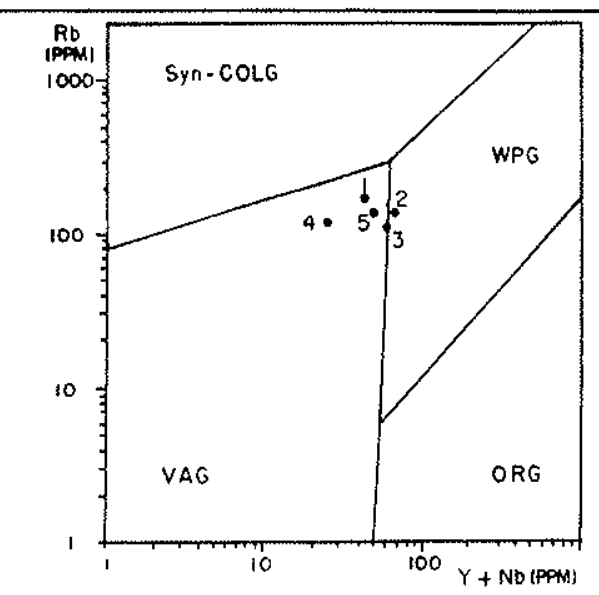

Fig. 5.1B - Diagrama $\mathrm{Rb} \times \mathrm{Y}+\mathrm{Nb}$ (Pearce et al. 1984) - Granitóides tipo Morro Inglês (1 a 4) e Rio do Poço (5).

No diagrama de multielementos (Pearce et al. 1984, Fig. 5.2), verifica-se tanto para as amostras dos granitóides tipo Morro inglês, como para a do granitóide Rio do Poço, um padrão geral de fracionamento relativamente suave, com enriquecimento de todos os elementos (50 vezes o condrito). Apresentam anomalias negativas em $\mathrm{Ba}, \mathrm{Nb}$ e $\mathrm{Zr}$, sendo a primeira, mais pronunciada na amostra representativa do granitóide tipo Rio do Poço. Este padrão indica similaridades com os granitóides intraplacas (WPG) discutidos em Pearce et al. (1984). Algumas diferenças se referem ao maior empobrecimento em $\mathrm{Y}$ e $\mathrm{Yb}$, apresentados pelos granitóides tipo Morro Inglês e Rio do Poço, não caracterizando um padrão horizontalizado do $\mathrm{Zr}$ ao $\mathrm{Yb}$. Segundo esses autores podem representar granitóides intrusivos em crosta continental fortemente atenuada.

Finalmente, sob o ponto de vista estrutural, observa-se tanto para os granitóides tipo Morro Inglês como Canavieiras (Anexo-3 - estereogramas 27, 28, 30 e 32), uma dispersão dos pólos relacionados a foliação $S_{n}$, com caimentos ora para $E$ (NE-SE) ora para W(NW-SW), sugerindo um dobramento aberto desta superfície. $O$ contato ocidental deste dominio é representado no setor sul-sudoeste pelo Lineamento do Rio Palmital e no setor oeste noroeste pelos Lineamentos Alexandra e Serra Negra. Nestas porções predominam rochas miloníticas, cujas lineações minerais, observadas em poucos afloramentos, sugerem uma tectônica de cisalhamento com importante componente lateral. Os indicadores cinemáticos presentes, notadamente nas 
proximidades do Lineamento do Rio Palmital, denotam para este setor sentido de movimento sinistral.

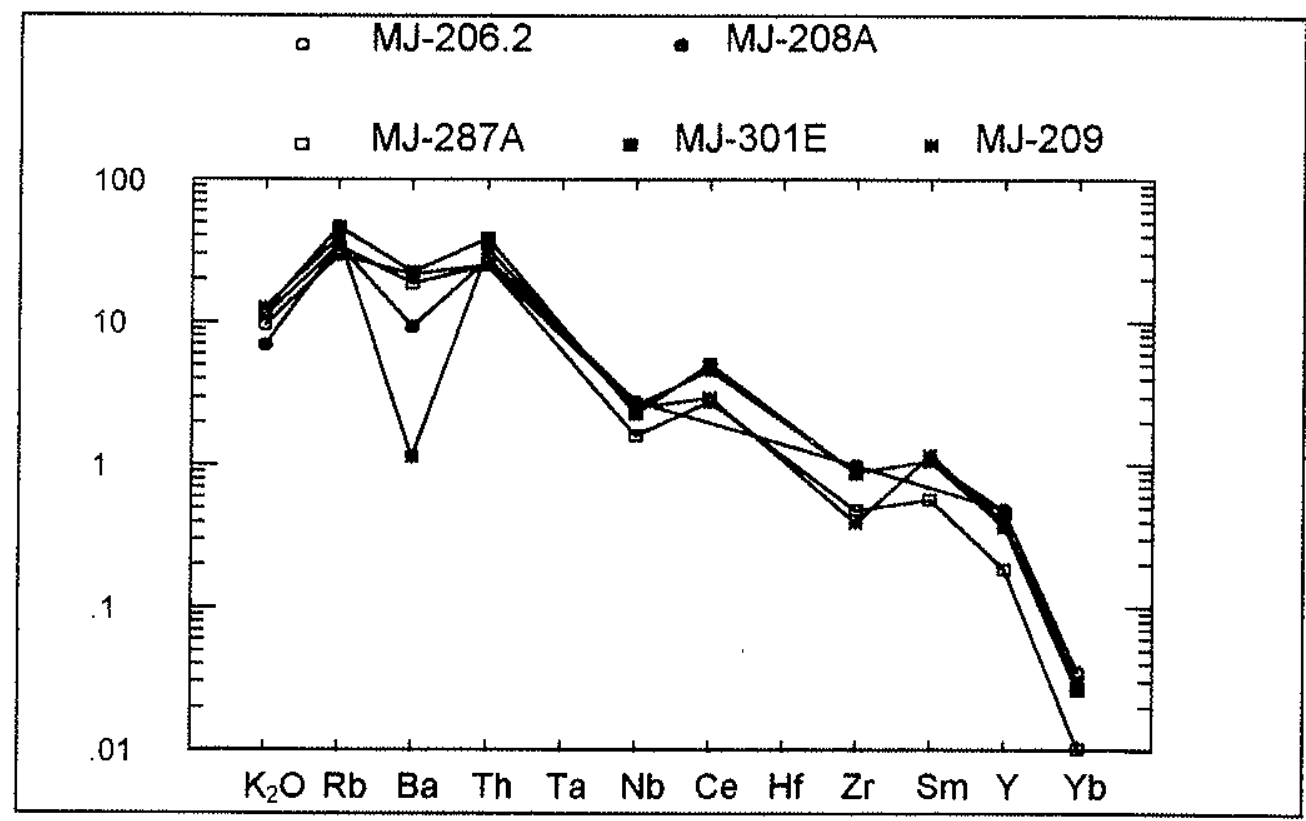

Fig. 5.2 - Diagrama de Multielementos - Granitóides tipo Morro Inglês e Rio do Poço (norm. Pearce et al. 1984)

\subsection{2. - Geocronologia}

As determinações radiométricas realizadas em rochas graníticas pertencentes ao Domínio Paranaguá, envolveram os métodos $\mathrm{Rb}-\mathrm{Sr}$ em rocha total, $\mathrm{K}-\mathrm{Ar}$ em biotitas, U-Pb em zircões, $\mathrm{Sm}-\mathrm{Nd}$ em rocha total $\left(\mathrm{T}_{\mathrm{DM}}\right)$, além de análises isotópicas de $\mathrm{Pb}\left(\mathrm{Pb}^{208} / \mathrm{Pb}^{204}\right),\left(\mathrm{Pb}^{207} / \mathrm{Pb}^{204}\right)$ e $\left(\mathrm{Pb}^{206} / \mathrm{Pb}^{204}\right)$. Tal estudo, aplicando metodologias de distintos valores interpretativos, teve por objetivo caracterizar, não só a época de formação dessas rochas e de seus protolitos crustais, mas também os possiveis reservatórios que contribuiram para a formação de crosta continental.

Parte dos resultados aqui discutidos foram publicados em Basei et al. (1990a) e Siga Jr. et al. (1994a). Algumas diferenças relacionadas às idades apresentadas neste trabalho se devem às novas determinações realizadas, bem como as repetições analíticas de amostras consideradas críticas. 
O estudo geocronológico $\mathrm{Rb}-\mathrm{Sr}$, em rocha total, envolveu a análise de 17 amostras, coletadas em quatro afioramentos de anfibólio-biotita-granitóides porfiríticos, tipo Morro Inglês (apêndice 1). Dois desses afloramentos (MJ-206 e 207) localizam-se nos arredores de Paranaguá, o terceiro (MJ-301) refere-se a pedreira próxima de Matinhos, e o último (MJ-287) situa-se pouco mais ao sul, nas imediações de Guaratuba.

Os dados analíticos $\mathrm{Rb}-\mathrm{Sr}$ relativos aos granitóides localizados nas proximidades de Paranaguá, apresentaram-se relativamente concentrados quando tratados em diagrama isocrônico (relações $\mathrm{Rb}^{87} / \mathrm{Sr}^{86}$ entre 0,90 e 1,45), indicando idade de $537 \pm 35 \mathrm{Ma}$, para uma relação inicial $\left(\mathrm{Sr}^{87} / \mathrm{Sr}^{86}\right)$; de $0,70820 \pm 0,00323$ (Fig. 5.3). A dispersão desfavorável dos pontos no eixo das abcissas torna impreciso tanto o valor da idade como o da razão inicial.

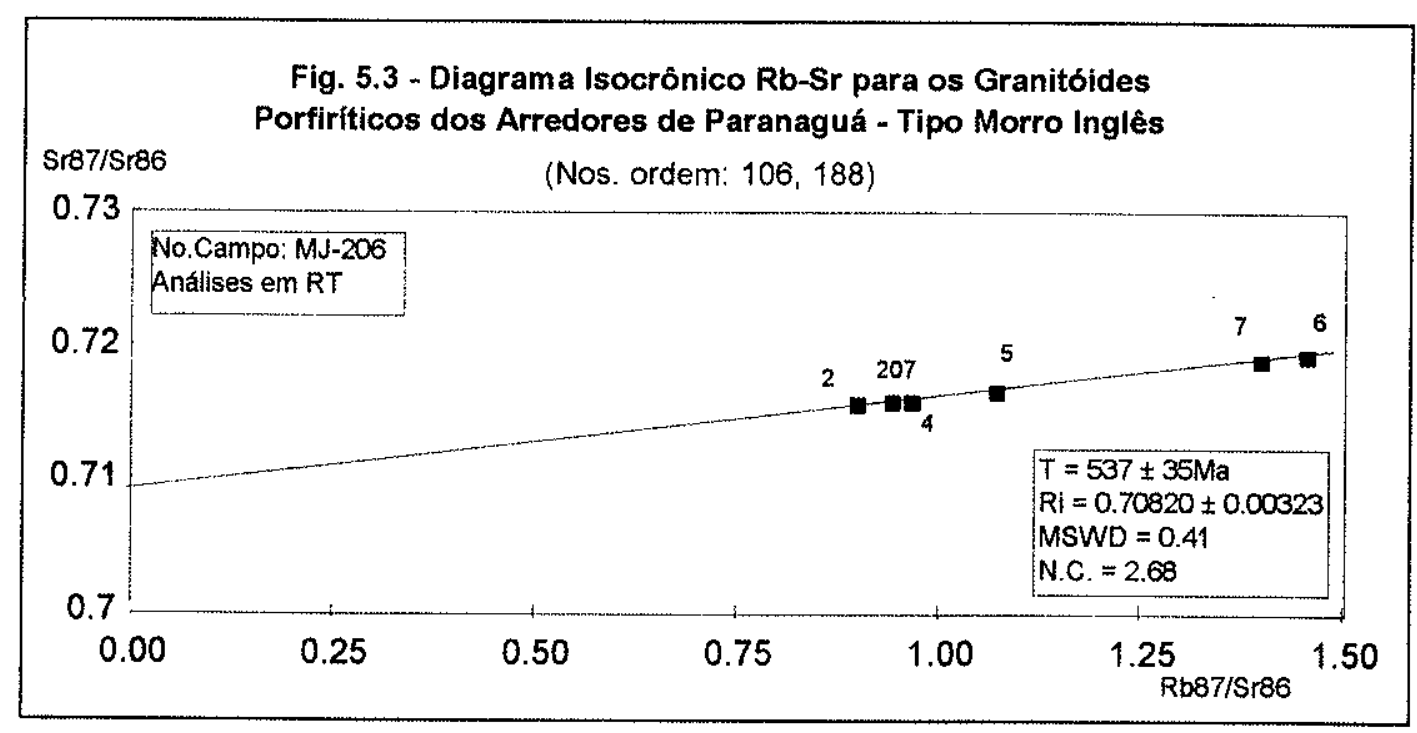

As amostras coletadas na pedreira de Matinhos (MJ-301), apresentaram melhor distribuição dos dados analíticos em diagrama isocrônico $\left(\mathrm{Rb}^{87} / \mathrm{Sr}^{86}\right.$ entre 1,25 e 2,30), sendo a idade obtida de $589 \pm 28 \mathrm{Ma}$, para uma relação inicial $\left(\mathrm{Sr}^{87} / \mathrm{Sr}^{86}\right)_{i}$ de $0,70757 \pm$ 0,00070 (Fig. 5.4). Padrão isocrônico Rb-Sr similar foi observado para os granitóides porfiriticos das proximidades de Guaratuba, que acusou idade de $562 \pm 33 \mathrm{Ma}$, para uma relação inicial $\left(\mathrm{Sr}^{87} / \mathrm{Sr}^{86}\right)_{i}$ de 0,70816 $\pm 0,00069$ (Fig. 5.5). 

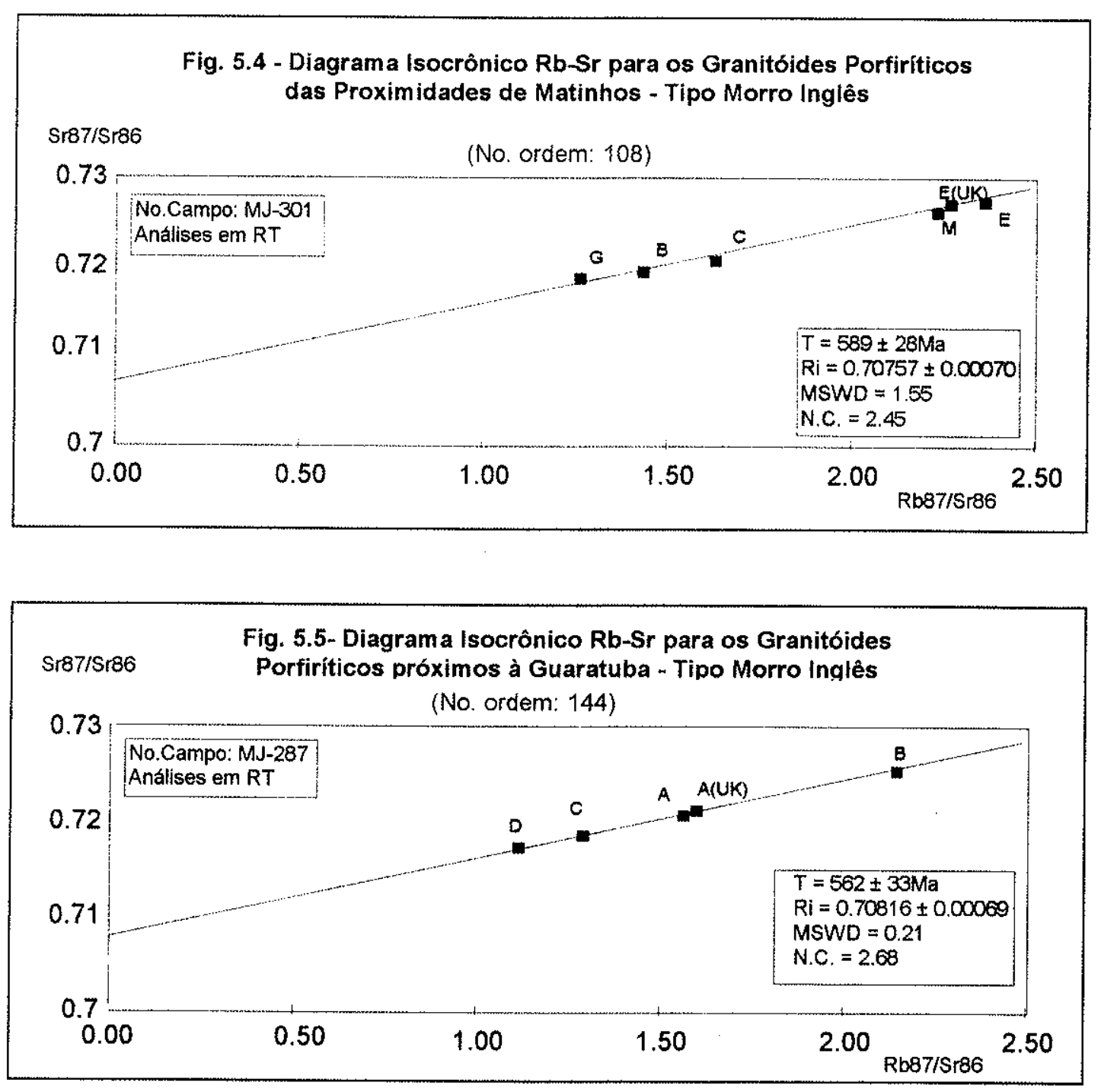

Os pontos analíticos, relativos a esses afloramentos quando tratados conjuntamente em diagrama isocrônico, apresentaram-se relativamente bem alinhados e distribuidos, definindo uma idade de $574 \pm 14 \mathrm{Ma}$, para uma relação inicial $\left(\mathrm{Sr}^{87} / \mathrm{Sr}^{86}\right)_{\mathrm{i}}$ de 0,70785 $\pm 0,00026$ (Fig. 5.6). Tal idade, em função da distribuição e alinhamento desses pontos, nos parece mais significativa, sendo interpretada como relativa ao fechamento do sistema isotópico Rb-Sr. O valor obtido para a relação inicial não é conclusivo no tocante a origem desse material, sendo relativamente alto para representar derivação mantélica e não o suficientemente alto para assegurar derivação crustal. 


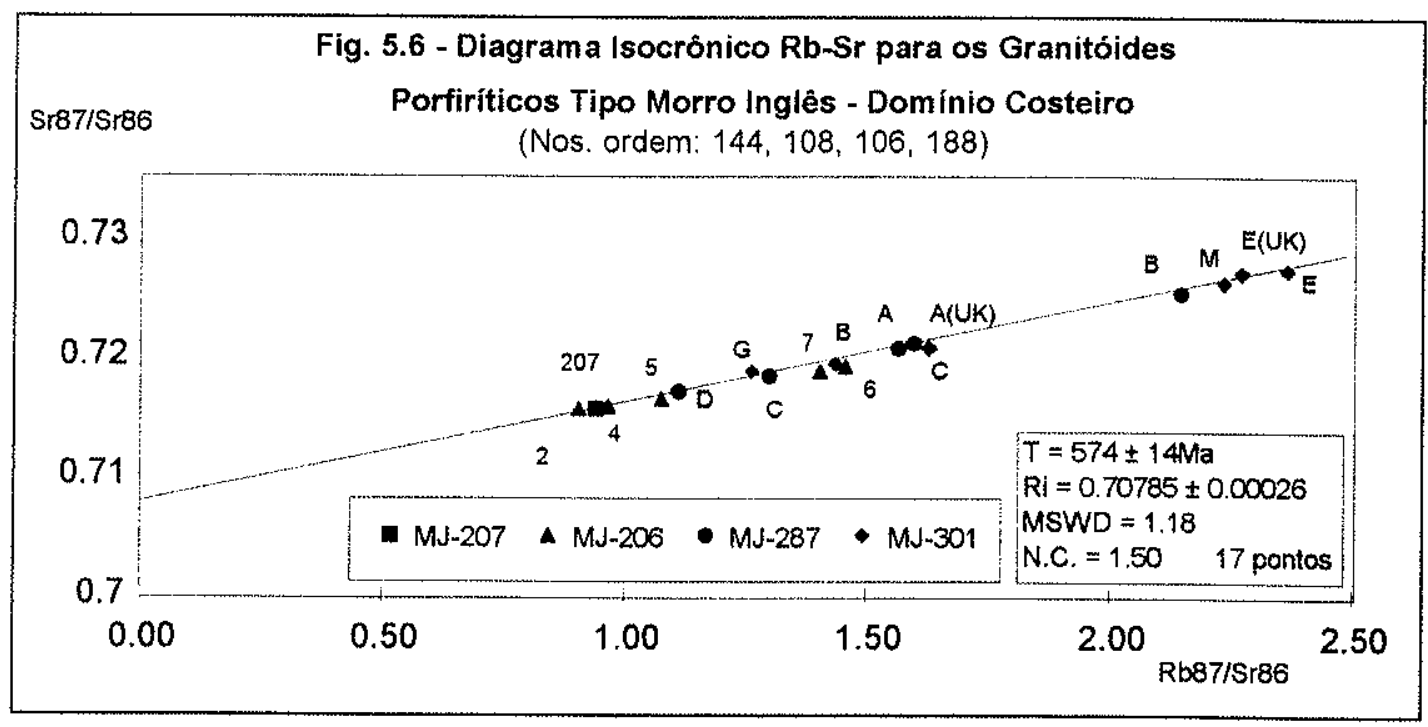

Valor isocrônico de referência pouco mais antigo de $621 \pm 13 \mathrm{Ma}$, para uma relação inicial de 0,7101 foi apresentado para rochas granitóides indiferenciadas localizadas entre Guaraqueçaba e llha de São Francisco por Teixeira (1982).

$\mathrm{O}$ estudo U-Pb desses granitóides tipo Morro Inglês, envolveu a análise de 5 frações de zircões da rocha de número de campo $\mathrm{MJ}-206.2$, coletada em afloramento próximo a Paranaguá (analisada também através do metodo $\mathrm{Rb}-\mathrm{Sr}$ ). Três das frações apresentaram-se bem alinhadas em diagrama $\mathrm{Pb}^{206} / \mathrm{U}^{235} \times \mathrm{Pb}^{207} / \mathrm{U}^{235}$, posicionando-se relativamente próximas ao intercepto superior da curva Concórdia. A idade obtida, de 614 土 9Ma indica a época de cristalização dos zircões destes granitóides (Fig. 5.7.A). Tal valor, mostra-se pouco superior a idade isocrônica $(574 \pm 14 \mathrm{Ma})$, sugerindo que o fechamento do sistema Rb-Sr deu-se tardiamente à cristalização dos zircões. Duas das frações analisadas posicionaram-se no diagrama Concórdia a direita do alinhamento de $614 \mathrm{Ma}$, indicando a presença de zircões com memória isotópica pretérita (Fig. 5.7.B). Utilizando-se o modelo de perda episódica de $\mathrm{Pb}$ (que teria ocorrido a $614 \mathrm{Ma}$ ) verifica-se que tais heranças isotópicas poderiam representar zircões formados no Paleoproterozóico. 

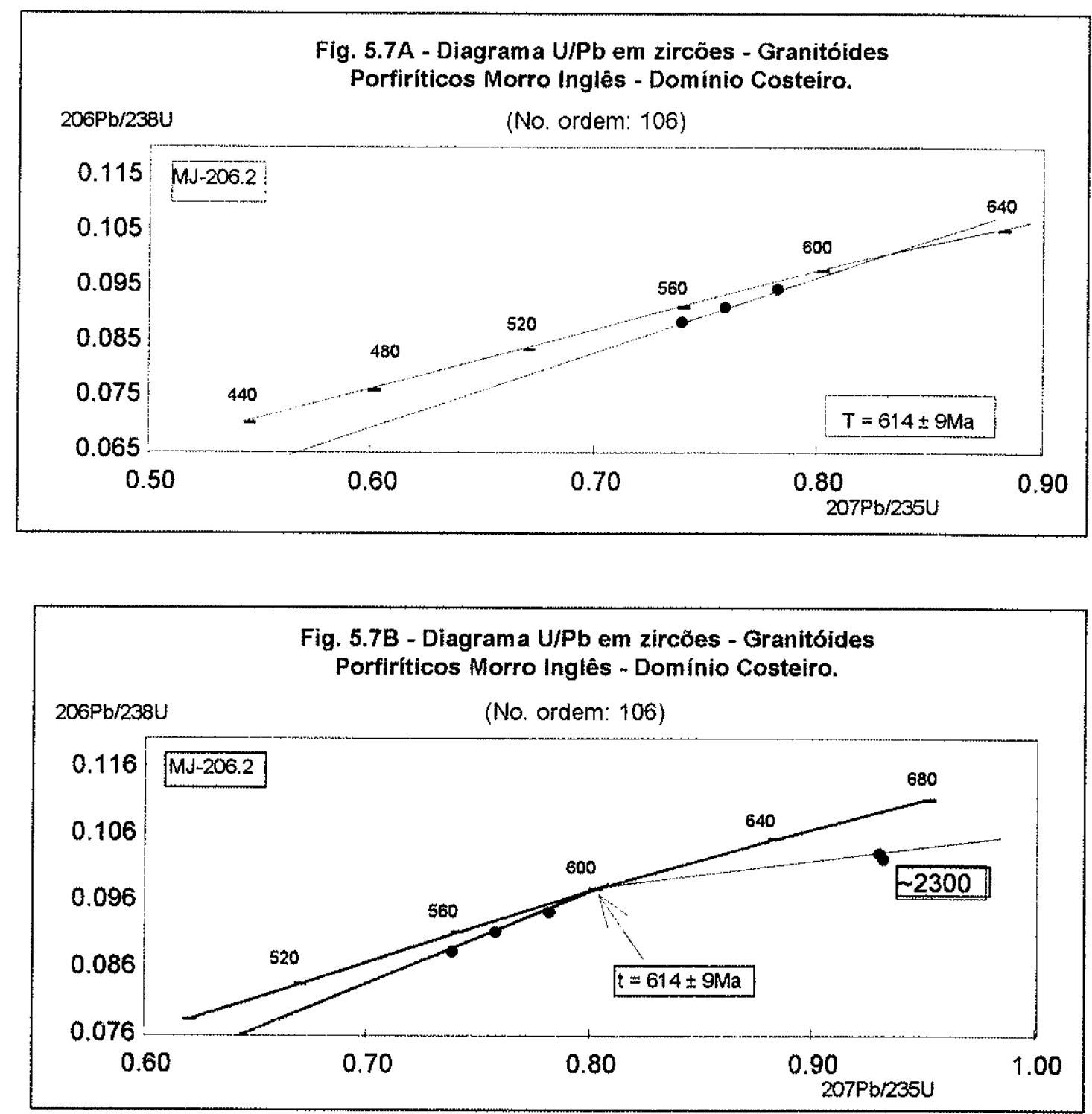

O estudo isotópico desses granitóides porfiríticos abrangeu, adicionalmente, análises de $\mathrm{Pb}$ em feldspatos potássicos das amostras MJ-301.H (pedreira em Matinhos), MJ-206.5 (Paranaguá) e MJ-287.B (Guaratuba). As relações $\mathrm{Pb}^{206} / \mathrm{Pb}^{204}$, $\mathrm{Pb}^{207} / \mathrm{Pb}^{204}$ e $\mathrm{Pb}^{208} / \mathrm{Pb}^{204}$ permitem diferenciar ambientes geológicos formadores de rocha, uma vez que tais reservatórios apresentam composições isotópicas distintas. Os valores de $\mathrm{Pb}$ foram plotados na figura 5.8 , onde estão individualizadas curvas de evolução desses isótopos para o manto, crosta inferior, crosta superior e de ambiente orogênico, segundo modelo da Plumbotectônica (Zartman \& Doe 1981). Os dados analíticos $\mathrm{Pb}^{207} / \mathrm{Pb}^{204} \times \mathrm{Pb}^{206} / \mathrm{Pb}^{204}$ (Fig. $5.8 \mathrm{~A}$ ) posicionaram-se no diagrama próximo 
(MJ-205.5) e pouco acima (MJ-301.H e 287.B) das respectivas curvas de evolução relativas a crosta inferior e manto, indicando contribuição de pelo menos um desses reservatórios, mas não diferenciando entre os mesmos. Tal diferenciação pode ser observada no diagrama $\mathrm{Pb}^{208} / \mathrm{Pb}^{204} \times \mathrm{Pb}^{206} / \mathrm{Pb}^{204}$ (Fig. 5.8B), onde os pontos analíticos posicionaram-se logo abaixo da curva de evolução para os materiais da crosta inferior, caracterizando uma significante participação desse reservatório na constituição dos granitóides estudados.

B

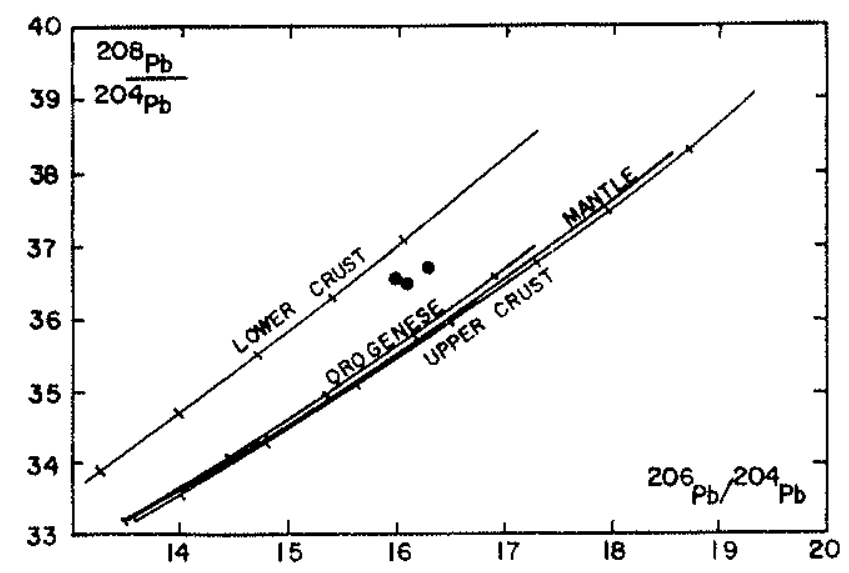

A

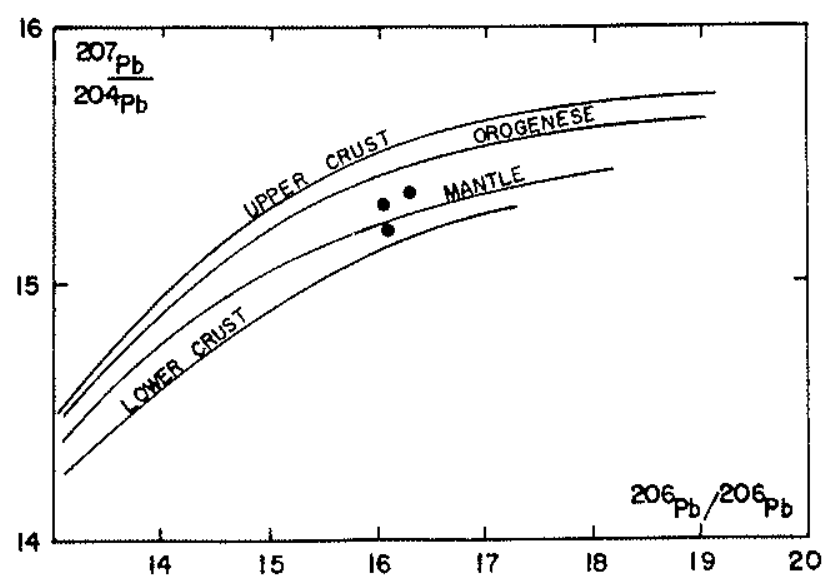

Fig. 5.8 - Modelo de Plumbotectônica de Zartman \& Doe (1981) para os Granitóides Tipo Morro Inglês 
Análises Sm-Nd (ToM) realizadas em amostras dos granitóides porfiriticos, tipo Morro Inglês, coletadas em afloramentos localizados a oeste de Paranaguá (MJ208.A), próximo de Guaratuba (MJ-287.A) e arredores de Matinhos (MJ-301.E), apresentaram idades modelo, respectivamente de $1.909 \mathrm{Ma}, 2.025 \mathrm{Ma}$ e $2.223 \mathrm{Ma}$ (Apêndice-1). Tais valores, caracterizam o Paleoproterozóico (ciclo Transamazônico) como o periodo principal em que os precursores crustais desses granitóides foram diferenciados do manto. Um parâmetro importante no estudo dos isótopos de $\mathrm{Nd}$ refere-se a comparação das relações iniciais $\mathrm{Nd}^{143} / \mathrm{Nd}^{144}$ dessas rochas quando de sua formação ( 615Ma) com as razões de seus repectivos reservatórios, na mesma época, sendo referido na literatura como $\varepsilon_{\text {Nd. }}$. Os valores obtidos para esse parâmetro. de -12 a -20 (fortemente negativos), são indicativos de um longo tempo de residência crustal dos protolitos que deram origem aos granitóides ora discutidos.

Os granitóides cataclásticos tipo Rio Canavieiras que ocorrem na porção ocidental do Domínio Paranaguá mostraram-se problemáticos às análises isotópicas. As hornblendas e/ou biotitas, além de escassas, apresentaram-se transformadas em tremolitas/actinolitas e cloritas, impossibilitando sua separação para fins de análises KAr. Adicionalmente, as inúmeras amostras coletadas ao longo dos rios Grande e Cubatãozinho apresentaram quantidades extremamente baixas em zircão, bem como relações $\mathrm{Rb}-\mathrm{Sr}$ bastante próximas, concentradas no eixo das abcissas, dificultando a utilização das metodologias U-Pb e Rb-Sr.

Para o granitóide isótropo tipo Rio do Poço, foram concentradas quatro frações de zircões, da amostra de número de campo MJ-209.C, coletada em afloramento localizado a oeste de Paranaguá. Essas frações apresentaram-se relativamente bem alinhadas em diagrama U-Pb, interceptando a curva Concórdia na idade de $609 \pm$ 28Ma (Fig. 5.9). Tal valor, representa a época de cristalização dos zircões desse corpo granítico, mostrando-se bastante próximo a idade obtida para os granitóides porfiríticos tipo Morro Inglês $(614 \pm 9 \mathrm{Ma})$. 


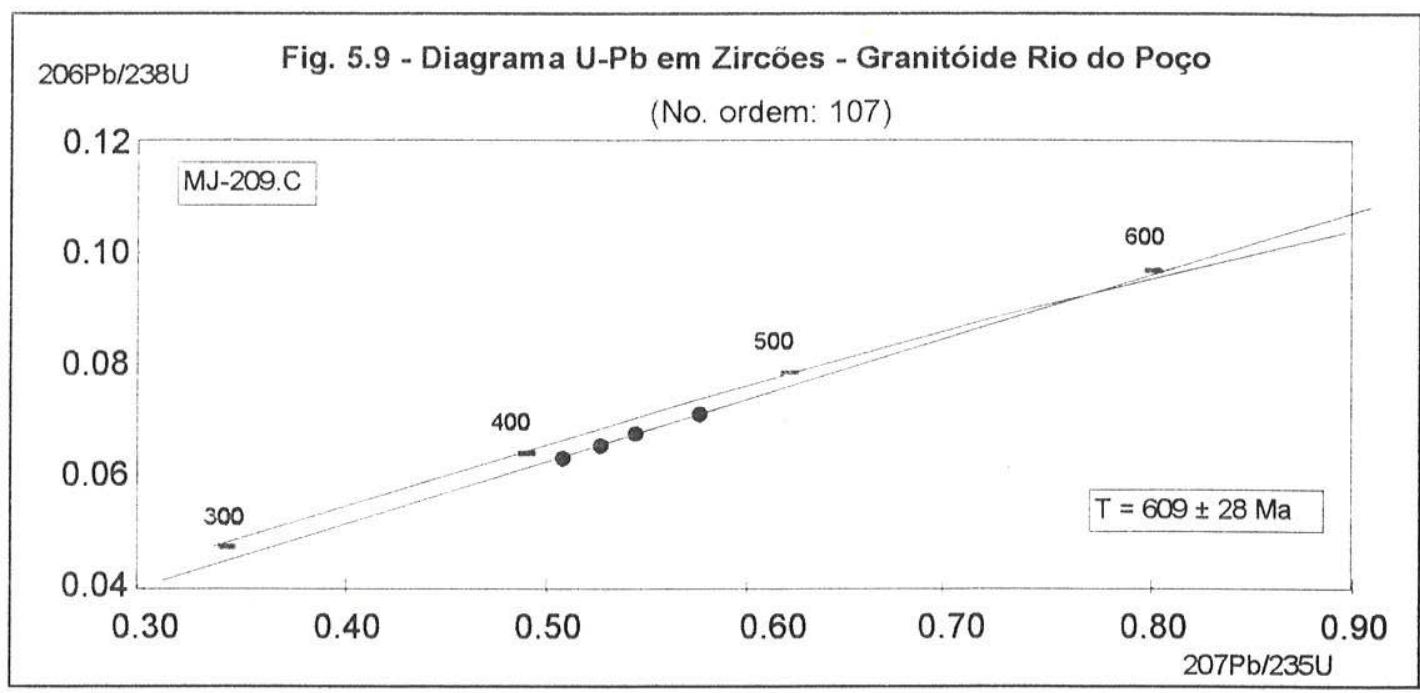

Os granitóides tipo Estrela foram tentativamente analisados através dos métodos $\mathrm{Rb}-\mathrm{Sr}$ (em rocha total), U-Pb (em zircões), $\mathrm{K}-\mathrm{Ar}$ (em biotitas) e $\mathrm{Sm}-\mathrm{Nd}$ ( $\mathrm{T}_{\mathrm{DM}}$ ). A grande similaridade nas relações $\mathrm{Rb} / \mathrm{Sr}$, observada para dezenas de amostras coletadas em diferentes afloramentos, impossibilitou a obtenção de idades precisas através desta sistemática. No diagrama isocrônico (Fig. 5.10) estão representados seis dados analíticos $\mathrm{Rb}-\mathrm{Sr}$, relativos a quatro afloramentos distribuídos ao longo dos rios São João e Cubatão. Verifica-se uma concentração desses pontos no eixo das abcissas (relações $\mathrm{Rb}^{87} / \mathrm{Sr}^{86}$ ) entre aproximadamente 0,6 e 1,0 indicando para a reta média (traçada entre os dois alinhamentos extremos), idade de $560 \pm 40 \mathrm{Ma}$ para uma relação inicial próxima de 0,708.

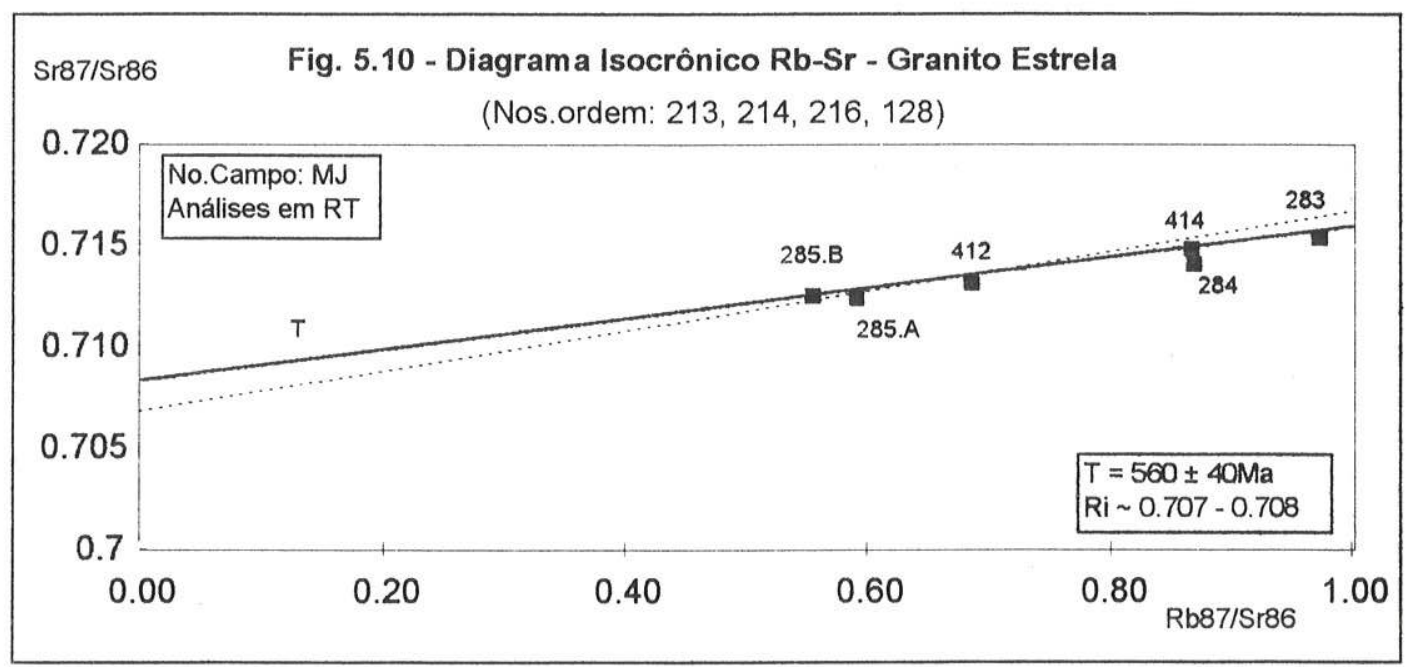


Duas frações de zircões, concentradas da amostra de número de campo MJ413.B, apresentaram seus pontos analíticos relativamente afastados do intercepto com a curva Concórdia, sugerindo quando a reta é forçada ao ponto zero, idade próxima de $590 \mathrm{Ma}$ (Fig. 5.11). Dados adicionais, bem como uma abrasão mais intensa dos zircões, se mostram necessários numa tentativa de analisar porções mais centrais desses minerais, menos afetados pelos processos de metamictização.

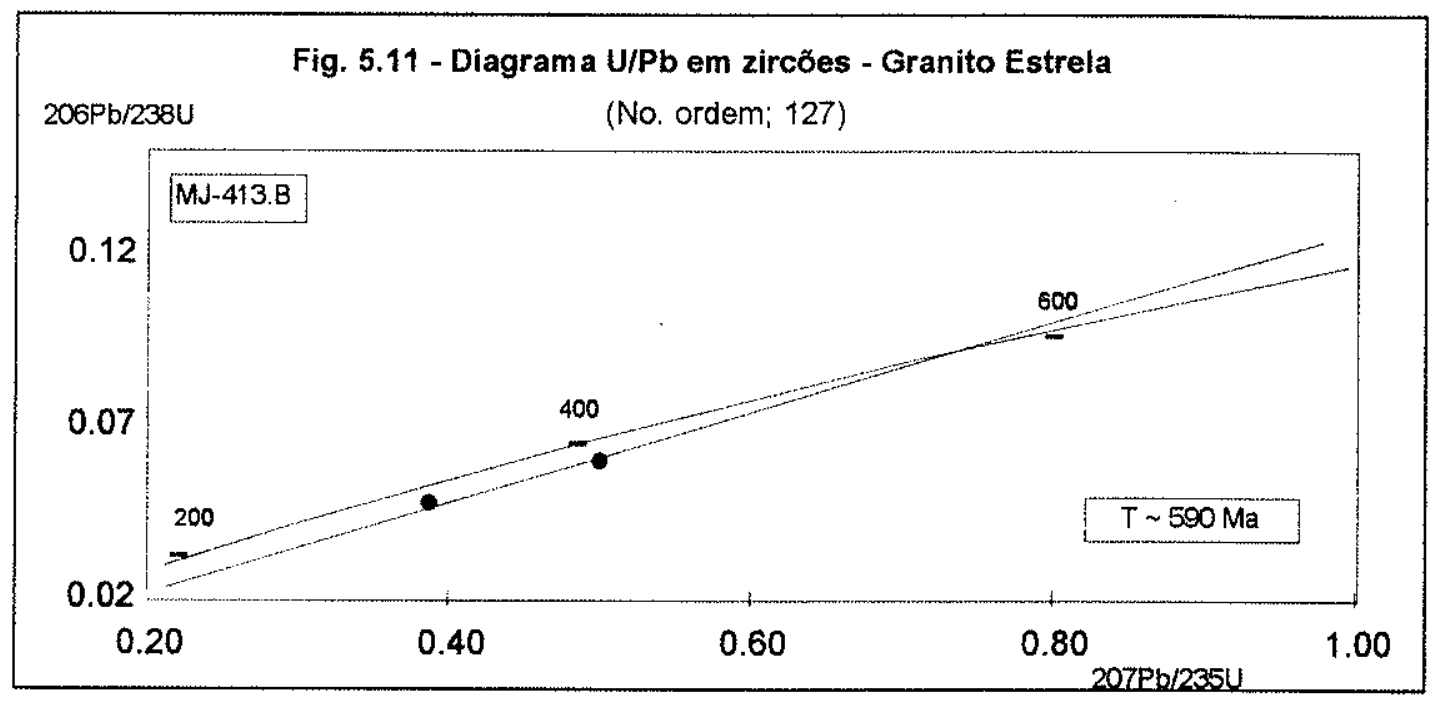

Os dados K-Ar relativos aos granitóides tipo Estrêla referem-se a análises obtidas em biotitas das amostras de números de campo MJ-283 e MJ-413.B que indicaram idades respectivamente de $536 \pm 17$ e $544 \pm 11 \mathrm{Ma}$ (apêndice 1).

Padrão geocronológico interessante refere-se as análises $\mathrm{Sm}-\mathrm{Nd}$ ( $T_{O M}$ ), relativas aos granitóides do setor ocidental deste cinturão, tipo Rio Canavieiras (MJ347) e Estrela (MJ-284 e 283), cujas idades modelo foram, respectivamente de $2.417 \mathrm{Ma}, 2.572 \mathrm{Ma}$ e $2.614 \mathrm{Ma}$ (apêndice 1). Tais valores, relacionados a época em que os precursores crustais dessas rochas se diferenciaram do manto, distinguem-se claramente dos observados para os granitóides tipo Morro Inglês (2.200-1.900Ma), distribuídos na porção centro-oriental do Domínio Paranaguá.

Os dados K-Ar relativos a biotitas dos granitóides tipo Morro Inglês, Rio do Poço e Estrela quando considerados conjuntamente em histograma, apresentam-se distribuídos no intervalo de 600-440Ma, ocorrendo concentração de idades entre 560- 
480Ma (Fig. 5.12). Este último intervalo deve representar o periodo principal de resfriamento/soerguimento deste cinturão granítico, caracterizando um longo período de tempo desde sua formação (615-580Ma), até atingir isotermas inferiores a $300^{\circ}$ $250^{\circ} \mathrm{C}$.

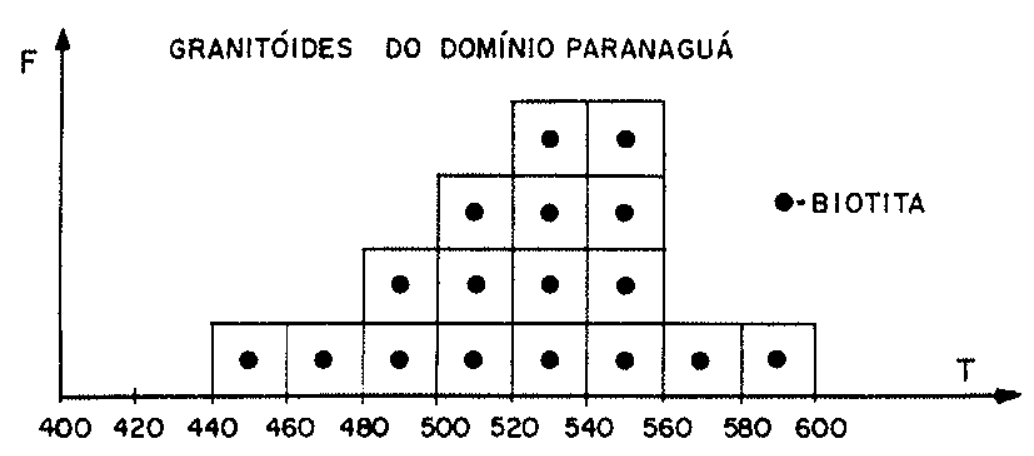

Fig. 5.12 - Histograma K-Ar - Granitóides do Dominio Paranaguá 


\section{DOMÍNIO PARANAGUÁ}

PRANCHA FOTOGRÁFICA 5 
- Foto 5a - Aspecto geral dos granitóides tipo Morro Inglês. Macroscopicamente são leucocráticos, cinza claros, foliados, de granulação média $e$ porfiríticos. Microscopicamente predominam k-feldspato (megacristais), plagioclásio (oligoclásio - andesina), quartzo, biotita e hornblenda. Os principais minerais acessórios são apatita, zircão, opacos e titanita, este último presente em quantidades significativas (MJ-201 - SE de Garuva).

- Foto $5 b$ - Intensa deformação dúctil observada nos granitóides tipo Morro Inglês. Os megacristais de K-feldspato mostram-se alongados adquirindo, as vezes, formas sigmoidais.

- Foto $5 \mathrm{c}$ - Detalhe de enclave de granulação fina, mesocrático, de composição quartzo-diorítica, comum nos granitóides tipo Morro Inglês (MJ-206 Paranaguá).

- Foto $5 d$ - Milonitos no contato do Domínio Paranaguá e Domínio Luís Alves (Z.C. Alexandra - Serra Negra). Rodovia Curitiba - Paranaguá (MJ397 - BR-277).

- Foto 5e - Granitóides tipo Rio do Poço (MJ-209): leucocráticos, cinza claros, granulação média, equigranulares, a plagioclásio (albita oligoclásio), k-feldspato, quartzo, biotita e muscovita (Rodovia Curitiba - Paranaguá - BR-277).

- Foto $5 f$ - Granitóides tipo Estrela: leucocráticos, cinza claros, granulação média, inequigranulares, a quartzo, plagioclásio (oligoclásio andesina), k-feldspato, biotita e hornblenda (MJ-283 - Rio São João).

- Foto $5 \mathrm{~g}$ - Feição protomilonítica comum nos granitóides tipo Canavieiras. Ao microscópio predominam quartzo com forte extinção ondulante, $k$ feldspato saussuritizado e sericitizado, plagioclásio com lamelas curvas e quebradas, tremolita-actinolita, clorita e epídoto (MJ-356 Rio Sambaqui). 

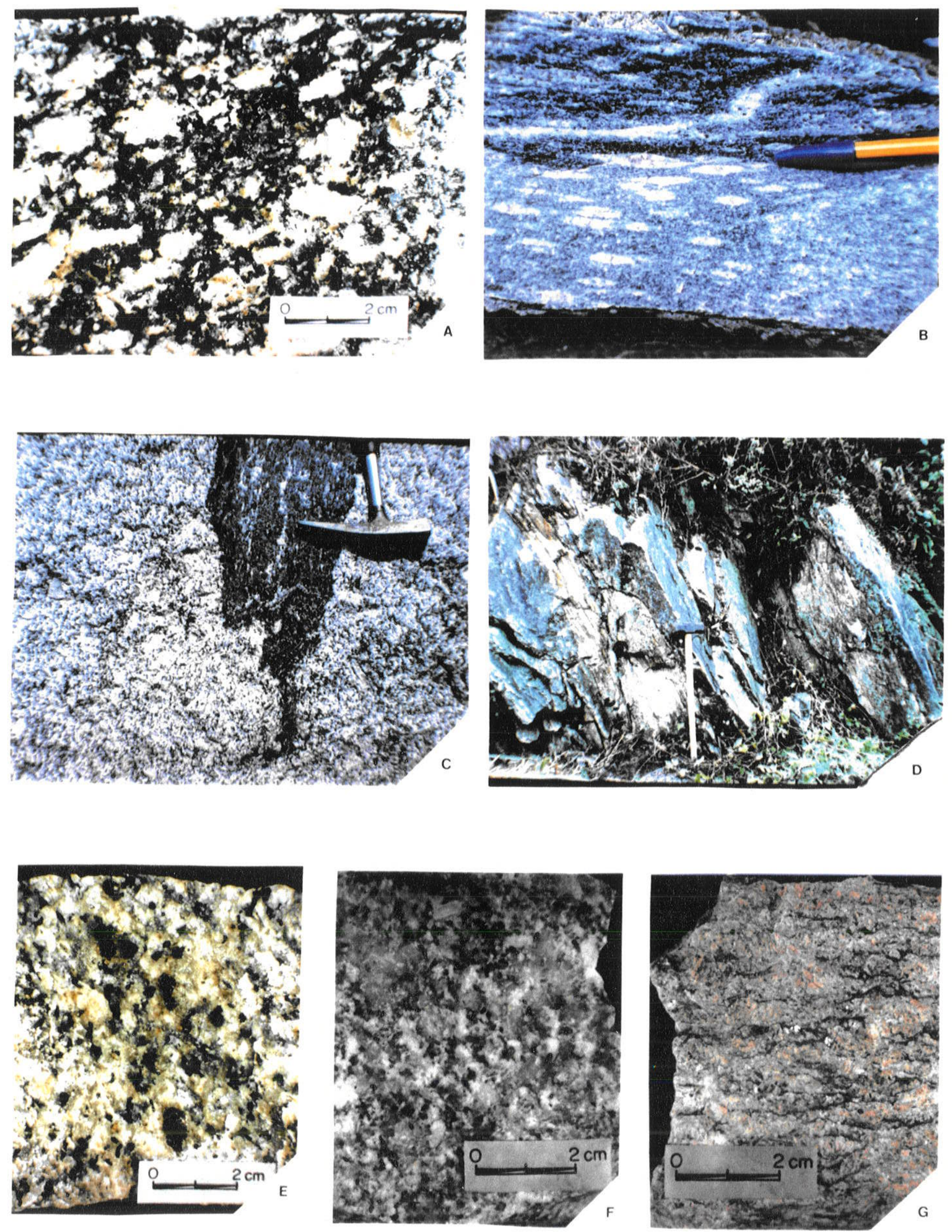


\section{CAPITULO 6}

\section{MAGMATISMO E SEDIMENTAÇÃO DE REGIMES EXTENSIONAIS PÓS-OROGÊNICOS}

\subsection{GRANITÓIDES ALCALINOS-PERALCALINOS}

Diversos corpos graniticos foram individualizados no setor nordeste de Santa Catarina e sudeste do Paraná, fruto de projetos que envoiveram mapeamento geológico básico, dentre os quais destacam-se os executados na década de 60 pela Comissão da Carta Geológica do Paraná e por Maack (1961) e, na década de 70, pela CPRM (Projeto Básico Leste de Santa Catarina).

Esses maciços graníticos apresentam dimensões variadas, constituindo desde pequenos stocks até batólitos, cujas denominaçōes tem por base a toponímia das regiões onde ocorrem: Agudos do Sul, Corupá, Serra Alta, Morro Redondo, Serra da Igreja, Graciosa, Anhangava, Marumbi, Piraí e Dona Francisca. Distribuem-se tanto no Domínio Curitiba como Luis Alves, predominado neste último, não ocorrendo nos terrenos pertencentes ao Domínio Paranaguá.

Caracterizam esses maciços a natureza alcalina, bem como sua isotropia, em constraste com a pronunciada foliação dos gnaisses e migmatitos encaixantes, com os quais os contatos são normalmente realizados através de zonas de falha.

Pretende-se discutir de maneira sucinta observações efetuadas em campo e em laboratório, neste caso, envolvendo aspectos petrográficos e geocronológicos, utilizando-se adicionalmente, dos dados existentes na literatura. Em termos petrográficos, foram descritas cerca de 50 lâminas, número este bastante reduzido quando considerada a grande variedade composicional e textural observada para cada um desses corpos. Tais observações petrográficas foram efetuadas com 0 objetivo principal de auxiliar as análises e interpretações geocronológicas.

As análises radiométricas pré-existentes, em número reduzido, envolveram determinações $\mathrm{K}-\mathrm{Ar}$ e $\mathrm{Rb}-\mathrm{Sr}$, e neste caso, diagramas isocrônicos contendo amostras de diferentes corpos. Essas idades caracterizam épocas relativas ao Neoproterozóico (ciclo Brasiliano) para a formação de grande parte desses maciços graníticos. 


\subsubsection{Aspectos Geológicos}

Embora as pesquisas realizadas tivessem como objetivo principal o estudo dos terrenos gnáissico-migmatíticos, um reconhecimento de grande parte dos maciços graníticos de natureza alcalina-peralcalina fez-se necessário, numa tentativa de melhor compreender e posicionar essa expressiva atividade plutônica no quadro geotectônico regional.

O Granito Agudos do Sul, cartografado pela Comissão da Carta Geológica do Paraná (Trein et al. 1969 a e b, Marini et al. 1970) e descrito por Fuck et al. (1967c), ocupa uma superficie superior a $400 \mathrm{Km}^{2}$, distribuindo-se no setor centro-sul estudado, próximo a divisa entre os estados do Paraná e Santa Catarina. Faz contato na porção sul e sudeste com rochas gnáissico-granulíticas do Dominio Luís Alves e a nortenoroeste com os gnaisses migmatíticos e granitóides deformados do Domínio Curitiba.

Nos trabalhos realizados pela Comissão da Carta Geológica do Paraná, Trein et al. (1969b), na folha de Tijucas do Sul (1:70.000), admitem caráter intrusivo desse maciço granítico, enquanto Marini et al. (1970), na folha de Mandirituba (1:70.000) mencionam passagem gradativa deste corpo (por ele denominado de Granito Palermo) para os migmatitos embrechíticos, ora reconhecidos como pertencentes aos granitóides deformados do setor sul do Domínio Curitiba.

Girardi (1974) do mesmo modo, inclui no maciço de Agudos do Sul rochas aflorantes na faixa Gramados - Piên - Poço Frio, salientando que, em parte dessa área, o material granítico apresenta-se deformado. Este autor admite o caráter intrusivo do granito Agudos, baseado na isotropia dessas rochas, em contraste com a pronunciada foliação dos gnaisses e migmatitos encaixantes. Adicionalmente, apresenta algumas determinações radiométricas $\mathrm{Rb}-\mathrm{Sr}$ com idade isocrônica próxima de $580 \mathrm{Ma}$, valor este relacionado aos granitos sin a tardi tectônicos do ciclo brasiliano (Cordani \& Kawashita 1971).

Fiori (1978), em estudos fotogeológicos, distingue cinco variedades faciológicas para o maciço granitico Agudos, admitindo três fases de intrusões sucessivas. Os fácies graníticos foram pelo autor agrupados em magnetita granitos ( $C, D, E)$ e ilmenita granitos $(A, B)$. 
Neste maciço, predominam rochas leucocráticas de granulação média a grossa cinza, cinza rosadas a róseas, equi a inequigranulares, ocasionalmente porfiriticas. Apresentam textura hipidiomórfica, granular, sendo constituídas por feldspato potássico (5-60\%, com ou sem geminação em grade, geraimente mesopertíticos), plagioclásio $(0-60 \%$, albita-oligoclásio, normalmente zonados), quartzo (10-35\%), biotita (0-15\%, mostrando variedades marrom avermelhada e verde) e hornblendas ( 0 $15 \%$, verdes). Como acessórios são comuns titanita, allanita, zircão, apatita, fluorita e opacos e como produto de transformação, muscovita, clorita, epidoto e carbonato.

A presença de rochas básicas, de composição notadamente gabro-diorítica, internas ao maciço granitico Agudos, foi assinalada por Girardi (1974) e Machiavelli (1991). São rochas meso a melanocráticas, com cores verde a cinza-esverdeada, de granulação fina a média, por vezes grossa, composta essencialmente por plagioclásio, clinopiroxênio, ortopiroxênio, hornblenda e biotita. $O$ contato entre os litotipos graníticos e básicos são referidos pelos autores citados como possivelmente transicional, com porções que sugerem mistura. Machiavelli (1991), estudando petrograficamente amostras coletadas no contato desses corpos, observou a presença de quartzo manteado por anfibólio, plagioclásio corroído e manteado por feldspato potássico e anfibólio, sugerindo uma fase de mistura contemporânea entre magma ácido e básico. Acrescente-se que, enclaves de serpentinitos foram observados nesses granitóides, a noroeste de Tijucas do Sul, constituindo xenólitos centimétricos a métricos, com formas tabulares e contatos irregulares.

O Granito Morro Redondo, ocupa uma superficie superior a $250 \mathrm{~km}^{2}$, distribuindo-se, aproximadamente, na porção central da região estudada, a oestenoroeste de Garuva, com exposições equivalentes em territórios paranaense e catarinense. Distribui-se no âmbito do Domínio Luís Alves, apresentando próximo as bordas feições cataclásticas e miloníticas. Sua identificação foi assinalada por Maack (1961), que se refere a um corpo possivelmente de natureza alcalina nas proximidades de Garuva. Posteriormente, este maciço granítico foi cartografado, no estado do Paraná, por Trein et al. 1969b e Muratori et al. 1969a (folhas Tijucas do Sul e Pedra Branca de Araraquara 1:70.000) e por Albuquerque et al. 1971, em Santa Catarina (Quadricula de Joinville, 1:250.000, Projeto Básico Leste de Santa Catarina, CPRM), sendo descrito por Fuck et al. (1967c). 
Variedades composicionais e texturais são comuns neste maciço granítico, fato facilmente caracterizado através das descrições de Trein et al. (1969b) e Albuquerque et al. (1971), respectivamente nas folhas Tijucas do Sul (PR, 1:70.000) e na quadrícula Joinville (Santa Catarina, 1:250.000). O primeiro autor descreve como litotipo mais comum, granitos equigranulares, leucocráticos, de coloração branca a cinza clara e granulação média, enquanto o segundo refere-se a rochas de coloração rosada a cinza claro de granulação grossa, por vezes, porfirítico.

De modo geral, observa-se a presença de granitos isótropos nas porções mais centrais e cataclasados nas bordas. Os litotipos mais comuns, apresentam granulação média, são equi a inequigranulares, raramente porfiríticos, leucocráticos e de coloração cinza-clara. Essas rochas apresentam normalmente textura hipidiomórfica, granular, sendo constituidas por quartzo (5-30\%), feldspato alcalino (20-60\%), normalmente pertítico, plagioclásio (albita, 5-30\%), biotita (0-10\%), hornblenda (0-10\%), anfibólios sódicos (riebeckita/arfvedsonita), piroxênios $\mathrm{Na}-\mathrm{Ca}$ (egirina/augita), além de olivina (faialita). Os acessórios comuns são titanita, zircão, apatita, rutilo, fluorita e opacos e como produtos de transformação ocorrem clorita, epídoto, muscovita e argilo minerais.

$\mathrm{Na}$ porção sul deste corpo granítico ocorrem ainda rochas vulcânicas de natureza alcalina, cujas relações de contato são ainda imprecisas.

O Granito Corupá, descrito por Albuquerque et al. (1971), estende-se por uma superfície de cerca de $60 \mathrm{~km}^{2}$ a nordeste da cidade homônima, constituindo o denominado Morro do Boi, que ocupa o setor sul-sudeste da bacia vulcano-sedimentar de Campo Alegre. Albuquerque et al. (1971) mencionam relações de contato intrusiva com os gnaisses do embasamento $e$, imprecisas com as seqüencias vulcanosedimentares. A observação de tais relações foram dificultadas, uma vez que nessa região os afloramentos são esparsos e normalmente intemperizados, ocorrendo muitas vezes como blocos.

Na borda oeste, o maciço de Corupá é em parte recoberto por sedimentos da Bacia do Paraná, e em parte faz contato com as rochas gnáissico-granuliticas do Domínio Luís Alves, como em sua porção oriental, e nas porçōes norte e sul faz contato, respectivamente, com as seqüências vulcano-sedimentares das Bacias de Campo Alegre e Corupá. 
Albuquerque et al. (1971), mencionam para o maciço granítico de Corupá, composições graníticas, quartzo-sieníticas e sieníticas, consideradas pelos autores como variações laterais.

Essas rochas mostram-se normalmente leucocráticas, equigranulares, ocasionalmente porfiriticas, com granulação média a grossa, e coloração pardoavermelhada a cinza-esverdeada. A textura é normalmente granular, hipidiomórfica e os minerais predominantes são: quartzo (2-15\%), feldspato potássico (com ou sem geminação em grade, normalmente pertítico, 30-65\%), plagioclásio (albita, 10-70\%), hornblenda $(0-10 \%)$, biotita $(0-10 \%)$, anfibólios sódicos (riebeckita/arfvedsonita), piroxênios $\mathrm{Na}-\mathrm{Ca}$ (egirina/augita), além de olivina (faialita). Os minerais acessórios comuns são titanita, apatita, zircão, fluorita e opacos, ocorrendo clorita, sericita, epídoto e carbonato como produtos de tranformação.

Trainini (1974) assinala a presença de um pequeno corpo granítico de composição alcalina na estrada que liga Corupá a São Bento do Sul a cerca de $10 \mathrm{~km}$ a sul desta última cidade, o qual denominou de Granito Serra Alta. Ocupa uma superfície próxima de $20 \mathrm{~km}^{2}$, distribuindo-se no âmbito do Dominio Luís Alves, ocorrendo associado a rochas vulcânicas ácidas (riolitos e traquitos). A presença de zonas radiométricamente anômalas motivou a execução de uma sondagem em sua borda sul, (furo CA-12 - Projeto Campo Alegre - Valiati 1974), que atingiu a profundidade de 120,60 metros, sempre atravessando rochas graníticas de natureza alcalina. Menciona, através de testemunho colhido na profundidade de 23 metros, a existência de um delgado veio de riolito com cerca de $1,5 \mathrm{~cm}$ de espessura cortando esses granitos alcalinos. Daitx \& Carvalho (1980) descrevem em afloramento próximo, relação inversa, isto é, diques de microgranito com cerca de $30 \mathrm{~cm}$ de espessura cortando rochas vulcânicas. Ebert (1971), estudando rochas vulcânicas próximas deste corpo granitico menciona seu caráter fortemente alcalino, acusando a presença de barkevicita, riebeckita e egirina.

- Granito Serra da Igreia, ocupa uma superfície próxima de $90 \mathrm{~km}^{2}$, distribuindo-se ao longo da serra homônima, à leste da bacia vulcano-sedimentar do Rio Guaratubinha, no estado do Paraná. Seus limites foram estabelecidos por Muratori et al. (1969b) por ocasião do mapeamento geológico da folha Serra da Igreja, na escala 1:70.000. Apresenta forma alongada no sentido NE-SW e relaçöes de contato por falha, com as rochas gnáissico-granulíticas do Domínio Luís Alves. Apenas em sua 
porção nordeste encontra-se balizado pelas rochas granito-gnáissicas do Domínio Paranaguá, apresentando-se nesta região intensamente deformado, com aspecto cataclástico e milonítico.

Esses granitos são normalmente leucocráticos, equi a inequigranulares, com granulação média e cores cinza claro, cinza rosado e róseo. Muratori et al. (1969b) reportam seu caráter subalcalino e Fuck et al. (1971) assinalam uma tendência alcalina,com presença de anfibólios e piroxênios sódicos.

O Granito da Graciosa, delimitado parcialmente por Maack (1961) e descrito por Cordani \& Girardi (1967), ocupa uma superfície superior a $300 \mathrm{~km}^{2}$, distribuindo-se no setor NE da área estudada, constituindo as Serras dos Orgãos, Graciosa, Mãe Catira, Farinha Seca e Ibiteraquire, onde se encontra o Pico Paraná, ponto culminante do estado. Este corpo apresenta direção geral nordeste, limitando-se com as rochas gnáissico-migmatiticas do Domínio Curitiba (a oeste) e com os granito-gnaisses do Domínio Paranaguá (a leste). Feições cataclásticas foram observadas próximo aos limites oriental e ocidental deste maciço, envolvendo tanto as rochas graníticas como as pertencentes aos terrenos gnáissicos adjacentes.

Este corpo granítico exibe uma grande variedade de litotipos, predominando rochas leucocráticas, com cores cinza-claro e rosado, granulação média, por vezes porfirítica, havendo porções praticamente isentas de minerais máficos e outras ricas em biotita e/ou anfibólio. Microscopicamente, apresentam textura hipidiomórfica, granular, sendo constituídas por quartzo (10-25\%), feldspato potássico (muitas vezes isento de geminação em grade, formando comumente intercrescimento pertíticos - 15$65 \%$ ), plagioclásio (albita-oligoclásio, 0-50\%), hornblenda (0-10\%), biotita $(0-10 \%)$, anfibólios sódicos (riebeckita/arfvedsonita, 0-10\%), piroxênios $\mathrm{Na}-\mathrm{Ca}$ (egirina/augita 0$10 \%)$, Como minerais acessórios ocorrem zircão, titanita, apatita, allanita, fluorita e opacos e, como produtos de transformação, clorita, muscovita, epídoto e carbonatos. Nas amostras com menor tendência alcalina predominam plagioclásio e feldspato potássico em cristais individualizados $e$, nas com maior caráter alcalino, a micropertita é dominante.

$\mathrm{Na}$ estrada da Graciosa, proximidades do rio Cascata, ocorrem rochas de granulação média, cinza-esverdeadas, de composição diorítica, cujas relações de contato com os granitos não foram observadas. Apresentam como minerais essenciais 
o plagiociásio (oligoclásio/andesina, 60-65\%), augita (20-30\%), hornblenda (5-10\%), quartzo $(2-3 \%)$ e biotita (2-5\%).

O Granito Anhangava, descrito por Fuck (1967a), ocupa uma superficie de aproximadamente $60 \mathrm{~km}^{2}$, constituindo o morro homônimo, a leste e nordeste de Piraquara. Faz parte da Serra do Mar, localmente conhecida como Serra do Baitaca e Serra da Boa Vista, sendo balizado pelas rochas gnáissico-migmatíticas do Dominio Curitiba. Fuck (1967a) menciona relações de contato intrusivas deste maciço, evidenciadas pela presença de filões félsicos semelhantes aos do granito Anhangava, que cortam os migmatitos aflorantes a leste de Piraquara.

Macroscópica e microscopicamente, este granito mostra-se bastante similar ao da Graciosa, exibindo uma grande variedade de litotipos, com predomínio de termos leucocráticos, cinza-claro, cinza-rosado e róseo, equi a inequigranulares, com granulação fina a média, às vezes grossa. Essas rochas apresentam textura hipidiomórfica, granular, sendo constituidas essencialmente por quartzo (10-25\%), feldspato potássico (10-65\%) plagioclásio (albita/oligoclásio, 0-30\%), biotita (0-10\%), hornblenda (0-10\%), anfibólios sódicos (riebeckita/arfvedsonita), piroxênios $\mathrm{Na}-\mathrm{Ca}$ (egirina/augita). Como minerais acessórios ocorrem zircão, titanita, allanita, apatita, fluorita e opacos e como produtos de transformação epidoto, clorita, sericita e carbonato. O feidspato potássico é normalmente micropertítico, ocorrendo, nos termos sub-alcalinos, em cristais isolados, com ou sem geminação em grade, sendo neste caso, o plagioclásio dominante o oligoclásio.

O Granito Marumbi (Maack 1961; Cordani \& Girardi 1967) ocupa uma superficie de aproximadamente $80 \mathrm{~km}^{2}$, distribuindo-se a sul do maciço da Graciosa, na serra homônima. Faz limite com as rochas gnáissico-migmatíticas do Domínio Curitiba, no setor ocidental e com os gnaisses granuliticos do Dominio Luís Alves, na porçäo oriental. Observa-se em campo, uma maior homogeneidade desses granitos, quando comparados com os maciços da Graciosa e Anhangava. Apresentam-se normalmente, leucocráticos, equigranulares com granulação média e cor cinza claro à cinza rosado, tendo como minerais dominantes quartzo, feldspato potássico, plagioclásio e biotita.

Maack (1961), através da análise de elementos maiores, de uma amostra coletada próxima a estação Marumbi, evidencia tendência menos alcalina deste corpo, em relação aos maciços Graciosa e Anhagava adjacentes. Tal tendência é também sugerida por Cordani \& Girardi (1967) em função de estudos petrográficos envolvendo 
diversas amostras deste corpo granitico, que apresentaram uma mineralogia a base de quartzo, feldspato potássico (normalmente pertítico), plagioclásio (albita) e biotita (verde a fortemente avermelhada).

Segundo Cordani \& Girardi (1967) as zonas de contato deste maciço granítico mostram-se intensamente perturbadas por falhamentos. Mencionam a existência de restos de teto ao longo da estrada de ferro Curitiba-Paranaguá, na altura da estação Engenheiro Lange.

A presença de feldspato potássico pertítico, e a composição sódica do plagioclásio, indicam para o granito Marumbi caráter alcalino, similar ao observado para o granito Agudos do Sul, não sendo descritos, nesses corpos, anfibólios ou piroxênios sódicos, comuns nos demais maciços. Os granitos Corupá, Serra Alta, Morro Redondo, Serra da Igreja, Graciosa e Anhangava, mostram variedades sienitograniticas. Os minerais máficos mostram tendências evolutivas desde francamente metaluminosos atè francamente peralcalinos. Nessa evolução temos a presença de faialitas (Corupá e M. Redondo) e clinopiroxênios (egirina/augita), que se mostram por vezes bordejados por anfibólios cálcico-sódicos, até totalmente sódicos (riebeckitas), diferindo nesse aspecto dos corpos graníticos Agudos e Marumbi.

As poucas amostras analisadas em diagrama QAP (Streckeisen 1976), indicam composições predominantemente granodioriticas para a maciço de Agudos e, alcalifeldspato-granítica a alcali-feldspato-quartzo-sienítica para os corpos Anhangava, Graciosa, Morro Redondo e Corupá (Fig. 6.1) .Acrescente-se que a utilização deste diagrama teve por objetivo classificar e ilustrar parte do conjunto analisado e, de modo algum, representar a grande variedade composicional desses maciços graníticos.

Os Granitos Dona Francisca e Piraí, constituem corpos menos expressivos, aflorantes na Serra do Mar, a leste da bacia vulcano-sedimentar de Campo Alegre, ocorrendo no âmbito das rochas gnáissico-granulíticas do Domínio Luís Alves. De acordo com Albuquerque et al. (1971) esses corpos apresentam extrema escassez de minerais máficos, sendo classificados como alaskitos. São rochas leucocráticas, equigranulares, de granulação fina a média e coloração avermelhada ou vermelho carne. Albuquerque et al. (1971) caracterizam uma mineralogia a base de quartzo, feldspato potássico (normalmente pertítico) e plagioclásio (oligoclásio), sendo a biotita rara e cloritizada. 


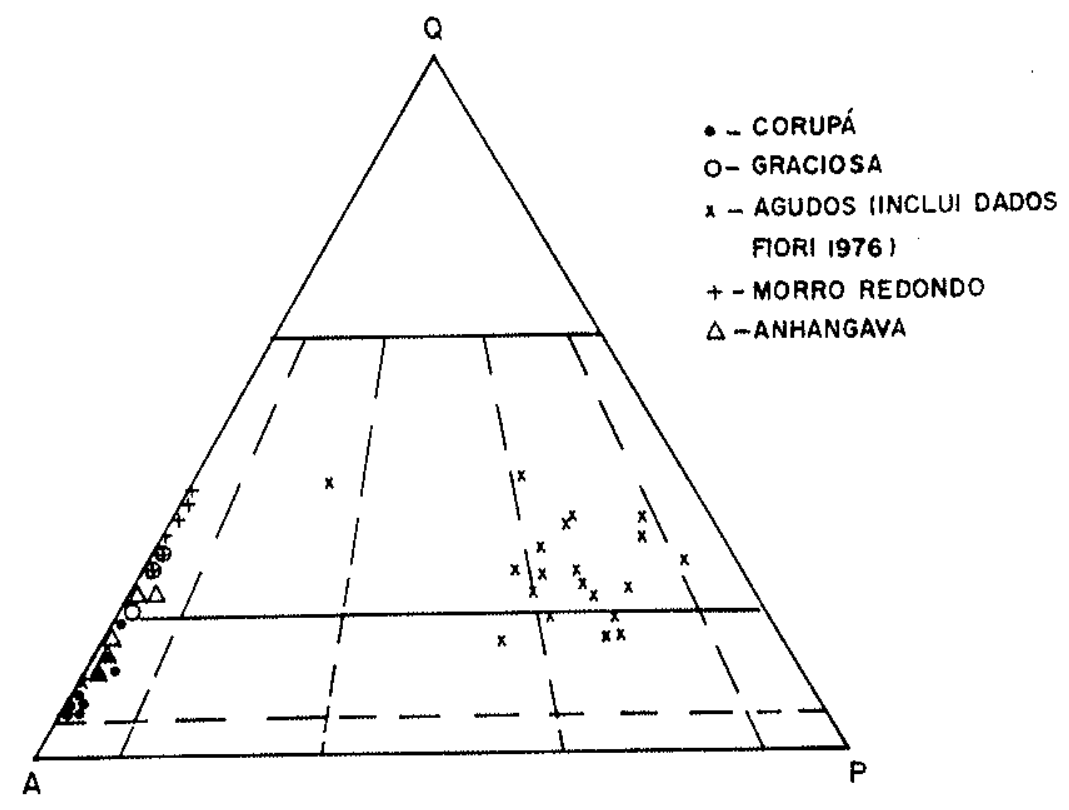

Fig. 6.1 - Diagrama QAP (Streckeisen 1976) - Maciços Graníticos da porção NE de Santa Catarina e SE do Paraná

Em termos geoquímicos, foram analisadas para elementos maiores, traços e terras raras somente sete amostras, pertencentes aos maciços graníticos Agudos do Sul (3), Corupá (1), Graciosa (1), Anhangava (1) e Morro Redondo (1).

Em diagrama $R_{1} \times R_{2}$ (De La Roche et al. 1980), os dados analíticos obtidos foram lançados conjuntamente com os de Kaul \& Cordani (1994) que, embora não diferenciados, representam os maciços graníticos da Serra do Mar, localizados no leste Paranaense e vizinhanças (Agudos do Sul, Corupá, Morro Redondo, Serra da Igreja, Anhangava, Graciosa, Marumbi, Alto Turvo e Guaraú). Observa-se uma distribuição dos dados, neste diagrama, segundo "trends" subalcalinos a alcalinos saturados (Fig. 6.2), campo este indicativo de transição de condições tardi-orogênicas para condições francamente anorogênicas (Batchelor \& Bowden 1985). Acrescente-se que os três dados relacionados ao maciço de Agudos do Sul distribuiram-se preferencialmente no âmbito dos granitóides subalcalinos. Os índices de Shand (1951) denotam caracteristicas metaluminosas/peraluminosas para o maciço de Agudos do Sul, 
metaluminosa para o corpo de Corupá e peralcalinas para os demais (Graciosa, Morro Redondo, Anhangava).

O diagrama de multielementos (Pearce et al 1984) sugere preliminarmente, função das poucas análises disponiveis, um padrão de fracionamento relativamente suave para o conjunto representado pelos granitóides Corupá, Graciosa, Morro Redondo e Anhangava (Fig. 6.3), com enriquecimento de todos os elementos em relação ao condrito (até cerca de 100 vezes). Acrescente-se que o granito Corupá não apresenta anomalia negativa em $\mathrm{Ba}$, comuns aos demais maciços. Uma comparação visual entre esse diagrama e os apresentados por Pearce et al. (1984) permite associá-los aos granitóides intraplacas (WPG), normalmente a anfibólios e piroxênios sódicos e, intrusivos em crosta continental fortemente atenuada ( exemplo dos granitóides da Nigéria - Bowden \& Tumer 1974, Imeokparia 1982). Os dados relativos ao maciço de Agudos do Sul (Fig. 6.4) indicam um padrão de fracionamento mais acentuado, denotando similarmente aos demais corpos, enriquecimento de todos os elementos em relação ao condrito (até cerca de 100 vezes) e anomalias negativas em Ba. Assemelham-se mais aos granitóides sin a pós colisionais (Pearce et al. 1984).

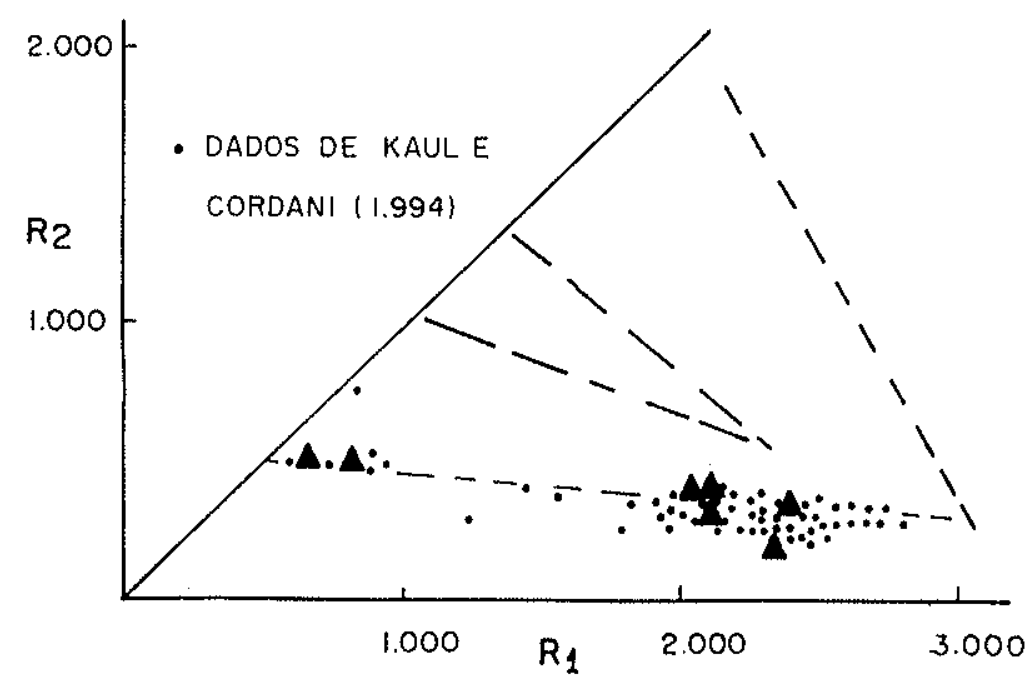

Fig. 6.2 - Diagrama $R_{1} \times R_{2}$ (De La Roche et al. 1980) - Maciços Graníticos da porção SE do Paraná e NE de Santa Catarina. 


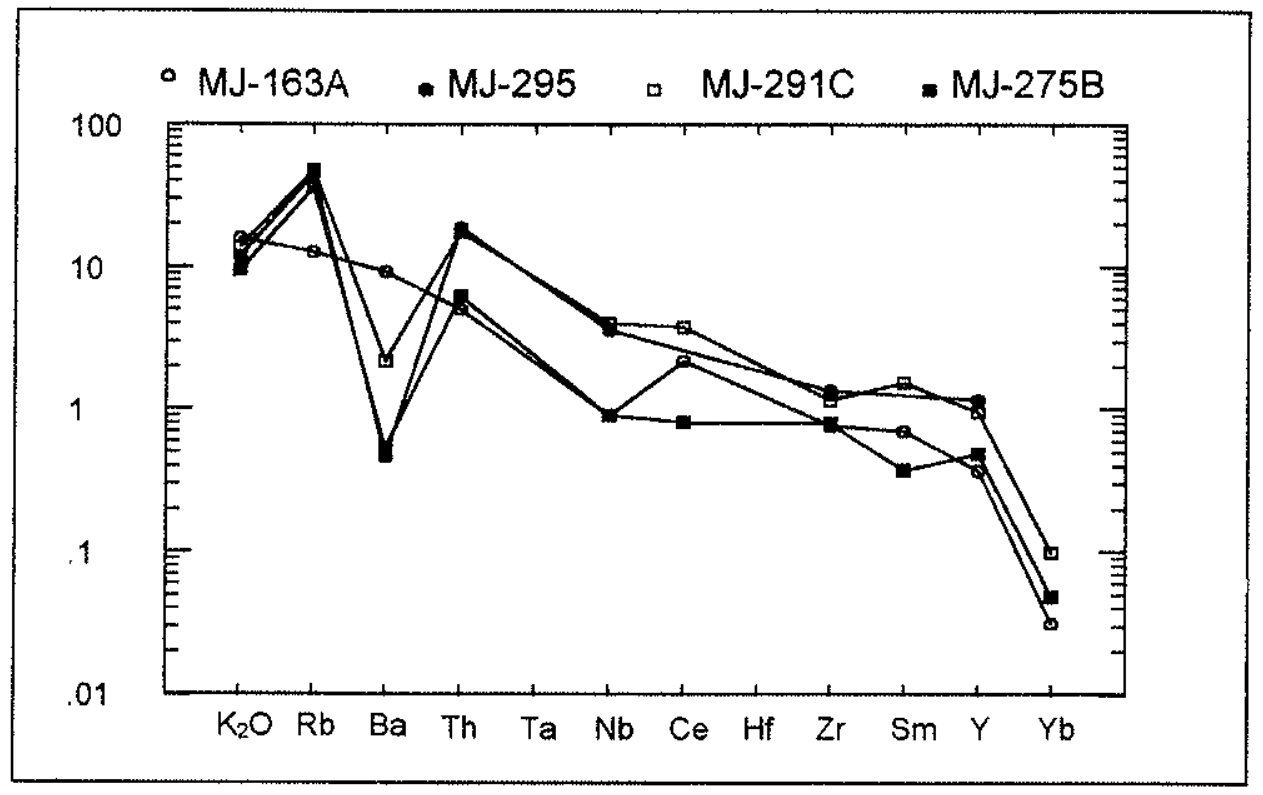

Fig. 6.3 - Diagrama de Multielementos - Maciços Graníticos da porção SE do Paraná e NE de Santa Catarina (norm - Pearce et al. 1984)

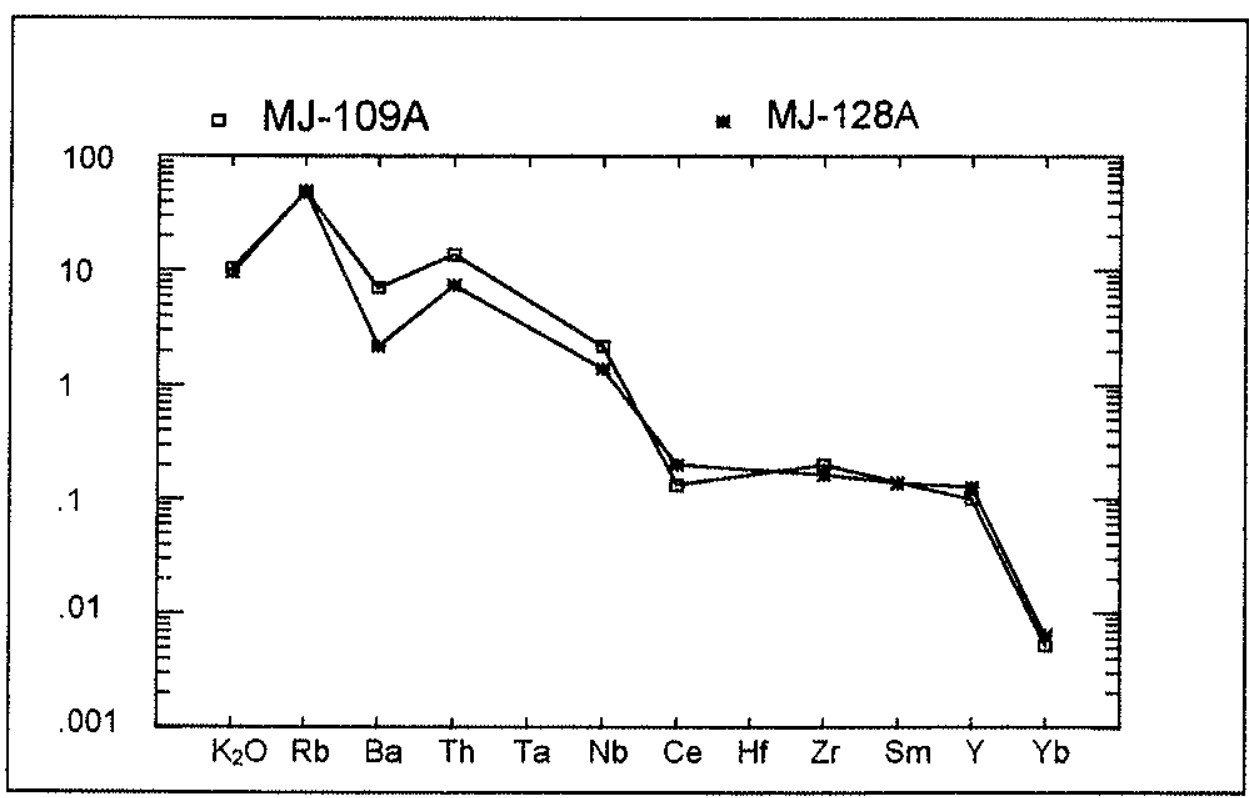

Fig. 6.4 - Diagrama de Multielementos - Rochas Graníticas do Maciço Agudos do Sul. (norm. - Pearce et al. 1984) 


\subsubsection{Geocronologia}

Os dados geocronológicos relativos aos maciços graníticos do setor nordeste Catarinense e sudeste Paranaense totalizam atualmente mais de 120 determinações radiométricas, envolvendo os métodos $\mathrm{Rb}-\mathrm{Sr}$ (em rocha total), $\mathrm{K}-\mathrm{Ar}$ (em minerais), U$\mathrm{Pb}$ (em zircões) e Sm-Nd (idades modelo, em rocha total) .

O estudo geológico e geocronológico dessa importante atividade plutônica encontra-se a nível de reconhecimento regional, uma vez que tratam-se de maciços graníticos expressivos (stocks e batolitos), que apresentam individualmente variedades composicionais e texturais significativas e, cuja colocação pode ter envolvido processos múltiplos, com duração de alguns milhões de anos.

Para o maciço granítico Agudos do Sul foram realizadas análises $U-\mathrm{Pb}$ de quatro frações de zircões, concentradas de amostra coletada em sua porção centronorte (afloramento de número de campo MJ-132). Os dados analíticos obtidos apresentaram-se relativamente alinhados em diagrama $\mathrm{U}-\mathrm{Pb}$, interceptando a curva Concórdia na idade de $594 \pm 26 \mathrm{Ma}$, interpretada como relativa à época de cristalização dos zircões e portanto de formação dessas rochas graníticas (Fig. 6.5). Tais zircões, mesmo submetidos a um processo de abrasão de 5 a 6 horas posicionaram-se relativamente afastados da curva Concórdia. Acredita-se que a intensificação de tal processo poderia ocasionar sensivel aproximação desses pontos analíticos da curva Concórdia, resultando em maior precisão na idade obtida.

A metodologia $\mathrm{Rb}-\mathrm{Sr}$, em rocha total, foi tentativamente aplicada para o corpo granitico de Agudos do Sul, a nivel de afloramento, porém a homogeneidade observada nas relações $\mathrm{Rb}-\mathrm{Sr}$ inviabilizou tais determinações para fins isocrônicos. Relativa distribuição dos pontos analíticos foi obtida utilizando-se de rochas graníticas composicional e texturalmente similares, coletadas em dois afloramentos próximos, localizados nos arredores de Agudos do Sul (amostras de números de campo MJ-109 e 128). Em diagrama isocrônico, esses dados distribuiram-se no eixo das abcissas (relações $\mathrm{Rb}^{87} / \mathrm{Sr}^{86}$ ) entre 1,9 e 2,4 (afloramento $\mathrm{MJ}$-109) e entre 3,0 e 4,5 (afloramento MJ-128), indicando para a reta que melhor se ajusta a esses pontos idade de $570 \pm$ $22 \mathrm{Ma}$, para uma relação inicial $\left(\mathrm{Sr}^{87} / \mathrm{Sr}^{86}\right)_{i}$ de $0,70735 \pm 0,00080$ (Fig. 6.6). Tal valor 


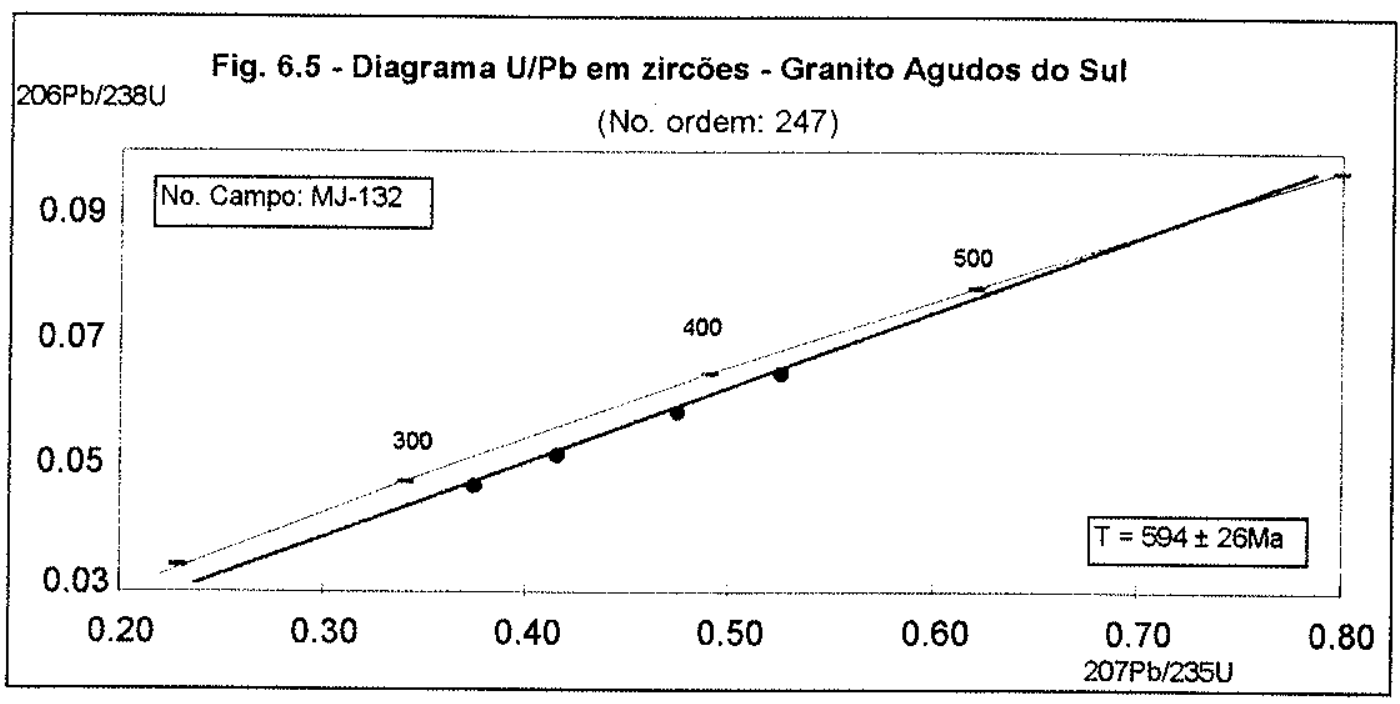

parece estar relacionado a época de fechamento do sistema $\mathrm{Rb}-\mathrm{Sr}$, que teria ocorrido após a cristalização dos zircões.

Girardi et al. (1974), apresentam um diagrama isocrônico $\mathrm{Rb}-\mathrm{Sr}$ de referência, para o granito Agudos do Sul, contendo três pontos analíticos, relacionados a amostras coletadas em diferentes afloramentos da porção sul deste maciço. $A$ idade obtida, de $600 \pm 23 \mathrm{Ma}$, para uma relação inicial $(\mathrm{Sr} 87 / \mathrm{Sr} 86)$, de $0,70401 \pm 0,00039$ mostra-se similar aos dados U-Pb ora apresentados (Fig. 6.7, recalculada para $\lambda=$ $1.42 \times 10^{-11}$ /ano).

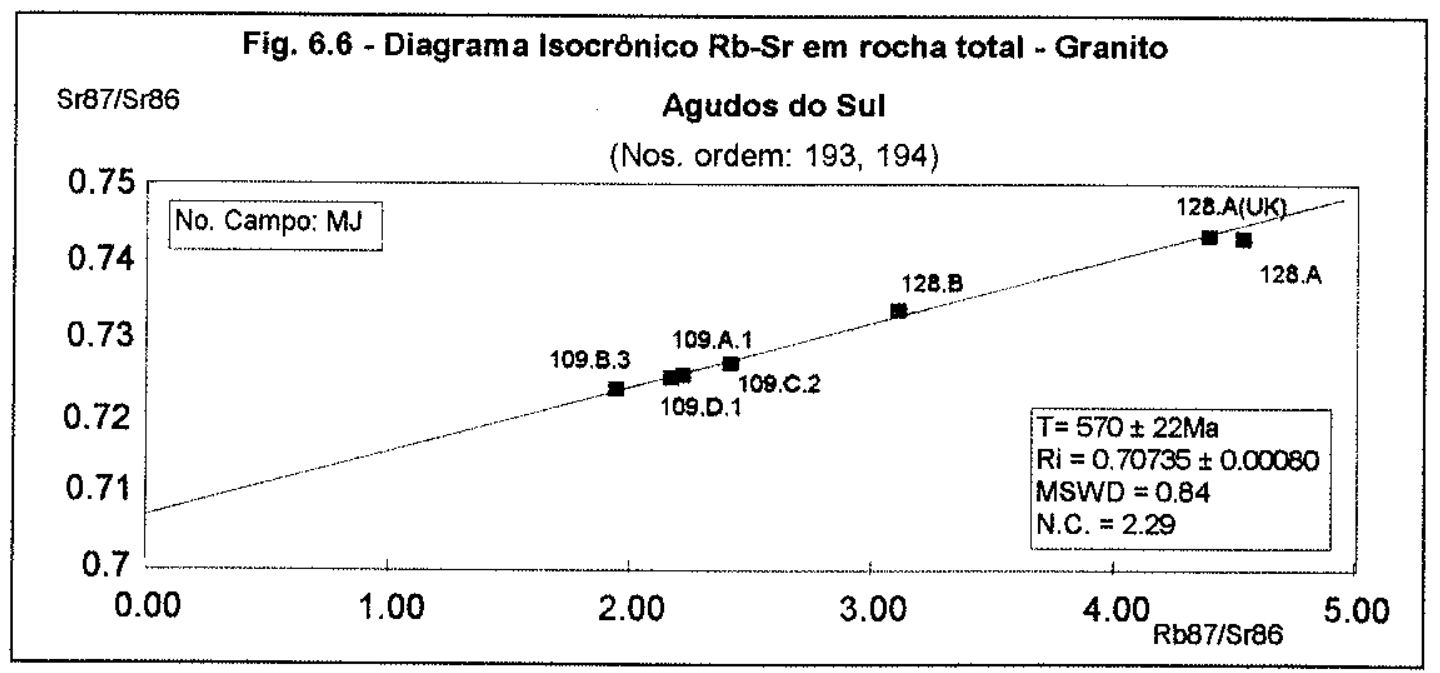




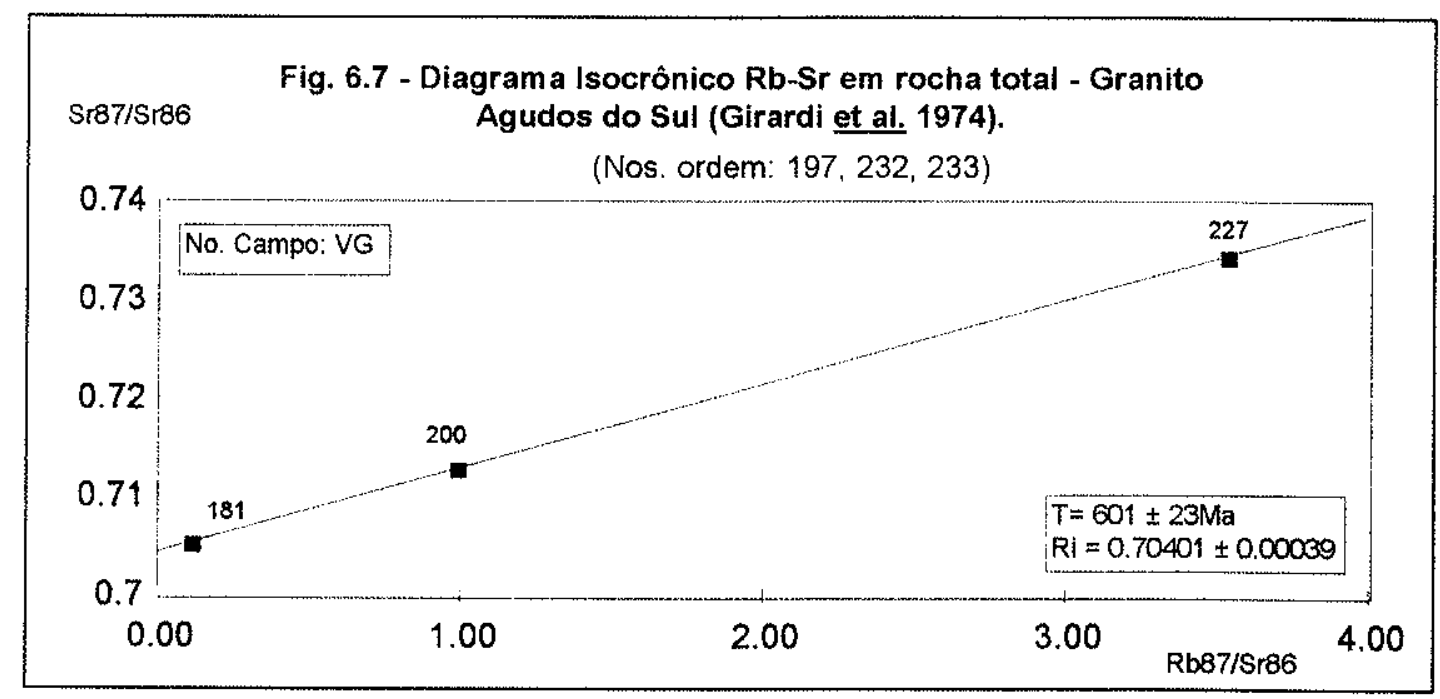

Acrescente-se que idades isocrônicas de $544 \pm 8 \mathrm{Ma}(\mathrm{ri}=0,709)$ e $596 \pm 22 \mathrm{Ma}$ $(r i=0,705)$, relativas a biotita-granitos respectivamente da porção norte e sul deste maciço, foram referidas por Kaul \& Cordani (1994).

Considerando-se os dados U-Pb e Rb-Sr, ora comentados, bem como os erros analíticos, relativamente elevados, o intervalo 600-570Ma, parece representar o periodo principal de formação dessas rochas graniticas.

Para o corpo granítico de Corupá, foram analisadas através do método U-Pb, quatro frações de zircões. Esses dados apresentaram-se relativamente alinhados em diagrama $\mathrm{U}-\mathrm{Pb}$, contendo um dos pontos analíticos posicionado próximo à curva Concórdia, definindo a idade de $580 \pm 6 \mathrm{Ma}$, interpretada como relativa a época de cristalização dos zircões (Fig. 6.8).

Amostras provenientes do mesmo afloramento (MJ-163), foram adicionalmente, analisadas através do método $\mathrm{Rb}-\mathrm{Sr}$, em rocha total. Os pontos analíticos apresentaram-se, em diagrama isocrônico, concentrados no eixo das abcissas $\left(\mathrm{Rb}^{87} / \mathrm{Sr}^{86}\right)$ próximas a 2,0 e entre $3,5-4,0$, indicando idade de $550 \pm 26 \mathrm{Ma}$, para uma relação inicial $\left(\mathrm{Sr}^{87} / \mathrm{Sr}^{88}\right)$, de $0,70703 \pm 0,00100$ (Fig. 6.9). Uma análise $\mathrm{Rb}$-Sr efetuada na amostra de número de campo MJ-164, coletada em afloramento bastante próximo ao anteriormente datado, mostrou comportamento coerente, posicionando-se ao longo dessa reta isocrônica com idade de $550 \pm 26 \mathrm{Ma}$. 

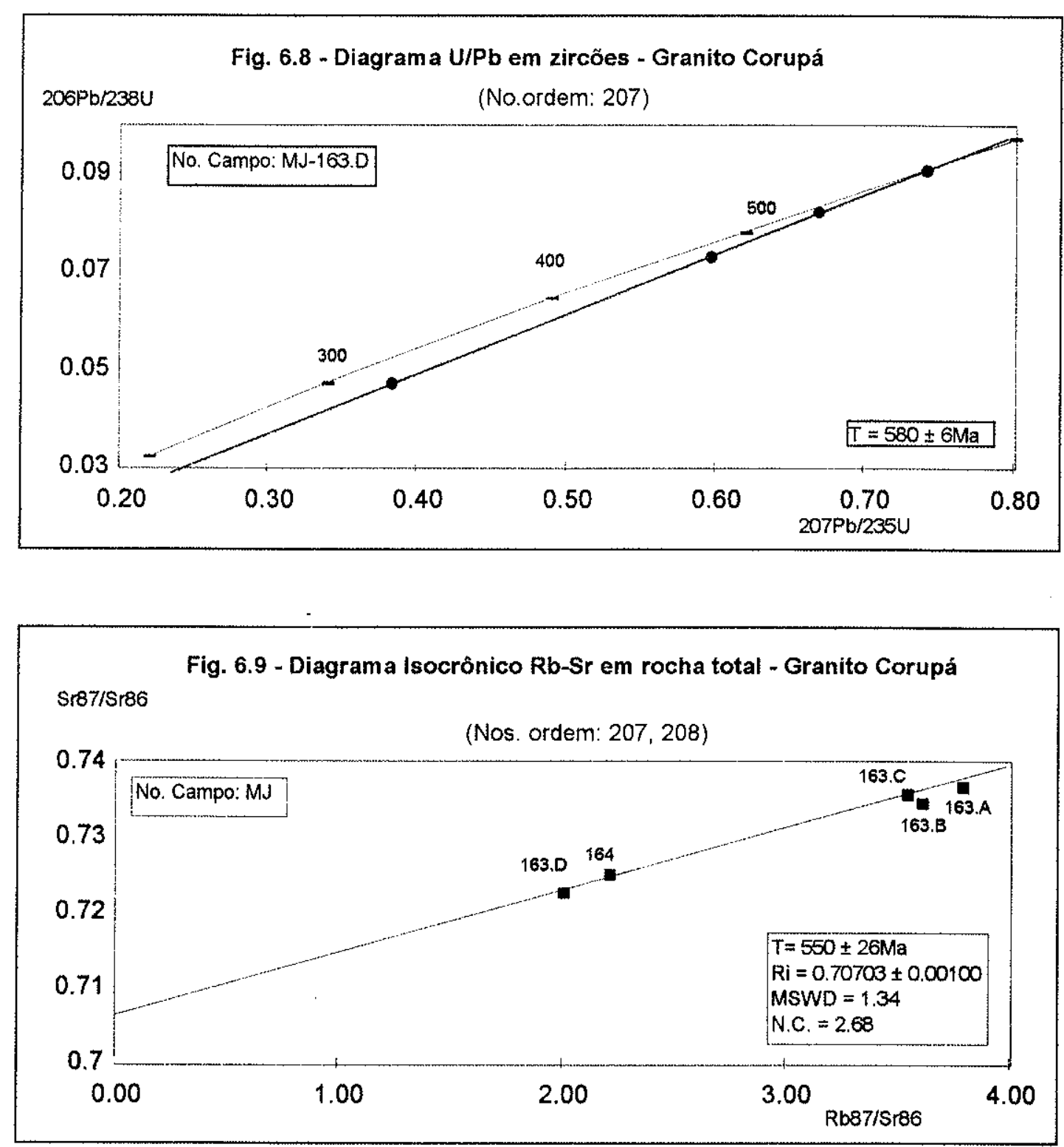

Para o corpo granítico da Graciosa, a relativa homogeneidade observada para as relações $\mathrm{Rb}$ - $\mathrm{Sr}$, impossibilitou seu estudo utilizando-se de diagramas isocrônicos. $\mathrm{O}$ único dado Rb-Sr obtido (amostra de número de campo MJ-294.2), junto a três outros existentes na literatura indicaram, quando tratados em diagrama isocrônico, idade de $584 \pm 12 \mathrm{Ma}$, para uma relação inicial $\left(\mathrm{Sr}^{87} / \mathrm{Sr}^{86}\right)_{i}$ de $0,70796 \pm 0,00018$ (Fig. 6.10). Embora tal valor se mostre coerente com os apresentados para os demais corpos graniticos, tal idade deve ser encarada com ressalvas, uma vez que os dados analíticos constituem, praticamente, dois agrupamentos em diagrama isocrônico, um 
próximo a origem ( $\mathrm{Rb}-\mathrm{Sr}$ entre 0,5 e 1,0$)$ e outro pouco mais afastado ( $\mathrm{Rb}$-Sr entre 4,0 e 5,0 ), não contendo pontos intermediários a esses conjuntos.

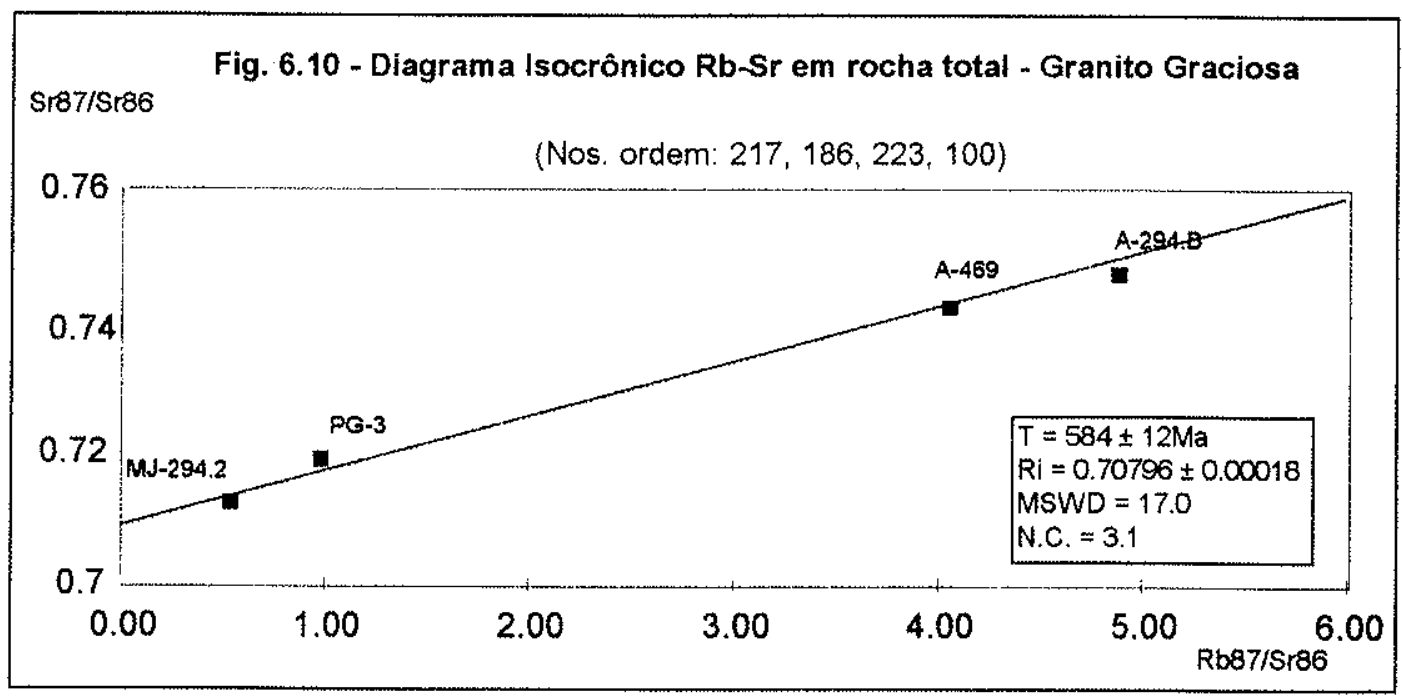

Kaul \& Cordani (1994) mencionam idades isocrônicas para o maciço da Graciosa de $545 \pm 15 \mathrm{Ma}(r . \mathrm{i} .=0,707)$ e de $584 \pm 8 \mathrm{Ma}($ r.i. $=0,707)$ envolvendo respectivamente granitos porfiríticos cinza e equigranulares róseo.

A metodologia U-Pb foi adicionalmente aplicada a 6 frações de zircões desse maciço granítico. Mesmo sofrendo um processo de abrasão de cerca de 72 horas, os pontos analíticos posicionaram-se no diagrama, relativamente afastados da Curva Concórdia, indicando uma idade de $594 \pm 64 \mathrm{Ma}$ (Fig. 6.11).

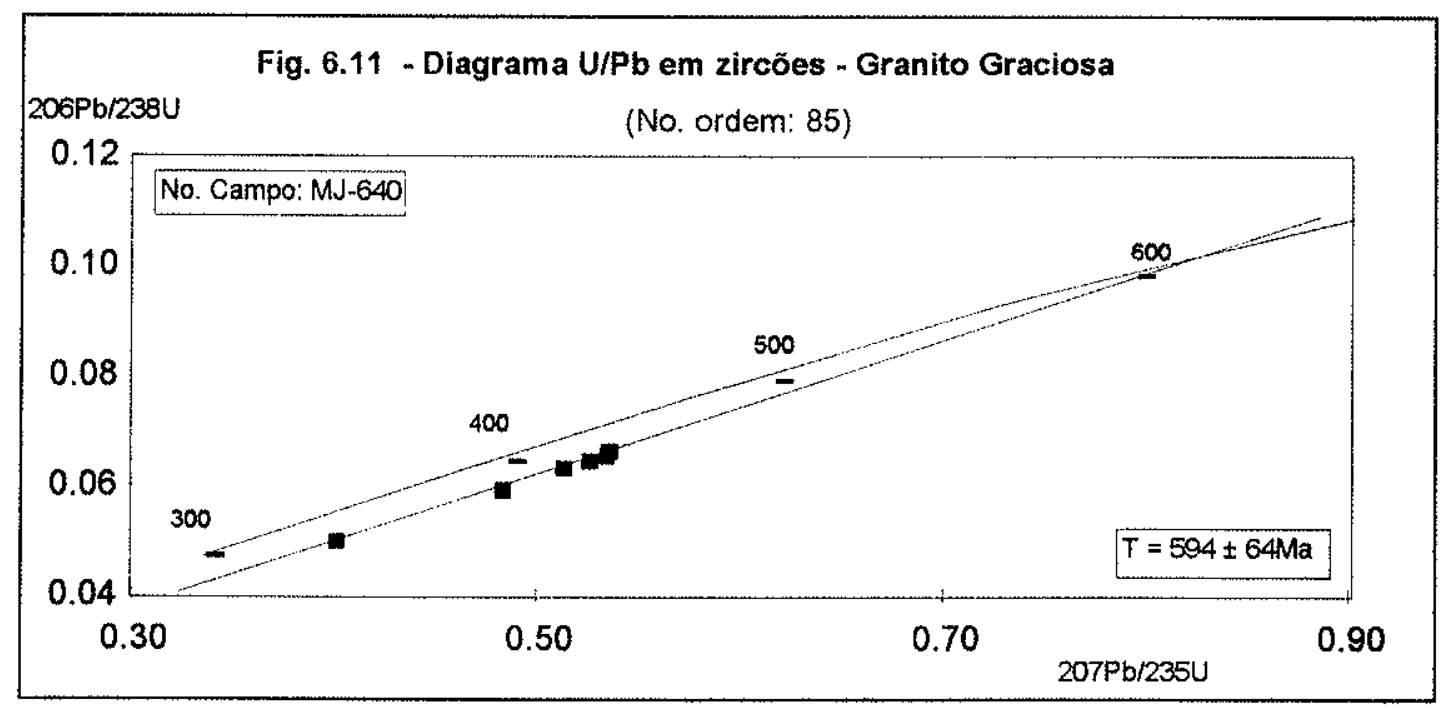


As relações iniciais $\left(\mathrm{Sr}^{87} / \mathrm{Sr}^{86}\right)$ i obtidas para esses maciços (Agudos, Corupá, Graciosa), entre 0,704 e 0,708, deixam dúvidas quanto as possiveis fontes desses granitóides, uma vez que não são suficientemente elevadas para sugerir processos de fusão de material com vida crustal anterior e, nem suficientemente baixas para indicar material oriundo de crosta inferior/manto superior.

Para o maciço granítico Anhangava, foram realizadas quatro determinações geocronológicas através do método $\mathrm{Rb}-\mathrm{Sr}$, em rocha total. Tratam-se de amostras coletadas em um único afloramento (MJ-291), localizado na porção norte desse corpo. Os dados analíticos apresentaram-se mal distribuidos em diagrama isocrônico, concentrando-se no eixo das abcissas $\left(\mathrm{Rb}^{87} / \mathrm{Sr}^{86}\right)$ entre 14 e 29 , não permitindo um bom controle da relação inicial. A melhor reta que se ajusta a esses pontos indicou idade de $600 \pm 20 \mathrm{Ma}$, para uma relação inicial de 0,71930 $\pm 0,00542$ (Fig. 6.12). Uma insignificante mudança nesse traçado, eleva substancialmente a razão inicial para valores próximos de 0,730 , fazendo com que a idade (neste caso, mínima) se aproxime de 560Ma. Dados adicionais são necessários para o estabelecimento mais preciso dessa idade.

Acrescente-se que idade isocrônica de $522 \pm 18 \mathrm{Ma}(r$.i. $=0,709)$ foi referida em Kaul \& Cordani (1994) como pertencente ao corpo granítico Anhangava. A discussão em termos de maior ou menor representatividade deste valor não pode ser fundamentada, uma vez que os autores não apresentam o diagrama isocrônico ou os dados analíticos $\mathrm{Rb}-\mathrm{Sr}$.

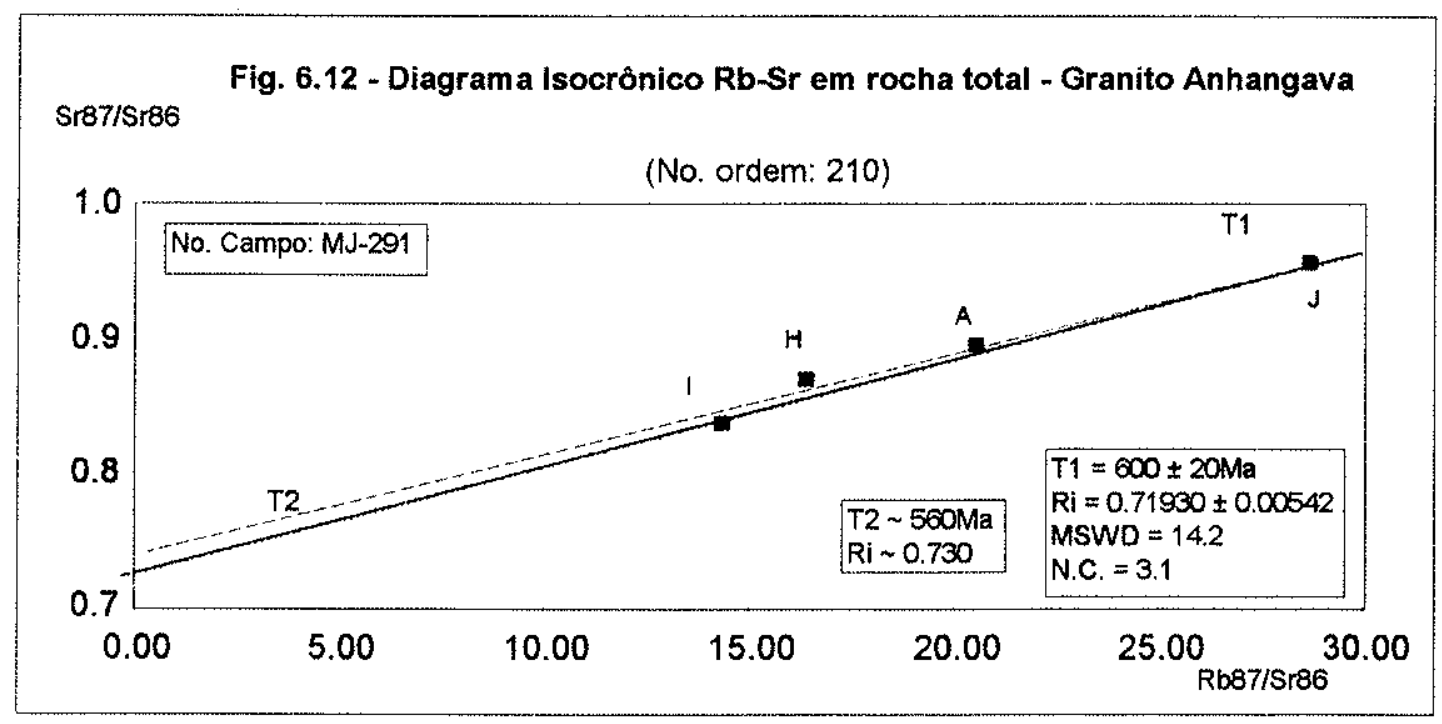


Para o corpo granítico Morro Redondo foram analisadas através do método $U$ $\mathrm{Pb}$ quatro frações de zircões, que sofreram abrasão por cerca de 72 horas. Dois desses dados posicionaram-se relativamente próximos a Curva Concórdia, definindo com os demais pontos analíticos idade de $589 \pm 37 \mathrm{Ma}$, interpretada como relativa a época de cristalização dos zircões (Fig. 6.13).

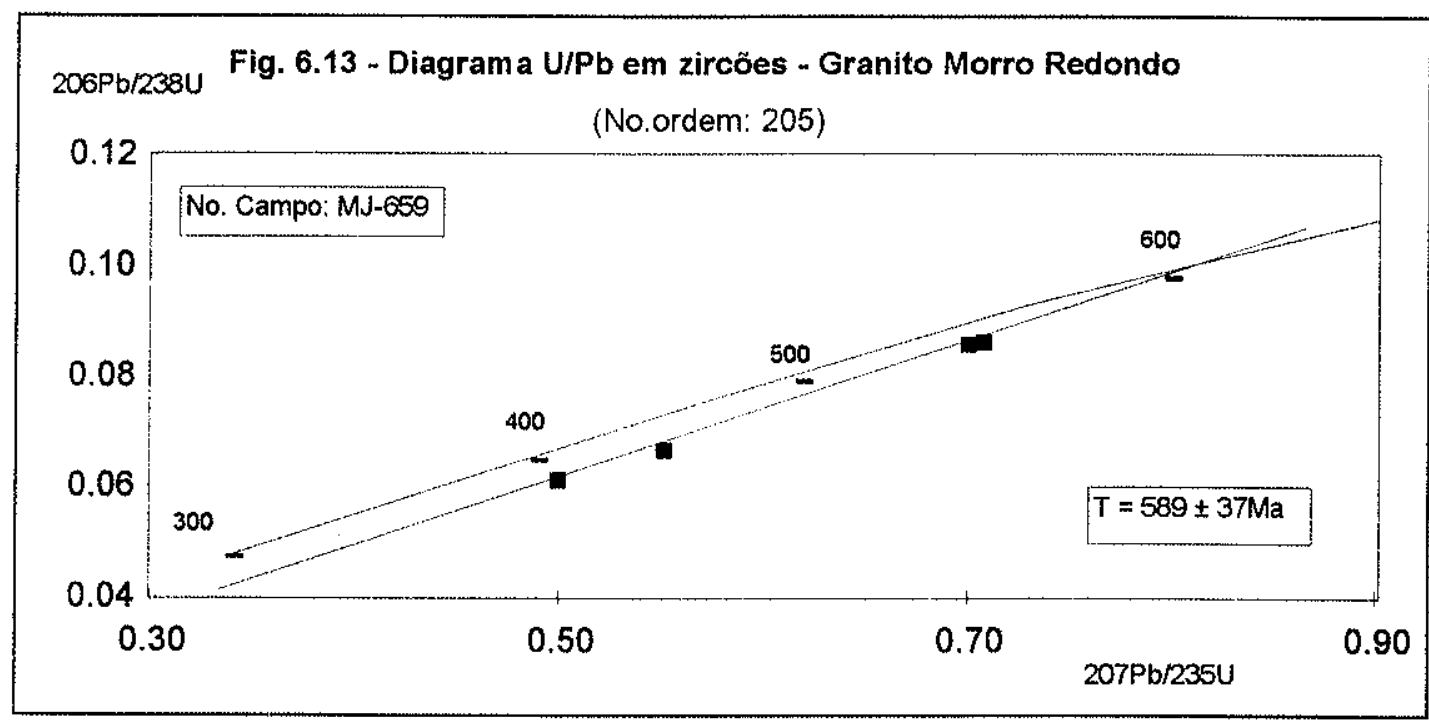

O estudo geocronológico $\mathrm{Rb}-\mathrm{Sr}$ de rochas graniticas, pertencentes ao maciço Morro Redondo, envolveu a pré-dosagem de dezenas de amostras, que se mostraram inviáveis ao tratamento isocrônico. A dificuldade em se datar rochas graníticas através do método $\mathrm{Rb}-\mathrm{Sr}$, a nivel de afloramento ou não, reside no fato destas apresentarem, normalmente, uma grande homogeneidade em termos de relações $\mathrm{Rb}-\mathrm{Sr}$, não permitindo uma dispersão significativa dos pontos analíticos em diagrama isocrônico. Os dados analíticos $\mathrm{Rb}-\mathrm{Sr}$ disponiveis para o maciço Morro Redondo, referem-se a quatro amostras provenientes de diferentes afloramentos, que tratados em diagrama isocrônico apresentaram dois dos pontos relativamente próximos, com relações $\mathrm{Rb}^{87} / \mathrm{Sr}^{86}$ entre 5,0 e 7,0 , e os demais substancialmente afastados, razões $\mathrm{Rb}^{87} / \mathrm{Sr}^{88}$ entre 20 e 40, não contendo pontos intermediários aos dois conjuntos (Fig. 6.14). As melhores retas traçadas nesse diagrama, apresentam idades de 580 e $525 \mathrm{Ma}$, para relações iniciais da ordem de 0,710 e 0,723 (Fig. 6.14). O primeiro valor deve refletir 
uma idade mais próxima a formação dessas rochas graniticas, função dos dados U-Pb antes discutidos e de uma análise K-Ar obtida em hornblenda, que revelou idade de $565 \pm 20 \mathrm{Ma}$, relacionada ao resfriamento desse corpo à isotermas inferiores à $500^{\circ} \mathrm{C}$.

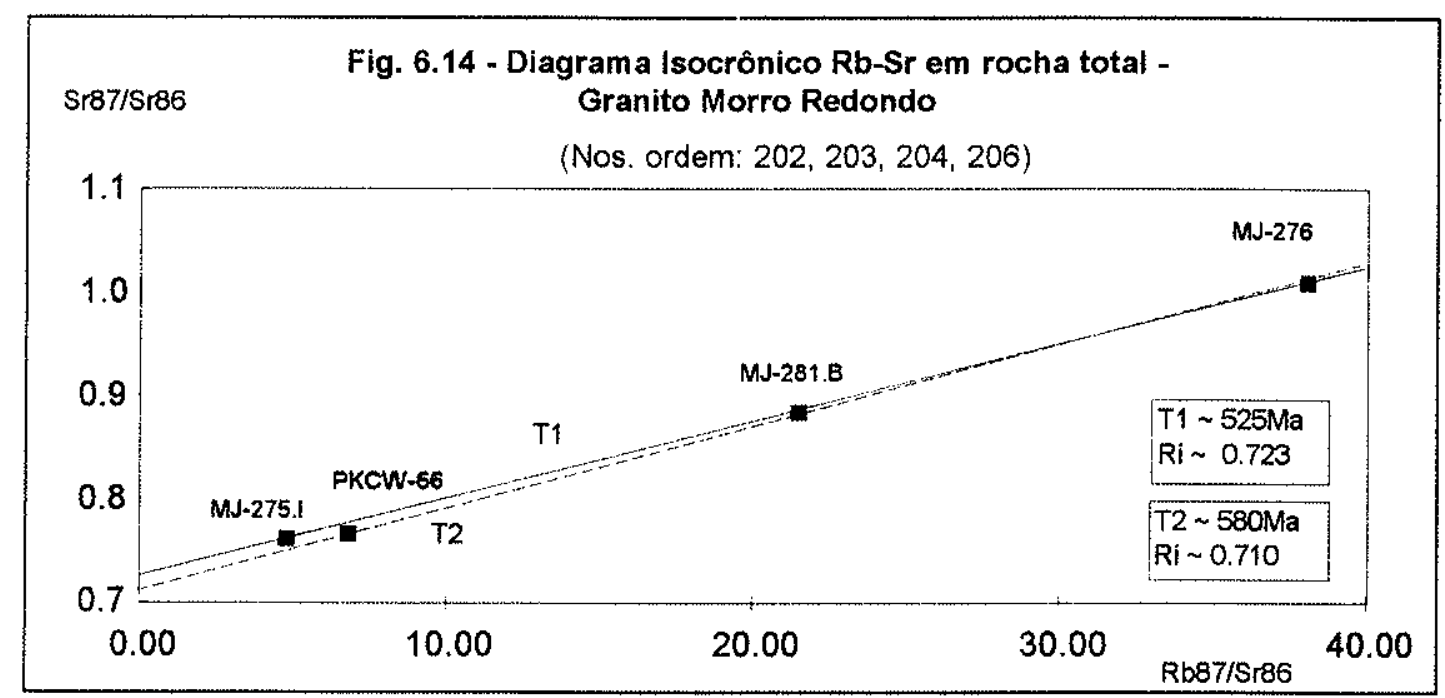

As relações iniciais, embora imprecisas, obtidas para os maciços graníticos Anhangava e Morro Redondo ( $>0,710$ ), se mostram substancialmente mais elevadas que as observadas para os demais corpos $(0,704-0,708)$.

Os dados U-Pb (zircões) e $\mathrm{Rb}-\mathrm{Sr}$ (isócronas em rocha total) obtidos para os maciços de Agudos do Sul, Corupá, Graciosa, Anhangava e Morro Redondo, indicam o intervalo 600-570Ma, relativos ao Neoproterozóico, como o principal período de formação dessas rochas graníticas de natureza alcalina-peralcalina.

As idades modelo Sm-Nd (TDM), indicam o intervalo 2.100-1.850Ma (Paleoproterozóico - ciclo Transamazônico), como principal para a diferenciação manto/crosta dos precursores crustais dos maciços graníticos Corupá, Anhangava, Agudos e Morro Redondo (apêndice 1). Salienta-se ainda que idades (Sm-Nd) do mesmo intervalo foram observadas para os corpos graníticos Cerne, Ouro, Cunhaporanga e Três Corregos, todos localizados no âmbito dos terrenos Açungui/Setuva, fora dos limites pesquisados.

Os dados K-Ar obtidos em anfibólios e biotitas, distribuem-se entre 595-495Ma, indicando o intervalo 585-540 como principal de resfriamento desses corpos graníticos (Fig. 6.15). Idades da ordem de 530-520Ma observadas principalmente para o granito 
Corupá, devem ser encaradas com ressalvas, uma vez que os anfibólios encontram-se associados a clinopiroxênios (egirina/augita) e olivinas (faialitas), minerais estes que não apresentam um comportamento térmico definido com relação ao argônio.

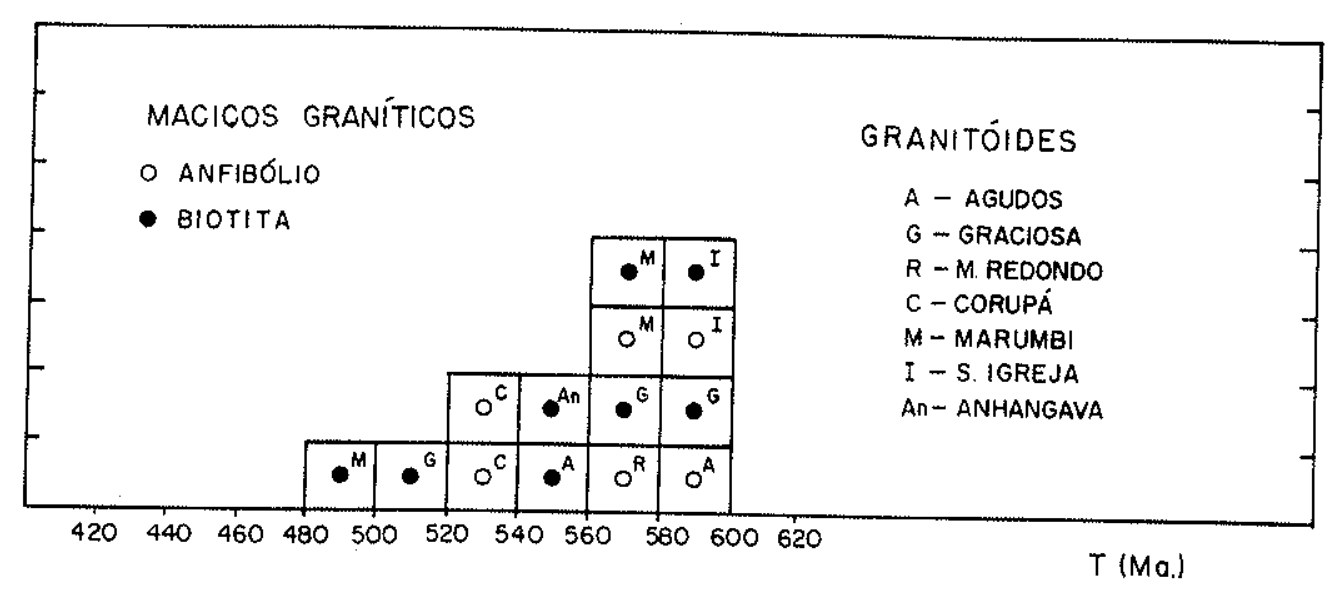

FIG:6.15- HISTOGRAMA K-AT-MACICOS GRANITICOS DA PORCÃO NE DE SANTA CATARINA E SE DO PARANÁ.

\section{2 - BACIAS VULCANO-SEDIMENTARES}

\subsubsection{Aspectos Geológicos}

Expressivas seqüências vulcano-sedimentares ocorrem na porção sudeste do Paraná e nordeste de Santa Catarina, representadas pelas Bacias de Campo Alegre, Guaratubinha e Corupá. Os estudos realizados nessas bacias limitaram-se a execução de alguns poucos perfis voltados, principalmente, a coleta de amostras para fins geocronológicos, com objetivo de melhor caracterizar a evolução desses conjuntos frente ao quadro geotectônico da região.

A Bacia do Rio Guaratubinha, localizada a SE de Curitiba, ocupa uma área de aproximadamente $200 \mathrm{~km}^{2}$, dispondo-se ao longo da borda noroeste do Domínio Luís Alves, apresentando direção geral NNE-SSW (Anexo 1). 
Os trabalhos executados pela Comissão da Carta Geológica do Paraná, na década de 60, com destaque para as folhas geológicas de São José dos Pinhais (Fuck 1967b), Tijucas do Sul (Trein et al. 1969b), Serra da Igreja e Pedra Branca de Araraquara (Muratori et al. 1969a e b), permitiram o melhor conhecimento desse conjunto vulcano-sedimentar, denominado por Fuck et al. (1967b) de Formação Guaratubinha.

A Formação Guaratubinha, segundo Fuck et al. (1967b, 1969a e 1971) é constituída por uma associação de rochas vulcânicas ácidas, intermediárias e rochas sedimentares, que se encontram em discordância angular sobre os migmatitos e granitóides do embasamento cristalino.

A ocorrência de rochas vulcânicas ácidas já havia sido referida por Oliveira (1927), na estrada de ferro que liga Curitiba a Paranaguá e posteriormente por Maack (1947), no pico Caratuba. Na região de Campo Largo da Roseira, Almeida (1949) menciona a existência de riolitos, igualmente referidos por Barbosa (1957).

A Formação Guaratubinha foi dividida por Daitx \& Carvalho (1980) em três seqüências litológicas: 1 - Sedimentar, 2 - Vulcânica Intermediária, 3 - Vulcânica Ácida.

$\mathrm{Na}$ seqüência sedimentar predominam arcósios, com intercalações de siltitos, argilitos e subordinariamente conglomerados. A presença de seixos de vulcanitos ácidos nesses conglomerados distingue essa seqüência basal das que ocorrem no âmbito das Bacias de Campo Alegre e Corupá. A seqüência vulcánica intermediária é representada predominantemente por rochas dacíticas e andesíticas. Na seqüência vulcânica ácida ocorrem lavas e rochas piroclásticas. Predominam riolitos porfiriticos com menor participação de riolitos fluidais, esferuliticos e felsitos.

Castro et al. (1994) caracterizam a Bacia de Guaratubinha como constituida essencialmente por rochas vuicanoclásticas e vulcânicas, sendo as rochas sedimentares ("sensu stricto") relevantes no contexto dessa bacia. Grande parte dos arenitos, arcósios e pelitos epiclásticos foram por esses autores considerados como rochas piroclásticas ou pelo menos vulcanoclásticas, reduzindo substancialmente a importância da seqüência sedimentar.

As rochas pertencentes a Bacia de Guaratubinha mostram-se muitas vezes afetadas por falhamentos e basculamentos, com as camadas apresentando mergulhos entre $25^{\circ}$ e $45^{\circ}$, geralmente para sudeste, por vezes verticalizadas. 
A Bacia de Campo Alegre localiza-se no dominio dos terrenos Luís Alves, ocupando uma área de aproximadamente $500 \mathrm{~km}^{2}$, na porção centro ocidental estudada. Os primeiros relatos desses litotipos devem-se a Carvalho \& Pinto (1938), que mencionam a ocorrência de arenitos e folhelhos entre Bateias e São Miguel, incluindo-os na Série Itararé. O reconhecimento de riolitos e tufos nessa região devese a Almeida (1949), que menciona similaridades com os vulcanitos de Castro e Itajaí.

No levantamento geológico da quadrícula de Blumenau (1:250.000), realizado por Albuquerque et al. (1971) esse conjunto vulcano-sedimentar foi cartografado e então denominado de Formação Campo Alegre (Grupo Itajaí). Assinalam a presença de pequenas ocorrências da Formação Baú.

Uma síntese dos principais litotipos pertencentes a Formação Campo Alegre bem como sua distinção das demais bacias (Formação Guaratubinha e Grupo Itajai), foi apresentada por Ebert \& Brochini (1971). Valiati (1974) através de perfís envolvendo dez furos de sondagem realizados na Bacia de Campo Alegre (mais de 2.000 metros perfurados), confirma a estratigrafia proposta por Ebert \& Brochini (1971).

Estudo detalhado da Bacia de Campo Alegre, foi posteriormente apresentado por Daitx \& Carvalho (1980), que realizaram um empilhamento estratigráfico com uma descrição minuciosa dos litotipos presentes. Esses autores identificaram na Bacia de Campo Alegre, cinco seqüências deposicionais: 1 - Seqüência Sedimentar Inferior (fácies conglomerática e arenítica), 2 - Seqüência Vulcânica Inferior (vulcanitos básicointermediários, lavas ácidas subordinadas, intercalações pouco espessas de siltitos e tufos), 3 - Seqüência Sedimentar-Intermediária (epi-vulcanoclástica: siltitos, tufitos e tufos; arcósios e folhelhos; intercalações de derrames básico-intermediários), 4 Seqüência Vulcânica Superior (ácida: derrames e diques de riolitos, traquitos e felsitos; tufos e brechas ácidas; raros siltitos e folhelhos), 5 - Seqüência Sedimentar Superior (epi-vulcanoclástica: siltitos epiclásticos; tufitos e tufos ácidos).

Daitx \& Carvalho (1980) mencionam a ocorrência nas bordas SW e SE da Bacia de Campo Alegre, de seixos graníticos nos conglomerados da seqüência basal. Estes, estão ausentes nas proximidades do maciço granítico de Agudos do Sul, sugerindo que esse corpo não se encontrava exposto na epoca de formação dos estratos psefíticos. 
Na Bacia de Campo Alegre, os estratos mostram mergulhos suaves em direção ao centro da mesma, com perturbações apenas de caráter local.

Rochas de natureza vulcano-sedimentar similares às presentes na Bacia de Campo Alegre ocorrem a sul da cidade de Corupá (SC). Ocupam uma área de aproximadamente $50 \mathrm{~km}^{2}$, estando encaixadas numa zona de faiha com direção geral NE-SW. Os estudos geológicos realizados na Bacia de Corupá se devem a Albuquerque et al. (1971), Ebert \& Brochini (1971), Ebert (1971) e Daitx \& Carvalho (1980).

Segundo Daitx \& Carvaiho (1980) as rochas de natureza vulcano-sedimentar pertencentes a Bacia de Corupá exibem uma quase total identidade litológica e estratigráfica com os termos correspondentes, presentes na Bacia de Campo Alegre, envolvendo conglomerados, arcósios, siltitos, vulcanitos ácidos a básicos e tufos.

O condicionamento dessa seqüência, no entanto, apresenta carcterísticas bastante distintas daquelas da área de Campo Alegre, denotando mergulhos dos estratos entre $20^{\circ}$ e $40^{\circ}$, por vezes subverticalizados, com caimentos normalmente para SE ou SW, caracterizando intensa atividade tectônica atuante nesta bacia.

Observa-se, portanto, no âmbito das três bacias (Campo Alegre, Guaratubinha e Corupá), a predominância de conglomerados polimíticos na base que gradam a arcósios, com diminuição sistemática da granulometria, indicando condições de maior estabilidade. O ambiente sugerido por Daitx \& Carvalho (1980), para esta seqüência, é do tipo deltáico ou flúvio-piemôntico. Perturbações ao final deste ciclo deposicional são mencionadas, em função da presença de bancos conglomeráticos intercalados a estratos arenosos. Rochas vulcânicas de natureza básica, foram identificadas por Fuck et al. (1967b) e Daitx \& Carvalho (1980) que mencionam para sua colocação períodos anteriores à deposição dessas seqüências areno-conglomeráticas.

Daitx \& Carvalho (1980) correlacionam nas três áreas (Campo Alegre, Guaratubinha e Corupá) as seqüências sedimentares inferiores (arenoconglomeráticas), sugerindo a individualização em bacias menores posteriormente, quando então, passariam a apresentar evoluções distintas.

Campanha et al. (1994) associam a formação desses depósitos a sistemas de cisalhamento transcorrentes. Configuram um conjunto de bacias tardi-tectônicas, originadas dentro de um sistema de bacias "pull-apart", desenvolvidas segundo o 
caráter transtensivo ou transpressivo das cunhas formadas pela união de zonas transcorrentes.

Finalmente, é importante ressaltar o caráter fortemente alcalino de parte dessas rochas vulcânicas, fato comprovado por Ebert (1971), que observou a presença de riebeckita e egirina em algumas amostras de traquitos e riolitos associados a Bacia de Guaratubinha.

\subsection{2 - Geocronologia}

O estudo geocronológico realizado envolveu análises $\mathrm{Rb}-\mathrm{Sr}$ (RTO) e U-Pb em zircões de rochas vulcânicas ácidas a intermediárias das Bacias de Guaratubinha e Campo Alegre.

O uso da metodologia $\mathrm{Rb}-\mathrm{Sr}$ foi dificultada, uma vez que amostras provenientes de mesmos afloramentos, apresentaram, sistematicamente, pouca variação nas relações $\mathrm{Rb} / \mathrm{Sr}$, impossibilitando a distribuição adequada dos pontos analíticos em diagramas isocrônicos.

Os dados $\mathrm{Rb}-\mathrm{Sr}$ de rochas riolíticas pertencentes a Bacia de Guaratubinha, referem-se a amostras coletadas em diferentes niveis vulcânicos da pedreira Tibagi (MJ-376 e A-4-11-G). Em diagrama isocrônico, grande parte desses dados concentraram-se no eixo das abcissas (relações $\mathrm{Rb}^{87} / \mathrm{Sr}^{86}$ ) entre 23 e 36, causando imprecisão na razão inicial $\left(\mathrm{Sr}^{87} / \mathrm{Sr}^{86}\right)$, obtida. A reta isocrônica construida indicou idade de $570 \pm 10$ Ma para uma relação inicial de 0,70947 $\pm 0,00176$ (Fig. 6.16).

Para o conjunto vulcânico Campo Alegre, foram realizadas cinco determinaçōes Rb-Sr, envolvendo amostras coletadas em quatro afloramentos distintos, localizados relativamente próximos (ao longo da estrada Oxford-Campo Alegre, amostras de números de campo: MJ-415, 416, 418 e 420). Esses dados, quando tratados em diagrama isocrônico, conjuntamente com outras três análises $\mathrm{Rb}-\mathrm{Sr}$ (amostras de número de campo SCMB-45=MJ-415 - Basei 1985), indicaram idade de $499 \pm 13 \mathrm{Ma}$, para uma relação inicial $\left(\mathrm{Sr}^{87} / \mathrm{Sr}^{86}\right)_{i}$ de $0,70853 \pm 0,00027$ (Fig. 6.17.A). Tal valor é definido principalmente pela amostra de número de campo $M J-418$, cuja relação $\mathrm{Rb}^{87} / \mathrm{Sr}^{86}$ próxima de 6,0 mostra-se bastante superior as demais, que se concentram entre 0,8 e 2,3. Um tratamento isocrônico, excluindo tal ponto analítico, 
geoquimicamente distinto, permite o traçado de uma reta com idade próxima de 570Ma, com relação inicial em torno de 0,707 (Fig. 6.17.B).
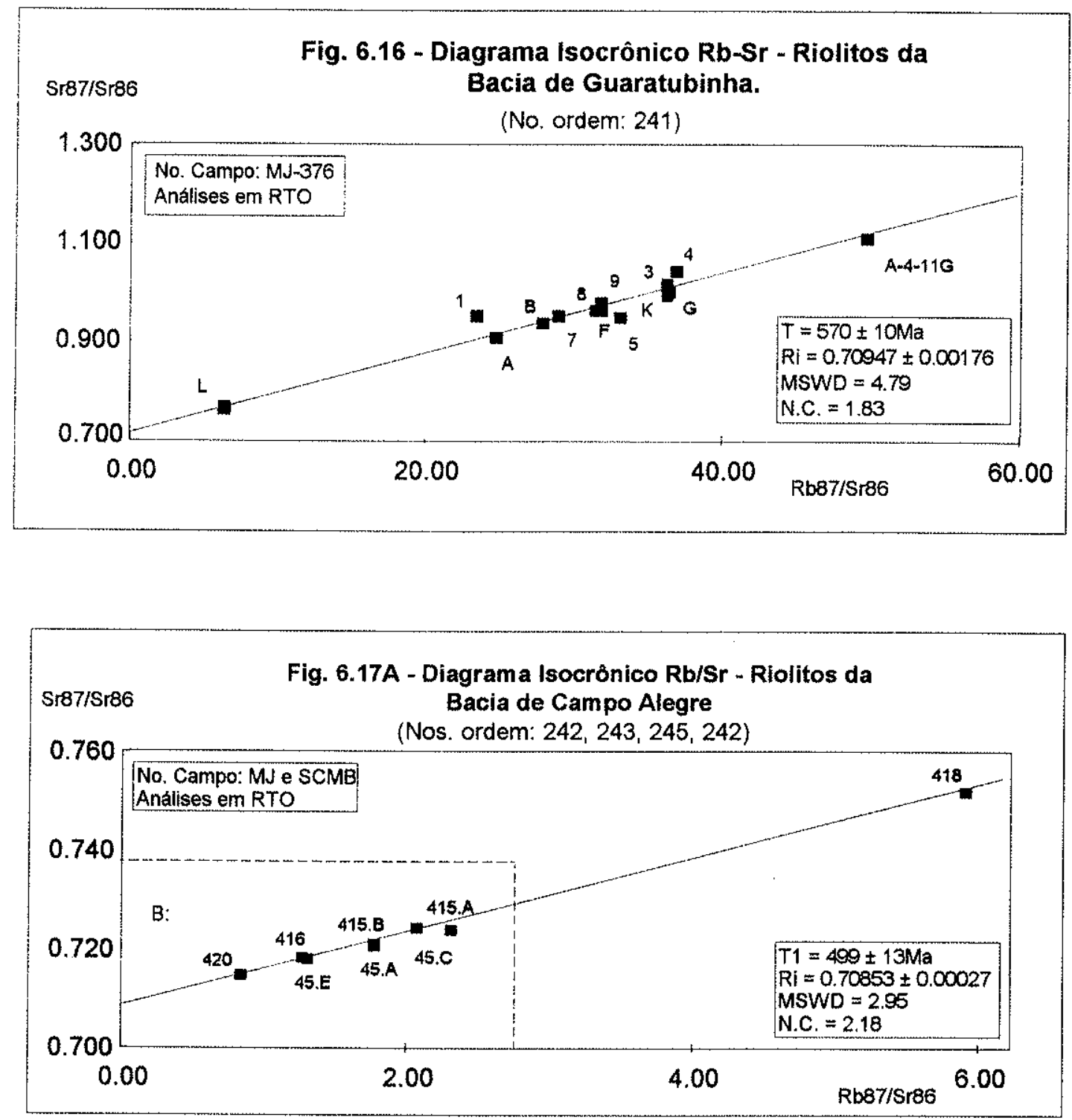

Numa tentativa de melhor precisar as idades obtidas através do método $\mathrm{Rb}-\mathrm{Sr}$, foram concentrados zircões de riolitos pertencentes a Bacia de Guaratubinha (MJ-376) e Campo Alegre (MJ-415). Devido a pequena quantidade de zircões presentes nessas rochas $e$ as suas dimensões reduzidas (inferiores a 150 mesh), a concentração desse 


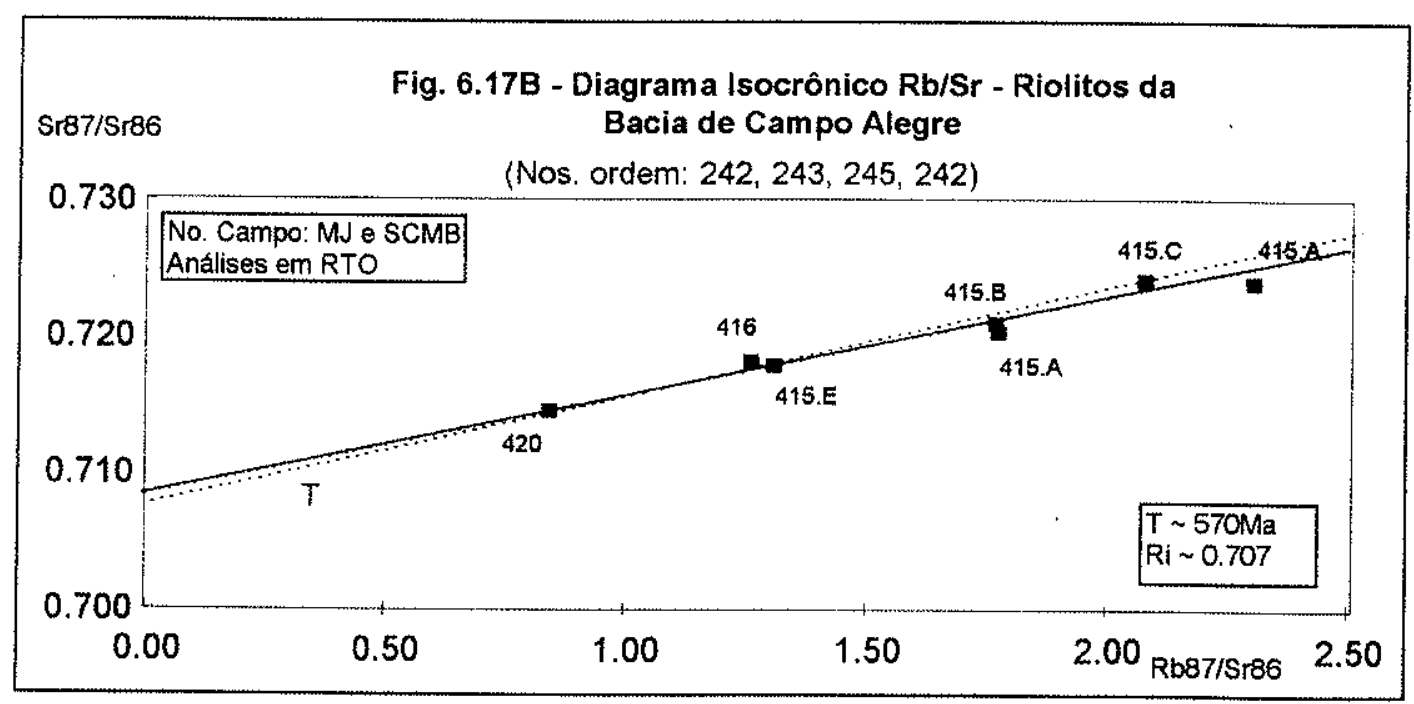

mineral exigiu grandes quantidades de amostra. Parte dos zircões obtidos apresentavam ainda impregnações escuras, necessitando de abrasão por período prolongado ( $72 \mathrm{hs}$ ), bem como de cuidadosa catação em lupa. Neste processo, foram concentradas cinco frações de zircões de riolitos da Bacia de Guaratubinha e somente duas frações relacionadas a riolitos da Bacia de Campo Alegre. A exceção da fração $M(4)$ pertencente a Bacia de Campo Alegre, as demais apresentaram-se relativamente alinhadas em diagrama $\mathrm{U}-\mathrm{Pb}$, indicando uma idade de $602 \pm 11 \mathrm{Ma}$ (Fig. 6.18). Tal valor é aqui interpretado como relativo a época de cristalização desses zircões e consequente formação dessas rochas vulcânicas.

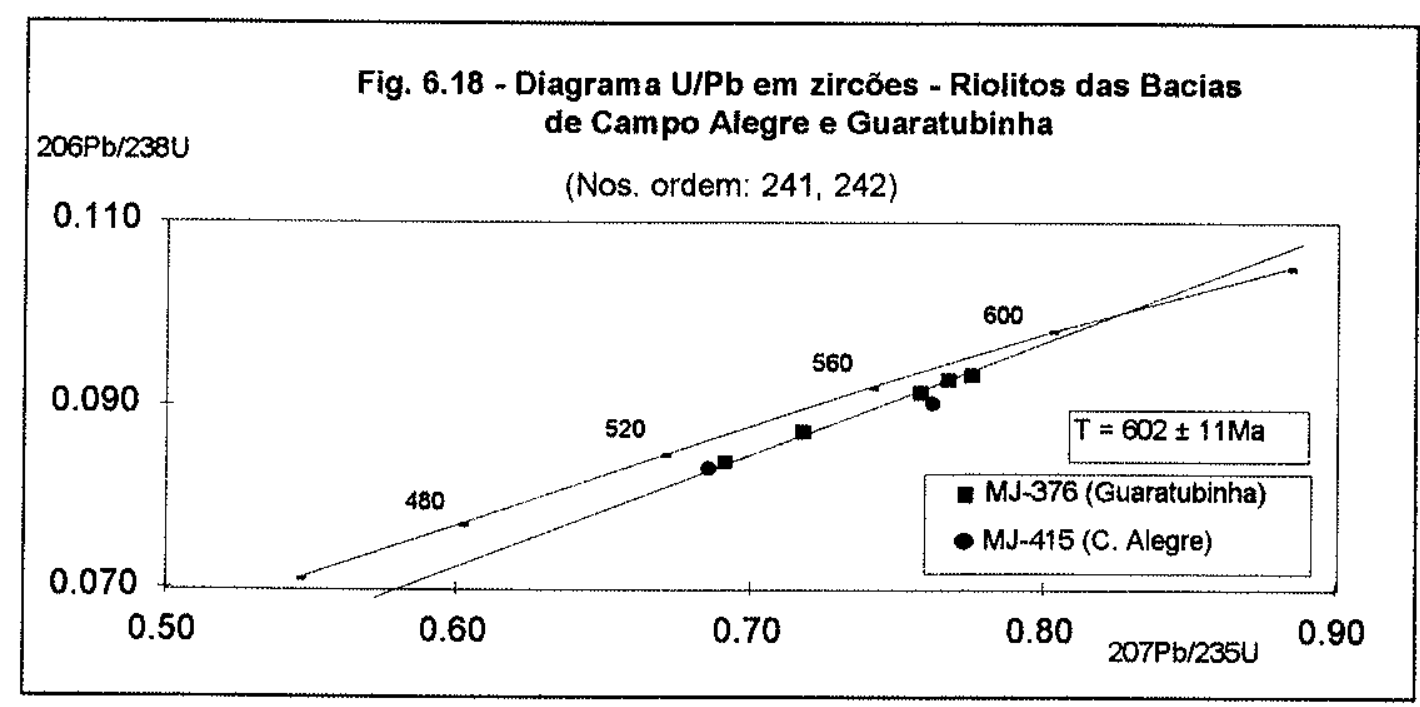


As idades obtidas, embora precárias, sugerem que o vulcanismo associado a formação dessas bacias tenha ocorrido entre 600-570Ma. Tal intervalo mostra-se similar ao observado para os maciços graníticos alcalinos- peralcalinos que ocorrem nos Domínios Luís Alves e Curitiba.

Dados K-Ar em rocha total de traquitos da Bacia de Campo Alegre (amostras de números de campo: CA-01 e CA-02 - Ebert \& Brochini, 1971, apêndice-1), acusaram respectivamente idades de $458 \pm 23 \mathrm{Ma}$ e $481 \pm 25 \mathrm{Ma}$. Tais valores devem ser encarados com ressalvas, uma vez que o sistema rocha total analisado é representado em sua maior parte por feldspatos (rochas de composição traquítica), que podem perder argônio mesmo a baixas temperaturas $e$, neste caso, as idades obtidas não teriam significado geológico. Acrescente-se que o material analisado apresentava fortes indícios de transformação, causado provavelmente durante os processos diagenéticos (Ebert \& Brochini 1971). 
Granitóides Alcalinos - Peralcalinos

PRANCHA FOTOGRÁFICA 6 
- Foto 6a - Granito Graciosa - Rocha leucocrática, cinza clara, de granulação média, inequigranular. Ao microscópio apresenta textura hipidiomórfica, granular, predominando: quartzo, $\mathrm{k}$-feldspato (pertítico), plagioclásio (albita), riebeckita e biotita (MJ-640).

- Foto 6b - Granito Anhangava - Rocha leucocrática cinza rosada de granulação média, inequigranular. Ao microscópio mostra textura hipidiomórfica, granular, a quartzo, k-feldspato (pertítico), plagioclásio (albita) e biotita (MJ-289).

- Foto 6c - Granito Agudos do Sul - Rocha leucocrática, cinza rosada de granulação média, equigranular. Ao microscópio apresenta textura hipidiomórfica, granular, a quartzo, k-feldspato (pertítico), plagioclásio (albita) e biotita (MJ-132).

- Foto 6d - Granito Corupá - Rocha leucocrática, cinza esverdeada, de granulação média, equigranular. Ao microscópio apresenta textura granular, hipidiomórfica, a quartzo, k-feldspato (pertítico), aegirina, faialita e hornblenda (MJ-164).

- Foto 6 e - Granito Morro Redondo - Rocha leucocrática, cinza esverdeada; de granulação média, equigranular. Ao microscópio apresenta textura hipidiomórfica, granular, a quartzo, k-feldspato (pertítico), riebeckita, aegirina e faialita (MJ-275).

- Foto $6 f$ - Fotomicrografia - Detalhe mostrando a presença de faialita no Granito Morro Redondo (MJ-275 - pol. descruzados - 100X). 

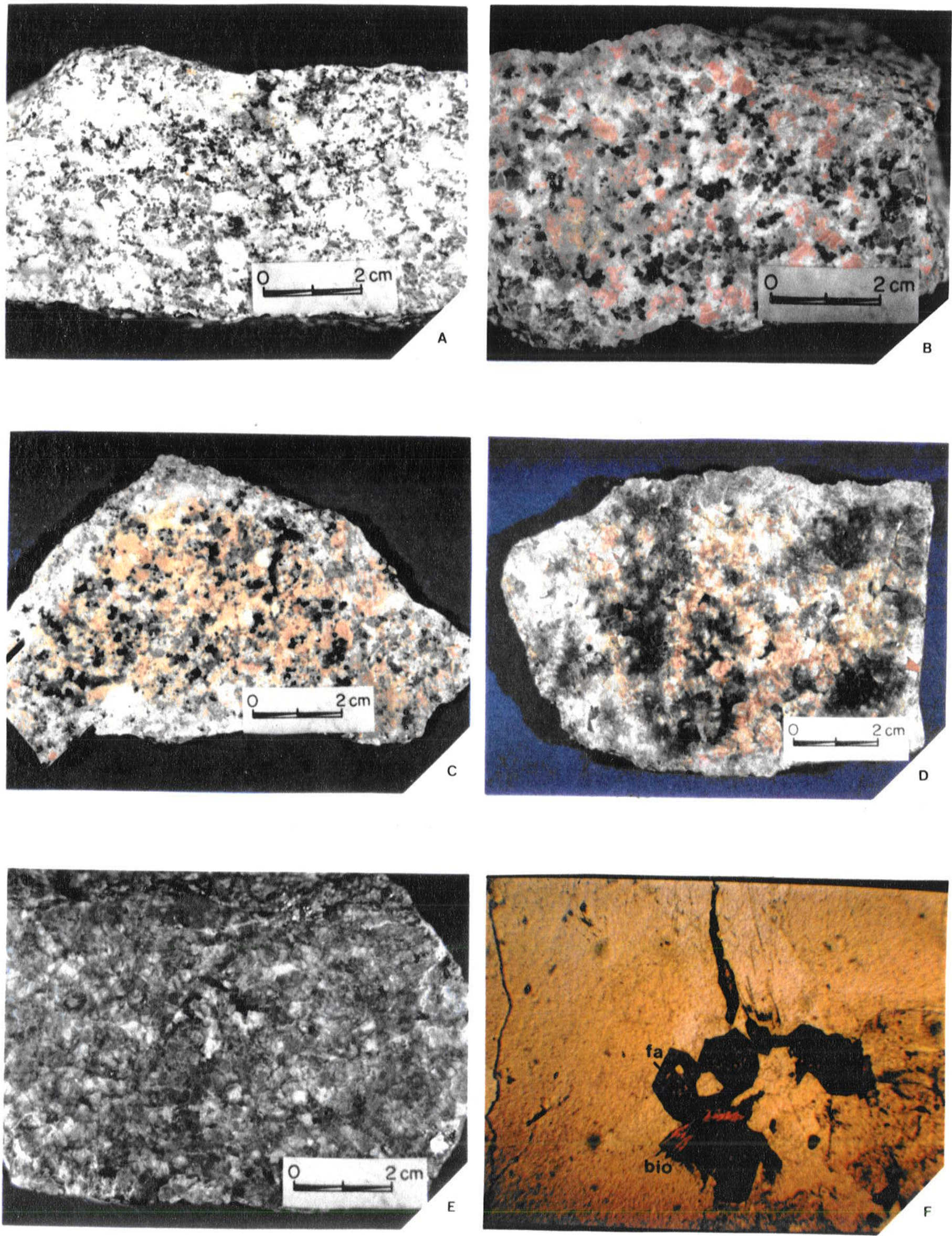


\section{CAPITULO 7}

\section{CONSIDERAÇÕES FINAIS}

\section{1 - SÍNTESE DAS INFORMAÇÕES GEOCRONOLÓGICAS}

Nos capítulos anteriores foram discutidos os dados geológico-geocronológicos relativos a cada domínio que compõem os terrenos pré-cambrianos a eo-paleozóicos da porção nordeste de Santa Catarina e sudeste do Paraná. Pretende-se aqui, realizar uma abordagem integrada e comparativa desses dados, numa tentativa de melhor compreender a evolução geotectônica da área investigada.

O padrão geocronológico observado para os Domínios Luís Alves, Curitiba e Paranaguá, bem como para $\circ$ magmatismo e vulcanismo associado aos regimes extensionais pós-orogênicos encontram-se sintetizados em forma de mapa (Fig. 7.1) e de histogramas (figs. 7.2 e 7.3). Os valores isocrônicos $\mathrm{Sm}-\mathrm{Nd}$ e $\mathrm{Rb}-\mathrm{Sr}$, em rocha total, bem como U-Pb em zircões, indicam episódios formadores de rochas, em sentido extenso, por meio de quaisquer processos petrogenéticos que conduzam ao aparecimento de associações minerais bem definidas, provenientes de cristalização magmática ou de recristalização metamórfica. As idades $\mathrm{K}$-Ar em minerais e rocha total, por outro lado, indicam, similarmente as idades isocrônicas $\mathrm{Rb}-\mathrm{Sr}$, em minerais, épocas relacionadas ao resfriamento regional, consideradas minimas, e que podem ser muito mais jovens que os episódios reais de cristalização magmática ou recristalização metamórfica. $\mathrm{Na}$ figura 7.2 encontram-se representadas, adicionalmente, as idades modelo $\mathrm{Sm}-\mathrm{Nd}\left(\mathrm{T}_{\mathrm{DM}}\right)$, interpretadas como relativas a época em que os precursores crustais (protolitos) se diferenciaram do manto superior.

A presença de rochas formadas no Arqueano com idades mal definidas, superiores a $2.200 \mathrm{Ma}$, com grande concentração entre $2.800-2.600 \mathrm{Ma}$ restringe-se ao domínio dos gnaisses granulíticos Luís Alves, sugerindo a existência de núcleos antigos, reconhecidos principalmente nos arredores da cidade homônima, de Pomerode, Dona Francisca e de Barra Velha. Interessante é que valores dessa ordem não se restringem às metodologias $\mathrm{Rb}-\mathrm{Sr}$ e U-Pb, havendo idades $\mathrm{K}-\mathrm{Ar}$, que embora precárias, sugerem a presença de núcleos Arqueanos, notadamente nos arredores de Barra Velha, poupados dos episódios tectônicos posteriores (Fig. 7.1). 
A importância do Paleoproterozóico (ciclo Transamazônico) é marcante em praticamente todo Domínio Luís Alves, com idades de formação distribuídas no intervalo 2.200-1.900Ma e de resfriamento entre 2.000 e 1.700Ma (figs. 7.1 e 7.2). Os dados Sm-Nd (T $\left.T_{D M}\right)$ indicam para os protolitos dessas rochas, derivação do manto superior tanto no Arqueano $(2.800 \pm 200 \mathrm{Ma})$, como no Paleoproterozóico $(2.400 \pm 100 \mathrm{Ma}$ e $2.100 \pm$ 200Ma, Fig. 7.2).

$\mathrm{Na}$ figura 7.4 encontram-se representados os valores médios obtidos para as relações inicias $\left(\mathrm{Sr}^{87} / \mathrm{Sr}^{86}\right)_{i}$ e sua evolução até o presente, incluindo rochas pertencentes aos Domínios Luís Alves, Curitiba e Paranaguá. Observa-se para os gnaisses granulíticos Luís Alves a existência de relações iniciais $\left(\mathrm{Sr}^{87} / \mathrm{Sr}^{86}\right)$ i próximas a curva de evolução do manto superior, tanto no Arqueano (ponto 1), como no Paleoproterozóico (ponto 3), períodos esses, cujos valores de $\varepsilon_{\mathrm{Nd}}$ se aproximam de zero ou se mostram pouco negativos. Tal padrão isotópico sugere processos de acresção/diferenciação de material do manto superior tanto no Arqueano como no Paleoproterozóico. Interessante é que neste último período existem valores de relações iniciais $\left(\mathrm{Sr}^{87} / \mathrm{Sr}^{86}\right)$, que se posicionam acima da curva de evolução dos materiais derivados do manto superior e bastante próximos a curva de evolução dos gnaisses granuliticos Arqueanos (ponto 2), com valores de $\varepsilon_{\text {Nd }}$ mais negativos. Esses dados indicam processos de formação de rocha no Paleoproterozóico, envolvendo o retrabalhamento crustal de reservatórios que apresentavam, nesta época, relações iniciais $\left(\mathrm{Sr}^{87} / \mathrm{Sr}^{86}\right)_{\text {i }}$ próximas a dos gnaisses granulíticos Arqueanos.

Observa-se ainda, através das determinações $\mathrm{K}-\mathrm{Ar}$, que grande parte desses terrenos encontrava-se a isotermas superiores a $500^{\circ} \mathrm{C}$ no Paleoproterozóico (difusão de argônio/neoformação de anfibólios nesta época) e, relativamente frios durante o Neoproterozóico, temperaturas inferiores a $300^{\circ}-250^{\circ} \mathrm{C}$ (idades em biotitas no intervalo 2.000-1.700Ma). Constituem exceção ao padrão mencionado alguns valores mais antigos (Arqueanos) obtidos em rochas básicas e ultrabásicas dos arredores de Barra Velha, bem como mais jovens (1.700-600Ma), neste caso relacionados a porções localizadas próximo ao contato com os domínios adjacentes.

O Dominio Luis Alves representa portanto, um segmento continental, que inclui porçōes formadas no Arqueano $(2.800-2.600 \mathrm{Ma}$ - possivel desenvolvimento das paragêneses a ortopiroxênio) e, principalmente no Paleoproterozóico (2.200-1.900Ma possivel desenvolvimento das paragêneses do fácies anfibolito), periodo este em que 
esses terrenos devem ter se posicionado a níveis crustais relativamente rasos (dados $\mathrm{K}$-Ar entre 2.000 e 1.700Ma.) A caracterização de seu prolongamento para norte, em direção ao Maciço Serra Negra, revela que as dimensões desse segmento deveriam ser bem maiores, com provável continuidade até as rochas granulito-migmatíticas pertencentes ao Maciço de Itatins, já no sudeste de São Paulo. Basei et al. (1992) sugerem que este domínio represente no Neoproterozóico uma microplaca, a qual denominam de Microplaca Luís Alves.

Os terrenos a norte, relativos ao Domínio Curitiba, mostram caracteristicas geológicas, geocronológicas e estruturais distintas daqueles pertencentes ao Domínio Luís Alves. Embora esse domínio preserve registros evolutivos do Paleoproterozóico (2.200$1.800 \mathrm{Ma}$ ), ciclo Transamazônico, importante fase de migmatização ocorreu durante o Neoproterozóico (Fig. 7.1 e 7.2).

O estudo geocronológico efetuado não indicou com precisão épocas relacionadas ao metamorfismo principal das rochas gnáissico-migmatíticas deste setor, caracterizando o intervalo 640-560Ma como relativo ao resfriamento regional dessas seqüências, com grande concentração de idades entre 620 e 600Ma (principal periodo de resfriamento - Fig. 7.3). Tal padrão reveste-se de fundamental importância, por caracterizar o posicionamento desses terrenos a isotermas inferiores a $450-500^{\circ} \mathrm{C}$ ( $\mathrm{K}-\mathrm{Ar}$ em anfibólios) durante o Neoproterozóico. Acrescente-se, que os granitóides da Suite Rio Piên, distribuidos na porção sul deste dominio, limitados por importantes zonas de cisalhamento, apresentam idades de formação do intervalo 620-600Ma, sugerindo tratar-se de um magmatismo desenvolvido em periodo próximo ao de resfriamento deste setor.

As relações iniciais $\left(\mathrm{Sr}^{87} / \mathrm{Sr}^{86}\right)_{i}$ relativas as rochas gnáissico-migmatíticas pertencentes ao Domínio Curitiba, embora precárias, mostram-se relativamente elevadas, tanto no Paleoproterozóico como no Neoproterozóico, sugerindo origem a partir de reservatórios crustais, com composiçōes isotópicas de $\mathrm{Sr}$ similares às observadas para os gnaisses granulíticos Luís Alves nesses periodos (Fig. 7.4, pontos 4 e 5). Padrão isotópico distinto é observado para os granitóides deformados da borda sul deste dominio (Suite Rio Piên), que apresentam relações iniciais $\left(\mathrm{Sr}^{87} / \mathrm{Sr}^{86}\right)$ inferiores às observadas para os gnaisses migmatíticos regionais. Tal fato impossibilita a formação dessas rochas, no Neoproterozóico, a partir de reservatórios similares aos observados para o conjunto migmatitico antes discutido. 
FIG: 7.1 - PADRÃO DE DISTRIBUICĀOA DE IDADES Rb-Sr, U-Pb, E K-ArPORÇÃO SE DO PARANÁ E NE DE SANTA CATARINA.

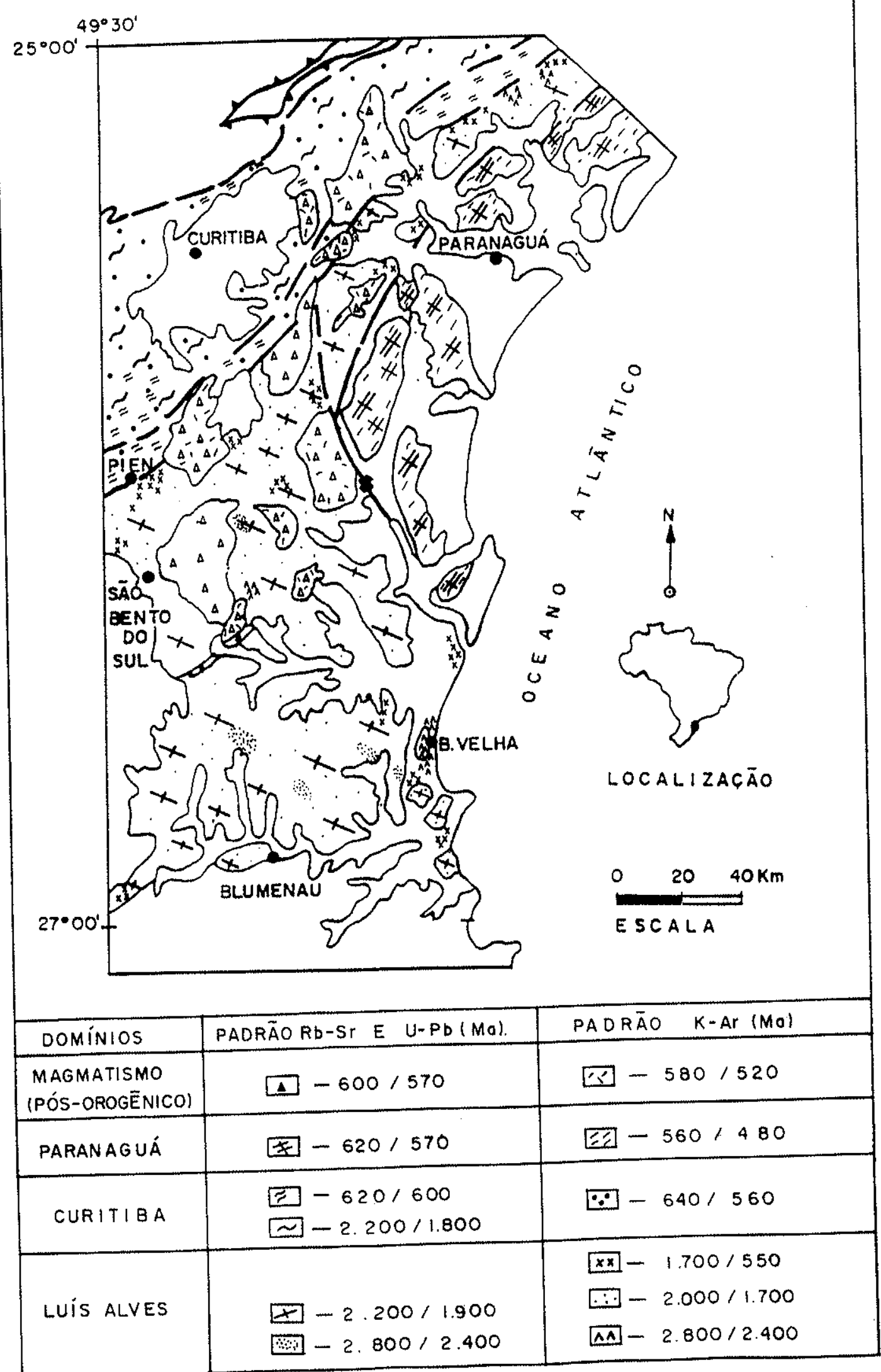




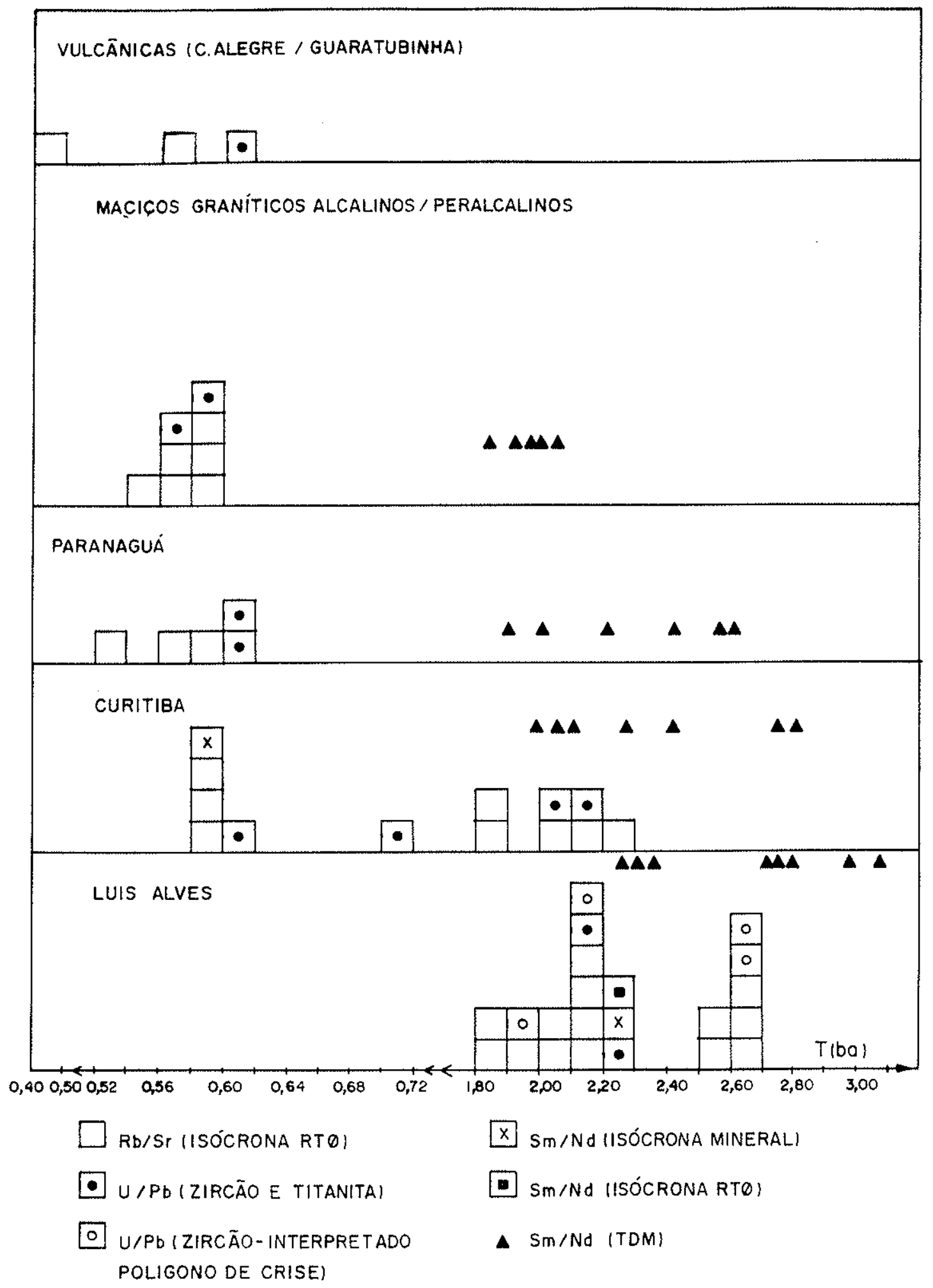

FIG: 7.2-HISTOGRAMA DE IDADES Rb- $\mathrm{Sr}, \mathrm{U}-\mathrm{Pb}, \mathrm{e}$ Sm-Nd PARA OS TERRENOS LOCALIZADOS NO SETOR SE DO PARANÁ E NE DE SANTA CATARINA. 


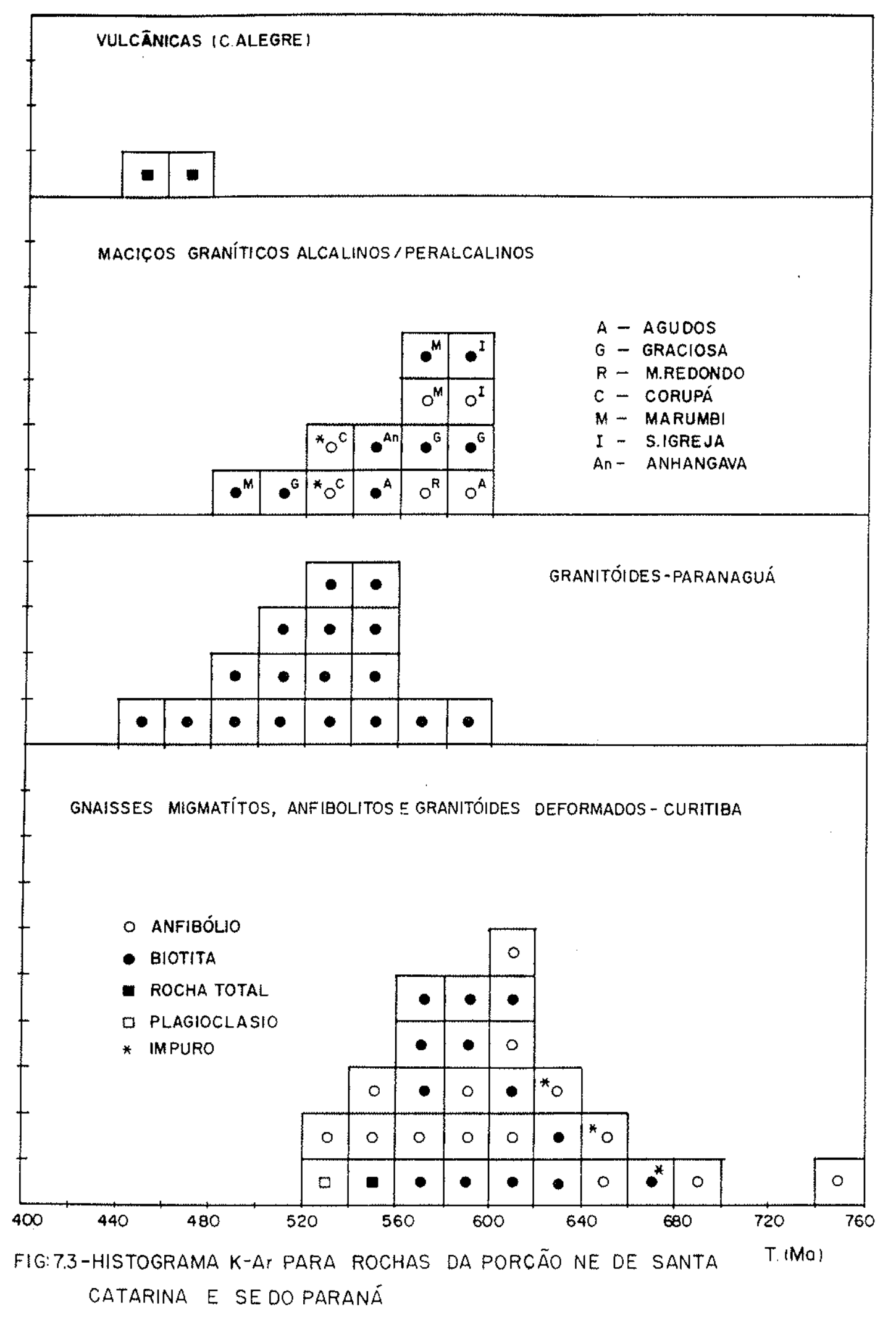




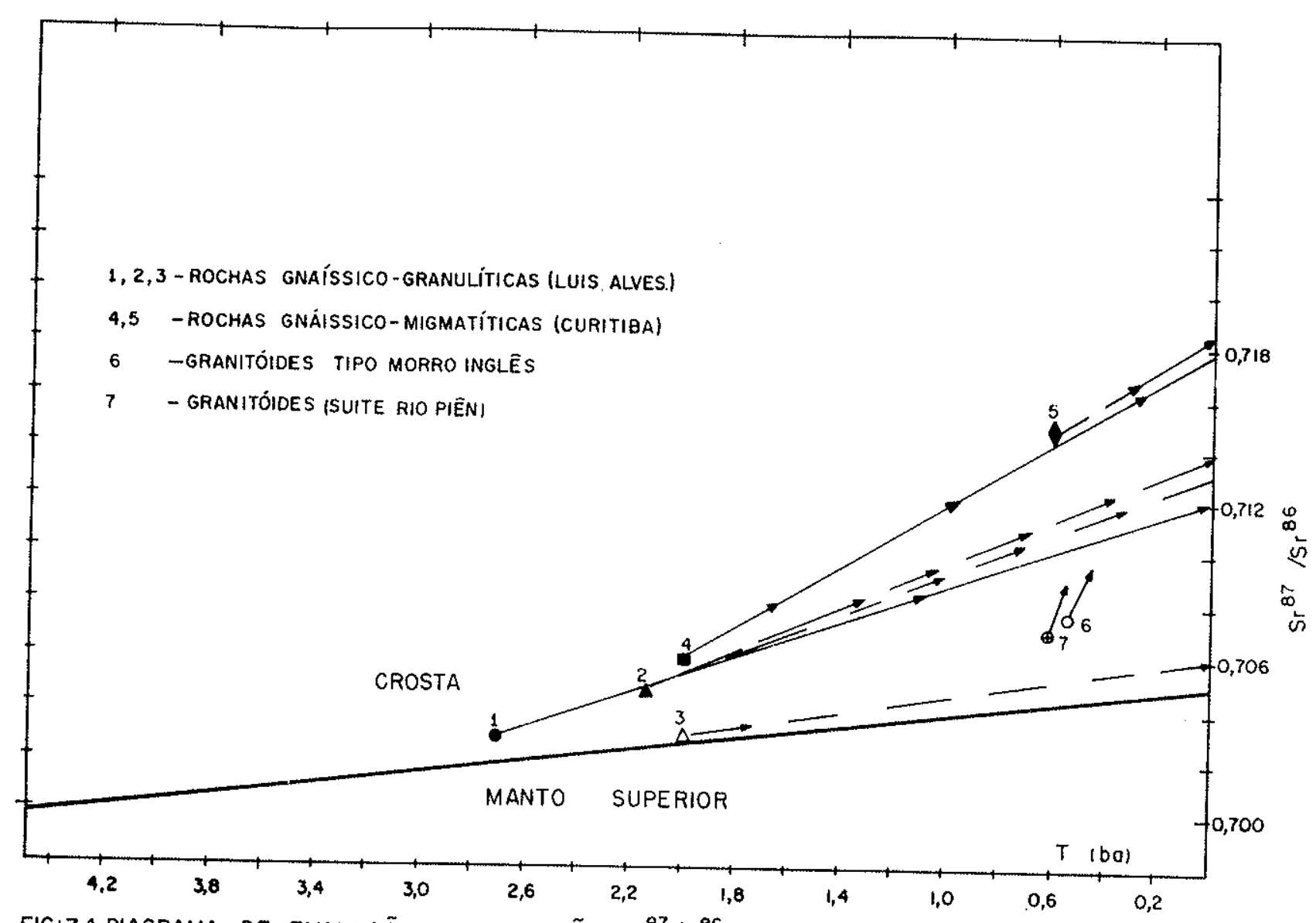

FIG:7.4-DIAGRAMA DE EVOLUCÃO DA RELACÃO $\mathrm{Sr} r^{87} / \mathrm{sr}^{86}-$ ROCHAS DA PORGÃO NE DE SANTA CATARINA E SE DO PARANÁ

As idades modelo Sm-Nd (TDM) indicam para derivação do manto superior, dos precursores crustais dos anfibóilo gnaisses desse domínio, épocas relacionadas ao Arqueano $(2.600 \pm 200 \mathrm{Ma})$ e, para os mobilizados migmatíticos e granitóides da Suite Rio Piên, valores do Paleoproterozóico $(2.100 \pm 200 \mathrm{Ma})$. Tal padrão radiométrico mostra similaridades com o observado para as rochas granuliticas pertencentes ao Dominio Luis Alves.

Os diagramas de evolução isotópica do índice $\varepsilon_{N d}$ indicam para as rochas gnáissico-migmatiticas bem como para os granitóides da Suite Rio Piên "trends" 
compativeis com os observados para os terrenos Luís Alves, derivados do manto tanto no Arqueano como no Paleoproterozóico, não evidenciando, como no caso do $\mathrm{Sr}$, fracionamento significativo (Fig. 7.5). Os valores de $\varepsilon_{\mathrm{Nd}}$ mostram-se menos negativos no Paleoproterozóico $(-1,2$ a $-6,5)$ do que no Neoproterozóico $(-20$ a -22$)$, sugerindo neste último caso longo período de residência crustal dos protolitos dessas rochas.

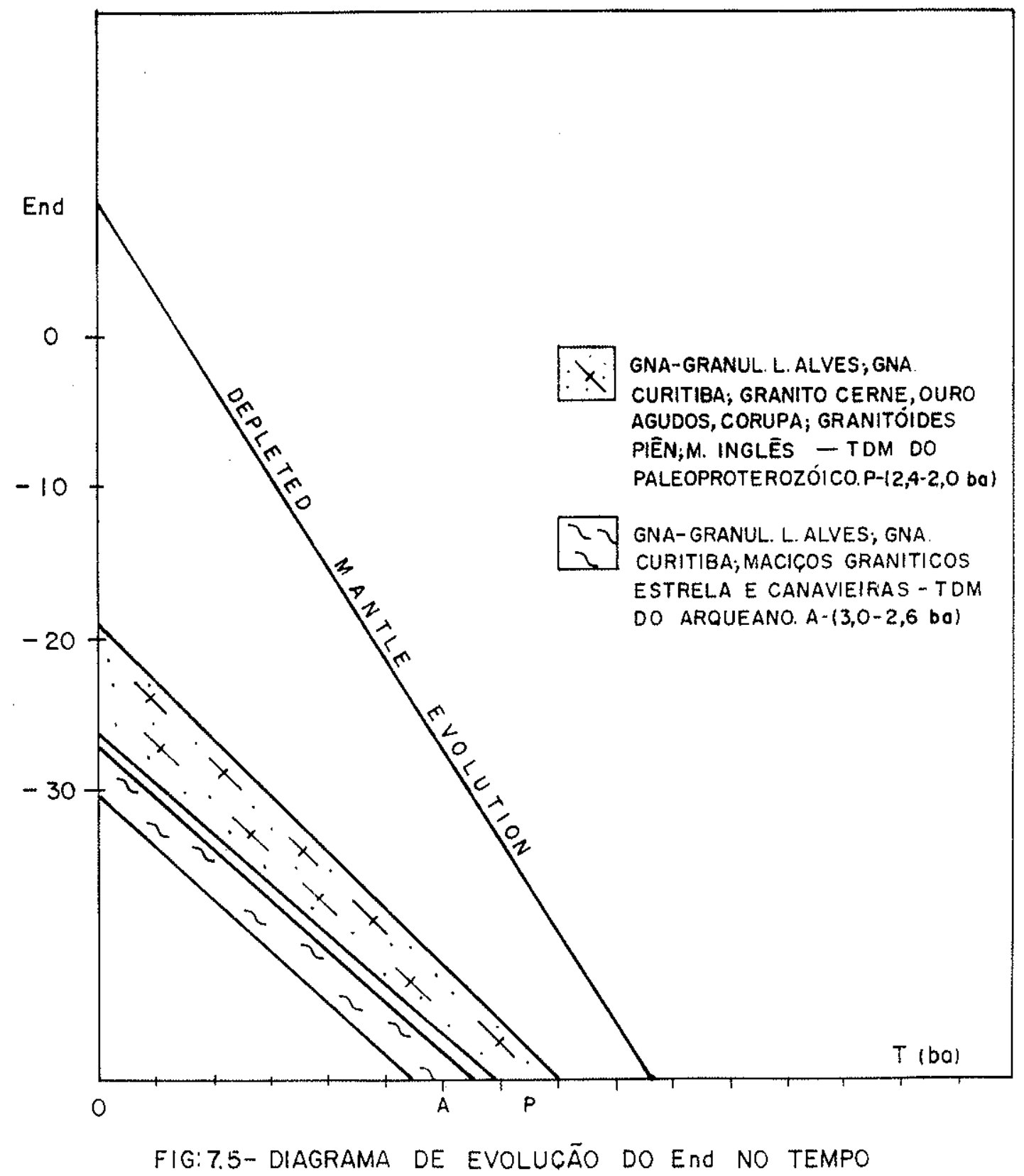


Basei et al. (1992), individualizaram esses terrenos setentrionais como pertencentes a uma microplaca distinta da Luís Alves (Microplaca Curitiba). Admitem processos de subducções e colisões no Neoproterozóico e no Cambriano, que se iniciariam com a justaposição da Microplaca Curitiba e do Cráton do Paraná. A seguir, a colisão entre as Microplacas Luis Alves e Curitiba, com o fechamento do oceano existente entre elas, seria decorrência de movimentação desses terrenos rumo noroeste. Neste modelo, os granitóides cálcio-alcalinos deformados (Suite Rio Piên), que balizam a porção sul do Dominio Curitiba foram referidos como representantes de raízes de um arco magmático Neoproterozóico. As rochas básicas e ultrabásicas que ocorrem na borda setentrional do Domínio Luis Alves foram admitidas como possiveis restos de assoalho oceânico obductado. Alguns aspectos, no entanto, a exemplo da ausência de metassedimentos relacionados a evolução do suposto oceano brasiliano, existente entre essas microplacas, necessitam de pesquisas adicionais, uma vez que o metamorfismo impresso nos granitóides da Suite Rio Piên e nas ultramáficas são do fácies xisto-verde. A presença de rochas básicas e ultrabásicas também não se restringe as regiōes limitrofes entre esses domínios (arredores de Campina dos Crispins), ocorrendo também associadas aos terrenos gnáissico-granulíticos Luis Alves (regiões de Campina dos Maias, Trigolândia, Tijucas do Sul, Vossoroca, São Bento do Sul, etc). Xistos magnesianos, com formas e dimensões variadas ocorrem adicionalmente associados aos gnaisses e migmatitos pertencentes ao Domínio Curitiba. Acrescente-se, que os dados geocronológicos indicam idade próxima de 2.250Ma para a formação das rochas ultrabásicas localizadas nos arredores de Campina dos Crispins e idades em torno de 2.700Ma para seus precursores do manto. Tais valores mostram-se compativeis com o padrão observado para grande parte das rochas gnáissico granulíticas pertencentes ao Domínio Luís Alves.

Tais fatos, aliados ao padräo estrutural observado para os litotipos pertencentes ao Domínio Curitiba, indicativo de uma tectônica controlada em grande parte por cisalhamentos com indicadores cinemáticos sugestivos de um transporte de baixo ângulo em direção ao Domínio Luis Alves, permitiram sugerir um modelo evolutivo alternativo. Neste modelo, os terrenos pertencentes ao Domínio Curitiba não representariam uma microplaca distinta e sim a margem noroeste da Microplaca Luís Alves, envolvida pela tectônica Neoproterozóica, reflexo de sua colisão com o Cráton do Paraná. Tratar-se-ia de uma zona de borda, intensamente deformada, migmatizada 
e granitizada, função desta tectônica colisional. Neste contexto, estariam atualmente expostas no Domínio Curitiba, rochas gnáissicas e migmatiticas do fácies anfibolito ao lado de niveis, relativamente, mais rasos, do fácies xisto-verde (granitóides deformados, rochas básicas e ultrabásicas e gnaisses granulíticos próximo as zonas de contato).,

No modelo proposto, os granitóides deformados que balizam o contato entre os Dominios Curitiba e Luís Alves, poderiam ter sua colocação relacionada à zonas transcorrentes, que limitam essas rochas magmáticas. A movimentação diferencial entre essas zonas de cisalhamento seria responsável pelo desenvolvimento, no interior das mesmas, de uma tectônica em regime tracional, que possibilitaria a colocação dessas rochas graníticas. Tal colocação teria ocorrido sincronicamente com os últimos estágios de deformação, $(615 \pm 30 \mathrm{Ma})$. Acrescente-se que esses granitóides encontram-se afetados pelos dobramentos abertos, tardios, com direções axiais NE-SW, que são observados em todo o Domínio Curitiba (anexo 3).

Outro compartimento importante, com evolução distinta, refere-se ao Domínio Paranaguá, representado por uma grande variedade de granitóides com idades de formação relativas ao Neoproterozóico. Os valores obtidos distribuem-se, principalmente entre 620 e $570 \mathrm{Ma}$, mostrando similaridades com o intervalo observado para o resfriamento dos terrenos Curitiba (Figs. 7.1; 7.2 e 7.3). Tal padrão, sugere que enquanto os terrenos Curitiba, encontravam-se a niveis crustais relativamente rasos (isotermas inferiores a $300-250^{\circ} \mathrm{C}$ ), no Dominio Paranaguá ocorria expressiva manifestação granítica (idades U-Pb e Rb-Sr relacionadas a formação dessas rochas). As idades Sm-Nd indicam épocas relativas ao Paleoproterozóico (2.200-1.900Ma) para os protolitos crustais dos granitóides tipo Morro Inglês, e mais antigas para os granitóides Canavieiras (2.400Ma) e Estrela (2.600Ma). Tais valores mostram-se interessantes, uma vez que os granitóides Canavieiras e Estrela distribuem-se na porção ocidental do Domínio Paranaguá, próximos ao contato com os gnaisses granulíticos Luís Alves, que apresentam idades Sm-Nd $\left(T_{D M}\right)$ dessa ordem. Os valores de $\varepsilon_{\mathrm{Nd}}$, bastante negativos no Neoproterozóico $(-12$ a -23$)$, sugerem um prolongado periodo de residência crustal para os protolitos dessas rochas graníticas. O padrão observado para o índice $\varepsilon_{\mathrm{Nd}}$ (Fig. 7.5), mostra-se coerente com o observado para os 
demais terrenos, distribuindo-se segundo "trends" Arqueanos (Canavieiras e Estrela) e Paleoproterozóicos (Morro Inglês).

Adicionalmente, as relações iniciais observadas para os granitóides Morro Inglês posicionaram-se no diagrama de evolução de $\mathrm{Sr}$ (no Neoproterozóico), acima da curva relativa aos gnaisses granulíticos Luís Alves derivados do manto no Paleoproterozóico, porém bem abaixo dos demais conjuntos, neste caso impossibilitando tratarem-se de reservatórios isotopicamente similares (Fig. 7.4).

Acrescente-se que esses granitóides apresentam intervalo de idades bastante amplo, desde sua formação (U-Pb: 620-600Ma), fechamento do sistema isotópico Rb$\mathrm{Sr}$ (600-570Ma), e resfriamento regional (K-Ar: 560 - 480Ma).

Padrão geocronológico similar, é descrito para os granitóides que ocorrem no Cinturão Kaoko, do lado Africano. Neste setor, os dados isotópicos indicam para os granitóides associados ao periodo de convergência continental, idades próximas de $650 \mathrm{Ma}$. Os granitóides relacionados à colisão continental (pós D-2) apresentaram idades da ordem de 590Ma. As fases tardias, relacionadas a retrocavalgamentos e ao desenvolvimento de grandes zonas de cisalhamento encontram-se datadas através dos granitóides de natureza pós tectônica, cujas idades mostram-se próximas a $570 \mathrm{Ma}$ (Porada 1989). Interessante é que o resfriamento deste cinturão, do lado Africano, prolongou-se até cerca de $480 \mathrm{Ma}$, similarmente ao padrão $\mathrm{K}$-Ar observado para os granitóides do Domínio Paranaguá.

O contato ocidental deste domínio com os terrenos Luís Alves é tectônico, marcado por importantes zonas de cisalhamento (Lineamentos do Rio Palmital, Alexandra e Serra Negra), que indicam na porção sul-sudoeste transporte lateral, com movimentação sinistral.

A aplicação do método $\mathrm{K}-\mathrm{Ar}$ em rochas pertencentes aos diferentes domínios estudados permitiu, não só caracterizar com precisão o padrão de resfriamento regional desses terrenos, mas também possibilitou tecer inferências sobre a tectônica que atuou na justaposição dos mesmos. Com este objetivo, foram confeccionados perfis K-Ar (térmicos) que seccionaram transversalmente os contatos entre os diferentes setores estudados (figs. 7.6 e 7.7). Observa-se um padrão térmico semeihante nos perfís Curitiba-Paranaguá (E-W, fig 7.6), e Curitiba-São Bento do Sul (N-S, Fig. 7.7), nos trechos que envolvem o Domínio Curitiba e seus limites tectônicos com o Domínio Luís Alves. A importância do evento tectono-termal brasiliano que 
atingiu as rochas pertencentes ao Domínio Curitiba é evidenciada através do patamar de idades principalmente entre 620 e $600 \mathrm{Ma}$. A passagem desses terrenos para os pertencentes ao Dominio Luís Alves é marcada por uma tendência de aumento gradativo das idades $\mathrm{K}$-Ar rumo a este último domínio, até atingir outro patamar relativo ao Ciclo Transamazônico $(2.000-1.700 \mathrm{Ma})$. O contato oriental, com o Cinturão Costeiro, mostra comportamento diferente, ocorrendo um salto das idades transamazônicas, representantes do Domínio Luis Alves para valores principalmente do intervalo 560-480Ma (Fig. 7.6). As diferenças térmicas observadas nos limites desses terrenos podem ser interpretadas como resultantes de superposições distintas dos mesmos. Assim, o limite norte sugere um envolvimento térmico expressivo e gradativo entre os terrenos Curitiba e Luís Alves, distinto do indicado para o setor sul oriental, onde a justaposição parece ter ocorrido a temperaturas mais baixas.

Importante granitogênese, notadamente de natureza alcalina-peralcalina, é representada nos Domínios Luis Alves e Curitiba pelos inúmeros "stocks" e batólitos graníticos (Graciosa, Anhangava, Marumbi, Serra da Igreja, Agudos do Sul, Morro Redondo, Dona Francisca, Pirai e Corupá). Esses maciços graníticos distribuem-se principalmente nas proximidades das grandes zonas de cisalhamento (Piên-Tijucas do Sul, Mandirituba-Piraquara, Corupá, Rio Palmital). O corpo de Agudos do Sul parece inclusive selar o contato entre os terrenos Luís Alves e Curitiba.

Os dados Sm-Nd relativos a época de diferenciação manto/crosta dos protolitos crustais desses granitos, concentram-se no intervalo 2.100-1.850Ma, caracterizando a grande importância do Paleoproterozóico (ciclo Transamazônico) na gênese de seus protolitos (Fig. 7.2). $O$ diagrama de evolução isotópica do índice $\varepsilon_{\mathrm{Nd}} \times \mathrm{T}$ indica padrão compatível com os observados para os demais terrenos com idades Sm-Nd (TDM) relativas ao Paleoproterozóico (Fig. 7.5). Os valores de $\varepsilon_{\mathrm{Nd}}$ calculados para a época de formação desses granitóides distribuem-se entre -7 e -13 . 

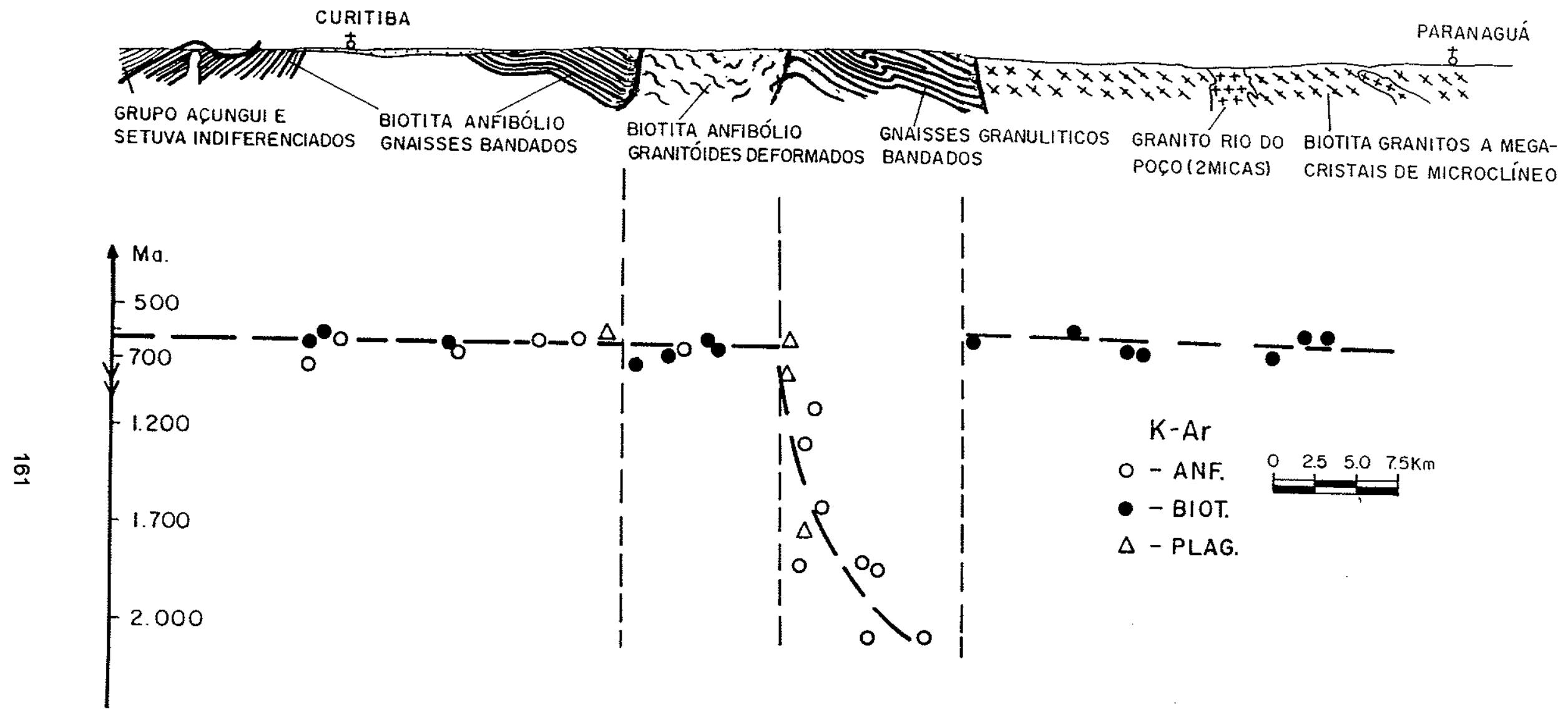

Fig. 7.6 - Perfil K-AR - Trecho Curitiba - Paranaguá 


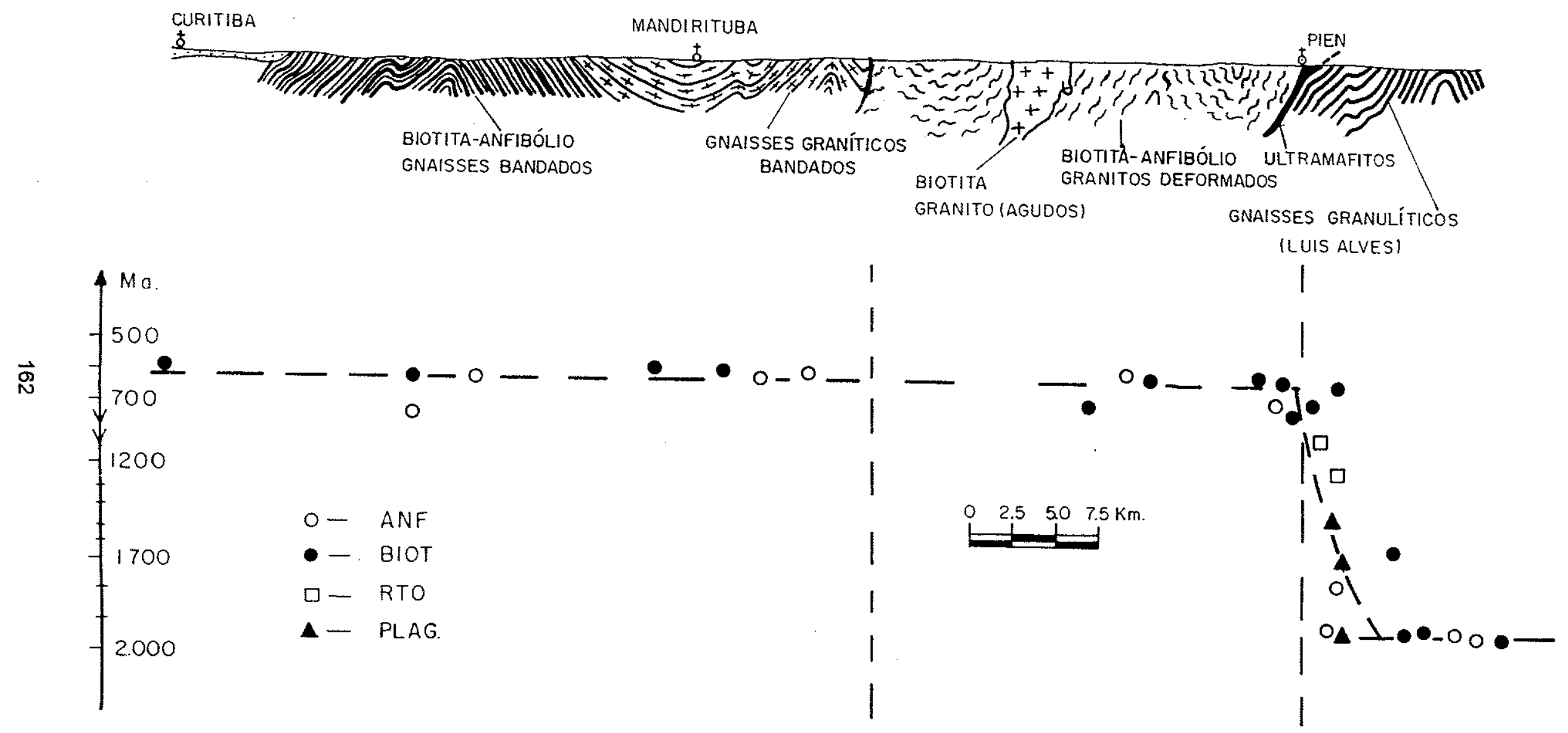

Fig. 7.7 - Perfil K-AR - Trecho Curitiba - São Bento do Sul 
As idades de formação da maioria desses corpos distribuem-se principaimente no intervalo 600-570Ma, periodo este que os terrenos Curitiba encontravam-se relativamente estáveis, enquanto na borda oriental do Domínio Luís Alves o processo era provavelmente colisional. A colocação desses maciços parece estar associada a regimes tectônicos predominantemente distensivos relacionados a processos de adelgaçamento crustal ocorridos no âmbito dos terrenos gnáissico-migmatíticos Curitiba, envolvendo parte do Domínio Luís Alves.

Os dados K-Ar, revelam ainda, que o Domínio Paranaguá permaneceu quente (isotermas superiores a $300-250^{\circ} \mathrm{C}$ ) por bem mais tempo (560-480Ma) que os domínios adjacentes, incluindo os granitóides intrusivos (585-520Ma, Fig. 7.3).

Expressivo vulcanismo ácido a intermediário ocorre adicionaimente no âmbito do Domínio Luís Alves, associado às bacias distensivas de Campo Alegre, Guaratubinha e Corupá. Embora os dados isotópicos Rb-Sr e U-Pb (zircões) mostremse precários, o intervalo 600-570Ma parece representar o período principal de colocação dessas rochas vulcânicas, periodo este, também relacionado a formação dos maciços graníticos de natureza alcalina-peralcalina (figs. 7.1 e 7.2). Tais dados corroboram com a hipótese de que neste período predominava um regime tectônico distensivo, relacionado ao adelgaçamento crustal, envolvendo o Domínio Curitiba e parte do Dominio Luís Alves.

Finalmente, dados K-Ar obtidos em plagioclásios e rocha total de rochas metabásicas e diques básicos, que ocorrem no âmbito dos terrenos estudados apresentaram idades relacionadas respectivamente ao Neoproterozóico (690-500Ma), e ao Jurássico e Cretáceo (200-120Ma - apêndice-1). No primeiro caso, tais manifestações distribuem-se principalmente nas proximidades dos contatos entre os terrenos estudados, associados possivelmente aos grandes falhamentos gerados ou reativados no Neoproterozóico. Os dados mais jovens necessitam de estudos complementares uma vez que, tais manifestações concentram-se no setor sulbrasileiro, principalmente no Cretáceo.

\section{2 - Implicações Tectónicas}

A configuração observada para os terrenos localizados entre os Cinturōes Ribeira (a norte) e Dom Feliciano (a sul) parece ser o resultado da aglutinação de 
entidades geotectônicas distintas, produzida por processos de subducções seguidas de colisões.

O atual quadro tectônico foi estabelecido durante o final do Neoproterozóico com continuidade até o Cambro-Ordoviciano, como resultado de processos de colagens relacionadas a formação do Gondwana Ocidental. Nesse período, o choque dos Crátons Congo-Kalahari contra os conjuntos dos Crátons São Francisco - Paraná e Amazônico, teria produzido o amalgamento de todos os blocos continentais existentes entre essas grandes massas continentais. Tais blocos representam hoje segmentos continentais, em meio aos cinturões de dobramento gerados ou retrabalhados nessa época.

Nesse sentido, é entendida que a atual configuração dos terrenos Luís Alves, envolvendo seu prolongamento para nordeste, em direção ao Maciço Serra Negra, com provável continuidade até o Maciço de Itatins (sudeste de São Paulo), bem como os terrenos pertencentes ao Domínio Curitiba (borda do segmento Luís Alves retrabalhada), poderia representar um microcontinente localizado entre os Crátons do Congo e do Paraná.

A extensão desse segmento para SW, envolvendo os Blocos São Gabriel e Taquarembó (no RGS) e o Bloco Flórida (no Uruguai), integrando o Cráton Rio de La Plata foi proposta por Fragoso César (1991). Os dados gravimétricos no entanto (Hallinan et al. 1993), indicam a continuidade do Domínio Luís Alves para SW até a latitude de aproximadamente $29^{\circ}$, onde é interrompido por anomalias negativas E-W, não caracterizando sua ligação com os demais terrenos a sul.

Existe a possibilidade ainda, dos terrenos Luís Alves estarem conectados, nesta época, ao Cráton do Congo, havendo uma ponte de ligação (Congo - Luís Alves), isolando dois oceanos distintos (Fig. 7.8). O reconhecimento de terrenos antigos (Arquenos e Paleoproterozóicos) junto a costa de Angola (África), bem como do Brasil (Itatins), sugere que cinturões de dobramento gerados ou retrabalhados durante o Neoproterozóico, não existiram entre esses segmentos continentais (neste caso haveria a ligação proposta) ou que os mesmos encontram-se submersos ou foram totalmente destruidos durante a constituição Meso-Cenozóica do Atlântico Sul (neste caso o Domínio Luís Alves representaria um microcontinente).

Acredita-se, com base no padrão estrutural observado para os terrenos Curitiba e do Cinturão Ribeira (Campanha et al. 1987, Soares 1988, Fiori 1990), que a 
movimentação relativa teria colocado os terrenos Luís Alves por debaixo do Cinturão Ribeira. O transporte relativo, envolvendo tanto as seqüências metassedimentares como as margens continentais do microcontinente colidente, seria de NW para SE. Tal processo teria se iniciado ao redor de $700 \pm 50 \mathrm{Ma}$ (idade atribuída aos granitóides Três Córregos e Cunhaporanga - Reis Neto 1994). O arco magmático Três Córregos seria gerado nessa época, na borda do Cráton do Paraná.

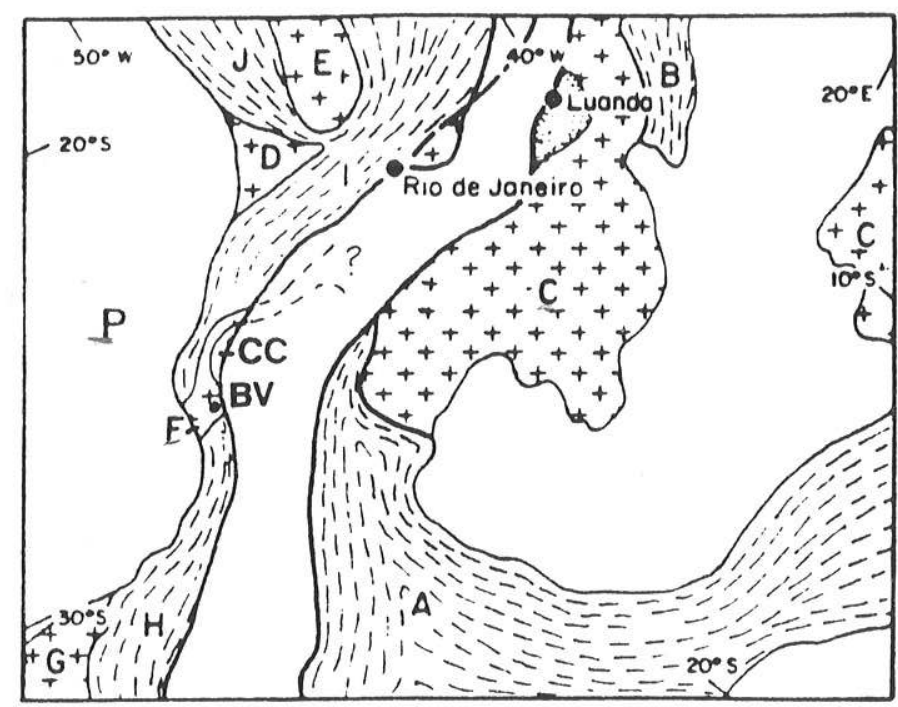

Fig. 7.8 - Correlação geológica Brasil - África. A - Cinturão Damara; B - Cinturão Oeste - Congo; C - Cráton do Congo; D - Maciço de Guaxupé; E - Cráton São Francisco; F - Domínio Luís Alves; G - Cráton Rio de la Plata; P - Cráton do Paraná; H Cinturão Dom Feliciano; I - Cinturão Ribeira; J - Cinturão Brasília; CC - Cinturão Paranaguá; BV - Barra Velha.

O fechamento completo do oceano existente entre os terrenos Luís Alves e Paraná e consequente colisão teria ocorrido em épocas anteriores a 620-600Ma, 
periodo este, associado aos processos tectônicos tardios (resfriamento) envolvendo o Domínio Curitiba. No modelo proposto, os terrenos pertencentes ao Domínio Curitiba representam portanto a borda do Microcontinente Luís Alves intensamente deformada, migmatizada e granitizada, conseqüência de uma tectônica controlada principalmente por cisalhamentos.

Acrecente-se que sob o ponto de vista geotectônico, fragmentos crustais que apresentem pelo menos uma margem ativa e dimensões inferiores a $10^{6} \mathrm{~km}^{2}$ (Condie 1989) devem ser classificados como microplacas. Observa-se, portanto que a evolução do microcontinente Luís Alves faz com que o mesmo adquira características de microplaca, denominação esta proposta por Basei et al. (1992).

A justaposição do Domínio Paranaguá parece ter-se dado após a colagem dos terrenos Luís Alves e Paraná. Os valores de idades, bem como a assinatura isotópica desses terrenos o diferenciam dos demais (Basei et al. 1990a) e sugerem a formação de granitóides a partir do retrabalhamento de rochas crustais (620-570Ma). O padrão $\mathrm{K}-\mathrm{Ar}$ (biotitas) indica ainda que o resfriamento deste segmento, ou de parte dele, atingiu o Cambro-Ordiviciano, evidenciando provavelmente, processos relacionados à aglutinação dos Crátons Congo-Kalahari com os Crátons São Francisco-Paraná e, consequente, formação do Gondwana Ocidental.

O Domínio Paranaguá pode representar a continuidade lateral do Cinturão Kaoko (do lado Africano - Fig. 7.8) e fazer parte da evolução de um grande cinturão colisional, que balizaria toda porção costeira das regiões sul e sudeste do território brasileiro, num quadro geotectônico cuja dinâmica deformacional é ainda incerta. Algumas semelhanças deste setor com os demais (a norte e a sul) são observadas a exemplo da intensa granitogênese, com épocas de formação relativamente próximas e, fontes de mesma idade, além do predomínio de encaixantes metassedimentares aluminosas e padrão estrutural coerente. As diferenças existentes podem ser devidas a geometria pretérita desses terrenos, dinâmica de deformação, bem como relacionada aos diferentes níveis estruturais atualmente expostos. 0 padrão gravimétrico (Hallinan et al. 1993), indica a continuidade do Domínio Paranaguá para sul, rumo ao dominio interno do Cinturão Dom Feliciano, em Santa Catarina. Sua extensão para o Rio Grande do Sul, em direção ao Batólito Pelotas não encontra suporte gravimétrico, podendo tal continuidade ter se dado mais a leste, na margem continental. 
Durante a justaposição do Domínio Paranaguá ocorre no âmbito dos terrenos adjacentes, já relativamente estabilizados, expressiva granitogênese de natureza alcalina-peralcalina bem como intenso vulcanismo ácido-intermediário relacionado a evolução das Bacias de Campo Alegre, Guaratubinha e Corupá. Tais manifestações sugerem uma associação com regimes tectônicos distensivos, produzidos pelos ajustes crustais decorrentes de uma procura de condições de maior estabilidade, após o espessamento provocado pelo tectonismo precedente.

A disposição desses maciços graníticos, por outro lado, em grande parte, orientados paralelamente ao limite do Cinturão Paranaguá, e as idades de formação relativamente próximas, sugere uma associação entre ambos, permitindo uma hipótese alternativa onde a geração destes corpos graníticos estaria relacionada a um adelgaçamento litosférico, produzido no ante-país, resultante desta justaposição.

Observa-se ainda que o intervalo de idades $\mathrm{K}-\mathrm{Ar}$, mais significativo, obtido para os maciços graníticos (585-520Ma), mostra-se pouco mais antigo que o observado para os terrenos do Cinturão Paranaguá (560-480Ma). Tal fato sugere a permanência deste último segmento à isotermas superiores a $250-300^{\circ} \mathrm{C}$ por mais tempo, periodo em que os corpos graníticos já se encontravam relativamente frios, denotando posicionamento em niveis crustais superiores.

Finalmente, com intuito de melhor caracterizar aspectos relacionados a evolução crustal da região pesquisada, foram analisados os valores disponíveis de $\varepsilon_{\mathrm{Nd}}$ em função das idades de formação dos diferentes tipos de rocha deste setor (Fig. 7.9). Observa-se durante o Neoproterozóico, um amplo intervalo de distribuição dos valores $\varepsilon_{\mathrm{Nd}}$, sistematicamente negativos $(-7$ a -23$)$, indicando que os processos de formação de rocha, deste periodo, envolveram predominantemente, o retrabalhamento de material com vida crustal pretérita. Interessante, é que grande parte desse material formado durante o Neoproterozóico indica, através de idades modelo Sm-Nd, épocas de diferenciação do manto superior relativas ao Paleoproterozóico. Neste período e, no Arqueano, os valores de $\varepsilon_{\mathrm{Nd}}$ são bem menos negativos, por vezes próximos de zero, sugerindo maior participação em sua constituição de material oriundo do manto superior. O padrão relativo aos terrenos sul-africanos (Harris et al. 1986), se distingue do observado na figura 7.9, principalmente por caracterizar volumes significativos de rocha formadas durante o Mesoproterozóico envolvendo principalmente processos de 
acresção de material do manto superior. Acrescente-se que na porção sul-africana, a distribuição dos valores de $\varepsilon_{\mathrm{Nd}}$ durante o Neoproterozóico se assemelha ao do setor estudado, evidenciando adicionalmente, acresção de material do manto superior, neste período.

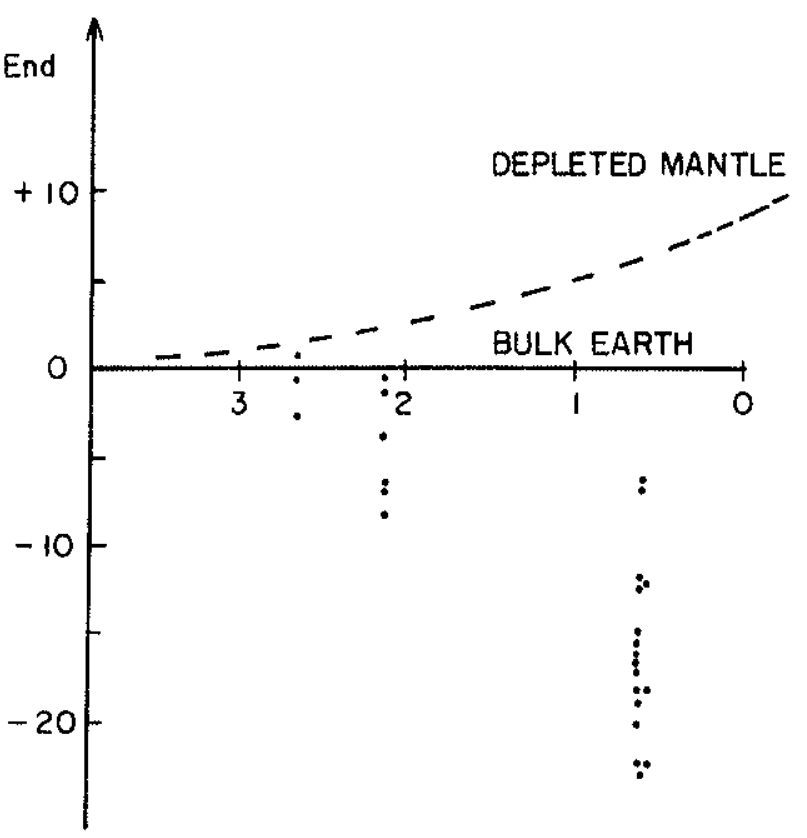

FIG: 7.9 - END X TEMPO - DADOS DO SETOR SE DO PARANÁ E NE DE SANTA CATARINA. 


\section{CAPITULO 8}

\section{REFERÊNCIAS BIBLIOGRÁFICAS}

ABREU, S.F. (1945) Fundamentos Geográficos da Mineração Brasileira. Revista Brasileira de Geografia, 7(1):3-137.

AHRENS, L.H. (1955) Implications of the Rhodesian age pattern. Geochimica et Cosmochimica Acta, 8(1):1-15.

ALBUQUERQUE, L.F.F.; ARIOLI, E.E.; DIAS, A.D.A.; KIRCHNER, C.A. (1971) Geologia das quadrículas de Blumenau e Joinville, SC. Porto Alegre, DNPM/CPRM, 101p. (Relatório interno).

ALMEIDA, F.F.M. (1949) Novo campo de riolitos e tufos no sul do Brasil. Mineração e Metalurgia, 14(82):101-103.

ALMEIDA, F.F.M. (1952) Contribuição à geomorfologia da região oriental de Santa Catarina. Boletim Paulista de Geografia, 10(1): 3-32.

ALMEIDA, F.F.M. (1967) Origem e evolução da Plataforma Brasileira. Rio de Janeiro, DGM/DNPM, Boletim 241, 36p.

ALMEIDA, F.F.M. ; AMARAL, G.; CORDANI, U.G.; KAWASHITA, K. (1973) The precambrian evolution of South America cratonic margin, south of the Amazon River. In: NIRN, A.E.M. \& STHELI, F.G. (Eds.). The ocean basins and margins. New York, Plenum Press, v.1, p.411-446.

AMARAL, G.; CORDANI, U.G.; KAWASHITA, K.; REYNOLDS, J.H. (1966) PotassiumArgon dates of basaltics rocks from southern Brazil. Geochimica et Cosmochimica Acta, 30(2):159-189.

ARNDT, N.T. \& GOLDSTEIN, S. (1987) USE AND ABUSE OF CRUST-FORMATION AGES. Geology, 15(10):893-895.

BARBARIN, B. (1990) Granitoids: main petrogenetic classifications in relation to origin and tectonic setting. Geological Journal, 25(3/4):227-238.

BARBOSA, O. (1940) Reservas de minérios de ferro em Santa Catarina. Mineraçăo e Metalurgia, 5(25): 21-24.

BARBOSA, O. (1957) Observaçס̃es e Comparaçס̃es sobre algumas ocorrencias vulcánicas no Peru, no México e no Brasil. Rio de Janeiro, DGM/DNPM, Boletim $167,43 p$. 
BARTON Jr., J.M. (1983) Pb isotopic studies of Banded Iron Formation, Central Zone, Limpopo Mobile Belt. Geological Society of South Africa (Special Publication), 8:43-44.

BARTORELLI, A.; MINIOLI, B.; KAWASHITA, K. (1968) Nota preliminar sobre rochas ultrabásicas de Itajuba - Santa Catarina. In: CONGRESSO BRASILEIRO DE GEOLOGIA, 22, Belo Horizonte. Anais. Belo Horizonte, SBG, v.1, p.243-246.

BASEI, M.A.S. (1985) O Cinturão Dom Feliciano em Santa Catarina. São Paulo, 190p. (Tese de Doutorado apresentada ao Instituto de Geociências da Universidade de São Paulo).

BASEI, M.A.S. \& SIGA Jr. O. (1992) Tectonic evolution of the Joinville Massif, southern Brazil. In: INTERNATIONAL GEOLOGICAL CONGRESS, 29, Kioto. Abstracts. Kioto, Japão, v.2, p.271.

BASEI, M.A.S. \& TEIXEIRA, W. (1987) Geocronologia dos terrenos pré-cambrianos a eopaleozóicos de Santa Catarina. In: SILVA, L.A. \& BERTOLUZZI, C.A. (eds.). Texto explicativo para o mapa geológico do estado de Santa Catarina 1:500.000. Florianópolis, DNPM/CPRM.

BASEI, M.A.S.; SIGA Jr., O.; VASCONCELLOS, J.P.B.C.; SILVA, P.C.S. (1988) Evolução e geotectônica dos terrenos pé-cambrianos a eopaleozóicos dos estados do Paraná e Santa Catarina. São Paulo, 20p. (Relatório Fapesp, Projeto 87/0175-9, inédito).

BASEI, M.A.S.; VASCONCELLOS, J.P.B.C.; SIGA Jr., O. (1989) Isotopic studies and tectonic setting of late proterozoic granites of south Brazil. In: INTERNATIONAL GEOLOGICAL CONGRESS, 28, Washington-D.C. Abstracts. Washington-DC, EUA, v.1, p.94.

BASEI, M.A.S.; SIGA Jr., O.; REIS NETO, J.M. (1990a) O Batolito Paranaguá. Proposição, idade, considerações petrogenéticas e implicações tectônicas. In: CONGRESSO BRASILEIRO DE GEOLOGIA, 36, Natal. Anais. Natal, SBG, v.4, p.1684-1699.

BASEI, M.A.S.; SIGA Jr., O.; MACHIAVELLLI, A. (1990b) Tectônica de nappes do Proterozóico Superior e Eopaleozóico da porção sul brasileira. In: REUNIÄO INTERNACIONAL DO PROJETO 270 - PICG, 3, São Paulo, IUGS/UNESCO.

BASEI, M.A.S.; SIGA Jr., O.; MACHIAVELLI, A. (1990c) Tectonic relationship between the Dom Feliciano Belt and the Joinville Massif, Southern Brazil. In: WORKSHOP "GEOQUIMIICA ISOTÓPICA, LITO-GEOQUIMICA E GEOCRONOLOGIA DAS REGIÕES SUL E SUDESTE DO BRASIL", São Paulo. Boletim de Resumos. São Paulo, SBG, v.1, p.17-19. 
BASEl, M.A.S.; SIGA Jr., O.; KAWASHITA, K. (1990d) A K-Ar profile through the Joinville Massif and the Dom Feliciano Belt, southern Brazil - tectonic implications. In: INTERNATIONAL CONFERENCE ON GEOCHRONOLOGY COSMOCHRONOLOGY AND ISOTOPE GEOLOGY, 7, Canberra. Abstracts. Camberra, Australia, v.27, p.8.

BASEI, M.A.S.; SIGA Jr., O.; MACHIAVELLI, A.; MANCINI, F. (1991) Evolução tectônica do Maciço de joinville (PR - SC). In: SIMPÓSIO NACIONAL DE ESTUDOS TECTÓNICOS,3, Rio Claro. Boletim de Resumos. Rio Claro, SBG, p.132-133.

BASEI, M.A.S.; SIGA Jr., O.; MACHIAVELLLI, A.; MANCINI, F. (1992) Evolução tectônica dos terrenos entre os Cinturões Ribeira e Dom Feliciano (PR - SC). Revista Brasileira de Geociências, 22(2):216-221.

BASEI, M.A.S.; SIGA Jr., O.; SATO, K.; SPRÖESSER, W. M. (1994) A instalação da metodologia Urânio-Chumbo na Universidade de São Paulo. Princípios metodológicos, aplicaões e resultados obtidos. Anais da Academia brasileira de Ciências (no prelo).

BATCHELOR, R.A. \& BOWDEN, P. (1985) Petrogenetic interpretation of granitoid rocks series using multicationic parameters. Chemical Geology, 48(1/4):43-55.

BATOLLA Jr., F.; HAMA; M.; LOPES Jr., I. (1977) Idades radiométricas Rb/Sr e KJAr em rochas cristalinas pré-brasilianas da região leste do Estado do Paraná. In: SIMPÓSIO REGIONAL DE GEOLOGIA, 1, São Paulo. Atas. São Paulo, SBG, p.324-337.

BIGARELLA, J.J. (1965) Nota explicativa acompanhando a Folha Geológica de Paranaguá. Boletim da Universidade Federal do Paraná, Geologia, 13: 6p.

BIONDI, J.C.; CAVA, L.T.; SOARES, P.C. (1989) Mapa Geológico do Estado do Paraná (Escala 1:650.000). Curitiba, DNPM/MINEROPAR.

BOWDEN, P. \& TURNER, D.C. (1974) Peralkaline and associated Ring Complex in the Nigeria - Niger Province, West Africa. In: SORENSEN, H. (Ed.). The Alkaline Rocks. New York, J. Wiley \& Sons, p. 330-351.

BOWDEN, P.; BATCHELOR, R.A.; CHAPPEL, B.W.; DIDIER, J.; LAMEYRE, J. (1984) Petrological, geochemical and source criteria for the classification of granitic rocks: A discussion. Physics of the Earth and Planetary Interiors, 35(1/3):1-11.

BRANNER, B. (1919) Outlines of the geology of Brazil to accompany the geological map of Brazil. Geological Society of America Bulletin, 30(2):189-338.

BRITO NEVES, B.B. \& CORDANI, U.G. (1991) Tectonic evolution of South America during the Late Proterozoic. Precambrian Research, 53(1/2):23-40. 
BROOKS, C.; HART, S.R.; WENT, I. (1972) Realistic use of two-error regression treatements as apllied to rubidium-strontium data. Reviews of Geophysics and Space Physics, 10(2):551-577.

BROWN, G.C. (1982) Calc-alkaline intrusive rocks: their diversity, evolution, and relation to volcanic arcs. In: THORPE, R. S. (Ed). Andesites. New York, J. Wiley \& Sons, p.437-461.

CAMPANHA, G.A.C. (1992) Tectônica proterozóica no alto e médio Vale do Ribeira, Estados de São Paulo e Paraná. São Paulo, 296p. (Tese de Doutorado apresentada ao Instituto de Geociências da Universidade de São Paulo).

CAMPANHA, G.A.C.; BISTRICHI, C.A.; ALMEIDA, M.A. (1987) Considerações sobre a organização litoestratigráfica da Faixa de Dobramentos Apiaí. In: SIMPOSIO SUL-BRASILEIRO DE GEOLOGIA, 3, Curitiba. Atas. Curitiba, SBG, v.2, p.725742.

CAMPANHA, G.A.C.; GIMENEZ FILHO, A.; SADOWSKI, G.R. (1994) Tectônica da Faixa Ribeira. In: CONGRESSO BRASILEIRO DE GEOLOGIA, 38, Camboriú. Boletim de Resumos Expandidos. Camboriú, SBG, v.1, p.271-272.

CAMPOS NETO, M.C. \& FIGUEIREDO, M.C.H. (1994) The Rio Doce orogeny, southeastern Brazil. Journal of South American Earth Sciences (no prelo).

CARNEIRO, C.D.R. (1974) Esboço e diferenciação tectônica do pré-Cambriano Superior no sul-sudeste do Brasil. In: CONGRESSO BRASILEIRO DE GEOLOGIA, 28, Porto Alegre. Resumo das Comunicações. Porto Alegre, SBG, v.1, p. $698-700$.

CARVALHO, P.F. (1936) Geologia do Municipio de Curitiba. Rio de Janeiro, DNPM/DMG. Boletim 82, 37p.

CARVALHO, P.F. \& PINTO, E.A. (1938) Reconhecimento geológico no Estado de Santa Catarina, Brasil. Rio de Janeiro, DNPM/DGM. Boletim 92, 30p.

CASTRO, N.A.; P. JR., V. REIS NETO, J.M. (1994) Formação Guaratubinha: a importância das rochas vulcanoclásticas. In: CONGRESSO BRASILEIRO DE GEOLOGIA, 38, Camboriú. Boletim de Resumos Expandidos. Camboriú, SBG, V.3, p.72-73.

CHIODI FILHO, C.; SANTOS, J.F.; SOARES, P.C.; MORETZOHN, J.S. (1989) Estudos de elementos terras raras para caracterização e avaliaçäo metalogenética de granitóides no Escudo Paranaense. In: CONGRESSO BRASILEIRO DE GEOQUÍMICA, 2, Porto Alegre. Anais. Porto Alegre, SBG, p.487-497.

CONDIE, K.C. (1989) Plate tectonics and crustal evolution. Oxford, Pergamon Press, $476 p$. 
CORDANI, U.G. (1974) Comentários sobre as determinações geocronológicas disponiveis nas Folhas Assunción e Curitiba. In: MONACO, O.A.; ZIR FILHO, J.A.; VALENTINE, N. (Eds.). Carta Geológica do Brasil ao Milionésimo, Folha Assunción- SG.21 e Curitiba- SG.22. Brasilia, DNPM, p.58-67.

CORDANI, U.G. (1980) Fundamentos de interpretaçäo geocronológica. In: CONGRESSO BRASILEIRO DE GEOLOGIA, 31, Camboriú. Boletim Especial. Camboriú, SBG, v.6, 22p.

CORDANI, U.G. \& BITTENCOURT, I. (1967) Determinações de idade K-Ar em rochas do Grupo Açungui. In: CONGRESSO BRASILEIRO DE GEOLOGIA, 21, Curitiba. Anais. Curitiba, SBG, v.1, p.218-233.

CORDANI, U.G. \& GIRARDI, V.A.V. (1967) Geologia da Folha de Morretes. Boletim da Universidade Federal do Paraná, Geologia, 26:40p.

CORDANI, U.G. \& KAWASHITA, K. (1971) Estudo geocronológico pelo método Rb-Sr de rochas graníticas intrusivas no Grupo Açungui. In: CONGRESSO BRASILEIRO DE GEOLOGIA, 25, São Paulo. Anais. São Paulo, SBG, v.1, p.105-110.

CORFU, F. \& STOTT, G.M. (1986) U/Pb ages for late magmatism and regional deformation in the Shebandowan Belt, Superior Province, Canada. Canadian Journal of Earth Sciences, 23(8):1075-1082.

COWARD, M.P. (1983) Thrust tectonics, thin skinned, and the continuation of thrusts to deep in the crust. Journal of Structural Geology, 5(2):113-123.

DAITX, E.C. \& CARVALHO, M.A.S. (1980) Projeto geoquímica na área de Guaratubinha - Piên. São Paulo, DNPM/CPRM, 184p. (Relatório interno).

De La ROCHE, H.; LETTERRIER, J.; GRANDCLAUDE, P.; MARCHAL, M. (1980) A classification of volcanic and plutonic rocks using R1R2 diagram and majorelements analyses - Its relationships with current nomenciature. Chemical Geology, 29(112):183-210.

DE PAOLO, D.J. (1988) Neodymiun isotope geochemistry: an introduction. Berlin, Springer Verlag, 187p.

DEWEY, J.F.; GASS, I.G.; CURRY, G.B.; HARRIS, N.B.W.; SENGÖR, A.M.C. (eds.) (1990) Allochthonous terranes. Cambridge, Cambridge University Press, 199p.

EBERT, H. (1971) O Grupo Guaratubinha ao norte do Estado de Santa Catarina. In: CONGRESSO BRASILEIRO DE GEOLOGIA, 25, São Paulo. Anais. São Paulo, SBG, v.1, p.147-165.

EBERT, H. \& BROCHINI, M.F. (1971) A Formação Campo Alegre, Santa Catarina. In: CONGRESSO BRASILEIRO DE GEOLOGIA, 25, São Paulo. Resumo das Comunicações. São Paulo, SBG, p.181-182. 
ERICHSEN, A.l. (1925) Nota preliminar sobre a jazida de ferro dos Municípios de Joinville e São Francisco do Sul, Brasil. Rio de Janeiro, DNPM/DGM, Boletim 13, $34 \mathrm{p}$.

EVENSEN, N.H.; HAMILTON, P.J.; O'NIONS, R.K. (1978) Rare earth abundances in chondritic meteorite. Geochimica et Cosmochimica Acta, 42(8):1119-1212.

FASSBINDER, E.; FUMAGALLI C.E.; FIORI, A.P. (1985) Estudo preliminar sobre lineamentos tectônicos no pré-Cambriano paranaense. In: SIMPOSIO SULBRASILEIRO DE GEOLOGIA, 2, Florianópolis. Anais. Florianópolis, SBG, p.172183.

FAURE, G. (1986) Principles of isotope geology. New York, John Wiley \& Sons, 589p.

FERREIRA, C.J. \& WERNICK, E. (1985) Petrografia dos granitóides dos escudos de Santa Catarina e Rio Grande do Sul. In: SIMPÓSIO SUL-BRASILEIRO DE GEOLOGIA, 2, Florianópolis. Anais. Florianópolis, SBG, p.124-125.

FIGUEIREDO, M.C.H.; BASEI, M.A.S.; MANTOVANI, M.S.M.; FRYER, B.J. (1991) O Complexo Granulítico de Santa Catarina: um arco insular arqueano? Boletim IGUSP, Publicação Especial, 9:35-40.

FIORI, A.P. (1978) Análise do caráter polidiapírico do Granito Agudos na região de Agudos do Sul, PR. Curitiba, MINEROPAR S/A, 28p. (Relatório interno).

FIORI, A.P. (1985) As falhas Lancinha e de Morro Agudo e estruturas secundárias associadas. In: SIMPOSIO SUL-BRASILEIRO DE GEOLOGIA, 2, Florianópolis. Anais. Florianópolis, SBG, p.159-171.

FIORI, A.P. (1990) Tectônica e estratigrafia do Grupo Açungui a norte de Curitiba, São Paulo. São Paulo, 261p. (Tese de Livre Docência apresentada ao Instituto de Geociências da Universidade de São Paulo)

FIORI, A.P. (1992) Tectônica e estratigrafia do Grupo Açungui, PR. Boletim IG-USP, Série Cientifica, 23:55-74.

FONSECA, A. do C. (1993) Esboço Geocronológico da região de Cabo Frio - Estado do Rio de Janeiro. São Paulo, 186p. (Tese de Doutoramento apresentada no Instituto de Geociências da Universidade de São Paulo).

FRAGOSO CESAR, A.R.S. (1980) O Cráton do Rio de La Plata e o Cinturão Dom Feliciano no Escudo Uruguaio-Sul Riograndense. In: CONGRESSO BRASILEIRO DE GEOLOGIA, 31, Camboriú. Anais. Camboriú, SBG, v. 5, p.2879-2892. 
FRAGOSO CESAR, A.R.S. (1991) Tectônica de placas no Ciclo Brasiliano: as orogenias dos cinturões Dom Feliciano e Ribeira no Rio Grande do Sul. São Paulo, 367p. (Tese de Doutorado apresentada ao instituto de Geociências da Universidade de São Paulo).

FRAGOSO CESAR, A.R.S. \& SOLIANI Jr., E. (1984) Compartimentação tectônica do Cráton Rio de La Plata. In: CONGRESSO BRASILEIRO DE GEOLOGIA, 33, Rio de Janeiro. Anais. Rio de Janeiro, SBG, v.5, p.2426-2434.

FRAYA, R. (1944) Dados complementares do "Plano de Bom Aproveitamento" da jazida de ferro do Banhado Dona Cristina e Morro da Serenata, Domínio de Dona Francisca. Rio de Janeiro, Companhia Brasileira de Aços Finos S/A, 47p. (Relatório interno).

FUCK, R.A (1966) Nota explicativa da Folha Geológica de Quero-Quero. Boletim da Universidade Federal do Paraná, Geologia, 19:21p.

FUCK, R.A. (1967a) Geologia da Folha de Piraquara. Curitiba, Comissão da Carta Geológica do Paraná, 37p. (Relatório inédito).

FUCK, R.A. (1967b) Geologia da Folha de São José dos Pinhais. Curitiba, Comissão da Carta Geológica do Paraná, 46p. (Relatório inédito).

FUCK, R.A. (1967c) Geologia da Folha Abapã. Boletim da Universidade Federal do Paraná, Geologia, 25:34p.

FUCK, R.A. (1967d) Geologia das Folhas de Jaguaricatu e Socavão. Curitiba, Comissão da Carta Geológica do Paraná, 42p. (Relatório inédito).

FUCK, R.A. (1991) Aprovada nova escala de tempo para o pré-Cambriano. Revista Brasileira de Geociências, 21(2):182-183.

FUCK, R.A.; TREIN, E.; MARINI, O.J (1967a) Geologia e petrografia dos migmatitos do Paraná. Boletim Paranaense de Geociências, 23/25:5-41.

FUCK. R.A.; MARINI, O.J.; TREIN, E (1967b) A Formação Guaratubinha. Boletim Paranaense de Geociências, 23/25:237-256.

FUCK, R.A.; MARINI, O.J., TREIN, E. (1967c) Contribuição ao estudo das rochas graníticas no Estado do Paraná. Boletim Paranaense de Geociências, 23/25:183219.

FUCK, R.A.; MURATORI, A.; TREIN, E. (1968) Folha geologica da llha do Mel (escala 1:70.000). Curitiba, Comissão da Carta Geológica do Paraná.

FUCK, R.A. ; TREIN, E.; MURATORI, A.; RIVEREAU, I.C. (1969a) Mapa geológico preliminar do litoral, da Serra do Mar e parte do Primeiro Planalto do Estado do Panará. Boletim Paranaense de Geociéncias, 27:123-152. 
FUCK, R.A.; MURATORI, A.; TREIN, E. (1969b) Folha geológica de Barra de Ararapira (escala 1:70.000). Curitiba, Comissão da Carta Geológica do Paraná.

FUCK, R.A.; MURATORI, A.; TREIN, E. (1969c) Folha geologica de Guaratuba (escala 1:70.000). Curitiba, Comissão da Carta geológica do Paraná.

FUCK, R.A.; MURATORI, A.; TREIN, E. (1969d) Folha geológica de Paranaguá (escala 1:70.000). Curitiba, Comissão da Carta geológica do Paraná.

FUCK, R.A. ; MARINI, O.J.; TREIN, E.; MURATORI, A. (1971) Geologia do leste paranaense. In: CONGRESSO BRASILEIRO DE GEOLOGIA, 25, São Paulo. Anais. Sao Paulo, SBG, v.1, p.121-130.

GIRARDI, V.A.V. (1971) Os anfibolitos da região de Morretes - Antonina, PR. Revista Brasileira de Geociências, 1(1):43-65.

GIRARDI, V.A.V. (1969) Petrologia das rochas metamónficas da região de MorretesAntonina, PR. São Paulo, 131p. (Tese de Doutorado apresentada ao Instituto de Geociências da Universidade de São Paulo).

GIRARDI, V.A.V. (1974) Petrologia do Complexo Básico-Ultrabásico de Piên - PR. São Paulo, 146p. (Tese de Livre Docência apresentada ao Instituto de Geociências da Universidade de São Paulo).

GIRARDI, V.A.V. (1976) Geologia e petrologia do Complexo Básico-Ultrabásico de Piên, Paraná. Revista Brasileira de Geociências, 6(2):109-124.

GIRARDI, V.A.V. \& ULBRICH, H.H.G.J. (1978) Saphirine-orthopiroxene spinel occorrence in the Pien Area, Paraná, southern Brazil. Revista Brasileira de Geociências, 8(4): 284-293.

GIRARDI, V.A.V. \& ULBRICH, H.H.G.J. (1980) Origin anf evolution of the Piên MaficUltramafic Complex, southern Brazil. Joumal of Geology, 88(3):251-269.

GIRARDI, V.A.V.; CORDANI, U.G.; CANDIDO, A; MELFI, A.J.; KAWASHITA, K. (1974) Geocronologia do Complexo Básico-Ultrabásico pré-brasiliano de Piên, PR. In: CONGRESSO BRASILEIRO DE GEOLOGIA, 28, Porto Alegre. Resumo das Comunicações. Porto Alegre, SBG, p.532-533.

GOIS, J.R.; SALAMUNI, E.; FIORI, A.P. (1985) Lineamentos e compartimentos tectônicos do pré-Cambriano paranaense. In: SIMPÓSIO SUL-BRASILEIRO DE GEOLOGIA, 2, Florianópolis. Anais. Florianópolis, SBG, p.159-171.

HALLINAN, S.E.; SHUKOWSKY, W.; MANTOVANI, M.S.M. (1993) Estruturação do embasamento precâmbrico da região sul do Brasil e Uruguai: novos modelos resultantes de densificação gravimétrica. In: SIMPOSIO INTERNACIONAL DEL NEOPROTEROZOICO-CAMBRICO DE LA CUENCA DEL PLATA, 1, La PalomaMinas. Resumenes Extensos. La Paloma-Minas, Uruguai, v.2, $n^{\circ} 31$. 
HALLINAN, S.E.; MANTOVANI, M.S.M.; SHUKOWSKY, W.; BRAGGION, Jr., I. (1993) Estrutura do Escudo Sul-Brasileiro: Uma revisão através de dados gravimétricos e magnetométricos. Revista Brasileira de Geociências, 23(2), no prelo.

HANES, A.J. (1991) K-Ar and Ar40/Ar39 geochronology: methods and applications. In: HEAMAN, L. \& LUDDEN, J.N. (Ed.). Short Course Handbook on Applications of Radiogenic Isotope Systems to Problems in Geology. Mineralogical Association of Canada, 19(2):27-57.

HARARA, M.O.; BASEI, M.A.S.; SIGA Jr., O. (1994) Contibuição ao estudo geológico da região de Piên - PR. In: CONGRESSO BRASILEIRO DE GEOLOGIA, 38, Camboriú. Boletim de Resumos Expandidos. Camboriú, SBG, v. 1, p.64-65.

HARRIS, N.B.W.; PEARCE, J.A.; TINDLE, A.G. (1986) Geochemical characteristics of collision-zone magmatism. In: COWARD, M.P. \& RIES, A.C. (Eds).Collision Tectonics. London, Geological Society Special Publication, 18:67-81.

HARTMANN, L.A. (1976) Ocorrência de granulitos em Luis Alves, SC. In.: CONGRESSO BRASILEIRO DE GEOLOGIA, 29, Belo Horizonte. Boletim de Resumos. Belo Horizonte, SBG, p.321.

HARTMANN, L.A. (1981) Petrogênese dos granulitos e ultramafitos de Luis Alves (SC). Porto Alegre, 104p. (Tese de Doutorado apresentada à Universidade Federal do Rio Grande do Sul).

HARTMANN, L.A. (1988) Geoquímica de terras raras e geotermobarometria de granulitos de Dom Pedrito e Luis Alves, no extremo sul do Brasil. Geochimica Brasiliensis, 2(1):1-14.

HARTMANN, L.A. \& NARDI, L.V.S. (1980) O cinturão granulítico atlântico nos estados do Rio Grande do Sul e Santa Catarina. Acta Geologica Leopoldensia, 4(7):3-12.

HARTMANN, L.A.; SILVA, L.C.; ORLANDI FILHO, V. (1979a) O Complexo Granulítico de Santa Catarina. Descriçäo e implicações genéticas. Acta Geológica Leopoldensia, 3(6):93-112.

HARTMANN, L.A.; NARDI, L.V.S.; CUPERTINO, J.A. (1979b) A cataclase dos granulitos de Luis Alves (SC). Acta Geológica Leopoldensia, 3(6):29-44.

HARTMANN, L.A.; BASEI, M.A.S.; SOMMER, M.W. (1994) Geochemistry of the lower proterozoic granulite - facies grant potassic syenite, southern Brazil. Precambrian Research, (no prelo).

HASUI, Y. \& OLIVEIRA, M.A.F. (1984) A Provincia Mantiqueira, Setor Central. In: ALMEIDA, F.F.M. \& HASUI, Y. (Eds). O pré-Cambriano do Brasil. São Paulo, Editora Blücher, $378 p$.

HASUI, Y.; CARNEIRO, C.D.R.; COIMBRA, A.M. (1975) The Ribeira Folded Belt. Revista Brasileira de Geociências, 5(4):257-266. 
IMEOKPARIA, E.G. (1982) Geochemistry and relationship to mineralisation of granitic rocks from the Afu Younger Granite Complex, Central Nigeria. Geological Magazine, 119(1):39-56.

ISSLER, R.S. \& FREIRE, F.A. (1985) A diversidade dos granitos da região sul do Brasil. In: SIMPÓSIO SUL-BRASILEIRO DE GEOLOGIA, 2, Florianópolis. Anais. Florianópolis, SBG, p.89-101.

JAHN, B. (1990) Early precambrian basic rocks of China. In: HALL, R.P. \& HUGHES, D.J. (Eds.). Eanly Precambrian Basic Magmatism. Glasgow, Blackie, p. 294-316.

JAHN, B. \& CUVELLIER, H. (1990) Direct dating of sedimentary sequences: $\mathrm{Pb} / \mathrm{Pb}$ geochronogy of carbonate rocks. In: INTERNATIONAL CONFERENCE ON GEOCHRONOLOGY, COSMOCHRONOLOGY AND ISOTOPE GEOLOGY, 7 , Canberra. Abstracts. Canberra, Geological Society of Australia, p.51.

JUNG, J. \& ROQUES, M. (1952) Introduction à l'etude zonéographique des formations cristallophyllienes. Bulletin de Service de la Carte Géologique de France, 50(235):1-62.

KAUL, P.F.T. (1979) Pré-Cambriano e Eopaleozóico do nordeste de Santa Catarina e leste do Paraná: reavaliação de dados e correlações com a África. In: SIMPÓSIO REGIONAL DE GEOLOGIA, 2, Rio Claro. Atas. Rio Claro, SBG, v.1, p.1-15.

KAUI, P.F.T. (1980) O Cráton de Luis Alves. In: CONGRESSO BRASILEIRO DE GEOLOGIA, 31, Camboriú. Anais. Camboriú, SBG, v.5, p.2677-2683.

KAUL, P.F.T. (1984) Significado dos granitos anorogênicos da Suíte Intrusiva Serra do Mar na evolução da crosta do sul-sudeste do Brasil, no âmbito das Folhas SG-22 - Curitiba e SG-23 - Iguape. In: CONGRESSO BRASILEIRO DE GEOLOGIA, 33, Rio de Janeiro. Anais. Rio de Janeiro, SBG, v.6, p.2815-2825.

KAUL, P.F.T. (1985) Magmatismo e evolução da crosta no sul-sudeste do Brasil, durante o Proterozóico Superior e Eopaleozóico. In: SIMPÓSIO SULBRASILEIRO DE GEOLOGIA, 2, Florianópolis. Anais. Florianópolis, SBG, p.126127.

KAUL, P.F.T. \& CORDANI, U.G. (1994) Aspectos petrográficos, geoquímicos e geocronológicos dos maciços graníticos da Serra do Mar no leste do Paraná e vizinhanças. In: CONGRESSO BRASILEIRO DE GEOLOGIA, 38, Camboriú. Boletim de Resumos Expandidos. Camboriú, SBG, v.2, p.371-372.

KAUL, P.F.T. \& TEIXEIRA, W. (1982) Archean and early proterozoic complexes of Santa Catarina, Paraná and São Paulo states, south-southeaster, Brazil: an outline of their geological evolution. Revista Brasileira de Geociências, 12(1/3): $172-182$. 
KAUL, P.F.T.; COUTINHO, J.B.L; ISSLER, R.S.; BONOW, C.W.; MOREIRA, M.L.O.; MARIMON, M.P.C; MOREIRA, H.L ; SILVA, R.N; MARINHO, D.; TEIXEIRA, W. (1984) Folhas SG-22/23/21 - Curitiba/lguape/Assunción. Levantamento de Recursos Naturais, IBGE, (no prelo).

KAWASHITA, K.; SONOKI, I.K.; SATO, K.; SONOKI, H.M. (1990) Regressōes lineares em geocronologia: isócronas, errócronas e pseudoisócronas. Boletim do IG-USP, Série Cientifica, 21:53-72.

KAWASHITA, K.; SATO, K.; DIAS, M.; TASSINARI, C.C.G. (1991) Metodologia Sm/Nd no IG-USP: testes e resultados preliminares. In: CONGRESSO BRASILEIRO DE GEOQUÍMCA, 3, São Paulo. Boletim de Resumos. São Paulo, SBGq/Sociedade Geológica de Portugal, v.2, p.442-446.

KROGH, T.E. (1973) A low-contamination method for hidrothermal decomposition of Zircon an extraction of $\mathrm{U}$ and $\mathrm{Pb}$ for isotopic age determinations. Geochimica et Cosmochimica Acta, 37(3):485-494.

KROGH, T.E. (1982a) Improved accuracy of U/Pb dating by selection of more concordant fractions using a high gradient magnetic separation technique. Geochimica et Cosmochimica Acta, 46(4):631-636.

KROGH, T.E. (1982b) Improved Accuracy of U/Pb Zircon ages by the creation of more concordant systems using an air abrasion technique. Geochimica et Cosmochimica Acta, 46(4):637-649.

LAMEYRE, J. \& BOWDEN, P. (1982) Plutonic rocks types series: discrimination of various granitoid series and related rocks. Journal of Volcanology and Geothermal Research, 14(1/2):169-186.

LANARI, C. (1944) Resumo dos ensaios de concentração do minério de ferro magnético de Joinville, Estado de Santa Catarina. Rio de Janeiro, Companhia Brasileira Aços Finos S/A, 32p. (Relatório inédito)

LIMA, Q.E. \& LOPES, O.F. (1985) Evolução geológica da Formação Rio das Cobras no leste do Estado do Paraná. In: SIMPOSIO SUL-BRASILEIRO DE GEOLOGIA, 2, Florianópolis. Atas. Florianópolis, SBG, p.53-60.

LOPES, J.A.U. (1966) Nota explicativa da folha geológica de Curitiba. Boletim da Universidade Federal do Parana, Geologia, 20p.

LOPES, J.A.U., BIGARELLA, J.J.; SALAMUNI, R.; FUCK, R.A.; MURATORI, A. (1965) Folha geológica de Curitiba (escala 1:50.000). Curitiba, Comissão da Carta Geológica do Paraná.

LOPES, O.F. (1983) Faixa do Perau: uma unidade faciológica e tectonometamórfica do Grupo Açungui. Revista Brasileira de Geociências, 13(3): 190-203. 
LOPES, O.F. (1987a) Zoneamento metamórfico da Formação Rio das Cobras do préCambriano do Estado do Paraná. In: SIMPÓSIO SUL-BRASILEIRO DE GEOLOGIA, 3, Curitiba. Atas. Curitiba, SBG, v.1, p.303-312.

LOPES, O.F. (1987b) O granito sin-tectônico Cubatãozinho: petrogênese e evolução geológica. In: SIMPÓSIO SUL-BRASILEIRO DE GEOLOGIA, 3, Curitiba. Atas. Curitiba, SBG, v.2,p.481-490.

LOPES, O.F. (1987c) Um modelo metalogenético para as mineralizações auríferas da Serra da Prata-PR. In: SIMPÓSIO SUL-BRASILEIRO DE GEOLOGIA, 3, Curitiba. Atas. Curitiba, SBG, v.2,p.491-496.

LOPES, O.F. (1992) Magmatismo alcalino ultrapotássico no Leste Paranaense. In: CONGRESSO BRASILEIRO DE GEOLOGIA, 37, São Paulo. Boletim de Resumos Expandidos. São Paulo, SBG, v.2, p.88.

LOPES, O.F.; ASSIS, E.A.; CARNEIRO, K.R. (1992) 'Magma mixing" no granito Morro Ingles na zona distensional da Serra da Prata - PR. In: CONGRESSO BRASILEIRO DE GEOLOGIA, 37, São Paulo. Boletim de Resumos Expandidos. São Paulo, SBG, v.1, p.346.

LUDWIG, K.R. (1990) Isoplot, a plotting and regression program for radiogenic isotope data, for IBM-PC compatible computers. Version 2.11: U.S. Geological Survey Open File Report, 88-557,33p.

LUGMAIR, G.W.; SCHEIRIM, N.B.; MARTI, K. (1975) Search for extint 46Sm: the isotopic abundance of $142 \mathrm{Nd}$ in the Juvinas Meteorite. Earth and Planetary Science Letters, 27(1):79-84.

MAACK, R. (1947) Breves notícias sobre a geologia dos estados de Santa Catarina e Paraná. Arquivos de Biologia e Tecnologia, 2:65-154.

MAACK, R. (1953) Mapa geológico do Estado do Paraná (escala 1:750.000). Curitiba, IBPT.

MAACK, R. (1961) Sobre a ocorrência de granitos alcalinos no Estado do Paraná e sua porção dentro das fases orogenéticas algonquianas. Boletim da Universidade Federal do Paraná, Geologia, 4: 52p.

MCCAFFREY, K.J.W. (1992) Igneous emplacement in a transpressive shear zone: Ox Montains Igneous Complex. Journal of the Geological Society of London, $149(2): 221-235$.

MACHIAVELLL, A. (1991) Os granitóides deformados da Região de Pien (PR): Um provável Arco Magmático do Proterozóico Superior. São Paulo, 89p. (Dissertação de Mestrado apresentada ao Instituto de Geociências da Universidade de São Paulo). 
MACHIAVELLLI, A.; BASEI, M.A.S.; SIGA Jr., O. (1991) Geoquímica e geocronologia dos granitóides deformados da região de Pien (PR). Provável arco magmático do Proterozóico Superior. In: CONGRESSO BRASILEIRO DE GEOQUÍMICA, 3, São Paulo. Resumos. São Paulo, SBGq, v.1, p.249-253.

MACHIAVELLLI, A.; BASEI, M.A.S.; SIGA Jr., O. (1993) Suíte Granitica Rio Pien: um arco magmático do Proterozóico Superior na Microplaca Curitiba. Geochimica Brasiliensis, 7(2):113-129.

MACHIAVELLI, A.; BASEI, M.A.S.; SIGA Jr., O. (1994) Geoquimica e geocronologia da Suite Granitica Rio Piên: implicações tectônicas. In: CONGRESSO BRASILEIRO DE GEOLOGIA, 38, Camboriú. Boletim de Resumos Expandidos. Camboriú, SBG, v.3, p.150-151.

MANTOVANI, M.S.M.; HAWKESWORTH, C.J.; BASEI, M.A.S. (1987) $\mathrm{Nd}$ and Pb isotope studies bearing on the crustal evolution of Southeastern Brazil. Revista Brasileira de Geociências, 17(3):263-268.

MANTOVANI, M.S.M.; SHUKOWSKY, W.; BASEI, M.A.S.; VASCONCELOS, A.C.B.C. (1989) Modelo gravimétrico das principais descontinuidades crustais nos terrenos pré-Cambrianos dos Estados do Paraná e Santa Catarina. Revista Brasileira de Geociências, 19(3):367-374.

MANTOVANI, M.S.M.; VASCONCELOS, A.C.B.C.; SHUKOWSKY, W.; MILANI, E.J.; BASEI, M.A.S.; HURTER, S.J.; FREITAS, S.R.C. (1991) Brusque transect from atlantic coast to bolivian border, southem Brazil. Washington, Inter-Union Comission Lithosphere / America Geophysical Union, 22p.

MARINI, O.J. (1967) Geologia da Folha de Araucária. Curitiba, Comissão da Carta Geológica do Paraná, 24p. (Relatório inédito).

MARINI, O.J. (1970) Geologia da Folha de Rio Branco do Sul (PR). Rio Claro, 190p. (Tese de Doutoramento apresentada à UNESP).

MARINI, O.J.; TREIN. E.; FUCK, R.A. (1970) Folha geológica de Mandirituba (escala 1:70.000). Curitiba, Comissão da Carta Geológica do Paraná.

MATTAUER, M. (1986) Les subductions intracontinentales des chaînes tertiaires d'Asie; leurs relations avec les décrochements. Bulletin de la Société Géologique de France, ( $8^{a}$ série), 2(1):143-157.

MELFI, A.J. (1967) Potassium-Argon ages for core samples of basaltic rocks from Southern Brazil. Geochimica et Cosmochimica Acta, 31(6):1079-1090.

MERCIER, J.L. (1984) La déformation des continents au voisinage des marges convergents. Bulletin de la Société Géologique de France, ( $7^{\text {a }}$ série), 26(3):551566. 
MICHARD, A.; GURRIET, P.; SOUNDANT, M.; ALBARED, F. (1985) Nd isotopes in french fanerozoic shales: external vs. internal aspects of crustal evolution. Geochimica et Chosmochimica Acta, 49(2):601-610.

MINIOLI, B. (1972) Aspectos Geológicos da região litorânea de Piçarras, Barra Velha, SC. São Paulo, 104p. (Tese de Doutorado apresentada ao Instituto de Geociências da Universidade de São Paulo).

MONACO, O.A.; ZIR FILHO, J.A.; VALENTINE, N. (1974) Carta geológica do Brasil ao milionésimo. Folhas Assunción (SG-21) e Curitiba (SG-22). Brasília, DNPM, 83p.

MOORBATH, S. \& TAYLOR, P.N. (1981) Isotope evidence for continental growth in the Precambrian. In: KRÖNER, A. (Ed.). Precambrian Plate Tectonic. Amsterdam, p. 491-525.

MOORBATH, S.; TAYLOR, P.N.; GOODWIN, R. (1981) Origin of granitic magma by crustal remobilization: $\mathrm{Rb} / \mathrm{Sr}$ and $\mathrm{Pb} / \mathrm{Pb}$ geochronology and isotope geochemistry of late Archean Qôrqut Granitic Complex of Southern West Greenland. Geochimica et Cosmochimica Acta, 45(7):1051-1060.

MOORBATH, S.; TAYLOR, P.N.; ORPEN, J.L.; TRELOAR, P.; WILSON, J.F. (1987) First direct radiometric dating of Archean Stromatolitic Limestone. Nature, 326(6116):865-567.

MOREIRA, M.L.O. \& MARIMON, M.P. (1980) Ensaio petrográfico e petroquímico das rochas do fácies granulito. Complexo Granulítico de Santa Catarina, Folha SC22-ZB, Camboriú, SC. In: CONGRESSO BRASILEIRO DE GEOLOGIA, 31 , Camboriú. Anais. Camboriú, SBG, v.4, p.2119-2133.

MORO, R. De P.X. (1993) A Bacia Ordoviciana do Grupo Castro - PR. São Paulo, 157p. (Dissertação de Mestrado apresentada ao Instituto de Geociências da Universidade de São Paulo).

MURATORI, A. (1966) Nota explicativa da Folha geológica de Campo Largo. Boletim da Universidade Federal do Paraná, Geologia, 21:33p.

MURATORI, A.; TREIN, E.; FUCK, R.A. (1969a) Folha geologica Pedra Branca de Araraguara (1:70.000). Curitiba, Comissão da Carta Geológica do Paraná.

MURATORI, A.; TREIN, E.; FUCK, R.A. (1969b) Folha geologica Serra da Igreja (1:70.000). Curitiba, Comissão da Carta Geológica do Paraná.

MURATORI, A.; TREIN, E.; FUCK, R.A.; HAUSEN, J.P.; BASUMALLICK, S. (1969c) Folha geológica de Guaraqueçaba (escala 1:70.000). Curitiba, Comissão da Carta Geológica do Paraná.

NOE, F.G. \& WAHLE, E. (1945) Magnetita de Joinville, SC, Brasil. Rio de Janeiro, LPM/DNPM, Boletim 15, p.61-79. 
NAKAMURA, N.; TATSUMOTO, M.; NUNES, P.D.; UNRUSH, D.M.; SCHW, A.P.; WILDEMAN, T.R. (1976) 4. B.Y. Old clast in Boulder 7, Apollo 17: a comprehensive chronological study by U-Pb, Rb-Sr and $\mathrm{Sm}-\mathrm{Nd}$ methods. In: LUNAR AND PLANETARY SCIENCE CONFERENCE, 7, Texas. Proceedings. Texas, USA, v.2, p.2309-2333.

OLIVEIRA, A.I. \& LEONARDOS, O.M. (1943) Geologia do Brasil. Ministério de Agricultura do Rio de Janeiro, Série Didática, 2:813p.

OLIVEIRA, E.P. (1925) Mapa geológico do Estado do Paraná (escala 1:1.000.000). Serviço Geológico e Mineralógico do Brasil.

OLIVEIRA, E.P. (1927) Geologia e recursos minerais do Estado do Paraná. Boletim do Serviço Geológico e Mineralógico do Brasil, Monografias, 6:172p.

ORLANDI FILHO, V. \& SILVA, L.C. (1979) Mapa de facies metamórficas do Estado de Santa Catarina - escala 1:1.000.000. Acta Geológica Leopoldensia, 3(6):125-133.

PAIVA, I.P.; LOPES Jr., I.; AGUIAR NETO, A. (1977) Folha geologica de Guaraqueçaba - SG-22-XD-III, escala 1:100.000. Projeto Leste do Paraná, CPRM/MME/DNPM.

PEARCE, J.A.; HARRIS, N.B.W.; TINDLE, A.G. (1984) Trace element discrimination diagrams for the tectonic interpretation of granitic rocks. Journal of Petrology, 25(4):956-983.

PERROTTA, M.M. \& MORAIS, S.M. (1992) A suite mangerito-norítica, Curitiba. In: CONGRESSO BRASILEIRO DE GEOLOGIA, 37, São Paulo. Boletim de Resumos Expandidos. São Paulo, SBG, v.1, p.417.

PICANÇO, J.L. (1994) Aplicação das sistemáticas Sm/Nd e Rb/Sr no Maciço de ltatins (SP). São Paulo, 140p. (Dissertação de Mestrado apresentada ao Instituto de Geociências da Universidade de São Paulo).

PIMENTEL, M.M. \& CHARNLEY, N. (1991) Intracrustal REE fractionation and implication for Sm-Nd model age calculations in late stage granitic rocks: an example from central Brasil. Chemical Geology, 186(2):123-138.

PORADA, H. (1989) Pan-African rifting and orogenesis in southern to equatorial Africa and eastern Brazil. Precambrian Research, 44(2):103-136.

RAMOS, V.A. (1988) Late Proterozoic-Early Paleozoic of South America - a collisional history. Episodes, 11(3):168-174.

REIS NETO, J.M. (1994) Faixa ltaiacoca: registro de uma colisão entre dois blocos continentais no neoproterozóico. São Paulo, 253p. (Tese de Doutorado apresentada ao instituto de Geociências da Universidade de São Paulo). 
REIS NETO, J.M.; SIGA Jr. O.; BASEl, M.A.S.; CASTRO, N.A. (1993) Complexo Básico e Ultrabásico de Pien: uma revisão estratigráfica. In: SIMPÓSIO SULBRASILEIRO DE GEOLOGIA, 5, Curitiba. Boletim de Resumos. Curitiba, SBG, p.43.

REIS NETO, J.M.; MORO, R.P.X.; SIGA Jr., O. (1994) Grupo Castro: idade e implicações tectônicas. In: CONGRESSO BRASILEIRO DE GEOLOGIA, 38 , Camboriú. Boletim de Resumos Expandidos. Camboriú, SBG, v.2, p.394-395.

RIBAS, S.M. (1993) O complexo máfico-ultramáfico de Tijucas do Sul, correlaçáo com o Complexo de Pien, PR e considerações metalogenéticas. Campinas, 130p. (Dissertação de Mestrado apresentada ao Instituto de Geociências da Universidade de Campinas).

ROSHOLT, J.N.; ZARTMAN, R.E.; NKOMA, I.T. (1973) Lead isotope systematics and Uranium depletion in the Granite Mountains, Wyoming. Geological Society of America Bulletin, 84(3):989-1002.

ROYDEN, L.H. (1993) The tectonic expression slab pull at continental convergent boundaries. Tectonics, 12(2):303-325.

RUBERTI, E. (1977) Mineralogia e química dos anfibolitos da região de MorretesAntonina, Paraná. São Paulo, 86p. (Dissertação de Mestrado apresentada ao Instituto de Geociências da Universidade de São Paulo).

RUBETI, E. \& GOMES, C.B. (1977) Mineralogia e química dos anfibolitos da região de Morretes-Antonina, PR. Revista Brasileira de Geociências, 7(4):325-348.

SANTOS, E.L.; SILVA, L.C.; ORLANDI FILHO, V.O.; COUTINHO, M.C.N.C.; ROISEMBERG, A.; RAMALHO, R.; HARTMANN, L.A. (1984) Os Escudos SulRiograndense e Catarinense e a Bacia do Paraná. In: SCHOBBENHAUS FILHO, C. (coord.). Geologia do Brasil. Brasilia, DNPM, p.332-335.

SATO, K.; TASSINARI, C.C.G.; KAWASHITA, K.; PETRONILHO, L. (1994) Método geocronológico Sm-Nd no IG-USP e suas aplicações. Anais da Academia Brasileira de Ciências, (no prelo).

SCHULZ JR., A;; ALBUQUERQUE, L.F.F.; GIFFONI, L.E. (1969) Geologia da quadrícula Rio do Sul, SC. Porto Alegre, DNPM. (Relatório Interno).

SENGÖR, A.M.C.; BURKE,K.; DEWEY, J.F. (1978) Rifts at high angles to orogenic belts: tests for their origin and the upper Rhine graben as an example. American Journal of Science, 278(1):24-40.

SHAND, S.J. (1951) The study of rocks. London, THOMAS MURBY \& Co. (Ed.), 236p. 
SIGA Jr., O.; BASEI, M.A.S.; MACHIAVELLI, A. (1993) Modelagem geocronológica do setor NE de Santa Catarina e SE do Paraná, Brasil. In: SIMPOSIO INTERNACIONAL DEL NEOPROTEROZOICO-CAMBRICO DE LA CUENCA DEL PLATA, 1, La Paloma-Minas. Resumenes Extensos. La Paloma-Minas, Uruguai, V. $2, n^{\circ} 30$.

SIGA Jr., O; BASEI, M.A.S.; MACHIAVELLI, A. (1990a) Evolução geotectônica do Maciço de Joinville, PR e SC. Jornadas Cientificas do Instituto de Geociências USP, Boletim especial, 116-118.

SIGA Jr., O; BASEI, M.A.S.; KAWASHITA, K. (1990b) Perfil Térmico K-Ar através do Maciço de Joinville (PR e SC) e do Cinturão Dom Feliciano (SC). Implicações tectônicas. In: CONGRESSO BRASILEIRO DE GEOLOGIA, 36, Natal. Anais. Natal, SBG, v.6, p.2773-2785.

SIGA Jr., O; BASEI, M.A.S.; MACHIAVELLI, A. (1991) Compartimentação geológicogeotectônica do Maciço de Joinville, PR e SC. Boletim IG-USP, Publicaçăo Especial, 9:67-73.

SIGA Jr., O; BASEI, M.A.S.; MACHIAVELLI, A. (1994a) Evolução geotectônica da porção NE de Santa Catarina e SE do Paraná, com base em interpretaçōes geocronológicas. Revista Brasileira de Geociências, (no prelo).

SIGA Jr., O; BASEI, M.A.S.; REIS NETO, J.M.; BUBA, R.M. (1994b) Maciços graníticos da porção sudeste do Paraná e nordeste de Santa Catarina: geocronologia e implicaçōes tectônicas. In: CONGRESSO BRASILEIRO DE GEOLOGIA, 38 , Camboriú. Boletim de Resumos Expandidos. Camboriú, SBG, v.2, p.400-401.

SILVA, L.C. (1984a) Os terrenos de médio a alto grau do pré-Cambriano de Santa Catarina. In: CONGRESSO BRASILEIRO DE GEOLOGIA, 33, Rio de Janeiro. Anais. Rio de Janeiro, SBG, v.3, p.3069-3080.

SILVA, L.C. (1984b) As sequências metavulcano-sedimentares do tipo Greenstone Belt e de cobertura do Escudo Catarinense. In: CONGRESSO BRASILEIRO DE GEOLOGIA, 33, Rio de Janeiro. Anais. Rio de Janeiro, SBG, v.6, p.2590-2598.

SILVA, L.C. (1987) Geologia do pré-Cambriano - Eopaleozóico de Santa Catarina. In: SILVA, L.C. \& BORTOLUZZI, C.A. Texto explicativo para o mapa geológico do Estado de SC. Florianópolis, DNPM/CPRM, p.12-90.

SILVA, L.C. \& DIAS, A.A. (1981a) Projeto Timbó-Barra Velha, Brasil. Porto Alegre, DNPM/CPRM, 282p. (Relatório interno).

SILVA, L.C. \& DIAS, A.A. (1981b) Os segmentos mediano e setentrional do Escudo Catarinense: I-Geologia. Acta Geologica Leopoldensia, 5(10):3-120.

SILVA L.C. \& DIAS, A.A. (1981c) Os segmentos mediano e setentrional do Escudo Catarinense: Il-Organização e evolução geotectônica. Acta Geológica Leopoldensia, 5(10):121-140. 
SOARES, P.C. (1987) Sequências tecto-sedimentares e tectônica deformadora no centro-oeste do Escudo Paranaense. In: SIMPÓSIO SUL-BRASILEIRO DE GEOLOGIA, 3, Curitiba. Atas. Curitiba, SBG, v.2, p.743-772.

SOARES, P.C. (1988) Tectônica colisional em torno do Bloco Paraná, Brasil. In: CONGRESSO LATINO-AMERICANO DE GEOLOGIA, 7, Belém. Anais. Belém, SBG, v.1, p.63-79.

SOARES, R.M.C.; GOMES, C.B.; RUBERTI, E. (1978) Coexisting pyroxene in mafic and ultramafic rocks from Barra Velha, Santa Catarina, Brazil. Jomal de Mineralogia, 7:129-134.

SOLIANI Jr., E. (1986) Os dados geocronológicos do Escudo Sul Rio Grandense e suas implicações de ordem geotectônica. São Paulo, 239p. (Tese de Doutorado apresentada ao Instituto de Geociências da Universidade de São Paulo).

SOLIANI Jr., E.; FRAGOSO CESAR, A.R.S.; TEIXEIRA, W.; KAWASHITA, K. (1984) Panorama geocronológico da porção meridional do Escudo Atlântico. In: CONGRESSO BRASILEIRO DE GEOLOGIA, 33, Rio de Janeiro. Anais. Rio de Janeiro, SBG, v.5, p.2435-2449.

STEIGER, R.H. \& JÄEGER, E. (1978) Subcomission on geochronology: convention on the use of decay constants in geochronology and cosmochronology. Contributions to the Geologic Time Scale. Studies in Geology, 6:67-72.

STRECKEISEN, A. (1976) To each plutonic rock its proper name. Earth Science Reviews, 12(1):1-33.

TAKEDA, F.K. (1958) Esboço geológico de Santa Catarina. Florianópolis, Conselho Regional de Geografia.

TASSINARI, C.C.G.; BARBOUR, A.P.; DAITX, E.C.; SATO, K. (1990) Aplicação dos isótopos de $\mathrm{Pb}$ e $\mathrm{Sr}$ na determinação da natureza das fontes das mineralizações de chumbo do Vale do Ribeira - SP e Pr. In: CONGRESSO BRASILEIRO DE GEOLOGIA, 36, Natal. Anais. Natal, SBG, v.3, p. 1254-1266.

TEIXEIRA, W. (1979) Avaliação preliminar do acervo geocronológico das folhas Assunción, Curitiba e lguape. Projeto RADAMBRASIL, DNPM/MME, 30p. (Relatório interno).

TEIXEIRA, W. (1982) Folhas Assunción, Curitiba e lguape. Considerações sobre os dados radiométricos e evolução geocronológica. Projeto RADAMBRASIL, DNPM/MME, 38p. (Relatório interno).

TRAININI, D.R. (1974) Projeto Campo Alegre. Porto Alegre, DNPM/CPRM, 70p. (Relatório interno). 
TREIN, E. (1967) Geologia da Folha de Contenda, PR. Boletim da Universidade Federal do Paraná, Geologia, 27:39p.

TREIN, E.; MURATORI, A.; BASUMALLICK, S.; FUCK, R.A.; MARINI, O.J.; DAIRIKI, J.; DAIRIKI, M. (1969a) Folha geológica de Piên (escala 1:70.000). Curitiba, Comissão da Carta Geológica do Paraná.

TREIN, E.; FUCK, R.A.; MURATORI, A. (1969b) Folha geológica de Tijucas do Sul (escala 1:70.000). Curitiba, Comissão da Carta Geológica do Paraná.

TREIN, E.; MURATORI, A.; BASUMALLICK, S.; BERTOLDO, A.L. (1970) Folha geológica de Antonina (escala 1:70.000). Curitiba, Comissão da Carta Geológica do Paraná.

VALIATI, D. (1974) Projeto sondagem Campo Alegre. Porto Alegre, CNE/CPRM, 2v., 66p. (Relatório interno).

WASSERBURG, G.J.; JACOBSEN, S.B.; DE PAOLO, D.J.; MCCULLOTH, M.T.; WEN, T. (1981) Precise determination of Sm-Nd rations, $\mathrm{Sm}$ and $\mathrm{Nd}$ isotopic abundances in standard solutions. Geochimica Cosmochimica Acta, 45:23112323.

WERNICK, E. \& PENALVA, F. (1978) Contribuição ao conhecimento das rochas granitóides do sul do Brasil. Revista Brasileira de Geociências, 8(2): 113-133.

WETHERILL, G.W. (1956) Discordant uranium lead ages. Transactions American Geophysic Union, 37(3):320-326.

WILLIAMSON, J.H. (1968) Least-squares fitting of a straight line. Canadian Joumal of Physiscs, 46:1845-1847.

WILSON, M. (1989) Igneous petrogenesis. London. UNWIN HYMAN (Ed.), 466p.

WINDLEY, B.F. (1981) Phanerozoic granulites. Journal of the Geological Society of London, 138(6):745-751.

WINDLEY, B.F. \& TARNEY, J. (1986) The structural evolution of the lower crust of orogenic belts, present and past. In: DAWSUN, J. B. ; CARSWELL, D.A.; HALL, J.; WEDEPHOLI, K.H. (eds). The nature of the lower continental crust. Geological Society, Special Publication, 24:221-230.

WINKLER, H.G.F. (1978) Petrogenesis de rocas metamorficas. Madri, H. Blume Ediciones, 346p.

ZARTMAN, R.E. \& DOE, B.R. (1981) Plumbotectonics - the model. Tectonophysiscs, 75(1/2):135-162. 
APENDICE 1

DADOS RADIOMÉTRICOS K-Ar

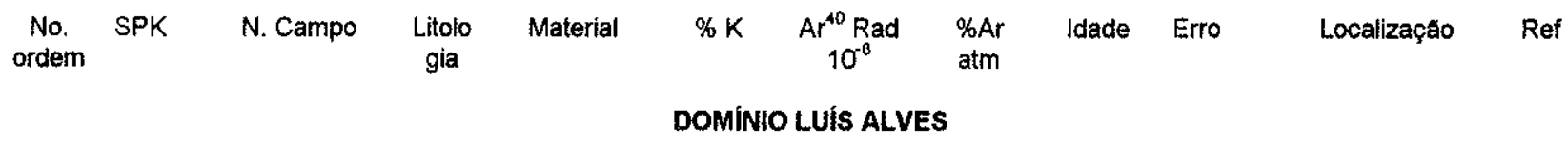

\begin{tabular}{|c|c|c|c|c|c|c|c|c|c|c|c|}
\hline 1 & 6443 & $M J-O 6$ & GRL & ANF & 0.8224 & 99.30 & 3.81 & 1807 & 37 & Guaramirim & NT \\
\hline $2^{*}$ & 6444 & $M J-13$ & GRL & ANF & 0.9256 & 115.88 & 3.12 & 1849 & 36 & Sul Piên & NT \\
\hline 3 & 6445 & $M J-\infty 8$ & GRL. & $\mathrm{BIO}$ & 4.5937 & 624.71 & 20.90 & 1946 & 34 & Jaraguá Sul & NT \\
\hline 4 & 6481 & MJ-92 & GRL & ANF & 1.3077 & 166.73 & 45.46 & 1870 & 56 & Sul Piên & NT \\
\hline 5 & 6367 & $M J-01$ & GRL. & B1O & 5.0254 & 670.25 & 0.24 & 1923 & 39 & Luis Alves & NT \\
\hline 5 & 6368 & MJ-01 & GRL. & ANF & 2.1141 & 280.93 & 1.82 & 1919 & 37 & Luis Alves & NT \\
\hline 6 & 6360 & $\mathrm{MJ}-02$ & GRL. & $\mathrm{BIO}$ & 4.4374 & 589.32 & 6.28 & 1919 & 46 & Luis Alves & NT \\
\hline 6 & 6370 & $\mathrm{MJ}-02$ & GRL & ANF & 1.0295 & 148.22 & 2.66 & 2016 & 56 & Lufs Alves & NT \\
\hline 7 & 6371 & MJ-04.A & GRL & $\mathrm{BIO}(\mathrm{l})$ & 2.3302 & 285.29 & 3.34 & 1823 & 40 & LuIs Alves & NT \\
\hline 8 & 6421 & MJ-176 & GRL & $A N F+B I O$ & 3.0548 & 506.38 & 3.34 & 2413 & 203 & Schroeder & NT \\
\hline 9 & 6422 & $M J-29.2$ & GRL & $A N F+B I O$ & 5.8048 & 733.08 & 1.47 & 1842 & 44 & Luis Alves & NT \\
\hline 9 & 6442 & $M J-29.2$ & GRL & $\mathrm{B} 1 \mathrm{O}$ & 7.3132 & 921.94 & 1.21 & 1858 & 55 & Luís Alves & NT \\
\hline 10 & 6423 & $M J-184 . A$ & GRL & $\mathrm{BIO}$ & 6.5438 & 830.85 & 3.67 & 1865 & 38 & Sul D. Franc. & NT \\
\hline 11 & 6439 & MJ-186 & GNS & $\mathrm{CL}+\mathrm{BIO}$ & 2.0542 & 130.26 & 22.83 & 1163 & 30 & Sul D. Franc. & NT \\
\hline 12 & 6577 & $M J-34 . A$ & GRL. & 810 & 6.9427 & 850.29 & 1.15 & 1824 & 24 & Luís Alves & NT \\
\hline 12 & 6579 & MJ-34.B & GRL & $\mathrm{BIO}$ & 7.0616 & 789.09 & 0.44 & 1720 & 33 & Luís Alves & NT \\
\hline $13^{*}$ & 6598 & $M J .80$ & GRL. & $\mathrm{BlO}$ & 6.9082 & 725.53 & 0.93 & 1654 & 54 & Sul Piên & NT \\
\hline 14 & 6600 & $M ل-86$ & GRL & RTO & 2.2772 & 66.21 & 23.09 & 626 & 18 & Sul Plên & NT \\
\hline 15 & $6 \% 56$ & MJ-332.B & GNS & BIO & 7.1833 & 756.48 & 1.06 & 1055 & 28 & S. Bento Sul & NT \\
\hline 16 & $6 \% 57$ & $M J-342.8$ & GRL & $B 10$ & 8.0853 & 987.91 & 1.00 & 1821 & 29 & Corupá & NT \\
\hline 17 & 4002 & PLA-02 & GRL & $\mathrm{BIO}$ & 6.3260 & 788.40 & 0.60 & 1850 & 130 & Luís Alves & 10 \\
\hline 18 & 4101 & PLA-14 & BSN & RTO & 0.2620 & 34.40 & 4.20 & 1903 & 27 & Luís Alves & 10 \\
\hline 19 & 4100 & $P L A+\infty$ & BSN & RTO & 0.9040 & 46.90 & 3.60 & 930 & 27 & Luís Alves & 10 \\
\hline 20 & 4089 & PLA-07 & GRL & $\mathrm{BIO}$ & 6.0180 & 706.00 & 0.60 & 1780 & 55 & Luís Alves & 10 \\
\hline 21 & 1857 & $B M-15$ & ANF & ANF & 0.7060 & 158.00 & 5.40 & 2605 & $\infty$ & Barra Vetha & 13 \\
\hline 21 & 2430 & $B M-15$ & ANF & ANF & 0.7160 & 175.00 & 2.30 & 2727 & 23 & Barra Velha & 13 \\
\hline 22 & 1862 & $B V \sim A$ & ANF & ANF & 0.2770 & 71.30 & 4.30 & 2804 & 73 & Barra Velha & 13 \\
\hline 23 & 1866 & BM-11 & PRX & PIR & 0.4050 & 102.00 & 3.40 & 2777 & 76 & Barra Velha & 13 \\
\hline 23 & 1353 & $411 / 67$ & PRX & PIR & 0.1200 & 23.80 & 3.70 & 2435 & 100 & Barra Velha & 01 \\
\hline 24 & 1976 & BM-20 & GNS & $\mathrm{BlO}$ & 5.5330 & 578.00 & 1.00 & $\uparrow 642$ & 13 & Barra Velha & 13 \\
\hline 25 & 1983 & BM-19 & GNS & B!O & 6.1300 & 682.00 & 1.00 & 1712 & 55 & Joinville & 13 \\
\hline 26 & 2129 & BM-10 & GNS & ANF & 0.8530 & 127.00 & 9.20 & 2050 & 63 & Barra Vetha & 13 \\
\hline 27 & 1984 & $B M-23$ & PRX & PIR & 0.0530 & 21.10 & 7.70 & 3417 & 20 & Barra Veltha & 13 \\
\hline 27 & 2317 & BM-46 & MIG & $K-F$ & 8.4700 & 322.00 & 1.20 & 771 & 30 & Barra Velha & 13 \\
\hline 27 & 2094 & $B M-46$ & MłG & ANF & 2.0610 & 145.00 & 6.50 & 1242 & 14 & Barra Velha & 13 \\
\hline 27 & 2007 & BV-07.B & MIG & ORT & 8.5000 & 350.00 & 38.00 & 824 & 10 & Barta Velha & 13 \\
\hline 28 & 2318 & $B M-49$ & ANF & ANF & 0.0380 & 13.70 & 22.00 & 3444 & 535 & Barra Velha & 13 \\
\hline 28 & 2319 & $B M-49 R$ & ANF & ANF & 0.0220 & 8.30 & 82.60 & 3415 & 197 & Barra Velha & 13 \\
\hline 28 & 1038 & VL-16/2/67 & PRX & RTO & 0.0450 & 16.90 & 9.50 & 3400 & 600 & Barra Velha & 01 \\
\hline 28 & 1292 & VL-6/7/67 & ANF & ANF & 0.2620 & 48.70 & 3.70 & 2350 & 100 & Barra Velha & 01 \\
\hline 29 & 1302 & $4 C-2 / 68$ & WEB & RTO & 2.4500 & 49.20 & 1.40 & 2450 & 100 & Barra Velha & 01 \\
\hline 29 & 1337 & $4 C-2 / 68 R$ & WEB & RTO & 2.5400 & 44.30 & 2.00 & 2260 & 100 & Barra Velha & 01 \\
\hline 29 & 1856 & BM-13 & TRQ & RTO & 1.7440 & 35.00 & 4.90 & 446 & 20 & Barra Velha & 13 \\
\hline 29 & 2101 & BM-32 & TRQ & RTO & 4.2230 & 471.00 & 1.90 & 1715 & 68 & Barra Vetha & 13 \\
\hline 29 & 1858 & BM-56 & TRQ & RTO & 3.4140 & 118.00 & 3.70 & 714 & 29 & Barra Veltha & 13 \\
\hline $30^{*}$ & 2006 & BV-16 & GNS & ORT & 4.2520 & 408.00 & 16.90 & 1552 & 60 & Barra Velha & 13 \\
\hline 30 & 5453 & SCMB-1126 & GRL & ANF & 0.5000 & 124.00 & 1.30 & 2728 & 74 & Barra Velha & $\infty$ \\
\hline 31 & 2008 & $8 M-16$ & MIG & $\mathrm{K}-\mathrm{F}$ & 7.1080 & 305.00 & 3.90 & 852 & 11 & Barta Velha & 13 \\
\hline 32 & 2106 & BM-18 & PRX & PIR & 0.1230 & 15.10 & 58.60 & 1826 & 77 & Barra Velha & 13 \\
\hline 33 & 4406 & JC-DT-42.A & GBN & PLG & 0.3590 & 55.20 & 4.50 & 2007 & 30 & Jaraguá Sul & 14 \\
\hline 34 & 4409 & JC-DT-32 & GNS & $\mathrm{BlO}$ & 6.8020 & 872.20 & 9.40 & 1878 & 43 & Blumenau & 14 \\
\hline 35 & 4410 & JC-DT-96 & QNR & ANF & 1.2500 & 260.60 & 1.40 & 2530 & 52 & Joinville & 14 \\
\hline 36 & 4411 & JC-DT-27 & GNS & $\mathrm{BIO}$ & 5.7880 & 725.80 & 0.30 & 1851 & 25 & Luís Alves & 14 \\
\hline 37 & 4495 & JC-DT-79 & GBO & PLG & 0.5900 & 42.40 & 14.20 & 1264 & 19 & D. Francisca & 14 \\
\hline $38^{*}$ & 4397 & PKCW -45 & $Q M Z$ & B10 & 6.6510 & 725.40 & 0.84 & 1693 & 21 & Rodeio & 14 \\
\hline 39 & 4691 & PK-212.1 & PRX & ANF & 0.4500 & 77.92 & 2.14 & 2247 & 80 & Jaraguá Sul & 14 \\
\hline 40 & 4588 & $J C-410$ & GNS & BIO & 6.2720 & 734.20 & 2.19 & 1773 & 38 & S. Bento Sul & 14 \\
\hline $41^{\star}$ & 4582 & JC- 455 & DTX & $\mathrm{BlO}$ & 0.8830 & 98.01 & 4.40 & 1715 & 77 & Timbó & 14 \\
\hline
\end{tabular}




\begin{tabular}{|c|c|c|c|c|c|c|c|c|c|c|}
\hline $\begin{array}{l}\text { No. } \\
\text { ordem }\end{array}$ & SPK & N. Campo & $\begin{array}{l}\text { Litolo } \\
\text { gia }\end{array}$ & Material & $\% \mathrm{~K}$ & 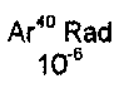 & $\begin{array}{l}\% \mathrm{Ar} \\
\mathrm{atm}\end{array}$ & Idade & Erro & Localizaçáo \\
\hline 42 & 4575 & $3 \mathrm{C}-49 . \mathrm{A}$ & GNS & BIO & 6.6160 & 1090.00 & 0.84 & 2182 & 49 & Jaraguá Sut \\
\hline 43 & 2100 & BM-58 & TRQ & RTO & 4.5170 & 126.00 & 18.20 & 596 & 8 & Barra Velha \\
\hline $44^{*}$ & 4665 & SCMB-172 & MIG & ANF & 1.3088 & 181.10 & 1.26 & 1967 & 37 & Luis Alves \\
\hline $44^{*}$ & 4685 & SCMB-172.E & MIG & BIO & 7.6926 & 848.60 & 1.01 & 1706 & 29 & Luis Alves \\
\hline 45 & 5036 & SCMB-303 & GRL & BIO & 5.7090 & 655.70 & $2 . \infty$ & 1739 & 45 & Luls Alves \\
\hline 46 & 5033 & SCMB-304 & GRL. & BIO & 5.7460 & 855.10 & 1.62 & 2055 & 56 & Luls Alves \\
\hline 47 & 50034 & SCMB-305 & GRL & $\mathrm{BIO}$ & 5.9280 & 713.60 & 5.02 & 1805 & 41 & Lufs Alves \\
\hline 48 & 5035 & SCMB-308 & GRL & BIO & 7.5055 & 884.40 & 2.60 & 1800 & 48 & Luís Alves \\
\hline $49^{*}$ & 5037 & SCMB-345.C & GRL & $\mathrm{BIO}$ & 6.0248 & 726.60 & 2.71 & 1806 & 46 & Ibirama \\
\hline $49^{*}$ & 5044 & SCMB-346.A & GRL & ANF & 1.2412 & 158.10 & 1.38 & 1869 & 32 & Ibirama \\
\hline 50 & 5455 & SCMB-1103.B & GRL & $\mathrm{BIO}$ & 6.4400 & 751.30 & 0.94 & 1768 & 37 & Luis Alves \\
\hline 51 & 5495 & CAN-33 & GRL & BIO & 5.4679 & 463.10 & 8.02 & 1430 & 35 & Luis Alves \\
\hline 52 & 5496 & SCMB-174 & GRL & ANF & 0.7869 & 109.20 & 1.31 & 1971 & 44 & Luís Alves \\
\hline $53^{*}$ & 5551 & SCMB-500 & GNS & ANF & 1.1621 & 142.20 & 1.97 & 1823 & 27 & S Blumenau \\
\hline $54^{*}$ & 5552 & SCMB-1127.B & GNS & BIO & 6.9536 & 234.30 & 4.40 & 708 & 11 & Itajai \\
\hline $55^{\star}$ & 5050 & SCMB-501.A & MIG & B1O & 7.5600 & 211.00 & 8.15 & $\infty 04$ & 8 & S Blumenau \\
\hline 56 & 2813 & VG-46 & GRL. & PLG & 0.2220 & 21.80 & 19.70 & 1570 & 23 & Pien \\
\hline 56 & 2814 & VG.79 & MNR & PLG & 0.2790 & 5.90 & 68.20 & 456 & 42 & Piên \\
\hline 57 & 2817 & VG-255.A & GRL & PLG & 0.7980 & 70.30 & 16.90 & 1454 & 36 & Piên \\
\hline 58 & 2818 & VG-97 & GRL & PLG & 0.1330 & 18.30 & 18.40 & 1955 & 31 & Plên \\
\hline 59 & 2815 & VG-263 & MIG & ANF & 1.0000 & 1.20 & 3.30 & 1787 & 25 & Pien \\
\hline 59 & 2816 & VG-2G3 & MIG & PLG & 0.8360 & 115.40 & 13.80 & 1961 & 56 & Piên \\
\hline$\infty$ & 2656 & VG-24 & MGB & ANF & 1.1900 & 153.40 & 32.10 & 1866 & 56 & Piên \\
\hline 60 & 2698 & VG-24 & MGB & PLG & 0.4740 & 25.80 & 41.30 & 1018 & 23 & Piên \\
\hline 61 & 2636 & VG-194 & MGB & B1O & 7.7630 & 213.50 & 13.30 & 583 & 37 & Piên \\
\hline 61 & 2786 & VG-194 & MGB & PLG & 0.5010 & 11.50 & 15.20 & 503 & 12 & Plên \\
\hline * & 6514 & $J R-06$ & GNS & B1O & 5.8072 & 198.03 & 1.98 & 715 & 15 & N Serra Negra \\
\hline 62 & $67 \Subset 5$ & MJ-AM-70.A & GRL. & BIO & 7.1138 & 937.61 & 0.71 & 1910 & 48 & Piên \\
\hline $\mathfrak{3}$ & 6766 & MJ-AM-27 & GRL & BIO & 7.7334 & 237.36 & 2.10 & 655 & 14 & Piên \\
\hline $64^{*}$ & 6762 & MJ-AM-53.A & GRL. & B1O & 5.1257 & 546.73 & 1.55 & 1672 & $\infty 8$ & Piên \\
\hline 65 & 6499 & $M J-226.2$ & ANF & ANF & 1.5406 & 154.94 & 0.46 & 1606 & 34 & S. Morretes \\
\hline 66 & 6508 & $M J-245$ & GNS & ANF & 1.1436 & 132.37 & 1.86 & 1760 & 32 & Tijucas Sul \\
\hline 67 & 6510 & MJ-246 & ANF & ANF & 0.3132 & 45.77 & 16.30 & 2033 & 39 & Tijucas Sul \\
\hline 68 & 6953 & $M J-386$ & GNS & ANF & 1.1590 & 133.96 & 1.93 & 1771 & 126 & S. Morretes \\
\hline 69 & 6337 & MJ -424 & MGB & ANF & 0.3485 & 43.73 & 9.45 & 1852 & 26 & N D. Francisca \\
\hline 70 & 1246 & $A-35$ & MIG & ANF & 1.8090 & 5.40 & 2.10 & 628 & 32 & Morretes \\
\hline 71 & 1242 & $A-413$ & MIG & ANF & 0.6020 & 17.60 & 14.40 & 620 & 34 & N Morretes \\
\hline 71 & 1672 & $A-420$ & ANF & ANF & 0.6730 & 44.60 & 11.40 & 1193 & 28 & N Morretes \\
\hline 72 & 1090 & $A-25 . A$ & ANF & ANF & 0.1420 & 4.70 & 50.10 & 601 & 65 & N Morretes \\
\hline 73 & 1249 & $A-306$ & ANF & ANF & 0.3290 & 9.80 & 56.70 & 629 & 56 & Cacatu \\
\hline 73 & 1826 & $A-307$ & ANF & PLG & 0.1030 & 11.70 & 15.30 & 1731 & 83 & Cacatu \\
\hline 74 & 1245 & $M O-249$ & ANF & ANF & 0.5920 & 50.40 & 7.50 & 1428 & 64 & Morretes \\
\hline 75 & 1823 & $A-184 . A$ & ANF & PLG & 0.7920 & 33.90 & 11.30 & 850 & 73 & N Morretes \\
\hline 75 & 1247 & A-184.A & ANF & ANF & 0.2180 & 40.50 & 4.70 & 2348 & 89 & N Morretes \\
\hline 76 & 1869 & $M O-42$ & ANF & ANF & 0.8500 & 96.10 & 1.90 & 1734 & 37 & Morretes \\
\hline 76 & 1707 & $M O-42$ & ANF & PLG & 1.4140 & 54.30 & 7.10 & 778 & 46 & Morretes \\
\hline 77 & 1688 & $A-117$ & XMG & RTO & 0.0070 & 1.60 & 84.40 & 2669 & 498 & N Morretes \\
\hline 78 & 4463 & LK-22.A & NOR & PLG & 0.5170 & 176.40 & 0.77 & 3192 & 37 & Serra Negra \\
\hline $79^{*}$ & 3468 & AA-107 & $\mathrm{CHQ}$ & FEL & 0.7590 & 183.90 & 5.90 & 2713 & 115 & Serra Negra \\
\hline $79^{*}$ & 3470 & AA-104 & $\mathrm{CHQ}$ & FEL & 0.4670 & 99.10 & 28.90 & 2530 & 36 & Serra Negra \\
\hline $79^{*}$ & 3488 & $A A=114$ & $\mathrm{CHQ}$ & FEL & 3.4930 & 190.70 & 3.20 & 1030 & 12 & Serra Negra \\
\hline $79^{\star}$ & 3484 & $A A-113$ & MIG & FEL & 5.4900 & 400.70 & 0.60 & 1349 & 39 & Serra Negra \\
\hline 80 & 4587 & PK-100 & GRD & $\mathrm{B} 1 \mathrm{O}$ & 6.4880 & 154.90 & 10.90 & 529 & 10 & Serra Negra \\
\hline 81 & 7036 & $M J-363$ & GRL & ANF & 1.6926 & 212.33 & 6.37 & 1852 & 36 & Cacatu \\
\hline 82 & 7072 & $M J \sim 421$ & GNS & RTO & 1.1615 & 80.64 & 5.54 & 1242 & 26 & NE C. Alegre \\
\hline 83 & 70009 & $M J-428$ & GNS & RTO & 2.8723 & 130.07 & 3.37 & 900 & 26 & NE C. Alegre \\
\hline 84 & 7079 & MJ -452 & GRL. & ANF & 0.4523 & 72.88 & 2.42 & 2153 & 26 & N Garuva \\
\hline * & 7166 & $M N-63 A$ & GNS & 810 & 6.8676 & 179.38 & 12.05 & 572 & 25 & BR-116 \\
\hline 93 & 6648 & MJ-268 & GNS & RTO & 1.9925 & 48.66 & 27.43 & 540 & 14 & NW P.BR. Arare \\
\hline
\end{tabular}

DOMINIO CURITIBA

$\begin{array}{llllllrrrrrr}86 & 6271 & \text { MJ-138 } & \text { GNS } & \text { BIO } & 5.8068 & 164.14 & 6.16 & 611 & 19 & \text { N Mandirituba } & \text { NT } \\ 86 & 6272 & \text { MJ-138 } & \text { GNS } & \text { ANF } & 1.8082 & 65.36 & 1.32 & 751 & 24 & \text { N Mandirituba } & \text { NT } \\ 87 & 6252 & \text { MJ-23 }=137 & \text { GNS } & \text { ANF } & 0.1438 & 3.98 & 80.09 & 602 & 76 & \text { N Mandirituba } & \text { NT }\end{array}$




\begin{tabular}{|c|c|c|c|c|c|c|c|c|c|c|}
\hline $\begin{array}{c}\text { No. } \\
\text { ordem }\end{array}$ & SPK & N. Campo & $\begin{array}{c}\text { Litolo } \\
\text { gia }\end{array}$ & Material & $\% \mathrm{~K}$ & 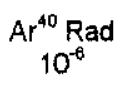 & $\begin{array}{l}\% A r \\
\text { atm }\end{array}$ & Idade & Erro & Localizaçăo \\
\hline 88 & 6274 & $M J-123 . A$ & MIG & $\mathrm{BIO}$ & 5.0642 & 133.79 & 3.98 & 577 & 15 & S Mandirituba \\
\hline 89 & 6254 & MJ-96.9 & MIG & $\mathrm{BIO}$ & 7.2175 & 194.60 & 23.00 & 588 & 27 & Atuba \\
\hline 90 & 6691 & MJ-316.1 & ANF & ANF & 0.3266 & 8.47 & 41.37 & 568 & 33 & Quitandinha \\
\hline 91 & 6654 & $\mathrm{MJ}-315 . \mathrm{F}$ & MIG & ANF & 1.8067 & 49.27 & 20.37 & 593 & 16 & Quitandinha \\
\hline 92 & 6653 & MJ-310.B & GNS & $\mathrm{BIO}$ & 5.7873 & 149.39 & 7.78 & 566 & 15 & W Mandirituba \\
\hline 94 & 6935 & $M J-378$ & GNS & PLG & 4.0438 & 95.17 & 22.90 & 523 & 13 & SE Curitiba \\
\hline 96 & 7091 & $M J-550$ & GNS & 810 & 5.4277 & 156.16 & 7.31 & 624 & 49 & Q. Barras \\
\hline 96 & 7089 & $M J-550$ & GNS & ANF & 1.4254 & 42.04 & 8.9 & $\mathfrak{3 8}$ & 54 & Q. Barras \\
\hline 97 & 1636 & $M 0-113$ & MIG & ANF & 1.2910 & 32.90 & 11.00 & 550 & 37 & Q. Barras \\
\hline 98 & 1248 & MO-1.A & MIG & 810 & 6.8350 & 184.00 & 1.40 & 578 & 30 & Q. Barras \\
\hline 99 & 1689 & MO-16.A & MIG & ANF & 1.0140 & 24.30 & 45.40 & 522 & 47 & Q. Barras \\
\hline 100 & 1241 & A-295 & GNS & ANF & 0.7780 & 19.80 & 7.10 & 550 & 28 & Cacatu \\
\hline 100 & 1243 & $A-467$ & ANF & ANF & 0.8410 & 23.20 & 4.10 & 590 & 30 & Cacatu \\
\hline 101 & 3501 & SC.93.A & MIG & ANF & 0.6810 & 22.30 & 3.40 & 680 & 10 & N. Curitiba \\
\hline * & 4380 & 873-JC-244 & MrX & BIO & 7.2380 & 201.60 & 1.96 & 604 & 7 & S Campo Largo \\
\hline 102 & 7190 & $M J-638 A$ & GNS & ANF & 2.2565 & 62.47 & 10.60 & 602 & 25 & $B R-116$ \\
\hline 102 & 7189 & MJ-638A & GNS & B1O & 6.7851 & 190.47 & 5.93 & 608 & 7 & BR-116 \\
\hline 103 & 7167 & MJ-636A & GNS & ANF & 1.0849 & 33.19 & 22.88 & 654 & 10 & BR-116 \\
\hline 104 & 7162 & MJ- 39.1 & GNS & $\mathrm{BIO}$ & 5.8489 & 161.10 & 6.78 & 598 & 10 & $B R-116$ \\
\hline $105^{*}$ & 7165 & $M M-89 D$ & $\mathrm{CHQ}$ & ANF & 1.1886 & 136.78 & 6.44 & 1755 & 70 & N Curitiba \\
\hline
\end{tabular}

\section{GRANITÓIDES DEFORMADOS PIÊN}

$\begin{array}{llllllrrrrrr}120 & 6767 & \text { MJ-321 } & \text { GRN } & \text { BIO } & 5.4661 & 158.46 & 3.40 & 625 & 20 & \text { Doce Fino } & \text { NT } \\ 120 & 6768 & \text { MJ-321 } & \text { GRN } & \text { ANF } & 1.0231 & 28.12 & 22.47 & 600 & 48 & \text { Doce Fino } & \text { NT } \\ 121 & 6760 & \text { MJ-AM-93 } & \text { GRN } & \text { BIO } & 5.1623 & 131.79 & 4.49 & 561 & 22 & \text { Plen } & 12 \\ 122 & 6761 & \text { MJ-AM-94 } & \text { GRN } & \text { BIO } & 6.3791 & 173.20 & 4.28 & 593 & 36 & \text { Plen } & 12 \\ 123 & 7080 & \text { MJ-467 } & \text { GRN } & \text { BIO (i) } & 5.2673 & 168.70 & 7.24 & 679 & 13 & \text { Pangare } & \text { NT } \\ 124 & 7164 & \text { MJ-649 } & \text { GRN } & \text { ANF (i) } & 0.9206 & 27.67 & 4.03 & 644 & 20 & \text { Pien } & \text { NT }\end{array}$

\begin{tabular}{|c|c|c|c|c|c|c|c|c|c|}
\hline 1936 & MJ-397 & GNS & PLG & 4.1228 & 119.41 & 3.24 & 625 & 26 & S Antonina \\
\hline 6501 & MJ-206.1 & GRN & $\mathrm{BIO}$ & 7.2424 & 146.45 & 6.24 & 457 & 12 & Paranagứá \\
\hline$\$ 570$ & MJ-200 & GRN & $\mathrm{BIO}$ & 5.4609 & 116.17 & 3.68 & 478 & 16 & Alexandra \\
\hline 65 & MJ-301K & GRN & $\mathrm{BIO}$ & 7.3491 & 159.70 & 4.32 & 487 & 15 & N Matinhos \\
\hline 7094 & MJ-561A & GRN & $B 10$ & 5.9872 & 146.88 & 8.98 & 542 & 21 & Guaraqueçaba \\
\hline 7092 & MJ-577 & GNS & $\mathrm{BIO}$ & 6.5433 & 165.03 & 4.10 & 555 & 15 & Guaraqueçaba \\
\hline 7095 & MJ 582 & GRN & B10 & 6.5701 & 148.35 & 5.76 & 504 & 19 & Serra. Negra \\
\hline 7006 & $M J-623 A$ & GRN & $\mathrm{BIO}$ & 6.1512 & 145.78 & 3.32 & 526 & 12 & Araquaril \\
\hline 7097 & $M J-625$ & GRN & BIO & 6.5980 & 170.31 & 3.43 & 567 & 28 & S. Fr. Sul \\
\hline 7090 & $M J-627$ & MIG & BIO & 6.9114 & 173.04 & 2.34 & 554 & 39 & S. Fr. Sul \\
\hline 4576 & JCEF-417 & PML & BIO & 7.5230 & 207.00 & 7.45 & 598 & 10 & Garuva \\
\hline 4584 & PK-90 & GNS & $\mathrm{BIO}$ & 7.7600 & 181.10 & 18.14 & 519 & 7 & Paranaguá \\
\hline 4396 & JC-DT-103 & GRD & $\mathrm{BIO}$ & 7.4990 & 180.60 & 1.08 & 533 & 7 & S. Fr. Sul \\
\hline 727 & UC-MAT & MIG & $\mathrm{BIO}$ & 7.8810 & 179.90 & 2.80 & 500 & 18 & Guaratuba \\
\hline - & UC-MAT & MIG & $\mathrm{B1O}$ & - & سسس. & - & 480 & - & Guaratuba \\
\hline 4408 & $L K-20$ & GRN & $\mathrm{BIO}$ & 6.1905 & 145.30 & 12.29 & 520 & 8 & Guaraqueçaba \\
\hline 7000 & MJ-413B & GRN & $\mathrm{BIO}$ & 5.7715 & 142.42 & 4.92 & 544 & 11 & Estréla \\
\hline 6606 & MJ-283 & GRN & $\mathrm{B} 1 \mathrm{O}$ & 6.8216 & $1 ळ 5.46$ & 2.91 & 536 & 17 & Estrêla \\
\hline
\end{tabular}

\section{MACICOS GRANITICOS}

$\begin{array}{llllllrrrrrr}125 & 6490 & \text { MJ-17 } & \text { GRN } & \text { ANF } & 1.9324 & 51.76 & 5.65 & 585 & 24 & \text { Agudos } & \text { NT } \\ 125 & 6492 & \text { MJ-17 } & \text { GRN } & \text { BIO } & 4.3660 & 106.81 & 13.54 & 541 & 28 & \text { Agudos } & \text { NT } \\ 126 & 6939 & \text { MJ-441.A } & \text { GRN } & \text { ANF } & 1.5963 & 41.08 & 11.77 & 505 & 20 & \text { M. Rectondo } & \text { NT } \\ 129 & 6568 & \text { MJ-288.B } & \text { GRN } & \text { BIO } & 5.4569 & 135.83 & 5.24 & 549 & 17 & \text { Anhangava } & \text { NT } \\ 130 & 6952 & \text { MJ-292.C } & \text { GRN } & \text { BIO } & 4.6932 & 126.52 & 2.12 & 587 & 11 & \text { Graciosa } & \text { NT } \\ 65 & 7163 & \text { MJ-640 } & \text { GRN } & \text { BIO } & 6.4568 & 167.72 & 6.63 & 569 & 11 & \text { Graciosa } & \text { NT } \\ 131 & 6573 & \text { MJ-300 } & \text { GRN } & \text { BIO } & 5.0850 & 118.77 & 4.19 & 519 & 13 & \text { Graciosa } & \text { NT } \\ 132 & 6940 & \text { MJ-405.C } & \text { GRN } & \text { ANF } & 1.3664 & 36.91 & 20.34 & 589 & 27 & \text { S. Igreja } & \text { NT } \\ 132 & 6941 & \text { MJ-405.C } & \text { GRN } & \text { BIO } & 5.2286 & 142.70 & 9.54 & 594 & 26 & \text { S. Igreja } & \text { NT } \\ 133 & 7099 & \text { MJ-166 } & \text { GRN } & \text { ANF } & 0.9590 & 23.07 & 15.65 & 533 & 21 & \text { Corupá } & \text { NT } \\ 134 & 4407 & \text { PK-CW-61 } & \text { GRN } & \text { ANF } & 0.6305 & 14.84 & 5.92 & 523 & 20 & \text { Corupá } & 14 \\ 135 & 1244 & \text { MO-133 } & \text { GRN } & \text { ANF } & 0.6680 & 17.90 & 14.90 & 577 & 36 & \text { Marumby } & 07\end{array}$




\begin{tabular}{|c|c|c|c|c|c|c|c|c|c|c|}
\hline $\begin{array}{l}\text { No. } \\
\text { ordem }\end{array}$ & SPK & N. Campo & $\begin{array}{l}\text { Litolo } \\
\text { gia }\end{array}$ & Material & $\% \mathrm{~K}$ & $\mathrm{Ar}_{10^{40}} \mathrm{Rad}^{-6}$ & $\begin{array}{l}\text { \%Ar } \\
\text { atm }\end{array}$ & Idade & Erro & Localizaçáo \\
\hline $\begin{array}{l}136 \\
137 \\
138\end{array}$ & $\begin{array}{r}1250 \\
1687 \\
121\end{array}$ & $\begin{array}{l}\text { MO-56.E } \\
M 0-161 \\
3 / 2016\end{array}$ & $\begin{array}{l}\text { GRN } \\
\text { GRN } \\
\text { GRN }\end{array}$ & $\begin{array}{l}\text { BIO } \\
\text { BlO } \\
\text { BlO }\end{array}$ & $\begin{array}{l}6.4240 \\
6.6450 \\
4.0800\end{array}$ & $\begin{array}{l}168.00 \\
150.10 \\
122.00\end{array}$ & $\begin{array}{l}2.70 \\
2.60 \\
1.10\end{array}$ & $\begin{array}{l}564 \\
496 \\
630\end{array}$ & $\begin{array}{l}29 \\
35 \\
20\end{array}$ & $\begin{array}{l}\text { Marumby } \\
\text { Marumby } \\
\text { A. Turvo }\end{array}$ \\
\hline \multicolumn{11}{|c|}{ ROCHAS VULCÂNICAS } \\
\hline \multirow[t]{2}{*}{$\begin{array}{l}139 \\
140\end{array}$} & $\begin{array}{l}1730 \\
1731\end{array}$ & $\begin{array}{l}\text { CA-02 } \\
\text { CA-01 }\end{array}$ & $\begin{array}{l}\text { TRQ } \\
\text { TRQ }\end{array}$ & $\begin{array}{l}\text { RTO } \\
\text { RTO }\end{array}$ & $\begin{array}{l}4.9810 \\
3.4260\end{array}$ & $\begin{array}{r}103.00 \\
74.90\end{array}$ & $\begin{array}{r}10.50 \\
4.60\end{array}$ & $\begin{array}{l}458 \\
481\end{array}$ & $\begin{array}{l}23 \\
25\end{array}$ & $\begin{array}{l}\text { C. Alegre } \\
\text { C. Alegre }\end{array}$ \\
\hline & \multicolumn{10}{|c|}{ ROCHAS BÁSICAS } \\
\hline 141 & 6497 & MJ-22 & DIA & PLG & 0.7615 & 4.98 & 53.28 & 161 & 17 & Mandirituba \\
\hline 106 & 6504 & MJ-206.B & DIA & RTO & 0.8710 & 6.99 & 29.38 & 196 & 13 & Paranaguá \\
\hline 142 & 6506 & $M J-221$ & GBO & PLG & 0.7834 & 6.62 & 53.35 & 206 & 29 & S Morretes \\
\hline 143 & 6604 & $M J-254$ & DIA & RTO & 0.7463 & 18.74 & 8.30 & 553 & 14 & N D. Francisca \\
\hline 144 & 6546 & MJ-287.1 & DIA & PLG & 2.5844 & 18.47 & 45.59 & 176 & 15 & Guaratuba \\
\hline 101 & 6602 & MJ-25.15 & DIA & RTO & 0.9185 & 4.60 & 25.77 & 125 & $\uparrow 1$ & N Curitiba \\
\hline 145 & 6603 & MJ-63 & DIA & RTO & 1.2237 & 8.66 & 27,82 & 174 & 9 & Jaraguá Sul \\
\hline 146 & 2634 & VG-170 & DIA & B1O & 2.2070 & 54.50 & 43.30 & 527 & 30 & Pien \\
\hline$\uparrow 46$ & 2647 & VG-170 & DIA & ANF & 1.1890 & 33.50 & 6.20 & $6 \infty$ & 14 & Piên \\
\hline 146 & 2812 & VG- 170 & DIA & PLG & 1.6410 & 32.20 & 18.10 & 435 & 13 & Piên \\
\hline $147^{*}$ & 971 & $1 G-330$ & DIA & $\mathrm{BIO}$ & 7.4300 & 248.00 & 6.50 & 60 & 20 & BR-116 \\
\hline 148 & 835 & MO-238 & AND & RTO & 3.0750 & 16.32 & 20.90 & 132 & 7 & Q. Barras \\
\hline 140 & 888 & $A-211$ & BAS & PLG & 1.4860 & 9.50 & 32.80 & 158 & 8 & Antonina \\
\hline 150 & 103 & UC-DB-52 & DIA & RTO & 1.0610 & 5.21 & $15 . \infty$ & 122 & 10 & BR-116 \\
\hline 151 & 1733 & $\mathrm{CA}-03$ & DIA & RTO & 1.5750 & 8.17 & 38.50 & 129 & 13 & C. Alegre \\
\hline 152 & 6938 & $\mathrm{MJ}-432$ & GBO & PLG & 1.6280 & 36.79 & 15.60 & 506 & 29 & NW Garuva \\
\hline 153 & 7037 & MJ-404 & DIA & RTO & 1.2667 & 10.34 & 26.19 & 190 & 10 & S Morretes \\
\hline
\end{tabular}


DADOS RADIOMÉTRICOS Rb-Sr

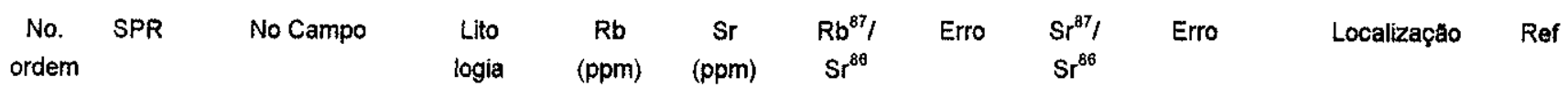

\section{DOMINIO LUIS ALVES}

\begin{tabular}{|c|c|c|}
\hline 54 & 10460 & $M J-27.4$ \\
\hline & 10461 & MJ-27.5 \\
\hline 15 & 10462 & MJ-27.6 \\
\hline & 10464 & $M J-27.9$ \\
\hline 15 & 10463 & $M J-27.10$ \\
\hline & 11119 & MJ-27.1 \\
\hline & UK & $M J-27.14$ \\
\hline & 9925 & MJ-191 \\
\hline & 9926 & MJ-192.a \\
\hline 15 & 11130 & MJ-192.a \\
\hline 15 & 9927 & $M J-192 . c$ \\
\hline 156 & 11120 & MJ-192.b \\
\hline & $1 \uparrow 121$ & MJ-192.c \\
\hline 157 & 9943 & MJ-194.a \\
\hline & 9928 & MJ-259 \\
\hline 15 & 9902 & MJ-167 \\
\hline & 9033 & $M J_{m} \uparrow 68$ \\
\hline & 9946 & MJ -169 \\
\hline 32 & 11122 & MJ-195 \\
\hline & 9929 & MJ-29.1 \\
\hline & 9950 & $M J-29.2$ \\
\hline 6 & 9944 & $M J-30$ \\
\hline & 9945 & $M J-31$ \\
\hline & 11131 & $M J-31 . R$ \\
\hline 12 & 9931 & $M J 34 . a$ \\
\hline & UK & $M J-41.3$ \\
\hline 15 & 10772 & $M J-332 . b$ \\
\hline 16 & 10773 & $M J-335 . a$ \\
\hline & 10792 & $M J-341 . a$ \\
\hline & 10793 & $M J-341 . b$ \\
\hline 16 & 10794 & MJ-341.d \\
\hline 16 & 10795 & $M J-342.6$ \\
\hline 6 & 10928 & $M J-A M-56$ \\
\hline & 10929 & MJ-AM-5 \\
\hline 6 & 10030 & MJ-AM-7C \\
\hline & 10931 & MJ-AM-75 \\
\hline & 10932 & $M J-A M-B C$ \\
\hline 3 & 4632 & $\operatorname{JCDC} 32$ \\
\hline & 4616 & $J C D C-50$ \\
\hline & 5157 & $J C-410$ \\
\hline & 5159 & $\mathrm{JC}-446$ \\
\hline & 4637 & PKCW-45 \\
\hline & 3657 & PLA-02 \\
\hline & 3635 & PIA-16.B \\
\hline & 3658 & PLA-O4 \\
\hline
\end{tabular}

\begin{tabular}{|c|c|c|c|c|c|c|}
\hline GRL. & 18.00 & 767.00 & 0.0680 & 0.0020 & 0.70444 & 0.0000 \\
\hline GRL & 12.37 & 798.73 & 0.0448 & 0.0008 & 0.70376 & 0.0000 \\
\hline GRL & 20.14 & 803.97 & 0.0725 & 0.0012 & 0.70448 & 0.0000 \\
\hline GRL. & 15.04 & 828.24 & 0.0525 & 0.0000 & 0.70404 & 0.0000 \\
\hline SRL & 25.47 & 757.91 & 0.0973 & 0.0016 & 0.70537 & 0.0000 \\
\hline$R L$ & 21.00 & 438.00 & 0.1300 & 0.0040 & 0.70602 & 0.0000 \\
\hline RL & 27.00 & 10032.00 & 0.0760 & 0.0020 & 0.70438 & 0.0000 \\
\hline $\mathrm{RL}$ & 12.00 & 809.60 & 0.0429 & 0.0002 & 0.70595 & 0.0000 \\
\hline RL & 16.90 & 121.90 & 0.4030 & 0.0008 & 0.72750 & 0.0000 \\
\hline RL & 15.00 & 115.00 & 0.3780 & 0.0110 & 0.72639 & 0.0002 \\
\hline$R \mathbf{R}$ & 15.60 & 110.90 & 0.4070 & 0.0020 & 0.72230 & 0.0000 \\
\hline RI. & 42.50 & 253.30 & 0.4870 & 0.0140 & 0.72862 & 0.0000 \\
\hline RL. & 14.80 & 106.40 & 0.4030 & 0.0110 & 0.73063 & 0.0000 \\
\hline RL & 69.00 & 477.60 & 0.4190 & 0.0120 & 0.72052 & 0.0000 \\
\hline GRL & 26.60 & 673.30 & 0.1140 & 0.0010 & 0.7 & 0.0000 \\
\hline RL. & 34.80 & 754.00 & 0.1340 & 0.0010 & 0.70792 & 0.0000 \\
\hline $\mathrm{RL}$ & 17.20 & 643.80 & 0.0770 & 0.0010 & 0.70623 & $\infty 00$ \\
\hline GRL & 47.20 & 408.80 & 0.3340 & 0.0000 & 0.71711 & 0.0000 \\
\hline RL & 16.00 & 490.00 & 0.0030 & 0.0030 & 0.7 & 0.0001 \\
\hline GRL & 30.30 & 681.10 & 0.1290 & 0.0010 & 0.70596 & 0.0000 \\
\hline RL & 17.00 & 743.90 & 0.1830 & 0.0010 & 0.7 & 0.00000 \\
\hline GRL & 45.60 & 297.00 & 0.4450 & 0.0130 & 0.71854 & 0.0000 \\
\hline GRL & 41.10 & 546.70 & 0.2180 & 0.0060 & 0.70670 & 0.0000 \\
\hline GRL & 26.50 & 535.90 & 0.1430 & 0.0040 & 0.70665 & 0.0000 \\
\hline GRL & 104.60 & 825.80 & 0.3670 & 0.0020 & 0.71437 & 0.00010 \\
\hline SRL. & 1.00 & 550.00 & 0.0050 & 0.0001 & 0.70273 & 0.00002 \\
\hline GRL & 52.00 & 701.50 & 0.2150 & 0.0000 & 0.70822 & 0.00000 \\
\hline SRL. & 87.00 & 725.50 & 0.3470 & 0.0100 & 0.71359 & 0.0000 \\
\hline GRL & 15.70 & 51200 & 0,0890 & 0.0010 & 0.70563 & 0.0000 \\
\hline$G R L$ & 86.50 & 909.50 & 0.2750 & 0.0080 & 0.71023 & $0.0000^{\prime}$ \\
\hline GRL. & 50.50 & 1232.50 & 0.1190 & 0.0030 & 0.70613 & 0.0000 \\
\hline GRL & 56.50 & 353.50 & 0.4630 & 0.0130 & 0.71914 & 0.0000 \\
\hline GRL & 63.00 & 555.00 & 0.3290 & 0.0090 & 0.71338 & 0.0000 \\
\hline GRL & 72.50 & 354.00 & 0.5030 & 0.0170 & 0.71746 & $0.0000 x$ \\
\hline GRL & 57.00 & 1135.50 & 0.1450 & 0.0040 & 0.706851 & 0.00008 \\
\hline GRL & 56.00 & 400.00 & 0.3970 & 0.0110 & 0.71536 & 0.00007 \\
\hline GRL & 43.00 & 612.50 & 0.2050 & 0.0060 & 0.71044 & 0.00007 \\
\hline GNS & 76.70 & 581.80 & 0.3820 & 0.0180 & 0.71440 & 0.00120 \\
\hline GNS & 103.00 & 285.30 & 1.0500 & 0.0200 & 0.73800 & 0.00040 \\
\hline GNS & 59.90 & 447.30 & 0.3900 & 0.0100 & 0.71840 & 0.00080 \\
\hline SRN & 65.20 & 478.60 & 0.3900 & 0.0100 & 0.71400 & 0.0012 \\
\hline$Q M Z$ & 106.00 & 550.60 & 0.5580 & 0.0170 & 0.72120 & 0.0012 \\
\hline GRL & 54.50 & 264.60 & 0.5900 & 0.0100 & 0.72370 & 0.0014 \\
\hline GRL & 116.50 & 186.80 & 1.8200 & 0.0400 & 0.77370 & 0.0011 \\
\hline GRL & 65.70 & 144.50 & 9,3200 & 0.0300 & 0.75310 & 0.0015 \\
\hline
\end{tabular}

N. Blumenau

N. Blumenau

N. Blumenau

N. Blumenau

N. Blumenau

N. Blumenau

N. Blumenau

Dna. Francisca

Dna. Francisca

Dna. Francisca

Dna. Francisca

Dna. Franclsca

Dna. Francisca

Dna. Francisca

Dna. Francisca

Dna. Francisca

Dna. Francisca

Dna. Francisca

Dna. Francisce

Dna. Francisca

Pomerode

Pomerode

Pomerode

Pomerode

Pomerode

Pomerode

S. Bento do Sul

S. Bento do Sul

S. Bento do Sul

S. Bento do Sul

S. Bento do Sul

$S$. Bento do Sul

S. Bento do Sul

S. Bento do Sul

S. Bento do Sut

S. Bento do Su?

S. Bento do Sul

Timbó

R. Cedros

S. Bento do Sul

Jaraguá do Sul

Rodeio

Luis Alves

Luis Alves

Luis Alves
NT

NT

NT

NT

NT

NT

NT

NT

NT

NT

NT

NT

NT

NT

NT

NT

NT

NT

NT

NT

NT

NT

NT

NT

NT

NT

NT

NT

NT

NT

NT

NT

12

12

12

12

12

14

14

14

14

14

10

10

10 


\begin{tabular}{|c|c|c|c|c|c|c|c|c|c|c|c|}
\hline $\begin{array}{l}\text { No. } \\
\text { ordem }\end{array}$ & SPR & No Campo & $\begin{array}{l}\text { Lito } \\
\text { logia }\end{array}$ & $\begin{array}{c}\mathrm{Rb} \\
(\mathrm{ppm})\end{array}$ & $\begin{array}{c}\mathrm{Sr} \\
(\mathrm{ppm})\end{array}$ & $\begin{array}{c}\mathrm{Rb}^{87 /} \\
\mathrm{Sr}^{86}\end{array}$ & Erro & $\begin{array}{l}\mathrm{Sr}^{87} \mathrm{l} \\
\mathrm{Sr}^{8 \mathrm{~B}}\end{array}$ & Erro & Localizaçăo & Ref \\
\hline 20 & 3650 & PLA-05 & UMF & 25.10 & 729.00 & 0.1000 & 0.0010 & 0.70730 & 0.00080 & Luis Alves & 10 \\
\hline 48 & 3660 & PLA-OB & UMF & 10.60 & 880.00 & 0.0350 & 0.0010 & 0.70620 & 0.00090 & Luis Alves & 10 \\
\hline 52 & 3661 & PLA-12 & GRL & 80.00 & 568.00 & 0.4100 & 0.0100 & 0.72000 & 0.00010 & Luis Alves & 10 \\
\hline 173 & 3662 & PLA-15 & GRL & 11.10 & $\approx 9.00$ & 0.0500 & 0.0010 & 0.70510 & 0.00100 & Luis Alves & 10 \\
\hline $44^{*}$ & 5601 & SCMB- $172 . A$ & MIG & 80.90 & 552.00 & 0.4200 & 0.0100 & 0.71770 & 0.00180 & Luis Alves & $\infty$ \\
\hline $44^{*}$ & 5602 & SCMB-172.B & MIG & 73.30 & 497.00 & 0.4300 & 0.0100 & 0.71610 & 0.00080 & Luis Alves & $\infty$ \\
\hline $44^{*}$ & 5605 & SCMB-172.E & MIG & $85 . \infty 0$ & 517.00 & 0.4800 & 0.0100 & 0.71910 & 0.00130 & Luis Alves & $\infty$ \\
\hline $44^{*}$ & 5603 & SCMB-172.C & MIG & 42.00 & 562.00 & 0.2170 & 0.0050 & 0.71270 & 0.00100 & Luis Alves & $\infty$ \\
\hline $44^{*}$ & 5604 & SCMB-172.D & MIG & 38.00 & 489.00 & 0.2250 & 0.0050 & 0.71340 & 0.00190 & Luis Alves & $\infty$ \\
\hline $44^{*}$ & 5606 & SCMB-172.F & MIG & 31.00 & 484.00 & 0.1850 & 0.0040 & 0.71040 & 0.00120 & Luis Alves & $\infty$ \\
\hline $44^{*}$ & 6657 & SCMB-172-6C & MIG & 61.70 & 666.00 & 0.2680 & 0.0080 & 0.71330 & 0.00010 & Luis Alves & $\infty$ \\
\hline $44^{*}$ & 6658 & SCMB-172-9A & MIG & 58.10 & 473.00 & 0.3560 & 0.0100 & 0.71730 & 0.00010 & Luís Alves & $\infty$ \\
\hline $44^{*}$ & 6659 & SCMB-172-11B & MIG & 91.70 & 472.00 & 0.5630 & 0.0160 & 0.72010 & 0.00010 & Luis Alves & $\infty 3$ \\
\hline $44^{*}$ & 6624 & SCMB $-172-1$ & MIG & 111.00 & 533.00 & 0.6040 & 0.0170 & 0.72130 & 0.00010 & Luis Alves & $\infty$ \\
\hline $44^{*}$ & 6665 & SCMB-172-4 & MIG & 55.90 & 403.00 & 0.4020 & 0.0110 & 0.71570 & 0.00010 & Luis Alves & $\infty 3$ \\
\hline 174 & 4255 & SCMB $41 . B$ & GRL & 98.40 & 502.00 & 0.5700 & 0.0100 & 0.71900 & 0.00140 & Blumenau & $\infty$ \\
\hline 174 & 4256 & SCMB-41.F & GRL & 138.00 & 665.00 & 0.6000 & 0.0100 & 0.72030 & 0.00120 & Blumenau & $\infty 3$ \\
\hline 174 & 4257 & SCMB-41.H & GRL & 131.00 & 775.00 & 0.4900 & 0.0100 & 0.71710 & 0.00110 & Blumenau & $\infty$ \\
\hline 175 & 4262 & SCMB-38.C & GRL. & 40.30 & 862.00 & 0.1400 & 0.0100 & 0.70560 & 0.00100 & Blumenau & $\infty 3$ \\
\hline 175 & 4264 & SCMB-38.F & GRL. & 22.50 & 816,00 & 0.0800 & 0.0100 & 0.70440 & 0.00140 & Blumenau & $\infty$ \\
\hline 56 & 515 & VG-46 & GRL & 5.20 & 244.60 & 0.0620 & 0.0020 & 0.70440 & 0.00050 & Plen & $\infty$ \\
\hline 176 & 516 & VG-67 & GRL & 3.10 & 141.10 & 0.0640 & 0.0010 & 0.70530 & 0.00160 & Pien & $\infty$ \\
\hline$\uparrow 77$ & 529 & VG-62. & GRL & 54.60 & 153.60 & 1.0320 & 0.0200 & 0.73350 & 0.00130 & Pien & $\infty$ \\
\hline 57 & 530 & VG-214 & GRL & 33.10 & 498.00 & 0.1920 & 0.0010 & 0.70770 & 0.00070 & Pien & $\infty$ \\
\hline 178 & UK & MJ-15.A & GRL & 15.00 & 491.00 & 0.3820 & 0.0180 & 0.70588 & 0.00002 & Pien & NT \\
\hline * & UK & JR-06 & GRL & 2.00 & 1027.00 & 1.0500 & 0.0200 & 0.70264 & 0.00001 & N. S. Negra & NT \\
\hline 179 & 115 & $A-183$ & GNS & 419.00 & 6.60 & 184.0000 & 3.0000 & 2.26000 & 0.13000 & Morretes & 07 \\
\hline 179 & 127 & $M 0-250$ & MIG & 261.00 & 34.50 & 22.0800 & 0.4300 & 0.88800 & 0.00500 & Morretes & 07 \\
\hline 180 & 4566 & AT-538.B & END & 2.00 & 489.90 & 0.0100 & 0.0010 & 0.70740 & 0.00140 & S. Negra & 07 \\
\hline 181 & 3689 & SN-3 & $\mathrm{CHQ}$ & 160.40 & 504.00 & 0.9200 & 0.0200 & 0.73760 & 0.00090 & S. Negra & 02 \\
\hline 181 & 3789 & SN-5 & $\mathrm{CHQ}$ & 3.50 & 619.00 & 0.0200 & 0.0010 & 0.70910 & 0.00100 & S. Negra & $\infty 2$ \\
\hline 181 & 3795 & $\mathrm{SN}-6$ & $\mathrm{CHQ}$ & 15.50 & 419.10 & 0.1070 & 0.0030 & 0.71260 & 0.00000 & S. Negra & 02 \\
\hline 185 & 11376 & MJ-302 & GNS & 30.80 & 775.20 & 0.1150 & 0.0030 & 0.70013 & 0.00019 & S S. José Pinhais & NT \\
\hline
\end{tabular}

\section{ROCHAS MÁFICASULTRAMÁFICAS DE PIÊN}

$\begin{array}{rllllrllll}235 & 11524 & \text { MJ-518B } & \text { UMF } & 2.84 & 4.05 & 2.0317 & 0.0342 & 0.71996 & 0.00015 \\ 235 & 11525 & \text { MJ-519 } & \text { UMF } & 0.83 & 21.31 & 0.1130 & 0.0019 & 0.70539 & 0.00008 \\ 236 & 11526 & \text { MJ-521 } & \text { UMF } & 0.42 & 0.95 & 1.2725 & 0.0215 & 0.72169 & 0.00039 \\ 234 & 11527 & \text { MJ-523C } & \text { UMF } & 7.93 & 119.86 & 0.1915 & 0.0033 & 0.70933 & 0.00005 \\ 234 & 11528 & \text { MJ-524A } & \text { UMF } & 0.20 & 3.10 & 0.1857 & 0.0033 & 0.71076 & 0.00009 \\ 234 & 11529 & \text { MJ-524B } & \text { UMF } & 0.40 & 17.74 & 0.0656 & 0.0011 & 0.70611 & 0.00016 \\ 237 & 11530 & \text { MJ-534 } & \text { UMF } & 0.87 & 31.02 & 0.0807 & 0.0014 & 0.70243 & 0.00017 \\ 234 & 12512 & \text { MJ-524A } & \text { UMF } & 0.20 & 2.80 & 0.1937 & 0.0029 & 0.71103 & 0.00023 \\ 234 & 12513 & \text { MJ-524B } & \text { UMF } & 0.40 & 19.50 & 0.0594 & 0.0009 & 0.70631 & 0.00008 \\ 235 & 12514 & \text { MJ-5188 } & \text { UMF } & 2.90 & 4.10 & 2.0601 & 0.0029 & 0.72037 & 0.00024 \\ 235 & 12515 & \text { MJ-519 } & \text { UMF } & 1.00 & 18.30 & 0.1515 & 0.0023 & 0.70576 & 0.000009 \\ 234 & 12516 & \text { MJ-5238-1 } & \text { UMF } & 0.50 & 6.20 & 0.2201 & 0.0031 & 0.70743 & 0.00010 \\ 234 & 12517 & \text { MJ-525 } & \text { UMF } & 0.30 & 6.40 & 0.1514 & 0.0021 & 0.70700 & 0.00009 \\ 234 & 12518 & \text { MJ-523A } & \text { UMF } & 2.60 & 472.30 & 0.0162 & 0.0002 & 0.70677 & 0.00008\end{array}$

$\begin{array}{ll}\text { c. Crispins } & \text { NT } \\ \text { c. Crispins } & \text { NT } \\ \text { c. Crispins } & \text { NT } \\ \text { c. Crispins } & \text { NT } \\ \text { c. Crispins } & \text { NT } \\ \text { c. Crispins } & \text { NT } \\ \text { C. Maias } & \text { NT } \\ \text { c. Crispins } & \text { NT } \\ \text { c. Crispins } & \text { NT } \\ \text { C. Crispins } & \text { NT } \\ \text { C. Crispins } & \text { NT } \\ \text { C. Crispins } & \text { NT } \\ \text { c. Crispins } & \text { NT } \\ \text { c. Crlspins } & \text { NT }\end{array}$




$\begin{array}{cccccccccccc}\begin{array}{c}\text { No. } \\ \text { ordem }\end{array} & \text { SPR } & \text { No Campo } & \begin{array}{c}\text { Lito } \\ \text { logia }\end{array} & \begin{array}{c}\mathrm{Rb} \\ (\mathrm{ppm})\end{array} & \begin{array}{c}\mathrm{Sr} \\ (\mathrm{ppm})\end{array} & \begin{array}{c}\mathrm{Rb}^{87} \mathrm{I} \\ \mathrm{Sr}^{88}\end{array} & \begin{array}{l}\text { Erro } \\ \mathrm{Sr}^{87} /\end{array} & \text { Erro } & \text { Localizaçáa } & \text { Ref } \\ 235 & 12519 & \text { MJ-518C } & \text { UMF } & 0.30 & 8.20 & 0.1094 & 0.0017 & 0.70005 & 0.00013 & \text { C. Crispins } & \text { NT }\end{array}$

\section{DOMINIO CURITIBA}

\begin{tabular}{|c|c|c|c|c|c|c|c|c|c|c|}
\hline 89 & 9384 & MJ-96.1 & MIG & 19.82 & 182.97 & 0.3156 & 0.0036 & 0.72072 & 0.00008 & Atuba \\
\hline 89 & 9385 & $M J-96.2$ & MIG & 29.62 & 153,86 & 0.5578 & 0.0043 & 0.71807 & 0.00007 & Atuba \\
\hline 89 & 11124 & MJ-96.3 & MIG & 115.00 & 264.00 & 1.2630 & 0.0360 & 0.72719 & 0.00008 & Atuba \\
\hline 89 & 11132 & MJ.96.3B1O & MIG & 625.00 & 46.00 & 40.8060 & 1.1120 & 1.000030 & 0.00013 & Atuba \\
\hline 89 & 11133 & MJ-96.3ANF & MIG & 179.00 & 83.00 & 6.2790 & 0.1760 & 0.76772 & 0.00006 & Atuba \\
\hline 89 & 9387 & MJ-96.4 & MIG & 111.20 & 600.00 & 0.5370 & 0.0150 & 0.72155 & 0.00006 & Atuba \\
\hline 89 & 10018 & MJ-96.5 & MIG & 126.80 & 763,00 & 0.4810 & 0.0130 & 0.71874 & 0.00005 & Atuba \\
\hline 89 & 9388 & MJ-96.6 & MIG & 76.70 & 264.70 & 0.8400 & 0.0240 & 0.72425 & 0.00007 & Atuba \\
\hline 89 & 9936 & MJ-96.7 & MIG & 102.19 & 650.04 & 0.4553 & 0.0025 & 0.71588 & 0.00020 & Atuba \\
\hline 89 & 9390 & MJ-96.8 & MIG & 113.70 & 592.50 & 0.5560 & 0.0160 & 0.72172 & 0.00006 & Atuba \\
\hline 89 & 9391 & MJ-96.12 & GRN & 245.70 & 423.10 & 1.6870 & 0.0480 & 0.74397 & 0.00006 & Atuba \\
\hline 89 & 9392 & MJ-96.13 & GRN & 162.40 & 336.20 & 1.4000 & 0.0400 & 0.74537 & 0.00007 & Atuba \\
\hline 91 & 10762 & MJ-315.A & MES & 43.50 & 685.50 & 0.1840 & 0.0050 & 0.71099 & 0.00020 & Qultandinna \\
\hline 91 & $107 \cong 3$ & MJ-315.B & MES & 51.20 & 756.00 & 0.1960 & 0.0060 & 0.71100 & 0.00010 & Quitandinha \\
\hline 91 & 10764 & MJ-315.C & LEU & 53.50 & 605.50 & 0.2560 & 0.0070 & 0.71554 & 0.000003 & Quitandinha \\
\hline 91 & 10765 & MJ-315.D & MES & 73.50 & 623.50 & 0.3410 & 0.0100 & 0.71479 & 0.00004 & Quitandinha \\
\hline 91 & 10766 & MJ-315. H & LEU & 78.50 & 536.00 & 0.4240 & 0.0120 & 0.71625 & 0.00004 & Quitandinha \\
\hline 91 & 10916 & MJ 315.E & LEU & 63.00 & 700.00 & 0.2610 & 0.0070 & 0.71504 & 0.00006 & Quitandinha \\
\hline 91 & 10917 & MJ-315.F & LEU & 37.00 & $\approx 54.00$ & 0.1640 & 0.0050 & 0.71137 & 0.00006 & Quitandinha \\
\hline 91 & 10918 & MJ-315.G & LEU & 73.00 & 562.00 & 0.3760 & 0.0110 & 0.71605 & 0.00007 & Quitandinha \\
\hline 90 & 10768 & $M J-316 . C$ & MES & 66.50 & 430.00 & 0.4480 & 0.0130 & 0.71708 & 0.00004 & Qultandinha \\
\hline 90 & 10769 & MJ-316.I & LEU & $\$ .50$ & 483.00 & 0.3950 & 0.0110 & 0.71646 & 0.00004 & Quitandinha \\
\hline 90 & 10770 & MJ-316.J & LEU & 44.50 & 481.00 & 0.2680 & 0.0800 & 0.71430 & 0.00004 & Quitandinha \\
\hline 90 & 10771 & MJ-316.1 & LEU & 31.50 & 490.00 & 0.1860 & 0.0050 & 0.71519 & 0.00004 & Quitandinha \\
\hline 90 & 10919 & MJ-316.E & L.EU & 32.00 & 294.50 & 0.3150 & 0.0090 & 0.71613 & 0.00000 & Quitandinha \\
\hline 90 & 10020 & MJ-316.F & MES & 47.00 & 336.50 & 0.4050 & 0.0110 & 0.71513 & 0.00009 & Quitandinha \\
\hline 90 & 10921 & MJ316.M & LEU & 64.00 & 433.50 & 0.4280 & 0.0120 & 0.71564 & 0.00011 & Quitandinha \\
\hline 90 & 11378 & MJ-316.8 & MES & 12.50 & 205.10 & 0.1770 & 0.0000 & 0.71205 & 0.00006 & Quttandinha \\
\hline 101 & 9045 & $M J-25.3$ & NOR & 87.60 & 288.50 & 0.8810 & 0.0250 & 0.73332 & 0.000008 & N Curittba \\
\hline 101 & 9046 & MJ-25.5 & NOR & 94.70 & 291.80 & 0.9420 & 0.0270 & 0.73430 & 0.00004 & N Curitiba \\
\hline 101 & 9047 & MJ-25.9 & NOR & 97.10 & 311.00 & 0.9060 & 0.0260 & 0.73329 & 0.00007 & N Curitiba \\
\hline 101 & 9048 & MJ-25.13 & NOR & 76.20 & 299.80 & 0.7370 & 0.0210 & 0.73115 & 0.00006 & N Curitiba \\
\hline 101 & 9049 & $M J-25.14$ & NOR & 62.80 & 282.90 & 0.6440 & 0.0180 & 0.72786 & 0.00006 & N Curitiba \\
\hline 101 & 11125 & MS-25.1 & NOR & 108.00 & 268.00 & 1.1700 & 0.0300 & 0.74069 & 0.000008 & N Curitiba \\
\hline 101 & 11126 & MJ-25.2 & NOR & 124.00 & 264.00 & 1.3650 & 0.0380 & 0.74659 & 0.00007 & N Curitiba \\
\hline 101 & 11127 & MJ-25.7 & NOR & $\$ 0.00$ & 266.00 & 0.9820 & 0.0280 & 0.73399 & 0.00009 & N Curitiba \\
\hline 101 & 11128 & $M J-25.10$ & NOR & 80.00 & 296.00 & 0.7840 & 0.0220 & 0.73312 & 0.00006 & N Curitiba \\
\hline 101 & 11129 & MJ-25.12 & NOR & 87.00 & 282.00 & 0.8950 & 0.0250 & 0.73340 & 0.00007 & N Curitiba \\
\hline 101 & UK & MJ-25.3 & NOR & 88.00 & 288.00 & 0.8870 & 0.0250 & 0.73352 & 0.00002 & N Curitiba \\
\hline $182^{*}$ & $\$ 1929$ & $M M-87 A$ & NOR & 99.30 & 358.70 & 0.8030 & 0.0230 & 0.72869 & 0.000007 & N Curitiba \\
\hline $182^{*}$ & 11930 & MM-87C & NOR & 104.80 & 354.90 & 0.8560 & 0.0240 & 0.72753 & 0.00018 & N Curtiba \\
\hline $105^{*}$ & 11931 & MM-67D & NOR & 44.20 & 420.00 & 0.3050 & 0.0000 & 0.71882 & 0.00000 & N Curitiba \\
\hline $105^{n}$ & 11932 & $M M-89 B$ & NOR & 88.90 & 362.70 & 0.7100 & 0.0200 & 0.72232 & 0.00008 & N Curttiba \\
\hline $105^{*}$ & 11933 & $M M-690$ & NOR & 72.80 & 415.40 & 0.5080 & 0.0140 & 0.72186 & 0.00000 & N Curitiba \\
\hline 183 & 11934 & MM-OSA & NOR & 87.80 & 246.70 & 1.0330 & 0.0290 & 0.74015 & 0.000006 & N Curitiba. \\
\hline 183 & 11935 & MM-95B & NOR & 92.30 & 229.30 & 1.1650 & 0.0330 & 0.70911 & 0.00006 & N Curitiba \\
\hline
\end{tabular}




\begin{tabular}{|c|c|c|c|c|c|c|c|c|c|c|c|}
\hline $\begin{array}{l}\text { No. } \\
\text { ordem }\end{array}$ & SPR & No Campo & $\begin{array}{l}\text { Lito } \\
\text { logia }\end{array}$ & $\begin{array}{c}\mathrm{Rb} \\
(\mathrm{ppm})\end{array}$ & $\begin{array}{c}\mathrm{Sr} \\
(\mathrm{ppm})\end{array}$ & $\begin{array}{l}\mathrm{Rb}^{87 /} \\
\mathrm{Sr}^{8 \mathrm{~B}}\end{array}$ & Erro & $\begin{array}{l}\mathrm{Sr}^{877} \\
\mathrm{Sr}^{8 \mathrm{~g}}\end{array}$ & Erro & lizaçăo & Ref \\
\hline 105 & 12258 & MM-89A & NOR & 67.00 & 394.00 & 0.4920 & & 0.71998 & 0.00007 & N Curitiba & 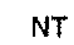 \\
\hline 105 & 12259 & MM-89C & NOR & 87.00 & 409.00 & 0.6160 & & 0.72198 & 0.00009 & N Curitiba & 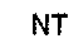 \\
\hline 96 & 12024 & MJ.550 & GNS & 73.30 & 609.90 & 0.3480 & 0.0010 & 0.71517 & 0.00006 & BR-116 & VT \\
\hline * & 12025 & MJ-633A & GNS & 14.58 & 489.05 & 0.0863 & 0.0013 & 0.70943 & 0.00006 & BR-116N & \\
\hline 184 & 12026 & MJ- $634 A$ & GNS & 87.99 & 1558.98 & 0.1133 & 0.0023 & 0.70783 & 0.00007 & BR-116 & IT \\
\hline 103 & 12027 & MJ-@36A & GNS & 76.80 & 455.70 & 0.4880 & 0.0140 & 0.71967 & 0.00012 & BR-116 & 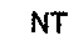 \\
\hline 102 & 12028 & MS-G38A & GNS & 81.24 & 451.27 & 0.5219 & 0.0079 & 0.72460 & 0.00009 & BR-116 & NT \\
\hline 102 & 12029 & MJ-638B & GNS & 81.46 & 546.51 & 0.4319 & 0.0063 & 0.72077 & 0.00006 & BR-116 & 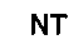 \\
\hline 102 & 12030 & MJ-638C & GNS & 89.34 & 427.13 & 0.6064 & 0.0090 & 0.72480 & 0.00007 & BR-116 & IT \\
\hline 86 & 11380 & MJ-138 & GNS & 77.00 & 656.80 & 0.3390 & 0.0100 & 0.71371 & 0.00009 & N Mandirituba & \\
\hline 87 & 11379 & MJ-23=137 & GNS & 2.30 & 198.70 & 0.0342 & 0.0006 & 0.70370 & 0.00005 & N Mandirituba & \\
\hline 87 & UK & MJ-137 & GNS & 1.00 & 197.00 & 0.0150 & 0.0010 & 0.70389 & 0.00001 & N Mandirituba & $\mathbf{S T}$ \\
\hline 88 & UK & $M J-123 . A$ & GNS & 88.00 & 882.00 & 0.2890 & 0.0080 & 0.70896 & 0.00002 & S Mandirituba & NT \\
\hline 186 & 132 & PG-02 & MIG & 148.00 & 110.40 & 3.9000 & 0.2000 & 0.74400 & 0.00300 & E Curitiba & 7 \\
\hline 73 & 130 & A.30B & MIG & 14.60 & 420.00 & 0.1010 & 0.0050 & 0.71400 & 0.00400 & NE Curittba & 37 \\
\hline * & 4614 & $873-J C-244$ & MIG & 53.50 & 467.10 & 0.3300 & 0.0100 & 0.71680 & 0.00080 & S Campo Largo & 14 \\
\hline 101 & 3811 & SC-93.C & LEU & 248.60 & 313.90 & 2.3000 & 0.0500 & 0.75850 & 0.00170 & N Curitiba & 84 \\
\hline 101 & 2298 & SC-93.D & LEU & 194.70 & 331.00 & 1.7100 & 0.0500 & 0.74900 & 0.00090 & N Curtiba & 24 \\
\hline $187^{*}$ & $37 \oplus 0$ & FB-74.B & GNS & 131.20 & 277.20 & 1.3800 & 0.0300 & 0.74500 & 0.00100 & $N$ Curtiba & 04 \\
\hline $187^{\star}$ & 2296 & $\mathrm{FB}-74 . \mathrm{C}$ & GNS & 123.70 & 317.00 & 1.1300 & 0.0300 & $0.737 \infty 0$ & 0.00110 & N Curitiba & 04 \\
\hline $187^{*}$ & 3812 & FB-74.A & GNS & 96.90 & 154.10 & 1.8300 & 0.0400 & 0.75250 & 0.00060 & $N$ Curtitiba & 04 \\
\hline 90 & 11817 & MJ-462A & $\mathrm{AES}(\mathrm{B} \mid \mathrm{O})$ & 498.11 & 25.88 & 58.3937 & 0.8100 & 1.20215 & 0.00024 & Quitandinha & $\mathrm{NT}$ \\
\hline 90 & 11718 & MJ-462A & MES(ANF) & 94.90 & 78.00 & 3.5370 & 0.1000 & 0.75386 & 0.00010 & Qultandinha & NT \\
\hline 90 & 11719 & MJ-462A & MES(RTO) & $\varpi 9.20$ & 417.80 & 0.4800 & 0.0140 & 0.71811 & 0.00008 & Qultandinha & IT \\
\hline 90 & 11820 & MJ-462C & LEU(BIO) & 303.37 & 25.22 & 35.9817 & 0.5003 & 1.03776 & 0.00026 & Quitandinha & NT \\
\hline 90 & 11721 & MJ-462C & LEU(ANF) & 20.90 & 60.60 & 1.0000 & 0.0280 & 0.72249 & 0.00005 & Quitandinha & NT \\
\hline 90 & 11722 & MJ-462C & LEU(RTO) & 24.52 & 531.07 & 0.1337 & 0.0018 & 0.71346 & 0.00007 & Quttandinha & NT \\
\hline 90 & $\{1821$ & MJ-462D & $\mathrm{MOB}(\mathrm{BIO})$ & 446.25 & 17.14 & 80.2785 & 1.2503 & 1.37834 & 0.00011 & Quitandinha & JT \\
\hline 90 & 11724 & MJ $-462 D$ & MOB(K-F) & 173.20 & 559.40 & 0.8970 & 0.0250 & 0.72231 & 0.00010 & Quitandinha & IT \\
\hline 90 & 11726 & MJ-462D & MOB(ANF) & 67.80 & 42.30 & 4. 6570 & 0.1310 & 0.74663 & 0.00006 & Quitandinha & TT \\
\hline 130 & 10820 & MJ-292.C & GNS & 98.00 & 631.00 & 0.4500 & 0.0130 & 0.71533 & 0.00006 & Graciosa & NT \\
\hline 217 & 10823 & MJ-294.1 & GNS & 32.50 & 618.00 & 0.1520 & 0.0040 & 0.70618 & 0.00005 & Graciosa & IT \\
\hline 249 & UK & MJ-296 & GNS & 28.00 & 560.00 & 0.1450 & 0.0040 & 0.70607 & 0.00002 & Graciosa & F \\
\hline
\end{tabular}

\section{GRANITÓIDES DEFORMADOS PIEN}

\begin{tabular}{|c|c|c|c|c|c|c|c|c|c|c|c|}
\hline 224 & 10796 & PIEN-01 & GRN & 88.00 & 1249.00 & 0.2040 & 0.0060 & 0.70819 & 0.00006 & Pien & NT \\
\hline 224 & 10797 & PIEN-D3 & GRN & 111.00 & 1210.50 & 0.2650 & 0.0080 & 0.70895 & 0.00006 & Pien & NT \\
\hline 224 & 10798 & PIEN-06 & GRN & 59.00 & 1297.50 & 0.1320 & 0.0040 & 0.70584 & 0.00006 & Pien & NT \\
\hline 224 & 10799 & PIEN-OB & GRN & 42.00 & 2761.00 & 0.0440 & 0.0010 & 0.70493 & 0.00006 & Piên & NT \\
\hline 224 & 10800 & PIEN-OO & GRN & 108.50 & 514.00 & 0.6110 & 0.0170 & 0.71282 & 0.00005 & Pien & NT \\
\hline 224 & $\mathrm{CF}$ & Pl.05 & GRN & & & 0.3370 & 0.0030 & 0.70948 & 0.00007 & Plen & 19 \\
\hline 224 & $\mathrm{CF}$ & Pl-07 & GRN & & & 0.2660 & 0.0030 & 0.70692 & 0.00007 & Pien & 19 \\
\hline 224 & CF & P1-08 & GRN & & & 0.0363 & 0.0010 & 0.70490 & 0.00007 & Piên & 19 \\
\hline 224 & $\mathrm{CF}$ & PI-DO & GRN & & & 0.6740 & 0.0070 & 0.71270 & 0.00007 & Plen & 19 \\
\hline 224 & $\mathrm{CF}$ & Pl-12 & GRN & & & 0.1530 & 0.0020 & 0.70860 & 0.00007 & Pien & 19 \\
\hline 225 & 10923 & MJ-AM-20 & GRN & 83.50 & 1376.50 & $0.17 \infty$ & 0.0050 & 0.70830 & 0.00012 & Plen & NT \\
\hline 226 & 10922 & MJ-AM-16 & GRN & 103.50 & 1270.00 & 0.2360 & 0.0070 & 0.70853 & 0.00011 & Plên & NT \\
\hline 122 & 10925 & MJ-AM-94 & GRN & 106.50 & 1240.00 & 0.2490 & 0.0070 & 0.70667 & 0.00011 & Pién & $\mathrm{NT}$ \\
\hline 63 & 10024 & MJ-AM-22 & GRN & 122.50 & 1206.50 & 0.2940 & 0.0080 & 0.70684 & 0.00007 & Pien & NT \\
\hline
\end{tabular}




\begin{tabular}{crl}
$\begin{array}{c}\text { No. } \\
\text { ordem }\end{array}$ & SPR & \multicolumn{1}{c}{ No Campo } \\
227 & 10927 & MJ-AM-97 \\
228 & 10926 & MJ-AM-95 \\
229 & 549 & VG-257 \\
230 & 530 & VG-152.B \\
231 & 531 & VG-162
\end{tabular}

\begin{tabular}{|c|c|c|c|c|c|c|c|c|}
\hline $\begin{array}{l}\text { Lito } \\
\text { logia }\end{array}$ & $\begin{array}{c}\mathrm{Rb} \\
(\mathrm{ppm})\end{array}$ & $\begin{array}{c}\mathrm{Sr} \\
(\mathrm{ppm})\end{array}$ & $\begin{array}{c}\mathrm{Rb}^{87} / \\
\mathrm{Sr}^{88}\end{array}$ & Erro & $\begin{array}{l}\mathrm{Sr}^{87} \mathrm{I} \\
\mathrm{Sr}^{86}\end{array}$ & Erro & Localizaçáo & Ref \\
\hline GRN & 59.00 & 1697.50 & 0.1010 & 0.0030 & 0.70645 & 0.00021 & Piến & NT \\
\hline GRN & 156.50 & 714.50 & 0.6340 & 0.0180 & 0.70991 & 0.00007 & Pien & NT \\
\hline MIG & 166.90 & 159.00 & 3.0430 & 0.0000 & 0.73610 & 0.00070 & Piên & $\infty$ \\
\hline MIG & 77.20 & 210.00 & 1.0630 & 0.0200 & 0.71710 & 0.00120 & Pien & $\infty$ \\
\hline MIG & 123.80 & 82.60 & 4.3560 & 0.0000 & 0.74890 & 0.00080 & Piên & $\infty$ \\
\hline
\end{tabular}

\section{DOMINIO PARANAGUÁ}

\begin{tabular}{|c|c|c|c|c|c|c|c|c|c|c|c|}
\hline 106 & 9622 & $M J-206.2$ & GRN & 128.20 & 412.10 & 0.9010 & 0.0250 & 0.71553 & 0.00005 & Paranaguá & NT \\
\hline 106 & 9623 & MJ-206.4 & GRN & 136.40 & 408.20 & 0.9680 & 0.0270 & 0.71573 & 0.00007 & Paranaguá & NT \\
\hline 106 & 9624 & MJ-206.5 & GRN & 145.00 & 391.50 & 1.0730 & 0.0300 & 0.71643 & 0.00005 & Paranaguá & NT \\
\hline 188 & 9625 & MJ-207 & GRN & 138.50 & 425.90 & 0.9420 & 0.0300 & 0.71566 & 0.00008 & Paranaguá & NT \\
\hline 106 & 9751 & MJ-206.6 & GRN & 211.70 & 420.80 & 1.4580 & 0.0400 & 0.71911 & 0.00004 & Paranaguá & NT \\
\hline 106 & 9752 & MJ-206.7 & GRN & 212.80 & 439.90 & 1.4020 & 0.0400 & 0.71877 & 0.00004 & Paranaguá & NT \\
\hline 189 & UK & $M J-208 . A$ & GRN & 139.00 & 187.00 & 2.1510 & 0.0000 & 0.72701 & 0.00002 & Paranaguá & NT \\
\hline 144 & 9632 & MJ-287.A & GRN & 161.30 & 298.50 & 1.5660 & 0.0400 & 0.72056 & 0.00007 & Guaratuba & NT \\
\hline 144 & UK & $M J-287 . A$ & GRN & 137.00 & 248.00 & 1.5080 & 0.0400 & 0.72115 & 0.00002 & Guaratuba & NT \\
\hline 144 & 9633 & MJ-287.B & GRN & 156.90 & 212.30 & 2.1430 & 0.0600 & 0.72531 & 0.00007 & Guaratuba & NT \\
\hline 144 & 9634 & $M J-287 . C$ & GRN & 191.40 & 430.20 & 1.2890 & 0.0400 & 0.71841 & 0.00005 & Guaratuba & NT \\
\hline 144 & 9635 & MJ-287.D & GRN & 156.80 & 407.70 & 1.1140 & 0.0500 & 0.71713 & 0.00007 & Guaratuba & NT \\
\hline 108 & 10465 & MJ-304.B & GRN & 163.70 & 330.50 & 1.4350 & 0.0400 & 0.74945 & 0.00006 & Matinhos & $\mathrm{NT}$ \\
\hline 108 & 10466 & MJ-301.C & GRN & 162.70 & 289.20 & 1.6300 & 0.0500 & 0.72057 & 0.00006 & Matinhos & NT \\
\hline 108 & 10467 & MJ-301.E & GRN & 208.60 & 256.00 & 2.3630 & 0.0700 & 0.72722 & 0.00001 & Matinhos & NT \\
\hline 108 & 10468 & $M J-301 . G$ & GRN & 139.90 & 320.60 & 1.2640 & 0.0400 & 0.71869 & 0.00006 & Matinhos & $\mathrm{NT}$ \\
\hline 108 & 10460 & MJ-301.M & GRN & 186.90 & 242.70 & 2.2330 & 0.0600 & 0.72613 & 0.00005 & Matinhos & NT \\
\hline 108 & UK & MJ-301.E & GRN & 187.00 & 238.00 & 2.2730 & 0.0500 & 0.72705 & 0.00001 & Matinhos & NT \\
\hline 117 & 4619 & JC-DT-103 & GRD & 109.60 & 505.00 & $0 . \Subset 00$ & 0.0100 & 0.71560 & 0.00260 & S Fr. Sul & 14 \\
\hline 190 & 5452 & PK-216 & BML & 75.10 & 844.20 & 0.2600 & 0.0100 & 0.71230 & 0.00050 & S Fr. Sul & 14 \\
\hline 191 & 5453 & PK-217 & GRN & 271.10 & 160.90 & 4.9000 & 0.1000 & 0.75250 & 0.00140 & S Fr. Sul & 14 \\
\hline * & 5454 & PK-158 & GRN & 166.30 & 170.10 & 2.8400 & 0.0600 & 0.74550 & 0.00090 & Ararapira & 14 \\
\hline 115 & 4156 & $J C-417$ & PML & 147.00 & 182.80 & 2.3300 & 0.0500 & 0.73140 & 0.00070 & Garuva & 14 \\
\hline 119 & 4618 & LK-2O & GRN & 219.10 & 62.70 & 10.2000 & 0.2000 & 0.79470 & 0.00110 & Guaraqueçaba & 14 \\
\hline 212 & 9858 & MJ-279.AVB & GRN & 202.60 & 1079.00 & 0.5440 & 0.0030 & 0.71347 & 0.00007 & Estrela & NT \\
\hline 213 & 9650 & $M J-285 . A$ & GRN & 92.00 & 451.50 & 0.5900 & 0.0170 & 0.71232 & 0.00003 & Estrela & NT \\
\hline 214 & 9860 & $M J-284$ & GRN & 95.60 & $318 . \infty$ & 0.8690 & 0.0250 & 0.71404 & 0.00006 & Estreta & NT \\
\hline 213 & 9861 & MJ-285.B & GRN & 96.00 & 500.20 & 0.5560 & 0.0160 & 0.71243 & 0.00007 & Estrela & NT \\
\hline 214 & UK & MJ-284 & GRN & 97.00 & 298.00 & 0.9430 & 0.0260 & 0.71336 & 0.00002 & Estrela & NT \\
\hline 128 & 10937 & $M J-283$ & GRN & 96.60 & 287.40 & 0.9740 & 0.0270 & 0.71540 & 0.00006 & Estrela & NT \\
\hline 215 & 11250 & $M J-411.8$ & GRN & 164.00 & 597.00 & 0.7950 & 0.0220 & 0.71270 & 0.00011 & Estrela & NT \\
\hline 216 & 11251 & $M J-412$ & GRN & 82.00 & 347.00 & 0.6840 & 0.0190 & 0.71303 & 0.00012 & Estrela & NT \\
\hline 127 & 11252 & $M J-413 . A$ & GRN & 114.00 & 217.50 & 1.5180 & 0.0430 & 0.71776 & 0.00009 & Estrela & NT \\
\hline 127 & 11253 & $M J-413 . B$ & GRN & 121.00 & 211.50 & 1.6570 & 0.0470 & 0.71787 & 0.00007 & Estrela & NT \\
\hline 192 & 11254 & $M S-414$ & GRN & 80.50 & 269.00 & 0.8670 & 0.0240 & 0.71473 & 0.00008 & Estrela & NT \\
\hline
\end{tabular}

\section{MACIÇOS GRANITICOS}

$\begin{array}{llll}193 & 9626 & \text { MJ-109-B.3 } & \text { GRN } \\ 193 & 9627 & \text { MJ-109-C.2 } & \text { GRN } \\ 193 & 9631 & \text { MJ-109-D.1 } & \text { GRN } \\ 194 & 9629 & \text { MJ-128.B } & \text { GRN }\end{array}$

$\begin{array}{llllll}171.80 & 257.10 & 1.9370 & 0.0550 & 0.72338 & 0.00005 \\ 178.50 & 214.30 & 2.4150 & 0.0580 & 0.72668 & 0.00006 \\ 174.30 & 232.50 & 2.1730 & 0.0610 & 0.72494 & 0.00008 \\ 183.00 & 170.60 & 3.1120 & 0.0880 & 0.73361 & 0.00005\end{array}$

Agudios

Agudos

Agudos

Agudos

NT
NT
NT 


\begin{tabular}{|c|c|c|c|c|c|c|c|c|c|c|}
\hline $\begin{array}{c}\text { No. } \\
\text { ordem }\end{array}$ & SPR & No Campo & $\begin{array}{l}\text { Lito } \\
\text { logia }\end{array}$ & $\begin{array}{c}\mathrm{Rb} \\
(\mathrm{ppm})\end{array}$ & $\begin{array}{c}\mathrm{Sr} \\
\text { (ppm) }\end{array}$ & $\begin{array}{l}\mathrm{Rb}^{87} / \\
\mathrm{Sr}^{88}\end{array}$ & Erro & $\begin{array}{l}\mathrm{Sr}^{87 /} \\
\mathrm{Sr}^{86}\end{array}$ & Erro & Localizaçáo \\
\hline 194 & 9630 & $M J-128 . A$ & GRN & 227.00 & 145.20 & 4.5400 & 0.1280 & 0.74317 & 0.00005 & Agudos \\
\hline 195 & 9934 & $M J-131$ & GRN & 91.90 & 1212.20 & - 0.2190 & 0.0010 & 0.70737 & 0.00000 & Agudos \\
\hline 196 & 9935 & $M J-129 . A$ & GRN & 85.10 & 1043.80 & 0.2360 & -0.0010 & 0.70728 & 0.00006 & Agudos \\
\hline 194 & UK & $M N-128 . A$ & GRN & 198.00 & 131.00 & 4.3000 & 0.1230 & 0.74332 & 0.00002 & Agudos \\
\hline 193 & UK & MJ-100-A.1 & GRN & 194.00 & 253.00 & 2.2230 & 0.0620 & 0.72505 & 0.00002 & Agudos \\
\hline 125 & 11116 & MJ-17-RTO & GRN & 60.30 & 1346.60 & 0.1300 & 0.0040 & 0.70734 & 0.00057 & Agudos \\
\hline 125 & 11117 & MJ-17-ANF & GRN & 113.00 & 363.00 & 0.9000 & 0.0260 & 0.71024 & 0.00008 & Agudos \\
\hline 125 & 14118 & $M J-17-B I O$ & GRN & 384.00 & 263.00 & 4.2250 & 0.1190 & 0.73152 & 0.00006 & Agudos \\
\hline 197 & 540 & VG-227 & GRN & 187.00 & 153.50 & 3.5360 & 0.0100 & 0.73430 & 0.00090 & Agudos \\
\hline 198 & 9000 & $M J-6 . A$ & GRN & 81.80 & 69.80 & 3.3000 & 0.0960 & 0.73033 & 0.00006 & Corupa \\
\hline 198 & 9401 & 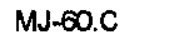 & GRN & 104.10 & 42.90 & 7.0540 & 0.1990 & 0.75245 & 0.00008 & Corupa \\
\hline 198 & 9400 & $M J-\infty . B$ & GRN & 124.10 & 23.00 & 15.8110 & 0.1900 & 0.81113 & 0.00510 & Corupa \\
\hline 199 & 9402 & MJ-58,3 & GRN & 89.70 & 66.30 & 3.9260 & 0.1110 & 0.73387 & 0.00006 & Corupa \\
\hline 199 & 10019 & MJ-58.2 & GRN & 1036.00 & 28.50 & 10.6000 & 0.5720 & 0.780003 & 0.00025 & Corupa \\
\hline 200 & 4860 & JC-DT-74 & SIE & 132.60 & 12.30 & 31.9180 & 0.7270 & 0.97170 & 0.00000 & Corupa \\
\hline 201 & 4636 & PK-CW-62 & GRN & 190.50 & 13.10 & 46.9200 & 1.0740 & 1.00950 & 0.00080 & Corupa \\
\hline 134 & 4620 & PK-CW-61 & GRN & 49.00 & 46.40 & 3.0600 & 0.0600 & 0.72830 & 0.00080 & Corupa \\
\hline 202 & 9753 & MJ-275.1 & GRN & 45.20 & 37.50 & 3.5030 & 0.0210 & 0.75743 & 0.00020 & M. Redondo \\
\hline 202 & 11302 & MJ-275.IMR & GRN & 41.50 & 24.85 & 4.8589 & 0.0859 & 0.760085 & 0.00020 & M. Redondo \\
\hline 202 & UK & $M J-275 . B$ & GRN & 144.00 & 3.00 & 163.6790 & 1.0000 & 2.51520 & 0.00040 & M. Redondo \\
\hline 202 & 10033 & MJ-275.F-1 & GRN & 157.30 & 10.20 & 45.6680 & 0.7720 & 0.90540 & 0.00031 & M. Redondo \\
\hline 2003 & 9754 & $M J-281 . A$ & GRN & 140.00 & 15.50 & 26.8510 & 0.1800 & 0.95804 & 0.00060 & M. Redondo \\
\hline 200 & 9755 & $M J-281.8$ & GRN & 127.70 & 23.40 & 16.0920 & 0.0980 & 0.88692 & 0.00021 & M. Redondo \\
\hline 2003 & 11304 & MJ-281.B-R & GRN & 126.99 & 17.37 & 21.5208 & 0.3660 & 0.88478 & 0.00037 & M. Redondo \\
\hline 204 & 9756 & $M J-276$ & GRN & 172.70 & 16.30 & 31.6320 & 0.1980 & 0.99731 & 0.00041 & M. Redondo \\
\hline 204 & 11305 & MJ-276.R & GRN & 162.53 & 12.40 & 39.0493 & 0.7117 & 1.00948 & 0.00145 & M. Redondo \\
\hline 205 & 12045 & $M J-658$ & GRN & 140.90 & 52.90 & 7.7560 & 0.2180 & 0.76979 & 0.00012 & M. Redondo \\
\hline 206 & 4615 & PK-CW-66 & GRN & 148.10 & 62.70 & 6.8700 & 0.1400 & 0.76700 & 0.00120 & M. Redondo \\
\hline 207 & UK & $M J-163 . A$ & GRN & 51.00 & 39.00 & 3.7950 & 0.1060 & 0.73666 & 0.00002 & Corupa \\
\hline 207 & 10009 & $M J-163 . B$ & GRN & 44.60 & 35.80 & 3.6150 & 0.1010 & 0.73432 & 0.00007 & Corupa \\
\hline 207 & 10040 & $M J-163 . C$ & GRN & 40.60 & 33.20 & 3.5490 & 0.0990 & 0.73565 & 0.00008 & Corupa \\
\hline 207 & 10941 & MJ-163.D & GRN & 36.80 & 53.10 & 2.0000 & 0.0560 & 0.72250 & 0.00008 & Corupa \\
\hline 208 & 10942 & MJ-164 & GRN & 36.80 & 48.10 & 2.2180 & 0.0620 & 0.72487 & 0.00011 & Corupa \\
\hline 209 & 10043 & MJ-165 & GRN & 26.70 & 79.20 & 0.9770 & 0.0270 & 0.71923 & 0.00007 & Corupa \\
\hline 210 & 9757 & $M J-291 . A$ & GRN & 190.50 & 27.40 & 20.5080 & 0.1160 & 0.89625 & 0.00029 & Anhangava \\
\hline 210 & 11350 & MJ-291.H & GRN & 133.10 & 23.80 & 16.4260 & 0.2780 & 0.87003 & 0.00067 & Anhangava \\
\hline 210 & 11351 & MJ-291.I & GRN & 133.40 & 27.20 & 14.3700 & 0.2410 & 0.83711 & 0.00014 & Anhangava \\
\hline 210 & 11352 & MJ-291.J & GRN & 222.70 & 23.00 & 28.7210 & 0.4920 & 0.96638 & 0.00084 & Anhangava \\
\hline 210 & 11531 & MJ-291.C & GRN & 194.98 & 12.87 & 45.3889 & 0.8515 & 1.06651 & 0.00044 & Anhangava \\
\hline 210 & UK & MJ-291.C & GRN & 193.00 & 11.00 & 52.5790 & 1.4720 & 1.06716 & 0.00005 & Anhangava \\
\hline 210 & 10935 & MJ-291.8 & GRN & 220.80 & 25.30 & 25.9220 & 0.4360 & 0.97146 & 0.00024 & Anhangava \\
\hline 211 & 133 & $M 0-150$ & GRN & 225.00 & 92.50 & 7.0500 & 0.1400 & 0.76000 & 0.00050 & Anhangava \\
\hline 130 & 10821 & MJ-292.E & GRN & 140.50 & 353.50 & 1.2070 & 0.0330 & 1.20549 & 0.00010 & Graciosa \\
\hline 217 & 10822 & MJ-294.2 & GRN & 110.00 & 595.00 & 0.5350 & 0.0150 & 0.71224 & 0.00006 & Graciosa \\
\hline 218 & 10824 & MJ-297 & GRN & 47.50 & $471 . \infty$ & 0.2920 & 0.0080 & 0.70050 & 0.00008 & Graciosa \\
\hline 220 & 11135 & MJ-298.3 & GRN & 37.00 & 492.00 & 0.2180 & 0.0060 & 0.70628 & 0.00007 & Graciosa \\
\hline 221 & 12021 & MJ-614 & GRN & 200.00 & 190.70 & 3.0430 & 0.0860 & 0.73335 & 0.00008 & Graciosa \\
\hline 222 & 120022 & MJ-615 & GRN & 179.00 & 133.40 & 3.8970 & 0.1100 & 0.74320 & 0.00013 & Graciosa \\
\hline 85 & 12023 & MJ-640 & GRN & 206.60 & 123.40 & 4.8640 & 0.1370 & 0.74679 & 0.00006 & Graciosa \\
\hline 186 & 128 & $P G-3$ & GRN & 148.00 & 428.00 & 0.9800 & 0.0200 & 0.71900 & 0.00050 & Graciosa \\
\hline
\end{tabular}




\begin{tabular}{|c|c|c|c|c|c|c|c|c|c|c|}
\hline $\begin{array}{l}\text { No. } \\
\text { ordem }\end{array}$ & SPR & No Campo & $\begin{array}{l}\text { Lito } \\
\text { logia }\end{array}$ & $\begin{array}{c}\mathrm{Rb} \\
(\mathrm{ppm})\end{array}$ & $\begin{array}{c}\mathrm{Sr} \\
(\mathrm{ppm})\end{array}$ & $\begin{array}{l}\mathrm{Rb}^{87} / \\
\mathrm{Sr}^{86}\end{array}$ & Erro & $\begin{array}{l}\mathrm{Sr}^{87} / \\
\mathrm{Sr}^{86}\end{array}$ & Erro & Localizaçăo \\
\hline 223 & 129 & $A-294 . B$ & GRN & 182.00 & 108.00 & 4.8800 & 0.1000 & 0.74700 & 0.00060 & Graciosa \\
\hline 100 & 126 & A -469 & GRN & 185.00 & 131.60 & 4.0600 & 0.0900 & 0.74200 & 0.00030 & Graciosa \\
\hline 135 & 114 & MO-257 & GRN & 202.00 & 17.30 & 33.7100 & 0.6600 & 0.97000 & 0.11000 & Marumby \\
\hline 232 & 537 & VG-181 & GRN & 58.90 & 1490.00 & 0.1140 & 0.0010 & 0.70500 & 0.00070 & Pien \\
\hline 233 & 538 & VG-200 & GRN & 96.00 & 280.30 & 0.9920 & 0.0200 & 0.71250 & 0.00020 & Plên \\
\hline
\end{tabular}

\section{ROCHAS VULCÅNICAS}

\begin{tabular}{|c|c|c|c|c|c|c|c|c|c|c|}
\hline 238 & 4634 & LKK-40 & RIO & 222.00 & 11.90 & 55.7660 & 1.3020 & 1.12610 & 0.00110 & Guaratub. \\
\hline 239 & 5163 & $\mathrm{JC}-494$ & RIO & 236.80 & 9.34 & $77.7 £ \infty 0$ & 1.6730 & 1.31540 & 0.00210 & Guaratub. \\
\hline 240 & 5158 & $\mathrm{JC}-499$ & DIA & 27.20 & 525.00 & 0.1500 & 0.0010 & 0.70650 & 0.00120 & Guaratub. \\
\hline 241 & 11496 & $M J-376-1$ & RIO & 228.60 & 22.00 & 30.7990 & 0.0862 & 0.95245 & 0.00008 & Guaratub. \\
\hline 241 & 11497 & $M J-376-2$ & RIO & 225.30 & 24.28 & 27.5118 & 0.5514 & 0.95938 & 0.00010 & Guaratub. \\
\hline 241 & 11498 & $M J-376-3$ & RIO & 256.30 & 18.60 & 41.0020 & 1.1510 & 1.01571 & 0.00056 & Guaratub. \\
\hline 241 & 11490 & MJ-376-4 & RIO & 219.00 & 17.71 & 36.9687 & 0.7411 & 1.04303 & 0.00033 & Guaratub. \\
\hline 241 & 10948 & MJ-376-5 & RIO & 194.30 & 19.05 & 29.8296 & 0.5019 & 0.94783 & 0.00024 & Guaratub. \\
\hline 241 & 11501 & $M J-376-7$ & RIO & 262.00 & 26.79 & 28.9824 & 0.5808 & 0.95267 & 0.00007 & Guaratub. \\
\hline 241 & 11502 & MJ-376 & RIO & 234.70 & 21.91 & 31.8157 & $0 . ळ 76$ & 0.97692 & 0.00021 & Guaratub. \\
\hline 241 & 11503 & MJ-376-10 & RIO & 240.30 & 21.81 & 32.7990 & 0.6574 & 0.99934 & 0.00013 & Guaratub. \\
\hline 241 & 11800 & MJ-376-8 & RIO & 232.42 & 21.91 & 31.4673 & 0.4551 & 0.96451 & 0.00017 & Guaratub. \\
\hline 241 & 11798 & $B-1-G$ & RIO & 214.54 & 9.61 & 68.2396 & 0.9455 & 1.28346 & 0.00009 & Guaratub. \\
\hline 241 & 11799 & $A-4-1-G$ & RIO & 213.80 & 12.93 & 49.7407 & 0.7213 & 1.10781 & 0.00000 & Guaratub. \\
\hline 241 & 12039 & $M J-376-A$ & RIO & 207.44 & 24.79 & 24.6863 & 0.3414 & 0.90506 & 0.00007 & Guaratub. \\
\hline 241 & 12040 & MJ $376-8$ & RIO & 217.50 & 23.04 & 27.9430 & 0.3861 & 0.93870 & 0.00010 & Guaratub. \\
\hline 241 & 12041 & MJ-376-F & RIO & 446.65 & 22.14 & 59.8667 & 0.9152 & 0.96266 & 0.00013 & Guaratub. \\
\hline 241 & 12042 & $M J-376-G$ & RIO & 235.33 & 19.26 & 36.3976 & 0.5090 & 1.00246 & 0.00013 & Guaratub. \\
\hline 241 & 12043 & MJ-376-K & RIO & 226.87 & 18.61 & 36.2839 & 0.5019 & 0.99498 & 0.00008 & Guaratub. \\
\hline 241 & 12044 & MJ-376-L & RIO & 118.30 & 86.60 & 6.3260 & 0.1780 & 0.76128 & 0.00006 & Guaratub. \\
\hline 242 & 11255 & $M J-415 . A$ & RIO & 162.00 & 204.00 & 2.3020 & 0.0050 & 0.72390 & 0.00007 & C. Alegre \\
\hline 242 & 11256 & $M J-415 . B$ & RIO & 145.50 & 238.00 & 1.7720 & 0.0500 & 0.72040 & 0.00009 & C. Alegre \\
\hline 243 & 11257 & MJ-416 & RIO & 112.50 & 258.00 & 1.2630 & 0.0360 & 0.71827 & 0.00013 & C. Alegre \\
\hline 244 & 11258 & $M J-418$ & RIO & 95.50 & 47.00 & 5.9060 & 0.1660 & 0.75176 & 0.00008 & C. Alegre \\
\hline 245 & 11259 & $M J-420$ & RIO & 212.00 & 728.00 & 0.8430 & 0.0240 & 0.71449 & 0.00007 & C. Alegre \\
\hline 242 & 4344 & SCMB $-45 A$ & RIO & 150.00 & 246.00 & 1.7700 & 0.0400 & 0.72100 & 0.00070 & C. Alegre \\
\hline 242 & 4345 & $S C M B-45 C$ & RIO & 156.00 & 217.00 & 2.0800 & 0.0500 & 0.72420 & 0.00080 & C. Alegre \\
\hline 242 & 4346 & SCMB-45E & RIO & 140.00 & 311.00 & 1.3100 & 0.0300 & 0.71790 & 0.00060 & C. Alegre \\
\hline * & 48 & VL-A & QPF & 195.00 & 25.60 & 22.8000 & 0.4500 & 0.84600 & 0.00500 & Castro \\
\hline * & 52 & VL.CC & QPF & 103.00 & 43.80 & 6.8000 & 0.1400 & 0.74700 & 0.00100 & Castro \\
\hline$*$ & 5 & VL-B & QPF & 87.50 & 50.00 & 5.0600 & 0.1000 & 0.74200 & 0.00400 & Castro \\
\hline * & 11792 & RCA-78A & RIO & 112.00 & 82.40 & 3.9450 & 0.1110 & 0.73636 & 0.00010 & Castro \\
\hline * & 11793 & RCA-78B & RIO & 102.80 & 59.80 & 4.9990 & 0.1410 & 0.75647 & 0.00000 & Castro \\
\hline * & 11794 & RCA-78C & RIO & 132.60 & 55.90 & 6.9060 & 0.1940 & 0.76762 & 0.00007 & Castro \\
\hline * & 11796 & RCA-7BE & RIO & 155.79 & 26.69 & 17.0024 & 0.2365 & 0.82667 & 0.00011 & Castro \\
\hline * & 11796 & RCA-78F & RIO & 136.00 & 40.70 & 9.7590 & 0.2730 & 0.80050 & 0.00013 & Castro \\
\hline - & 11797 & RCA-78G & RIO & 168.54 & 35.58 & 13.8320 & 0.1918 & 0.79869 & 0.00007 & Castro \\
\hline * & 12158 & $\mathrm{RCA}-5 \mathrm{~B}$ & AND & 30.94 & 394.62 & 0.2269 & 0.0032 & 0.70680 & 0.00007 & Castro \\
\hline * & 12159 & RCA-5E & AND & 28.72 & 404.93 & 0.2052 & 0.0031 & 0.70675 & 0.00017 & Castro \\
\hline
\end{tabular}




\section{DADOS RADIOMÉTRICOS U.Pb - ZIRCÕES}

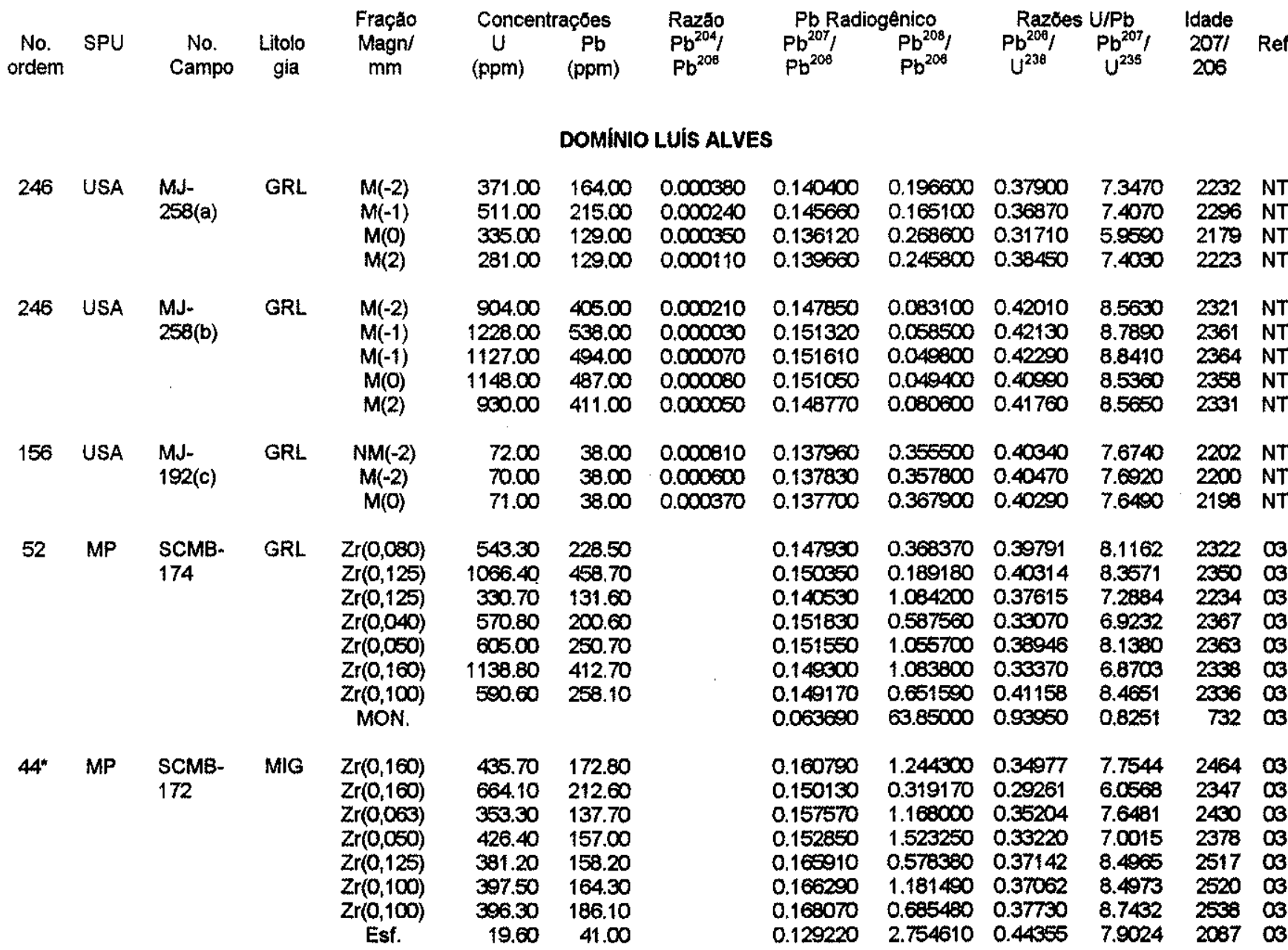

DOMINIO CURITIBA

\begin{tabular}{|c|c|c|c|c|c|c|c|c|c|c|c|}
\hline USA & $\begin{array}{l}\text { MJ- } \\
25.11\end{array}$ & GRN & $\begin{array}{c}N M(-2) \\
M(0) \\
M(2)\end{array}$ & $\begin{array}{r}98.00 \\
85.00 \\
101.00\end{array}$ & $\begin{array}{l}42.00 \\
36.00 \\
46.00\end{array}$ & $\begin{array}{l}0.000310 \\
0.000370 \\
0.002050\end{array}$ & $\begin{array}{l}0.129330 \\
0.130020 \\
0.129800\end{array}$ & $\begin{array}{l}0.161900 \\
0.171500 \\
0.156000\end{array}$ & $\begin{array}{l}0.37820 \\
0.37530 \\
0.37470\end{array}$ & $\begin{array}{l}6.7430 \\
6.7280 \\
6.7090\end{array}$ & $\begin{array}{l}2009 \\
2098 \\
2096\end{array}$ \\
\hline USA & $1 J-138$ & $\mathrm{GN}$ & $\begin{array}{c}N M(-1) \\
M(-1) \\
M(0) \\
M(2)\end{array}$ & $\begin{array}{l}222.00 \\
246.00 \\
290.00 \\
309.00\end{array}$ & $\begin{array}{r}86.00 \\
99.00 \\
110.00 \\
112.00\end{array}$ & $\begin{array}{l}0.000140 \\
0.000880 \\
0.000160 \\
0.000140\end{array}$ & $\begin{array}{l}0.132300 \\
0.132310 \\
0.132320 \\
0.131490\end{array}$ & $\begin{array}{l}0.082500 \\
0.078900 \\
0.065700 \\
0.078800\end{array}$ & $\begin{array}{l}0.37120 \\
0.37050 \\
0.36730 \\
0.34600\end{array}$ & $\begin{array}{l}6.7720 \\
6.7600 \\
6.7010 \\
6.2890\end{array}$ & $\begin{array}{l}2129 \\
2129 \\
2129 \\
2118\end{array}$ \\
\hline
\end{tabular}

\section{DOMINIO PARANAGUA}

$\begin{array}{llllll}106 \text { USA } & \text { MJ. } & \text { GRN } & M(-2) & 358.00 \\ & 206.2 & & M(-2) & 450.00 \\ & & & M(-1) & 489.00 \\ & & & M(1) & 642.00 \\ & & & M(2) & 699.00\end{array}$

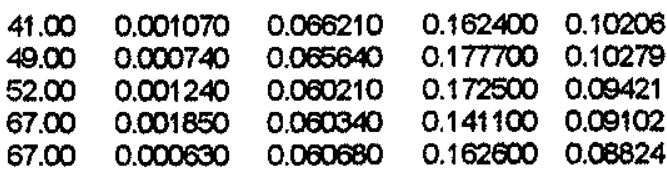

$4900 \quad 0.000740$

$52.00 \quad 0.001240$

$67.00 \quad 0.000630$
0.060680
0.9317

0.9902

0.7821

0.7573

0.7383
813 NT 795 NT 611 NT $616 \mathrm{NT}$ $628 \mathrm{NT}$ 


\begin{tabular}{|c|c|c|c|c|c|c|c|c|c|c|c|c|c|}
\hline $\begin{array}{l}\text { No. } \\
\text { ordem }\end{array}$ & SPU & $\begin{array}{l}\text { No. } \\
\text { Campo }\end{array}$ & $\begin{array}{l}\text { Litolo } \\
\text { gia }\end{array}$ & $\begin{array}{c}\text { Fraçato } \\
\text { Magni } \\
\text { mm }\end{array}$ & $\underset{(\mathrm{ppm})}{\text { Concen }}$ & $\begin{array}{c}\text { açōes } \\
\mathrm{Pb} \\
(\mathrm{ppm})\end{array}$ & $\begin{array}{l}\text { Razáo } \\
\mathrm{Pb}^{204} / \\
\mathrm{Pb}^{208}\end{array}$ & $\begin{array}{l}\mathrm{Pb} \text { Radic } \\
\mathrm{Pb}^{207} / \\
\mathrm{Pb}^{206}\end{array}$ & $\begin{array}{l}\text { génico } \\
\mathrm{Pb}^{208}, \\
\mathrm{~Pb}^{208}\end{array}$ & $\begin{array}{c}\text { Razoes } \\
\mathrm{Pb}^{208} / \mathrm{I} \\
\mathrm{U}^{238}\end{array}$ & $\begin{array}{l}\mathrm{U} / \mathrm{Pb} \\
\mathrm{Pb}^{207} / \\
\mathrm{U}^{235}\end{array}$ & $\begin{array}{l}\text { Idade } \\
207 \mid \\
206\end{array}$ & Ref. \\
\hline \multicolumn{14}{|c|}{ GRANITO RIO DO POCGO } \\
\hline 107 & 3 & $\begin{array}{l}\text { MJ- } \\
209 . C\end{array}$ & GRN & $\begin{array}{l}M(0) \\
M(1) \\
M(2) \\
M(3)\end{array}$ & $\begin{array}{l}1603.48 \\
1410.69 \\
1358.81 \\
1392.15\end{array}$ & $\begin{array}{r}119.90 \\
97.64 \\
98.97 \\
92.68\end{array}$ & $\begin{array}{l}0.001054 \\
0.000707 \\
0.002079 \\
0.001158\end{array}$ & $\begin{array}{l}0.059028 \\
0.058736 \\
0.058436 \\
0.058575\end{array}$ & $\begin{array}{l}0.091160 \\
0.086150 \\
0.081380 \\
0.087740\end{array}$ & $\begin{array}{l}0.07081 \\
0.06727 \\
0.06536 \\
0.06284\end{array}$ & $\begin{array}{l}0.5763 \\
0.5445 \\
0.5266 \\
0.5076\end{array}$ & $\begin{array}{l}568 \\
557 \\
546 \\
551\end{array}$ & $\begin{array}{l}\text { NT } \\
\text { NT } \\
\text { NT } \\
\text { NT }\end{array}$ \\
\hline \multicolumn{14}{|c|}{ GRANITO ESTRELA } \\
\hline 127 & 7 & $\begin{array}{l}\text { MJ- } \\
413 . B\end{array}$ & GRN & $\begin{array}{l}M(0) \\
M(1) \\
M(3)\end{array}$ & $\begin{array}{l}447.02 \\
802.38 \\
906.79\end{array}$ & $\begin{array}{l}39.91 \\
49.85 \\
47.63\end{array}$ & $\begin{array}{l}0.001340 \\
0.000404 \\
0.001702\end{array}$ & $\begin{array}{l}0.075265 \\
0.060692 \\
0.059089\end{array}$ & $\begin{array}{l}0.136910 \\
0.119870 \\
0.100500\end{array}$ & $\begin{array}{l}0.07915 \\
0.05970 \\
0.04749\end{array}$ & $\begin{array}{l}0.8214 \\
0.4996 \\
0.3869\end{array}$ & $\begin{array}{r}1075 \\
628 \\
570\end{array}$ & $\begin{array}{l}\text { NT } \\
\text { NT } \\
\text { NT }\end{array}$ \\
\hline & & \multicolumn{12}{|c|}{ GRANITÓIDES DEFORMADOS - PIÊN } \\
\hline 120 & 2 & $\begin{array}{l}M J-321 \\
=P P-10\end{array}$ & GRN & $\begin{array}{c}\mathrm{NM}(0) \\
M(0)\end{array}$ & $\begin{array}{l}255.45 \\
286.38\end{array}$ & $\begin{array}{l}28.61 \\
31.64\end{array}$ & $\begin{array}{l}0.004092 \\
0.002517\end{array}$ & $\begin{array}{l}0.063080 \\
0.063314\end{array}$ & $\begin{array}{l}0.186490 \\
0.189980\end{array}$ & $\begin{array}{l}0.10028 \\
0.10022\end{array}$ & $\begin{array}{l}0.8722 \\
0.8749\end{array}$ & $\begin{array}{l}711 \\
719\end{array}$ & $\begin{array}{l}\text { NT } \\
\text { NT }\end{array}$ \\
\hline 121 & 1 & AM-93 & GRN & $\begin{array}{l}M(1) \\
M(0) \\
M(-1)\end{array}$ & $\begin{array}{l}173.51 \\
210.95 \\
191.64\end{array}$ & $\begin{array}{l}20.15 \\
19.61 \\
23.82\end{array}$ & $\begin{array}{l}0.013900 \\
0.005590 \\
0.009800\end{array}$ & $\begin{array}{l}0.064301 \\
0.072917 \\
0.066600\end{array}$ & $\begin{array}{l}0.091180 \\
0.087570 \\
0.072490\end{array}$ & $\begin{array}{l}0.08528 \\
0.09201 \\
0.10441\end{array}$ & $\begin{array}{l}0.7561 \\
0.9251 \\
0.9588\end{array}$ & $\begin{array}{r}751 \\
1011 \\
825\end{array}$ & $\begin{array}{l}12 \\
12 \\
12\end{array}$ \\
\hline 124 & 8 & $M J-649$ & GRN & $\begin{array}{c}M(-2) \\
M(2) \\
M(-1) \\
N M(-2)\end{array}$ & $\begin{array}{l}182.89 \\
177.76 \\
294.56 \\
150.83\end{array}$ & $\begin{array}{l}19.58 \\
20.66 \\
31.36 \\
17.26\end{array}$ & $\begin{array}{l}0.000214 \\
0.001577 \\
0.000207 \\
0.000205\end{array}$ & $\begin{array}{l}0.060136 \\
0.060685 \\
0.060465 \\
0.060009\end{array}$ & $\begin{array}{l}0.19347 \\
0.19674 \\
0.19023 \\
0.18754\end{array}$ & $\begin{array}{l}0.09804 \\
0.09832 \\
0.09774 \\
0.09940\end{array}$ & $\begin{array}{l}0.81292 \\
0.82265 \\
0.81486 \\
0.82243\end{array}$ & $\begin{array}{l}600 \\
628 \\
620 \\
604\end{array}$ & $\begin{array}{l}\text { NT } \\
\text { NT } \\
\text { NT } \\
\text { NT }\end{array}$ \\
\hline
\end{tabular}

GRANITO MORRO REDONDO

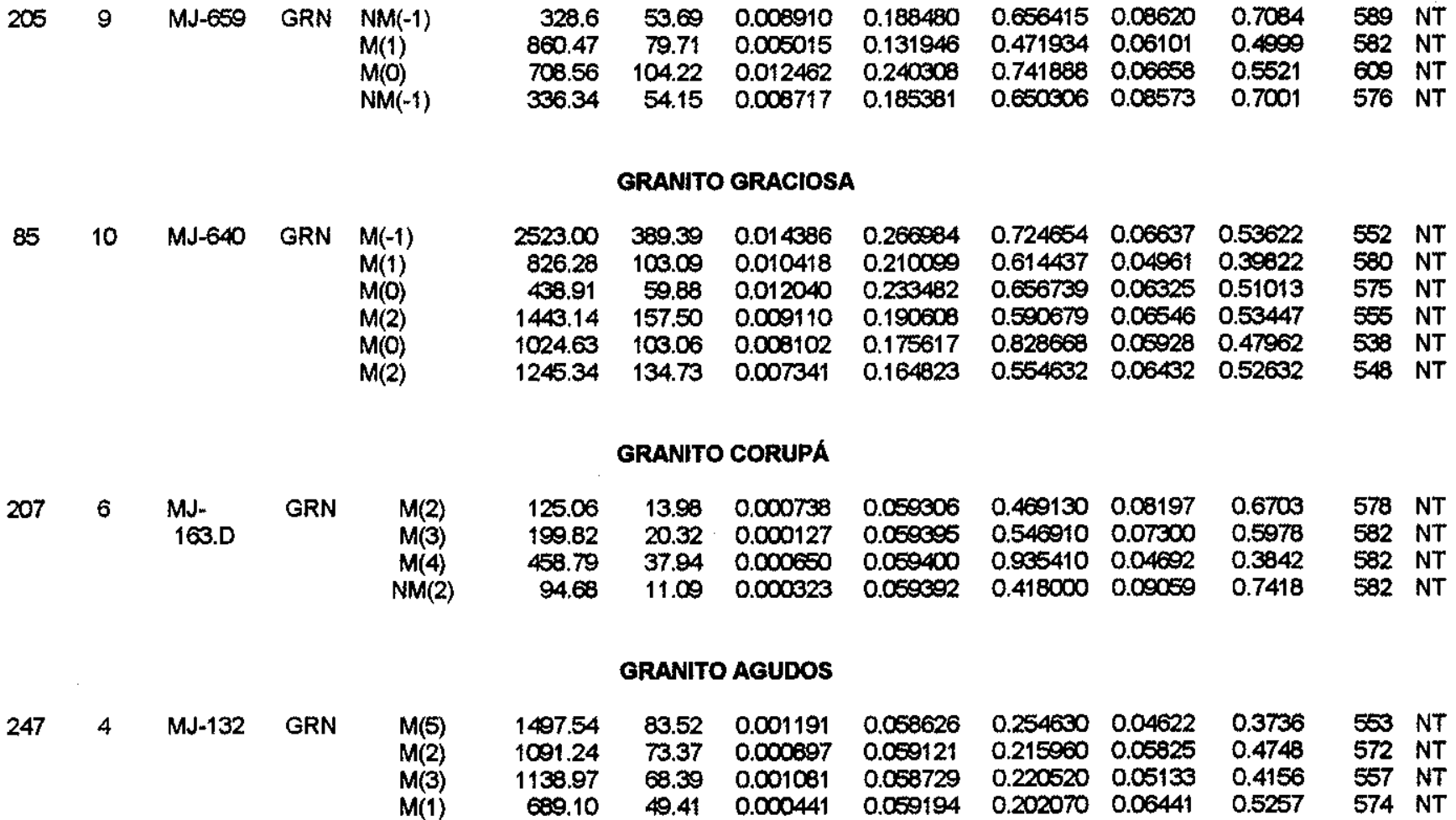




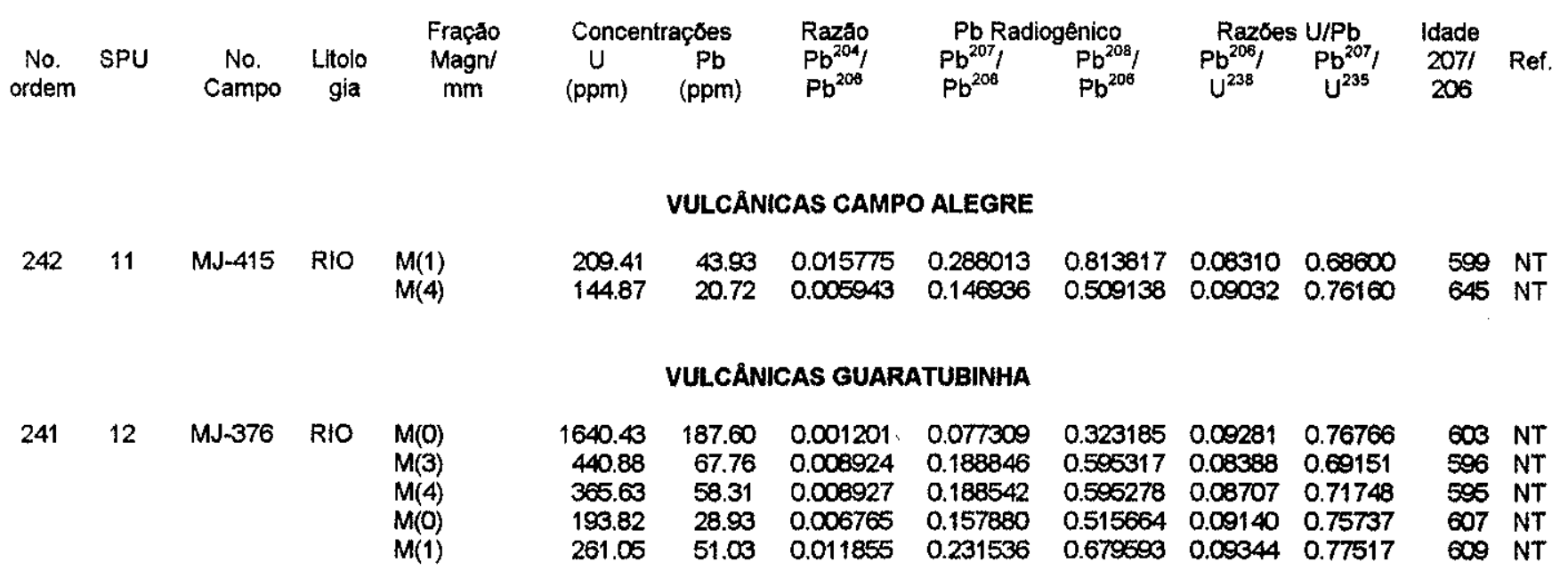


DADOS RADIOMÉTRICOS Pb-Pb

No. ordem No. Lab. No. Campo Litologia $\begin{array}{lllll}\mathrm{Pb}^{206}, & \mathrm{~Pb}^{201} / & \mathrm{Pb}^{204} & \mathrm{~Pb}^{204} & \mathrm{~Pb}^{2004}\end{array} \quad$ Ref.

K-FELDSPATOS - GRANITOIDES DO DOMINIO PARANAGUÁ

$\begin{array}{llllllll}108 & \text { USA } & \text { MJ-301.H } & \text { GRN } & 16.043 & 15.267 & 36.491 & \text { NT } \\ 106 & \text { USA } & \text { MJ-206.5 } & \text { GRN } & 16.084 & 15.183 & 36.312 & \text { NT } \\ 144 & \text { USA } & \text { MJ-287.B } & \text { GRN } & 16.248 & 15.319 & 36.636 & \text { NT }\end{array}$

ROCHA TOTAL - DOMINIO LUIS ALVES

$\begin{array}{llllllll}51 & \text { MP } & \text { CAN-33.C } & \text { PEG } & 16.478 & 15.766 & 37.898 & 3 \\ 51 & \text { MP } & \text { CAN-33.D } & \text { GNS } & 16.008 & 15.711 & 36.118 & 3 \\ 51 & \text { MP } & \text { CAN-33.E } & \text { GNS } & 16.125 & 15.712 & 36.749 & 3 \\ 50 & \text { MP } & \text { SCMB-1103.A } & \text { GNS } & 16.271 & 15.775 & 35.792 & 3 \\ 50 & \text { MP } & \text { SCMB-1103.B } & \text { GNS } & 16.105 & 15.716 & 36.611 & 3 \\ 50 & \text { MP } & \text { SCMB-1103.C } & \text { GNS } & 15.664 & 15.671 & 38.009 & 3 \\ 51 & \text { MP } & \text { CAN-33.A } & \text { PEG } & 15.861 & 15.690 & 36.101 & 3 \\ 51 & \text { MP } & \text { CAN-33.A } & \text { PEG } & 15.965 & 15.702 & 36.470 & 3 \\ 51 & \text { MP } & \text { CAN-33.B } & \text { PEG } & 16.517 & 15.782 & 36.724 & 3 \\ 50 & \text { MP } & \text { SCMB-1103.D } & \text { PEG } & 16.220 & 15.746 & 37.972 & 3 \\ 52 & \text { MP } & \text { SCMB-174.RA } & \text { GNS } & 16.454 & 15.784 & 35.552 & 3 \\ 50 & \text { MP } & \text { SCMB-1103.E } & \text { GNS } & 16.162 & 15.735 & 36.477 & 3 \\ 51 & \text { MP } & \text { CAN-33.G } & \text { GNS } & 16.235 & 15.754 & 36.669 & 3 \\ 51 & \text { MP } & \text { CAN-33.F } & \text { GNS } & 16.353 & 15.736 & 37.404 & 3 \\ 51 & \text { MP } & \text { CAN-32 } & \text { GNS } & 16.656 & 15.767 & 36.378 & 3 \\ 52 & \text { MP } & \text { SCMB-174.RB } & \text { GNS } & 16.168 & 15.678 & 35.684 & 3 \\ * & \text { UK } & \text { C.11** } & \text { GRL } & 17.126 & 15.773 & 38.404 & 18\end{array}$

** - Composiçăo de 5 amostras 
DADOS RADIOMÉTRICOS SM-NA EM ROCHA TOTAL

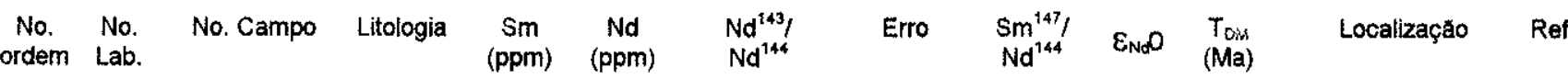

GRANITOS INTRUSIVOS

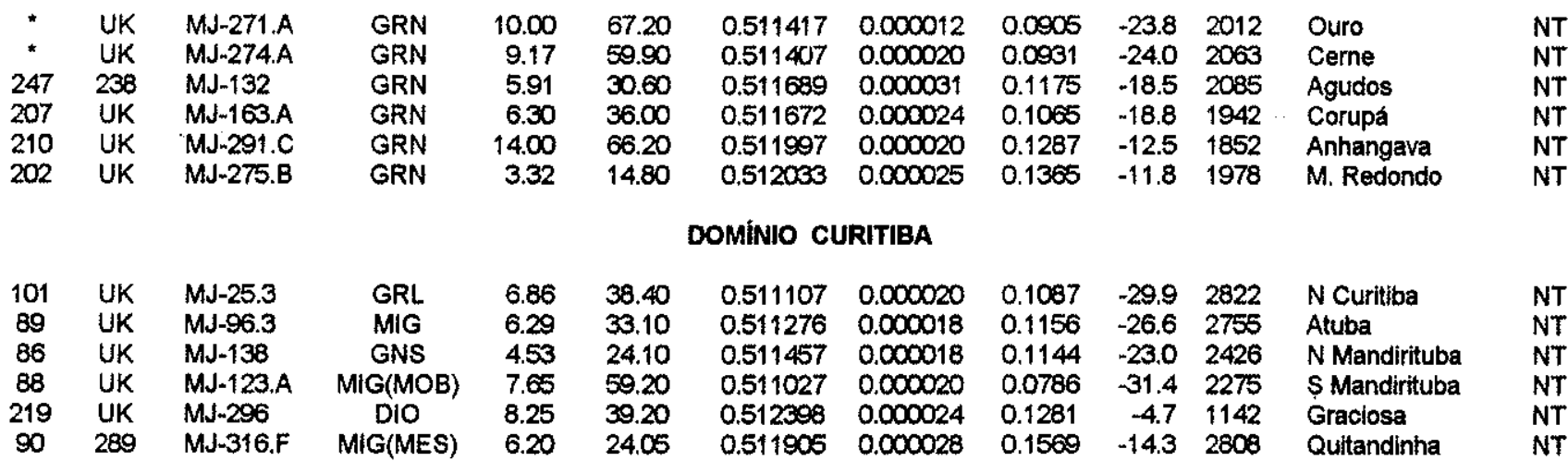

GRANITÓIDES DEFORMADOS PIÉn

$\begin{array}{lllllllllllll}226 & 54 & \text { MJ-AM-16 } & \text { GRN } & 6.03 & 41.42 & 0.511318 & 0.000028 & 0.0886 & -25.7 & 2057 & \text { PIen } & \text { NT } \\ 228 & 56 & \text { MJ-AM-95 } & \text { GRN } & 2.134 & 13.362 & 0.511488 & 0.000032 & 0.0972 & -22.4 & 1992 & \text { Pien } & \text { NT } \\ 225 & 55 & \text { MJ-AM-20 } & \text { GRN } & 4.122 & 28.678 & 0.511263 & 0.000030 & 0.0875 & -26.8 & 2104 & \text { Plen } & \text { NT }\end{array}$

DOMÍNIO PARANAGUÁ

$\begin{array}{llllrrrrrrrrr}189 & \text { UK } & \text { MJ-208.A } & \text { GRN } & 9.71 & 58.30 & 0.511629 & 0.000018 & 0.1013 & -19.7 & 1909 & \text { Morro ingles } & \text { NT } \\ 108 & \text { UK } & \text { MJ301.E } & \text { GRN } & 9.64 & 62.70 & 0.511289 & 0.000006 & 0.0936 & -26.3 & 2223 & \text { Morro ingles } & \text { NT } \\ 144 & \text { UK } & \text { MJ-287.A } & \text { GRN } & 5.16 & 36.30 & 0.511349 & 0.000004 & 0.0865 & -25.1 & 2025 & \text { Morro ingles } & \text { NT } \\ 214 & \text { UK } & \text { MJ-284 } & \text { GRN } & 32.70 & 176.00 & 0.511345 & 0.000020 & 0.1134 & -25.2 & 2572 & \text { Estrela } & \text { NT } \\ 128 & 240 & \text { MJ-263 } & \text { GRN } & 6.14 & 36.37 & 0.511075 & 0.000030 & 0.1027 & -30.5 & 2614 & \text { Estrela } & \text { NT } \\ 248 & 241 & \text { MJ-347 } & \text { GRN } & 3.60 & 23.49 & 0.511080 & 0.000035 & 00033 & -30.4 & 2417 & \text { Canavieiras } & \text { NT }\end{array}$

DOMINIO LUIS ALVES

$\begin{array}{cclllllllllll}154 & \text { UK } & \text { MJ-27.14 } & \text { GRL } & 5.20 & 27.60 & 0.511545 & 0.000014 & 0.1146 & -21.3 & 2303 & \text { Pomerode } & \text { NT } \\ 7 & \text { UK } & \text { MJ-41.3 } & \text { GRL } & 2.74 & 16.90 & 0.511323 & 0.000036 & 0.0987 & -25.6 & 2270 & \text { L. Alves } & \text { NT } \\ 162 & 252 & \text { MJ-195 } & \text { GRL } & 4.15 & 20.38 & 0.511263 & 0.000026 & 0.1239 & -26.8 & 2887 & \text { Dna. Fancisca } & \text { NT } \\ 178 & \text { UK } & \text { MJ-15.A } & \text { GRL } & 0.68 & 3.59 & 0.511233 & 0.000016 & 0.1153 & -27.4 & 2800 & \text { Pien } & \text { NT } \\ * & \text { UK } & \text { JR-06 } & \text { GRL } & 8.16 & 41.60 & 0.511571 & 0.000020 & 0.1194 & -20.8 & 2373 & \text { S.S. Negra } & \text { NT } \\ * & \text { UK } & \text { C-11** } & \text { GRL } & & & 0.511190 & 0.000010 & 0.1810 & -28.3 & 2730 & \text { Luis Alves } & 18 \\ 250 & 253 & \text { MJ-367 } & \text { GRL } & 2.80 & 17.56 & 0.510920 & 0.000035 & 0.0970 & -33.5 & 2797 & \text { Tagaçaba } & \text { NT } \\ 185 & 89 & \text { MJ-461.B } & \text { MNR } & 6.60 & 35.41 & 0.511014 & 0.000026 & 0.1134 & -31.7 & 2980 & \text { S.S.J. Pinhais } & \text { NT } \\ 162 & \text { UK } & \text { MJ-195 } & \text { GRL } & 4.42 & 22.70 & 0.511133 & 0.000020 & 0.1185 & -29.4 & 3086 & \text { Dona Francisca } & \text { NT }\end{array}$

ROCHAS BÁSICAS - ULTRABÁSICAS PIEN

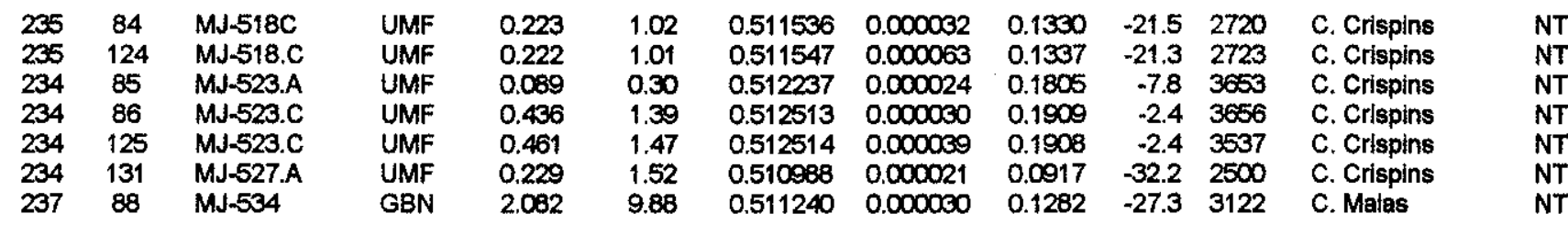

* - Composiçáa de 5 amostras 
DADOS RADIOMÉTRICOS SM-Nd EM MINERAIS

\begin{tabular}{|c|c|c|c|c|c|c|c|c|c|c|c|}
\hline $\begin{array}{l}\text { No. } \\
\text { ordem }\end{array}$ & $\begin{array}{l}\text { No. } \\
\text { Lab. }\end{array}$ & No. Campo & $\begin{array}{c}\text { Litolo } \\
\text { gia }\end{array}$ & $\begin{array}{l}\mathrm{Nd}^{143} / \\
\mathrm{Nd}^{144}\end{array}$ & Erro & $\begin{array}{l}\mathrm{Sm}^{147} / \\
\mathrm{Nd}^{1344}\end{array}$ & Erro & $\varepsilon_{0}$ & $\begin{array}{c}T_{D M} \\
(\mathrm{Ga})\end{array}$ & Localizaçâao & Ref \\
\hline \multicolumn{12}{|c|}{ DOMINIO CURITIBA } \\
\hline $\begin{array}{l}87 \\
87 \\
87 \\
87\end{array}$ & $\begin{array}{l}\text { UK } \\
\text { UK } \\
\text { UK } \\
\text { UK }\end{array}$ & $\begin{array}{l}\text { MJ-137-RTO } \\
M J-137-G R A \\
M J-137-A N F \\
M J-137-P L G\end{array}$ & $\begin{array}{l}\text { GNS } \\
\text { GNS } \\
\text { GNS } \\
\text { GNS }\end{array}$ & $\begin{array}{l}0.512474 \\
0.513846 \\
0.512573 \\
0.512377\end{array}$ & $\begin{array}{l}0.000016 \\
0.000010 \\
0.000006 \\
0.000008\end{array}$ & $\begin{array}{l}0.154158 \\
0.506108 \\
0.168309 \\
0.107969\end{array}$ & $\begin{array}{l}0.0057 \\
0.0167 \\
0.0056 \\
0.00036\end{array}$ & $\begin{array}{l}-3.20 \\
23.56 \\
-1.27 \\
-5.00\end{array}$ & $\begin{array}{l}1.44 \\
0.39 \\
1.54 \\
0.99\end{array}$ & $\begin{array}{l}\text { N Mandirituba } \\
\text { N Mandirituba } \\
\text { N Mandirituba } \\
\text { N Mandirituba }\end{array}$ & $\begin{array}{l}\text { NT } \\
\text { NT } \\
\text { NT } \\
\text { NT }\end{array}$ \\
\hline \multicolumn{12}{|c|}{ DOMINIO LUIS ALVES } \\
\hline $\begin{array}{l}249 \\
249 \\
249 \\
249 \\
249\end{array}$ & $\begin{array}{l}\text { UK } \\
\text { UK } \\
\text { UK } \\
\text { UK } \\
\text { UK }\end{array}$ & $\begin{array}{l}\text { ANF } \\
\text { ESF } \\
\text { MIC } \\
\text { PIR } \\
\text { ALL }\end{array}$ & $\begin{array}{l}\text { GRL } \\
\text { GRL } \\
\text { GRL } \\
\text { GRL } \\
\text { GRL }\end{array}$ & $\begin{array}{l}0.511658 \\
0.511442 \\
0.511146 \\
0.511781 \\
0.510265\end{array}$ & $\begin{array}{l}0.000006 \\
0.000002 \\
0.000041 \\
0.000005 \\
0.000004\end{array}$ & $\begin{array}{l}0.130015 \\
0.116226 \\
0.085819 \\
0.137209 \\
0.036375\end{array}$ & $\begin{array}{l}0.0043 \\
0.0038 \\
0.0028 \\
0.0045 \\
0.0048\end{array}$ & $\begin{array}{l}-19.12 \\
-23.33 \\
-29.10 \\
-16.72 \\
-46.29\end{array}$ & $\begin{array}{l}2.43 \\
2.42 \\
2.21 \\
2.40 \\
2.35\end{array}$ & $\begin{array}{l}\text { Luls Alves } \\
\text { Luls Alves } \\
\text { Luis Alves } \\
\text { Luís Alves } \\
\text { Luls Alves }\end{array}$ & $\begin{array}{l}21 \\
21 \\
21 \\
21 \\
21\end{array}$ \\
\hline
\end{tabular}




\section{ROCHAS}

AND - Andesito

ANF - Anfibolito

BML - Blastomilonito

BSN - Basanito

CHQ - Chamoquito

DIA - Diabásio

DIO - Diorito

DTX - Diatexito

END - Enderbito

GBN - Gabronorito

GBO - Gabro

GRD - Granodiorito

GRL - Granulito

GRN - Granito

GNS - Gnaisse

LEU - Leucossoma (migmatito)

MAF - Máfica (indiferenciada)

MES - Mesossoma (migmatito)

MGB - Metagabro

MOB - Mobilizado (qzo-feldspático)

MNR - Metanorito

MIG - Migmatito

MTX - Metatexito

NOR - Norito

PEG - Pegmatito

PML - Protomilonito

PRD - Peridotito

PRX - Piroxênito

QMZ - Quartzo Monzonito

QNR - Quartzo Norito

QPF - Quartzo Pórfiro

RIO - Riolito

SIE - Sienito

TRQ - Traquito

UMF - Ultramáfica (indiferenciada)

XMG - Xisto Magnesiano

WEB - Websterito
MINERAIS:

GRA - Granada

ESF - Esfeno

ALL - Allanita

ANF - Anfibólio

BIO - Biotita

$\mathrm{CL}$ - Clorita

ESF - Esfeno

FEL - Feldspato

KF - K-Feldspato

MIC - Microclínio

ORT - Ortoclásio

PLG - Plagioclásio

RTO - Rocha Total

PIR - Piroxênio

i - Impuro

- $\left(^{\star}\right)$ no lugar do No.ordem - ponto fora dos limites do mapa (Anexo -1)

- No.ordem com $\left(^{\star}\right)$ - ponto fora da área estudada, porém dentro dos limites do mapa (Anexo-1) 


\section{Constantes Utilizadas}

Método K-Ar:

$\lambda_{\beta}=4.962 \times 10^{-10}$ anos $^{-1}$

$\left(A r^{40} / A r^{36}\right)_{a t m}=295.5$

$K^{40}$ total $=0.581 \times 10^{-10}$ anos $^{-1}$

$K^{40}=0.01167 \% K_{t}$

Método Rb-Sr

$\lambda_{\mathrm{Rb}}=1.42 \times 10^{-11}$ anos $^{-1}$

$\left(\mathrm{Rb}^{85} / \mathrm{Rb}^{87}\right)_{N}=2.59265$

$\left(\mathrm{Sr}^{86} / \mathrm{Sr}^{88}\right)_{N}=0.1194$

Método U-Pb / Pb-Pb

$$
\begin{array}{ll}
\lambda_{238}=1.55125 \times 10^{-10} \text { anos }^{-1} & \lambda_{232}=4.9475 \times 10^{-11} \text { anos }^{-1} \\
\lambda_{235}=9.8485 \times 10^{-10} \text { anos }^{-1} & a_{0}=\left(\mathrm{Pb}^{206} / \mathrm{Pb}^{204}\right)_{T}=9.307 \\
U^{238} / \mathrm{U}^{235}=137.88 & b_{0}=\left(\mathrm{Pb}^{207} / \mathrm{Pb}^{204}\right)_{\mathrm{T}}=10.294
\end{array}
$$

\section{Método Sm-Nd}

$\lambda_{147}=6.54 \times 10^{-12}$ anos $^{-1}$

$\left(\mathrm{Nd}^{143} / \mathrm{Nd}^{144}\right)_{0} \mathrm{CHUR}=0.512638$

$D M=0.513114$

$\left(\mathrm{Sm}^{147} / \mathrm{Nd}^{144}\right)_{0} \mathrm{CHUR}=0.1967$

$D M=0.222$ 
REFERÊNCIAS (Dados Radiométricos)

1 - BARTORELLI et al. (1968)

2 - BASEl (1979, dados inéditos - CPGeo/USP)

3 - BASEI (1985)

4 - BATOLLA Jr et al. (1977)

5 - CORDANI \& GIRARDI (1967)

6 - CORDANI \& KAWASHITA (1971)

7 - CORDANI \& ABRÃO (1970, dados inéditos - CPGeo/USP - in Cordani 1974)

8 - EBERT (1971)

9 - GIRARDI et al. (1974)

10 - HARTMANN et al. (1979)

11 - KAWASHITA (1969, dados inéditos - CPGeo/USP - in Cordani 1974)

12 - MACHIAVELLI (1991)

13 - MINIOLI (1972)

14 - KAUL et al. (1984)

15 - AMARAL et al. (1966)

16 - CORDANI \& BITTENCOURT (1967)

17 - MELFI (1967)

18 - MANTOVANI et al (1987)

19 - REIS NETO, J.M. (1991, dados iriéditos - CF)

20 - MORO (1993)

21 - HARTMANN et al., (1994)

$\mathrm{NT}^{\star}$ - Amostras coletadas pela CPRM e analisadas pelo autor.

NT - Neste trabalho

Siglas utilizadas:

USA $=$ análises realizadas em Kansas

UK $=$ análise realizadas em Milton Keynes

$\mathrm{CF}=$ análises realizadas em Clermont Ferrant

$\mathrm{MP}=$ análises realizadas em Montpellier 
APÊNDICE 2

DOMIINIO LUÍS ALVES

\begin{tabular}{|c|c|c|c|c|c|}
\hline & MJ27-14 & MJ41-3 & MJ10 & MJ92 & MJ15A \\
\hline $\mathrm{SiO}_{2}$ & 52.73 & 63.56 & 65.06 & 45.50 & 60.16 \\
\hline & 0.57 & 0.50 & 0.74 & 1.30 & 0.64 \\
\hline${ }_{2} \mathrm{O}$ & 22.43 & 14.19 & 15.02 & 17.88 & 17.38 \\
\hline $\mathrm{Fe}_{2} \mathrm{O}_{3}$ * & 5.26 & 10.83 & 6.36 & 14.54 & 6.32 \\
\hline no & 0.07 & 0.15 & 0.06 & 0.21 & 0.09 \\
\hline $\operatorname{lgO}$ & 3.35 & 1.83 & 2.90 & 5.90 & 2.27 \\
\hline aO & 7.93 & 1.70 & 2.54 & 9.81 & 5.40 \\
\hline$a_{2} \mathrm{O}$ & 4.98 & 2.34 & 3.12 & 2.98 & 4.61 \\
\hline${ }_{2} \mathrm{O}$ & 1.76 & 3.73 & 2.87 & 0.79 & 1.31 \\
\hline${ }_{2} \mathrm{O}_{5}$ & 0.05 & 0.10 & 0. & 0.26 & 0.21 \\
\hline$s$ & 0.01 & 0.03 & 0.0 & 0.03 & 0.01 \\
\hline LOI & 2.13 & 0.86 & 1.1 & 0.61 & 1.27 \\
\hline $\mathrm{Ba}$ & 037.00 & 1164.00 & 1220.00 & 467.00 & 868.00 \\
\hline $\mathrm{Cr}$ & 43.00 & 46.00 & 210.00 & 0.00 & 31.00 \\
\hline $\mathrm{Cu}$ & 10.00 & 54.00 & 30.00 & 68.00 & 39.00 \\
\hline $\mathrm{Ga}$ & 24.00 & 13.00 & 18.00 & 21.00 & 19.00 \\
\hline $\mathrm{N}$ & 5.00 & 16.00 & 12.00 & 10.00 & 6.00 \\
\hline $\mathrm{Ni}$ & 25.00 & 29.00 & 79.0 & 27.00 & 24.00 \\
\hline $\mathrm{Pb}$ & 4.00 & 26.00 & 11. & 8.00 & 12.00 \\
\hline$R b$ & 27.00 & 121.00 & 84.00 & 1.00 & 15.00 \\
\hline $\mathrm{Sr}$ & 1032.00 & 198.00 & 471.00 & 968.00 & 491.00 \\
\hline Th & 0.00 & 65.00 & 2.00 & 0.00 & 0.00 \\
\hline 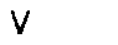 & 117.00 & 65.00 & 136.00 & 310.00 & 67.00 \\
\hline$Y$ & 16.00 & 56.00 & 5.00 & 25.00 & 13.00 \\
\hline $\mathrm{Zn}$ & 45.00 & 76.00 & 93.00 & 108.00 & 86.00 \\
\hline $\mathrm{Zr}$ & 28.00 & 188.00 & 205.00 & 59.00 & 109.00 \\
\hline $\mathrm{TiO}_{2}$ & 0.55 & 0.60 & 0.85 & 1.33 & 0.60 \\
\hline La & 19 & 17.01 & 40. & 19.60 & 31.53 \\
\hline c & 4940 & 35.2 & 63.3 & 54.10 & 65.29 \\
\hline $\mathrm{N}$ & 27 & 16.94 & 19. & 35.40 & 27.97 \\
\hline $\mathrm{Sm}$ & 5.20 & 2.74 & 2.43 & 7.20 & 4.40 \\
\hline E & 1.49 & 1, & 1. & & 1.59 \\
\hline $\mathrm{Gd}$ & 3.46 & 1.7 & 0. & 0.00 & 2.79 \\
\hline $\mathrm{Tb}$ & 0.00 & 0.0 & & 0.89 & 0.00 \\
\hline D. & 2.8 & 1.1 & 0.8 & 0.00 & 2.07 \\
\hline $\mathrm{H}_{\mathrm{k}}$ & 0.5 & 0.2 & & 0. & 0.43 \\
\hline Er & 1.4 & 0.4 & 0. & 0.00 & 1.25 \\
\hline$Y b$ & 1. & 0.4 & 0. & 1.99 & 0.97 \\
\hline Lu & 0.14 & 0.08 & 0.13 & 0.33 & 0.14 \\
\hline
\end{tabular}

DOMINIO CURITIBA

\begin{tabular}{rrrr} 
MJ137 & \multicolumn{1}{c}{ MJ138 } & \multicolumn{1}{c}{ MJ96-3 } & \multicolumn{1}{c}{ MJ25-3 } \\
& & & \\
50.95 & 63.63 & 60.71 & 71.55 \\
2.10 & 0.63 & 0.77 & 0.54 \\
16.32 & 15.96 & 16.06 & 13.31 \\
14.86 & 5.99 & 7.37 & 3.51 \\
0.19 & 0.10 & 0.14 & 0.07 \\
2.42 & 2.08 & 2.98 & 0.39 \\
9.19 & 4.59 & 5.03 & 1.84 \\
2.98 & 4.01 & 4.08 & 2.80 \\
0.29 & 2.45 & 1.86 & 5.15 \\
0.37 & 0.21 & 0.35 & 0.12 \\
0.02 & 0.01 & 0.01 & 0.00 \\
0.58 & 0.72 & 0.72 & 0.55
\end{tabular}

$\begin{array}{rrrr}43.00 & 645.00 & 423.00 & 2242.00 \\ 0.00 & 22.00 & 33.00 & 5.00 \\ 94.00 & 10.00 & 31.00 & 5.00 \\ 24.00 & 17.00 & 17.00 & 15.00 \\ 15.00 & 8.00 & 9.00 & 14.00 \\ 23.00 & 13.00 & 19.00 & 4.00 \\ 10.00 & 8.00 & 15.00 & 38.00 \\ 1.00 & 68.00 & 119.00 & 79.00 \\ 197.00 & 623.00 & 241.00 & 273.00 \\ 0.00 & 0.00 & 4.00 & 1.00 \\ 157.00 & 118.00 & 145.00 & 15.00 \\ 42.00 & 20.00 & 25.00 & 30.00 \\ 118.00 & 79.00 & 77.00 & 68.00 \\ 202.00 & 128.00 & 152.00 & 518.00 \\ 2.04 & 0.68 & 0.85 & 0.45\end{array}$

$\begin{array}{rrrr}13.40 & 22.07 & 30.93 & 42.41 \\ 39.57 & 50.86 & 69.61 & 85.27 \\ 29.99 & 24.13 & 33.08 & 38.38 \\ 7.65 & 4.53 & 6.29 & 6.86 \\ 2.42 & 1.34 & 1.68 & 4.41 \\ 6.90 & 3.30 & 4.60 & 5.09 \\ 0.00 & 0.00 & 0.00 & 0.00 \\ 7.09 & 2.97 & 4.13 & 4.89 \\ 1.43 & 0.63 & 0.86 & 1.01 \\ 3.84 & 1.96 & 2.57 & 2.78 \\ 3.15 & 1.56 & 2.06 & 2.20 \\ 0.40 & 0.25 & 0.29 & 0.28\end{array}$


MACIÇOS GRANÍTICOS

\begin{tabular}{|c|c|c|c|c|c|c|c|}
\hline & $\begin{array}{c}\text { MJ-163A } \\
\text { (Cor) }\end{array}$ & $\begin{array}{c}\text { MJ-109A } \\
\text { (A. Sul) }\end{array}$ & $\begin{array}{c}\text { MJ-128A } \\
\text { (A. Sul) }\end{array}$ & $\begin{array}{c}\text { MJ-129A } \\
\text { (A. Sul) }\end{array}$ & $\begin{array}{c}M J-295 \\
\text { (Grac.) }\end{array}$ & $\begin{array}{c}\text { MJ-291C } \\
\text { (Anh.) }\end{array}$ & $\begin{array}{l}\text { MJ-275B } \\
\text { (M. Red) }\end{array}$ \\
\hline $\begin{array}{l}\mathrm{SiO}_{2} \\
\mathrm{TiO}_{2} \\
\mathrm{Al}_{2} \mathrm{O}_{3} \\
\mathrm{Fe}_{2} \mathrm{O}_{3}{ }^{*} \\
\mathrm{MnO} \\
\mathrm{MgO} \\
\mathrm{CaO} \\
\mathrm{Na}_{2} \mathrm{O} \\
\mathrm{K}_{2} \mathrm{O} \\
\mathrm{P}_{2} \mathrm{O}_{5} \\
\mathrm{LOI}\end{array}$ & $\begin{array}{r}64.02 \\
0.54 \\
17.20 \\
4.36 \\
0.14 \\
0.44 \\
1.42 \\
5.51 \\
6.37 \\
0.07 \\
0.40\end{array}$ & $\begin{array}{r}75.18 \\
0.04 \\
14.21 \\
0.56 \\
0.03 \\
0.14 \\
0.80 \\
5.59 \\
4.15 \\
0.03 \\
0.33\end{array}$ & $\begin{array}{r}75.41 \\
0.02 \\
14.20 \\
0.71 \\
0.04 \\
0.15 \\
0.61 \\
5.34 \\
3.85 \\
0.04 \\
0.42\end{array}$ & $\begin{array}{r}73.49 \\
0.14 \\
15.52 \\
1.13 \\
0.03 \\
0.33 \\
0.62 \\
5.74 \\
3.47 \\
0.04 \\
0.58\end{array}$ & $\begin{array}{r}76.45 \\
0.16 \\
11.78 \\
2.36 \\
0.06 \\
0.13 \\
0.29 \\
4.20 \\
4.78 \\
0.04 \\
0.27\end{array}$ & $\begin{array}{r}66.96 \\
0.43 \\
15.60 \\
5.11 \\
0.14 \\
0.14 \\
1.41 \\
5.86 \\
5.60 \\
0.06 \\
0.27\end{array}$ & $\begin{array}{r}76.05 \\
0.11 \\
10.34 \\
4.74 \\
0.07 \\
0.13 \\
0.11 \\
4.88 \\
3.81 \\
0.04 \\
0.26\end{array}$ \\
\hline $\begin{array}{l}\mathrm{Ba} \\
\mathrm{Cr} \\
\mathrm{Cu} \\
\mathrm{Ga} \\
\mathrm{Nb} \\
\mathrm{Ni} \\
\mathrm{Pb} \\
\mathrm{Rb} \\
\mathrm{Sr} \\
\mathrm{Th} \\
\mathrm{V} \\
\mathrm{Y} \\
\mathrm{Zn} \\
\mathrm{Zr} \\
\mathrm{TiO}_{2}\end{array}$ & $\begin{array}{r}462.00 \\
7.00 \\
5.00 \\
20.00 \\
9.00 \\
1.00 \\
8.00 \\
51.00 \\
39.00 \\
4.00 \\
0.00 \\
26.00 \\
49.00 \\
260.00 \\
0.48\end{array}$ & $\begin{array}{r}355.00 \\
16.00 \\
0.00 \\
33.00 \\
22.00 \\
0.00 \\
166.00 \\
194.00 \\
253.00 \\
11.00 \\
0.00 \\
7.00 \\
58.00 \\
69.00 \\
0.03\end{array}$ & $\begin{array}{r}110.00 \\
19.00 \\
0.00 \\
35.00 \\
14.00 \\
1.00 \\
172.00 \\
198.00 \\
131.00 \\
6.00 \\
5.00 \\
9.00 \\
44.00 \\
56.00 \\
0.02\end{array}$ & & $\begin{array}{r}23.00 \\
8.00 \\
0.00 \\
29.00 \\
36.00 \\
5.00 \\
27.00 \\
181.00 \\
5.00 \\
15.00 \\
12.00 \\
82.00 \\
99.00 \\
459.00 \\
0.18\end{array}$ & $\begin{array}{r}109.00 \\
2.00 \\
4.00 \\
29.00 \\
40.00 \\
6.00 \\
25.00 \\
193.00 \\
11.00 \\
14.00 \\
0.00 \\
67.00 \\
93.00 \\
393.00 \\
0.38\end{array}$ & $\begin{array}{r}27.00 \\
1.00 \\
1.00 \\
38.00 \\
9.00 \\
7.00 \\
5.00 \\
144.00 \\
3.00 \\
5.00 \\
3.00 \\
34.00 \\
182.00 \\
271.00 \\
0.12\end{array}$ \\
\hline $\begin{array}{l}\mathrm{La} \\
\mathrm{Ce} \\
\mathrm{Nd} \\
\mathrm{Sm} \\
\mathrm{Eu} \\
\mathrm{Gd} \\
\mathrm{Tb} \\
\mathrm{Dy} \\
\mathrm{Ho} \\
\mathrm{Er} \\
\mathrm{Yb} \\
\mathrm{Lu}\end{array}$ & $\begin{array}{r}32.95 \\
76.85 \\
35.95 \\
6.30 \\
1.86 \\
4.50 \\
0.00 \\
4.28 \\
0.88 \\
2.62 \\
2.51 \\
0.40\end{array}$ & $\begin{array}{l}2.92 \\
4.70 \\
1.80 \\
0.00 \\
0.19 \\
0.00 \\
0.12 \\
0.00 \\
0.00 \\
0.00 \\
0.42 \\
0.00\end{array}$ & $\begin{array}{l}7.20 \\
7.10 \\
7.70 \\
1.25 \\
0.35 \\
0.00 \\
0.17 \\
0.00 \\
0.00 \\
0.00 \\
0.51 \\
0.07\end{array}$ & & $\begin{array}{l}0.00 \\
0.00 \\
0.00 \\
0.00 \\
0.00 \\
0.00 \\
0.00 \\
0.00 \\
0.00 \\
0.00 \\
0.00 \\
0.00\end{array}$ & $\begin{array}{r}55.14 \\
132.50 \\
66.20 \\
13.97 \\
1.10 \\
11.05 \\
0.00 \\
12.48 \\
2.67 \\
7.83 \\
7.89 \\
1.05\end{array}$ & $\begin{array}{r}12.13 \\
28.47 \\
14.78 \\
3.38 \\
0.16 \\
3.30 \\
0.00 \\
4.23 \\
0.91 \\
2.98 \\
3.87 \\
0.62\end{array}$ \\
\hline $\begin{array}{l}\text { A } \\
\text { NKC } \\
\text { NK }\end{array}$ & $\begin{array}{l}0.169 \\
0.182 \\
0.157\end{array}$ & $\begin{array}{l}0.139 \\
0.149 \\
0.134\end{array}$ & $\begin{array}{l}0.139 \\
0.138 \\
0.127\end{array}$ & & $\begin{array}{l}0.115 \\
0.124 \\
0.119\end{array}$ & $\begin{array}{l}0.153 \\
0.179 \\
0.154\end{array}$ & $\begin{array}{l}0.101 \\
0.121 \\
0.119\end{array}$ \\
\hline
\end{tabular}


DOMINIO PARANAGUÁ

\begin{tabular}{|c|c|c|c|c|c|}
\hline & $\mathrm{MJ}-206.2$ & $M J-208 A$ & $M J-287 A$ & $\mathrm{MJ}-301 \mathrm{E}$ & MJ-209 \\
\hline $\mathrm{SiO}_{2}$ & 67.64 & 70.80 & 73.42 & 71.20 & 76.51 \\
\hline $\mathrm{TiO}_{2}$ & 0.76 & 0.93 & 0.32 & 0.36 & 0.10 \\
\hline $\mathrm{Al}_{2} \mathrm{O}_{3}$ & 14.89 & 11.83 & 14.57 & 14.45 & 12.87 \\
\hline $\mathrm{Fe}_{2} \mathrm{O}_{3}{ }^{*}$ & 4.29 & 6.10 & 2.18 & 2.72 & 1.59 \\
\hline Mno & 0.07 & 0.10 & 0.04 & 0.07 & 0.03 \\
\hline MgO & 1.25 & 1.38 & 0.62 & 0.55 & 0.13 \\
\hline $\mathrm{CaO}$ & 2.77 & 2.22 & 1.47 & 1.55 & 0.64 \\
\hline $\mathrm{Na}_{2} \mathrm{O}$ & 3.74 & 2.78 & 3.82 & 3.61 & 3.40 \\
\hline $\mathrm{K}_{2} \mathrm{O}$ & 3.82 & 2.79 & 4.50 & 4.77 & 5.08 \\
\hline $\mathrm{P}_{2} \mathrm{O}_{5}$ & 0.21 & 0.36 & 0.07 & 0.10 & 0.04 \\
\hline LOI & 0.65 & 0.43 & 0.44 & 0.52 & 2.91 \\
\hline $\mathrm{Ba}$ & 1088 & 465 & 936 & 1135 & 57 \\
\hline $\mathrm{Cr}$ & 11 & 16 & 12 & 13 & 9 \\
\hline $\mathrm{Cu}$ & 9 & 11 & 0 & 2 & 0 \\
\hline $\mathrm{Ga}$ & 19 & 19 & 19 & 16 & 20 \\
\hline $\mathrm{Nb}$ & 26 & 28 & 16 & 23 & 25 \\
\hline $\mathrm{Ni}$ & 11 & 14 & 6 & 4 & 3 \\
\hline $\mathrm{Pb}$ & 20 & 15 & 24 & 44 & 31 \\
\hline $\mathrm{Rb}$ & 118 & 139 & 137 & 187 & 158 \\
\hline $\mathrm{Sr}$ & 368 & 187 & 248 & 238 & 16 \\
\hline Th & 20 & 22 & 20 & 31 & 26 \\
\hline V & 54 & 74 & 26 & 29 & 0 \\
\hline Y & 33 & 34 & 13 & 26 & 28 \\
\hline $\mathrm{Zn}$ & 58 & 82 & 35 & 55 & 46 \\
\hline $\mathrm{Zr}$ & 298 & 338 & 163 & 297 & 134 \\
\hline $\mathrm{TiO}_{2}$ & 0.69 & 1.02 & 0.31 & 0.41 & 0.11 \\
\hline La & 92.50 & 0.00 & 58.70 & 92.03 & 50.00 \\
\hline $\mathrm{Ce}$ & 163.00 & 0.00 & 97.30 & 180.00 & 105.00 \\
\hline $\mathrm{Nd}$ & 58.30 & 0.00 & 36.30 & 62.65 & 48.90 \\
\hline $\mathrm{Sm}$ & 9.71 & 0.00 & 5.16 & 9.64 & 10.60 \\
\hline Eu & 1.78 & 0.00 & 0.96 & 1.36 & 0.31 \\
\hline Gd & 0.00 & 0.00 & 0.00 & 5.97 & 0.00 \\
\hline $\mathrm{Tb}$ & 1.28 & 0.00 & 0.46 & 0.00 & 1.20 \\
\hline Dy & 0.00 & 0.00 & 0.00 & 4.57 & 0.00 \\
\hline Ho & 0.00 & 0.00 & 0.00 & 0.89 & 0.00 \\
\hline Er & 0.00 & 0.00 & 0.00 & 2.46 & 0.00 \\
\hline $\overrightarrow{Y b}$ & 2.85 & 0.00 & 0.82 & 2.13 & 2.39 \\
\hline Lu & 0.43 & 0.00 & 0.12 & 0.29 & 0.39 \\
\hline A & 0.146 & 0.116 & 0.143 & 0.142 & 0.126 \\
\hline NKC & 0.150 & 0.114 & 0.136 & 0.136 & 0.120 \\
\hline NK & 0.101 & 0.075 & 0.109 & 0.109 & 0.109 \\
\hline
\end{tabular}


ROCHAS BÁSICAS E ULTRABÁSICAS - PIÊN

\begin{tabular}{rrrrrrr} 
MJ-518A & MJ-518C & MJ-523A & MJ-523B1 & MJ-523C & MJ-524A & MJ-524B \\
C.C. & \multicolumn{1}{c}{ C.C. } & \multicolumn{1}{c}{ C.C. } & \multicolumn{1}{l}{ C.C. } & C.C. & C.C. & C.C. \\
PRX & PRX & \multicolumn{1}{c}{ PRX } & \multicolumn{1}{c}{ PRX } & GBN & PRX & PRX \\
& & & & & & \\
42.20 & 42.10 & 44.30 & 50.40 & 45.90 & 44.40 & 42.50 \\
0.09 & 0.10 & 0.11 & 0.07 & 0.16 & 0.09 & 0.08 \\
7.30 & 3.00 & 4.90 & 5.50 & 11.00 & 6.90 & 3.80 \\
8.87 & 9.27 & 9.00 & 8.66 & 5.92 & 9.19 & 8.60 \\
0.14 & 0.12 & 0.13 & 0.13 & 0.09 & 0.14 & 0.12 \\
31.30 & 35.90 & 33.40 & 31.60 & 17.50 & 32.40 & 34.70 \\
3.80 & 1.20 & 2.10 & 1.30 & 15.00 & 2.70 & 1.80 \\
0.08 & 0.04 & 0.13 & 0.10 & 1.50 & 0.06 & 0.10 \\
0.02 & 0.00 & 0.02 & 0.02 & 0.22 & 0.00 & 0.00 \\
0.24 & 0.36 & 0.29 & 0.25 & 0.12 & 0.27 & 0.33 \\
0.66 & 0.42 & 0.63 & 0.58 & 0.16 & 0.57 & 0.51
\end{tabular}

$\mathrm{Ba}$

$\mathrm{Cu}$

$\mathrm{Ga}$

$\mathrm{Nb}$

$\mathrm{Pb}$

$\mathrm{Rb}$

$\mathrm{Sr}$

$\checkmark$

Y

$\mathrm{Zn}$

$\mathrm{SiO}_{2}$

$\mathrm{TiO}_{2}$

$\mathrm{Fe}_{2} \mathrm{O}_{3}$ *

$\mathrm{MnO}$

$\mathrm{MgO}$

$\mathrm{Na}_{2} \mathrm{O}$

$\mathrm{K}_{2} \mathrm{O}$

$\mathrm{Cr}_{2} \mathrm{O}_{3}$

$\begin{array}{ll}0 & 0 \\ 0 & 0\end{array}$

$0 \quad 0$

0

13

0

0

0

6

6

1.79

9.61

1.93

0.48

0.12

0.46

1.33

4.52

1.86

0.44

0.09

0.33

0
0

0
0

230

0
0

0

$\mathrm{Eu}$

Gd

Dy

0.49

0.13

0.37

0.08

0.26

0.28

0.60

0.05

2.34
4.95
1.31
0.35
0.07
0.37

0.59
0.13
0.41
0.39
0.06

2.03

3.77

1.35

0.28

0.05

0.39

0.36

0.09

0.36

0.33

0.06

14.48
23.03
4.12
0.86
0.26
1.22

1.70
0.38
1.18
0.96
0.13

1.78

5.21

1.81

0.37

0.08

0.45

0.61

0.16

0.58

0.51

0.13

0.39
0.06

0.13

0.52

0.13

0.41

0.34

0.08 
ROCHAS BÁSICAS E ULTRABÁSICAS

\begin{tabular}{|c|c|c|c|c|c|c|c|}
\hline & MJ-525 & $M J-527 A$ & MJ-530 & MJ-533A & MJ-533B & MJ-534 & MJAM-142 \\
\hline & $\begin{array}{l}\text { C.C. } \\
\text { PRX }\end{array}$ & $\begin{array}{l}\text { C.C. } \\
\text { PRD }\end{array}$ & $\begin{array}{l}\text { Trig. } \\
\text { PRX }\end{array}$ & $\begin{array}{l}\text { C.M. } \\
\text { PRD }\end{array}$ & $\begin{array}{l}\text { C.M. } \\
\text { PRD }\end{array}$ & $\begin{array}{l}\text { C.M. } \\
\text { GBN }\end{array}$ & $\begin{array}{l}\text { C.M. } \\
\text { GBN }\end{array}$ \\
\hline $\mathrm{SiO}_{2}$ & 49.30 & 39.00 & 45.90 & 40.20 & 39.10 & 47.80 & 48.60 \\
\hline $\mathrm{TiO}_{2}$ & 0.05 & 0.06 & 0.07 & 0.05 & 0.05 & 0.34 & 0.25 \\
\hline $\mathrm{Al}_{2} \mathrm{O}_{3}$ & 7.30 & 1.50 & 5.00 & 0.68 & 0.90 & 10.80 & 9.60 \\
\hline $\mathrm{Fe}_{2} \mathrm{O}_{3}{ }^{*}$ & 10.75 & 7.73 & 8.46 & 6.89 & 6.92 & 11.09 & 11.15 \\
\hline $\mathrm{MnO}$ & 0.16 & 0.11 & 0.13 & 0.09 & 0.09 & 0.17 & 0.09 \\
\hline $\mathrm{MgO}$ & 30.30 & 37.90 & 30.80 & 38.90 & 38.70 & 18.50 & 20.90 \\
\hline $\mathrm{CaO}$ & 0.49 & 0.99 & 4.30 & 0.23 & 0.36 & 9.30 & 8.50 \\
\hline $\mathrm{Na}_{2} \mathrm{O}$ & 0.04 & 0.04 & 0.11 & 0.00 & 0.03 & 0.86 & 0.34 \\
\hline $\mathrm{K}_{2} \mathrm{O}$ & 0.00 & 0.00 & 0.00 & 0.00 & 0.00 & 0.03 & 0.02 \\
\hline $\mathrm{NiO}$ & 0.20 & 0.42 & 0.25 & 0.43 & 0.45 & 0.09 & 0.13 \\
\hline $\mathrm{Cr}_{2} \mathrm{O}_{3}$ & 0.83 & 0.38 & 0.51 & 0.39 & 0.42 & 0.32 & 0.38 \\
\hline $\mathrm{Ba}$ & 65 & 0 & 0 & 0 & 0 & 0 & 0 \\
\hline $\begin{array}{l}\mathrm{Cu} \\
\mathrm{Ga}\end{array}$ & 0 & 0 & 0 & 0 & 0 & 0 & 0 \\
\hline $\mathrm{Nb}$ & 0 & 0 & 0 & 0 & 0 & 0 & 0 \\
\hline $\mathrm{Pb}$ & & & & & & & \\
\hline $\mathrm{Rb}$ & 0 & 0 & 0 & 0 & 0 & 0 & 10 \\
\hline $\begin{array}{l}\mathrm{Sr} \\
\mathrm{Th}\end{array}$ & 0 & 25 & 13 & 3 & 7 & 31 & 3 \\
\hline V & 0 & 0 & 0 & 0 & 0 & 0 & 0 \\
\hline$Y$ & 0 & 0 & 0 & 0 & 0 & 8 & 8 \\
\hline $\mathrm{Zn}$ & & & & & & & \\
\hline $\mathrm{Zr}$ & 5 & 0 & 0 & 0 & 0 & 32 & 18 \\
\hline La & 1.57 & 1.94 & 0.83 & 1.01 & 1.30 & 7.32 & 1.64 \\
\hline $\mathrm{Ce}$ & 3.63 & 5.85 & 4.08 & 2.82 & 3.09 & 17.30 & 7.88 \\
\hline $\mathrm{Nd}$ & 1.08 & 2.29 & 0.95 & 0.92 & 1.08 & 11.04 & 2.80 \\
\hline $\mathrm{Sm}$ & 0.26 & 0.27 & 0.29 & 0.16 & 0.19 & 2.32 & 0.73 \\
\hline $\mathrm{Eu}$ & 0.04 & 0.08 & 0.08 & 0.03 & 0.04 & 0.49 & 0.23 \\
\hline $\begin{array}{l}G d \\
T b\end{array}$ & 0.25 & 0.21 & 0.25 & 0.13 & 0.18 & 1.57 & 0.77 \\
\hline Dy & 0.26 & 0.24 & 0.47 & 0.11 & 0.12 & 1.57 & 1.18 \\
\hline Ho & 0.07 & 0.05 & 0.12 & 0.02 & 0.03 & 0.33 & 0.27 \\
\hline $\mathrm{Er}$ & 0.28 & 0.13 & 0.45 & 0.07 & 0.09 & 0.99 & 0.91 \\
\hline $\mathrm{Yb}$ & 0.38 & 0.16 & 0.45 & 0.08 & 0.13 & 0.79 & 0.83 \\
\hline Lu & 0.06 & 0.03 & 0.07 & 0.02 & 0.02 & 0.12 & 0.12 \\
\hline
\end{tabular}




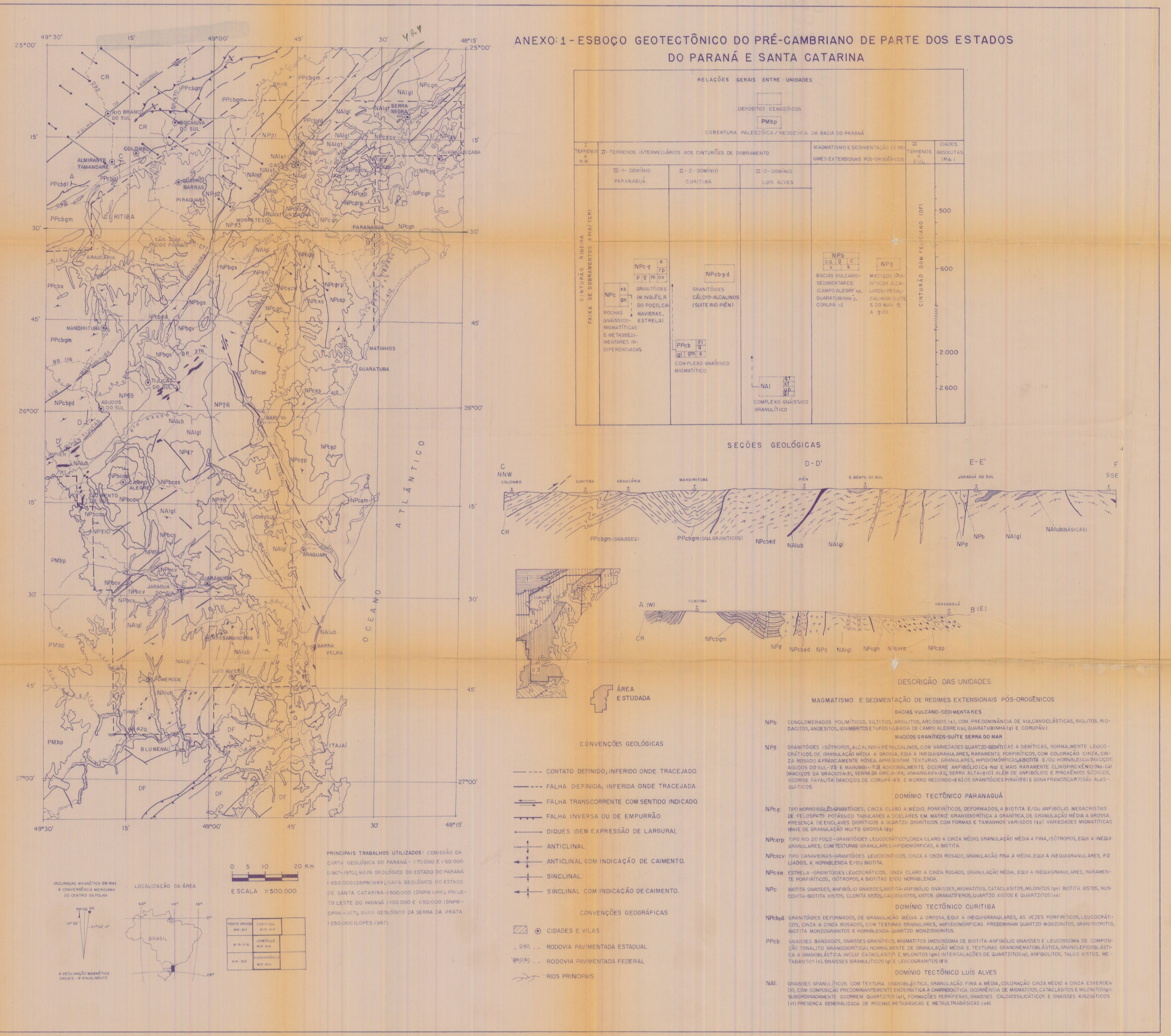




\section{ANEXO-2- MAPA DE LOCALIZACÃO DAS AMOSTRAS DATADAS}

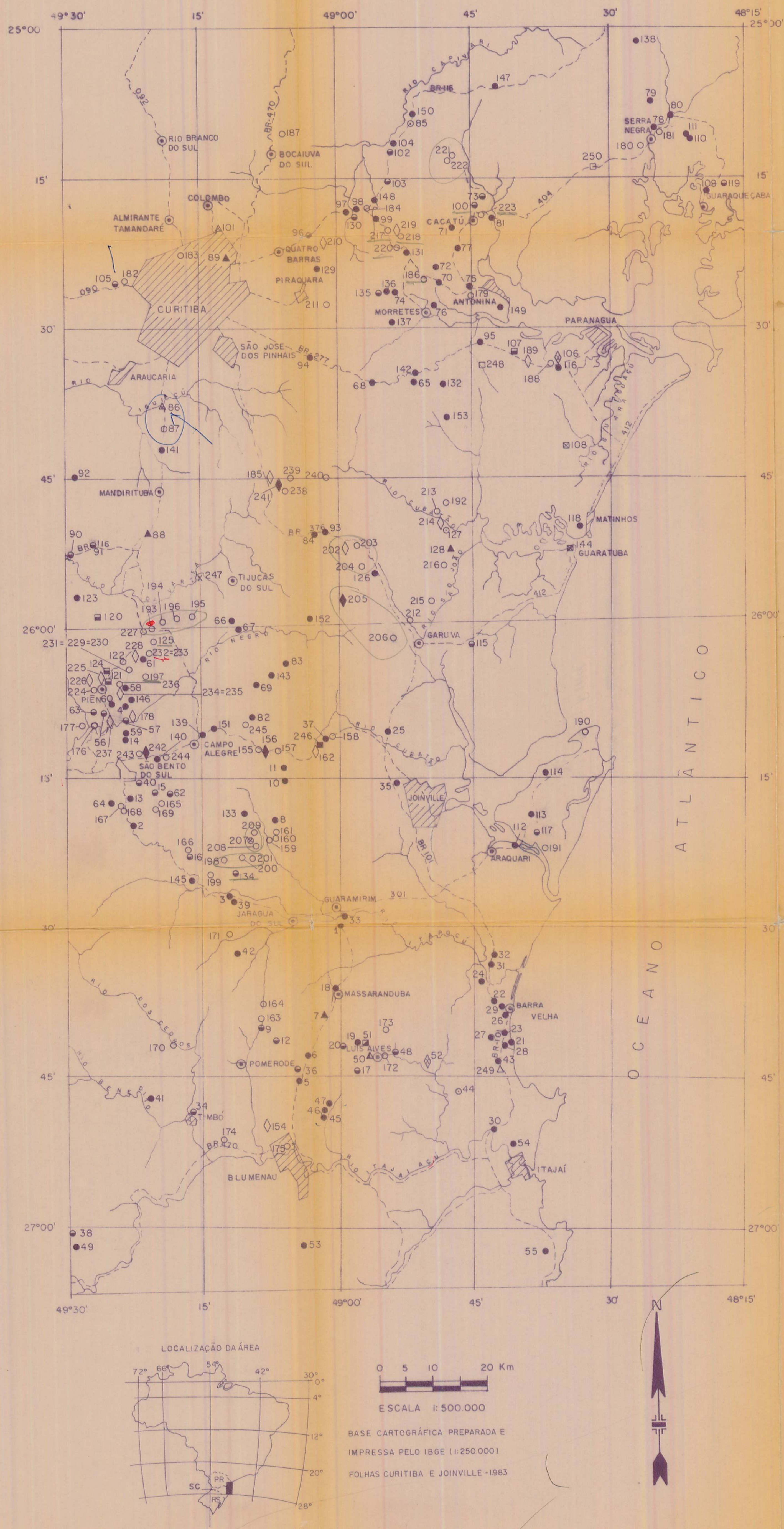

MÉTODOS DE ANÁLISE

- $k-\operatorname{Ar}$

$\mathrm{ORb}-\mathrm{Sr}$

in $u-p p$

$\triangle S m-N d$ (mineral)

$\square \mathrm{Sm}-\mathrm{Nd}$ (rocha total)

- K-Ar e Rb-Sr

a $K$-Ar e U $-\mathrm{Pb}$

$\Delta K-A r$ e $P b-P b$

$\rightarrow \mathrm{RB}-\mathrm{Sr}$ e U-PD

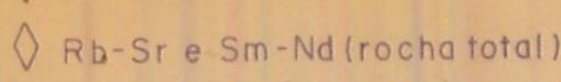

x U-Pb, Sm-Nd(mineral) e Sm-Nd (rocha total)

○ $K-A r, R b-S r$ e $U-P b$

(a) $K-A r, U-P b$ e $P b-P b$

a $\mathrm{K}$-Ar, $\mathrm{Pb}-\mathrm{Pb}$ e Rb-Sr

O K-Ar, Rb-Sre Sm-Nd (mineral)

A $\mathrm{K}$-Ar, Rb-Sre Sm-Nd(rocha total)

(4) Rb-Sr,Pb-Pb e Sm-Nd (rocha total)

Q Rb-Sr, U-Pb e Sm-Nd (rocha total)

$\otimes \mathrm{K}-\mathrm{Ar}, \mathrm{Rb}-\mathrm{Sr}, \mathrm{Pb}-\mathrm{Pb}$ e $\mathrm{Sm}-\mathrm{Nd}$ (rocha total)

$\Delta K-A r, R b-S r, U-P b$ e Sm-Nd (rochatotal)

$\Leftrightarrow \mathrm{K}-\mathrm{Ar}, \mathrm{Rb}-\mathrm{Sr}, \mathrm{U}-\mathrm{Pb}$ e $\mathrm{Pb}-\mathrm{Pb}$

CONVENGOẼS GEOGRÁFICAS

QZ ๑ CIDADES E VILAS

-..- RODOVIAS

O40-RODOVIA: PAVIMENTADA ESTADUAL

BR-040 RODOVIA PAVIMENTADA FEDERAL

D) DRENAGEM

Simbolos por anctodolegia 
ANEXO 3 - DADOS ESTRUTURAIS - TERRENOS LOCALIZADOS ENTRE OS CINTURŐES RIBEIRA (NORTE) E DOM FELICIANO (SUL) 